\begin{tabular}{|l|l|}
\hline 2. To: (Receiving organization) & 3. From: (Originating Organization) \\
Distribution & Technical Baseline \\
\hline 5. Proj./Prog./Dept./Div.: & 6. Design Authority/ Design Agent/Cog \\
33410 & Engr.: \\
\hline
\end{tabular}

8. Originator Remarks:

This transmits the Waste Management Project Technical

Base] ine Description.

11. Receiver Remarks: 11A. Design Basel ine Document? [] res [X] No

4. Related EOT No.:

$\mathrm{N} / \mathrm{A}$

7. Purchase Order No.:

$N / A$

9. Equip./Component No.:

$\mathrm{N} / \mathrm{A}$

10. System/Bldg./Facility: Waste Management Project

12. Major Assm. Dwg. No.:

N/A

13. Permit/Permit Application No.: $N / A$

14. Required Response Date: $\mathrm{N} / \mathrm{A}$

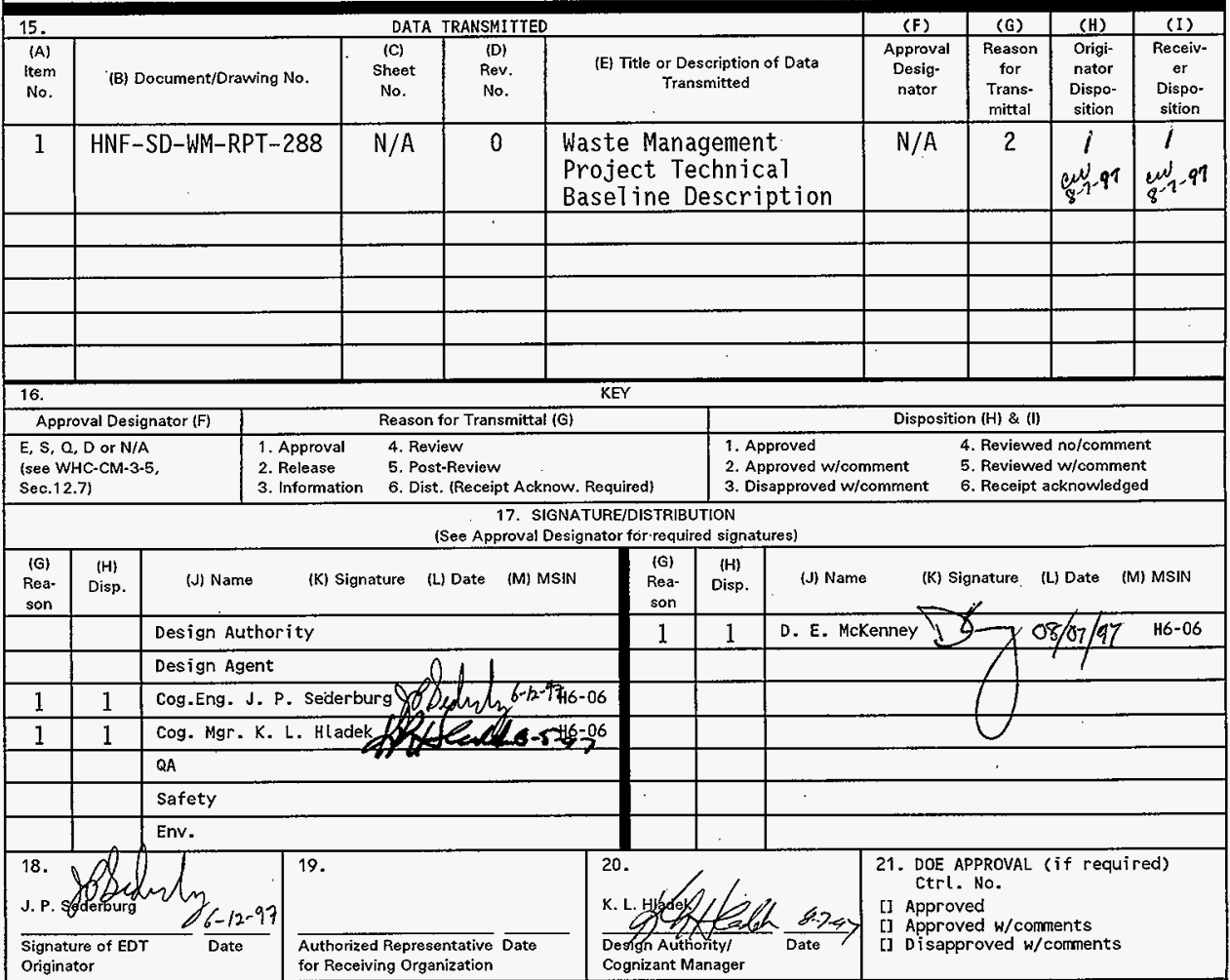




\title{
Waste Management Project Technical Baseline Description
}

\section{J. P. Sederburg}

RUST Federal Services of Hanford Inc., Richland, WA 99352

U.S. Department of Energy Contract DE-AC06-96RL13200

\author{
EDT/ECN: $618517 \quad$ UC: 2020 \\ Org Code: $33410 \quad$ Charge Code: A1001 \\ B\&R Code: EW3130020 Total Pages: $542 \underset{8 \rightarrow 12}{\mathrm{~cm}} \mathrm{q} \mathrm{ew}$
}

Key Words: baseline, systems engineering, system engineering, mission analysis, function and requirement analysis, alternative analysis, system definition, project documentation, project bases, facility bases

Abstract: A systems engineering approach has been taken to describe the technical baseline under which the Waste Management Project is current7y operating. The document contains a mission analysis, function analysis, requirement analysis, interface definitions, alternative analysis, system definition, documentation requirements, implementation definitions, and discussion of uncertainties facing the Project.

TRADEMARK DISCLAIMER. Reference herein to any specific commercial product, process, or service by trade name, trademark, manufacturer, or otherwise, does not necessarily constitute or imply its endorsement, recommendation, or favoring by the United states Government or any agency thereof or its contractors or subcontractors.

Printed in the United States of America. To obtain copies of this document, contact: Document Control Services, P.O. Box 950, Mailstop H6-08, Richland WA 99352, Phone (509) 372-2420; Fax (509) 376-4989.
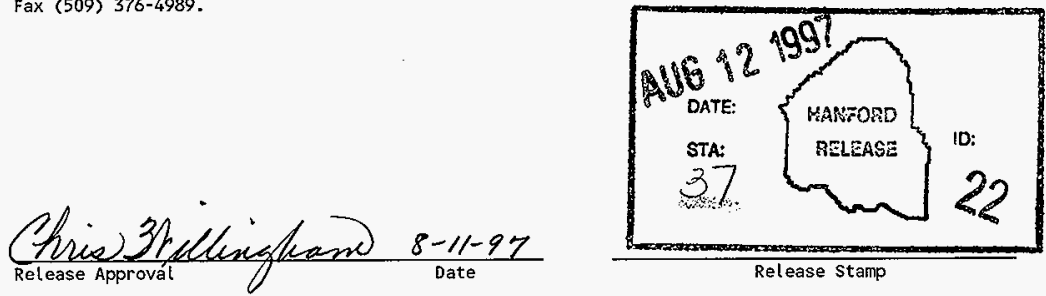

\section{Approved for Public Release}




\section{Waste Management Project Technical Baseline Description}

Prepared for the U.S. Department of Energy Assistant Secretary for Environmental Management

Project Hanford Management Contractor for the

U.S. Department of Energy under Contract DE-ACO6-96RL13200

Approved for public release; distribution is unlimited 


\section{OVERVIEW}

The Waste Management Project Technical Baseline Description is a comprehensive document that describes the current baseline of the Waste Management Project (Project) as managed by Rust Federal Services of Hanford, Inc.

\section{PURPOSE}

The Waste Management Project Technical Baseline Description uses a systems engineering approach to establish the Project's technical baseline. This document views the Project as a single system and documents the elements needed to successfully manage a project of this magnitude. By defining the Project's baseline, the effects of uncertainties and internally and externally driven changes to key Project elements can be understood. In turn, the effects of these changes on the mission, functions, interfaces, etc. can be assessed and controlled.

\section{APPROACH}

The approach taken in developing the Waste Management Project Technical Baseline Description is based on systems engineering. Systems engineering is a generalized, systematic methodology for defining large, complex, and/or first-of-a-kind problems, evaluating solutions to these problems, and implementing an appropriate solution. The methodology adopted by the Project is shown in Figure 0-1. The methodology establishes the Project technical baseline using seven iterative steps.

1. Mission analysis

2. Functional analysis

3. Requirements allocation

4. Interface definition

5. System synthesis and integration

6. Alternative evaluation/optimization

7. Implementation.

Mission analysis defines the need that the mission is fulfilling and provides a statement of the mission based on that need. The mission analysis also defines the objectives of the Project, the scope of the mission, and constraints placed on the Project. Mission analysis is covered in Chapter 1.0 .

Functional analysis identifies the functions that are performed to meet the mission. These functions can then be allocated at increasingly greater levels of detail to provide an increasingly explicit depiction of the mission statement. Functional analysis is covered in Chapter 2.0. 
Requirements analysis identifies the requirements associated with each function. Requirements analysis is covered in separate documentation. Requirements are allocated at each functional level to provide greater detail of the requirements. Requirements allocation is covered in Chapter 3.0.

Interfaces are defined as necessary to successfully complete the mission. These interfaces are described as external, which is external to the Project, but internal to the Hanford Site; internal to the Project; and offsite, which is off the Hanford Site. Interfaces are defined in Chapter 4.0.

System synthesis and integration (or system definition) depicts the system that satisfies the requirements to meet the mission. All elements of the system are to be considered in arriving at the integrated scheme. System definition is suitably described by showing the system interfaces. Showing the interfaces also permits traceability between system elements. The system description is presented in Chapter 6.0.

Alternative evaluation and optimization identifies practical tradeoffs using criteria such as operational needs, schedule, budget, health and safety, environmental impact, and life-cycle costs. Alternative evaluation and optimization is a continuous process that refines previous decisions; it occurs at all levels of functional detail. The alternative evaluation is presented in Chapter 5.0.

\section{CONTENTS}

The Waste Management Project Technical Baseline Description is presented in nine chapters describing mission analysis (Chapter 1.0), functional analysis (Chapter 2.0), requirements allocation (Chapter 3.0), interface definitions (Chapter 4.0), alternative analysis (Chapter 5.0), system description (Chapter 6.0), documentation (Chapter 7.0), implementation (Chapter 8.0), and Project uncertainties (Chapter 9.0).

\section{MISSION ANALYSIS}

The Hanford Strategic Plan states that one of the Hanford Site's two missions is to "...safely cleanup and manage the site's legacy wastes." As part of the Hanford Site Mission, the Project is responsible for safely managing waste and other materials.

To meet these and other needs, the Project has defined its mission as the following:

Rust Federal Services of Hanford, Inc., provides expert solutions and implements safe, integrated, and cost-effective waste management strategies. Support services provided include Site Generator Services, Waste Storage Facility Operations and Maintenance, Waste Treatment and Disposal Services, Decontamination Services, and Site Analytical Services. 
Hanford Site Mission Statement
Figure 0-1. Systems Engineering Process for System Definition

of the Waste Management Project.
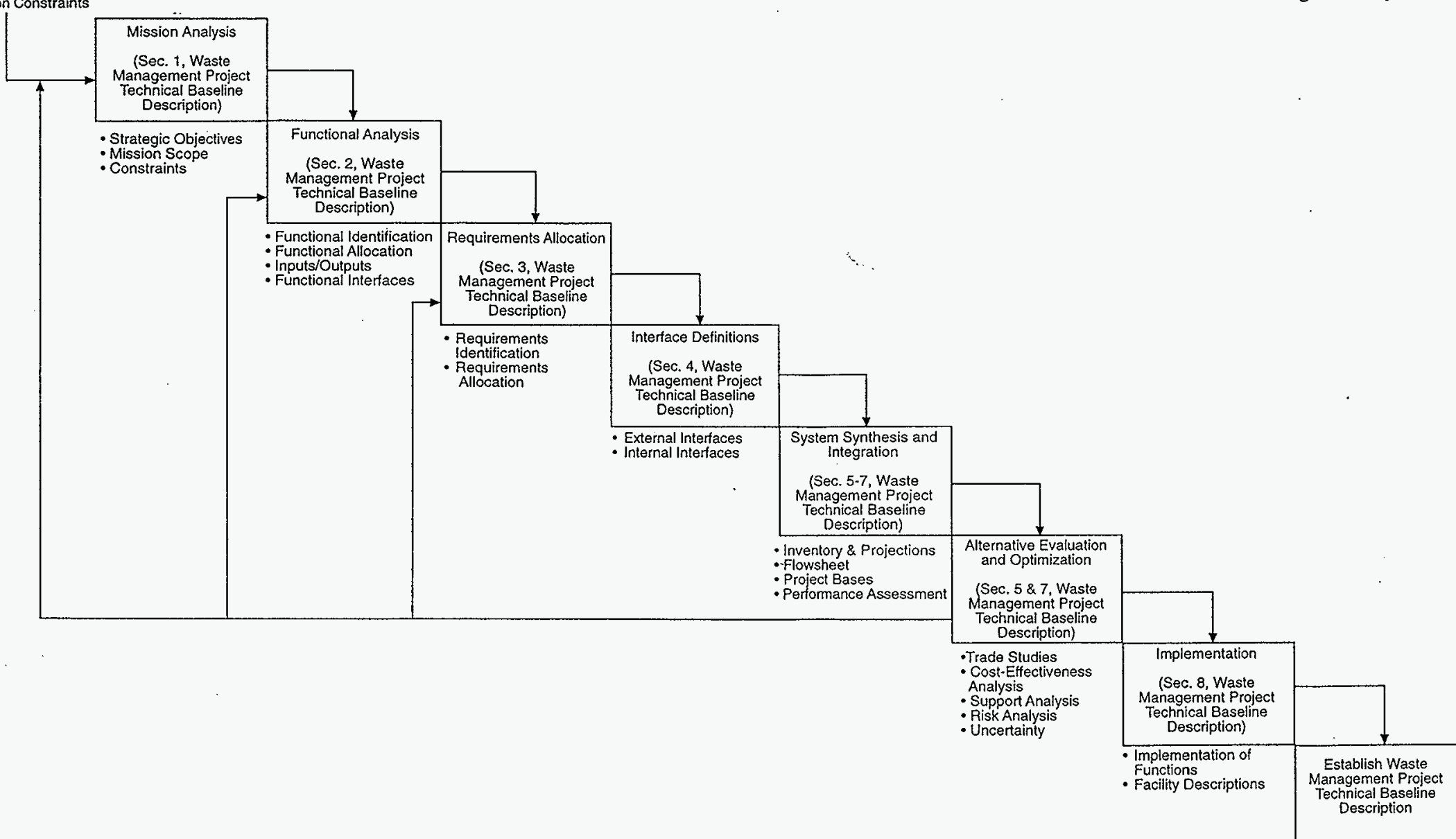
The Project manages solid and liquid waste that can be radioactive, nonradioactive, hazardous, and non-hazardous. The Project also manages other special materials such as reactor irradiated nuclear materials, equipment requiring decontamination, and samples requiring analyses.

\section{FUNCTIONAL ANALYSIS}

The functional analysis establishes the baseline Project functions by defining them as they become necessary to meet the Project's mission. Functions are specific actions, activities, or processes that achieve or support the achievement of the Project's technical mission. This functional analysis is limited to only technical functions and does not include programmatic functions (program management, project management, etc.).

\section{REQUIREMENTS ALLOCATION}

Requirements define how well a function must perform. Requirements set limits on functions and their outputs. Requirements include but are not limited to mission specifications, regulatory constraints, external policies, and internal policies. The Solid Waste Disposal Standards/Requirements Identification Document identifies the set of requirements that provides an adequate level of protection for Site workers, the public, and the environment. This document was developed to meet the intent of Defense Nuclear Facilities Safety Board Recommendation 90-2. It includes federal, state, U.S. Department of Energy, and other requirements. When federal and state requirements are essentially the same, only the state requirement is cited because the state must typically implement an equivalent or more restrictive program. Future revisions to the Waste Management Project Technical Baseline Description will include discussions of requirements for liquid waste and analytical services. All requirements will be allocated to functions after the Project requirements are clearly defined.

\section{INTERFACE DEFINITIONS}

Interface control documents are being established by the Project to define the boundaries of the Project and other project and program boundaries. Interfaces defined in the Waste Management Project Technical Baseline Description include the following:

- Solid Waste and Liquid Waste

- $\quad$ Liquid Waste and Analytical Services

- Analytical Services and Solid Waste

- Spent Nuclear Fuel and the Project

- Tank Waste Remediation System and the Project

- Environmental Restoration and the Project

- Fast Flux Test Facility and the Project

- Plutonium Finishing Plant 
Plutonium Uranium Extraction (Facility) and the Project

- Other Transition Projects Facilities and the Project

- $\quad$ Pacific Northwest National Laboratory and the Project

- B Plant/Waste Encapsulation and Storage Facility

- $\quad$ Site Infrastructure Providers and the Project

- $\quad$ Tank Waste Remediation System Privatization - Phase I and the Project

- Offsite Interfaces with the Project.

The Project intends that, as a minimum, each interface will be described in an interface control document; however, some interface control documents will require more extensive work to complete. These have not been written yet. Interface control documents include a baseline description of the waste that will be generated during the next several years.

\section{ALTERNATIVE ANALYSIS}

The alternative analysis delineates Project alternatives evaluated at a low enough level to clearly identify sufficient management and dispositioning of waste, equipment, and materials. Alternative evaluations establish decision criteria that focus decision makers on compliant and viable options for achieving the mission. Alternatives have been examined for the solid waste subproject. Future revisions of the Waste Management Project Technical Baseline Description will include more detailed analyses of the liquid waste and analytical services subprojects.

\section{SYSTEM DEFINITION}

Figure $\mathrm{O}-2$ is an overview of the Project system. Its three main subprojects, Solid Waste, Liquid Waste, and Analytical Services, are depicted.

\section{Solid Waste}

Each type of waste (transuranic and transuranic-mixed waste, low-level mixed waste, low-level waste, and hazardous waste) managed by the Project has distinctive characteristics Some of this waste (e.g., retrievably stored transuranic) will be retrieved. Storage for waste awaiting treatment will be required for existing and projected transuranic and transuranic-mixed waste and low-level mixed waste. Treatment will be required for almost all waste categories managed by the Project. (A large volume of Category I low-level waste will not be treated before disposal.) Disposal will be required for all solid waste managed, but the Project does not provide transuranic or Greater Than Category III waste disposal because these are U.S. Department of Energy Complex-level issues.

The Program plans to retrieve transuranic waste stored in burial ground trenches and caissons since May 1, 1970. Retrieval will be accomplished through the following three projects. 
HNF-SD-WM-RPT-288

Revision 0

Figure 0-2. Waste Management Project.

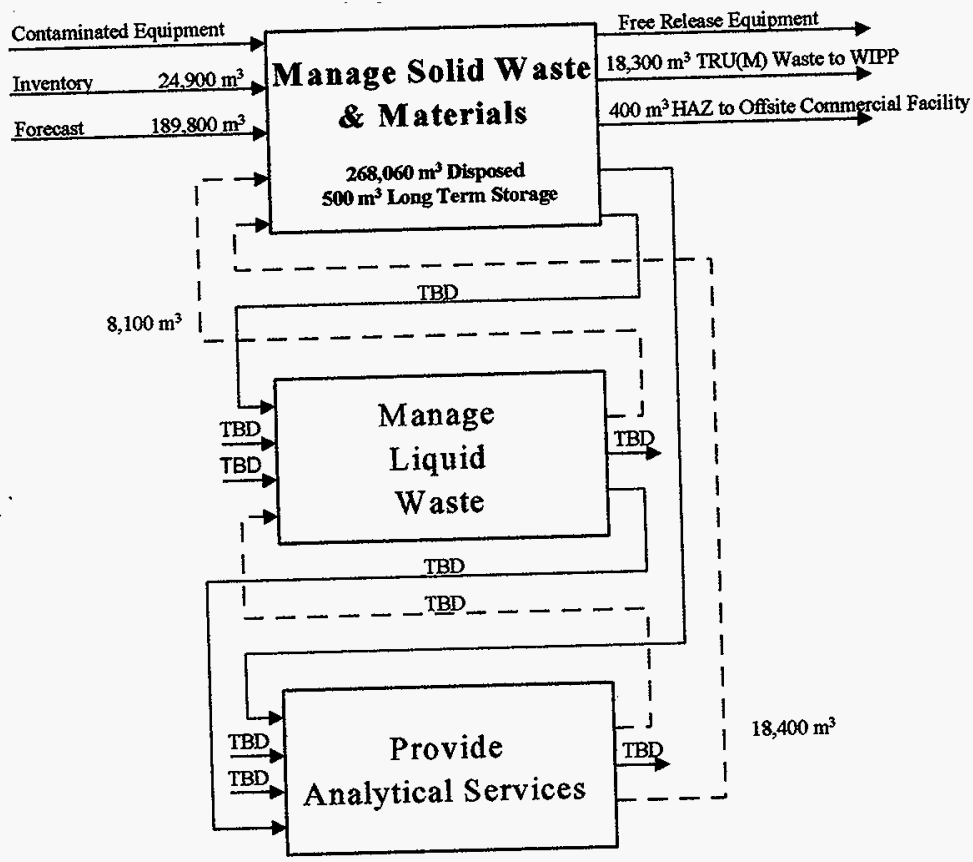


Solid Waste Retrieval Phase 1 (Project W-113). Solid Waste Retrieval Phase 1 will retrieve the retrievably stored containers from Trench 4 of Burial Ground $218-W-4 C$. This accounts for roughly one-third of the containers and one-sixth of the volume of retrievably stored transuranic waste.

Alpha Caisson Retrieval (Project W-156). Alpha Caisson Retrieval will remove remote-handled transuranic waste stored in the four alpha caissons located in Burial Ground 218-W-4B

- Solid Waste Retrieval Phase 2 (Project W-221). Solid Waste Retrieval Phase 2 will retrieve the remaining inventory of retrievably stored transuranic waste.

The Project plans to treat inventories of currently managed and/or projected transuranic and transuranic mixed waste, low-level mixed waste, and low-level waste. The treatment function has been separated into a number of projects or services. The most significant projects and services are described in the following paragraphs.

Waste Receiving and Processing Module 1. The Waste Receiving and Processing Module 1 has been designed to sort, process, and repackage retrievably stored and newly generated transuranic solid waste for shipment to the Waste Isolation Pilot Plant in Carlsbad, New Mexico.

Contact-Handled Low-Level Mixed Waste Commercial Stabilization Treatment. The Contact-Handled Low-Level Mixed Waste Commercial Stabilization Treatment contract will provide commercial treatment services for stored and projected contact-handled low-level mixed waste that does not require thermal treatment.

Commercial Thermal Treatment. The Commercial Thermal Treatment contract for services will provide treatment for that portion of the contact-handled low-level mixed waste for which thermal treatment will be the technology-based standard for treatment.

T Plant. The T Plant complex will provide decontamination services for the Hanford Site.

Future Facilities Defined Under the Hanford Federal Facility Agreement and Consent Order ${ }^{1}$ Milestone M-91 (formerly Milestone M-33). These facilities will process remotehandled and oversize transuranic waste, low-level mixed waste, and Greater Than Category III waste.

Storage functions will encompass interim and long-term storage capabilities. The individual storage requirements are determined by the specific waste types to be stored. Storage is necessary for contact-handled packages of radioactive and hazardous solid waste received from

${ }^{1}$ Washington State Department of Ecology, U.S. Environmental Protection Agency, and U.S. Department of Energy, Olympia, Washington, 1994, Hanford Federal Facility Agreement and Consent Order, as amended. 
offsite and onsite generators as well as waste recovered from retrieval operations. Storage facilities and projects include the Transuranic Storage and Assay Facility (224-T) ${ }^{2}$, which contains primarily transuranic waste that meets Hanford Site solid waste acceptance criteria, and the Central Waste Complex, which consists of several buildings and modules used to store radioactive and mixed waste.

Disposal functions provide for the ultimate disposition of the solid waste on and off the Hanford Site. Disposal facility performance is based on the type of solid waste being disposed of. Separate disposal functions are identified for transuranic waste, low-level mixed waste, low-level waste, and hazardous waste. The disposal functions for transuranic waste (Waste Isolation Pilot Plant), hazardous waste (transported off site to a permitted treatment and disposal facility), and Greater Than Category III low-level waste (none defined) are outside the Project scope. The Project provides disposal for inventories of currently managed and/or projected low-level mixed waste and low-level waste. Mixed-waste disposal trenches provide permanent disposal capability for low-level mixed waste. The low-level burial grounds provide permanent disposal capability for low-level waste.

\section{Liquid Waste}

Future revisions of the Waste Management Project Technical Baseline Description will include more detailed discussions of the liquid waste subprojects and systems.

\section{Analytical Services}

Future revisions of the Waste Management Project Technical Baseline Description will include more detailed discussions of the analytical services subprojects and systems.

\section{DOCUMENTATION}

A vast amount of analysis, study, design, evaluation, planning, etc., is required for the Project to satisfactorily meet its mission. This information is documented to meet requirements placed on the Project and to substantiate the Project's technical baseline.

Each project and facility under the Project's control must develop a number of documents to satisfy the requirements placed on that project or facility. Depending on the scope of the project, these requirements may include project management; system integration; environmental permitting and regulatory requirements; safety analysis; design, engineering, and construction management; environmental, safety, health, and quality assurance; operational interface;

\footnotetext{
${ }^{2}$ To be emptied by the end of Fiscal Year 1997.
} 
transportation; and analytical requirements. Facilities also have documentation requirements, including plant operating procedures, maintenance procedures, safety analysis documents, permits, and operational safety requirements documents. The level of completion of this documentation depends on the status and schedule of each project and facility.

\section{IMPLEMENTATION}

The Project uses various facilities, contracts, and project resources to provide the capabilities needed to accomplish its mission. These implementing devices provide the bridge from "what" must be done technically (i.e., the Project functions) to "how" it is or will be implemented in terms of specific facilities, commercial contracts, projects, or natural systems. The "hows" for the Project also are summarized.

\section{UNCERTAINTIES}

Project uncertainties are identified to highlight key areas of potential change that could affect the system defined by the Project to accomplish its mission. It should be noted that "uncertainties" includes "unknowns," as well as "alternatives" on which decisions have not yet been made. Uncertainties have been categorized by the level at which the uncertainty will have to be reconciled. Uncertainties exist at the U.S. Department of Energy Complex level, at the Hanford Site level, and at the Project level.

The DOE Complex-level uncertainties are related to problems that affect the entire U.S. Department of Energy Complex and their possible effect on Project planning. For the most part, the Project cannot control these uncertainties, but must react to changes to assumptions, laws, regulations, and guidelines. Some of the U.S. Department of Energy Complex-level uncertainties include the Federal Facilities Compliance Act of $1992^{3}$, the interface with the Waste Isolation Pilot Plant in Carlsbad, New Mexico, the availability of certified laboratories to handle transuranic waste, and the policy on disposal of Greater Than Category III low-level waste.

Hanford Site-level uncertainties are within the control of the Hanford Site, but cross current organizational boundaries. The Project and other Site organizations will have to work to resolve these uncertainties. Some of the Hanford Site-level uncertainties include integration of. remote-handled waste processing and storage needs, disposition of long-length equipment generated by the Tank Waste Remediation System, accuracy of waste forecasts, and decision making regarding pre-1970 transuranic-contaminated buried waste.

Project-level uncertainties are related to areas within the Project's operational scope. The Project will have to work to resolve these uncertainties.

${ }^{3}$ Federal Facilities Compliance Act of 1992, 42 USC 6901, et seq. 
HNF-SD-WM-RPT-288

Revision 0

This page intentionally left blank.

0-12 
HNF-SD-WM-RPT-288

Revision 0

\section{CONTENTS}

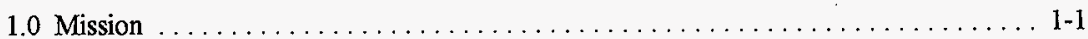

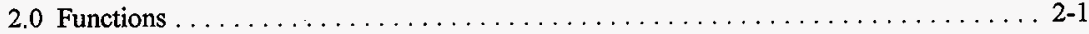

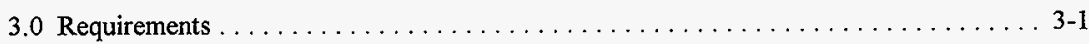

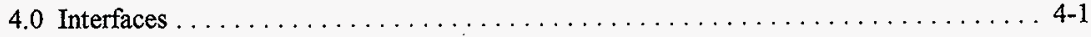

5.0 Alternatives $\ldots \ldots \ldots \ldots \ldots \ldots \ldots \ldots \ldots \ldots \ldots \ldots \ldots \ldots \ldots \ldots \ldots \ldots \ldots$

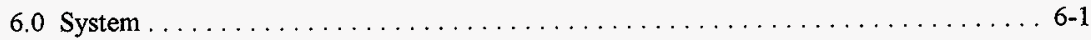

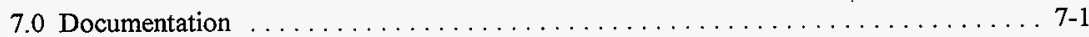

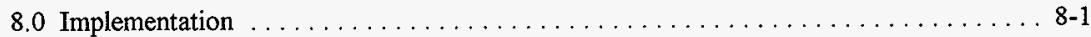

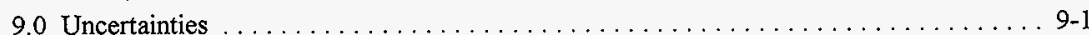

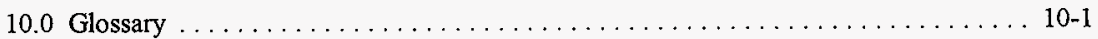


HNF-SD-WM-RPT-288

Revision 0

This page intentionally left blank. 


\section{CONTENTS}

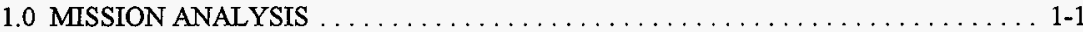

1.1 INTRODUCTION $\ldots \ldots \ldots \ldots \ldots \ldots \ldots \ldots \ldots \ldots \ldots \ldots \ldots \ldots \ldots, 1$

1.1.1 Background $\ldots \ldots \ldots \ldots \ldots \ldots \ldots \ldots \ldots \ldots \ldots \ldots \ldots \ldots \ldots, 1-1$

1.1.2 Systems Engineering Approach . . . . . . . . . . . . . . . . . . . . 1-1

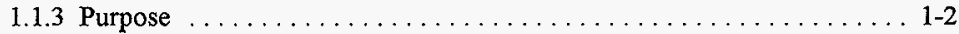

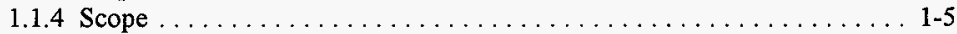

1.1.5 Project Need and Mission Statement ................... 1-5

1.2 PROJECT MISSION ANALYSIS RESULTS $\ldots \ldots \ldots \ldots \ldots \ldots \ldots \ldots \ldots$

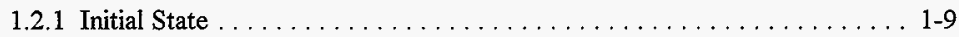

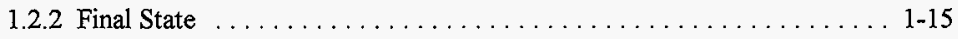

1.2.3 Measures of Success ............................ 1-16

1.3 REFERENCES . . . . . . . . . . . . . . . . . . . . . . . . . 1-17

\section{LIST OF FIGURES}

1-1. Systems Engineering Process for System Definition

of the Waste Management Project . . . . . . . . . . . . . . . . . . . . . . 1-3

1-2. Waste Management Project Boundaries . . . . . . . . . . . . . . . . . 1-11

\section{LIST OF TABLES}

1-1. Initial State of the Waste Management Project on September 30, $1996 \ldots \ldots \ldots$. . . 1-13

1-2. Final State of the Waste Management Project . . . . . . . . . . . . . . . . . . . 1-14

1-3. Partial List of Topics that the Waste Management

Project Uses to Measure its Success . . . . . . . . . . . . . . . . . 1-16 


\section{LIST OF TERMS}

$\begin{array}{ll}\text { CERCLA } & \text { Comprehensive Environmental Response, Compensation, and Liability Act } \\ \text { OWC } & \text { Central Waste Complex } \\ \text { D\&D } & \text { decontamination and decommissioning } \\ \text { DOE-HQ } & \text { U.S. Department of Energy-Headquarters } \\ \text { Ecology } & \text { Washington State Department of Ecology } \\ \text { EPA } & \text { U.S. Environmental Protection Agency } \\ \text { GTCIII } & \text { Greater Than Category III } \\ \text { LDR } & \text { land disposal restriction } \\ \text { LLW } & \text { low-level waste } \\ \text { MLLW } & \text { mixed low-level waste } \\ \text { PWR } & \text { Pressurized Water Reactor } \\ \text { Project } & \text { Waste Management Project } \\ \text { RCRA } & \text { Resource Conservation and Recovery Act of } 1976 \\ \text { RINM } & \text { reactor-irradiated nuclear material } \\ \text { RL } & \text { U.S. Department of Energy, Richland Operations Office } \\ \text { TRIGA } & \text { Training Reactor, Isotopes, General Atomics } \\ \text { TRU } & \text { transuranic } \\ \text { TRUSAF } & \text { Transuranic Waste Storage and Assay Facility } \\ \text { TSD } & \text { treatment, storage, and disposal } \\ \text { WAC } & \text { Washington Administrative Code } \\ \text { WIPP } & \text { Waste Isolation Pilot Plant }\end{array}$




\section{WASTE MANAGEMENT PROJECT TECHNICAL BASELINE DESCRIPTION}

\subsection{MISSION ANALYSIS}

\subsection{INTRODUCTION}

The mission analysis provides a mission statement for the Waste Management Project (Project) based on need. Rust Federal Services of Hanford, Inc., has been designated by Fluor Daniel Hanford, Inc., to manage solid and liquid waste and provide analytical services within the structure of the Project Hanford Management Contract. This section defines the objectives, scope, and constraints of the Project.

\subsubsection{Background}

The Hanford Strategic Plan (DOE/RL-96-92) (RL 1996a) states that one of two missions of the Hanford Site is to ". . . safely clean up and manage the site's legacy wastes." As part of the Hanford Site mission, the Project is responsible for safely managing waste and other materials. The Fiscal Year 1995 Hanford Mission Plan, Volume 1, "Site Guidance" (RL 1994) and the Systems Engineering Criteria Document and Implementing Directive (RL 1996b) provide specific guidance for the Project regarding its mission, material management responsibilities, and material disposition responsibilities. Project Hanford (RL 1996c) provides specific information about the Project's mission and the ultimate treatment, storage, and disposal (TSD) of materials within its scope. This guidance is used by the Project's staff during systems engineering activities to develop the Project's technical baseline.

\subsubsection{Systems Engineering Approach}

Systems engineering is a generalized, systematic methodology for defining large, complex, and/or first-of-a-kind problems; evaluating solutions to the problems; and implementing the solution. The methodology adopted by the Project in developing this technical baseline description is based on systems engineering (Figure 1-1). The methodology consists of six iterative steps to establish the Project's technical baseline: (1) mission analysis, (2) functional analysis, (3) requirements allocation, (4) interface definition, (5) system synthesis and integration, and (6) alternative evaluation and optimization. Executing these six steps develops the technical baseline for the Project.

Mission analysis defines the mission of the Project in a specific context. It defines the need the mission is fulfilling and provides a statement of the mission based on that need. The analysis 
also defines the objectives of the Project in completing the mission. The mission analysis identifies the scope of the mission and the constraints placed on the Project for completing the mission. The result is a bounding set of parameters that begin to define the Project

Functional analysis identifies the functions that must be performed to complete the mission. Once identified, these functions can be allocated at increasing levels of detail to more explicitly depict the mission statement.

Requirements are subsequently allocated to each function to provide even greater detail about the need each function meets. This in turn leads to an even greater understanding of the Project's mission.

Interface definition provides even more emphasis on defining the system boundaries. Clearly defined interfaces between the Project and external programs and projects more precisely define the information and materials that must be transferred into and out of the Project to successfully complete its objectives. The result is a practical understanding of the Project's mission.

System synthesis and integration depicts the concepts that satisfy the requirements that must be met to complete the mission. All elements of the system are to be considered in arriving at an integrated scheme. System definition is suitably described by illustrating system interfaces, permitting traceability among system elements, and providing a means for change control of the system. The system definition is illustrated by a Project flowsheet that is based on the functions and requirements of the Project.

Alternative evaluation and optimization identifies desirable and practical tradeoffs among stated operational needs, design, schedule and budget, ability to be produced and constructed, supportability, affordability, and life-cycle costs, as appropriate. Optimization should be continually identified and evaluated. Tradeoff studies should be accomplished at the various levels of functional or system detail to support the decision needs. Among the many techniques available to provide alternative evaluation and optimization are tradeoff studies, cost-effectiveness analysis, value engineering, support analysis, and risk analysis.

\subsubsection{Purpose}

The mission analysis establishes the baseline technical mission of the Project. This is accomplished by defining the scope of the mission, objectives of the Project, and constraints placed on the Project for completing the mission. 
HNF-SD-WM-RPT-288 Revision 0

Figure 1-1. Systems Engineering Process for System Definition of the Waste Management Project.

Hanford Site Mission Statement

- Mission Objectives

-Mission Constraint

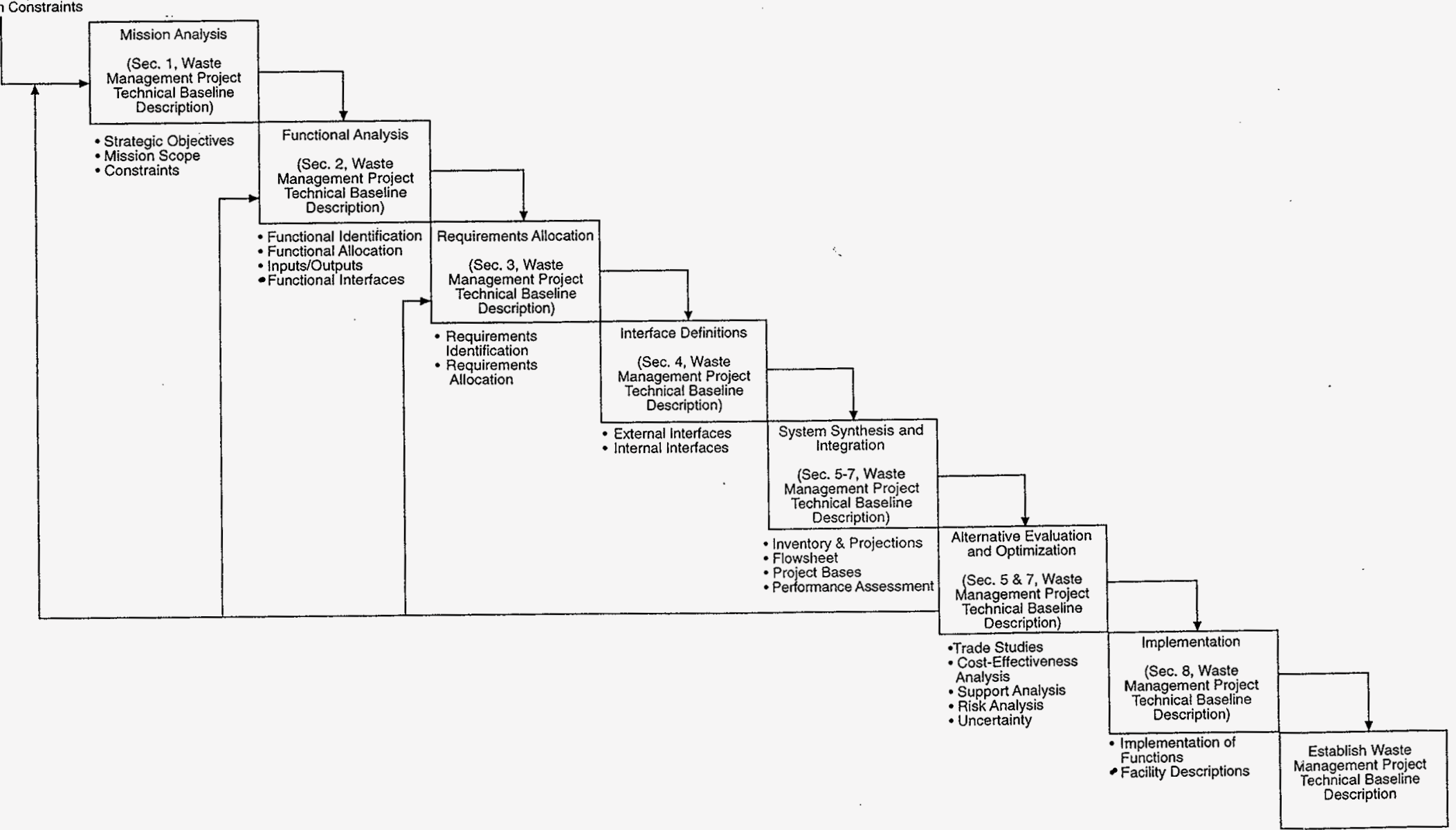




\section{HNF-SD-WM-RPT-288}

Revision 0

\subsubsection{Scope}

The mission analysis documents the following:

- Initial conditions - The beginning or as-found holdings (buildings, equipment, waste, etc.) that fell under the auspices of the Project when this systems engineering analysis was initiated

- Final conditions-The final states to be achieved by the Project system at completion, or interim points

- Measures of success-Determine the effectiveness of the current system in achieving the final condition.

The mission analysis identifies (1) the Project's baseline strategy or working position and (2) its scope based on initial conditions, requirements associated with the final state, and measures of success.

\subsubsection{Project Need and Mission Statement}

The Hanford Strategic Plan (RL 1996a) defines the environmental management mission as having three components: "protect the health and safety of the public, workers, and the environment, control hazardous materials, and utilize the assets (people, infrastructure, site) for other missions." Thus, multiple needs exist that relate to the Hanford Site's environmental management mission. They include the need for "solid waste to be dispositioned consistent with national policies for management of transuranic, low-level, and low-level mixed and hazardous waste." This includes the "receipt of onsite and offsite wastes for disposal in the 200 Area." Also, support services are needed to disposition hazardous and radioactive liquid waste to meet the Site requirement for "cleanup." Furthermore, a cross-cutting need exists fo effectively manage the analyses of solid, liquid, and gaseous samples on the Site, and to oversee management of waste minimization efforts, pollution prevention measures, and effluent environmental management actions.

To meet these needs, the Project has defined its mission as the following:

Rust Federal Services of Hanford, Inc., provides expert solutions and implements safe, integrated, and cost-effective waste management strategies. Support services provided include Site Generator Services, Waste Storage Facility Operations and Maintenance, Waste Treatment and Disposal Services, Decontamination Services, and Site Analytical Services. 
These services are undertaken in a way that improves the likelihood of success for Rust Federal Services of Hanford, Inc,, and lowers the Project's life-cycle costs for the U.S. Department of Energy (DOE) Complex.

As part of the mission to clean up the Site, the Project is responsible for the following:

- Managing buried waste located in burial grounds identified in DOE/RL-88-20, Low-Level Burial Grounds Dangerous Waste Permit Application (DOE-RL 1990) (Burial Grounds 218-E-10, 218-E-12B, 218-W-3A, 218-W-3AE, 218-W-3B, 218-W-4B, 218-W-4C, 218-W-5, and 218-W-6 [future site])

- Managing stored solid waste located mainly in buildings that are part of the Hanford Central Waste Complex and the Transuranic Waste Storage and Assay Facility (TRUSAF) ${ }^{1}$

- Managing receipts of newly generated solid waste from onsite programs and projects and offsite generators

- Providing TSD of hazardous and radioactive solid waste ${ }^{2}$

- Storing Shippingport Pressurized Water Reactor Core II blanket fuel rods in the T Plant canyon, and Training Reactor, Isotopes, General Atomics (TRIGA) fuel in the active burial grounds in the 200 Areas

- Providing decontamination services for high- and low-dose waste and contaminated equipment

- Managing low-dose-rate waste equipment for repair and return to service

- Providing disposition for nonradioactive, nonhazardous, hazardous, and radioactive liquid waste from onsite programs and projects through the operation and maintenance of the 200 and 300 Area Effluent Operating Facilities

- Providing effluent environmental monitoring services

- Concentrating dilute liquid waste and dispositioning the resultant process condensate

${ }^{1}$ The TRUSAF will be emptied of transuranic waste on or before August 31, 1997.

${ }^{2}$ Treatment (T) and disposal (D) are accomplished via contract. 
- Providing analytical services for onsite programs and offsite clients, as needed through operation and maintenance of the 222-S Complex, the Waste Sampling and Characterization Facility Complex and commercial laboratory services, and by integrating all Site analytical services

- Providing guidance and assistance on pollution prevention and waste minimization strategies.

The mission excludes management of solid waste buried in inactive burial grounds that will be remediated by the environmental restoration mission area. The mission also excludes solid waste, as defined in the Comprehensive Environmental Response, Compensation, and Liability Act of 1980 (CERCLA), that is generated on Site by the Environmental Restoration Contractor. Further, the mission excludes liquid waste stored in the single- or double-shell tanks (except when it enters the 242-A Evaporator).

The following paragraphs describe the types of waste managed within the Project.

Transuranic (TRU) Waste. The Project will manage all retrieved, stored, and newly generated solid TRU and solid TRU mixed waste. The Project is responsible for retrieving solid waste placed in retrievable storage since 1970. The Project will provide onsite storage for solid TRU waste until an offsite disposal system is prepared to accept Hanford Site material. The Project will provide for treatment and certification of solid TRU waste to meet waste acceptance criteria for disposal. The Project will also arrange for transportation of the solid TRU waste prepared for offsite disposal at the Waste Isolation Pilot Plant (WIPP) in Carlsbad, New Mexico. Liquid TRU waste currently stored in double-shell tanks (such as 241-AW-103 and 241-AW-105) is not within the Project's mission.

Mixed Low-Level Waste (MLLW). The Project is responsible for the receipt, treatment, interim storage, and disposal of multiple categories of solid MLLW assigned to the Hanford Site for disposition. The Project provides systems (including tracking databases, waste configuration, and permit maintenance) to ensure that MLLW meets regulatory requirements. Where offsite treatment is required to allow disposal of the waste, Project responsibility includes onsite storage and arranging for transport to the offsite treatment location. Final disposition will occur in a Resource Conservation and Recovery Act of 1976 (RCRA)-permitted onsite disposal system. Washington Administrative Code (WAC) 173-303, "Dangerous Waste Regulations," also applies. Project responsibility includes closure and post-closure maintenance of the disposal system. The Project also is responsible for some liquid MLLW, which will be described in future revisions to this document.

Low-Level Waste (LLW). The Project is responsible for the receipt, treatment (if appropriate), interim storage (if appropriate), and disposal of multiple categories of solid LLW assigned to the Hanford Site for disposition. Final disposition will occur in an onsite disposal system. Project responsibility includes closure of the disposal system. Where offsite treatment is required to allow disposal of the waste or enhance use of the disposal system, Project 


\section{Revision 0}

responsibility includes onsite storage and arranging for transport to the offsite treatment location. The Project is responsible for some liquid LLW, which will be described in future revisions to this document.

Hazardous Waste. The Project currently manages a Toxic Substances Control Act of 1976 and dangerous waste contract performed by a subcontractor to provide the central collection point for hazardous solid waste generated on the Hanford Site. However, the Project also can verify and ship hazardous solid waste to an offsite TSD site for onsite programs that prefer to have the Project directly manage their hazardous waste. The Project also manages hazardous waste generated within its scope of responsibility. The project is responsible for some hazardous liquid waste, which will be described in future revisions to this document.

Treated Effluent. The Project collects liquid waste that has been generated and treated on the Hanford Site and provides for its disposal.

Industrial Waste. The Project collects liquid industrial waste that requires treatment on the Hanford Site and provides for its treatment and disposal.

The following paragraphs describe the types of services provided by the Project.

Analytical Services. The Project provides analytical services to onsite programs and offsite clients, as needed, in a safe and legally compliant manner. Analytical services include sampling, field services, analysis, development services, research support, and sample data management services. Sample analysis capabilities exist (in site-operable laboratories or commercially) for high-level waste, TRU waste, MLLW, and LLW, as well as hazardous liquid and solid waste. Soil, surface water, effluent, groundwater, and atmospheric sampling capabilities also are available to the Site and potential offsite clients; however, offsite needs are typically provided for by others outside the Project.

Effluent Environmental Monitoring. The Project provides for monitoring services of the environment just outside the boundaries of the various projects and operating plants onsite. This provision is principally for the monitoring of gaseous environmental effects. The Pacific Northwest National Laboratory provides liquid monitoring (in the middle of the Columbia River). Bechtel Hanford, Inc. provides deep groundwater monitoring.

Pollution Prevention. The Project provides guidance and assistance on pollution prevention strategies.

Waste Minimization. The Project provides guidance and assistance on strategies that minimize generation of waste.

Decontamination Services. The Project provides services for decontamination of highdose-rate waste and contaminated equipment to meet applicable standards for disposal, storage, reuse, or free release. The Project also performs decontamination, waste verification and 
characterization, and repackaging of incoming wastes to reduce radiation fields. In addition, the Project recategorizes waste from mixed to non-mixed and/or Greater Than Category III low-level to. Category III low-level or, if possible, to levels that make the waste a releasable (nonradioactive) material. Equipment contaminated with low-dose-rate waste also is managed for repair and returned to service.

Storage of Reactor-Irradiated Nuclear Material (RINM). The Project (through the T)Plant canyon) provides storage for spent fuel, namely the Shippingport Pressurized Water Reactor Core II blanket fuel rods (Lytle 1995). In addition, a small amount of TRIGA fuel in the active burial grounds in the 200 Areas has been classified as RINM and is to be managed as such (Lytle 1995). The disposition of this RINM will be addressed in future retrieval projects. The Project may provide functions required to implement the record of decision for the environmental impact statement on this waste. In the interim, the Project will continue managing the storage of the RINM and may complete interim actions to ensure future safe management.

\subsection{PROJECT MISSION ANALYSIS RESULTS}

Figure 1-2 summarizes the Project's boundaries, the waste and materials that are included in the Project, and the waste and products coming from the Project. Sections 1.2.1 through 1.2.3 and Tables 1-1 through 1-3 contain the details of the information shown in Figure 1-2.

\subsubsection{Initial State}

The Project manages the existing inventory of solid waste located in active burial grounds and Project-managed facilities. The Project also plans for management of forecasted solid waste expected to be generated from various missions.

The existing inventory of solid waste consists of stored TRU waste generated since 1970 , stored MLLW generated since 1987, and buried solid waste placed in Burial Grounds 218-E-10, 218-E-12B, 218-W-3A, 218-W-3AE, 218-W-4B, 218-W-4C, 218-W-5, and 218-W-6 (future site, no waste placed), which are active burial grounds operating under RCRA interim status. Figure 1-2 shows that the forecasted solid waste to be managed by the Project comes from several sources: Tank Waste Remediation System Project, Facility Transition Program, Spent Nuclear Fuel Program, Environmental Restoration - Decontamination and Decommissioning Program, Landlord Program, other onsite contractors, and offsite generators.

Besides managing the solid waste itself, the Project manages the solid waste treatment, decontamination, storage, and disposal facilities necessary to execute its mission. The Project has identified projects and commercial contracts for services that will provide necessary TSD capabilities that are not available for the Project to execute its mission. 


\section{HNF-SD-WM-RPT-288}

Revision 0

This page intentionally left blank. 

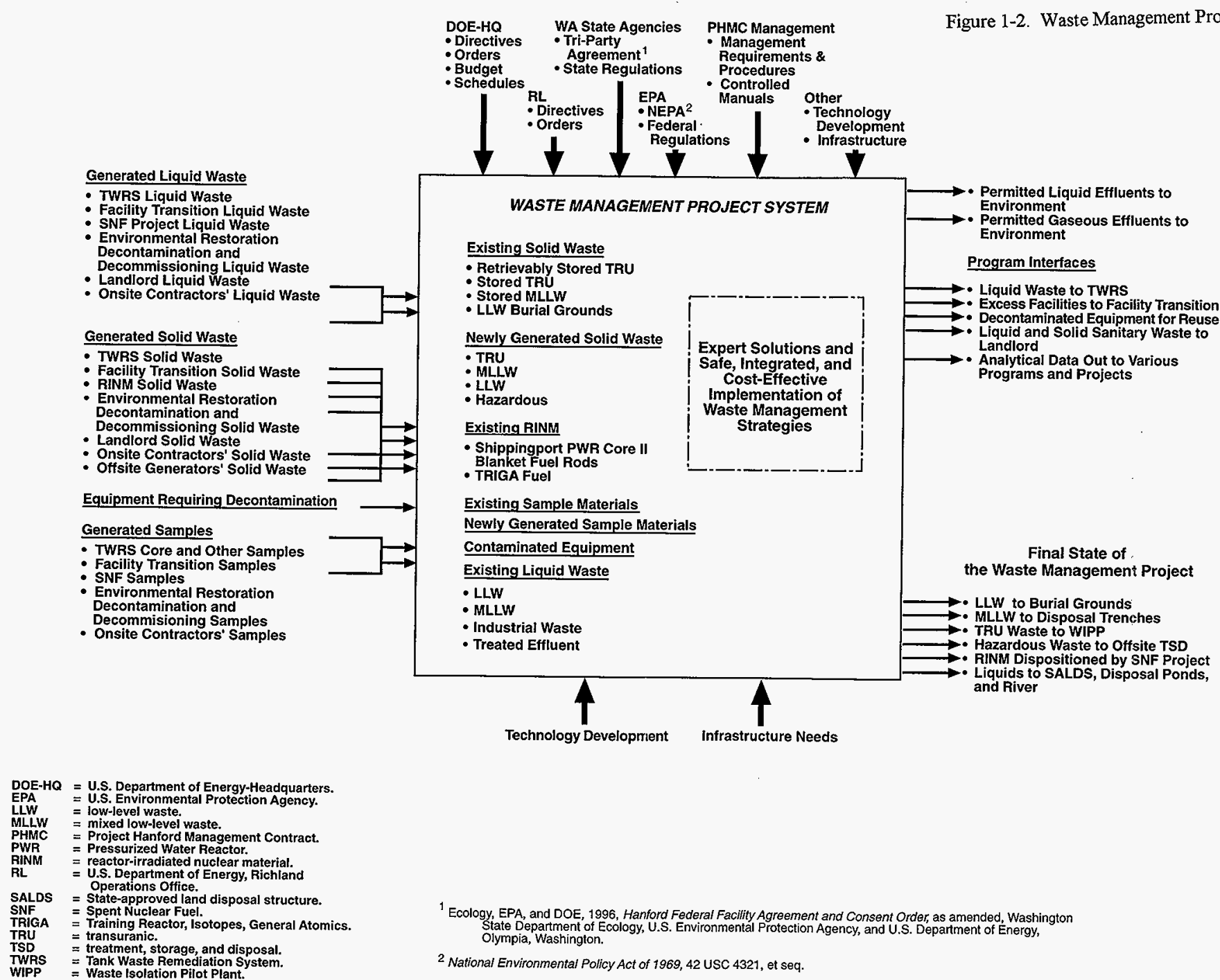

1 Ecology, EPA, and DOE, 1996, Hanford Federal Facility Agreement and Consent Order, as amended, Washington
State Department of Ecology, U.S. Environmental Protection Agency, and U.S. Department of Energy,

${ }^{2}$ National Environmental Policy Act of 1969, 42 USC 4321, et seq. 
In May 1987, the DOE stopped regulating radioactive solid materials as byproduct materials and began regulating radioactive and hazardous mixed waste under RCRA. The U.S. Department of Energy, Richland Operations Office was required to submit RCRA Part A Permit applications for facilities (including burial grounds) that treated, stored, or disposed of RCRA-regulated waste. The DOE decided in 1987 to file permit applications for only a limited number of burial grounds: 218-E-10, 218-E-12B, 218-W-3A, 218-W-3AE, 218-W-4B, 218-W-4C, 218-W-5, and 218-W-6 (future site, no waste placed). All remaining burial grounds at the Hanford Site did not receive permits and, therefore, will receive no additional waste. Remediation of these burial grounds and any other CERCLA-regulated sites is under the direction of the environmental restoration mission area. Table 1-1 identifies the current state of these and other initial states of the Project.

Table 1-1. Initial State of the Waste Management Project on September 30, 1996. (2 sheets)

\begin{tabular}{|c|c|}
\hline Topic & Initial condition description \\
\hline Stored solid LLW & The Project has $200 \mathrm{~m}^{3}$ of stored solid LLW. \\
\hline Stored solid MILLW & The Project has $8,200 \mathrm{~m}^{3}$ of stored solid MLLW. \\
\hline Stored solid TRU waste & The Project has $16,300 \mathrm{~m}^{3}$ of retrievably stored and stored solid TRU waste. \\
\hline Stored hazardous solid waste & The Project has no appreciable inventory of stored hazardous solid waste. \\
\hline Stored liquid LLW & The Project has $2,400 \mathrm{~m}^{3}$ of stored CERCLA ${ }^{2}$-defined liquid LLW. \\
\hline Stored liquid MLLW & The Project has $4,700 \mathrm{~m}^{3}$ of stored liquid MLLW. \\
\hline Stored liquid TRU waste & The Project has no appreciable inventory of stored liquid TRU waste. \\
\hline Stored hazardous liquid waste & The Project has no appreciable inventory of stored hazardous liquid waste. \\
\hline Stored liquid treated effluent & The Project has no appreciable inventory of stored liquid treated effluent. \\
\hline Stored liquid industrial waste & The Project has no appreciable inventory of stored liquid industrial waste. \\
\hline Stored sodium & The Project has $42,000 \mathrm{~m}^{3}$ of stored sodium. \\
\hline Stored RINM & The Project has $29 \mathrm{~m}^{3}$ of stored RINM. \\
\hline Disposed-of submarine compartments & The Project has $50,000 \mathrm{~m}^{3}$ of stored submarine compartments. \\
\hline $\begin{array}{l}\text { Materials and equipment requiring } \\
\text { decontamination }\end{array}$ & $\begin{array}{l}\text { The Project has no appreciable inventory of materials and equipment that } \\
\text { require decontamination. }\end{array}$ \\
\hline Sample materials requiring analysis & $\begin{array}{l}\text { The Project has no more than a } 2 \text {-month backlog inventory of samples that } \\
\text { require analysis. }\end{array}$ \\
\hline 340 Waste Handling Facility & $340,340-\mathrm{A}$, and $340-\mathrm{B}$ Buildings \\
\hline 307 Retention Basins & 307 Building \\
\hline $\begin{array}{l}300 \text { Area Treated Effluent Disposal } \\
\text { Facility }\end{array}$ & 310 Building \\
\hline $\begin{array}{l}200 \text { Area Treated Effluent Disposal } \\
\text { Facility }\end{array}$ & $6653,225 \mathrm{~W}, 225 \mathrm{E}, 216 \mathrm{E}-43-\mathrm{A}$, and $216 \mathrm{E}-43-\mathrm{B}$ Buildings \\
\hline Effluent Treatment Facility & $2025 \mathrm{E}$ and $2025 \mathrm{EA}$ Buildings \\
\hline 242-A Evaporator & 242-A, 242-A-702, 242-A-207, 242-A-81, 242-AB, and associated buildings \\
\hline Liquid Effluent Retention Facility & 242-AL-42, 242-AL-43, and 242-AL-44 Buildings \\
\hline
\end{tabular}


HNF-SD-WM-RPT-288

Revision 0

Table 1-1. Initial State of the Waste Management Project on September 30, 1996. (2 sheets)

\begin{tabular}{|c|c|}
\hline Topic & Initial condition description \\
\hline $\begin{array}{l}\text { K Basins water development } \\
\text { laboratories }\end{array}$ & $1706 \mathrm{KE}, 1706 \mathrm{KEL}$, and $1706 \mathrm{KER}$ Buildings \\
\hline 222-S Facility & $\begin{array}{l}\text { 222-S, 207-SL, 212S, 219S, SSS-SA, SSS-SB, 222-SC, 222-SD, 222-SE, } \\
\text { 222-SF, 222-SG, 222-SH, 225-WB, 27045, 2716S, and 2734S Buildings }\end{array}$ \\
\hline $\begin{array}{l}\text { Waste Sampling and Characterization } \\
\text { Facility }\end{array}$ & $6266,6265,6266 \mathrm{~A}, 6266 \mathrm{~B}, 6267,6268,6269$, and 6270 Buildings \\
\hline 200 Area solid waste storage facilities & $\begin{array}{l}\text { The CWC consists of the following buildings: } 2401 \mathrm{~W}, 2402 \mathrm{~W}, 2402 \mathrm{WA} \text {, } \\
2402 \mathrm{WB}, 2402 \mathrm{WC}, 2402 \mathrm{WD}, 2402 \mathrm{WE}, 2402 \mathrm{WF}, 2402 \mathrm{WG}, 2402 \mathrm{WH} \text {, } \\
2402 \mathrm{~W}, 2402 \mathrm{WJ}, 2402 \mathrm{WK}, 2402 \mathrm{WL}, 2403 \mathrm{WA}, 2403 \mathrm{WB}, 2403 \mathrm{WC} \text {, } \\
2403 \mathrm{WD}, 2404 \mathrm{WA}, 2404 \mathrm{WB}, 2404 \mathrm{WC} \text {, and MO288. }\end{array}$ \\
\hline $\begin{array}{l}\text { Transuranic Waste Storage and Assay } \\
\text { Facility }\end{array}$ & 224-T and MO289 Buildings \\
\hline $\begin{array}{l}\text { Waste Receiving and Processing } \\
\text { Facility }\end{array}$ & $2336 \mathrm{~W}, 2740 \mathrm{~W}$, and $2620 \mathrm{~W}$ Buildings \\
\hline Burial grounds & $\begin{array}{l}\text { 218-E-10, 218-E-12B, 218-W-3A, 218-W-3B, 218-W-4B, 218-W-5, } \\
\text { 218-W-6, 218-W-4C, 218-W-3AE, and MO223 Buildings }\end{array}$ \\
\hline Sodium Storage & $2727 \mathrm{~W}$ Building ${ }^{b}$ \\
\hline $\begin{array}{l}\text { Nonradioactive Hazardous Waste } \\
\text { Facility }\end{array}$ & 616 Building \\
\hline T Plant facilities & $\begin{array}{l}\text { 211T, 211T52, 214T, 221T, 221TA, 221TB, 2706T, 2712T, 2715T, 271T, } \\
\text { 277T, 291T, 292T, 296T, MO371, MO433, MO739, MO892, MO909, and } \\
\text { Tunnel Trailer Buildings }\end{array}$ \\
\hline Miscellaneous facilities & $\begin{array}{l}\text { 218-W5252, 218-W5252A, 285W, 286W, MO278, MO279, MO437, } \\
\text { MO438, MO535, MO720, MO721, MO743, MO941, and 225WA }\end{array}$ \\
\hline
\end{tabular}

${ }^{\circ}$ Comprehensive Environmental Response, Compensation, and Liability Act of 1980, 42 USC 9601, et seq.

The Tank Waste Remediation System owns the 2727-W Building, the Fast Flux Test Facility owns the sodium, and the Project provides administrative assistance in management.

\footnotetext{
$\mathrm{CWC}=$ Central Waste Complex.

Ecology $=$ Washington State Department of Ecology.

GTCIII $=$ Greater Than Category III.

$\mathrm{LLW}=$ low-level waste.

MLLW $=$ mixed low-level waste.

Project $=$ Waste Management Project

RINM $=$ reactor-irradiated nuclear material.

$\mathrm{TRU}=$ transuranic.
} 
HNF-SD-WM-RPT-288

Revision 0

Table 1-2. Final State of the Waste Management Project.

\begin{tabular}{|c|c|}
\hline Topic & Final condition description \\
\hline Solid TRU waste & $\begin{array}{l}\text { Properly packaged, certified, and loaded into appropriate containers } \\
\text { on transport vehicles for shipment to WIPP. }\end{array}$ \\
\hline Solid MLLW & Dispositioned in permitted disposal facility satisfying LDRs. \\
\hline Solid Category I and III LLW & Disposed of in near-surface burial ground. \\
\hline Solid LLW that is Greater Than Category III & To be determined. \\
\hline Shippingport PWR Core II blanket fuel rods & $\begin{array}{l}\text { Transferred to the Spent Nuclear Fuel Project (or rquivalent at time of } \\
\text { shipping. }\end{array}$ \\
\hline RINM currently stored in burial grounds & $\begin{array}{l}\text { Transferred to the Spent Nuclear Fuel Project (or equivalent at time of } \\
\text { shipping). }\end{array}$ \\
\hline Hazardous solid waste & Waste shipped offsite for treatment and disposal. \\
\hline $\begin{array}{l}\text { Excess facilities that are clean (i.e., no } \\
\text { radioactive or nonradioactive contaminants) }\end{array}$ & Landlord for reuse or demolition. \\
\hline $\begin{array}{l}\text { Excess facilities that are contaminated (i.e., } \\
\text { radioactive or nonradioactive) }\end{array}$ & $\begin{array}{l}\text { Transition to Facility Stabilization (deactivation) then to } \\
\text { Environmental Restoration (D\&D and closure). }\end{array}$ \\
\hline Burial grounds and disposal facilities & RCRA* closure. \\
\hline Dispositioned liquid effluents & $\begin{array}{l}\text { Liquid effluents that have been treated or which otherwise meet } \\
\text { discharge requirements. }\end{array}$ \\
\hline $\begin{array}{l}\text { Decontaminated equipment and materials for } \\
\text { reuse }\end{array}$ & Return to service and/or resale. \\
\hline Decontaminated waste & Dispositioned in accordance with categorization above. \\
\hline Sample material residues & $\begin{array}{l}\text { Packaged as liquid or solid waste and dispositioned in accordance } \\
\text { with categorization above. }\end{array}$ \\
\hline
\end{tabular}

*Resource Conservation and Recovery Act of 1976, 42 USC 6901, et seq.

- $\mathrm{D} \& \mathrm{D}=$ decontamination and decommissioning.

Ecology $=$ Washington State Department of Ecology.

$\mathrm{LDR}=$ land disposal restriction.

$\mathrm{LLW}=$ low-level waste.

MLLW $=$ mixed low-level waste.

PWR $=$ Pressurized Water Reactor.

RINM = reactor-irradiated nuclear material.

TRU $=$ transuranic.

WIPP $=$ Waste Isolation Pilot Plant.

\subsubsection{Final State}

Figure 1-2 identifies the waste and products that result from executing the Project mission. The Project will manage solid TRU waste, LLW, MLLW, and hazardous waste. The inventory of solid waste managed by the Project will fall into one of these categories. Each of these four categories of solid waste has different final disposal requirements and will be disposed of 
separately. Solid TRU waste will be processed for disposal at WIPP. Solid LLW will be disposed of near surface on the Hanford Site. Solid MLLW also will be disposed of near surface on the Hanford Site in a separate disposal system from solid LLW. Hazardous solid waste will be transported to offsite hazardous waste TSD facilities.

When the Project's mission is completed, the waste treatment and storage facilities will be deactivated and turned over to the Decontamination and Decommissioning Program for decommissioning. Treatment, storage, and disposal facilities will be closed in accordance with applicable regulations. These and other final states of the Project are described in Table 1-3.

Table 1-3. Partial List of Topics that the Waste Management Project Uses to Measure its Success.

\begin{tabular}{|l|l|}
\hline \multicolumn{1}{|c|}{ Title } & \multicolumn{1}{|c|}{ Definition of success } \\
\hline safety & $\begin{array}{l}\text { Deleterious health effects will be maintained as low as } \\
\text { reasonably achievable. Worker and public safety will be } \\
\text { maximized by minimizing worker radiological exposure, } \\
\text { worker industrial hazards, and public radiological exposure } \\
\text { and transportation hazards. }\end{array}$ \\
\hline Environmental impacts & $\begin{array}{l}\text { Graded compliance with regulatory requirements will be } \\
\text { negotiated. Minimum long-term environmental } \\
\text { contamination, maximum recycling of materials, and } \\
\text { minimum secondary waste will be targeted. }\end{array}$ \\
\hline Technical assurance & $\begin{array}{l}\text { Use of mature process will be maximized. New and/or } \\
\text { emerging technologies will be used where clear } \\
\text { enhancements can be realized to maximize operability and } \\
\text { reliability. Furthermore, maximum flexibility and minimum } \\
\text { regulatory uncertainty will be the goal. }\end{array}$ \\
\hline Schedule & $\begin{array}{l}\text { Tri-Party Agreement* and other (to be determined) schedule } \\
\text { requirements will be met. }\end{array}$ \\
\hline Life-cycle cost & $\begin{array}{l}\text { Systems engineering, value engineering, and risk evaluation } \\
\text { will be used to maximize life-cycle cost effectiveness. }\end{array}$ \\
\hline
\end{tabular}

*Ecology, EPA, and DOE, 1996, Hanford Federal Facility Agreement and Consent Order, as amended, Washington State Department of Ecology, U.S. Environmental Protection Agency, and U.S. Department of Energy, Olympia, Washington.

\subsubsection{Measures of Success}

Measures of success are quantifiable characteristics used to assess Project performance and form a basis for decision making. The main success measure will be satisying the Project Hanford Management Contract. Table 1-3 is a partial list of the criteria that the Project uses to measure its success. Various performance agreements contain further documentation of these and other measures. The ultimate intent is to quantify performance measures and define success criteria. This section will be defined and developed more thoroughly in future revisions of this document. 
HNF-SD-WM-RPT-288

Revision 0

\subsection{REFERENCES}

Comprehensive Environmental Response, Compensation, and Liability Act of 1980 , 42 USC 9601, et seq.

DOE-RL, 1990, Low-Level Burial Grounds Dangerous Waste Permit Application, DOE/RL-88-20, 5 Vol., U.S. Department of Energy, Richland Operations Office, Richland, Washington.

Ecology, EPA, and DOE, 1996, Hanford Federal Facility Agreement and Consent Order, as amended, Washington State Department of Ecology, U.S. Environmental Protection Agency, and U.S. Department of Energy, Olympia, Washington.

Lytle, J. E., 1995, Resolution of Spent Nuclear Fuel Vulnerability Action Plan - Definition of Remote-Handled Transuranic Waste (Memorandum to C. A. Hansen, U.S. Department of Energy, Richland Operations Office, Richland, Washington, March 1), U.S. Department of Energy, Washington, D.C.

Resource Conservation and Recovery Act of 1976, 42 USC 6901, et seq.

RL, 1994, Fiscal Year 1995 Hanford Mission Plan, Volume 1, "Site Guidance," DOE/RL-93-102, U.S. Department of Energy, Richland Operations Office, Richland, Washington.

RL, 1996a, Hanford Strategic Plan, DOE/RL-96-92, Rev. 0, U.S. Department of Energy, Richland Operations Office, Richland, Washington.

RL, 1996b, Systems Engineering Criteria Document and Implementing Directive, RLID 430.1, U.S. Department of Energy, Richland Operations Office, Richland, Washington.

RL, 1996c, Project Hanford, U.S. Department of Energy, Richland Operations Office, Richland, Washington.

Toxic Substances Control Act of 1976, 15 USC 2601, et seq.

WAC 173-303, "Dangerous Waste Regulations," Washington Administrative Code, as amended. 
FNN-SD-WM-RPT-288

Revision 0

This page intentionally left blank. 
HNF-SD-WM-RPT-288

Revision 0

CONTENTS

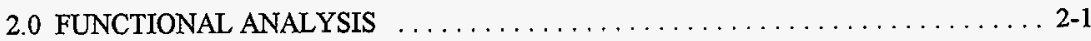

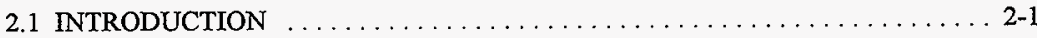

2.1.1 Background $\ldots \ldots \ldots \ldots \ldots \ldots \ldots \ldots \ldots \ldots \ldots \ldots \ldots \ldots \ldots \ldots \ldots \ldots \ldots, 2-1$

2.1.2 Purpose ................................ 2-1

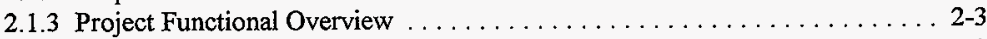

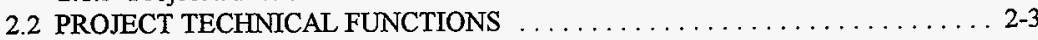

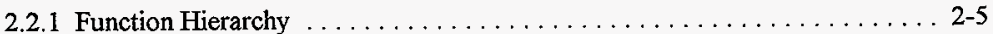

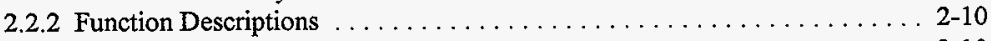

2.2.3 Functional Flow Block Diagrams . . . . . . . . . . . . . . . . 2-10

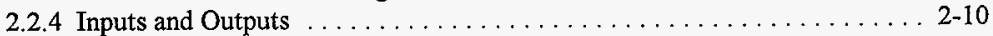

2.2 .5 Site-Level Functional Hierarchy . . . . . . . . . . . . . . . . . . 2-9.6

2.2.6 How to Use the Functions - Guidance for the Non-Systems Engineer . . . 2-116

2. 3 REFERENCES ............................... 2-117 
HNF-SD-WM-RPT-288

Revision 0

\section{LIST OF FIGURES}

2-1. Conceptual Relationship Between the Technical Components and the Non-Technical Components Through the Work Breakdown Structure . . . . . 2-2

2-2. Function X.0, Conduct Waste Management .................. 2-4

2-3. Function X.1, Manage Solid Waste and Materials $\ldots \ldots \ldots \ldots \ldots \ldots \ldots \ldots \ldots \ldots \ldots$

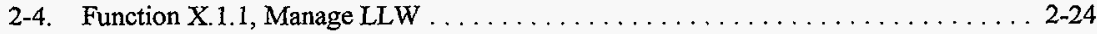

2-5. Function X.1.1.1, Manage CH Cat I LLW . . . . . . . . . . . . . . 2-25

2-6. Function X.1.1.2, Manage CH Cat III LLW ................... 2-26

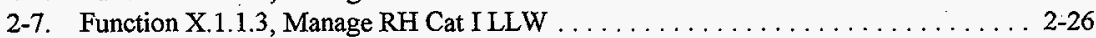

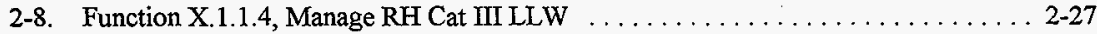

2-9. Function X.1.1.5, Manage LLW Disposal Site . . . . . . . . . . . . . . . 2-28

2-10. Function X.1.2, Manage MLLW ......................... 2-29

2-11. Function X.1.2.1, Manage CH MLLW ....................... 2-30

2-12. Function X.1.2.2, Manage RH Cat I MLLW .................. 2-31

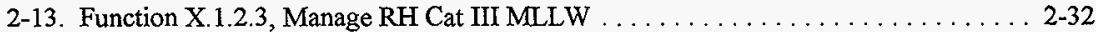

2-14. Function X.1.2.4, Manage MLLW Disposal Site $\ldots \ldots \ldots \ldots \ldots \ldots \ldots \ldots . . \ldots \ldots . \ldots \ldots$

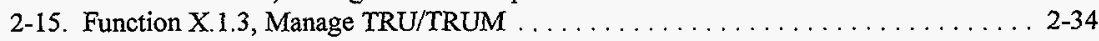

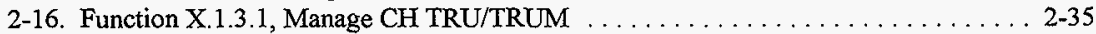

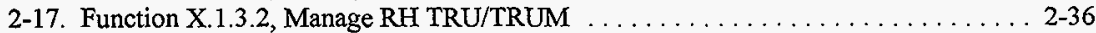

2-18. Function X.1.5, Manage Contaminated Equipment .............. 2-37

2-19. Function X.1.9, Operate and Maintain Active Solid Waste Facilities ......... 2-38

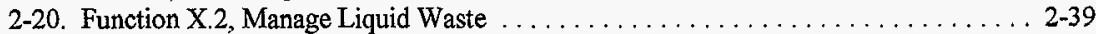

2-21. Function X.2.1, Concentrate Liquid Tank Waste ................. 2-40

2-22. Function X.2.2, Manage CERCLA-Generated Liquid Effluent Streams ....... . 2-41

2-23. Function X.2.3, Manage Listed RCRA/Mixed Waste Liquid Effluent Streams . . . . . 2-42

2-24. Function X.2.5, Manage LLW Effluent Streams $\ldots \ldots \ldots \ldots \ldots \ldots \ldots \ldots \ldots .2-43$

2-25. Function X.2.6, Discharge Treated Liquid Effluents ............... 2-43

2-26. Function X.2.7, Operate and Maintain Active LW Facilities ............. 2-44

2-27. Function X.4, Provide Analytical Services .................. 2-45

2-28. Function X.4.1, Provide High-Level Radioactive Sample Services . . . . . . . . 2-46

2-29. Function X.4.1.1, Provide Routine High-Level Sample Services . . . . . . . . . . . 2-46

2-30. Function X.4.2, Provide Low-Level Radioactive Sample Services . . . . . . . . . . 2-47

2-31. Function X.4.2.1, Provide Routine Low-Level Sample Services . . . . . . . . . . . . . 2-47

2-32. Function X.4.3, Provide Mobile In-Field Analytical Services . . . . . . . . . 2-48

2-33. Function X.4.3.1, Provide Routine In-Field Low-Level Services $\ldots \ldots \ldots \ldots \ldots .2$. . . . . . .

2-34. Function X.4.4, Provide Commercial Laboratory Services . . . . . . . . . . . . . 2 2-49

2-35. Function X.4.5, Operate and Maintain Active Laboratory Facilities . . . . . . . 2-50

2-36. Function X.4.5.2, Archive Samples .................... 2-5I

2-37. Site Systems Engineering Functional Hierarchy $\ldots \ldots \ldots \ldots \ldots \ldots \ldots \ldots . . \ldots \ldots$ 


\section{LIST OF TABLES}

2-1. Functional Hierarchy for Function X.1, Manage Solid Waste and Materials . . . . . . 2-5

2-2. Functional Hierarchy for Function X.2, Manage Liquid Waste . . . . . . . . . . 2-8

2-3. Functional Hierarchy for Function X.4, Provide Analytical Services . . . . . . . . . . . 2-9

2-4. Functional Description for Function X.1, Manage Solid Waste and Materials . . . . . 2-11

2-5. Functional Description for Function X.2, Manage Liquid Waste . . . . . . . . . . 2-19

2-6. Functional Description for Function X.4, Provide Analytical Services . . . . . . . 2-21

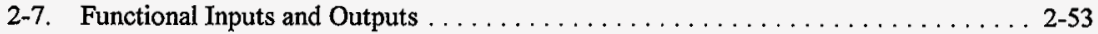

2-8. Hanford Site Program Sample Projection Summary . . . . . . . . . . . . . . . . . . 2-93

2-9. Yearly Sample Projections Summary by Radiation Level . . . . . . . . . . . . . . . 2-93

2-10. Yearly Sample Analysis Projections Summary by Analyte . . . . . . . . . . . . . . 2-94

2-11. Yearly Sample Projections by Protocol . . . . . . . . . . . . . . . . . 2-95

2-12. Yearly Sample Projections by Matrix . . . . . . . . . . . . . . . . . . . . . . . 2-95

2-13. Site Systems Engineering Functions . . . . . . . . . . . . . . . . . . . 2-96

2-14. Functional Crosswalk - Site Systems Engineering to Waste Management . . . . . 2-105

2-15. Functional Crosswalk - Waste Management to Site Systems Engineering . . . . . 2-111 


\section{LIST OF TERMS}

$\begin{array}{ll}\text { AT } & \text { alpha total } \\ \text { CH } & \text { contact-handled } \\ \text { CP } & \text { Central Plateau } \\ \text { CR-VI } & \text { chrome VI } \\ \text { CWC } & \text { Central Waste Complex } \\ \text { D\&D } & \text { decontamination and decommissioning } \\ \text { DOE } & \text { U.S. Department of Energy } \\ \text { DSC } & \text { differential scanning } \\ \text { DST } & \text { double-shell tank } \\ \text { DU } & \text { depleted uranium } \\ \text { EM } & \text { Assistant Secretary for Environmental Management } \\ \text { ER } & \text { Environmental Restoration } \\ \text { ERDF } & \text { Environmental Restoration Disposal Facility } \\ \text { ETF } & \text { Effluent Treatment Facility } \\ \text { FFTF } & \text { Fast Flux Test Facility } \\ \text { FY } & \text { fiscal year } \\ \text { GEA } & \text { gamma energy analysis } \\ \text { GTCIII } & \text { Greater Than Category III } \\ \text { HEU } & \text { highly enriched uranium } \\ \text { HL } & \text { high-level } \\ \text { HLW } & \text { high-level waste } \\ \text { HVAC } & \text { heating, ventilation, and air conditioning } \\ \text { LERF } & \text { Liquid Effluent Retention Facility } \\ \text { LEU } & \text { low-enriched uranium } \\ \text { LL } & \text { low-level } \\ \text { LLW } & \text { low-level waste } \\ \text { LMSI } & \text { Lockheed Martin Services, Inc. } \\ \text { LW } & \text { liquid waste } \\ \text { MHLW } & \text { mixed high-level waste } \\ \text { MLLW } & \text { mixed low-level waste } \\ \text { NDA } & \text { nondestructive assay } \\ \text { NDE } & \text { nondestructive examination } \\ \text { NPDES } & \text { National Pollutant Discharge Elimination System } \\ \text { NU } & \text { normal uranium } \\ \text { PA } & \text { performance assessment } \\ \text { PCB } & \text { polychlorinated biphenyl } \\ \text { PFP } & \text { Plutonium Finishing Plant } \\ \text { PNNL } & \text { Pacific Northwest National Laboratory } \\ \text { Project } & \text { Waste Management Project } \\ \text { PRTR } & \text { plutonium recycle test reactor } \\ & \end{array}$




\section{LIST OF TERMS (cont)}

PUREX

REDOX

$\mathrm{RH}$

ROD

RWM

SALDS

SNF

SpG

SST

SW

SWIFT

TAT

TBD

TCLP

TEDF

TGA

TIC

TOC

TRIGA

TRU

TRU/TRUM

TRUM

TRUPACT

TRUSAF

TSD

TWRS

WBS

WESF

WIPP

WRAP

WSCF

VOA
Plutonium-Uranium Extraction

reduction and oxidation

remote-handled

Record of Decision

restricted waste management

state-approved land disposal structure

spent nuclear fuel

specific gravity

single-shell tank

solid waste

Solid Waste Information Forecast Tool

turn-around-time

to be determined

toxic characteristic leaching procedure

Treated Effluent Disposal Facility

thermal gravimetric analysis

total inorganic carbon

total organic carbon

Training Reactor, Isotopes, General Atomics

transuranic

transuranic and transuranic mixed

transuranic mixed

transuranic package transporter

Transuranic Waste Storage and Assay Facility

treatment, storage, and disposal

Tank Waste Remediation System

work breakdown structure .

Waste Encapsulation Storage Facility

Waste Isolation Pilot Plant

Waste Receiving and Processing

Waste Sampling and Characterization Facility

volatile organic analysis 
HNF-SD-WM-RPT-288

Revision 0

\subsection{FUNCTIONAL ANALYSIS}

\subsection{INTRODUCTION}

This section defines and describes the primary technical activities and processes (i.e., functions) that make up the mission for the Waste Management Project (Project). Functions form the building blocks on which the interfaces, requirements, and detailed design considerations are identified, examined, and communicated. The functions are a key element in defining the technical baseline. Engineering decisions about what a function includes and how the functions interrelate, form a model of the real world, present and future. Activities that are not included in functions are in the "domain." Through this perspective of what makes up the Project or "system," engineering and management personnel can plan and communicate.

The technical baseline defines a major portion of the overall Project baseline. However, it excludes management, engineering services, and administrative functions that are defined in the work breakdown structure (WBS) dictionary supporting the individual Project baseline summaries in the annual budget cycle. All functions presented here are technical in nature.

\subsubsection{Background}

A system consists of technical and nontechnical (i.e., management, administrative, and other) components. These components are defined in terms of the activities and processes that must work together to form a complete operative system. These relationships, and how they relate to the WBS, are depicted conceptually in Figure 2-1. The technical functions are grouped as major subsystems, usually along product lines to emphasize their primary purpose. The technical aspects of the system are then linked with the other activities and processes needed to form a complete operative system. Together, the functions are defined in an integrated WBS. The "system" in Figure 2-1 can be correlated to the Project. Section 2.2 covers the specific Project functions and product lines and how they relate to each other in more detail. The non-technical components are not discussed. They are ouside the scope of this report.

\subsubsection{Purpose}

The purposes for which the functions in this section of the technical baseline have been formulated and presented can be succinctly stated as follows.

- Establish a common understanding (model) for engineering, budget, and management personnel to use in improving and controlling the Project baseline. 
Figure 2-1. Conceptual Relationship Between the Technical Components and the Non-Technical Components Through the Work Breakdown Structure.

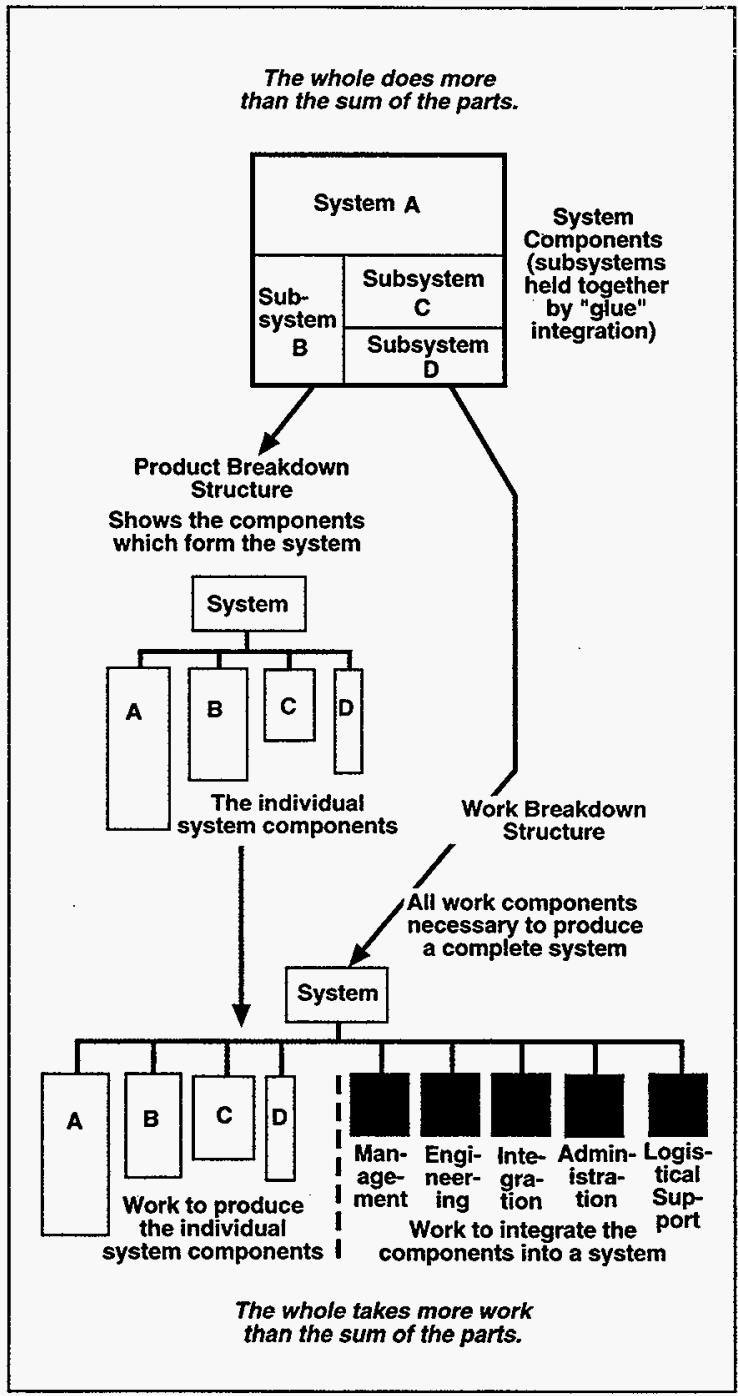

H96120196.10a 
HNF-SD-WM-RPT-288

Revision 0

- Define the foundation on which the interfaces, requirements, and detailed design considerations for the Project are or will be identified, examined, and communicated.

- Provide an anchor to which to tie and manage the Project's evolving performance and functional requirements, trade studies, and design (solution).

- Establish a functional architecture along a time-proven product line view that facilitates the ability of the Project to integrate and evolve in its new environment, i.e., to more effectively and efficiently implement its scope.

\subsubsection{Project Functional Overview}

In defining its functional architecture, the Project has essentially taken the time-proven product line view that is frequently used by the National Aeronautics and Space Administration and the U.S. Department of Defense. The products that the Project produces or will produce are generally treated and/or dispositioned waste, sample analysis results, or services to enable functions or products within or outside the Project to be executed. The top-level or parent function that represents the technical scope for the Project is "Conduct Waste Management," and is defined as "X.0." The first-level functions that make up this function are presented in Figure 2-2. Immediately evident is the one-to-one correspondence with the projects that are formally recognized under the management approach described in Project Hanford (RL 1996). These first-level functions are further decomposed along product lines and described in Sections 2.2.1 through 2.2.5.

\subsection{PROJECT TECHNICAL FUNCTIONS}

Consistent with RL's policy of applying a "graded" systems engineering approach, the technical functions for the Project have been decomposed only to the level necessary and sufficient to form a bridge between the design engineering and planning worlds or, for the more mature components of the Project, only to the level for which value is added. As mentioned in Section 2.1, non-technical or management and administrative functions are not part of the technical baseline and are defined in the WBS dictionary. Each first-level technical function is presented in the following sections in the form of a functional hierarchy, a function description, relational logic (a functional flow block diagram), and inputs and outputs. 
Figure 2-2. Function X.0, Conduct Waste Management.

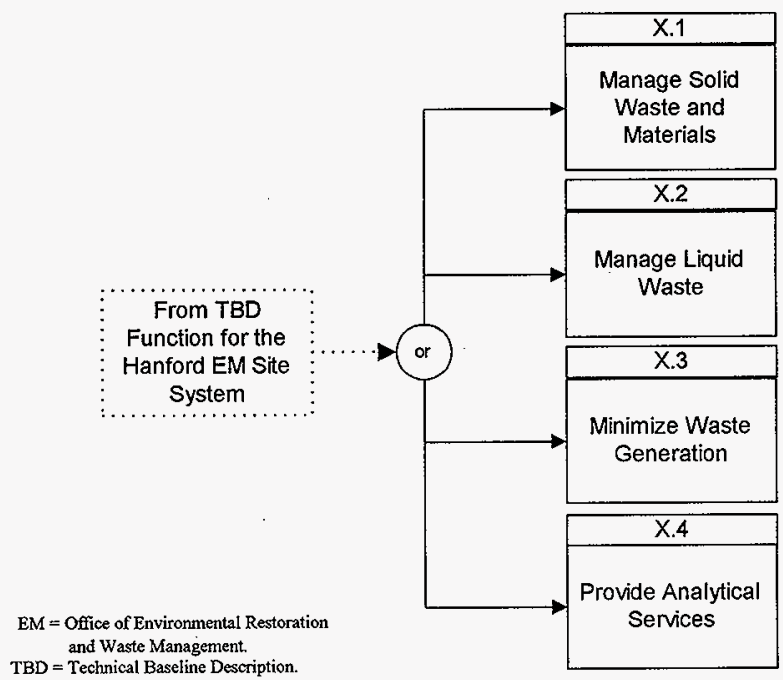




\section{FINF-SD-WM-RPT-288}

Revision 0

\subsubsection{Function Hierarchy}

Tables 2-1 through 2-3 present, in numerical order, the first-level functions and their subordinate functional hierarchies. Reading from left to right, the offset from the left margin of the function titles indicates hierarchial relationships. The sequential number assigned to each function, e.g., X.1.3.2, also reflects this hierarchy and is unique; therefore, it is to be used as an index (reference) to that function. While reviewing the following hierarchies, the major product lines for the Project will be evident from the function titles. Distinctions between product lines were made in consideration of several factors, predominantly whether the attributes of the product result in significant differences in underlying requirements and complexity and, therefore, cost or technical approaches. For example, requirements for remote-handled waste significantly increase its processing cost over that of contact-handled $(\mathrm{CH})$ waste.

Table 2-1. Functional Hierarchy for Function X.1, Manage Solid Waste and Materials.

(4 sheets)

\begin{tabular}{|c|c|}
\hline Function no. & Function title \\
\hline X.I & Manage Solid Waste and Materials \\
\hline $\mathrm{X} .1 .1$ & Manage LLW \\
\hline X.1.1.1 & Manage CH Cat I LLW \\
\hline X.1.1.1.1 & Receive CH Cat I LLW Containers \\
\hline X.1.1.1.2 & Assess CH Cat I LL W Drum Nondestructively \\
\hline $\mathrm{X} .1 .1 .1 .3$ & Open-Sort CH Drum Contents \\
\hline $\mathrm{X} .1 .1 .1 .4$ & Implement RWM Handling Process \\
\hline $\mathrm{X} .1 .1 .1 .5$ & Super-Compact Cat I LLW Contents \\
\hline X.1.1.1.6 & Repackage CH Cat I LLW \\
\hline X.1.1.1.7 & Transport Disposition-Ready CH LLW \\
\hline $\mathrm{X} .1 .1 .2$ & Manage CH Cat III LLW \\
\hline X.1.1.2.1 & Receive CH Cat III LLW Containers \\
\hline X.1.1.2.2 & Package CH Cat III LLW \\
\hline $\mathrm{X} .1 .1 .3$ & Manage RH Cat ILLW \\
\hline X.1.1.3.1 & Receive RH Cat ILLW Containers \\
\hline X.1.1.3.2 & Remove RH Cat I LLW Overpack/Shielding \\
\hline X.1.1.3.3 & Assess RH Cat I LLW Drum Nondestructively \\
\hline X.1.1.3.4 & Open-Sort RH Drum Contents \\
\hline $\mathrm{X} .1 .1 .3 .5$ & Implement RWM Handling Process \\
\hline $\mathrm{X} .1 .1 .3 .6$ & Super-Compact Cat I LLWW Contents \\
\hline X.1.1.3.7 & Repackage RH Cat I LLW \\
\hline X.1.1.3.8 & Transport Disposition-Ready RHLLW \\
\hline X.1.1.4 & Manage RH Cat III LLW \\
\hline X.1.1.4.1 & Receive RH Cat III LIW Containers \\
\hline $\mathrm{X} .1 .1 .4 .2$ & Remove Cat III LLW Overpack/Shielding \\
\hline X.1.1.4.3 & Assess RH Cat III LLWW Drum Nondestructively \\
\hline X.1.1.4.4 & Open-Sort RH Drum Contents \\
\hline X.1.1.4.5 & Implement RWM Handling Process \\
\hline X.1.1.4.6 & Super-Compact Cat III LLW Contents \\
\hline X.1.1.4.7 & Repackage RH Cat III LLW \\
\hline X.1.1.4.8 & Transport Disposition-Ready RHLLW \\
\hline
\end{tabular}


HNF-SD-WM-RPT-288

Revision 0

Table 2-1. Functional Fierarchy for Function X.1, Manage Solid Waste and Materials. (4 sheets)

\begin{tabular}{|c|c|}
\hline Function no. & Function title \\
\hline $\mathrm{X} .1 .1 .5$ & Manage LLW Disposal Site \\
\hline X.1.1.5.1 & Operate LLW Burial Ground \\
\hline X.1.1.5.2 & Disposition Cat I \& III LLW \\
\hline X.1.1.5.3 & Deactivate LLW Burial Ground \\
\hline $\bar{X} .1 .1 .6$ & Manage GTC III LLW \\
\hline $\mathrm{X} .1 .1 .6 .1$ & Store Containerized GTC III LLW \\
\hline $\mathrm{X} .1 .1 .6 .2$ & Transport [Ship] GTC III LLW \\
\hline $\mathrm{X} .1 .1 .6 .3$ & Treat/Disposition GTC III LLW \\
\hline $\mathrm{X} .1 .2$ & Manage MLLW \\
\hline X.1.2.1 & Manage CH MLLW \\
\hline $\mathrm{X} .1 .2 .1 .1$ & Receive CH Cat I and III MLLW Containers \\
\hline $\mathrm{X} .1 .2 .1 .2$ & Store CHMLLW \\
\hline $\mathrm{X} .1 .2 .1 .3$ & Remove CH MLLW Overpack \\
\hline $\mathrm{X} .1 .2 .1 .4$ & Assess CHMLLW Drum Nondestructively \\
\hline $\mathrm{X} .1 .2 .1 .5$ & Transport/Ship CH MLLW \\
\hline $\mathrm{X} .1 .2 .1 .6$ & Conduct Stabilization Treatment \\
\hline $\mathrm{X} .1 .2 .1 .7$ & Conduct Thermal Treatment \\
\hline $\mathrm{X} .1 .2 .1 .8$ & Conduct Other Specialized Treatments \\
\hline $\mathrm{X} .1 .2 .1 .9$ & Perform Acceptance Evaluation and Compliance \\
\hline X.1.2.1.10 & Transport/Ship Disposition-Ready CH MLLW \\
\hline $\mathrm{X} .1 .2 .2$ & Manage RH Cat I MLLW \\
\hline X.1.2.2.1 & Receive RH Cat I MLLW Containers \\
\hline$X .1 .2 .2 .2$ & Store RH Cat I MLLW \\
\hline $\mathrm{X} .1 .2 .2 .3$ & Remove RH MLLW Overpack/Shielding \\
\hline X.1.2.2.4 & Assess RHMLLW Drum Nondestructively \\
\hline $\mathrm{X} .1 .2 .2 .5$ & Open-Sort RH LLW/MLLW Contents \\
\hline $\mathrm{X} .1 .2 .2 .6$ & Treat RH Cat I MLLW \\
\hline $\mathrm{X} .1 .2 .2 .7$ & Repackage RH Cat I MLLW \\
\hline X.1.2.2.8 & Transport Disposition-Ready RH Cat I MLLW \\
\hline $\mathrm{X} .1 .2 .3$ & Manage RH Cat III MLLW \\
\hline $\mathrm{X} .1 .2 .3 .1$ & Receive RH Cat III MLLW Containers \\
\hline $\mathrm{X} .1 .2 .3 .2$ & Store RH Cat III MLLW \\
\hline X.1.2.3.3 & Remove RHMLLW Overpack/Shielding \\
\hline $\mathrm{X} .1 .2 .3 .4$ & Assess RH MLLW Drum Nondestructively \\
\hline $\mathrm{X} .1 .2 .3 .5$ & Open-Sort RH LLW/MLLW Contents \\
\hline $\mathrm{X} .1 .2 .3 .6$ & Treat RH Cat III MLLW \\
\hline $\mathrm{X} .1 .2 .3 .7$ & Repackage RH Cat III MLLW \\
\hline X.1.2.3.8 & Transport Disposition-Ready RH Cat III MLLW \\
\hline $\mathrm{X} .1 .2 .4$ & Manage MLLW Disposal Site \\
\hline $\mathrm{X} .1 .2 .4 .1$ & Operate MLLW Disposal Trench \\
\hline X.1.2.4.2 & Disposition Cat I \& III MLLW \\
\hline X.1.2.4.3 & Deactivate MLLW Disposal Trench \\
\hline $\mathrm{X} .1 .2 .5$ & Manage GTC III MLLW \\
\hline $\mathrm{X} .1 .2 .5 .1$ & Store Containerized GTC III MLLW \\
\hline $\mathrm{X} .1 .2 .5 .2$ & Transport [Ship] Disposition-Ready GTC III MLLW \\
\hline $\mathrm{X} .1 .2 .5 .3$ & Treat/Disposition GTC III LLW \\
\hline
\end{tabular}


HNF-SD-WM-RPT-288

Revision 0

Table 2-1. Functional Hierarchy for Function X.1, Manage Solid Waste and Materials. (4 sheets)

\begin{tabular}{|c|c|}
\hline Function no. & Function title \\
\hline $\mathrm{X} .1 .3$ & Manage TRU/TRUM \\
\hline $\mathrm{X} .1 .3 .1$ & Manage CH TRU/TRUM \\
\hline X.1.3.1.1 & Receive CH TRU/TRUM Containers \\
\hline $\mathrm{X} .1 .3 .1 .2$ & Retrieve Retrievably Stored CH TRU/TRUM \\
\hline $\mathrm{X} .1 .3 .1 .2 .1$ & Excavate TRU/TRUM Drum \\
\hline $\mathrm{X} .1 .3 .1 .2 .2$ & Inspect TRU/TRUM Drum \\
\hline $\mathrm{X} .1 .3 .1 .2 .3$ & Assess CH Container Nondestructively \\
\hline $\mathrm{X} .1 .3 .1 .2 .4$ & Package TRU/TRUM Drum in Overpack \\
\hline X.1.3.1.3 & Provide CH TRU/TRUM Preprocessing Storage \\
\hline $\mathrm{X} .1 .3 .1 .3 .1$ & Transport Overpacked TRU/TRUM to Storage \\
\hline $\mathrm{X} .1 .3 .1 .3 .2$ & Store Overpacked TRU/TRUM \\
\hline $\mathrm{X} .1 .3 .1 .3 .3$ & Transport Overpacked TRU/TRUM to Processing \\
\hline X.1.3.1.4 & Remove TRU/TRUM Overpack \\
\hline $\mathrm{X} .1 .3 .1 .4 .1$ & Remove Waste from Overpack \\
\hline X.1.3.1.4.2 & Recycle Overpack \\
\hline $\mathrm{X} .1 .3 .1 .5$ & Assess CH Container Nondestructively \\
\hline $\mathrm{X} .1 .3 .1 .6$ & Open-Sort CH TRU/TRUM Contents \\
\hline $\mathrm{X} .1 .3 .1 .7$ & Treat CH TRU \\
\hline $\mathrm{X} .1 .3 .1 .8$ & Treat CH TRUM \\
\hline X.1.3.1.9 & Package IRU for WIPP \\
\hline $\mathrm{X} .1 .3 .1 .10$ & Package TRUM for WIPP \\
\hline $\mathrm{X} .1 .3 .2$ & Manage RH TRU/TRUM \\
\hline X.1.3.2.1 & Receive RH TRU/TRUM \\
\hline $\mathrm{X} .1 .3 .2 .2$ & Retrieve Retrievably Stored RH TRU/TRUM \\
\hline $\mathrm{X} .1 .3 .2 .3$ & Remove TRU/TRUM Overpack/Shielding \\
\hline $\mathrm{X} .1 .3 .2 .4$ & Assess RH Container Nondestructively \\
\hline $\mathrm{X} .1 .3 .2 .5$ & Open-Sort RH TRU/TRUM Contents \\
\hline $\mathrm{X} .1 .3 .2 .6$ & Treat RH TRU \\
\hline $\mathrm{X} .1 .3 .2 .7$ & Treat RH TRUM \\
\hline $\mathrm{X} .1 .3 .2 .8$ & Package TRU for WIPP \\
\hline $\mathrm{X} .1 .3 .2 .9$ & Package TRUM for WIPP \\
\hline X.1.3.3 & Transport Disposition-Ready TRU/TRUM to Onsite Storage \\
\hline $\mathrm{X} .1 .3 .4$ & Store Disposition-Ready TRU/TRUM Containers \\
\hline $\mathrm{X} .1 .3 .5$ & Ship Disposition-Ready TRU/TRUM \\
\hline$X .1 .4$ & (Placehoider - TBD) \\
\hline $\mathrm{X} .1 .5$ & Manage Contaminated Equipment \\
\hline $\mathrm{X} .1 .5 .1$ & Receive Contaminated Equipment \\
\hline X.1.5.2 & Decontaminate Equipment \\
\hline X.1.5.3 & Repair Low-dose Rate Equipment \\
\hline $\mathrm{X} .1 .5 .4$ & Transport Disposition-Ready Equipment \\
\hline $\mathrm{X} .1 .6$ & Store Radioactive Materials \\
\hline $\mathrm{X} .1 .6 .1$ & Store TRIGA Fuel \\
\hline $\mathrm{X} .1 .6 .2$ & Store Sodium \\
\hline $\mathrm{X} .1 .6 .3$ & Store Shippingport Reactor Core \\
\hline $\mathrm{X} .1 .7$ & Ship Hazardous Waste to Offsite TSD Facility \\
\hline $\mathrm{X} .1 .8$ & Maintain Inactive SW Facilities \\
\hline
\end{tabular}


HNF-SD-WM-RPT-288

Revision 0

Table 2-1. Functional Hierarchy for Function X. 1, Manage Solid Waste and Materials. (4 sheets)

\begin{tabular}{|l|c|}
\hline Function no. & Function title \\
\hline X.1.9 & Operate and Maintain Active Solid Waste Facilities \\
\hline X.1.9.1 & Operate and Maintain Plant Systems \\
\hline X.1.9.2 & Operate and Maintain Facility Support Systems \\
\hline X.1.9.3 & Operate and Maintain Protection Systems \\
\hline X.1.9.4 & Maintain Information Management Systems \\
\hline X.1.9.5 & Manage Facility Wastes \\
\hline X.1.10 & Provide Generator Services \\
\hline
\end{tabular}

Table 2-2. Functional Hierarchy for Function X.2, Manage Liquid Waste. (2 sheets)

\begin{tabular}{|c|c|}
\hline Function no. & Function title \\
\hline $\mathrm{X} .2$ & Manage Liquid Waste \\
\hline $\mathrm{X} .2 .1$ & Concentrate Liquid Tank Waste \\
\hline $\mathrm{X} .2 .1 .1$ & Receive Liquid Tank Waste for Evaporation \\
\hline $\mathrm{X} .2 .1 .2$ & Evaporate Liquid from Tank Waste \\
\hline $\mathrm{X} .2 .1 .3$ & Analyze Process Stream \\
\hline $\mathrm{X} .2 .1 .4$ & Return Concentrated Liquid Tank Waste to Tank Farm \\
\hline $\mathrm{X} .2 .1 .5$ & Transfer Process Condensate \\
\hline $\mathrm{X} .2 .2$ & Manage CERCLA-Generated Liquid Effluent Streams \\
\hline $\mathrm{X} .2 .2 .1$ & Receive CERCLA-Generated Liquid Waste \\
\hline $\mathrm{X} .2 .2 .2$ & Store Liquid Waste \\
\hline $\mathrm{X} .2 .2 .3$ & Treat Liquid Waste \\
\hline $\mathrm{X} .2 .2 .4$ & Prepare Solid Waste for Disposition \\
\hline $\mathrm{X} .2 .2 .5$ & Transfer Treated Effluent for Disposal \\
\hline $\mathrm{X} .2 .3$ & Manage Listed RCRA/Mixed Waste Liquid Effluent Streams \\
\hline $\mathrm{X} .2 .3 .1$ & Receive Effluent Stream from Generator \\
\hline X.2.3.2 & Store Effluent Stream \\
\hline $\mathrm{X} .2 .3 .3$ & Treat Effluent Stream \\
\hline $\mathrm{X} .2 .3 .4$ & Prepare Solid Waste for Disposition \\
\hline $\mathrm{X} .2 .3 .5$ & Transfer Effluent for Disposal \\
\hline $\mathrm{X} .2 .3 .6$ & Transfer Effluent to TWRS \\
\hline $\mathrm{X} .2 .4$ & Manage Non-Listed/Industrial Effluent Streams \\
\hline $\mathrm{X} .2 .5$ & Manage Low-Level Waste Effluent Streams \\
\hline $\mathrm{X} .2 .5 .1$ & Receive Low-Level Waste Effluent Stream \\
\hline $\mathrm{X} .2 .5 .2$ & Store Low-Level Effluent Stream \\
\hline $\mathrm{X} .2 .5 .3$ & Treat Effluent Stream \\
\hline $\mathrm{X} .2 .5 .4$ & Prepare Solid Waste for Disposition \\
\hline $\mathrm{X} .2 .5 .5$ & Transfer Treated Effluent for Disposal \\
\hline $\mathrm{X} .2 .6$ & Discharge Treated Liquid Effluents \\
\hline X.2.6.1 & Receive Discharge-Ready Liquid Effluent \\
\hline $\mathrm{X} .2 .6 .2$ & Hold Pending Discharge \\
\hline $\mathrm{X} .2 .6 .3$ & Discharge at Approved Disposal Site \\
\hline $\mathrm{X} .2 .7$ & Operate and Maintain Active Liquid Waste Facilities \\
\hline $\mathrm{X} .2 .7 .1$ & Operate and Maintain Plant Systems \\
\hline $\mathrm{X} .2 .7 .2$ & Operate and Maintain Facility Support Systems \\
\hline
\end{tabular}


Table 2-2. Functional Hierarchy for Function X.2, Manage Liquid Waste. (2 sheets)

\begin{tabular}{|l|c|}
\hline Function no. & Function fitle \\
\hline X.2.7.3 & Operate and Maintain Protection Systems \\
\hline X.2.7.4 & Maintain Information Management Systems \\
\hline X.2.7.5 & Manage Facility Wastes \\
\hline X.2.8 & Maintain Inactive LW Facilities \\
\hline
\end{tabular}

Table 2-3. Functional Hierarchy for Function X.4, Provide Analytical Services. ( 2 sheets)

\begin{tabular}{|c|c|}
\hline Function no. & Function title \\
\hline $\bar{X} .4$ & Provide Analytical Services \\
\hline $\mathrm{X} .4 .1$ & Provide High-Level Radioactive Sample Services \\
\hline $\mathrm{X} .4 .1 .1$ & Provide Routine High-Level (HL) Sample Services \\
\hline$X .4 .1 .1 .1$ & Receive HL Radioactive Sample \\
\hline X.4.1.1.2 & Prepare HL Sample for Analysis \\
\hline $\mathrm{X} .4 .1 .1 .3$ & Analyze HL Sample \\
\hline $\mathrm{X} .4 .1 .1 .4$ & Report Sample Analysis Results \\
\hline X.4.1.2 & Provide High-Level (HL) Developmental Services \\
\hline X.4.2 & Provide Low-Level Radioactive Sample Services \\
\hline $\mathrm{X} .4 .2 .1$ & Provide Routine Low-Level (LL) Sample Services \\
\hline X.4.2.1.1 & Receive LL Radioactive Sample \\
\hline $\mathrm{X} .4 .2 .1 .2$ & Collect LL Radioactive Sample \\
\hline $\mathrm{X} .4 .2 .1 .3$ & Prepare LL Sample for Analysis \\
\hline $\mathrm{X} .4 .2 .1 .4$ & Analyze LL Sample \\
\hline $\mathrm{X} .4 .2 .1 .5$ & Report Sample Analysis Results \\
\hline X.4.2.2 & Provide Low-Level (LL) Developmental Services \\
\hline$X .4 .3$ & Provide Mobile In-Field Analytical Services \\
\hline $\mathrm{X} .4 .3 .1$ & Provide Routine In-Field Low-Level (LL) Services \\
\hline $\mathrm{X} .4 .3 .1 .1$ & Receive LL Radioactive Sample \\
\hline $\mathrm{X}, 4.3 .1 .2$ & Collect LL Radioactive Sample \\
\hline$X .4 .3 .1 .3$ & Prepare LL Sample for Analysis \\
\hline $\mathrm{X} .4 .3 .1 .4$ & Analyze LL Sample \\
\hline X.4.3.1.5 & Report Sample Analysis Results \\
\hline $\mathrm{X} .4 .3 .2$ & Provide In-Field Low-Level (LL) Developmental Services \\
\hline $\mathrm{X} .4 .4$ & Provide Commercial Laboratory Services \\
\hline $\mathrm{X} 4.4 .1$ & Receive Low/Non-Rad Sample \\
\hline $\mathrm{X} .4 .4 .2$ & Collect Low/Non-Rad Sample \\
\hline $\mathrm{X} .4 .4 .3$ & Prepare Sample for Off-site Analysis \\
\hline $\mathrm{X} .4 .4 .4$ & Ship Low/Non-Rad Sample \\
\hline $\mathrm{X} .4 .4 .5$ & Analyze Low/Non-Rad Sample \\
\hline X.4.4.6 & Monitor Commercial Analysis Process \\
\hline $\mathrm{X} .4 .4 .7$ & Report Sample Analysis Results \\
\hline $\mathrm{X} .4 .5$ & Operate and Maintain Active Laboratory Facilities \\
\hline $\mathrm{X} .4 .5 .1$ & Provide Standards Laboratory Services \\
\hline $\mathrm{X} .4 .5 .2$ & Archive Samples \\
\hline $\mathrm{X} .4 .5 .2 .1$ & Archive High-Level Radioactive Samples \\
\hline $\mathrm{X} .4 .5 .2 .2$ & Archive Low-Level Radioactive Samples \\
\hline
\end{tabular}


HNF-SD-WM-RPT-288

Revision 0

Table 2-3. Functional Hierarchy for Function X.4, Provide Analytical Services.

(2 sheets)

\begin{tabular}{|l|c|}
\hline Function no. & Function title \\
\hline X.4.5.3 & Maintain Analytical Equipment Operational \\
\hline X.4.5.4 & Operate and Maintain Utility Systems \\
\hline X.4.5.5 & Manage Laboratory Wastes \\
\hline X.4.5.6 & Operate and Maintain Protection Systems \\
\hline X.4.5.7 & Maintain Information Management Systems Operational \\
\hline X.4.6 & Maintain Inactive Laboratory Facilities \\
\hline
\end{tabular}

\subsubsection{Function Descriptions}

Tables 2-4 through 2-6 present, in numerical order, the Project functions with their respective descriptions in tabular form. If defining a specific function further was not perceived as valuable, a lower level description is not presented.

\subsubsection{Functional Flow Block Diagrams}

Figures 2-3 through 2-35 present, in numerical order, the relationships of the first-level functions and their corresponding lower-level functions as block diagrams." If further defining the logic for a function was not perceived valuable, additional logic definition is not provided. The charts are read from the left upper corner to the right or right lower corner. The most useful information will generally be the detailed logic charts at level three or four. These depict the product line functionally from beginning to end as it applies to the Project. When the logic for a waste stream is shown, it reflects the primary path only. Secondary waste streams are identified in the input/output section under the applicable function(s).

\subsubsection{Inputs and Outputs}

The added value of the systems approach in the development and execution phases is often attributed to identifying, understanding, and managing the interfaces. Table 2-7 presents, in numerical order of the Project functions, the primary inputs and outputs for the product lines, which are generally found at about the third functional level in the hierarchy. Each input or output is summarized to alert managers and engineers of important interfaces and the state of knowledge concerning that interface. For example, the destination of an output might be absent because knowledge is lacking or an input might be listed that is "anticipated" but not yet

\footnotetext{
* The customary rules for using the "and" and "or" logic on the higher-level functions were not strictly followed in the block diagram figures because they unnecessarily complicated the information the chart should convey to the reader. For example, the logic for Function X.1.1 uses the "or" condition only once and in a loose sense to denote that, implicitly, any one of the six subsequent functions may apply. In contrast, the more complicated product line logios do follow the customary rules for functional flow block diagrams.
} 
Table 2-4. Functional Description for Function X.1, Manage Solid Waste and Materials. (8 sheets)

\begin{tabular}{|c|c|c|}
\hline Function no. & Function title & Function description \\
\hline $\mathrm{X} .1$ & Manage Solid Waste and Materials & $\begin{array}{l}\text { Store, handle and/or decontaminate, assess, treat, package, transport on-site, ship off-site or } \\
\text { disposition, and receive and/or retrieve solid waste and specific radioactive materials and } \\
\text { equipment. }\end{array}$ \\
\hline $\mathrm{X} .1 .1$ & Manage LLW & $\begin{array}{l}\text { Receive, handle, assess, treat, package, transport on-site, and ship off-site or disposition } \\
\text { solid waste categorized as LLW. }\end{array}$ \\
\hline$X .1 .1 .1$ & Manage CH Cat I LLW & $\begin{array}{l}\text { Receive, handle, assess, treat, package, transport on-site, and ship off-site or disposition } \\
\text { solid waste categorized as contact-handled Category I LLW. }\end{array}$ \\
\hline X.1.1.1.1 & Receive CH Cat I LLW Containers & $\begin{array}{l}\text { Take physical and legal custody of drums, standard waste boxes (SWBs), and/or large } \\
\text { containers with appropriate paperwork. Provide temporary storage of sample drums at } \\
\text { processing facility to await subsequent examination and repackaging. }\end{array}$ \\
\hline $\mathrm{X} .1 .1 .1 .2$ & $\begin{array}{l}\text { Assess CH Cat I LLW Drum Non- } \\
\text { destructively }\end{array}$ & $\begin{array}{l}\text { Examine and/or certify the integrity and content of the container without opening it through } \\
\text { the use of various NDE/NDA techniques which may include head gas sampling, gamma } \\
\text { energy analysis, real-time radiography, ultrasound, visual inspection, weighing. }\end{array}$ \\
\hline X.1.1.1.3 & Open-Sort CH Drum Contents & $\begin{array}{l}\text { Open container and sort contents to identify waste items requiring special (restricted WM) } \\
\text { handling procedures prior to disposition. }\end{array}$ \\
\hline X.1.I.1.4 & Implement RWM Handling Process & $\begin{array}{l}\text { TBD [Activities/processes are still under study. May involve compaction, solidification or } \\
\text { absorption of liquids, and/or immobilization of particulate for small quantities of waste.] }\end{array}$ \\
\hline X.1.1.1.5 & Super-Compact Cat I LLW Contents & Using compaction equipment, significantly reduce the volume of LLW prior to repacking. \\
\hline $\mathrm{X} .1 .1 .1 .6$ & Repackage CH Cat I LLW & Package as appropriate for disposition at on-site LLW burial ground. \\
\hline X.1.1.1.7 & Transport Disposition-Ready CH LLW & $\begin{array}{l}\text { Physically transport waste container by vehicle to burial ground; includes completion of } \\
\text { accompanying paperwork. }\end{array}$ \\
\hline X.1.1.2 & Manage CH Cat III LLWW & $\begin{array}{l}\text { Receive and package for disposition solid waste categorized as remote-handled Category } \\
\text { III LLW. }\end{array}$ \\
\hline X.1.1.2.1 & Receive CH Cat III LLW Containers & $\begin{array}{l}\text { Take physical and legal custody of containers with appropriate paperwork. (Containers are } \\
\text { sometimes already sealed in Figh Integrity Containers which are disposition-ready.) }\end{array}$ \\
\hline $\mathrm{X} .1 .1 .2 .2$ & Package CH Cat III LLW & $\begin{array}{l}\text { Package and seal waste not already in High Integrity Containers (HICs) for final } \\
\text { disposition. }\end{array}$ \\
\hline X.1.1.3 & Manage RH Cat I LLW & $\begin{array}{l}\text { Receive, handle, assess, treat, package, transport on-site, and ship off-site or disposition } \\
\text { solid waste categorized as remote-handled Category I LLW. }\end{array}$ \\
\hline
\end{tabular}


Table 2-4. Functional Description for Function X.1, Manage Solid Waste and Materials. (8 sheets)

\begin{tabular}{|c|c|c|}
\hline Function no. & Function title & Function description \\
\hline $\mathrm{X} .1 .1 .3 .1$ & Receive RH Cat I LLW Containers & \\
\hline$X .1 .1 .3 .2$ & Remove RH Cat I LLW Overpack/Shielding & \\
\hline$X .1 .1 .3 .3$ & $\begin{array}{l}\text { Assess RH Cat I LLW Drum Non- } \\
\text { destructively }\end{array}$ & $\begin{array}{l}\text { Examine and/or certify the integrity and content of the container without opening it through } \\
\text { the use of various NDE/NDA techniques which may include head gas sampling, gamma } \\
\text { energy analysis, real-time radiography, ultrasound, visual inspection, weighing. }\end{array}$ \\
\hline$X .1 .1 .3 .4$ & Open-Sort RH Drum Contents & \\
\hline$X .1 .1 .3 .5$ & Implement RWM Handling Process & $\begin{array}{l}\text { TBD [Activities/processes are still under study. May involve compaction, solidification or } \\
\text { absorption of liquids, and/or immobilization of particulate for small quantities of waste.] }\end{array}$ \\
\hline $\mathrm{X} .1 .1 .3 .6$ & Super-Compact Cat I LLW Contents & Using compaction equipment, significantly reduce the volume of LLW prior to repacking. \\
\hline $\mathrm{X} .1 .1 .3 .7$ & Repackage RH Cat I LLW & $\begin{array}{l}\text { Package as appropriate for disposition at on-site LLW burial ground and apply overpack for } \\
\text { transport. }\end{array}$ \\
\hline X.1.1.3.8 & Transport Disposition-Ready RH LLW & \\
\hline $\mathrm{X} .1 .1 .4$ & Manage RH Cat III LLW & $\begin{array}{l}\text { Receive, handle, assess, treat, package, transport on-site, and ship off-site or disposition } \\
\text { solid waste categorized as remote-handled Category III LLW. }\end{array}$ \\
\hline X.1.1.4.1 & Receive RH Cat III LLW Containers & $\begin{array}{l}\text { Take physical and legal custody of containers with appropriate paperwork. Containers are } \\
\text { sometimes already sealed in High Integrity Containers (HICs) which are disposition-ready. }\end{array}$ \\
\hline $\mathrm{X} .1 .1 .4 .2$ & Package CH Cat III LLW & Package and seal waste in High Integrity Containers (HICs) for final disposition. \\
\hline X.1.1.5 & Manage LLW Disposal Site & \\
\hline X.1.1.5.1 & Operate LLW Burial Ground & \\
\hline X.1.1.5.2 & Disposition Cat I \& III LLW & \\
\hline X.1.1.5.3 & Deactivate LLW Burial Ground & $\begin{array}{l}\text { [May become an EM-40 responsibility. Some activities may have to be performed prior to } \\
\text { transferring responsibility to EM-40.] }\end{array}$ \\
\hline X.1.1.6 & Manage GTC III LLW & \\
\hline X.1.1.6.1 & Store Containerized GTC III LLW & \\
\hline X.1.1.6.2 & Transport [Ship] GTC III LLW & TBD [Awaiting DOE decision on final disposition.] \\
\hline
\end{tabular}


Table 2-4. Functional Description for Function X.1, Manage Solid Waste and Materials. (8 sheets)

\begin{tabular}{|c|c|c|}
\hline Function no. & Function title & Function description \\
\hline $\mathrm{X} .1 .1 .6 .3$ & Treat/Disposition GTC III LLW & TBD [Awaiting DOE decision on final disposition.] \\
\hline$X .1 .2$ & Manage MLLW & $\begin{array}{l}\text { Receive, store, handle, assess, treat, package, transport on-site, and ship off-site or } \\
\text { disposition solid waste categorized as MLLW. }\end{array}$ \\
\hline $\mathrm{X} .1 .2 .1$ & Manage CH MLLW & \\
\hline $\mathrm{X} .1 .2 .1 .1$ & Receive CH Cat I and III MLLW Containers & $\begin{array}{l}\text { Take physical and legal custody of drums, standard waste boxes (SWBs), and/or large } \\
\text { containers with appropriate paperwork. }\end{array}$ \\
\hline $\mathrm{X} .1 .2 .1 .2$ & Store CH MLLW & \\
\hline $\mathrm{X} .1 .2 .1 .3$ & Remove CH MLLW Overpack & \\
\hline$X .1 .2 .1 .4$ & Assess CH MLLW Drum Non-destructively & $\begin{array}{l}\text { Examine and/or certify the integrity and content of the container without opening it through } \\
\text { the use of various NDE/NDA techniques which may include head gas sampling, gamma } \\
\text { energy analysis, real-time radiography, ultrasound, visual inspection, weighing. }\end{array}$ \\
\hline $\mathrm{X} .1 .2 .1 .5$ & Transport/Ship CH MLLW & $\begin{array}{l}\text { Commercial vendor function: includes transport/shipping of waste from Rust facilities to } \\
\text { commercial treatment facility which may be located on-site (transport) or off-site (ship). }\end{array}$ \\
\hline $\mathrm{X} .1 .2 .1 .6$ & Conduct Stabilization Treatment & $\begin{array}{l}\text { (TBD) (Activities/processes are still under study. Likely to be implemented by a } \\
\text { commercial vendor.) }\end{array}$ \\
\hline$X .1 .2 .1 .7$ & Conduct Thermal Treatment & $\begin{array}{l}\text { Commercial vendor function: includes NDENNDA, open-sort of contents, thermal } \\
\text { treatment process(es), and packaging of disposition-ready Cat I and III waste containers for } \\
\text { Hanford Site MLLW burial trench. }\end{array}$ \\
\hline $\mathrm{X} .1 .2 .1 .8$ & Conduct Other Specialized Treatments & $\begin{array}{l}\text { TBD [Activities/processes are still under study. Likely to be performed at Hanford by Rust. } \\
\text { Compaction, solidification or absorption of liquids, neutralization of corrosives, } \\
\text { immobilization of particulate, reaction of reactive substances.] }\end{array}$ \\
\hline X.1.2.1.9 & $\begin{array}{l}\text { Perform Acceptance Evaluation and } \\
\text { Compliance } \\
\end{array}$ & $\begin{array}{l}\text { Evaluate the waste package as appropriate for compliance with disposition requirements } \\
\text { for the Hanford MLLW burial trench. }\end{array}$ \\
\hline$X .1 .2 .1 .10$ & $\begin{array}{l}\text { Transport/Ship Disposition-Ready CH } \\
\text { MLLW }\end{array}$ & $\begin{array}{l}\text { Commercial vendor function: includes transport/shipping of disposition-ready waste to Rust } \\
\text { facilities from commercial treatment facility which may be located on-site (transport) or off- } \\
\text { site (ship). }\end{array}$ \\
\hline $\mathrm{X} .1 .2 .2$ & Manage RH Cat I MLLWW & \\
\hline X.1.2.2.1 & Receive RH Cat $I$ MLLW Containers & $\begin{array}{l}\text { Take physical and legal custody of drums, standard waste boxes (SWBs), and/or large } \\
\text { containers with appropriate paperwork. }\end{array}$ \\
\hline
\end{tabular}


Table 2-4. Functional Description for Function X.1, Manage Solid Waste and Materials. (8 sheets)

\begin{tabular}{|c|c|c|}
\hline Function no. & Function title & Function description \\
\hline $\mathrm{X} .1 .2 .2 .2$ & Store RH Cat I MLLW & \\
\hline X.1.2.2.3 & Remove RH MLLWW Overpack/Shielding & \\
\hline X.1.2.2.4 & Assess RH MLLW Drum Non-destructively & $\begin{array}{l}\text { Examine and/or certify the integrity and content of the container without opening it through } \\
\text { the use of various NDE/NDA techniques which may include head gas sampling, gamma } \\
\text { energy analysis, real-time radiography, ultrasound, visual inspection, weighing. }\end{array}$ \\
\hline X.1.2.2.5 & Open-Sort RH LLW/MLLW Contents & \\
\hline$X .1 .2 .2 .6$ & Treat RH Cat I MLLW & $\begin{array}{l}\text { TBD [Activities/processes are still under study. Compaction, solidification or absorption of } \\
\text { liquids, neutralization of corrosives, immobilization of particulate, reaction of reactive } \\
\text { substances.] }\end{array}$ \\
\hline $\mathrm{X} .1 .2 .2 .7$ & Repackage RH Cat I MLLW & $\begin{array}{l}\text { Package as appropriate for disposition at on-site MLLW burial trench and apply overpack } \\
\text { for transport. }\end{array}$ \\
\hline $\mathrm{X} .1 .2 .2 .8$ & $\begin{array}{l}\text { Transport Disposition-Ready RH Cat I } \\
\text { MLLW }\end{array}$ & \\
\hline $\mathrm{X} .1 .2 .3$ & Manage RH Cat III MLLW & \\
\hline X.1.2.3.1 & Receive RH Cat III MLLW Containers & $\begin{array}{l}\text { Take physical and legal custody of drums, standard waste boxes (SWBs), and/or large } \\
\text { containers with appropriate paperwork. }\end{array}$ \\
\hline$X .1 .2 .3 .2$ & Store RH Cat III MLLW & \\
\hline $\mathrm{X} .1 .2 .3 .3$ & Remove RHMLLW Overpack/Shielding & \\
\hline X.1.2.3.4 & Assess RH MLLW Drum Non-destructively & $\begin{array}{l}\text { Examine and/or certify the integrity and content of the container without opening it through } \\
\text { the use of various NDE/NDA techniques which may include head gas sampling, gamma } \\
\text { energy analysis, real-time radiography, ultrasound, visual inspection, weighing. }\end{array}$ \\
\hline $\mathrm{X} .1 .2 .3 .5$ & Open-Sort RH LLW/MLLW Contents & \\
\hline $\mathrm{X} .1 .2 .3 .6$ & Treat RH Cat III MLLW & $\begin{array}{l}\text { TBD [Activities/processes are still under study. Compaction, solidification or absorption of } \\
\text { liquids, neutralization of corrosives, immobilization of particulate, reaction of reactive } \\
\text { substances.] }\end{array}$ \\
\hline X.1.2.3.7 & Repackage RH Cat III MLLW & $\begin{array}{l}\text { Package using high integrity containers as appropriate for disposition at on-site MLLW } \\
\text { burial trench and apply overpack for transport. }\end{array}$ \\
\hline
\end{tabular}


Table 2-4. Functional Description for Function X.1, Manage Solid Waste and Materials. (8 sheets)

\begin{tabular}{|c|c|c|}
\hline Function no. & Function title & Function description \\
\hline X.1.2.3.8 & $\begin{array}{l}\text { Transport Disposition-Ready RH Cat III } \\
\text { MLLW }\end{array}$ & \\
\hline X.1.2.4 & Manage MLLW Disposal Site & \\
\hline $\mathrm{X} .1 .2 .4 .1$ & Operate MLLW Disposal Trench & \\
\hline X.1.2.4.2 & Disposition Cat I \& III MLLW & \\
\hline$X .1 .2 .4 .3$ & Deactivate MLLW Disposal Trench & $\begin{array}{l}\text { [May become an EM- } 40 \text { responsibility. Some activities may have to be performed prior to } \\
\text { transferring responsibility to EM-40.] }\end{array}$ \\
\hline$X .1 .2 .5$ & Manage GTC III MLLW & \\
\hline$X .1 .2 .5 .1$ & Store Containerized GTC III MLLW & \\
\hline $\mathrm{X} .1 .2 .5 .2$ & $\begin{array}{l}\text { Transport [Ship] Disposition-Ready GTC III } \\
\text { MLLW . }\end{array}$ & TBD [Awaiting DOE decision on final disposition.] \\
\hline $\mathrm{X} .1 .2 .5 .3$ & Treat/Disposition GTC III LLW & TBD [Awaiting DOE decision on final disposition.] \\
\hline$X .1 .3$ & Manage TRU/TRUM & $\begin{array}{l}\text { Receive or retrieve, store, handle, assess, treat, package, transport on-site, and ship off-site } \\
\text { solid waste categorized as TRU or TRUM. }\end{array}$ \\
\hline $\mathrm{X} .1 .3 .1$ & Manage CH TRU/TRUM & . \\
\hline $\mathrm{X} .1 .3 .1 .1$ & Receive $\mathrm{CH}$ TRU/TRUM Containers & $\begin{array}{l}\text { Take physical and legal custody of drums, standard waste boxes (SWBs), and/or large } \\
\text { containers with appropriate paperwork. }\end{array}$ \\
\hline $\mathrm{X} .1 .3 .1 .2$ & $\begin{array}{l}\text { Retrieve Retrievably Stored } \mathrm{CH} \\
\text { TRU/TRUM }\end{array}$ & \\
\hline $\mathrm{X} .1 .3 .1 .2 .1$ & Excavate TRU/TRUM Drum & . \\
\hline X.1.3.1.2.2 & Inspect TRU/TRUM Drum & $\begin{array}{l}\text { Conduct visual inspection and ultrasonic inspection of waste drum integrity prior to moving } \\
\text { it. Cover drum fully with Supersack as needed. }\end{array}$ \\
\hline$X .1 .3 .1 .2 .3$ & Assess CH Container Non-destructively & $\begin{array}{l}\text { Conduct screening exam of the integrity and content of the container without opening it } \\
\text { through the use of various techniques which may include head gas sampling, gamma energy } \\
\text { analysis, real-time radiography, ultrasound, visual inspection, weighing. }\end{array}$ \\
\hline$X .1 .3 .1 .2 .4$ & Package TRU/TRUM Drum in Overpack & Package drum and supersack in overpack for on-site preprocessing storage. \\
\hline
\end{tabular}


Table 2-4. Functional Description for Function X.1, Manage Solid Waste and Materials. (8 sheets)

\begin{tabular}{|c|c|c|}
\hline Function no. & Function title & Function description \\
\hline $\mathrm{X} .1 .3 .1 .3$ & $\begin{array}{l}\text { Provide CH TRU/TRUM Preprocessing } \\
\text { Storage }\end{array}$ & \\
\hline $\mathrm{X} .1 .3 .1 .3 .1$ & $\begin{array}{l}\text { Transport Overpacked TRU/TRUM to } \\
\text { Storage }\end{array}$ & \\
\hline $\mathrm{X} .1 .3 .1 .3 .2$ & Store Overpacked TRU/TRUM & \\
\hline $\mathrm{X} .1 .3 .1 .3 .3$ & $\begin{array}{l}\text { Transport Overpacked TRU/TRUM to } \\
\text { Processing }\end{array}$ & \\
\hline$X .1 .3 .1 .4$ & Remove TRU/TRUM Overpack & $\begin{array}{l}\text { Remove overpack surround waste container; includes recycling reusable overpack by } \\
\text { decontaminating as needed and transporting to TBD location. }\end{array}$ \\
\hline $\mathrm{X} .1 .3 .1 .4 .1$ & Remove Waste from Overpack & \\
\hline $\mathrm{X} .1 .3 .1 .4 .2$ & Recycle Overpack & Decontaminate overpack for reuse and transport to TBD location. \\
\hline$X .1 .3 .1 .5$ & Assess CH Container Non-destructively & $\begin{array}{l}\text { Examine and/or certify the integrity and content of the container without opening it through } \\
\text { the use of various NDE/NDA techniques which may include head gas sampling, gamma } \\
\text { energy analysis, real-time radiography, ultrasound, visual inspection, weighing. }\end{array}$ \\
\hline$X .1 .3 .1 .6$ & Open-Sort CH TRU/TRUM Contents & \\
\hline X.1.3.1.7 & Treat CH TRU & \\
\hline$X .1 .3 .1 .8$ & Treat CH TRUM & \\
\hline X.1.3.1.9 & Package TRU for WIPP & Package as appropriate for disposition at WIPP. \\
\hline $\mathrm{X} .1 .3 .1 .10$ & Package TRUM for WIPP & Package as appropriate for disposition at WIPP. \\
\hline $\mathrm{X} .1 .3 .2$ & Manage RH TRU/TRUM & \\
\hline$X .1 .3 .2 .1$ & Receive RH TRU/TRUM & $\begin{array}{l}\text { Take physical and legal custody of drums, standard waste boxes (SWBs), and/or large } \\
\text { containers with appropriate paperwork. }\end{array}$ \\
\hline$X .1 .3 .2 .2$ & $\begin{array}{l}\text { Retrieve Retrievably Stored RH } \\
\text { TRU/TRUM }\end{array}$ & \\
\hline X.1.3.2.3 & Remove TRU/TRUM Overpack/Shielding & \\
\hline
\end{tabular}


Table 2-4. Functional Description for Function X.1, Manage Solid Waste and Materials. (8 sheets)

\begin{tabular}{|c|c|c|}
\hline Function no. & Function title & Function description \\
\hline $\mathrm{X} .1 .3 .2 .4$ & Assess RH Container Non-destructively & $\begin{array}{l}\text { Examine and/or certify the integrity and content of the container without opening it through } \\
\text { the use of various NDENDA techniques which may include head gas sampling, gamma } \\
\text { energy analysis, real-time radiography, ultrasound, visual inspection, weighing. }\end{array}$ \\
\hline$X .1 .3 .2 .5$ & Open-Sort RH TRU/TRUM Contents & \\
\hline$X .1 .3 .2 .6$ & Treat RH TRU & TBD [Activities/processes are still under study.] \\
\hline X.1.3.2.7 & Treat RH TRUM & TBD [Activities/processes are still under study.] \\
\hline X.1.3.2.8 & Package TRU for WIPP & Package as appropriate for disposition at WIPP. \\
\hline X.1.3.2.9 & Package TRUM for WIPP & Package as appropriate for disposition at WIPP. \\
\hline $\mathrm{X} .1 .3 .3$ & $\begin{array}{l}\text { Transport Disposition-Ready TRU/TRUM } \\
\text { to Onsite Storage }\end{array}$ & (This function is tentative.) \\
\hline $\mathrm{X} .1 .3 .4$ & $\begin{array}{l}\text { Store Disposition-Ready TRU/TRUM } \\
\text { Containers }\end{array}$ & (This function is tentative.) \\
\hline$X .1 .3 .5$ & Ship Disposition-Ready TRU/TRUM & $\begin{array}{l}\text { Load TRUPACT containers, load transport vehicle, coordinate shipment, provide shipping } \\
\text { paperwork. (This function is tentative.) }\end{array}$ \\
\hline$X .1 .4$ & (Placeholder - TBD) & \\
\hline $\mathrm{X} .1 .5$ & Manage Contaminated Equipment & $\begin{array}{l}\text { Decontamination services provided for Hanford contaminated equipment. Receive, } \\
\text { decontaminate, and either manage repair of contaminated equipment or transport to } \\
\text { appropriate on-site disposition facility. }\end{array}$ \\
\hline $\mathrm{X} .1 .5 .1$ & Receive Contaminated Equipment & $\begin{array}{l}\text { Take physical and legal custody of equipment and/or equipment packaged in standard } \\
\text { and/or large containers with appropriate paperwork. }\end{array}$ \\
\hline $\mathrm{X} .1 .5 .2$ & Decontaminate Equipment & $\begin{array}{l}\text { Decontaminate high-dose rate equipment to meet criteria for disposition or to conduct safe } \\
\text { repair. }\end{array}$ \\
\hline $\mathrm{X} .1 .5 .3$ & Repair Low-dose Rate Equipment & Repair or manage repair to return equipment to use. \\
\hline $\mathrm{X} .1 .5 .4$ & Transport Disposition-Ready Equipment & Transport equipment to on-site MLLW disposal site. \\
\hline $\mathrm{X} .1 .6$ & Store Radioactive Materials & \\
\hline $\mathrm{X} .1 .6 .1$ & Store TRIGA Fuel & $\begin{array}{l}\text { Store the Training Reactor, Isotopes, General Atomics (TRIGA) fuel pending DOE ROD } \\
\text { on ultimate disposition. }\end{array}$ \\
\hline $\mathrm{X} .1 .6 .2$ & Store Sodium & Store sodium pending DOE ROD on ultimate disposition. \\
\hline $\mathrm{X} .1 .6 .3$ & Store Shipping port Reactor Core & $\begin{array}{l}\text { Store the Shipping port Pressurized Water Reactor Core II pending DOE ROD on ultimate } \\
\text { disposition. }\end{array}$ \\
\hline
\end{tabular}


Table 2-4. Functional Description for Function X.1, Manage Solid Waste and Materials. (8 sheets)

\begin{tabular}{|l|l|l|}
\hline \multicolumn{1}{|c|}{ Function no. } & \multicolumn{1}{|c|}{ Function title } & \multicolumn{1}{c|}{ Function description } \\
\hline X.1.7 & $\begin{array}{l}\text { Ship Hazardous Waste to Off-site TSD } \\
\text { Facility }\end{array}$ & Coordinate shipment of on-site hazardous waste to off-site TSD facility. \\
\hline X.1.8 & Maintain Inactive SW Facilities & Perform necessary and sufficient maintenance for safety. \\
\hline X.1.9 & Operate and Maintain Active SW Facilities & $\begin{array}{l}\text { Operate and maintain all RFSH active solid waste facilities (excludes active LLW/MLLW } \\
\text { burial grounds/trenches). (Activities equate to Hanford's definition of "min safe.") Perform } \\
\text { transition activities for transfer to EM-60 or 40 Programs. }\end{array}$ \\
\hline X.1.9.1 & Operate and Maintain Plant Systems & $\begin{array}{l}\text { Operate and maintain plant systems operational; includes waste/material TSD and transfer } \\
\text { systems, and/or other equipment directly fulfilling facility's primary purpose. }\end{array}$ \\
\hline X.1.9.2 & $\begin{array}{l}\text { Operate and Maintain Facility Support } \\
\text { Systems }\end{array}$ & $\begin{array}{l}\text { Operate and maintain facility support systems operational; includes HVAC, humidifiers, } \\
\text { potable water, service water, sanitary wastewater, electrical and communications systems } \\
\text { and/or other supporting systems/equipment. }\end{array}$ \\
\hline X.1.9.3 & Operate and Maintain Protection Systems & Operate and/or maintain persomnel safety and protection systems, facility fire system, etc. \\
\hline X.1.9.4 & Maintain Information Management Systems & \\
\hline X.1.9.5 & Manage Facility Wastes & \\
\hline X.1.10 & Provide Generator Services & \\
\hline
\end{tabular}


Table 2-5. Functional Description for Function X.2, Manage Liquid Waste. (2 sheets)

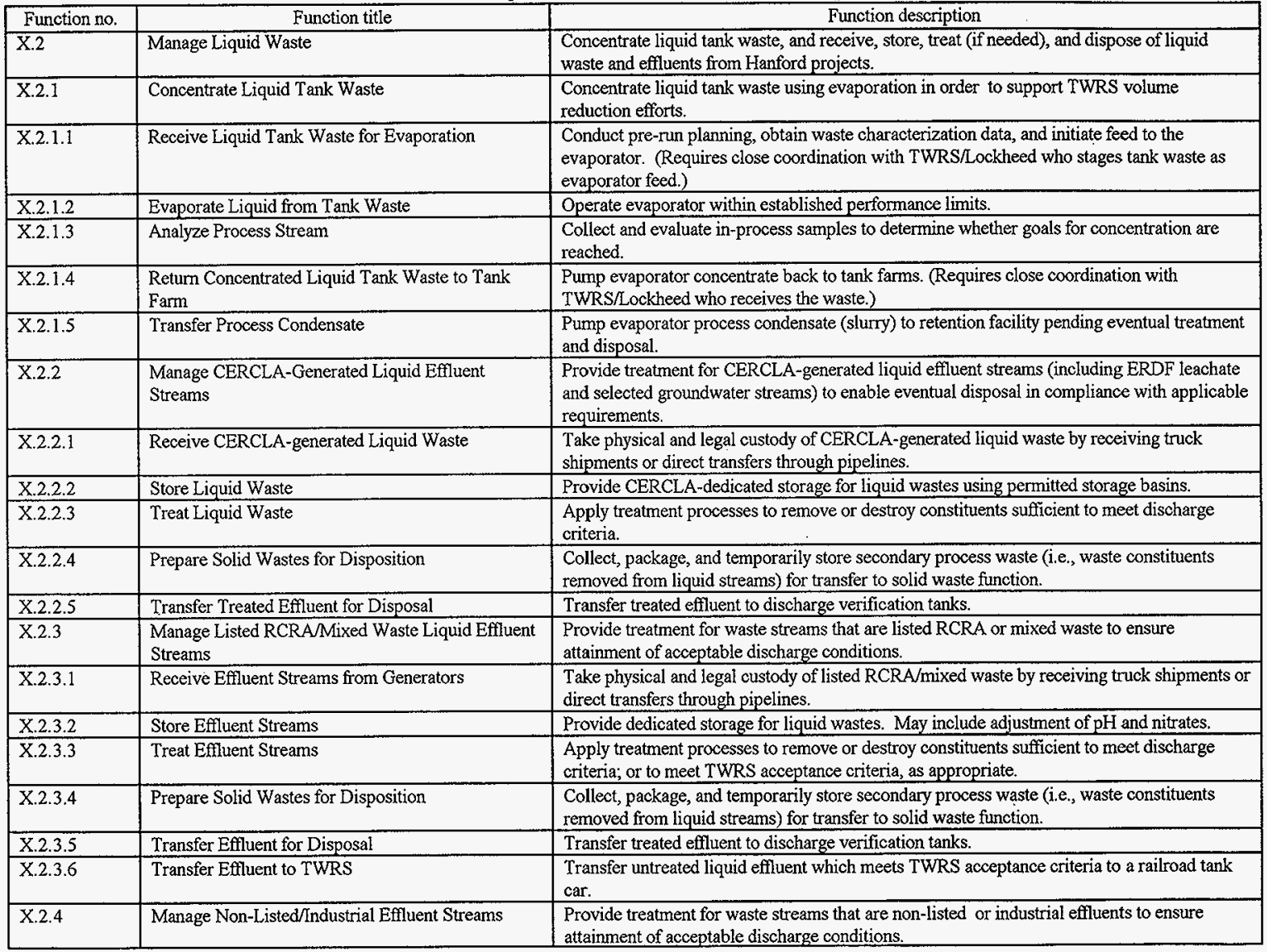


Table 2-5. Functional Description for Function X.2, Manage Liquid Waste. (2 sheets)

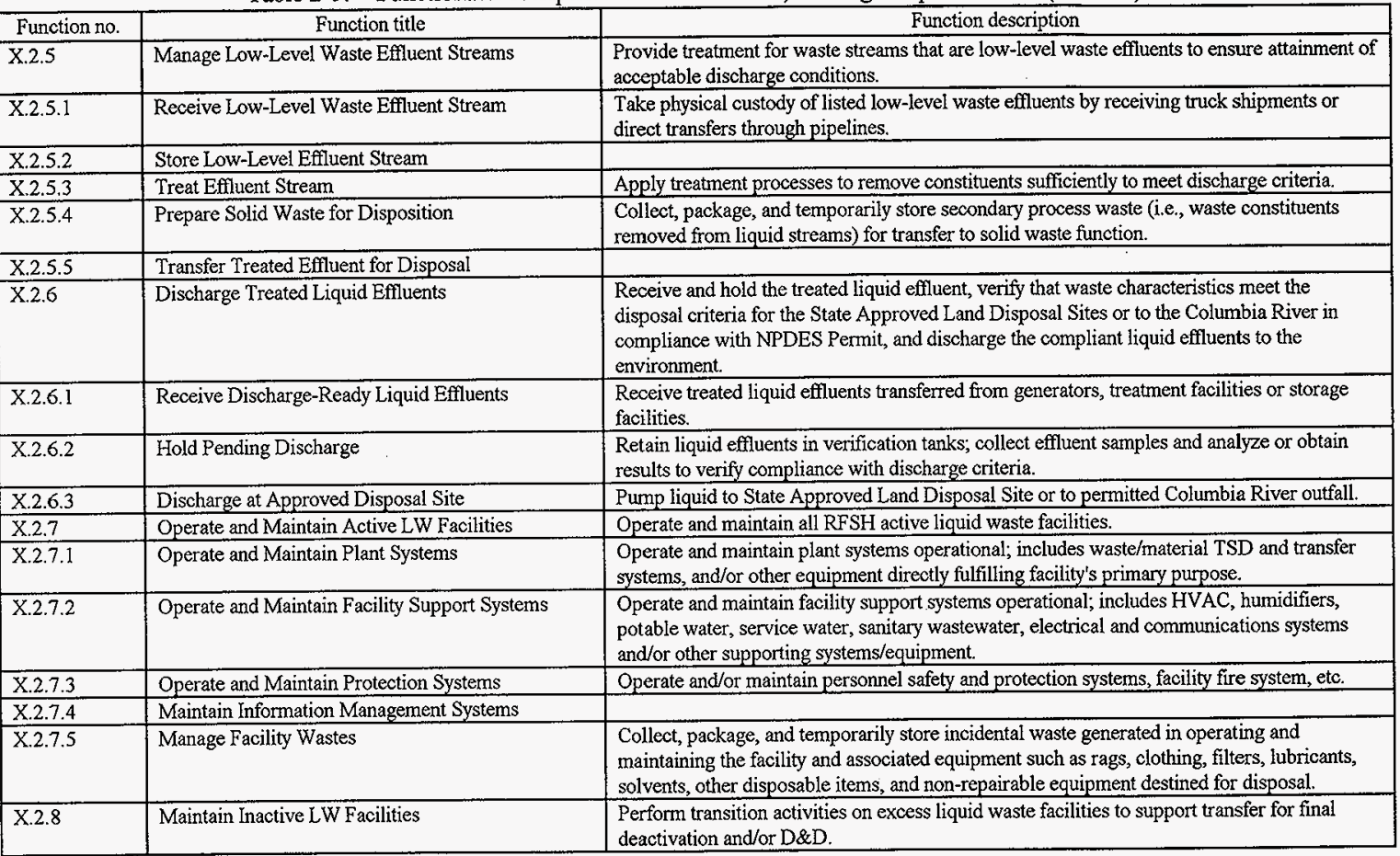


Revision 0

\begin{tabular}{|c|c|c|c|c|c|c|c|c|c|c|c|c|c|c|c|c|c|c|c|}
\hline 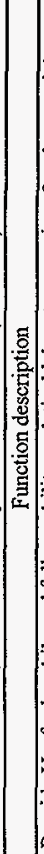 & 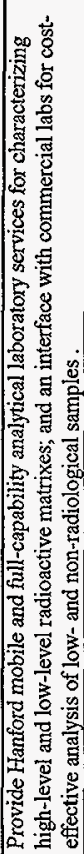 & 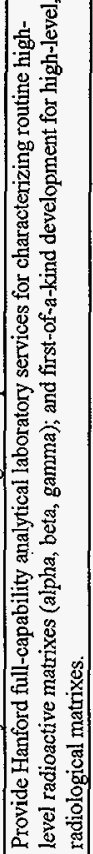 & 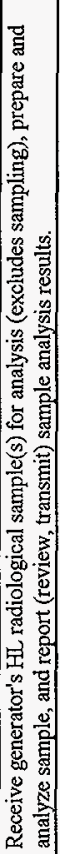 & 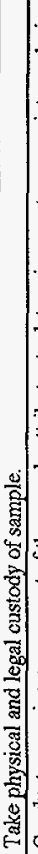 & 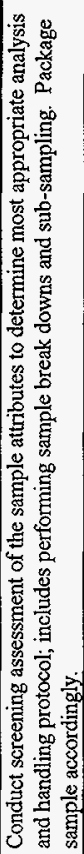 & 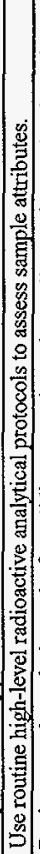 & 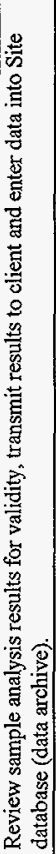 & 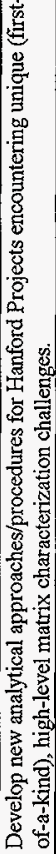 & 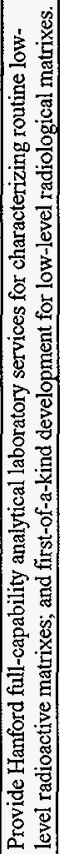 & 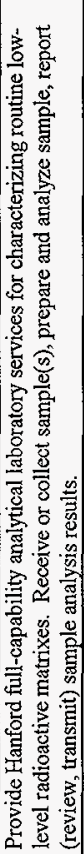 & 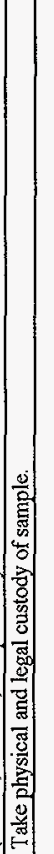 & 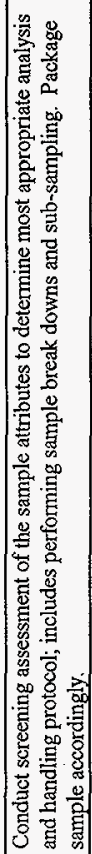 & 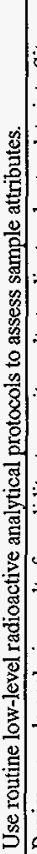 & 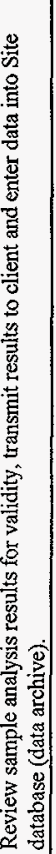 & 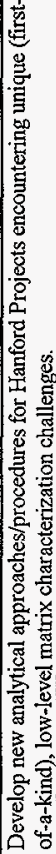 & 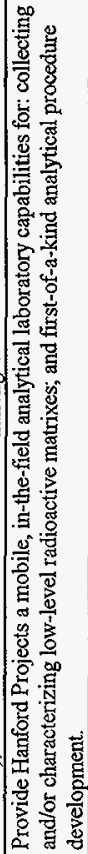 & 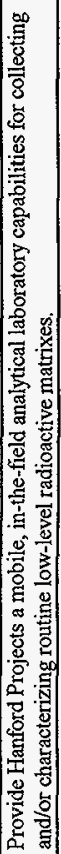 & 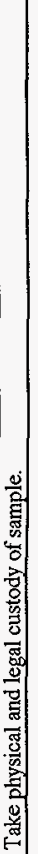 & \\
\hline 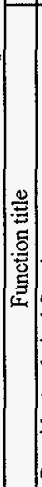 & 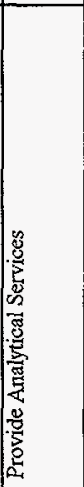 & 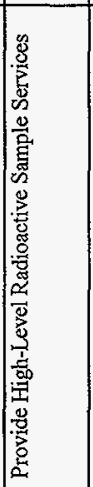 & 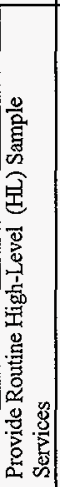 & 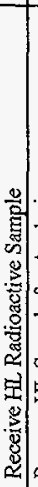 & 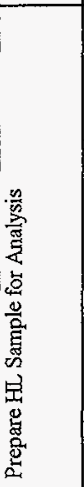 & 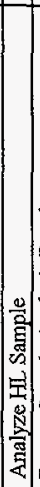 & 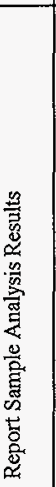 & 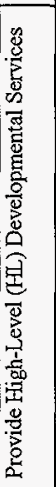 & 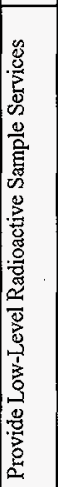 & 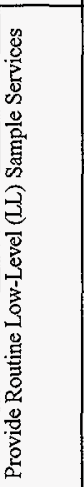 & 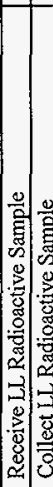 & 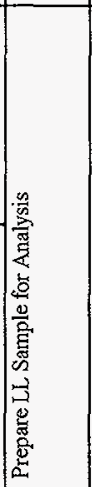 & 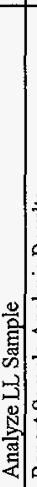 & 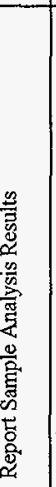 & 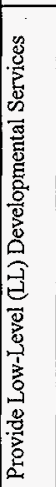 & 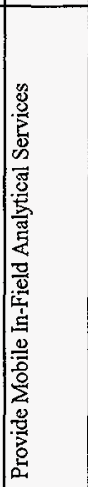 & 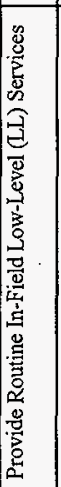 & 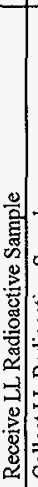 & \\
\hline 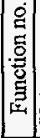 & $\forall$ & $\begin{array}{l}\vec{t} \\
\dot{x}\end{array}$ & $\vec{z}$ & $\begin{array}{l}3 \\
3 \\
\dot{x}\end{array}$ & $\vec{j}$ & $\left|\begin{array}{c}2 \\
\hdashline \\
\dot{v} \\
\dot{x}\end{array}\right|$ & $\vec{r}$ & $\dot{x}$ & $\underset{\underset{x}{x}}{\stackrel{\sim}{x}}$ & ن & 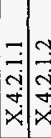 & 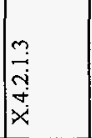 & 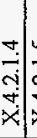 & & $\begin{array}{l}y \\
\dot{x} \\
\ddot{x}\end{array}$ & $\underset{x}{x}$ & $\dot{\theta}$ & 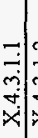 & \\
\hline
\end{tabular}


Table 2-6. Functional Description for Function X.4, Provide Analytical Services. (2 sheets)

\begin{tabular}{|c|c|c|}
\hline Function no. & Function title & Function description \\
\hline $\mathrm{X} .4 .3 .1 .3$ & Prepare LL Sample for Analysis & $\begin{array}{l}\text { Conduct screening assessment of the sample attributes to determine most appropriate analysis } \\
\text { and handling protocol. Package sample accordingly. }\end{array}$ \\
\hline $\mathrm{X} .4 .3 .1 .4$ & Analyze LL Sample & $\begin{array}{l}\text { Use routine low-level radioactive analytical protocols within the capability of the mobile } \\
\text { laboratory to assess sample attributes. }\end{array}$ \\
\hline $\mathrm{X} .4 .3 .1 .5$ & Report Sample Analysis Results & $\begin{array}{l}\text { Review sample analysis results for validity, transmit results to client and enter data into Site } \\
\text { database (data archive). }\end{array}$ \\
\hline X.4.3.2 & $\begin{array}{l}\text { Provide In-Field Low-Level (LL) Developmental } \\
\text { Services }\end{array}$ & $\begin{array}{l}\text { Provide Hanford Projects a mobile, in-the-field capability for developing first-of-a-kind } \\
\text { analytical procedures for collecting and/or characterizing unique low-level radioactive matrixes. }\end{array}$ \\
\hline $\mathrm{X} .4 .4$ & Provide Commercial Laboratory Services & $\begin{array}{l}\text { Collect and/or receive generator's low/non-radioactive sample(s) for analysis, prepare and ship } \\
\text { sample to commercial laboratory, monitor the commercial analysis, and report (review, } \\
\text { transmit) sample analysis results. }\end{array}$ \\
\hline $\mathrm{X} .4 .4 .1$ & Receive Low/Non-Rad Sample & Take physical and legal custody of sample. \\
\hline $\mathrm{X} .4 .4 .2$ & Collect Low/Non-Rad Sample & \\
\hline $\mathrm{X} .4 .4 .3$ & Prepare Sample for Off-site Analysis & $\begin{array}{l}\text { Conduct screening assessment of the sample attributes to determine most appropriate } \\
\text { commercial lab to do the analysis. Package sample for shipment. }\end{array}$ \\
\hline $\mathrm{X} .4 .4 .4$ & Ship Low/Non-Rad Sample & Ship sample to appropriate commercial laboratory. \\
\hline X.4.4.5 & Analyze Low/Non-Rad Sample & Analyze sample and properly disposition to a commercial TSD facility or return to Hanford. \\
\hline X.4.4.6 & Monitor Commercial Analysis Process & $\begin{array}{l}\text { Maintain close contact with the commercial laboratory for timely and correct analysis of the } \\
\text { sample. Includes routine assessments for contract and QA compliance. }\end{array}$ \\
\hline $\mathrm{X} .4 .4 .7$ & Report Sample Analysis Results & $\begin{array}{l}\text { Review sample analysis results for validity, transmit results to client and enter data into Site } \\
\text { database (data archive). }\end{array}$ \\
\hline $\mathrm{X} .4 .5$ & Operate and Maintain Active Laboratory Facilities & $\begin{array}{l}\text { Maintain RFSH analytical laboratory facilities (fixed and mobile) in a fully operational and safe } \\
\text { condition per the facility mission/purpose. (Activities equate to Hanford's definition of "min } \\
\text { safe.") }\end{array}$ \\
\hline$X .4 .5 .1$ & Provide Standards Laboratory Services & $\begin{array}{l}\text { Maintain chemical and equipment standards, receive equipment, calibrate and certify laboratory } \\
\text { and equipment for measurement accuracy/precision. }\end{array}$ \\
\hline $\mathrm{X} .4 .5 .2$ & Archive Samples & \\
\hline X.4.5.2.1 & Archive High-Level Radioactive Samples & \\
\hline $\mathrm{X} .4 .5 .2 .2$ & Archive Low-Level Radioactive Samples & \\
\hline $\mathrm{X} .4 .5 .3$ & Maintain Analytical Equipment Operational & Operate and/or maintain personnel safety systems (eye and full-body showers), fire system, etc. \\
\hline X.4.5.4 & Operate and Maintain Utility Systems & \\
\hline $\mathrm{X} .4 .5 .5$ & Manage Laboratory Wastes & \\
\hline$X .4 .5 .6$ & Operate and Maintain Protection Systems & \\
\hline X.4.5.7 & $\begin{array}{l}\text { Maintain Information Management Systems } \\
\text { Operational }\end{array}$ & \\
\hline $\mathrm{X} .4 .6$ & Maintain Inactive Laboratory Facilities & \\
\hline
\end{tabular}


Figure 2-3. Function X.1, Manage Solid Waste and Materials.

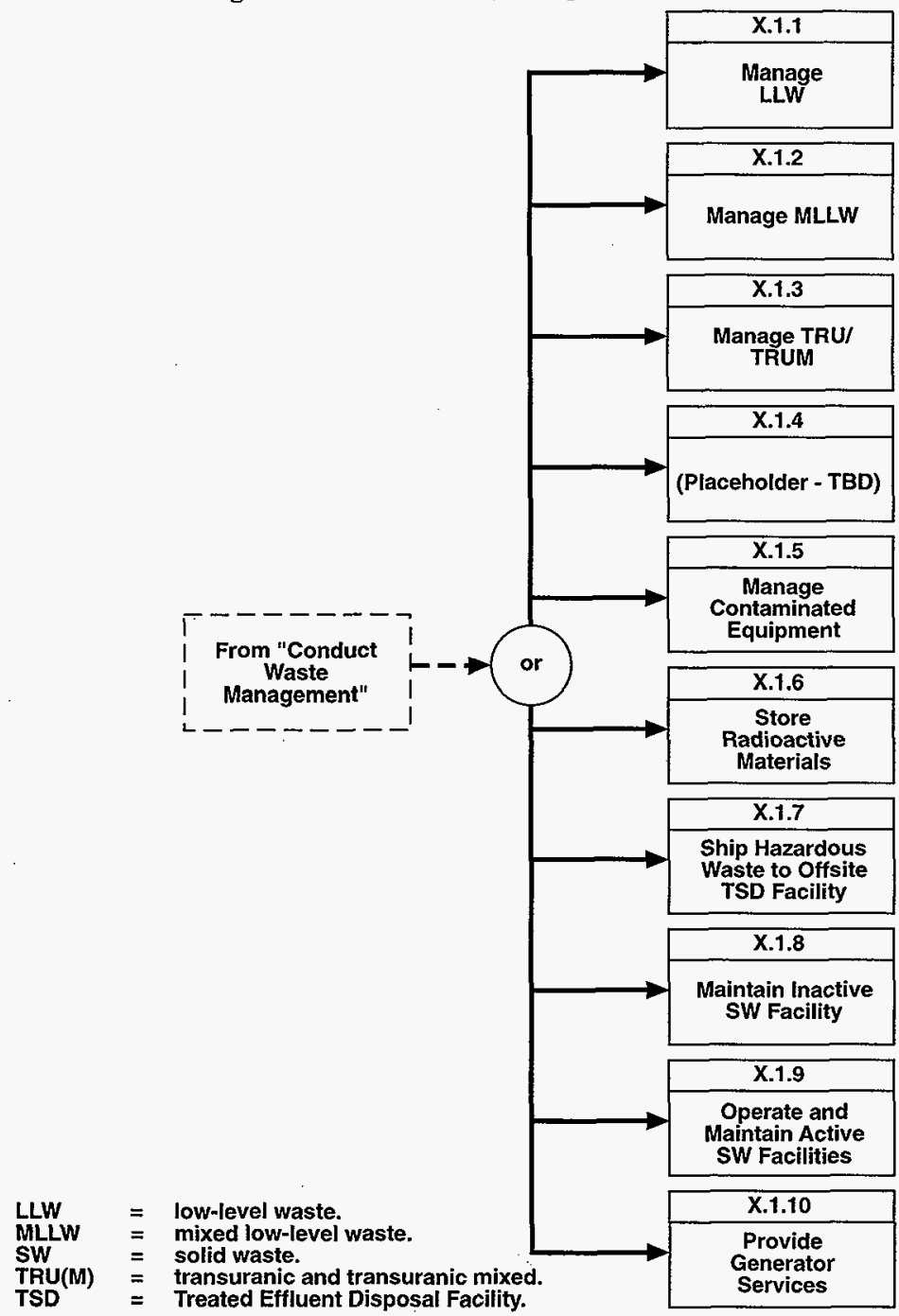




\section{Revision 0}

Figure 2-4. Function X.1.1, Manage LLW.

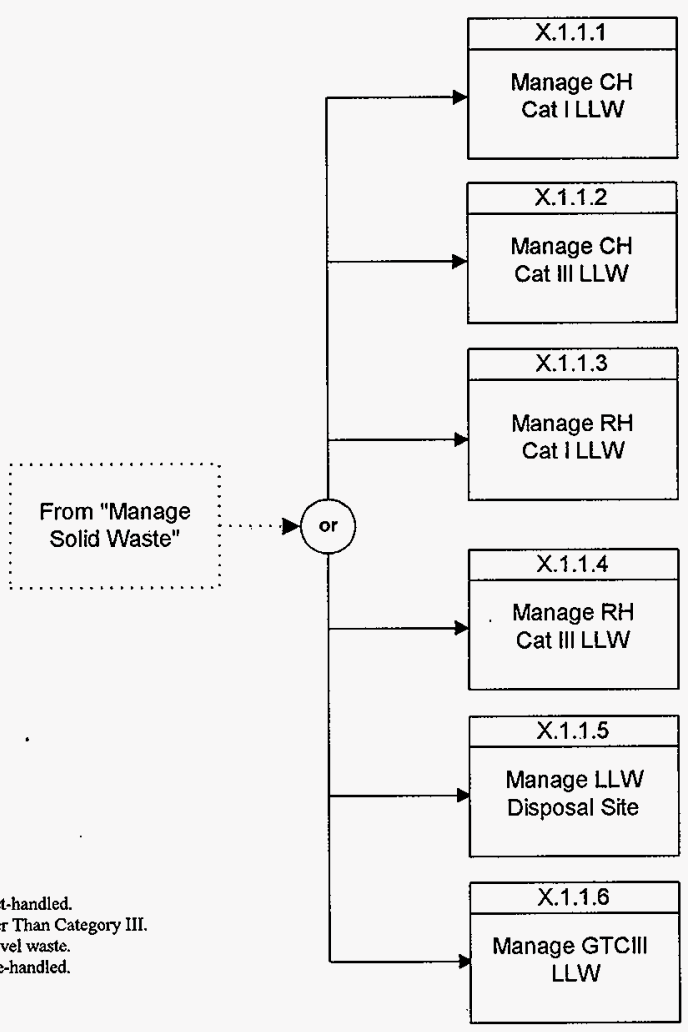

$\mathrm{CH}=$ contact - handled. GTCIII = Greater Than Category III

$L L W=$ low-level waste.

$\mathrm{RH}=$ remote-handled. 
HNF-SD-WM-RPT-288

Revision 0

Figure 2-5. Function X.1.1.1, Manage CH Cat I LLW.

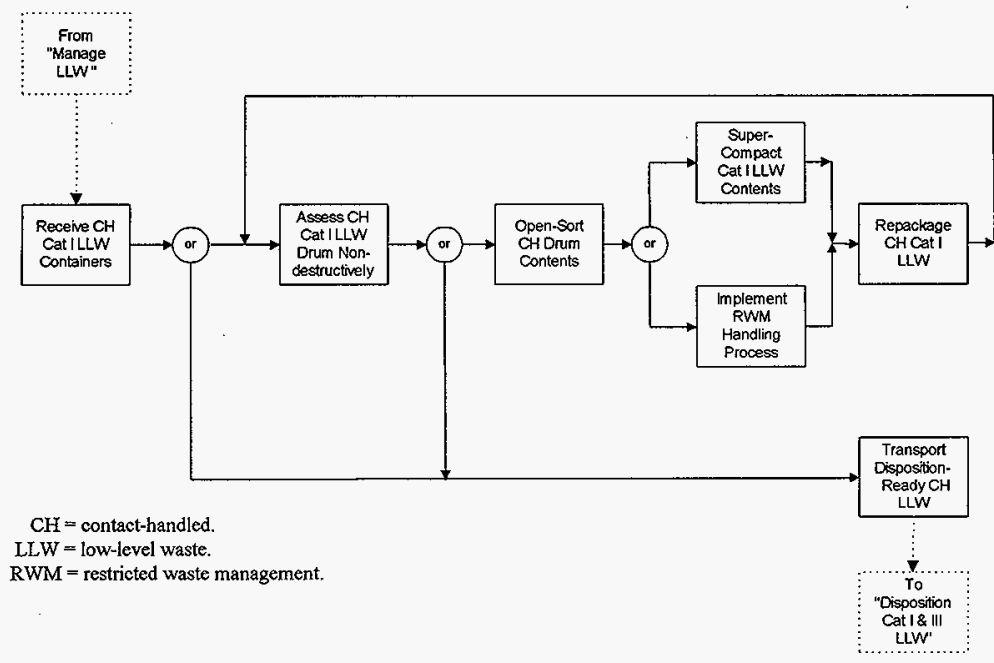


HNF-SD-WM-RPT-288

Revision 0

Figure 2-6. Function X.1.1.2, Manage CH Cat III LLW.

draft

example

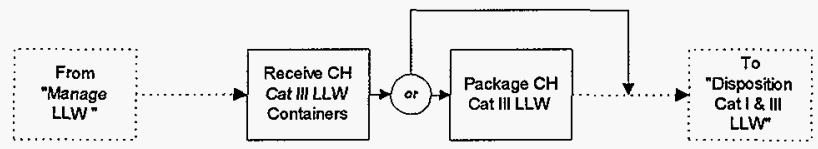

Figure 2-7. Function X.1.1.3, Manage RH Cat I LLW.

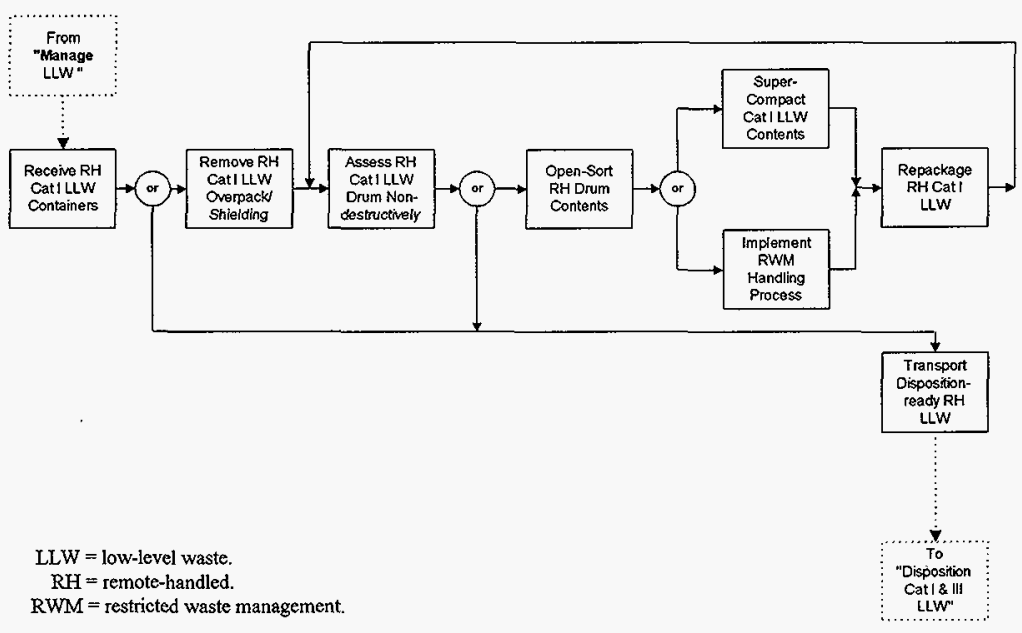


HNF-SD-WM-RPT-288

Revision 0

Figure 2-8. Function X.1.1.4, Manage RH Cat III LLW.

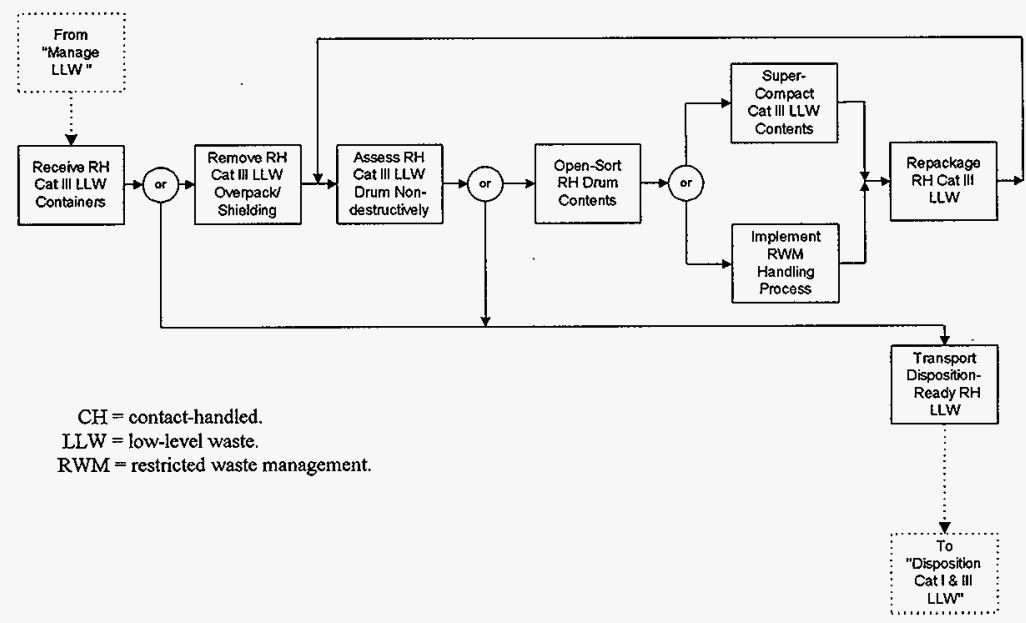


HNNF-SD-WM-RPT-288

Revision 0

Figure 2-9. Function X.1.1.5, Manage LLW Disposal Site.

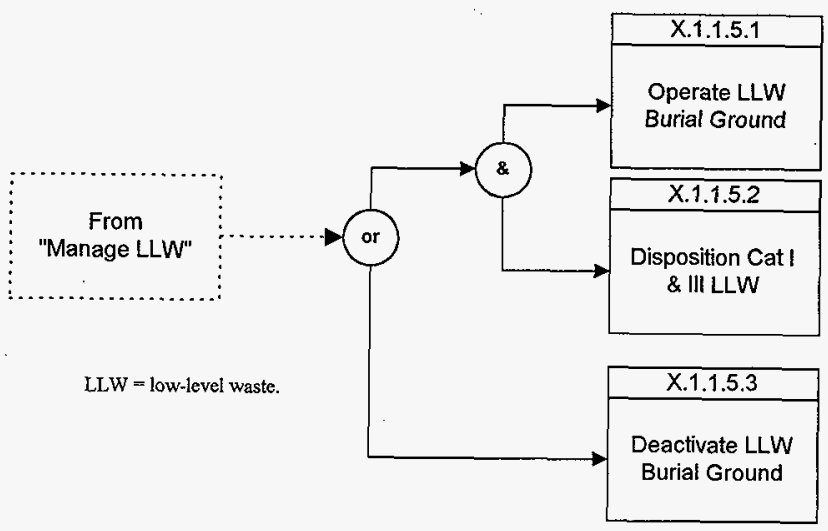




\section{HNF-SD-WM-RPT-288}

\section{Revision 0}

Figure 2-10. Function X.1.2, Manage MLLW.

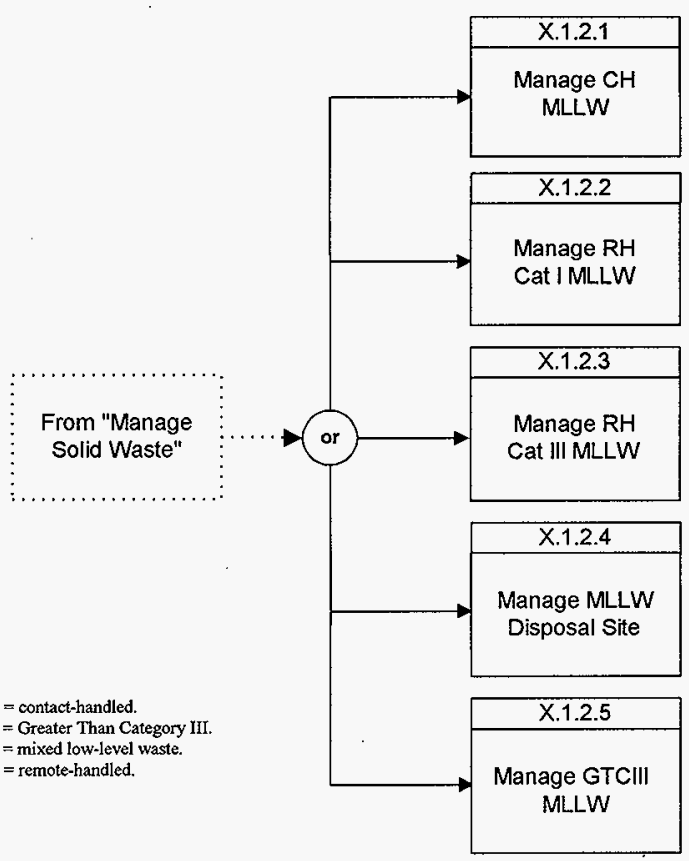


Revision 0

Figure 2-11. Function X.1.2.1, Manage CH MLLW.

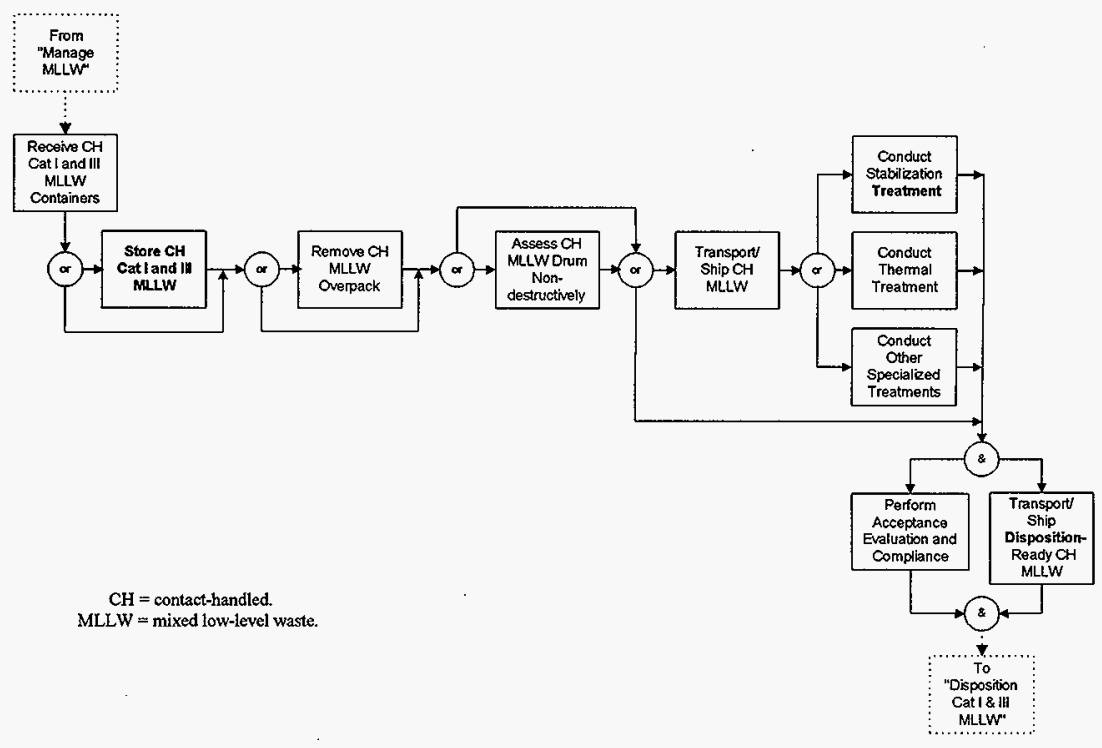




\section{HNF-SD-WM-RPT-288}

Revision 0

Figure 2-12. Function X.1.2.2, Manage RH Cat I MLLW.

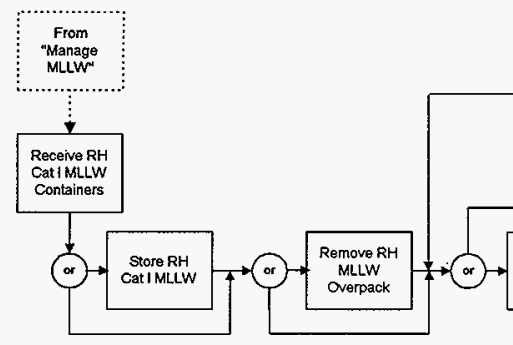

LLW $=$ low-level waste.

MLLW $=$ mixed low-level waste.

$\mathrm{RH}=$ remote-handled. 


\section{HNF-SD-WM-RPT-288}

Revision 0

Figure 2-13. Function X.1.2.3, Manage RH Cat III MLLW.

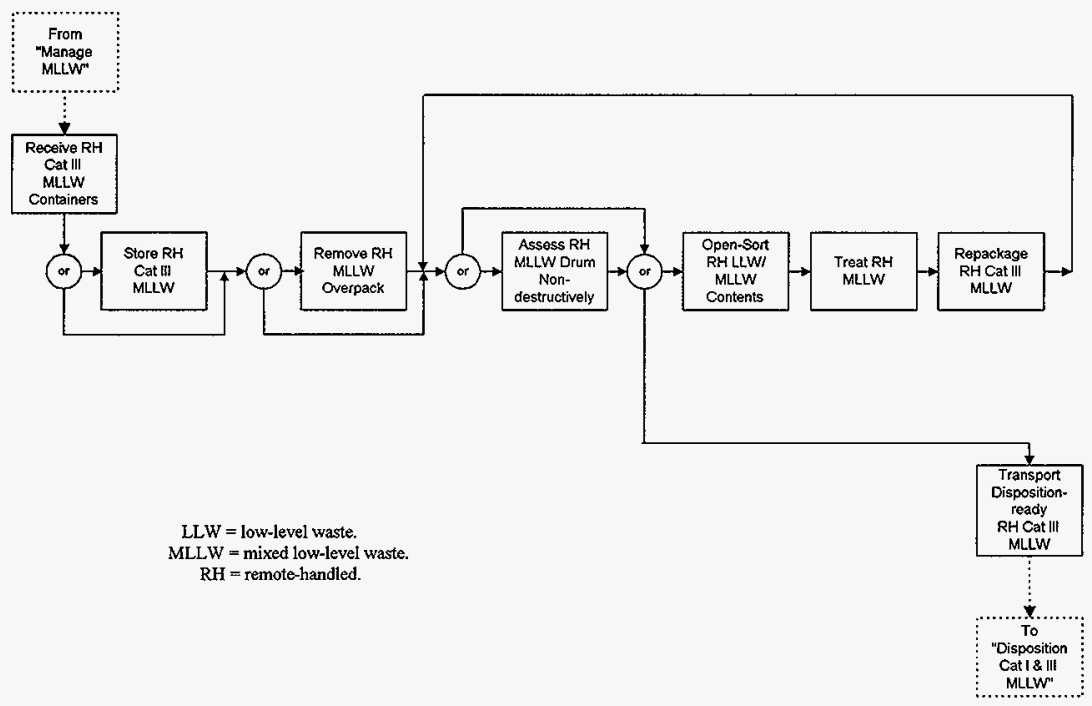


Figure 2-14. Function X.1.2.4, Manage MLLW Disposal Site.

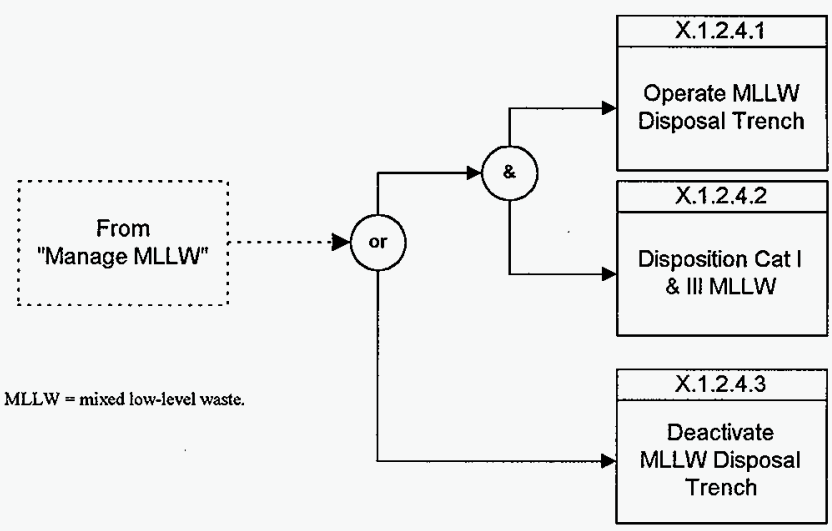


Figure 2-15. Function X.1.3, Manage TRU/TRUM.

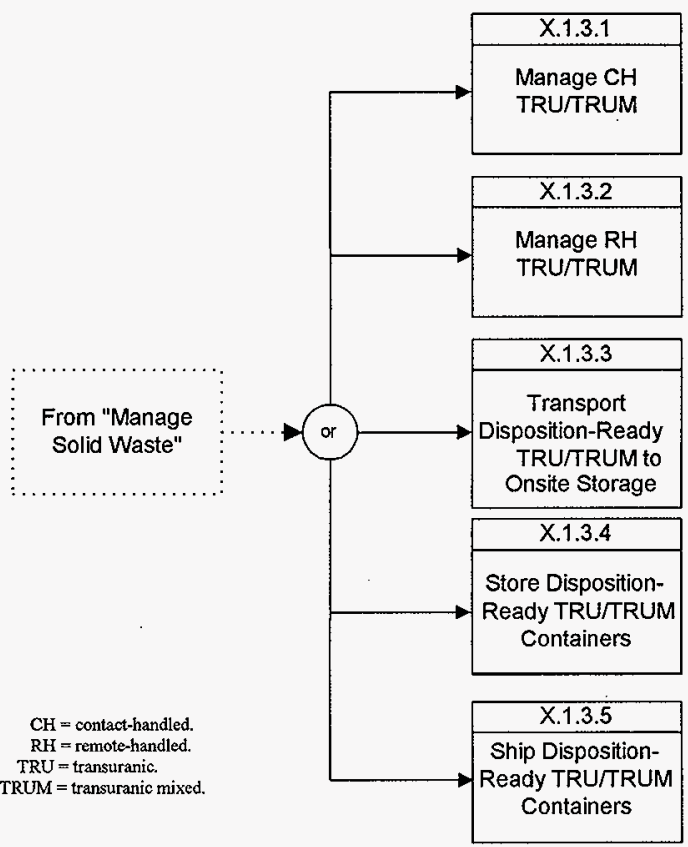


HNF-SD-WM-R.PT-288

Revision 0

Figure 2-16. Function X.1.3.1, Manage CH TRU/TRUM.

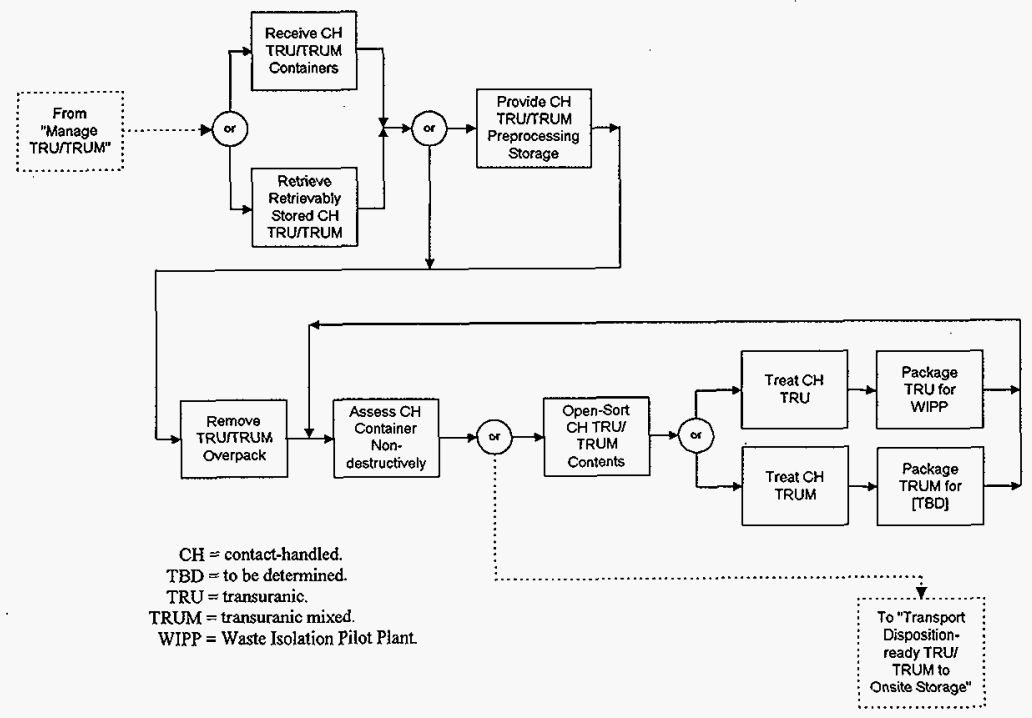




\section{HNF-SD-WM-RPT-288}

Revision 0

Figure 2-17. Function X.1.3.2, Manage RH TRU/TRUM.

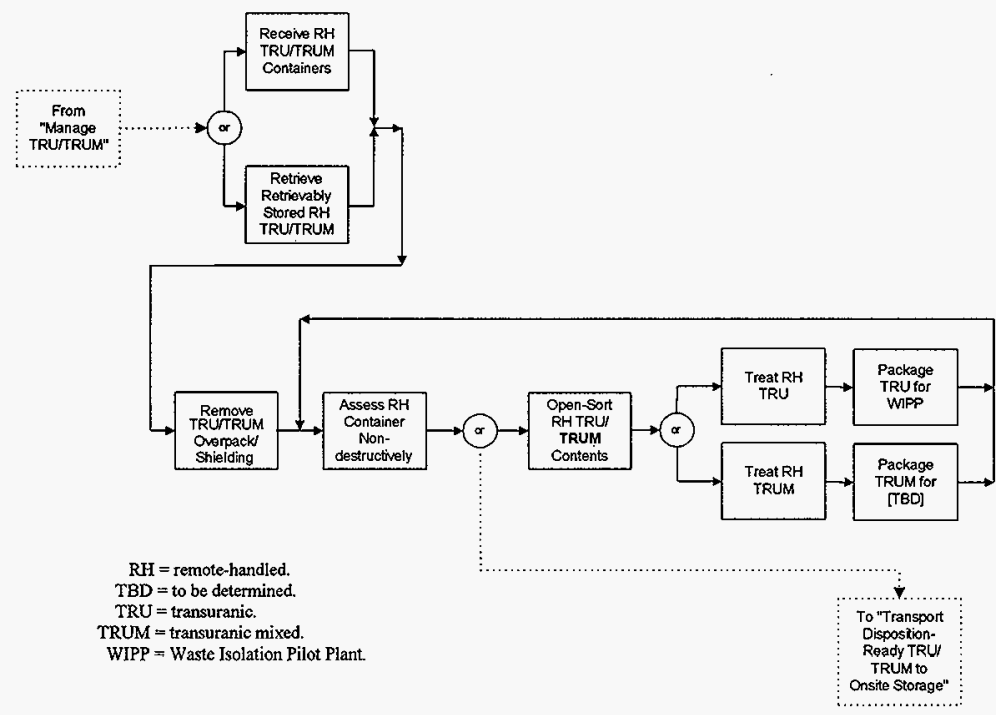


HNF-SD-WM-RPT-288

Revision 0

Figure 2-18. Function X.1.5, Manage Contaminated Equipment.

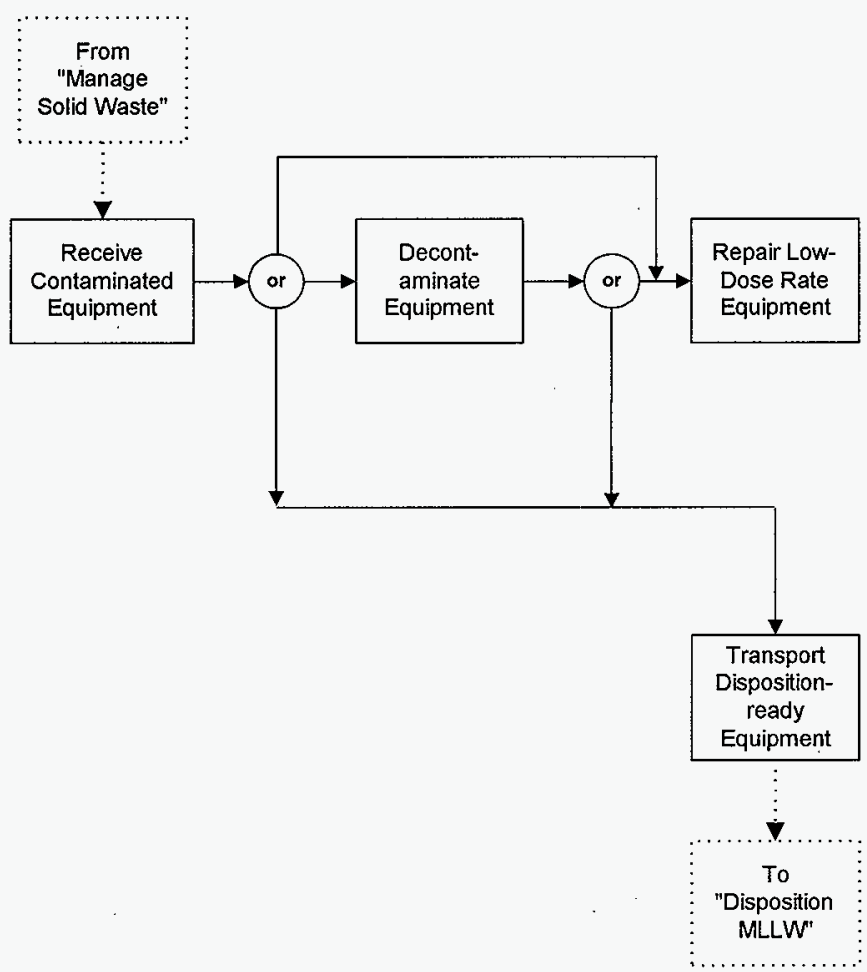


Figure 2-19. Function X.1.9, Operate and Maintain Active Solid Waste Facilities.

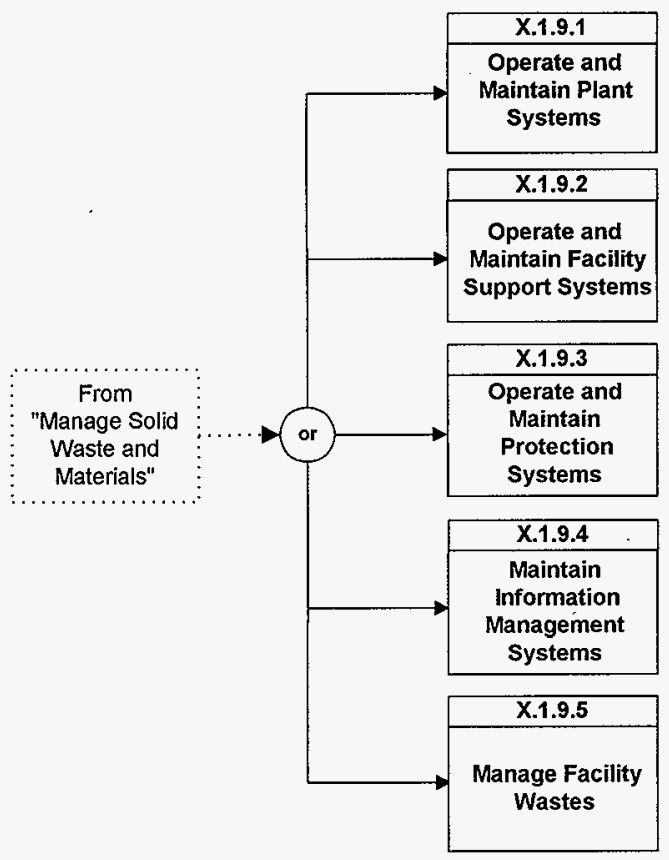


Figure 2-20. Function X.2, Manage Liquid Waste.

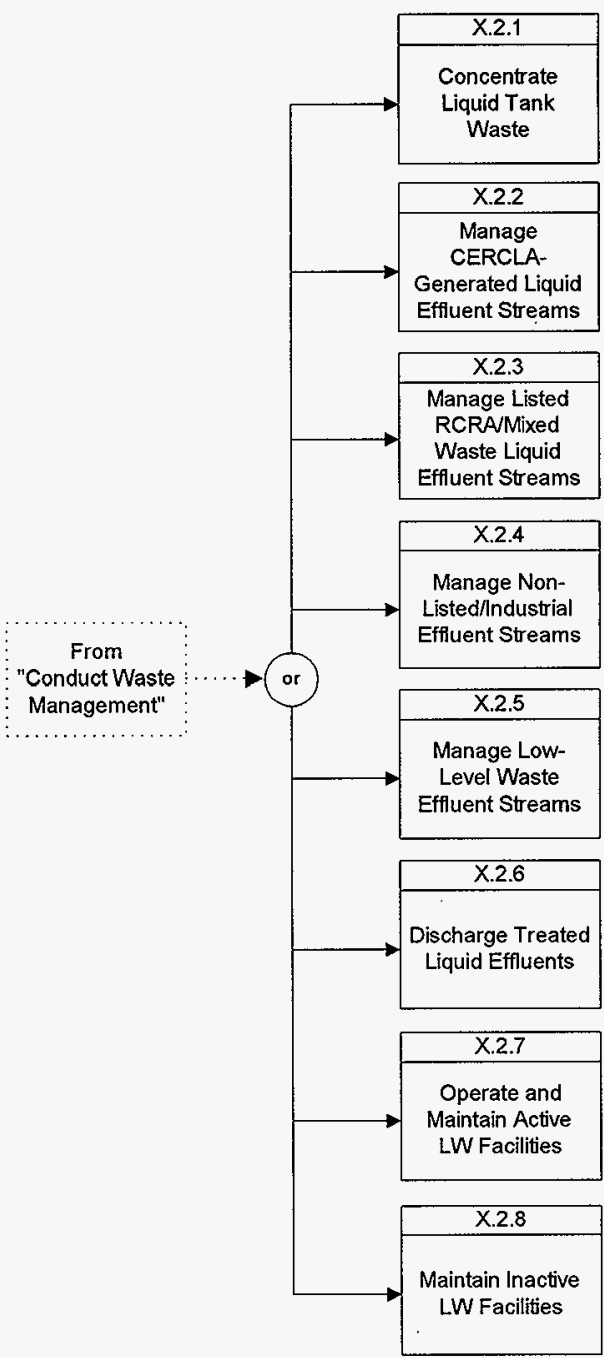




\section{Revision 0}

Figure 2-21. Function X.2.1, Concentrate Liquid Tank Waste.

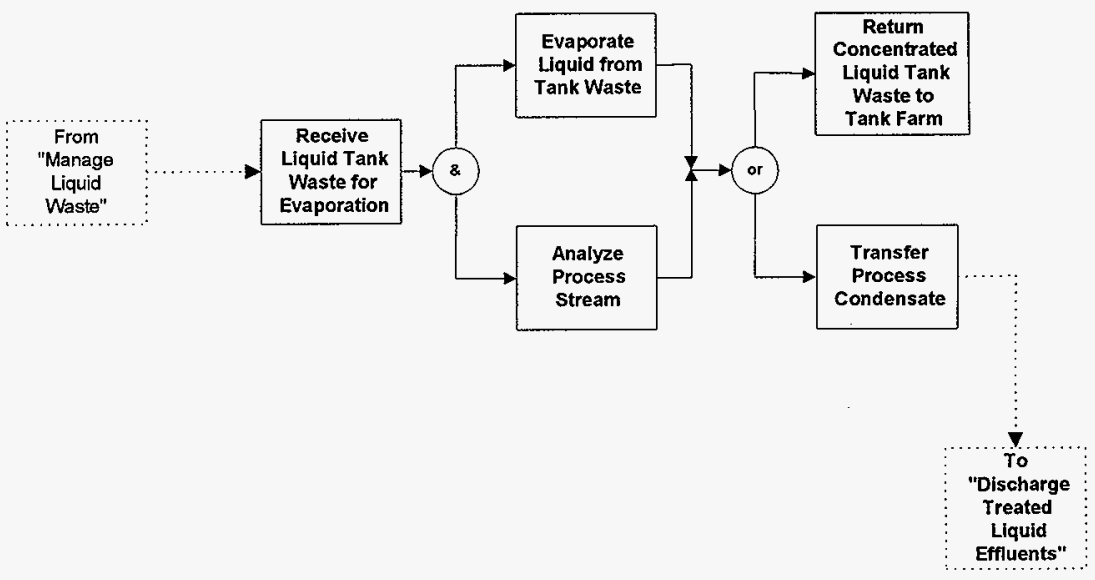


HNF-SD-WM-RPT-288

Revision 0

Figure 2-22. Function X.2.2, Manage CERCLA-Generated Liquid Effluent Streams.

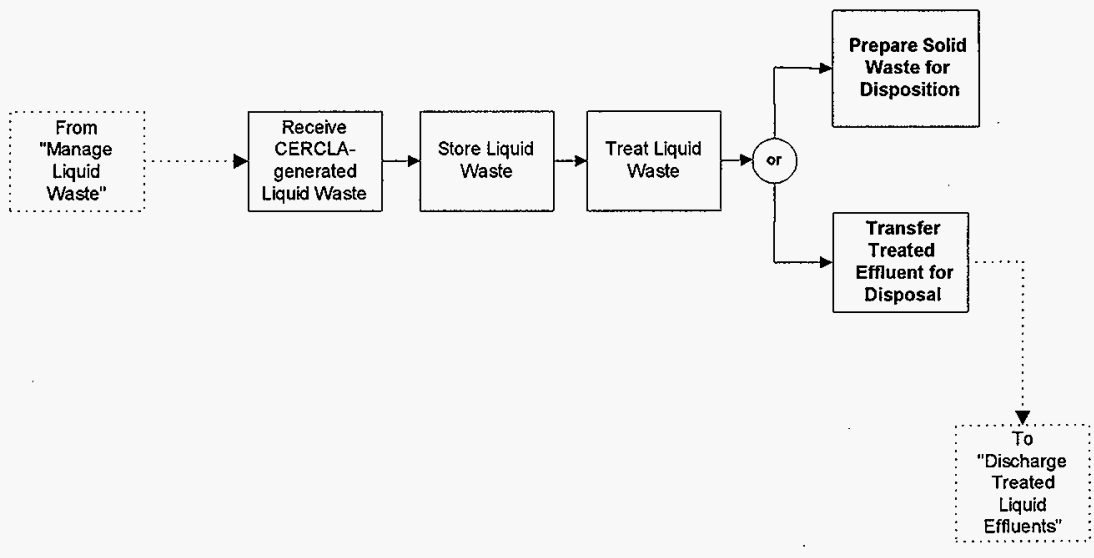


HNF-SD-WM-RPT-288

Revision 0

Figure 2-23. Function X.2.3, Manage Listed RCRA/Mixed Waste Liquid Effluent Streams.

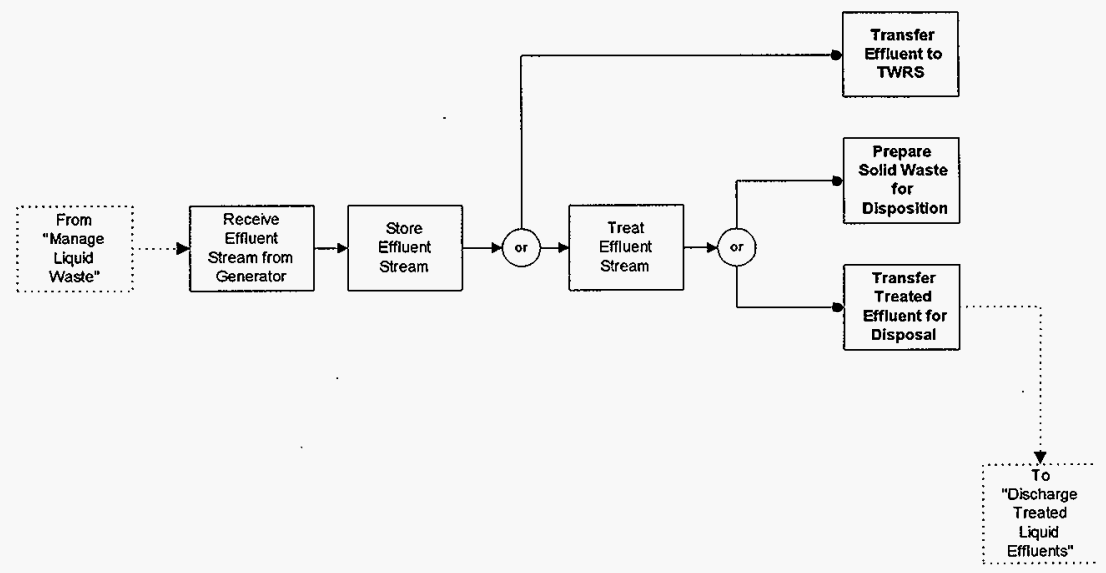




\section{HNF-SD-WM-RPT-288}

Revision 0

Figure 2-24. Function X.2.5, Manage LLW Effluent Streams.

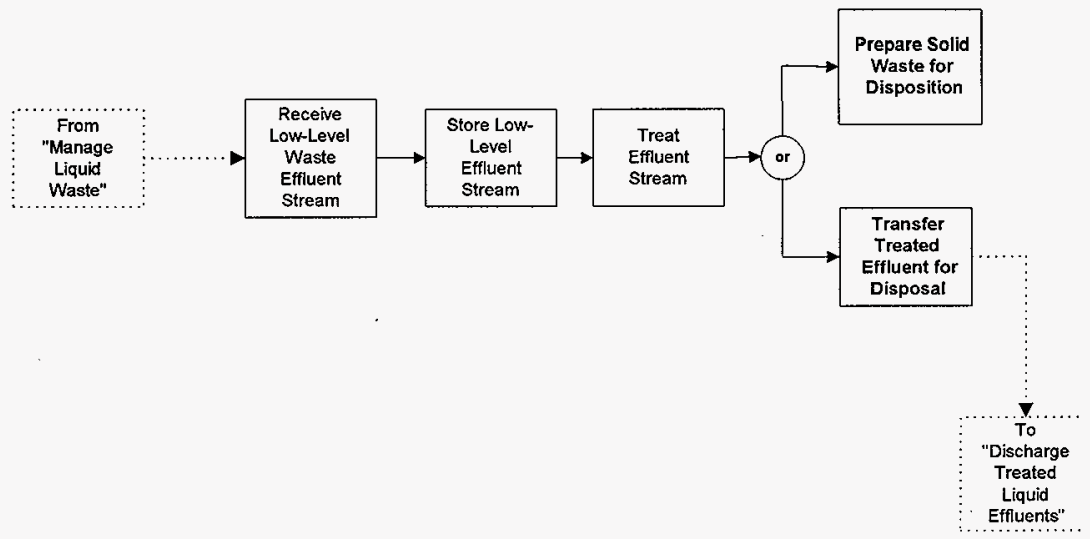

Figure 2-25. Function X.2.6, Discharge Treated Liquid Effluents.

\begin{tabular}{|c|c|c|c|}
\hline $\begin{array}{l}\text { From } \\
\text { "Manage } \\
\text { Liquid } \\
\text { Waste" }\end{array}$ & $\begin{array}{l}\text { Receive } \\
\text { Discharge- } \\
\text { Ready Liquid } \\
\text { Effluent }\end{array}$ & $\begin{array}{c}\text { Hold } \\
\text { Pending } \\
\text { Discharge }\end{array}$ & $\begin{array}{l}\text { Discharge at } \\
\text { Approved } \\
\text { Disposal } \\
\text { Site }\end{array}$ \\
\hline
\end{tabular}




\section{Revision 0}

Figure 2-26. Function X.2.7, Operate and Maintain Active LW Facilities.

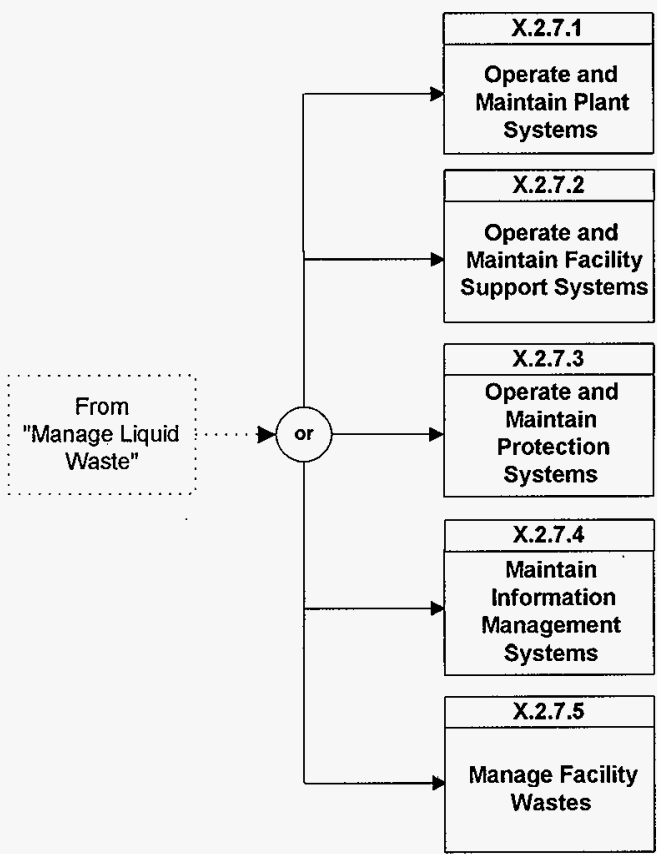




\section{Revision 0}

Figure 2-27. Function X.4, Provide Analytical Services.

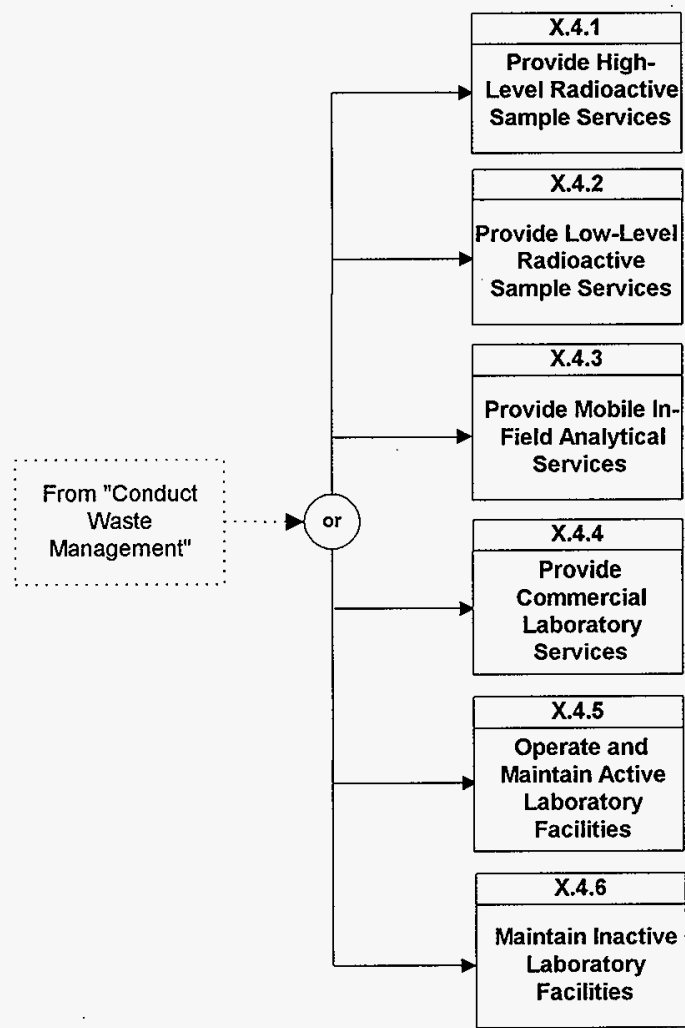


Figure 2-28. Function X.4.1, Provide High-Level Radioactive Sample Services.

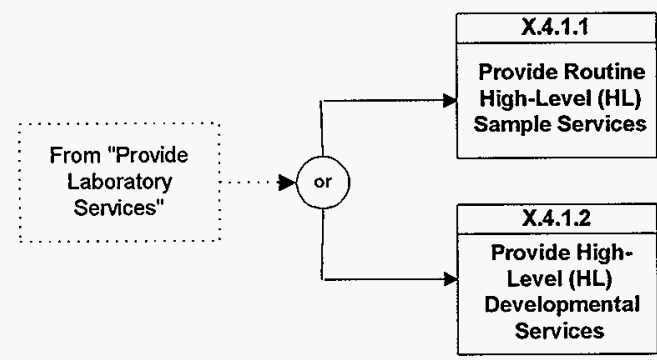

Figure 2-29. Function X.4.1.1, Provide Routine High-Level Sample Services.

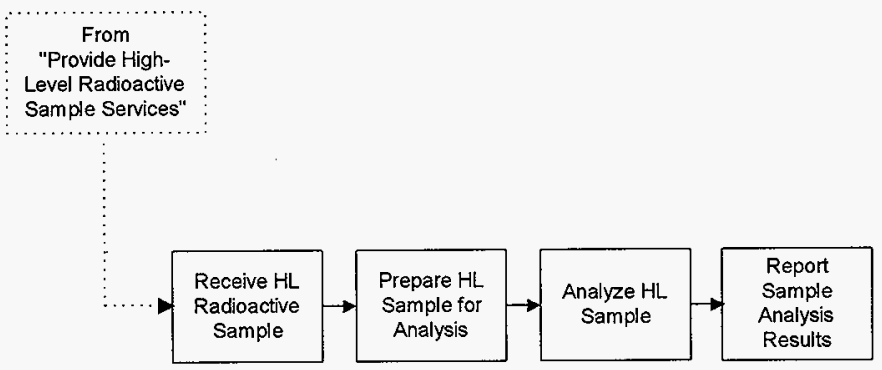


HNF-SD-WM-RPT-288

Revision 0

Figure 2-30. Function X.4.2, Provide Low-Level Radioactive Sample Services.

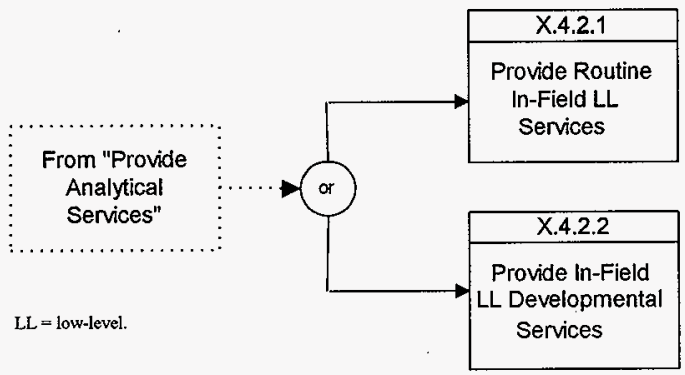

Figure 2-31. Function X.4.2.1, Provide Routine Low-Level Sample Services.

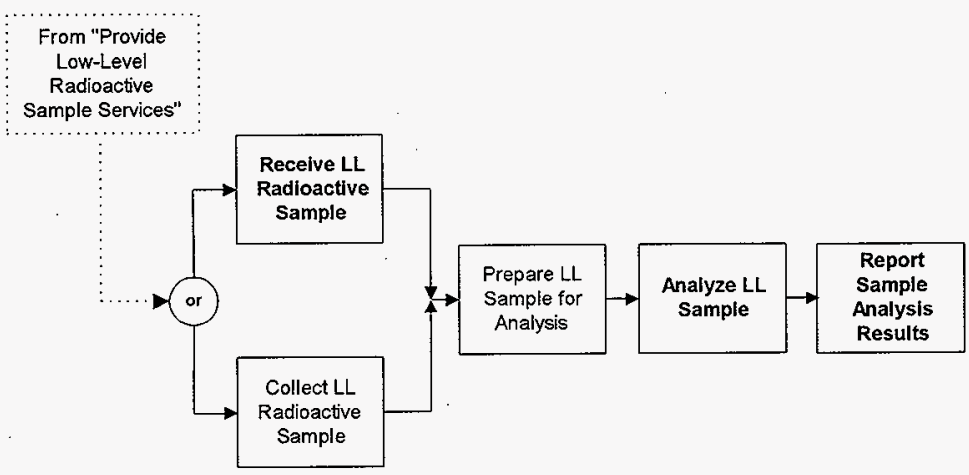




\section{Revision 0}

Figure 2-32. Function X.4.3, Provide Mobile In-Field Analytical Services.

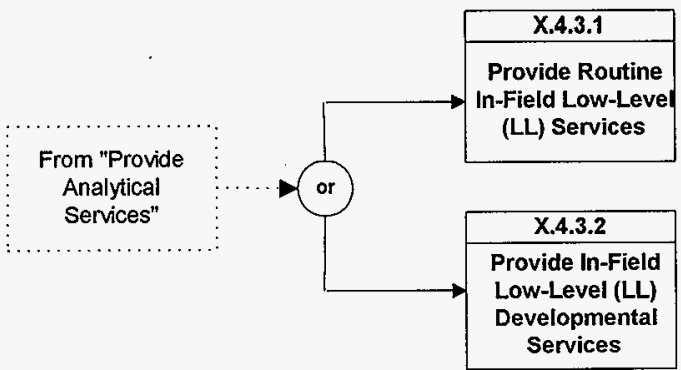

Figure 2-33. Function X.4.3.1, Provide Routine In-Field Low-Level Services.

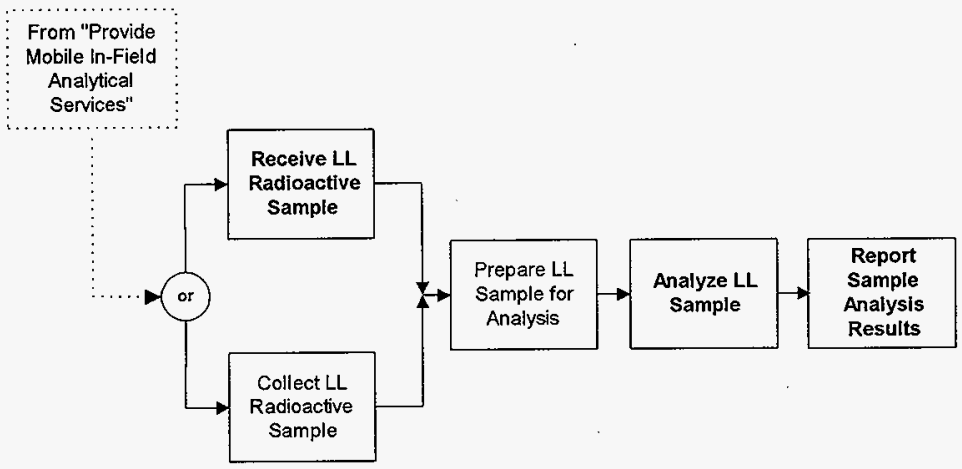




\section{HNF-SD-WM-RPT-288 \\ Revision 0}

Figure 2-34. Function X.4.4, Provide Commercial Laboratory Services.

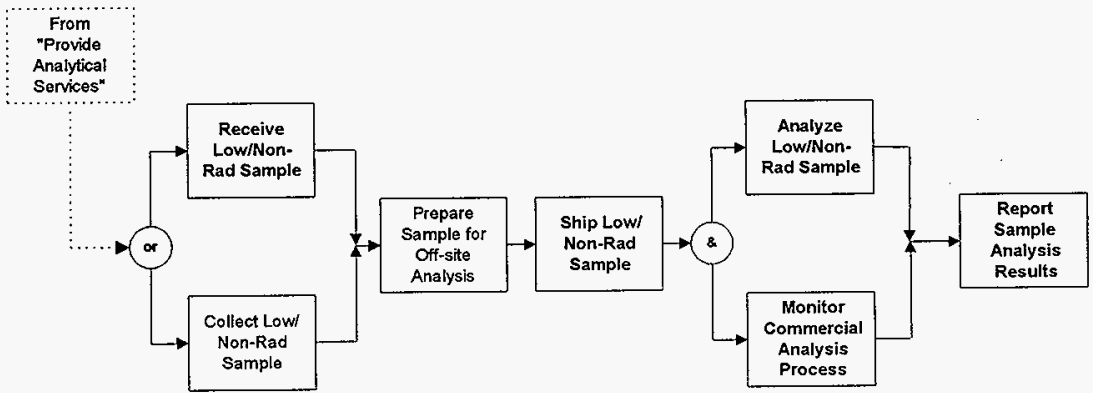


HNF-SD-WM-RPT-288

Revision 0

Figure 2-35. Function X.4.5, Operate and Maintain Active Laboratory Facilities.

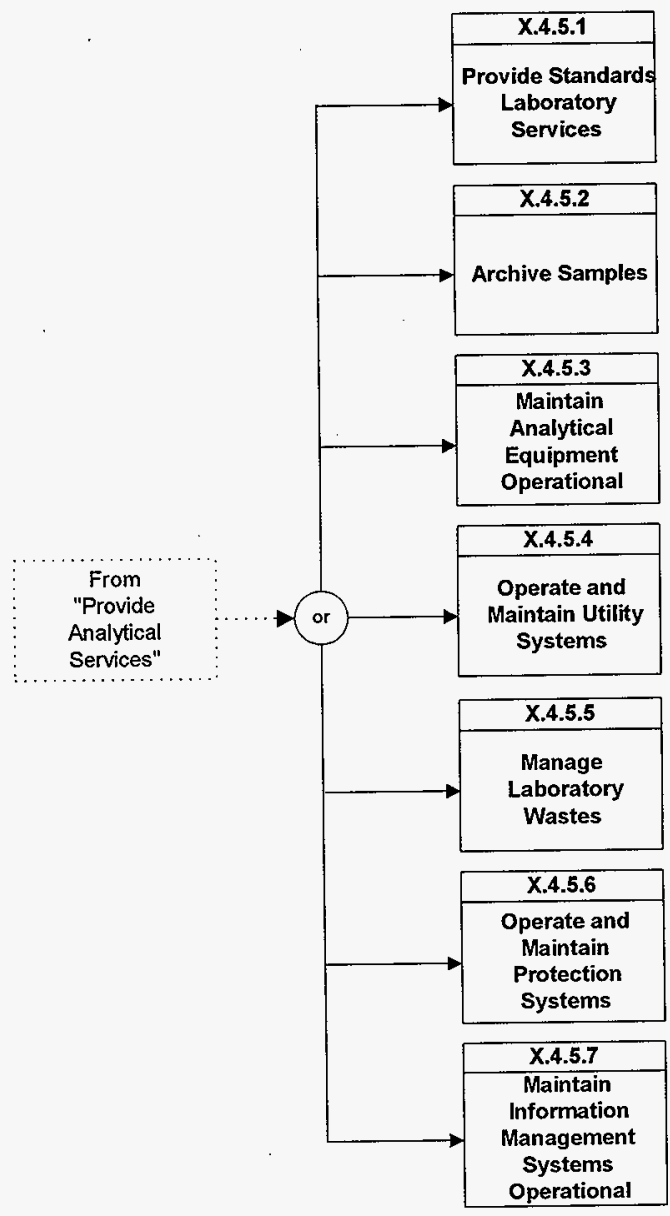




\section{HNF-SD-WM-RPT-288}

Revision 0

Figure 2-36. Function X.4.5.2, Archive Samples.

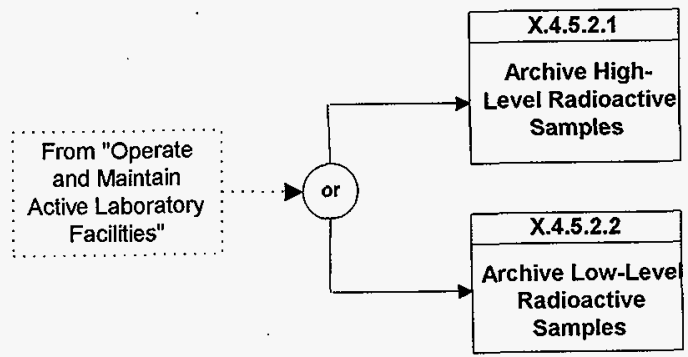


confirmed. When known, the magnitude and timing of the input or output are provided. Some amplifying information is provided to help "trigger" plans to reassess the input or output if its underlying basis changes.

Table 2-7 is not intended to be all inclusive. Detailed engineering and execution of the functions (operations of facilities, etc.) will likely identify additional inputs and outputs that must be dealt with continually.

Interface control documents (agreements) govern some of the primary interfaces with other Hanford Site projects outside the Project; these are described in Section 4.0.

The following information is specific to the inputs and outputs presented for Function X.1, Manage Solid Waste and Materials.

- The Solid Waste Information Forecast Tool (SWIFT) contains more detailed and current data than the waste volume data presented here. It is published periodically on the Internet at http://www-hanford.gov/docs/ep0918/index.htm. However, this treatment is the critical link to the functions and, in Section 3.0, to the requirements.

- The solid waste inputs and outputs are presented in descending order of magnitude. Most of the data are from SWIFT, Version 97.1. SWIFT does not differentiate by category to the level to which some of the product lines in the functional hierarchy for solid waste have been decomposed. SWIFT data are available for these categories: low-level waste (LLW), CH mixed low-level waste (MLLW), remote-handled (RH) MLLW, CH transuranic and transuranic mixed (TRU/TRUM), RH TRUM, Greater Than Category III (GTCIII) MLLW, and GTCIII LLW. The input descriptions in Table 2-7 denote when the volume estimates are for the more inclusive category.

The following information is specific to the inputs and outputs presented for Function X.4, Provide Analytical Services.

- The inputs and outputs specific to Function X.4, "Provide Analytical Service" have not been identified in this revision. Instead, the five-year forcast of sample analysis requirements for the Hanford Analytical Services Program (HASP) is provided. HASP includes RFSH, BHI, and PNNL analytical service capabilities.

- The inputs to Analytical Services are characterized by customer as the projected annual number of samples. During fiscal years (FY) 1995 and 1996, needs for analytical service decreased substantially at the Hanford Site. Sample projections for FY 1997 reflect a level similar to FY 1996. Significant decreases in analytical needs are projected for FYs 1999 through 2001. The projections for FYs 1997 through 2001 are summarized in five tables: Table 2-8 provides the overall Hanford Site sample projection summary, and Tables 2-9 through 2-12 categorize the information by radiation level, analysis (i.e., by "analyte"), protocol, and sample matrix, respectively. These sample attributes are critical when laboratory resources are allocated. 
Table 2-7. Functional Inputs and Outputs. (41 sheets)

\begin{tabular}{|c|c|c|c|c|}
\hline \multicolumn{5}{|c|}{ Function X.1.1.1, Manage CH Cat I LLW } \\
\hline Identifier & Title & From & $\begin{array}{c}\text { Function } \\
\text { number }\end{array}$ & Description \\
\hline \multirow[t]{17}{*}{ Input } & \multirow[t]{17}{*}{$\begin{array}{l}\text { CH Cat I LLW Generated from } \\
\text { Hanford Site Operations and } \\
\text { Offsite Facilities }\end{array}$} & TWRS & & $\begin{array}{l}\text { The TWRS Project will generate } 63,590 \mathrm{~m}^{3} \text { of LLW during retrieval and } \\
\text { processing of HLW from Hanford Site tanks. The TWRS forecasted life } \\
\text { cycle ends in } 2032 \text {, while most activity will be completed by } 2028 \text {. A } \\
\text { portion of the LLW generated during TWRS operations will be CH Cat I } \\
\text { LLW. }\end{array}$ \\
\hline & & Low-Level Vitrification Project & & $34,560 \mathrm{~m}^{3}$ \\
\hline & & High-Level Vitrification Project & & $20,880 \mathrm{~m}^{3}$ \\
\hline & & SST/DST Tank Farm Operations & . & $7,490 \mathrm{~m}^{3}$ \\
\hline & & SST Retrieval (149 tanks) & & $600 \mathrm{~m}^{3}$ \\
\hline & & Tank Farm Restoration & & $60 \mathrm{~m}^{3}$ \\
\hline & & Offsite & & $\begin{array}{l}\text { Offsite programs or facilities are forecasted to send } 46,500 \mathrm{~m}^{3} \text { of LLW to } \\
\text { the Hanford Site from } 1997 \text { to } 2070 \text {. A certain portion of this LLW will } \\
\text { be CH Cat I. The following are the top ten LLW contributors. }\end{array}$ \\
\hline & & Argonne National Laboratory-East & & $20,040 \mathrm{~m}^{3}$ \\
\hline & & Lawrence Berkeley Laboratory & & $11,520 \mathrm{~m}^{3}$ \\
\hline & & Princeton Plasma Physics Laboratory & & $4,030 \mathrm{~m}^{3}$ \\
\hline & & Brookhaven National Laboratory & & $3,090 \mathrm{~m}^{3}$ \\
\hline & & Fermi National Accelerator Lab. & & $1,520 \mathrm{~m}^{3}$ \\
\hline & & Stanford Linear Accelerator Center & & $1,170 \mathrm{~m}^{3}$ \\
\hline & & Rockwell-Canoga Park & & $1,150 \mathrm{~m}^{3}$ \\
\hline & & Battelle Columbus Laboratory & & $1,030 \mathrm{~m}^{3}$ \\
\hline & & University of California-Davis & & $980 \mathrm{~m}^{3}$ \\
\hline & & General Atomics & & $660 \mathrm{~m}^{3}$ \\
\hline
\end{tabular}


Table 2-7. Functional Inputs and Outputs. (41 sheets)

\begin{tabular}{|c|c|c|c|c|}
\hline \multicolumn{5}{|c|}{ Function X.1.1.1, Manage CH Cat I LLW (Continued) } \\
\hline Identifier & Title & From & $\begin{array}{l}\text { Function } \\
\text { number }\end{array}$ & Description \\
\hline \multirow[t]{14}{*}{ Input } & \multirow[t]{14}{*}{$\begin{array}{l}\text { CH Cat I LLW Generated from } \\
\text { Hanford Site Operations and } \\
\text { Offsite Facilities }\end{array}$} & Provide Analytical Services & $\mathrm{X} .4$ & $\begin{array}{l}\text { Analytical Services will generate } 14,650 \mathrm{~m}^{3} \text { of LLW from } 1997 \text { to the end } \\
\text { of the life cycle in } 2070 \text {. The annual generation of waste is constant at } \\
\text { about } 50 \mathrm{~m}^{3} / \mathrm{yr} \text { between } 1997 \text { and } 2032 \text {, and at about } 40 \mathrm{~m}^{3} / y \mathrm{yr} \text { between } \\
2033 \text { and } 2070 \text {. Waste can include nonarchived samples, by-products, and } \\
\text { other debris waste. A portion of the LLW will be CH Cat I LLW. }\end{array}$ \\
\hline & & 222-S Analytical Laboratory & & $14,590 \mathrm{~m}^{3}$ \\
\hline & & $6266 \mathrm{WSCF}$ & & $60 \mathrm{~m}^{3}$ \\
\hline & & PNNL & & $\begin{array}{l}\text { PNNL, will generate } 7,880 \mathrm{~m}^{3} \text { of LLW during the normal laboratory } \\
\text { operations most of which involve the } 300 \text { Area, which will be closed } \\
\text { down by } 2010 \text {. A portion of this LLW will be CH Cat I LLW. }\end{array}$ \\
\hline & & Facility Transitions & & $\begin{array}{l}\text { Facility Transitions will generate } 6,470 \mathrm{~m}^{3} \text { of LLW during deactivation } \\
\text { activities of those facilities that are no longer in the operational phase. As } \\
\text { stored material and wastes are removed, the facilities will be deactivated } \\
\text { and transferred to the D\&D program. The forecasted life cycle for waste } \\
\text { generated by Facility Transitions extends to } 2034 \text {. Types of waste } \\
\text { generated within this program include operational/maintenance waste, } \\
\text { deactivation waste, and surveillance and maintenance waste, with the } \\
\text { latter being a minimal contributor. A portion of the projected LLW } \\
\text { generated will be CH Cat I LLW. }\end{array}$ \\
\hline & & $2345 Z$ PFP & & $3,880 \mathrm{~m}^{3}$ \\
\hline & & 324 Building & & $690 \mathrm{~m}^{3}$ \\
\hline & & WESF & & $460 \mathrm{~m}^{3}$ \\
\hline & & 303K Fuels Fabrication Transition & & $400 \mathrm{~m}^{3}$ \\
\hline & & 202A PUREX Operation & & $390 \mathrm{~m}^{3}$ \\
\hline & & 225B B Plant & & $270 \mathrm{~m}^{3}$ \\
\hline & & 327 Building & & $220 \mathrm{~m}^{3}$ \\
\hline & & FFTF Transition Project & & $80 \mathrm{~m}^{3}$ \\
\hline & & 309 PRTR Vault Waste & & $70 \mathrm{~m}^{3}$ \\
\hline
\end{tabular}


Table 2-7. Functional Inputs and Outputs. (41 sheets)

\begin{tabular}{|c|c|c|c|c|}
\hline \multicolumn{5}{|c|}{ Function X.1.1.1, Manage CH Cat I LLW (Continued) } \\
\hline Identifier & Title & From & $\begin{array}{l}\text { Function } \\
\text { number }\end{array}$ & Description \\
\hline \multirow[t]{8}{*}{ Input } & \multirow[t]{8}{*}{$\begin{array}{l}\text { CH Cat I LLW Generated from } \\
\text { Hanford Site Operations and } \\
\text { Offsite Facilities }\end{array}$} & Manage Liquid Waste & $\mathrm{X} .2$ & $\begin{array}{l}\text { The Liquid Effluents program will generate } 5,490 \mathrm{~m}^{3} \text { of LLW during the } \\
\text { treatment of liquid effluents from the TWRS } 242-\mathrm{A} \text { Evaporator and from } \\
\text { the } 300 \text { Area. The forecasted life cycle for generators in this program } \\
\text { extends to } 2034 \text {. A portion of the forecasted LLW will be CH Cat I LLW. }\end{array}$ \\
\hline & & $\begin{array}{l}300 \text { Area/Treated Effluent Disposal } \\
\text { Facilities }\end{array}$ & & $5,410 \mathrm{~m}^{3}$ \\
\hline & & $\begin{array}{l}\text { C018H } 200 \text { Area Effluent Treatment } \\
\text { Facility }\end{array}$ & & $80 \mathrm{~m}^{3}$ \\
\hline & & Manage Solid Waste and Materials & $\mathrm{X} .1$ & $\begin{array}{l}\text { The Solid Waste program will generate } 3,500 \mathrm{~m}^{3} \text { of LLW while receiving, } \\
\text { storing, treating, decontaminating, and disposing of radioactive and } \\
\text { nonradioactive hazardous solid waste. The Solid Waste program is } \\
\text { forecasted to continue until } 2070 \text {. The LLW expected to be generated will } \\
\text { include a portion that is classified as CH Cat I LLW. }\end{array}$ \\
\hline & & $221 \mathrm{~T} / 2706 \mathrm{~T} \mathrm{~T}$ Plant Operations & & $3,070 \mathrm{~m}^{3}$ \\
\hline & & WRAP 1 & & $390 \mathrm{~m}^{3}$ \\
\hline & & 218E/W LLW Burial Grounds & & $40 \mathrm{~m}^{3}$ \\
\hline & & 224-T TRUSAF & & $2 m^{3}$ \\
\hline
\end{tabular}


Table 2-7. Functional Inputs and Outputs. (41 sheets)

\begin{tabular}{|c|c|c|c|c|}
\hline \multicolumn{5}{|c|}{ Function X.1.1.1, Manage CH Cat I LLW (Continued) } \\
\hline Identifier & Title & From & $\begin{array}{c}\text { Function } \\
\text { number }\end{array}$ & Description \\
\hline \multirow[t]{14}{*}{ Input } & \multirow[t]{14}{*}{$\begin{array}{l}\text { CH Cat I LLW Generated from } \\
\text { Hanford Site Operations and } \\
\text { Offsite Facilities }\end{array}$} & Non-Programmatic & & $\begin{array}{l}\text { Non-programmatic generators will contribute } 2,330 \mathrm{~m}^{3} \text { of LLW to the } \\
\text { waste stream. These generators include those not currently within the } \\
\text { Hanford Site program, and those with uncertainties regarding which } \\
\text { program is responsible for their future waste-generating activities } \\
\text { ("orphan" facilities). The forecasted life cycle for all non-programmatic } \\
\text { generators ends in 2037. A portion of each generator's LLW can contain } \\
\text { CH Cat I LLW. }\end{array}$ \\
\hline & & 300 Area Facilities Non-Transition & & $1,420 \mathrm{~m}^{3}$ \\
\hline & & REDOX Non-Transition & & $300 \mathrm{~m}^{3}$ \\
\hline & & PUREX Non-Transition & & $170 \mathrm{~m}^{3}$ \\
\hline & & 400 Area Facilities Non-Transition & & $100 \mathrm{~m}^{3}$ \\
\hline & & B Plant Non-Transition & & $90 \mathrm{~m}^{3}$ \\
\hline & & T Plant Non-Transition & & $80 \mathrm{~m}^{3}$ \\
\hline & & PFP Non-Transition & & $70 \mathrm{~m}^{3}$ \\
\hline & & Site Support Non-Transition & & $50 \mathrm{~m}^{3}$ \\
\hline & & U Plant Non-Transition & & $30 \mathrm{~m}^{3}$ \\
\hline & & SNF & & $\begin{array}{l}\text { The SNF Project will generate } 1,990 \mathrm{~m}^{3} \text { of LLW. Solid waste is } \\
\text { generated during disposition of SNFs at } \mathrm{K} \text { Basins. The life cycle of SNFs } \\
\text { ends in } 2000 \text {. A portion of the LLW generated can contain CH Cat I } \\
\text { LLW. }\end{array}$ \\
\hline & & K Basins Fuel Sampling Project & & $1,030 \mathrm{~m}^{3}$ \\
\hline & & 100K K Basins Operations & & $960 \mathrm{~m}^{3}$ \\
\hline & & RCRA Monitoring & & $\begin{array}{l}\text { A total of } 130 \mathrm{~m}^{3} \text { of } \mathrm{LLW} \text { is expected to be generated as a result of well } \\
\text { drilling. RCRA } \\
\text { potential contamination to ensure that radioactive and hazardous materials } \\
\text { are not leaving the Hanford Site. Such drilling activity is expected to } \\
\text { continue until } 2070 \text {, but due to the planned breakup of Hanford Technical } \\
\text { Services, the forecasted waste generated only extends to } 2001 \text {. }\end{array}$ \\
\hline
\end{tabular}


Table 2-7. Functional Inputs and Outputs. (41 sheets)

\begin{tabular}{|c|c|c|c|c|}
\hline \multicolumn{5}{|c|}{ Function X.1.1.1, Manage CH Cat I LLW (Continued) } \\
\hline Identifier & Title & From & $\begin{array}{l}\text { Function } \\
\text { number }\end{array}$ & Description \\
\hline Input & $\begin{array}{l}\text { CH Cat I LLW Generated from } \\
\text { Hanford Site Operations and } \\
\text { Offsite Facilities }\end{array}$ & D\&D and ER (EM-40) & & $\begin{array}{l}\text { D\&D volume estimates have not been provided for any facilities that are } \\
\text { not on the Surplus Facilities List. Therefore, D\&D waste generated } \\
\text { during D\&D of future facilities and tank farms is not estimated at this } \\
\text { time. Such facilities include the High-Level Vitrification Plant, PUREX } \\
\text { tunnels, tank farms, and other facilities not on the Surplus Facilities List. } \\
\text { LLW is not expected to be generated when ER activities are performed. }\end{array}$ \\
\hline \multirow[t]{2}{*}{ Input } & \multirow[t]{2}{*}{$\begin{array}{l}\text { Waste Reclassified as CH Cat I } \\
\text { LLW in the Manage Solid Waste } \\
\text { and Materials Function (X.1) }\end{array}$} & Manage CH Cat III LLW & $\mathrm{X} .1 .1 .2$ & $\begin{array}{l}\text { During nondestructive examination/nondestructive assay and/or sorting } \\
\text { operations of CH Cat III LLW, some waste may warrant reclassification } \\
\text { as CH Cat I LLW. }\end{array}$ \\
\hline & & Manage CH TRU/TRUM & $\mathrm{X} .1 .3 .1$ & $\begin{array}{l}\text { During nondestructive examination/mondestructive assay and/or sorting } \\
\text { operations of CH TRU/TRUM, some waste may warrant reclassification } \\
\text { as CH Cat I LLW. }\end{array}$ \\
\hline Identifier & Title & To & $\begin{array}{l}\text { Function } \\
\text { number }\end{array}$ & Description \\
\hline Output & Disposition-Ready LLW & Manage LLW Disposal Site & $X .1 .1 .5$ & $\begin{array}{l}\text { Packaged CH Cat I LLW ready for disposition to the proper burial } \\
\text { ground. Eight burial grounds (218-E-10, 218-E-12B, 218-W-3A, } \\
218-W-3 A E, 218-W-4 B, 218-W-4 C, 218-W-5 \text {, and } 218-W-6) \text { are } \\
\text { potential receptors for the waste. }\end{array}$ \\
\hline Output & Contaminated equipment & Manage Contaminated Equipment & $\mathrm{X} .1 .5$ & $\begin{array}{l}\text { Equipment used in the Manage CH Cat I LLW function (X.1.1.1) } \\
\text { requiring decontamination and repair before it is ready for disposition or } \\
\text { reuse. }\end{array}$ \\
\hline Output & By-Product CH Cat I LLW & Manage LLW Disposal Site & $X .1 .1 .5$ & $\begin{array}{l}\text { Containers, debris, overpack, and other CH Cat I LLW generated during } \\
\text { Function X.1.1.1 that are ready for disposition to the proper burial ground. } \\
\text { Eight burial grounds (218-E-10, 218-E-12B, 218-W-3A, 218-W-3AE, } \\
218-\mathrm{W}-4 \mathrm{~B}, 218-\mathrm{W}-4 \mathrm{C}, 218-\mathrm{W}-5 \text {, and } 218-\mathrm{W}-6) \text { are potential receptors } \\
\text { for the waste. }\end{array}$ \\
\hline
\end{tabular}


Table 2-7. Functional Inputs and Outputs. (41 sheets)

\begin{tabular}{|c|c|c|c|c|}
\hline \multicolumn{5}{|c|}{ Function X.1.1.2, Manage CH Cat III LLW } \\
\hline Identifier & Title & From & $\begin{array}{c}\text { Function } \\
\text { number }\end{array}$ & Description \\
\hline \multirow[t]{17}{*}{ Input } & \multirow[t]{17}{*}{$\begin{array}{l}\text { CH Cat III LLW Generated from } \\
\text { Hanford Site Operations and } \\
\text { Offsite Facilities }\end{array}$} & TWRS & & $\begin{array}{l}\text { The TWRS Project will generate } 63,600 \mathrm{~m}^{3} \text { of LLW during retrieval and } \\
\text { processing of HLW from the Hanford Site tanks. The TWRS forecasted } \\
\text { life cycle ends in } 2032 \text {, while most activity will be completed by } 2028 \text {. A } \\
\text { portion of the LLW generated during TWRS operations will be CH Cat III } \\
\text { LLW. }\end{array}$ \\
\hline & & Low-Level Vitrification Project & & $34,560 \mathrm{~m}^{3}$ \\
\hline & & High-Level Vitrification Project & & $20,880 \mathrm{~m}^{3}$ \\
\hline & & SST/DST Tank Farm Operations & & $7,490 \mathrm{~m}^{3}$ \\
\hline & & SST Retrieval (149 tanks) & & $600 \mathrm{~m}^{3}$ \\
\hline & & Tank Farm Restoration & & $60 \mathrm{~m}^{3}$ \\
\hline & & Offsite & & $\begin{array}{l}\text { Offisite programs or facilities are forecasted to send } 46,500 \mathrm{~m}^{3} \text { of LLW to } \\
\text { the Hanford Site from } 1997 \text { to } 2070 \text {. A certain portion of this LLW will } \\
\text { be CH Cat III. The following are the top ten LLW contributors. }\end{array}$ \\
\hline & & Argonne National Laboratory-East & & $20,040 \mathrm{~m}^{3}$ \\
\hline & & Lawrence Berkeley Laboratory & & $11,520 \mathrm{~m}^{3}$ \\
\hline & & Princeton Plasma Physics Laboratory & & $4,030 \mathrm{~m}^{3}$ \\
\hline & & Brookhaven National Laboratory & & $3,090 \mathrm{~m}^{3}$ \\
\hline & & Fermi National Accelerator Lab. & & $1,520 \mathrm{~m}^{3}$ \\
\hline & & Stanford Linear Accelerator Center & & $1,170 \mathrm{~m}^{3}$ \\
\hline & & Rockwell-Canoga Park & & $1,150 \mathrm{~m}^{3}$ \\
\hline & & Battelle Columbus Laboratory & & $1,030 \mathrm{~m}^{3}$ \\
\hline & & University of California-Davis & & $980 \mathrm{~m}^{3}$ \\
\hline & & General Atomics & & $660 \mathrm{~m}^{3}$ \\
\hline
\end{tabular}


Table 2-7. Functional Inputs and Outputs. (41 sheets)

\begin{tabular}{|c|c|c|c|c|}
\hline \multicolumn{5}{|c|}{ Function X.1.1.2, Manage CH Cat III LLW (Continued) } \\
\hline Identifier & Title & From & $\begin{array}{c}\text { Function } \\
\text { number }\end{array}$ & Description \\
\hline \multirow[t]{14}{*}{ Input } & \multirow[t]{14}{*}{$\begin{array}{l}\text { CH Cat III LLW Generated from } \\
\text { Hanford Site Operations and } \\
\text { Offsite Facilities }\end{array}$} & Provide Analytical Services & $\mathrm{X} .4$ & $\begin{array}{l}\text { Analytical Services will generate } 14,640 \mathrm{~m}^{3} \text { of LLW from } 1997 \text { to the end } \\
\text { of the life cycle in } 2070 \text {. The annual generation of waste is constant at } \\
\text { about } 50 \mathrm{~m}^{3} / \mathrm{yr} \text { between } 1997 \text { and } 2032 \text {, and at about } 40 \mathrm{~m}^{3} / \mathrm{yr} \text { between } \\
2033 \text { and } 2070 \text {. Waste can include nonarchived samples, by-products, } \\
\text { and other debris waste. A portion of the LLW will be CH Cat III LLW. }\end{array}$ \\
\hline & & 222-S Analytical Laboratory & & $14,590 \mathrm{~m}^{3}$ \\
\hline & & 6266 WSCF & & $60 \mathrm{~m}^{3}$ \\
\hline & & PNNL & & $\begin{array}{l}\text { PNNL will generate } 7,880 \mathrm{~m}^{3} \text { of LLW during the normal laboratory } \\
\text { operations most of which involve the } 300 \text { Area, which will be closed } \\
\text { down by } 2010 \text {. A portion of this LLW will be CH Cat III LLW. }\end{array}$ \\
\hline & & Facility Transitions & & $\begin{array}{l}\text { Facility Transitions will generate } 6,470 \mathrm{~m}^{3} \text { of LLW during deactivation } \\
\text { activities of those facilities that are no longer in the operational phase. As } \\
\text { stored material and wastes are removed, the facilities will be deactivated } \\
\text { and transferred to the D\&D program. The forecasted life cycle for waste } \\
\text { generated by Facility Transitions extends to } 2034 \text {. Types of waste } \\
\text { generated within this program include operational/maintenance waste, } \\
\text { deactivation waste, and surveillance and maintenance waste, with the } \\
\text { latter being a minimal contributor. A portion of the projected LLW } \\
\text { generated will be CH Cat III LLW. }\end{array}$ \\
\hline & & $2345 Z$ PFP & & $3,880 \mathrm{~m}^{3}$ \\
\hline & & 324 Building & & $690 \mathrm{~m}^{3}$ \\
\hline & & WESF & & $460 \mathrm{~m}^{3}$ \\
\hline & & 303K Fuels Fabrication Transition & & $400 \mathrm{~m}^{3}$ \\
\hline & & 202A PUREX Operation & & $390 \mathrm{~m}^{3}$ \\
\hline & & 225B B Plant & & $270 \mathrm{~m}^{3}$ \\
\hline & & 327 Building & & $220 \mathrm{~m}^{3}$ \\
\hline & & FFTF Transition Project & & $80 \mathrm{~m}^{3}$ \\
\hline & & 309 PRTR Vault Waste & & $70 \mathrm{~m}^{3}$ \\
\hline
\end{tabular}


Table 2-7. Functional Inputs and Outputs. (41 sheets)

\begin{tabular}{|c|c|c|c|c|}
\hline \multicolumn{5}{|c|}{ Function X.1.1.2, Manage CH Cat III LLW (Continued) } \\
\hline Identifier & Title & From & $\begin{array}{l}\text { Function } \\
\text { number }\end{array}$ & Description \\
\hline \multirow[t]{8}{*}{ Input } & \multirow[t]{8}{*}{$\begin{array}{l}\text { CH Cat III LLW Generated from } \\
\text { Hanford Site Operations and } \\
\text { Offsite Facilities }\end{array}$} & Manage Liquid Waste & $\mathrm{X} .2$ & $\begin{array}{l}\text { The Liquid Effluents program will generate } 5,490 \mathrm{~m}^{3} \text { of } L L W \text { during the } \\
\text { treatment of liquid effluents from the TWRS } 242 \text {-A Evaporator and from } \\
\text { the } 300 \text { Area. The forecasted life cycle for generators in this program } \\
\text { extends to 2034. A portion of the forecasted LLW will be CH Cat III } \\
\text { LLW. }\end{array}$ \\
\hline & & $\begin{array}{l}300 \text { Area/Treated Effluent Dispasal } \\
\text { Facilities }\end{array}$ & & $5,410 \mathrm{~m}^{3}$ \\
\hline & & $\begin{array}{l}\text { C018H } 200 \text { Area Effluent Treatment } \\
\text { Facility }\end{array}$ & & $80 \mathrm{~m}^{3}$ \\
\hline & & Manage Solid Waste and Materials & $\mathrm{X} .1$ & $\begin{array}{l}\text { The Solid Waste program will generate } 3,500 \mathrm{~m}^{3} \text { of LLW while receiving, } \\
\text { storing, treating, decontaminating, and dispasing of radioactive and } \\
\text { nonradioactive hazardous solid waste. The Solid Waste program is } \\
\text { forecasted to continue until } 2070 \text {. The LLW expected to be generated will } \\
\text { include a portion that is classified as CH Cat III LLW. }\end{array}$ \\
\hline & & 221T/2706T T Plant Operations & & $3,070 \mathrm{~m}^{3}$ \\
\hline & & WRAP I & & $390 \mathrm{~m}^{3}$ \\
\hline & & 218E/W LLW Burial Grounds & & $40 \mathrm{~m}^{3}$ \\
\hline & & 224-T TRUSAF & & $2 \mathrm{~m}^{3}$ \\
\hline
\end{tabular}


Table 2-7. Functional Inputs and Outputs. (41 sheets)

\begin{tabular}{|c|c|c|c|c|}
\hline \multicolumn{5}{|c|}{ Function X.1.1.2, Manage CH Cat III LLW (Continued) } \\
\hline Identifier & Title & From & $\begin{array}{l}\text { Function } \\
\text { number }\end{array}$ & Description \\
\hline \multirow[t]{14}{*}{ Input } & \multirow[t]{14}{*}{$\begin{array}{l}\text { CH Cat III LLW Generated from } \\
\text { Hanford Site Operations and } \\
\text { Offsite Facilities }\end{array}$} & Non-Programmatic & & $\begin{array}{l}\text { Non-programmatic generators will contribute } 2,330 \mathrm{~m}^{3} \text { of LLW to the } \\
\text { waste stream. These generators include those not currently within the } \\
\text { Hanford Site program, and those with uncertainties regarding which } \\
\text { program is responsible for their future waste-generating activities } \\
\text { ("orphan" facilities). The forecasted life cycle for all non-programmatic } \\
\text { generators ends in 2037. A portion of each generator's LLW can contain } \\
\text { CH Cat III LLW. }\end{array}$ \\
\hline & & 300 Area Facilities Non-Transition & & $1,420 \mathrm{~m}^{3}$ \\
\hline & & REDOX Non-Transition & & $300 \mathrm{~m}^{3}$ \\
\hline & & PUREX Non-Transition & & $170 \mathrm{~m}^{3}$ \\
\hline & & 400 Area Facilities Non-Transition & & $100 \mathrm{~m}^{3}$ \\
\hline & & B Plant Non-Transition & & $90 \mathrm{~m}^{3}$ \\
\hline & & T Plant Non-Transition & & $80 \mathrm{~m}^{3}$ \\
\hline & & PFP Non-Transition & & $70 \mathrm{~m}^{3}$ \\
\hline & & Site Support Non-Transition & & $50 \mathrm{~m}^{3}$ \\
\hline & & U Plant Non-Transition & & $30 \mathrm{~m}^{3}$ \\
\hline & & SNF & & $\begin{array}{l}\text { SNF will generate } 1,990 \mathrm{~m}^{3} \text { of LLW. Solid waste is generated during } \\
\text { disposition of SNFs at K Basins. The life cycle of SNFs ends in } 2000 \text {. A } \\
\text { portion of the LLW generated can contain CH Cat III LLW. }\end{array}$ \\
\hline & & K Basins Fuel Sampling Project & & $1,030 \mathrm{~m}^{3}$ \\
\hline & & 100K K Basins Operations & & $960 \mathrm{~m}^{3}$ \\
\hline & & RCRA $^{2}$ Monitoring & & $\begin{array}{l}\text { A total of } 130 \mathrm{~m}^{3} \text { of } L L W \text { is expected to be generated as a result of well } \\
\text { drilling. RCRA }{ }^{2} \text { Monitoring well drilling is monitoring groundwater for } \\
\text { potential contamination to ensure that radioactive and hazardous materials } \\
\text { are not leaving the Hanford Site. Such drilling activity is expected to } \\
\text { continue until } 2070 \text { but due to the planned breakup of Hanford Technical } \\
\text { Services, the forecasted waste generated only extends to } 2001 \text {. }\end{array}$ \\
\hline
\end{tabular}


Table 2-7. Functional Inputs and Outputs. (41 sheets)

\begin{tabular}{|c|c|c|c|c|}
\hline \multicolumn{5}{|c|}{ Function X.1.1.2, Manage CH Cat III LLW (Continued) } \\
\hline Identifier & Title & From & $\begin{array}{l}\text { Function } \\
\text { number }\end{array}$ & Description \\
\hline Input & $\begin{array}{l}\text { CH Cat III LLW Generated from } \\
\text { Hanford Site Operations and } \\
\text { Offsite Facilities }\end{array}$ & D\&D and ER (EM-40) & & $\begin{array}{l}\text { D\&D volume estimates have not been provided for any facilities that are } \\
\text { not on the Surplus Facilities List. Therefore, D\&D waste generated } \\
\text { during D\&D of future facilities and tank farms is not estimated at this } \\
\text { time. Such facilities include the High-Level Vitrification Plant, PUREX } \\
\text { tunnels, tank farms, and other facilities not on the Surplus Facilities List. } \\
\text { LLW is not expected to be generated when ER activities are performed. }\end{array}$ \\
\hline Input & $\begin{array}{l}\text { Waste Reclassified as CH Cat III } \\
\text { LLW in the Manage Solid Waste } \\
\text { and Materials Function (X.1) }\end{array}$ & Manage CH TRU/TRUM & $\mathrm{X} .1 .3 .1$ & $\begin{array}{l}\text { During nondestructive examination/nondestructive assay and/or sorting } \\
\text { operations of CH TRU/TRUM, some waste may warrant reclassification } \\
\text { as CH Cat III LLW. }\end{array}$ \\
\hline Identifier & Title & To & $\begin{array}{l}\text { Function } \\
\text { number }\end{array}$ & Description \\
\hline Output & Disposition-Ready LLW & Manage LLW Disposal Site & X.1.1.5 & $\begin{array}{l}\text { Packaged CH Cat III LLW ready for disposition to the proper burial } \\
\text { ground. Eight burial grounds }(218-\mathrm{E}-10,218-\mathrm{E}-12 \mathrm{~B}, 218-\mathrm{W}-3 \mathrm{~A}, 218-\mathrm{W} \text { - } \\
3 \mathrm{AE}, 218-\mathrm{W}-4 \mathrm{~B}, 218-\mathrm{W}-4 \mathrm{C}, 218-\mathrm{W}-5,218-\mathrm{W}-6) \text { are potential receptors } \\
\text { for the waste. }\end{array}$ \\
\hline Output & Contaminated Equipment & Manage Contaminated Equipment & X.1.5 & $\begin{array}{l}\text { Equipment used in the Manage CH Cat III LLW function (X.1.1.2) } \\
\text { requiring decontamination and repair before it is ready for disposition or } \\
\text { reuse. }\end{array}$ \\
\hline Output & By-Product CH Cat III LLW & Manage LLW Disposal Site & $\mathrm{X} .1 .1 .5$ & $\begin{array}{l}\text { Containers, debris, overpack, and other CH Cat III LLW generated during } \\
\text { Function X.1.1.2 that are ready for disposition to the proper burial ground. } \\
\text { Eight burial grounds (218-E-10, 218-E-12B, 218-W-3A, 218-W-3AE, } \\
218-\mathrm{W}-4 \mathrm{~B}, 218-\mathrm{W}-4 \mathrm{C}, 218-\mathrm{W}-5,218-\mathrm{W}-6) \text { are potential receptors for the } \\
\text { waste. }\end{array}$ \\
\hline
\end{tabular}


Table 2-7. Functional Inputs and Outputs. (41 sheets)

\begin{tabular}{|c|c|c|c|c|}
\hline \multicolumn{5}{|c|}{ Function X.1.1.3, Manage RH Cat I LLW } \\
\hline Identifier & Title & From & $\begin{array}{l}\text { Function } \\
\text { number }\end{array}$ & Description \\
\hline \multirow[t]{17}{*}{ Input } & \multirow[t]{17}{*}{$\begin{array}{l}\text { RH Cat I LLW Generated from } \\
\text { Hanford Site Operations and } \\
\text { Offsite Facilities }\end{array}$} & TWRS & & $\begin{array}{l}\text { The TWRS Project will generate } 63,600 \mathrm{~m}^{3} \text { of LLW during retrieval and } \\
\text { processing of HLW from the Hanford Site tanks. The TWRS forecasted } \\
\text { life cycle ends in } 2032 \text {, while most activity will be completed by } 2028 \text {. A } \\
\text { portion of the LLW generated during TWRS operations will be RH Cat I } \\
\mathrm{LLW} \text {. }\end{array}$ \\
\hline & & Low-Level Vitrification Project & & $34,560 \mathrm{~m}^{3}$ \\
\hline & & High-Level Vitrification Project & & $20,880 \mathrm{~m}^{3}$ \\
\hline & & SST/DST Tank Farm Operations & & $7,490 \mathrm{~m}^{3}$ \\
\hline & & SST Retrieval (149 tanks) & & $600 \mathrm{~m}^{3}$ \\
\hline & & Tank Farm Restoration & & $60 \mathrm{~m}^{3}$ \\
\hline & & Offsite & & $\begin{array}{l}\text { Offsite programs or facilities are forecasted to send } 46,500 \mathrm{~m}^{3} \text { of LLW to } \\
\text { the Hanford Site from } 1997 \text { to } 2070 \text {. A certain portion of this LLW will } \\
\text { be RH Cat I. The following are the top ten LLW contributors. }\end{array}$ \\
\hline & & Argonne National Laboratory-East & & $20,040 \mathrm{~m}^{3}$ \\
\hline & & Lawrence Berkeley Laboratory & & $11,520 \mathrm{~m}^{3}$ \\
\hline & & Princeton Plasma Physies Laboratory & & $4,030 \mathrm{~m}^{3}$ \\
\hline & & Brookhaven National Laboratory & & $3,090 \mathrm{~m}^{3}$ \\
\hline & & Fermi National Accelerator Lab. & & $1,520 \mathrm{~m}^{3}$ \\
\hline & & Stanford Linear Accelerator Center & & $1,170 \mathrm{~m}^{3}$ \\
\hline & & Rockwell-Canoga Park & & $1,150 \mathrm{~m}^{3}$ \\
\hline & & Battelle Columbus Laboratory & & $1,030 \mathrm{~m}^{3}$ \\
\hline & & University of California-Davis & & $980 \mathrm{~m}^{3}$ \\
\hline & & General Atomics & & $660 \mathrm{~m}^{3}$ \\
\hline
\end{tabular}


Table 2-7. Functional Inputs and Outputs. (41 sheets)

\begin{tabular}{|c|c|c|c|c|}
\hline \multicolumn{5}{|c|}{ Function X.1.1.3, Manage RH Cat I LLW (Continued) } \\
\hline Identifier & Title & From & $\begin{array}{c}\text { Function } \\
\text { number }\end{array}$ & Description \\
\hline \multirow[t]{14}{*}{ Input } & \multirow[t]{14}{*}{$\begin{array}{l}\text { RH Cat I LLW Generated from } \\
\text { Hanford Site Operations and } \\
\text { Offsite Facilities }\end{array}$} & Provide Analytical Services & $\mathrm{X} .4$ & $\begin{array}{l}\text { Analytical Services will generate } 14,640 \mathrm{~m}^{3} \text { of LLW from } 1997 \text { to the end } \\
\text { of the life cycle in } 2070 \text {. The annual generation of waste is constant at } \\
\text { about } 50 \mathrm{~m}^{3} / y \mathrm{x} \text { between } 1997 \text { and } 2032 \text {, and at about } 40 \mathrm{~m}^{3} / \mathrm{yr} \text { between } \\
2033 \text { and } 2070 \text {. Waste can include nonarchived samples, by-products, } \\
\text { and other debris waste. A portion of the LLW will be RH Cat I LLW. }\end{array}$ \\
\hline & & 222-S Analytical Laboratory & & $14,590 \mathrm{~m}^{3}$ \\
\hline & & $6266 \mathrm{WSCF}$ & & $60 \mathrm{~m}^{3}$ \\
\hline & & PNNL & & $\begin{array}{l}\text { PNNL will generate } 7,880 \mathrm{~m}^{3} \text { of LLW during the normal laboratory } \\
\text { operations most of which involve the } 300 \text { Area, which will be closed } \\
\text { down by } 2010 \text {. A portion of this LLW will be RH Cat I LLW. }\end{array}$ \\
\hline & & Facility Transitions & & $\begin{array}{l}\text { Facility Transitions will generate } 6,470 \mathrm{~m}^{3} \text { of LLW during deactivation } \\
\text { activities of those facilities that are no longer in the operational phase. As } \\
\text { stored material and wastes are removed, the facilities will be deactivated } \\
\text { and transferred to the D\&D program. The forecasted life cycle for waste } \\
\text { generated by Facility Transitions extends to } 2034 \text {. Types of waste } \\
\text { generated within this program include operational/maintenance waste, } \\
\text { deactivation waste, and surveillance and maintenance waste, with the } \\
\text { latter being a minimal contributor. A portion of the projected LLW } \\
\text { generated will be RH Cat I LLW. }\end{array}$ \\
\hline & & $2345 Z$ PFP & & $3,880 \mathrm{~m}^{3}$ \\
\hline & & 324 Building & & $690 \mathrm{~m}^{3}$ \\
\hline & & WESF & & $460 \mathrm{~m}^{3}$ \\
\hline & & 303K Fuels Fabrication Transition & & $400 \mathrm{~m}^{3}$ \\
\hline & & 202A PUREX Operation & & $390 \mathrm{~m}^{3}$ \\
\hline & & 225B B Plant & & $270 \mathrm{~m}^{3}$ \\
\hline & & 327 Building & & $220 \mathrm{~m}^{3}$ \\
\hline & & FFTF Transition Project & & $80 \mathrm{~m}^{3}$ \\
\hline & & 309 PRTR Vault Waste & & $70 \mathrm{~m}^{3}$ \\
\hline
\end{tabular}


Table 2-7. Functional Inputs and Outputs. (41 sheets)

\begin{tabular}{|c|c|c|c|c|}
\hline \multicolumn{5}{|c|}{ Function X.1.1.3, Manage RH Cat I LLW (Continued) } \\
\hline Identifier & Title & From & $\begin{array}{l}\text { Function } \\
\text { number }\end{array}$ & Description \\
\hline \multirow[t]{8}{*}{ Input } & \multirow[t]{8}{*}{$\begin{array}{l}\text { RH Cat I LLW Generated from } \\
\text { Hanford Site Operations and } \\
\text { Offsite Facilities }\end{array}$} & Manage Liquid Waste & $\mathrm{X} .2$ & $\begin{array}{l}\text { The Liquid Effluents program will generate } 5,490 \mathrm{~m}^{3} \text { of LLW during the } \\
\text { treatment of liquid effluents from the TWRS } 242-\mathrm{A} \text { Evaporator and from } \\
\text { the } 300 \text { Area. The forecasted life cycle for generators in this program } \\
\text { extends to 2034. A portion of the forecasted LLW will be RH Cat I LLW. }\end{array}$ \\
\hline & & $\begin{array}{l}300 \text { Area/Treated Effluent Disposal } \\
\text { Facilities }\end{array}$ & & $5,410 \mathrm{~m}^{3}$ \\
\hline & & $\begin{array}{l}\text { C018H } 200 \text { Area Effluent } \\
\text { Treatment Facility }\end{array}$ & & $80 \mathrm{~m}^{3}$ \\
\hline & & Manage Solid Waste and Materials & $X .1$ & $\begin{array}{l}\text { The Solid Waste program will generate } 3,500 \mathrm{~m}^{3} \text { of } L L W \text { while receiving, } \\
\text { storing, treating, decontaminating, and disposing of radioactive and } \\
\text { nonradioactive hazardous solid waste. The Solid Waste program is } \\
\text { forecasted to continue until } 2070 \text {. The LLW expected to be generated will } \\
\text { include a portion that is classified as RH Cat I LLW. }\end{array}$ \\
\hline & & $221 \mathrm{~T} / 2706 \mathrm{~T} \mathrm{~T}$ Plant Operations & & $3,070 \mathrm{~m}^{3}$ \\
\hline & & WRAP 1 & & $390 \mathrm{~m}^{3}$ \\
\hline & & 218E/W LLW Burial Grounds & & $40 \mathrm{~m}^{3}$ \\
\hline & & 224-T TRUSAF & & $2 \mathrm{~m}^{3}$ \\
\hline
\end{tabular}


Table 2-7. Functional Inputs and Outputs. (41 sheets)

\begin{tabular}{|c|c|c|c|c|}
\hline \multicolumn{5}{|c|}{ Function X.1.1.3, Manage RH Cat I LLW (Continued) } \\
\hline Identifier & Title & From & $\begin{array}{l}\text { Function } \\
\text { number }\end{array}$ & Description \\
\hline \multirow[t]{14}{*}{ Input } & \multirow[t]{14}{*}{$\begin{array}{l}\text { RH Cat I LLW Generated from } \\
\text { Hanford Site Operations and } \\
\text { Offsite Facilities }\end{array}$} & Non-Programmatic & & $\begin{array}{l}\text { Non-programmatic generators will contribute } 2,330 \mathrm{~m}^{3} \text { of LLW to the } \\
\text { waste stream. These generators include those not currently within the } \\
\text { Hanford Site program, and those with uncertainties regarding which } \\
\text { program is responsible for their future waste-generating activities } \\
\text { "orphan" facilities). The forecasted life cycle for all non-programmatic } \\
\text { generators ends in 2037. A portion of each generator's LLW can contain } \\
\text { RH Cat I LLW. }\end{array}$ \\
\hline & & 300 Area Facilities Non-Transition & & $1,420 \mathrm{~m}^{3}$ \\
\hline & & REDOX Non-Transition & & $300 \mathrm{~m}^{3}$ \\
\hline & & PUREX Non-Transition & & $170 \mathrm{~m}^{3}$ \\
\hline & & 400 Area Facilities Non-Transition & & $100 \mathrm{~m}^{3}$ \\
\hline & & B Plant Non-Transition & & $90 \mathrm{~m}^{3}$ \\
\hline & & $\dot{\mathrm{T}}$ Plant Non-Transition & & $80 \mathrm{~m}^{3}$ \\
\hline & & PFP Non-Transition & & $70 \mathrm{~m}^{3}$ \\
\hline & & Site Support Non-Transition & & $50 \mathrm{~m}^{3}$ \\
\hline & & U Plant Non-Transition & & $30 \mathrm{~m}^{3}$ \\
\hline & & SNF & & $\begin{array}{l}\text { SNF will generate } 1,990 \mathrm{~m}^{3} \text { of LLW. Solid waste is generated during } \\
\text { disposition of SNFs at K Basins. The life cycle of SNFs ends in } 2000 \text {. A } \\
\text { portion of the LLW generated can contain RH Cat I LLW. }\end{array}$ \\
\hline & & K Basins Fuel Sampling Project & & $1,030 \mathrm{~m}^{3}$ \\
\hline & & $100 \mathrm{~K} \mathrm{~K}$ Basins Operations & & $960 \mathrm{~m}^{3}$ \\
\hline & & $\mathrm{RCRA}^{2}$ Monitoring & & $\begin{array}{l}\text { A total of } 130 \mathrm{~m}^{3} \text { of } \mathrm{LLW} \text { is expected to be generated as a result of well } \\
\text { drilling. RCRA } \mathrm{A}^{\mathrm{a}} \text { Monitoring well drilling is monitoring groundwater for } \\
\text { potential contamination to ensure that radioactive and hazardous materials } \\
\text { are not leaving the Hanford Site. Such drilling activity is expected to } \\
\text { continue until } 2070 \text { but due to the planned breakup of Hanford Technical } \\
\text { Services, the forecasted waste generated only extends to } 2001 \text {. }\end{array}$ \\
\hline
\end{tabular}


Table 2-7. Functional Inputs and Outputs. (41 sheets)

\begin{tabular}{|c|c|c|c|c|}
\hline \multicolumn{5}{|c|}{ Function X.1.1.3, Manage RH Cat I LLW (Continued) } \\
\hline Identifier & Title & From & $\begin{array}{l}\text { Function } \\
\text { number }\end{array}$ & Description \\
\hline Input & $\begin{array}{l}\text { RH Cat I LLW Generated from } \\
\text { Hanford Site Operations and } \\
\text { Offsite Facilities }\end{array}$ & D\&D and ER (EM-40) & & $\begin{array}{l}\text { D\&D volume estimates have not been provided for any facilities that are } \\
\text { not on the Surplus Facilities List. Therefore, D\&D waste generated } \\
\text { during D\&D of future facilities and tank farms is not estimated at this } \\
\text { time. Such facilities include the High-Level Vitrification Plant, PUREX } \\
\text { tunnels, tank farms, and other facilities not on the Surplus Facilities List. } \\
\text { LLW is not expected to be generated when ER activities are performed. }\end{array}$ \\
\hline \multirow[t]{2}{*}{ Input } & \multirow[t]{2}{*}{$\begin{array}{l}\text { Waste Reclassified as RH Cat I } \\
\text { LLW in the Manage Solid Waste } \\
\text { and Materials Function (X.1) }\end{array}$} & Manage RH Cat III LLW & $\mathrm{X} .1 .1 .4$ & $\begin{array}{l}\text { During nondestructive examination/nondestructive assay and/or sorting } \\
\text { operations of RH Cat III LLW, some waste may warrant reclassification } \\
\text { as RH Cat I LLW. }\end{array}$ \\
\hline & & Manage RH TRU/TRUM & $\mathrm{X} .1 .3 .2$ & $\begin{array}{l}\text { During nondestructive examination/nondestructive assay and/or sorting } \\
\text { operations of RH TRU/TRUM, some waste may warrant reclassification } \\
\text { as RH Cat I LLW. }\end{array}$ \\
\hline Identifier & Title & To & $\begin{array}{l}\text { Function } \\
\text { number }\end{array}$ & Description \\
\hline Output & Disposition-Ready LLW & Manage LLW Disposal Site & $\mathrm{X} .1 .1 .5$ & $\begin{array}{l}\text { Packaged RH Cat I LLW ready for disposition to the proper burial } \\
\text { ground. Eight burial grounds (218-E-10, 218-E-12B, 218-W-3A, 218-W- } \\
3 \mathrm{AE}, 218-\mathrm{W}-4 \mathrm{~B}, 218-\mathrm{W}-4 \mathrm{C}, 218-\mathrm{W}-5,218-\mathrm{W}-6) \text { are potential receptors } \\
\text { for the waste. }\end{array}$ \\
\hline Output & Contaminated Equipment & Manage Contaminated Equipment & $\mathrm{X} .1 .5$ & $\begin{array}{l}\text { Equipment used in the Manage RH Cat I LLW function (X.1.1.3) } \\
\text { requiring decontamination and repair before it is ready for disposition or } \\
\text { reuse. }\end{array}$ \\
\hline Output & By-Product RH Cat I LLW & Manage LLW Disposal Site & $\mathrm{X} .1 .1 .5$ & $\begin{array}{l}\text { Containers, debris, overpack, and other RH Cat I LLW generated during } \\
\text { Function X.1.1.3 that are ready for disposition to the proper burial ground, } \\
\text { Eight burial grounds (218-E-10, 218-E-12B, 218-W-3A, 218-W-3AE, } \\
218-W-4 B, 218-W-4 C, 218-W-5,218-W-6) \text { are potential receptors for the } \\
\text { waste. }\end{array}$ \\
\hline
\end{tabular}


Table 2-7. Functional Inputs and Outputs. (41 sheets)

\begin{tabular}{|c|c|c|c|c|}
\hline \multicolumn{5}{|c|}{ Function X.1.1.4, Manage RH Cat III LLW } \\
\hline Identifier & Title & From & $\begin{array}{l}\text { Function } \\
\text { number }\end{array}$ & Description \\
\hline \multirow[t]{17}{*}{ Input } & \multirow[t]{17}{*}{$\begin{array}{l}\text { RH Cat III LLW Generated from } \\
\text { Hanford Site Operations and } \\
\text { Offsite Facilities }\end{array}$} & TWRS & & $\begin{array}{l}\text { The TWRS Project will generate } 63,600 \mathrm{~m}^{3} \text { of LLW during retrieval and } \\
\text { processing of HLW from the Hanford Site tanks. The TWRS forecasted } \\
\text { life cycle ends in } 2032 \text {, while most activity will be completed by } 2028 \text {. A } \\
\text { portion of the LLW generated during TWRS operations will be RH Cat III } \\
\text { ILW. }\end{array}$ \\
\hline & & Low-Level Vitrification Project & & $34,560 \mathrm{~m}^{3}$ \\
\hline & & High-Level Vitrification Project & & $20,880 \mathrm{~m}^{3}$ \\
\hline & & SST/DST Tank Farm Operations & & $7,490 \mathrm{~m}^{3}$ \\
\hline & & SST Retrieval (149 tanks) & & $600 \mathrm{~m}^{3}$ \\
\hline & & Tank Farm Restoration & & $60 \mathrm{~m}^{3}$ \\
\hline & & Offsite & & $\begin{array}{l}\text { Offsite programs or facilities are forecasted to send } 46,500 \mathrm{~m}^{3} \text { of LLW to } \\
\text { the Hanford Site from } 1997 \text { to } 2070 \text {. A certain portion of this LLW will } \\
\text { be RH Cat III. The following are the top ten LLW contributors. }\end{array}$ \\
\hline & & Argonne National Laboratory-East & & $20,040 \mathrm{~m}^{3}$ \\
\hline & & Lawrence Berkeley Laboratory & & $11,520 \mathrm{~m}^{3}$ \\
\hline & & Princeton Plasma Physics Laboratory & & $4,030 \mathrm{~m}^{3}$ \\
\hline & & Brookhaven National Laboratory & & $3,090 \mathrm{~m}^{3}$ \\
\hline & & Fermi National Accelerator Lab. & & $1,520 \mathrm{~m}^{3}$ \\
\hline & & Stanford Linear Accelerator Center & & $1,170 \mathrm{~m}^{3}$ \\
\hline & & Rockwell-Canoga Park & & $1,150 \mathrm{~m}^{3}$ \\
\hline & & Battelle Columbus Laboratory & & $1,030 \mathrm{~m}^{3}$ \\
\hline & & University of California-Davis & & $980 \mathrm{~m}^{3}$ \\
\hline & & General Atomics & & $660 \mathrm{~m}^{3}$ \\
\hline
\end{tabular}


Table 2-7. Functional Inputs and Outputs. (41 sheets)

\begin{tabular}{|c|c|c|c|c|}
\hline \multicolumn{5}{|c|}{ Function X.1.1.4, Manage RH Cat III LLW (Continued) } \\
\hline Identifier & Title & From & $\begin{array}{l}\text { Function } \\
\text { number }\end{array}$ & Description \\
\hline \multirow[t]{14}{*}{ Input } & \multirow[t]{14}{*}{$\begin{array}{l}\text { RH Cat III LLW Generated from } \\
\text { Hanford Site Operations and } \\
\text { Offsite Facilities }\end{array}$} & Provide Analytical Services & $X .4$ & $\begin{array}{l}\text { Analytical Services will generate } 14 ; 640 \mathrm{~m}^{3} \text { of LLW from } 1997 \text { to the end } \\
\text { of the life cycle in } 2070 \text {. The annual generation of waste is constant at } \\
\text { about } 50 \mathrm{~m}^{3} / \mathrm{yr} \text { between } 1997 \text { and } 2032 \text {, and at about } 40 \mathrm{~m}^{3} / \mathrm{yr} \text { between } \\
2033 \text { and } 2070 \text {. Waste can include nonarchived samples, by-products, } \\
\text { and other debris waste. A portion of the LLW will be RH Cat III LLW. }\end{array}$ \\
\hline & & 222-S Analytical Laboratory & & $14,590 \mathrm{~m}^{3}$ \\
\hline & & $6266 \mathrm{WSCF}$ & & $60 \mathrm{~m}^{3}$ \\
\hline & & PNNL & & $\begin{array}{l}\text { PNNL will generate } 7,880 \mathrm{~m}^{3} \text { of LLW during the normal laboratory } \\
\text { operations most of which involve the } 300 \text { Area, which will be closed } \\
\text { down by } 2010 \text {. A portion of this LLW will be RH Cat III LLW. }\end{array}$ \\
\hline & & Facility Transitions & & $\begin{array}{l}\text { Facility Transitions will generate } 6,470 \mathrm{~m}^{3} \text { of LLW during deactivation } \\
\text { activities of those facilities that are no longer in the operational phase. As } \\
\text { stored material and wastes are removed, the facilities will be deactivated } \\
\text { and transferred to the D\&D program. The forecasted life cycle for waste } \\
\text { generated by Facility Transitions extends to } 2034 \text {. Types of waste } \\
\text { generated within this program include operational/maintenance waste, } \\
\text { deactivation waste, and surveillance and maintenance waste, with the } \\
\text { latter being a minimal contributor. A portion of the projected LLW } \\
\text { generated will be RH Cat III LLW. }\end{array}$ \\
\hline & & $2345 Z \mathrm{PFP}$ & & $3,880 \mathrm{~m}^{3}$ \\
\hline & & 324 Building & & $690 \mathrm{~m}^{3}$ \\
\hline & & WESF & & $460 \mathrm{~m}^{3}$ \\
\hline & & 303K Fuels Fabrication Transition & & $400 \mathrm{~m}^{3}$ \\
\hline & & 202A PUREX Operation & & $390 \mathrm{~m}^{3}$ \\
\hline & & 225B B Plant & & $270 \mathrm{~m}^{3}$ \\
\hline & & 327 Building & & $220 \mathrm{~m}^{3}$ \\
\hline & & FFTF Transition Project & & $80 \mathrm{~m}^{3}$ \\
\hline & & 309 PRTR Vault Waste & & $70 \mathrm{~m}^{3}$ \\
\hline
\end{tabular}


Table 2-7. Functional Inputs and Outputs. (41 sheets)

\begin{tabular}{|c|c|c|c|c|}
\hline \multicolumn{5}{|c|}{ Function X.1.1.4, Manage RH Cat III LLW (Continued) } \\
\hline Identifier & Title & From & $\begin{array}{l}\text { Function } \\
\text { number }\end{array}$ & Description \\
\hline \multirow[t]{8}{*}{ Input } & \multirow[t]{8}{*}{$\begin{array}{l}\text { RH Cat IIL LLW Generated from } \\
\text { Hanford Site Operations and } \\
\text { Offsite Facilities }\end{array}$} & Manage Liquid Waste & $X .2$ & $\begin{array}{l}\text { The Liquid Effluents program will generate } 5,490 \mathrm{~m}^{3} \text { of LLW during the } \\
\text { treatment of liquid effluents from the TWRS } 242 \text {-A Evaporator and from } \\
\text { the } 300 \text { Area. The forecasted life cycle for generators in this program } \\
\text { extends to } 2034 \text {. A portion of the forecasted LLW will be RH Cat III } \\
\text { LLW. }\end{array}$ \\
\hline & & $\begin{array}{l}300 \text { Area/Treated Effluent Disposal } \\
\text { Facilities }\end{array}$ & & $5,410 \mathrm{~m}^{3}$ \\
\hline & & $\begin{array}{l}\text { C018H } 200 \text { Area Effluent Treatment } \\
\text { Facility }\end{array}$ & & $80 \mathrm{~m}^{3}$ \\
\hline & & Manage Solid Waste and Materials & $\mathrm{X} .1$ & $\begin{array}{l}\text { The Solid Waste program will generate } 3,500 \mathrm{~m}^{3} \text { of LLW while receiving, } \\
\text { storing, treating, decontaminating, and disposing of radioactive and } \\
\text { nonradioactive hazardous solid waste. The Solid Waste program is } \\
\text { forecasted to continue until } 2070 \text {. The LLW expected to be generated will } \\
\text { include a portion that is classified as RH Cat III LLW. }\end{array}$ \\
\hline & & 221T/2706T T Plant Operations & & $3,070 \mathrm{~m}^{3}$ \\
\hline & & WRAP 1 & & $390 \mathrm{~m}^{3}$ \\
\hline & & 218E/W LLW Burial Grounds & & $40 \mathrm{~m}^{3}$ \\
\hline & & 224-T TRUSAF & & $2 \mathrm{~m}^{3}$ \\
\hline
\end{tabular}


Table 2-7. Functional Inputs and Outputs. (41 sheets)

\begin{tabular}{|c|c|c|c|c|}
\hline \multicolumn{5}{|c|}{ Function X.1.1.4, Manage RH Cat III LLW (Continued) } \\
\hline Identifier & Title & From & $\begin{array}{l}\text { Function } \\
\text { number }\end{array}$ & Description \\
\hline \multirow[t]{14}{*}{ Input } & \multirow[t]{14}{*}{$\begin{array}{l}\text { RH Cat III LLW Generated from } \\
\text { Hanford Site Operations and } \\
\text { Offsite Facilities }\end{array}$} & Non-Programmatic & & $\begin{array}{l}\text { Non-programmatic generators will contribute } 2,330 \mathrm{~m}^{3} \text { of LLW to the } \\
\text { waste stream. These generators include those not currently within the } \\
\text { Hanford Site program, and those with uncertainties regarding which } \\
\text { program is responsible for their future waste-generating activities } \\
\text { ("orphan" facilities). The forecasted life cycle for all non-programmatic } \\
\text { generators ends in 2037. A portion of each generator's LLW can contain } \\
\text { RH Cat II LLW. }\end{array}$ \\
\hline & & 300 Area Facilities Non-Transition & & $1,420 \mathrm{~m}^{3}$ \\
\hline & & REDOX Non-Transition & & $300 \mathrm{~m}^{3}$ \\
\hline & & PUREX Non-Transition & & $170 \mathrm{~m}^{3}$ \\
\hline & & 400 Area Facilities Non-Transition & & $100 \mathrm{~m}^{3}$ \\
\hline & & B Plant Non-Transition & & $90 \mathrm{~m}^{3}$ \\
\hline & & T Plant Non-Transition & & $80 \mathrm{~m}^{3}$ \\
\hline & & PFP Non-Transition & & $70 \mathrm{~m}^{3}$ \\
\hline & & Site Support Non-Transition & & $50 \mathrm{~m}^{3}$ \\
\hline & & U Plant Non-Transition & & $30 \mathrm{~m}^{3}$ \\
\hline & & SNF & & $\begin{array}{l}\text { SNF will generate } 1,990 \mathrm{~m}^{3} \text { of LLW. Solid waste is generated during } \\
\text { disposition of SNFs at } \mathrm{K} \text { Basins. The life cycle of SNFs ends in } 2000 \text {. A } \\
\text { portion of the LLW generated can contain RH Cat III LLW. }\end{array}$ \\
\hline & & K Basins Fuel Sampling Project & & $1,030 \mathrm{~m}^{3}$ \\
\hline & & 100K K Basins Operations & & $960 \mathrm{~m}^{3}$ \\
\hline & & RCRA $^{*}$ Monitoring & & $\begin{array}{l}\text { A. total of } 130 \mathrm{~m}^{3} \text { of LLW is expected to be generated as a result of well } \\
\text { drilling. RCRA Monitoring well drilling is monitoring groundwater for } \\
\text { potential contamination to ensure that radioactive and hazardous materials } \\
\text { are not leaving the Hanford Site. Such drilling activity is expected to } \\
\text { continue until } 2070 \text { but due to the planned breakup of Hanford Technical } \\
\text { Services, the forecasted waste generated only extends to } 2001 \text {. }\end{array}$ \\
\hline
\end{tabular}


Table 2-7. Functional Inputs and Outputs. (41 sheets)

\begin{tabular}{|c|c|c|c|c|}
\hline \multicolumn{5}{|c|}{ Function X.1.1.4, Manage RH Cat III LLW (Continued) } \\
\hline Identifier & Title & From & $\begin{array}{l}\text { Function } \\
\text { number }\end{array}$ & Description \\
\hline Input & $\begin{array}{l}\text { RH Cat III LLW Generated from } \\
\text { Hanford Site Operations and } \\
\text { Offsite Facilities. }\end{array}$ & D\&D and ER (EM-40) & & $\begin{array}{l}\text { D\&D volume estimates have not been provided for any facilities that are } \\
\text { not on the Surplus Facilities List. Therefore, D\&D waste generated } \\
\text { during D\&D of future facilities and tank farms is not estimated at this } \\
\text { time. Such facilities include the High-Level Vitrification Plant, PUREX } \\
\text { tunnels, tank farms, and other facilities not on the Surplus Facilities List. } \\
\text { LLW is not expected to be generated when ER activities are performed. }\end{array}$ \\
\hline Input & $\begin{array}{l}\text { Waste Reclassified as RH Cat III } \\
\text { LLW in the Manage Solid Waste } \\
\text { and Materials Function (X.1) }\end{array}$ & Manage RH TRU/TRUM & X.1.3.1 & $\begin{array}{l}\text { During nondestructive examination/nondestructive assay and/or sorting } \\
\text { operations of RH TRU/TRUM, some waste may warrant reclassification } \\
\text { as RH Cat III LLW. }\end{array}$ \\
\hline Identifier & Title & To & $\begin{array}{l}\text { Function } \\
\text { number }\end{array}$ & Description \\
\hline Output & Disposition-Ready LLW & Manage LLW Disposal Site & X.1.1.5 & $\begin{array}{l}\text { Packaged RH Cat III LLW ready for disposition to the proper burial } \\
\text { ground. Eight burial grounds (218-E-10, 218-E-12B, 218-W-3A, 218-W- } \\
3 \mathrm{AE}, 218-\mathrm{W}-4 \mathrm{~B}, 218-\mathrm{W}-4 \mathrm{C}, 218-\mathrm{W}-5,218-\mathrm{W}-6) \text { are potential receptors } \\
\text { for the waste. }\end{array}$ \\
\hline Output & $\begin{array}{l}\text { Waste Reclassified as RH Cat I } \\
\text { LLW in the Manage Solid Waste } \\
\text { and Materials function (X.1) }\end{array}$ & Manage RH Cat I LLW & $\mathrm{X} .1 .1 .3$ & $\begin{array}{l}\text { During nondestructive examination/nondestructive assay and/or sorting } \\
\text { operations of RH Cat III LLW, some waste may warrant reclassification } \\
\text { as RH Cat I LLW. }\end{array}$ \\
\hline Output & Contaminated Equipment & Manage Contaminated Equipment & $\mathrm{X} .1 .5$ & $\begin{array}{l}\text { Equipment used in the Manage RH Cat III LLW function (X.1.1.4) } \\
\text { requiring decontamination and repair before it is ready for disposition or } \\
\text { reuse. }\end{array}$ \\
\hline Output & By-Product RH Cat III LLW & Manage LLW Disposal Site & X.1.1.5 & $\begin{array}{l}\text { Containers, debris, overpack, and other RH Cat III LLW generated during } \\
\text { Function X.1.1.4 that are ready for disposition to the proper burial ground. } \\
\text { Eight burial grounds (218-E-10, 218-E-12B, 218-W-3A, 218-W-3AE, } \\
\text { 218-W-4B, 218-W-4C, 218-W-S, 218-W-6) are potential receptors for the } \\
\text { waste. }\end{array}$ \\
\hline \multicolumn{5}{|c|}{ Function X.1.1.5, Manage LLW Disposal Site } \\
\hline Identifier & Title & From & $\begin{array}{l}\text { Function } \\
\text { number }\end{array}$ & Description \\
\hline Input & Disposition-Ready CH Cat I LLW & Manage CH Cat I LLW & X.1.1.1 & $\begin{array}{l}\text { Packaged CH Cat I LLW ready for disposition to the proper burial } \\
\text { ground. }\end{array}$ \\
\hline Input & $\begin{array}{l}\text { Disposition-Ready CH Cat III } \\
\text { LLW }\end{array}$ & Manage CH Cat III LLW & X.1.1.2 & $\begin{array}{l}\text { Packaged CH Cat III LLW ready for disposition to the proper burial } \\
\text { ground. }\end{array}$ \\
\hline
\end{tabular}


Table 2-7. Functional Inputs and Outputs. (41 sheets)

\begin{tabular}{|c|c|c|c|c|}
\hline \multicolumn{5}{|c|}{ Function X.1.1.5, Manage LLW Disposal Site (Continued) } \\
\hline Input & Disposition-Ready RH Cat I LLW & Manage RH Cat I LLW & $\mathrm{X} .1 .1 .3$ & $\begin{array}{l}\text { Packaged RH Cat I LLW ready for disposition to the proper burial } \\
\text { ground. }\end{array}$ \\
\hline Input & $\begin{array}{l}\text { Disposition-Ready RH Cat III } \\
\text { LLW }\end{array}$ & Manage RH Cat III LLW & $X .1 .1 .4$ & $\begin{array}{l}\text { Packaged RH Cat III LLW ready for disposition to the proper burial } \\
\text { ground. }\end{array}$ \\
\hline Identifier & Title & To & $\begin{array}{c}\text { Function } \\
\text { number }\end{array}$ & Description \\
\hline Output & Contaminated Equipment & Manage Contaminated Equipment & $X .1 .5$ & $\begin{array}{l}\text { Equipment used in the Manage LLW Disposal Site function (X.1.1.5) } \\
\text { requiring decontamination and repair before it is ready for disposition or } \\
\text { reuse. }\end{array}$ \\
\hline \multicolumn{5}{|c|}{ Function X.1.1.6, Manage GTCIII LLW } \\
\hline Identiffer & Title & From & $\begin{array}{c}\text { Function } \\
\text { number }\end{array}$ & Description \\
\hline Input & $\begin{array}{l}\text { GTCIII LLW Generated from } \\
\text { Hanford Site Operations and } \\
\text { Offsite Facilities }\end{array}$ & PNNL and DST Retrieval & & $\begin{array}{l}\text { Both programs have changed planning assumptions, thus no GTCIII LLW } \\
\text { is forecasted. }\end{array}$ \\
\hline
\end{tabular}


Table 2-7. Functional Inputs and Outputs. (41 sheets)

\begin{tabular}{|c|c|c|c|c|}
\hline \multicolumn{5}{|c|}{ Function X.1.2.1, Manage CH MLLW } \\
\hline Identifier & Title & From & $\begin{array}{l}\text { Function } \\
\text { number }\end{array}$ & Description \\
\hline \multirow[t]{17}{*}{ Input } & \multirow[t]{17}{*}{$\begin{array}{l}\text { CH MLLW Generated from } \\
\text { Hanford Site Operations and } \\
\text { Offsite Facilities }\end{array}$} & TWRS & & $\begin{array}{l}\text { The TWRS Project will generate } 18,260 \mathrm{~m}^{3} \text { of CH MLLW during retrieval } \\
\text { and processing of HLW from the Hanford Site tanks. The TWRS } \\
\text { forecasted life cycle ends in } 2032 \text {, while most activity will be completed } \\
\text { by } 2028 \text {. }\end{array}$ \\
\hline & & High-Level Vitriffcation Project & & $5,220 \mathrm{~m}^{3}$ \\
\hline & & Low-Level Vitrification Project & & $5,120 \mathrm{~m}^{3}$ \\
\hline & & SST/OST Tank Farm Operations & & $3,760 \mathrm{~m}^{3}$ \\
\hline & & W343 DST Retrieval (17 tanks) & & $1,480 \mathrm{~m}^{3}$ \\
\hline & & SST Retrieval (149 tanks) & & $890 \mathrm{~m}^{3}$ \\
\hline & & Tank Farm Restoration & & $880 \mathrm{~m}^{3}$ \\
\hline & & DST Retrieval Systems (10 tanks) & & $870 \mathrm{~m}^{3}$ \\
\hline & & Tank Farm Ventilation Upgrade & & $40 \mathrm{~m}^{3}$ \\
\hline & & Cross-Site Transfer System & & $5 \mathrm{~m}^{3}$ \\
\hline & & Non-Programmatic & & $\begin{array}{l}\text { Non-programmatic generators will contribute } 4,190 \mathrm{~m}^{3} \text { of CH MLLW to } \\
\text { the waste stream. These generators include those not currently within the } \\
\text { Hanford Site program, and those with uncertainties regarding which } \\
\text { program is responsible for their future waste-generating activities } \\
\text { ("orphan" facilities). The forecasted life cycle for all non-programmatic } \\
\text { generators ends in } 2037 \text {. }\end{array}$ \\
\hline & & Stored Equipment & & $4,000 \mathrm{~m}^{3}$ \\
\hline & & PFP Non-Transition & & $80 \mathrm{~m}^{3}$ \\
\hline & & 300 Area Facilities Non-Transition & & $60 \mathrm{~m}^{3}$ \\
\hline & & PUREX Non-Transition & & $40 \mathrm{~m}^{3}$ \\
\hline & & REDOX Non-Transition & & $2 \mathrm{~m}^{3}$ \\
\hline & & U Plant Non-Transition. & & $3 \mathrm{~m}^{3}$ \\
\hline
\end{tabular}


Table 2-7. Functional Inputs and Outputs. (41 sheets)

\begin{tabular}{|c|c|c|c|c|}
\hline \multicolumn{5}{|c|}{ Function X.1.2.1, Manage CH MLLW (Continued) } \\
\hline Identifier & Title & From & $\begin{array}{c}\text { Function } \\
\text { number }\end{array}$ & Description \\
\hline \multirow[t]{15}{*}{ Input } & \multirow[t]{15}{*}{$\begin{array}{l}\text { CH MLLW Generated from } \\
\text { Hanford Site Operations and } \\
\text { Offsite Facilities }\end{array}$} & Provide Analytical Services & $\mathrm{X} .4$ & $\begin{array}{l}\text { Analytical Services will generate } 3,600 \mathrm{~m}^{3} \text { of CH MLLW from } 1997 \text { to } \\
\text { the end of the life cycle in } 2070 \text {. The annual generation of all waste is } \\
\text { constant at about } 50 \mathrm{~m}^{3} / \mathrm{yr} \text { between } 1997 \text { and } 2032 \text {, and at about } 40 \mathrm{~m}^{3} / \mathrm{yr} \\
\text { between } 2033 \text { and } 2070 \text {. Waste can include nonarchived samples, by- } \\
\text { products, and other debris waste. }\end{array}$ \\
\hline & & 222-S Analytical Laboratory & & $3,570 \mathrm{~m}^{3}$ \\
\hline & & 6266 WSCF & & $30 \mathrm{~m}^{3}$ \\
\hline & & Manage Liquid Waste & $\mathrm{X} .2$ & $\begin{array}{l}\text { The Liquid Effluents program will generate } 2,540 \mathrm{~m}^{3} \text { of } \mathrm{CHMLLW} \\
\text { during the treatment of liquid effluents from the TWRS } 242 \text {-A Evaporator } \\
\text { and from the } 300 \text { Area. The forecasted life cycle for generators in this } \\
\text { program extends to } 2034 \text {. }\end{array}$ \\
\hline & & $\begin{array}{l}\text { C018H } 200 \text { Area Effluent Treatment } \\
\text { Facility }\end{array}$ & & $2,540 \mathrm{~m}^{3}$ \\
\hline & & Facility Transitions & & $\begin{array}{l}\text { Facility Transitions will generate } 770 \mathrm{~m}^{3} \text { of CH MLLW during } \\
\text { deactivation activities of those facilities that are no longer in the } \\
\text { operational phase. As stored material and wastes are removed, the } \\
\text { facilities will be deactivated and transferred to the D\&D program. The } \\
\text { forecasted life cycle for waste generated by Facility Transitions extends to } \\
\text { 2034. Types of waste generated within this program include } \\
\text { operational/maintenance waste, deactivation waste, and surveillance and } \\
\text { maintenance waste, with the latter being a minimal contributor. }\end{array}$ \\
\hline & & 2345Z PFP & & $710 \mathrm{~m}^{3}$ \\
\hline & & WESF & & $30 \mathrm{~m}^{3}$ \\
\hline & & 324 Building & & $20 \mathrm{~m}^{3}$ \\
\hline & & 202A PUREX Operation & & $10 \mathrm{~m}^{3}$ \\
\hline & & 327 Building & & $4 \mathrm{~m}^{3}$ \\
\hline & & 225B B Plant & & $2 \mathrm{~m}^{3}$ \\
\hline & & 309 PRTR Vault Waste & & $1 \mathrm{~m}^{3}$ \\
\hline & & 335 Sodium Test Facility & & $1 \mathrm{~m}^{3}$ \\
\hline & & FFTF Transition Project & & $1 \mathrm{~m}^{3}$ \\
\hline
\end{tabular}


Table 2-7. Functional Inputs and Outputs. (41 sheets)

\begin{tabular}{|c|c|c|c|c|}
\hline \multicolumn{5}{|c|}{ Function X.1.2.1, Manage CH MLLW (Continued) } \\
\hline Identifier & Title & From & $\begin{array}{c}\text { Function } \\
\text { number }\end{array}$ & Description \\
\hline \multirow[t]{17}{*}{ Input } & \multirow[t]{17}{*}{$\begin{array}{l}\text { CHMLLW Generated from } \\
\text { Hanford Site Operations and } \\
\text { Offsite Facilities }\end{array}$} & PNNL & & $\begin{array}{l}\text { PNNL will generate } 490 \mathrm{~m}^{3} \text { of CH MLLW during the normal laboratory } \\
\text { operations most of which involve the } 300 \text { Area, which will be closed } \\
\text { down by } 2010 \text {. }\end{array}$ \\
\hline & & Manage Solid Waste and Materials & $\mathrm{X} .1$ & $\begin{array}{l}\text { The Solid Waste program will generate } 310 \mathrm{~m}^{3} \text { of CH MLLW while } \\
\text { receiving, storing, treating, decontaminating, and disposing of radioactive } \\
\text { and nonradioactive hazardous solid waste. The Solid Waste program is } \\
\text { forecasted to continue until } 2070 \text {. }\end{array}$ \\
\hline & & $221 \mathrm{~T} / 2706 \mathrm{~T} \mathrm{~T}$ Plant Operations & & $220 \mathrm{~m}^{3}$ \\
\hline & & WRAP 1 & & $80 \mathrm{~m}^{3}$ \\
\hline & & CWC & & $20 \mathrm{~m}^{3}$ \\
\hline & & 224-T TRUSAF & & $2 m^{3}$ \\
\hline & & Offsite & & $\begin{array}{l}\text { Offsite programs or facilities are forecasted to send } 200 \mathrm{~m}^{3} \text { of CH MLLW } \\
\text { to the Hanford Site from } 1997 \text { to } 2070 \text {. }\end{array}$ \\
\hline & & Princeton Plasma Physics Laboratory & & $60 \mathrm{~m}^{3}$ \\
\hline & & Rockwell-Canoga Park & & $50 \mathrm{~m}^{3}$ \\
\hline & & Puget Sound Naval Shipyards & & $30 \mathrm{~m}^{3}$ \\
\hline & & Paducha Energy Systems & & $20 \mathrm{~m}^{3}$ \\
\hline & & Knolls Atomic Power Laboratory & & $10 \mathrm{~m}^{3}$ \\
\hline & & Battelle Columbus Laboratory & & $8 \mathrm{~m}^{3}$ \\
\hline & & General Atomics & & $7 \mathrm{~m}^{3}$ \\
\hline & & University of Utah & & $7 \mathrm{~m}^{3}$ \\
\hline & & Pearl Harbor Naval Shipyards & & $5 \mathrm{~m}^{3}$ \\
\hline & & Portsmouth Energy Systerns & & $1 \mathrm{~m}^{3}$ \\
\hline
\end{tabular}


Table 2-7. Functional Inputs and Outputs. (41 sheets)

\begin{tabular}{|c|c|c|c|c|}
\hline \multicolumn{5}{|c|}{ Function X.1.2.1, Manage CH MLLW (Continued) } \\
\hline Identifier & Title & From & $\begin{array}{l}\text { Function } \\
\text { number }\end{array}$ & Description \\
\hline \multirow[t]{6}{*}{ Input } & \multirow[t]{6}{*}{$\begin{array}{l}\text { CH MLLW Generated from } \\
\text { Hanford Site Operations and } \\
\text { Offsite Facilities }\end{array}$} & RCRA Monitoring & & $\begin{array}{l}\text { A total of } 130 \mathrm{~m}^{3} \text { of CH MLLW is expected to be generated as a result of } \\
\text { well drilling. RCRA' Monitoring well driling is monitoring groundwater } \\
\text { for potential contamination to ensure that radioactive and hazardous } \\
\text { materials are not leaving the Hanford Site. Such drilling activity is } \\
\text { expected to continue until } 2070 \text { but due to the planned breakup of Hanford } \\
\text { Technical Services, the forecasted waste generated only extends to } 2001 \text {. }\end{array}$ \\
\hline & & ER (EM-40) & & $\begin{array}{l}\text { Surplus Facilities performs cleanup activities to preserve, protect, or } \\
\text { restore the Hanford Site to allow for other beneficial uses. Surplus } \\
\text { Facilities' activity will continue until 200l; however, the ER program will } \\
\text { continue after this time. }\end{array}$ \\
\hline & & Surplus Facilities & & $10 \mathrm{~m}^{3}$ \\
\hline & & SNF & & $\begin{array}{l}\text { MLLW is generated during disposition of SNFs at K Basins. The life } \\
\text { cycle of SNFs ends in } 2000 \text {. }\end{array}$ \\
\hline & & $100 \mathrm{~K} \mathrm{~K}$ Basins Operations & & $5 \mathrm{~m}^{3}$ \\
\hline & & D\&D & & $\begin{array}{l}\text { D\&D volume estimates have not been provided for any facilities that are } \\
\text { not on the Surplus Facilities List. Therefore, D\&D waste generated } \\
\text { during D\&D of future facilities and tank farms is not estimated at this } \\
\text { time. Such facilities include the High-Level Vitrification Plant, PUREX } \\
\text { tunnels, tank farms, and other facilities not on the Surplus Facilities List. }\end{array}$ \\
\hline Input & $\begin{array}{l}\text { Waste Reclassified as CH MLLW } \\
\text { in the Manage Solid Waste and } \\
\text { Materials Function (X.1) }\end{array}$ & Manage CH TRU/TRUM & X.1.3.1 & $\begin{array}{l}\text { During nondestructive examination/nondestructive assay and/or sorting } \\
\text { operations of CH TRU/TRUM, some waste may warrant reclassification } \\
\text { as CH MLLW. }\end{array}$ \\
\hline Identifier & Title & To & $\begin{array}{l}\text { Function } \\
\text { number }\end{array}$ & Description \\
\hline Output & Disposition-Ready MLLW & Manage MLLW Disposal Site & $\mathrm{X} .1 .2 .4$ & Packaged CH MLLW ready for disposition to the MLLW disposal site. \\
\hline Output & Contaminated Equipment & Manage Contaminated Equipment & $\mathrm{X} .1 .5$ & $\begin{array}{l}\text { Equipment used in the Manage CH LLW function (X.1.2.1) requiring } \\
\text { decontamination and repair before it is ready for disposition or reuse. }\end{array}$ \\
\hline Output & By-Product RH Cat III LLW & Manage MLLW Disposal Site & $\mathrm{X} .1 .2 .4$ & $\begin{array}{l}\text { Containers, debris, overpack, and other CH MLLW generated during } \\
\text { Function X.1.1.4 that are ready for disposition to the MLLW disposal } \\
\text { trench. }\end{array}$ \\
\hline
\end{tabular}


Table 2-7. Functional Inputs and Outputs. (41 sheets)

\begin{tabular}{|c|c|c|c|c|}
\hline \multicolumn{5}{|c|}{ Function X.1.2.2, Manage RH Cat I MLLW } \\
\hline Identifier & Title & From & $\begin{array}{l}\text { Function } \\
\text { number }\end{array}$ & Description \\
\hline \multirow[t]{13}{*}{ Input } & \multirow[t]{13}{*}{$\begin{array}{l}\text { RH MLLW Generated from } \\
\text { Hanford Site Operations and } \\
\text { Offsite Facilities }\end{array}$} & TWRS & & $\begin{array}{l}\text { The TWRS Project will generate a total of } 29,040 \mathrm{~m}^{3} \text { of RH MLLW } \\
\text { during retrieval and processing of } \mathrm{HLW} \text { from the Hanford Site tanks. The } \\
\text { TWRS forecasted life cycle ends in } 2032 \text {, while most activity will be } \\
\text { completed by } 2028 \text {. A portion of this waste will be RH Cat I MLLW. }\end{array}$ \\
\hline & & SST Long-Length Equipment & & $22,520 \mathrm{~m}^{3}$ \\
\hline & & DST Retrieval Systems (10 tanks) & & $3,050 \mathrm{~m}^{3}$ \\
\hline & & W343 DST Retrieval (17 tanks) & & $1,760 \mathrm{~m}^{3}$ \\
\hline & & SST/DST Tank Farm Operations & & $940 \mathrm{~m}^{3}$ \\
\hline & & SST Retrieval (149 tanks) & & $390 \mathrm{~m}^{3}$ \\
\hline & & Tank Farm Restoration & & $380 \mathrm{~m}^{3}$ \\
\hline & & \begin{tabular}{|l|} 
Facility Transitions \\
\end{tabular} & & $\begin{array}{l}\text { Facility Transitions will generate } 70 \mathrm{~m}^{3} \text { of RH MLLW during deactivation } \\
\text { activities of those facilities that are no longer in the operational phase. As } \\
\text { stored material and wastes are removed, the facilities will be deactivated } \\
\text { and transferred to the D\&D program. The forecasted life cycle for waste } \\
\text { generated by Facility Transitions extends to } 2034 \text {. Types of waste } \\
\text { generated within this program include operational/maintenance waste, } \\
\text { deactivation waste, and surveillance and maintenance waste, with the } \\
\text { latter being a minimal contributor. A portion of the RH MLLW generated } \\
\text { by this program will be RH Cat I MCLW. }\end{array}$ \\
\hline & & $300 \mathrm{~K}$ Fuels Fabrication Transition & & $70 \mathrm{~m}^{3}$ \\
\hline & & PNNL & & $\begin{array}{l}\text { PNNL will generate } 50 \mathrm{~m}^{3} \text { of RH MLLW during the normal laboratory } \\
\text { operations most of which involve the } 300 \text { Area, which will be closed } \\
\text { down by } 2010 \text {. A portion of this waste will be RH Cat IMLLW. }\end{array}$ \\
\hline & & Offsite & & $\begin{array}{l}\text { Offsite programs or facilities are forecasted to send } 5 \mathrm{~m}^{3} \text { of RH MLLW to } \\
\text { the Hanford Site from } 1997 \text { to } 2070 \text {. A portion of this waste will be RH } \\
\text { Cat I MLLW. }\end{array}$ \\
\hline & & Knolls Atomic Power Laboratory & & $5 \mathrm{~m}^{3}$ \\
\hline & & D\&D & & $\begin{array}{l}\text { D\&D volume estimates have not been provided for any facilities that are } \\
\text { not on the Surplus Facilities List. Therefore, D\&D waste generated } \\
\text { during D\&D of future facilities and tank farms is not estimated at this } \\
\text { time. Such facilities include the High-Level Vitrification Plant, PUREX } \\
\text { tunnels, tank farms, and other facilities not on the Surplus Facilities List. }\end{array}$ \\
\hline
\end{tabular}


Table 2-7. Functional Inputs and Outputs. (41 sheets)

\begin{tabular}{|c|c|c|c|c|}
\hline \multicolumn{5}{|c|}{ Function X.1.2.2, Manage RH Cat I MLLW (Continued) } \\
\hline Identifier & Title & From & $\begin{array}{l}\text { Function } \\
\text { number }\end{array}$ & Description \\
\hline \multirow[t]{2}{*}{ Input } & \multirow{2}{*}{$\begin{array}{l}\text { Waste Reclassified as RH Cat I } \\
\text { MCLW in the Manage Solid } \\
\text { Waste and Materials Function } \\
\text { (X.1) }\end{array}$} & Manage RH Cat III MLLW & $\mathrm{X} .1 .2 .3$ & $\begin{array}{l}\text { During nondestructive examination/nondestructive assay and/or sorting } \\
\text { operations of RH Cat III MLLW, some waste may warrant reclassification } \\
\text { as RH Cat I MLLW. }\end{array}$ \\
\hline & & Manage RH TRU/TRUM & $\mathrm{X} .1 .3 .2$ & $\begin{array}{l}\text { During nondestructive examination/nondestructive assay and/or sorting } \\
\text { operations of RH TRU/TRUM, some waste may warrant reclassification } \\
\text { as RH MLLW. }\end{array}$ \\
\hline Identifier & Title & To & $\begin{array}{c}\text { Function } \\
\text { number }\end{array}$ & Description \\
\hline Output & $\begin{array}{l}\text { Disposition-Ready RH Cat I } \\
\text { MLLW }\end{array}$ & Manage MLLW Disposal Site & X.1.2.4 & $\begin{array}{l}\text { Packaged RH Cat I MLLW ready for disposal in the mixed waste disposal } \\
\text { trench. }\end{array}$ \\
\hline Output & Contaminated Equipment & Manage Contaminated Equipment & $\mathrm{X} .1 .5$ & $\begin{array}{l}\text { Equipment used in the Manage RH Cat I MLLW function (X.1.2.2) } \\
\text { requiring decontamination and repair before it is ready for disposition or } \\
\text { reuse. }\end{array}$ \\
\hline Output & By-Product RH Cat III LLW & Manage MLLW Disposal Site & X.1.2.4 & $\begin{array}{l}\text { Containers, debris, overpack, and other RH MLLW generated during } \\
\text { Function X.1.2.2 that are ready for disposition to the MLLW disposal site. }\end{array}$ \\
\hline
\end{tabular}


Table 2-7. Functional Inputs and Outputs. (41 sheets)

\begin{tabular}{|c|c|c|c|c|}
\hline \multicolumn{5}{|c|}{ Function X.1.2.3, Manage RH Cat III MLLW } \\
\hline Identifier & Title & From & $\begin{array}{l}\text { Function } \\
\text { number }\end{array}$ & Description \\
\hline \multirow[t]{13}{*}{ Input } & \multirow[t]{13}{*}{$\begin{array}{l}\text { RH MLLW Generated from } \\
\text { Hanford Site Operations and } \\
\text { Offsite Facilities }\end{array}$} & TWRS & & $\begin{array}{l}\text { The TWRS Project will generate a total of } 29,040 \mathrm{~m}^{3} \text { of RH MLLW } \\
\text { during retrieval and processing of HLW from the Hanford Site tanks. The } \\
\text { TWRS forecasted life cycle ends in } 2032 \text {, while most activity will be } \\
\text { completed by 2028. A portion of this waste will be RH Cat III MLLW. }\end{array}$ \\
\hline & & SST Long-Length Equipment & & $22,520 \mathrm{~m}^{3}$ \\
\hline & & DST Retrieval Systems (10 tanks) & & $3,050 \mathrm{~m}^{3}$ \\
\hline & & W343 DST Retrieval (17 tanks) & & $1,760 \mathrm{~m}^{3}$ \\
\hline & & SST/DST Tank Farm Operations & & $940 \mathrm{~m}^{3}$ \\
\hline & & SST Retrieval (149 tanks) & & $390 \mathrm{~m}^{3}$ \\
\hline & & Tank Farm Restoration & & $380 \mathrm{~m}^{3}$ \\
\hline & & Facility Transitions & & $\begin{array}{l}\text { Facility Transitions will generate } 70 \mathrm{~m}^{3} \text { of } \mathrm{RH} M \mathrm{MLW} \text { during deactivation } \\
\text { activities of those facilities that are no longer in the operational phase. As } \\
\text { stored material and wastes are removed, the facilities will be deactivated } \\
\text { and transferred to the D\&D program. The forecasted life cycle for waste } \\
\text { generated by Facility Transitions extends to } 2034 \text {. Types of waste } \\
\text { generated within this program include operational/maintenance waste, } \\
\text { deactivation waste, and surveillance and maintenance waste, with the } \\
\text { latter being a minimal contributor. A portion of the RH MULW generated } \\
\text { by this program will be RH Cat III MLLW. }\end{array}$ \\
\hline & & 300K Fuels Fabrication Transition & & $70 \mathrm{~m}^{3}$ \\
\hline & & PNNL & & $\begin{array}{l}\text { PNNL will generate } 50 \mathrm{~m}^{3} \text { of RH MLLW during the normal laboratory } \\
\text { operations most of which involve the } 300 \text { Area, which will be closed } \\
\text { down by } 2010 \text {. A portion of this waste will be RH Cat III MLLW. }\end{array}$ \\
\hline & & Offsite & & $\begin{array}{l}\text { Offsite programs or facilities are forecasted to send } 5 \mathrm{~m}^{3} \text { of RH MLLW to } \\
\text { the Hanford Site from } 1997 \text { to } 2070 \text {. A portion of this waste will be RH } \\
\text { Cat III MLLW. }\end{array}$ \\
\hline & & Knolls Atomic Power Laboratory & & $5 \mathrm{~m}^{3}$ \\
\hline & & D\&D & & $\begin{array}{l}\text { D\&D volume estimates have not been provided for any facilities that are } \\
\text { not on the Surplus Facilities List. Therefore, D\&D waste generated } \\
\text { during D\&D of future facilities and tank farms is not estimated at this } \\
\text { time. Such facilities include the High-Level Vitrification Plant, PUREX } \\
\text { tunnels, tank farms, and other facilities not on the Surplus Facilities List. }\end{array}$ \\
\hline
\end{tabular}


Table 2-7. Functional Inputs and Outputs. (41 sheets)

\begin{tabular}{|c|c|c|c|c|}
\hline \multicolumn{5}{|c|}{ Function X.1.2.3, Manage RH Cat MI MLLW (Continued) } \\
\hline Identifier & Title & From & $\begin{array}{l}\text { Function } \\
\text { number }\end{array}$ & Description \\
\hline Input & $\begin{array}{l}\text { Waste Reclassified as RH Cat III } \\
\text { MLLW in the Manage Solid } \\
\text { Waste and Materials Function } \\
\text { (X.1) }\end{array}$ & Manage RH TRU/TRUM & X.1.3.2 & $\begin{array}{l}\text { During nondestructive examination/nondestructive assay and/or sorting } \\
\text { operations of RH TRU/TRUM, some waste may warrant reclassification } \\
\text { as RH Cat III MLLW. }\end{array}$ \\
\hline Identifier & Title & To & $\begin{array}{l}\text { Function } \\
\text { number }\end{array}$ & Description \\
\hline Output & $\begin{array}{l}\text { Disposition-Ready RH Cat III } \\
\text { MLLW }\end{array}$ & Manage MCL W Disposal Site & X.1.2.4 & $\begin{array}{l}\text { Packaged RH CAT III MLLW ready for disposal in the mixed waste } \\
\text { disposal trench. }\end{array}$ \\
\hline Output & $\begin{array}{l}\text { Waste Reclassified as RH Cat I } \\
\text { MLLW in the Manage Solid } \\
\text { Waste and Materials Function } \\
\text { (X.1) }\end{array}$ & Manage RH Cat I MLLW & X.1.2.2 & $\begin{array}{l}\text { During nondestructive examination/nondestructive assay and/or sorting } \\
\text { operations of RH Cat III MLLW, some waste may warrant reclassification } \\
\text { as RH Cat I MLLW. }\end{array}$ \\
\hline Output & Contaminated Equipment & Manage Contaminated Equipment & $\mathrm{X} .1 .5$ & $\begin{array}{l}\text { Equipment used in the Manage RH Cat III MLLW function (X.1.2.2) } \\
\text { requiring decontamination and repair before it is ready for disposition or } \\
\text { reuse. }\end{array}$ \\
\hline Output & By-Product RH Cat III LLW & Manage MLLW Disposal Site & $\mathrm{X} .1 .2 .4$ & $\begin{array}{l}\text { Containers, debris, overpack, and other RH MLLW generated during } \\
\text { Function X.1.2.2 that are ready for disposition to the MLLW disposal site. }\end{array}$ \\
\hline \multicolumn{5}{|c|}{ Function X.1.2.4, Manage MLLW Disposal Site } \\
\hline Identifier & Title & From & $\begin{array}{l}\text { Function } \\
\text { number }\end{array}$ & Description \\
\hline Input & Disposition-Ready CH MLLW & Manage CH MLLW & $\mathrm{X} .1 .2 .1$ & Packaged CH MLLW ready for disposition to the proper burial trench. \\
\hline Input & $\begin{array}{l}\text { Disposition-Ready RH Cat I } \\
\text { MLLW }\end{array}$ & Manage RH Cat I MLLW & $\mathrm{X} .1 .2 .2$ & $\begin{array}{l}\text { Packaged RH Cat I MLLW ready for disposition to the proper burial } \\
\text { trench. }\end{array}$ \\
\hline Input & $\begin{array}{l}\text { Disposition-Ready RH Cat III } \\
\text { MLLW }\end{array}$ & Manage RH Cat III MLLW & $\mathrm{X} .1 .2 .3$ & $\begin{array}{l}\text { Packaged RH Cat III MCLW ready for disposition to the proper burial } \\
\text { trench. }\end{array}$ \\
\hline Input & Disposition-Ready Equipment & Manage Contaminated Equipment & $X .1 .5$ & $\begin{array}{l}\text { Equipment that could not be repaired for reuse and needs no other } \\
\text { processing before being classified as disposition-ready. }\end{array}$ \\
\hline Identifier & Title & To & $\begin{array}{l}\text { Function } \\
\text { number }\end{array}$ & Description \\
\hline Output & Contaminated Equipment & Manage Contaminated Equipment & X.1.5 & $\begin{array}{l}\text { Equipment used in the Manage MLLW Disposal Site (X.1.2.4) requiring } \\
\text { decontamination and repair before it is ready for disposition or reuse. }\end{array}$ \\
\hline
\end{tabular}


Table 2-7. Functional Inputs and Outputs. (41 sheets)

\begin{tabular}{|c|c|c|c|c|}
\hline \multicolumn{5}{|c|}{ Function X1.2.5 Manage GTC III MLLW } \\
\hline Identifier & Title & From & $\begin{array}{l}\text { Function } \\
\text { Number }\end{array}$ & Description \\
\hline Input & $\begin{array}{l}\text { GTCIII MLLW Generated from } \\
\text { Hanford Site Operations and } \\
\text { Offsite Facilities }\end{array}$ & PNNL and DST Retrieval & & $\begin{array}{l}\text { Both programs have changed planning assumptions, thus no GTCII } \\
\text { MLLW is forecasted. }\end{array}$ \\
\hline \multicolumn{5}{|c|}{ Function X.1.3.1, Manage CH TRU/TRUM } \\
\hline Identifier & Title & From & $\begin{array}{l}\text { Function } \\
\text { number }\end{array}$ & Description \\
\hline \multirow[t]{8}{*}{ Input } & \multirow[t]{8}{*}{$\begin{array}{l}\text { CH TRU/TRUM Waste } \\
\text { Generated from Hanford Site } \\
\text { Operations and Offsite Facilities }\end{array}$} & Facility Transitions & & $\begin{array}{l}\text { Facility Transitions will generate } 3,110 \mathrm{~m}^{3} \text { of CH TRU/TRUM during } \\
\text { deactivation activities of those facilities that are no longer in the } \\
\text { operational phase. As stored material and wastes are removed, the } \\
\text { facilities will be deactivated and transferred to the D\&D program. The } \\
\text { forecasted life cycle for waste generated by Facility Transitions extends to } \\
\text { 2034. Types of waste generated within this program include } \\
\text { operational/maintenance waste, deactivation waste, and surveillance and } \\
\text { maintenance waste, with the latter being a minimal contributor. }\end{array}$ \\
\hline & & $2345 Z$ PFP & & $3,050 \mathrm{~m}^{3}$ \\
\hline & & 327 Building & & $60 \mathrm{~m}^{3}$ \\
\hline & & 324 Building & & $4 \mathrm{~m}^{3}$ \\
\hline & & 309 PRTR Vault Waste & & $1 \mathrm{~m}^{3}$ \\
\hline & & TWRS & & $\begin{array}{l}\text { The TWRS Project will generate } 1,360 \mathrm{~m}^{3} \text { of CH TRU/TRUM during } \\
\text { retrieval and processing of } \mathrm{HLW} \text { from the Hanford Site tanks. The TWRS } \\
\text { forecasted life cycle ends in } 2032 \text {, while most activity will be completed } \\
\text { by } 2028 \text {. }\end{array}$ \\
\hline & & High-Level Vitrification Project & & $870 \mathrm{~m}^{3}$ \\
\hline & & SST Long-Length Equipment & & $490 \mathrm{~m}^{3}$ \\
\hline
\end{tabular}


Table 2-7. Functional Inputs and Outputs. (41 sheets)

\begin{tabular}{|c|c|c|c|c|}
\hline \multicolumn{5}{|c|}{ Function X.1.3.1, Manage CH TRU/TRUM (Continued) } \\
\hline Identifier & Title & From & $\begin{array}{l}\text { Function } \\
\text { number }\end{array}$ & Description \\
\hline \multirow[t]{16}{*}{ Input } & \multirow[t]{16}{*}{$\begin{array}{l}\text { CH TRU/TRUM Waste } \\
\text { Generated from Hanford Site } \\
\text { Operations and Offsite Facilities }\end{array}$} & Non-Programmatic & & $\begin{array}{l}\text { Non-programmatic generators will contribute } 1,320 \mathrm{~m}^{3} \text { of } \mathrm{CH} \\
\text { TRU/TRUM to the waste stream. These generators include those not } \\
\text { currently within the Hanford Site program, and those with uncertainties } \\
\text { regarding which program is responsible for their future waste-generating } \\
\text { activities ("orphan" facilities). The forecasted life cycle for all non- } \\
\text { programmatic generators ends in } 2037 \text {. }\end{array}$ \\
\hline & & 300 Area Facilities Non-Transition & & $730 \mathrm{~m}^{3}$ \\
\hline & & REDOX Non-Transition & & $210 \mathrm{~m}^{3}$ \\
\hline & & PUREX Non-Transition & & $110 \mathrm{~m}^{3}$ \\
\hline & & 400 Area Facilities Non-Transition & & $70 \mathrm{~m}^{3}$ \\
\hline & & B Plant Non-Transition & & $60 \mathrm{~m}^{3}$ \\
\hline & & PFP Non-Transition & & $60 \mathrm{~m}^{3}$ \\
\hline & & T Plant Non-Transition & & $40 \mathrm{~m}^{3}$ \\
\hline & & Site Support Non-Transition & & $30 \mathrm{~m}^{3}$ \\
\hline & & U Plant Non-Transition & & $10 \mathrm{~m}^{3}$ \\
\hline & & PNNL & & $\begin{array}{l}\text { PNNL will generate } 240 \mathrm{~m}^{3} \text { of CH TRU/TRUM during the normal } \\
\text { laboratory operations most of which involve the } 300 \text { Area, which will be } \\
\text { closed down by } 2010 \text {. }\end{array}$ \\
\hline & & ER (EM-40) & & $\begin{array}{l}\text { Surplus Facilities performs cleanup activities to preserve, protect, or } \\
\text { restore the Hanford Site to allow for other beneficial uses. Surplus } \\
\text { Facilities' activity will continue until } 2001 \text {; however, the ER program will } \\
\text { continue after this time. }\end{array}$ \\
\hline & & Surplus Facilities & & $230 \mathrm{~m}^{3}$ \\
\hline & & Offsite & & $\begin{array}{l}\text { Offsite programs or facilities are forecasted to send less than } 2 \mathrm{~m}^{3} \text { of } \mathrm{CH} \\
\text { TRU/TRUM to the Hanford Site from } 1997 \text { to } 2070 .\end{array}$ \\
\hline & & Ames Laboratory - Ames, Iowa & & $<1 \mathrm{~m}^{3}$ \\
\hline & & Lawrence Berkeley Laboratory & & $<1 \mathrm{~m}^{3}$ \\
\hline
\end{tabular}


Table 2-7. Functional Inputs and Outputs. (41 sheets)

\begin{tabular}{|c|c|c|c|c|}
\hline & & Provide Analytical Services & X.4 & $\begin{array}{l}\text { Analytical Services will generate } 20 \mathrm{~m}^{3} \text { of CH TRU/TRUM from } 1997 \text { to } \\
\text { the end of the life cycle in } 2070 \text {. Waste can include nonarchived samples, } \\
\text { by-products, and other debris waste. }\end{array}$ \\
\hline & & 222-S Analytical Laboratory & & $20 \mathrm{~m}^{3}$ \\
\hline \multicolumn{5}{|c|}{ Function X.1.3.1, Manage CH TRU/TRUM (Continued) } \\
\hline Identifier & Title & From & $\begin{array}{l}\text { Function } \\
\text { number }\end{array}$ & Description \\
\hline \multirow[t]{2}{*}{ Input } & \multirow[t]{2}{*}{$\begin{array}{l}\text { CH TRU/TRUM Waste } \\
\text { Generated from Hanford Site } \\
\text { Operations and Offsite Facilities }\end{array}$} & SNF & & $\begin{array}{l}\text { SNF will generate } 20 \mathrm{~m}^{3} \text { of CH TRU/TRUM. Solid waste is generated } \\
\text { during disposition of SNFs at the K Basins. The life cycle of SNFs ends } \\
\text { in } 2000 \text {. }\end{array}$ \\
\hline & & K Basins Fuel Sampling Project & & $20 \mathrm{~m}^{3}$ \\
\hline Input & $\begin{array}{l}\text { Waste Reclassified as CH } \\
\text { TRU/TRUM in the Manage Solid } \\
\text { Waste and Materials Function } \\
\text { (X.1) }\end{array}$ & Manage RH TRU/TRUM & $\mathrm{X} .1 .3 .2$ & $\begin{array}{l}\text { During nondestructive examination/nondestructive assay and/or sorting } \\
\text { operations of RH TRU/TRUM, some waste may warrant reclassification } \\
\text { as CH TRU/TRUM. }\end{array}$ \\
\hline Identifier & Title & To & $\begin{array}{l}\text { Function } \\
\text { number }\end{array}$ & Description \\
\hline Output & $\begin{array}{l}\text { Disposition-Ready } \mathrm{CH} \\
\text { TRU/TRUM Ready for Storage }\end{array}$ & $\begin{array}{l}\text { Transport Dispasition-Ready } \\
\text { TRU/TRUM to Onsite Storage }\end{array}$ & $\mathrm{X} .1 .3 .3$ & Packaged CH TRU/TRUM ready for onsite transportation. \\
\hline \multirow[t]{3}{*}{ Output } & \multirow[t]{3}{*}{$\begin{array}{l}\text { Waste Reclassified in the Manage } \\
\text { CH TRU/TRUM Function }\end{array}$} & Manage CH Cat I LLW & X.1.1.1 & $\begin{array}{l}\text { During nondestructive examination/nondestructive assay and/or sorting } \\
\text { operations of CH TRU/TRUM, some waste may warrant reclassification } \\
\text { as CH Cat I LLW. }\end{array}$ \\
\hline & & Manage CH Cat III LLW & $\mathrm{X} .1 .1 .2$ & $\begin{array}{l}\text { During nondestructive examination/nondestructive assay and/or sorting } \\
\text { operations of CH TRU/TRUM, some waste may warrant reclassification } \\
\text { as CH Cat III LLW. }\end{array}$ \\
\hline & & Manage CH MLLW & $\mathrm{X} .1 .2 .1$ & $\begin{array}{l}\text { During nondestructive examination/nondestructive assay and/or sorting } \\
\text { operations of CH TRU/TRUM, some waste may warrant reclassification } \\
\text { as CH MLLW. }\end{array}$ \\
\hline Output & Contaminated Equipment & Manage Contaminated Equipment & X.1.5 & $\begin{array}{l}\text { Equipment used in the Manage CH TRU/TRUM function (X.1.3.1) } \\
\text { requiring decontamination and repair before it is ready for disposition or } \\
\text { reuse. }\end{array}$ \\
\hline
\end{tabular}


Table 2-7. Functional Inputs and Outputs. (41 sheets)

\begin{tabular}{|c|c|c|c|c|}
\hline \multicolumn{5}{|c|}{ Function X.1.3.2, Manage RH TRU/TRUM } \\
\hline Identifier & Title & From & $\begin{array}{l}\text { Function } \\
\text { number }\end{array}$ & Description \\
\hline \multirow[t]{11}{*}{ Input } & \multirow[t]{11}{*}{$\begin{array}{l}\text { RH TRU/TRUM Waste } \\
\text { Generated from Hanford Site } \\
\text { Operations and Offsite Facilities }\end{array}$} & TWRS & & $\begin{array}{l}\text { The TWRS Project will generate } 1,450 \mathrm{~m}^{3} \text { of RH TRU/TRUM during } \\
\text { retrieval and processing of HCW from the Hanford Site tanks. The TWRS } \\
\text { forecasted life cycle ends in } 2032 \text {, while most activity will be completed } \\
\text { by } 2028 \text {. }\end{array}$ \\
\hline & & High-Level Vitrification Project & & $870 \mathrm{~m}^{3}$ \\
\hline & & SST Long-Length Equipment & & $490 \mathrm{~m}^{3}$ \\
\hline & & DST Retrieval Systems (10 tanks) & & $90 \mathrm{~m}^{3}$ \\
\hline & & PNNL & & $\begin{array}{l}\text { PNNL will generate } 110 \mathrm{~m}^{3} \text { of RH TRU/TRUM during the normal } \\
\text { laboratory operations most of which involve the } 300 \text { Area, which will be } \\
\text { closed down by } 2010 \text {. }\end{array}$ \\
\hline & & SNF & & $\begin{array}{l}\text { SNF will generate } 60 \mathrm{~m}^{3} \text { of RH TRU/TRUM. Solid waste is generated } \\
\text { during disposition of SNFs at K Basins. The life cycle of SNFs ends in } \\
2000 \text {. }\end{array}$ \\
\hline & & $100 \mathrm{~K}$ Basins Operations & & $60 \mathrm{~m}^{3}$ \\
\hline & & Manage Solid Waste and Materials & $\mathrm{X} .1$ & $\begin{array}{l}\text { The Solid Waste program will generate } 30 \mathrm{~m}^{3} \text { of RH TRU/TRUM while } \\
\text { receiving, storing, treating, decontaminating, and disposing of radioactive } \\
\text { and nonradioactive hazardous solid waste. The Solid Waste program is } \\
\text { forecasted to continue until } 2070 \text {. }\end{array}$ \\
\hline & & $221 \mathrm{~T} / 2706 \mathrm{~T} \mathrm{~T}$ Plant Operations & & $30 \mathrm{~m}^{3}$ \\
\hline & & Facility Transitions & & $\begin{array}{l}\text { Facility Transitions will generate } 10 \mathrm{~m}^{3} \text { of RH TRU/TRUM during } \\
\text { deactivation activities of those facilities that are no longer in the } \\
\text { operational phase. As stored material and wastes are removed, the } \\
\text { facilities will be deactivated and transferred to the D\&D program. The } \\
\text { forecasted life cycle for waste generated by Facility Transitions extends to } \\
\text { 2034. Types of waste generated within this program include } \\
\text { operational/maintenance waste, deactivation waste, and surveillance and } \\
\text { maintenance waste, with the latter being a minimal contributor. }\end{array}$ \\
\hline & & 324 Building & & $10 \mathrm{~m}^{3}$ \\
\hline Identifier & Title & To & $\begin{array}{l}\text { Functi on } \\
\text { nmber }\end{array}$ & Description \\
\hline Output & $\begin{array}{l}\text { Disposition-Ready RH } \\
\text { TRU/TRUM Ready for Storage }\end{array}$ & $\begin{array}{l}\text { Transport Disposition-Ready } \\
\text { TRU/TRUM to Onsite Storage }\end{array}$ & $\mathrm{X} .1 .3 .3$ & Packaged RH TRU/TRUM ready for onsite transportation. \\
\hline
\end{tabular}


Table 2-7. Functional Inputs and Outputs. (41 sheets)

\begin{tabular}{|c|c|c|c|c|}
\hline \multicolumn{5}{|c|}{ Function X.1.3.2, Manage RH TRU/TRUM (Continued) } \\
\hline \multirow[t]{5}{*}{ Output } & \multirow[t]{5}{*}{$\begin{array}{l}\text { Waste Reclassified in the Manage } \\
\text { RH TRU/TRUM Function }\end{array}$} & Manage RH Cat I LLW. & $\mathrm{X} .1 .1 .3$ & $\begin{array}{l}\text { During nondestructive examination/nondestructive assay and/or sorting } \\
\text { operations of RH TRU/TRUM, some waste may warrant reciassification } \\
\text { as RH Cat I LLW. }\end{array}$ \\
\hline & & Manage RH Cat III LLW & X.1.1.4 & $\begin{array}{l}\text { During nondestructive examination/nondestructive assay and/or sorting } \\
\text { operations of RH TRU/TRUM, some waste may warrant reclassification } \\
\text { as RH Cat III LLW. }\end{array}$ \\
\hline & & Manage RH Cat I MLLW & $\mathrm{X} .1 .2 .2$ & $\begin{array}{l}\text { During nondestructive examination/nondestructive assay and/or sorting } \\
\text { operations of RH TRU/TRUM, some waste may warrant reclassification } \\
\text { as RH Cat I MLLW. }\end{array}$ \\
\hline & & Manage RH Cat III MLLW & $\mathrm{X} .1 .2 .3$ & $\begin{array}{l}\text { During nondestructive examination/nondestructive assay and/or sorting } \\
\text { operations of RH TRU/TRUM, some waste may warrant reclassification } \\
\text { as RH Cat III MLLW. }\end{array}$ \\
\hline & & Manage CH TRU/TRUM & $\mathrm{X} .1 .3 .1$ & $\begin{array}{l}\text { During nondestructive examination/nondestructive assay and/or sorting } \\
\text { operations of RH TRU/TRUM, some waste may warrant reclassification } \\
\text { as CH TRU/TRUM. }\end{array}$ \\
\hline Output & Contaminated Equipment & Manage Contaminated Equipment & X.1.5 & $\begin{array}{l}\text { Equipment used in the Manage RH TRU/TRUM function (X.1.3.2) } \\
\text { requiring decontamination and repair before it is ready for disposition or } \\
\text { reuse. }\end{array}$ \\
\hline \multicolumn{5}{|c|}{ Function X.1.3.3, Transport Disposition-Ready TRU/TRUM to Onsite Storage } \\
\hline Identifier & Title & From & $\begin{array}{l}\text { Function } \\
\text { number }\end{array}$ & Description \\
\hline Input & $\begin{array}{l}\text { Disposition-Ready CH } \\
\text { TRU/TRUM Ready for Storage }\end{array}$ & Manage CH TRU/TRUM & X.1.3.1 & Packaged $\mathrm{CH}$ TRU/TRUM ready for onsite transportation. \\
\hline Input & $\begin{array}{l}\text { Disposition-Ready RH } \\
\text { TRU/TRUM Ready for Storage }\end{array}$ & Manage RH TRU/TRUM & $\mathrm{X} .1 .3 .2$ & Packaged RH TRU/TRUM ready for onsite transportation. \\
\hline Identifier & Title & To & $\begin{array}{l}\text { Function } \\
\text { number }\end{array}$ & Description \\
\hline Output & $\begin{array}{l}\text { Disposition-Ready TRU/TRUM } \\
\text { Ready for Storage }\end{array}$ & $\begin{array}{l}\text { Store Disposition-Ready TRU/TRUM } \\
\text { Containers }\end{array}$ & $\mathrm{X} .1 .3 .4$ & Transfer TRU/TRUM containers to onsite storage facilities \\
\hline Output & Contaminated Equipment & Manage Contaminated Equipment & $\mathrm{X} .1 .5$ & $\begin{array}{l}\text { Equipment used in the Transport Disposition-Ready TRU/TRUM to } \\
\text { Onsite Storage function (X.1.3.3) requiring decontamination and repair } \\
\text { before it is ready for disposition or reuse. }\end{array}$ \\
\hline
\end{tabular}


Table 2-7. Functional Inputs and Outputs. (41 sheets)

\begin{tabular}{|c|c|c|c|c|}
\hline \multicolumn{5}{|c|}{ Function X.1.3.4, Store Disposition-Ready TRU/TRUM Containers } \\
\hline Identifier & Title & From & $\begin{array}{l}\text { Function } \\
\text { number }\end{array}$ & Description \\
\hline Input & $\begin{array}{l}\text { Disposition-Ready TRU/TRUM } \\
\text { Ready for Storage }\end{array}$ & $\begin{array}{l}\text { Transport Disposition-Ready } \\
\text { TRU/TRUM }\end{array}$ & $\mathrm{X} .1 .3 .3$ & TRU/TRUM containers transported and ready for onsite storage. \\
\hline Identifier & Title & To & $\begin{array}{l}\text { Function } \\
\text { number }\end{array}$ & Description \\
\hline Output & $\begin{array}{l}\text { Disposition-Ready TRU/TRUM } \\
\text { Ready for Offsite Shipping }\end{array}$ & $\begin{array}{l}\text { Ship Disposition-Ready TRU/TRUM } \\
\text { Containers }\end{array}$ & $\mathrm{X} .1 .3 .5$ & $\begin{array}{l}\text { Transfer TRU/TRUM containers to offsite shipping function of final } \\
\text { disposal (to WIPP). }\end{array}$ \\
\hline Output & Contaminated Equipment & Manage Contaminated Equipment & X.1.5 & $\begin{array}{l}\text { Equipment used in the Store Disposition-Ready TRU/TRUM Containers } \\
\text { function (X.1.3.4) requiring decontamination and repair before it is ready } \\
\text { for disposition or reuse. }\end{array}$ \\
\hline \multicolumn{5}{|c|}{ Function X.1.5, Manage Contaminated Equipment } \\
\hline Identifier & Title & From & $\begin{array}{c}\text { Function } \\
\text { number }\end{array}$ & Description \\
\hline \multirow[t]{13}{*}{ Input } & \multirow[t]{13}{*}{ Contaminated Equipment } & Manage CH Cat I LLW & X.1.1.1 & \multirow{13}{*}{$\begin{array}{l}\text { During the management of solid waste, certain functions will have some } \\
\text { equipment that will need to be decontaminated. Low-dose rate equipment } \\
\text { can be returned to the proper function in which it is used. }\end{array}$} \\
\hline & & Manage CH Cat III LLW & $\mathrm{X} .1 .1 .2$ & \\
\hline & & Manage RH Cat I LLW & $\mathrm{X} .1 .1 .3$ & \\
\hline & & Manage RH Cat III LLW & $X .1 .1 .4$ & \\
\hline & & Manage LLW Disposal Site & $\mathrm{X} .1 .1 .5$ & \\
\hline & & Manage CH MLLW & $\mathrm{X} .1 .2 .1$ & \\
\hline & & Manage RH Cat I MLLW & $\mathrm{X} .1 .2 .2$ & \\
\hline & & Manage RH Cat III MLLW & $\mathrm{X} .1 .2 .3$ & \\
\hline & & Manage MLLW Disposal Site & $X .1 .2 .4$ & \\
\hline & & Manage CH TRU/TRUM & $\mathrm{X} .1 .3 .1$ & \\
\hline & & Manage RH TRU/TRUM & $\mathrm{X} .1 .3 .2$ & \\
\hline & & $\begin{array}{l}\text { Transport Disposition-Ready } \\
\text { TRU/TRUM } \\
\end{array}$ & X.1.3.3 & \\
\hline & & $\begin{array}{l}\text { Store Disposition-Ready TRU/TRUM } \\
\text { Containers }\end{array}$ & $\mathrm{X} .1 .3 .4$ & \\
\hline
\end{tabular}


Table 2-7. Functional Inputs and Outputs. (41 sheets)

\begin{tabular}{|c|c|c|c|c|}
\hline \multicolumn{5}{|c|}{ Function X.1.5, Manage Contaminated Equipment (Continued) } \\
\hline Identifier & Title & To & $\begin{array}{l}\text { Function } \\
\text { number }\end{array}$ & Description \\
\hline \multirow[t]{13}{*}{ Output } & \multirow[t]{13}{*}{ Decontaminated Equipment } & Manage CH Cat I LLW & $\mathrm{X} .1 .1 .1$ & \multirow{13}{*}{$\begin{array}{l}\text { Decontaminated equipment will be sent back to the proper function. Only } \\
\text { low-dose equipment can be reused; decontaminated equipment that does } \\
\text { not meet low-dose criteria will be processed for disposition according to } \\
\text { the waste type. }\end{array}$} \\
\hline & & Manage CH Cat III LLW & $\mathrm{X} .1 .1 .2$ & \\
\hline & & Manage RH Cat I LLW & X.1.1.3 & \\
\hline & & Manage RH Cat III LLW & X.1.1.4 & \\
\hline & & Manage LLW Disposal Site & $\mathrm{X} .1 .1 .5$ & \\
\hline & & Manage CH MLLW & $\mathrm{X} .1 .2 .1$ & \\
\hline & & Manage RH Cat IMLLW & $\mathrm{X} .1 .2 .2$ & \\
\hline & & Manage RH Cat III MLLW & $\mathrm{X} .1 .2 .3$ & \\
\hline & & Manage MLLW Disposal Site & $\mathrm{X} .1 .2 .4$ & \\
\hline & & Manage CH TRU/TRUM & X.1.3.1 & \\
\hline & & Manage RH TRU/TRUM & $\mathrm{X} .1 .3 .2$ & \\
\hline & & $\begin{array}{l}\text { Transport Disposition-Ready } \\
\text { TRU/TRUM } \\
\end{array}$ & X.1.3.3 & \\
\hline & & $\begin{array}{l}\text { Store Disposition-Ready TRU/TRUM } \\
\text { Containers }\end{array}$ & X.1.3.4 & \\
\hline Output & Disposition-Ready Equipment & Manage MLLW Disposal Site & $\mathrm{X} .1 .2 .4$ & $\begin{array}{l}\text { Transport equipment, which could not be repaired for reuse and needs no } \\
\text { other processing before being classified disposition-ready, to onsite } \\
\text { MLLW disposal trench(s). }\end{array}$ \\
\hline \multicolumn{5}{|c|}{ Function X.2.1, Concentrate Liquid Tank Waste } \\
\hline Identifier & Title & From & $\begin{array}{l}\text { Function } \\
\text { number }\end{array}$ & Description \\
\hline Input & Liquid Tank Waste & TWRS - Tank Farm Operations Project & & $\begin{array}{l}\text { Tank Farm Operations provides dilute liquid tank waste as feed to the } \\
\text { 242-A Evaporator. }\end{array}$ \\
\hline Identifier & Title & To & $\begin{array}{c}\text { Function } \\
\text { number }\end{array}$ & Description \\
\hline Output & Concentrated Tank Waste & TWRS-Tank Farm Operations Project & & \\
\hline Output & 242-A Evaporator Cooling Water & $\begin{array}{l}\text { Receive Discharge-Ready Liquid } \\
\text { Efluent }\end{array}$ & $X .2 .6 .1$ & $\begin{array}{l}\text { 242-A Evaporator Cooling Water (80-300 Mgal/yr, } 1997 \text { through 2011) } \\
\text { (Pending Project W-252) }\end{array}$ \\
\hline
\end{tabular}


Table 2-7. Functional Inputs and Outputs. (41 sheets)

\begin{tabular}{|c|c|c|c|c|}
\hline \multicolumn{5}{|c|}{ Function X.2.1, Concentrate Liquid Tank Waste (Continued) } \\
\hline Output & $\begin{array}{l}\text { 242-A Evaporator Steam } \\
\text { Condensate }\end{array}$ & $\begin{array}{l}\text { Receive Discharge-Ready Liquid } \\
\text { Effluent }\end{array}$ & $\mathrm{X} .2 .6 .1$ & $\begin{array}{l}\text { 242-A Evaporator Steam Condensate (1-6 Mgal/yr, } 1997 \text { through 2011) } \\
\text { (Pending Project W-252) }\end{array}$ \\
\hline \multicolumn{5}{|c|}{ Function X.2.2, Manage CERCLA-Generated Liquid Effluent Streams } \\
\hline Identifier & Title & From & $\begin{array}{l}\text { Function } \\
\text { number }\end{array}$ & Description \\
\hline \multirow[t]{4}{*}{ Input } & \multirow{4}{*}{$\begin{array}{l}\text { CERCLA-Generated Liquid } \\
\text { Effluent Streams }\end{array}$} & Environmental Restoration & & \\
\hline & & Groundwater Management Project & & $\begin{array}{l}\text { Extracted groundwater from 200-UP-1 (44 Mgal, } 1997 \text { through 98). } \\
\text { "Purge water" from groundwater monitoring ( } 500 \mathrm{kgal} / \mathrm{y})\end{array}$ \\
\hline & & N Pilot Project & & $\begin{array}{l}\text { N Basin water (Emergency Dump Basin) water (1.6 Mgal, 1997). } \\
\text { N Area D\&D water (107N and other buildings) (95 kgal) }\end{array}$ \\
\hline & & Remedial Action Project: ERDF Project & & ERDF Leachate ( $20 \mathrm{kgal} / \mathrm{y}, 1997$ through 2018$)$ \\
\hline Identifier & Title & To & $\begin{array}{c}\text { Function } \\
\text { number }\end{array}$ & Description \\
\hline Output & CERCLA-generated solid waste & $\begin{array}{l}\text { ER Remedial Action Project: ERDF } \\
\text { Project }\end{array}$ & & $\begin{array}{l}\text { Includes solid wastes generated during the treatment of CERCLA- } \\
\text { generated liquid effluents, i.e., secondary wastes extracted from effluents. }\end{array}$ \\
\hline \multicolumn{5}{|c|}{ Function X.2.3, Manage Listed RCRA/Mixed Waste Liquid Effluent Streams } \\
\hline Identifier & Title & From & $\begin{array}{c}\text { Function } \\
\text { number }\end{array}$ & Description \\
\hline \multirow[t]{7}{*}{ Input } & \multirow[t]{7}{*}{$\begin{array}{l}\text { RCRA/Mixed Waste Liquid } \\
\text { Effluent Streams }\end{array}$} & TWRS: Privatization Projects & & \begin{tabular}{|l|} 
TWRS Phase $1 \sim 5 \mathrm{Mgal} / \mathrm{yr}, 2002-2011$ \\
TWRS Phase 2 16 Mgal/yr, $2011-2029$. \\
\end{tabular} \\
\hline & & Concentrate Liquid Tank Waste & $\mathrm{X} .2 .1$ & Evaporator process condensate $\sim 1 \mathrm{Mgal} / \mathrm{yr}$ \\
\hline & & Manage Solid Waste & $\mathrm{X} .1$ & $\begin{array}{l}\text { LLMW Trench leachate: } \\
200 \mathrm{kgal} / \mathrm{yr}, 1998-2017 \\
\end{array}$ \\
\hline & & Analytical Services & $\mathrm{X} .4$ & $\begin{array}{l}\text { 222-S Lab waste: } 30 \mathrm{kgal} / \mathrm{yr}, 1997 \text { through } 2025 \text {. WSCF Lab waste: } 12 \\
\mathrm{kgal} / \mathrm{yr}\end{array}$ \\
\hline & & Spent Nuclear Fuel Project & & \begin{tabular}{|l|} 
K Basins water: $2.4 \mathrm{Mgal} 2002-2004$ \\
K. Basins level control water: $290 \mathrm{kgal}$ through 2000 \\
\end{tabular} \\
\hline & & \begin{tabular}{|l|} 
Facility Stabilization Project \\
\end{tabular} & & 242-A Evaporator deactivation wastewater: $100 \mathrm{kgal}, 2012-2013$ \\
\hline & & $\begin{array}{l}\text { PNNL Waste Management Project (and } \\
\text { other } 300 \text { Area facilities) }\end{array}$ & & $\begin{array}{l}300 \text { Area Radioactive Liquid Waste System. Inputs from } 324,325,326 \text {, } \\
327,329 \text { facilities through diverter valves. }\end{array}$ \\
\hline
\end{tabular}


Table 2-7. Functional Inputs and Outputs. (41 sheets)

\begin{tabular}{|c|c|c|c|c|}
\hline \multicolumn{5}{|c|}{ Function X.2.3, Manage Listed RCRA/Mixed Waste Liquid Effluent Streams (Continued) } \\
\hline Identifier & Title & To & $\begin{array}{l}\text { Function } \\
\text { number }\end{array}$ & Description \\
\hline Output & $\begin{array}{l}\text { Non-CERCLA-generated solid } \\
\text { waste }\end{array}$ & Manage Solid Waste and Materials & $\mathrm{X} .1$ & $\begin{array}{l}\text { Includes solid wastes generated during the treatment of non-CERCLA- } \\
\text { generated liquid effluents (i.e., secondary wastes extracted from } \\
\text { effluents). }\end{array}$ \\
\hline Output & 300 Area-Generated tank waste & TWRS Tank Farm Operations Project & & $\begin{array}{l}\text { Includes radioactive liquid waste collected at the } 340 \text { Building and } \\
\text { shipped via rail tank car to 204-AR. }\end{array}$ \\
\hline \multicolumn{5}{|c|}{ Function X.2.4, Manage Non-Listed/Industrial Effluent Streams } \\
\hline Identifier & Title & From & $\begin{array}{l}\text { Function } \\
\text { number }\end{array}$ & Description \\
\hline Input & $\begin{array}{l}\text { Non-Listed/Industrial Effluent } \\
\text { Streams }\end{array}$ & $\begin{array}{l}\text { PNNL Waste Management Project (and } \\
\text { other } 300 \text { Area facilities) }\end{array}$ & & $\begin{array}{l}300 \text { Area Retention Process Sewer imputs from } 324,325,326,327,329 \\
\text { facilities. } \\
300 \text { Area Process Sewer inputs from most } 300 \text { Area facilities and some } \\
\text { storm water. }\end{array}$ \\
\hline Identifier & Title & To & $\begin{array}{l}\text { Function } \\
\text { number }\end{array}$ & Description \\
\hline Output & $\begin{array}{l}\text { Non-CERCLA-generated solid } \\
\text { waste }\end{array}$ & Manage Solid Waste and Materials & $\mathrm{X} .1$ & $\begin{array}{l}\text { Includes solid wastes generated during the treatment of non-CERCLA- } \\
\text { generated liquid effluents (i.e., secondary wastes extracted from } \\
\text { effluents). }\end{array}$ \\
\hline \multicolumn{5}{|c|}{ Function X.2.5, Manage Low-Level Waste Effluent Streams } \\
\hline Identifier & Title & From & $\begin{array}{l}\text { Function } \\
\text { number }\end{array}$ & Description \\
\hline Input & $\begin{array}{l}\text { Low-Level Waste Effluent } \\
\text { Streams }\end{array}$ & & & uncertain \\
\hline Identifier & Title & To & $\begin{array}{l}\text { Function } \\
\text { number }\end{array}$ & Description \\
\hline Output & $\begin{array}{l}\text { Non-CERCLA-generated solid } \\
\text { waste }\end{array}$ & Manage Solid Waste and Materials & $\mathrm{X} .1$ & $\begin{array}{l}\text { Includes solid wastes generated during the treatment of non-CERCLA- } \\
\text { generated liquid effluents (i.e., secondary wastes extracted from } \\
\text { effluents). }\end{array}$ \\
\hline
\end{tabular}


Table 2-7. Functional Inputs and Outputs. (41 sheets)

\begin{tabular}{|c|c|c|c|c|}
\hline \multicolumn{5}{|c|}{ Function X.2.6, Discharge Treated Liquid Effluents } \\
\hline Identifier & Title & From & $\begin{array}{l}\text { Function } \\
\text { number }\end{array}$ & Description \\
\hline \multirow[t]{9}{*}{ Input } & \multirow[t]{9}{*}{ Treated Liquid Effluents } & TWRS & & $\begin{array}{l}\text { TWRS Phase 1: (35 Mgal/yr, } 2002 \text { through 2012). } \\
\text { TWRS Phase 2: (160 Mgal/yr, } 2011 \text { through 2034). } \\
\text { 241-A Tank Farm cooling water: (87 Mgal in 1997; 2.6Mgal/yr, } 1997 \\
\text { through 2018) (Project W-252). }\end{array}$ \\
\hline & & Concentrate Liquid Tank Waste & $\times .2 .1$ & $\begin{array}{l}\text { 242-A Evaporator cooling water: }(80-300 \mathrm{Mgal} / \mathrm{yr}, 1997 \text { through 2011) } \\
\text { (Project W-252). } \\
242-\mathrm{A} \text { Evaporator steam condensate: }(1-6 \mathrm{Mgal} / \mathrm{yr} 1997 \text { through } 2011) \\
\text { (Project W-252). } \\
242-\mathrm{A}-81 \text { Water Services Building wastewater: }(500 \mathrm{kgal} / \mathrm{yr} 1997 \\
\text { through 2011). }\end{array}$ \\
\hline & & PFP Project & & $\begin{array}{l}\text { PFP wastewater: (13 Mgal/yr, } 1997 \text { through 2003; } 5 \mathrm{Mgal} / \mathrm{yr} 2004 \\
\text { through 2034) }\end{array}$ \\
\hline & & PUREX Project & & PUREX chemical sewer: (132 Mgal, 1997 only) \\
\hline & & B Plant Project & & B Plant chemical sewer : (80 Mgal, 1997 through 1998) \\
\hline & & WESF Project & & B Plant/WESF cooling water: (4.2 Mgal/yr, 1997 through 2020) \\
\hline & & Provide Analytical Services & $\mathrm{X} .4$ & 222-S Laboratory wastewater : (1.5 Mgal/yr, 1997 through 2026) \\
\hline & & Manage Solid Waste and Materials & $\mathrm{X} .1$ & I Plant wastewater: ( $350 \mathrm{kgal} / \mathrm{yr}, 1997$ through 2029 ) \\
\hline & & Infrastructure Project & & $\begin{array}{l}\text { 284-W Power Plan wastewater: (1.1Mgal/yr through 2034) } \\
\text { 284-E Power Plant wastewater: (57Mgal/yr, } 1997 \text { through 2000; } 16 \\
\text { Mgal/yr } 1998 \text { through 2034) }\end{array}$ \\
\hline Identifier & Title & To & $\begin{array}{l}\text { Function } \\
\text { number }\end{array}$ & Description \\
\hline Output & 300 Area TEDF treated effluents & Columbia River & & Permitted discharge to river \\
\hline Output & 200 East TEDF treated effluents & Soil Column (SALDS) & & Permitted discharge \\
\hline Output & 200 West ETF treated effluents & Soil Column (SALDS) & & Permitted discharge \\
\hline
\end{tabular}


Table 2-7. Functional Inputs and Outputs. (41 sheets)

\begin{tabular}{|l|l|c|l|l|}
\hline \multicolumn{3}{|c|}{ Title } & Function X.2.7, Operate and Maintain Active LW Facilities \\
\hline Identifier & \multicolumn{1}{|c|}{ To } & $\begin{array}{l}\text { Function } \\
\text { number }\end{array}$ & Description \\
\hline Output & $\begin{array}{l}\text { Non-CERCLA-generated } \\
\text { incidental solid waste }\end{array}$ & Manage Solid Waste and Materials & X.1 & $\begin{array}{l}\text { Includes incidental solid wastes generated during the treatment of non- } \\
\text { CERCLA-generated liquid effluents, e.g., clothes, rags, lubricants, filters, } \\
\text { unrepairable equipment, etc. }\end{array}$ \\
\hline
\end{tabular}

'Resource Conservation and Recovery Act of 1976,42 USC 6901, et seq.

'Comprehensive Environmental Response, Compensation, and Liability Act of 1980, 42 USC 9601, et seq

CH = contact handled.

CWC = Central Waste Complex.

D\&D $=$ decontamination and decommissioning

DST = double-shell tank.

ER = Environmental Restoration

ERDF = Environmental Restoration Disposal Facility.

ETF $=$ Effluent Treatment Facility

$\begin{aligned} \text { ETF } & =\text { Effluent Treatment Facility } \\ \text { FFTF } & \text { Fast Fux Test Facility. }\end{aligned}$

LLW = low-level waste.

PFP = Plutonium Finishing Plant.

PNNL = Pacific Northwest National Laboratory.

PRTR = plutonium recycle test reactor.

PUREX $\approx$ Plutonium-Uranium Extraction

REDOX = reduction and oxidation.

SALDS = State-approved land disposal structure.

SNF = spent nuclear fuel.

SST = single-shell tank

TEDF = Treated Effluent Disposal Facility.

TRUSAF $=$ Transuranic Storage and Assay Facility

TWRS = Tank Waste Remediation System.

WESF $=$ Waste Encapsulation Storage Facility.

$\begin{aligned} \text { WESF } & =\text { Waste Encapsulation Storage Facility. } \\ \text { WRAP } & =\text { Waste Receiving and Processing. }\end{aligned}$

WRAP $=$ Waste Receiving and Processing.
WSCF $=$ Waste Sampling and Characterization Facility. 
HNF-SD-WM-RPT-288

Revision 0

- No information is presented describing inputs regarding the respective customer's expectations for analysis turn-around-time (TAT) or the distribution of the samples during the respective year. The TAT and distribution of demand impact resource planning. The projections presented in Tables 2-8 through 2-12 need to be verified and should be considered preliminary.

Table 2-8. Hanford Site Program Sample Projection Summary.

\begin{tabular}{|l|c|c|c|c|c|}
\hline \multicolumn{1}{|c|}{ Hanford Site project/program } & FY 1997 & FY 1998 & FY 1999 & FY 2000 & FY 2001 \\
\hline Analytical Services & 8,398 & 8,338 & 8,318 & 8,318 & 8,318 \\
\hline Environmental Restoration & 6,735 & 4,985 & 4,225 & 1,885 & 1,885 \\
\hline Industrial Hygiene & 2,000 & 2,000 & 2,000 & 2,000 & 2,000 \\
\hline Liquid Waste & 1,518 & 1,518 & 1,518 & 1,518 & 1,518 \\
\hline Site Monitoring & 8,189 & 8,189 & 8,189 & 8,189 & 8,189 \\
\hline Solid Waste and Materials & 1,968 & 1,505 & 1,174 & 933 & 749 \\
\hline Spent Nuclear Fuels & 937 & 1,058 & 1,030 & 1,030 & 0 \\
\hline Tank Waste Remediation System & 2,075 & 2,432 & 1,830 & 319 & 18 \\
\hline Transition Projects & 2,010 & 1,719 & 1,635 & 1,639 & 1,629 \\
\hline Total projects/programs & 33,830 & 31,744 & 29,919 & 25,831 & 24,306 \\
\hline
\end{tabular}

FY $=$ fiscal year.

Table 2-9. Yearly Sample Projections Summary by Radiation Level.

\begin{tabular}{|c|c|c|c|c|c|}
\hline Radiation level & $\begin{array}{c}\text { FY } \\
1997\end{array}$ & $\begin{array}{l}\text { FY } \\
1998\end{array}$ & $\begin{array}{c}\text { FY } \\
1999\end{array}$ & $\begin{array}{c}\mathrm{FY} \\
2000\end{array}$ & $\begin{array}{c}\mathrm{FY} \\
2001\end{array}$ \\
\hline Nonradioactive & 6,383 & 6,454 & 6,233 & 6,234 & 6,233 \\
\hline$<1 \mathrm{mR} / \mathrm{h}$ beta-gamma; $<10 \mathrm{nCi} / \mathrm{g}$ alpha & 18,789 & 18,220 & 17,578 & 17,274 & 16,077 \\
\hline 1 to $<10 \mathrm{mR} / \mathrm{h}$ beta-gamma; $<10 \mathrm{nCi} / \mathrm{g}$ alpha & 6,478 & 5,197 & 4,573 & 1,870 & 1,868 \\
\hline$<10 \mathrm{mR} / \mathrm{h}$ beta-gamma; $<200 \mathrm{nCi} / \mathrm{g}$ alpha & 172 & 49 & 43 & 44 & 24 \\
\hline $\begin{array}{l}10 \text { to }<100 \mathrm{mR} / \mathrm{h} \text { beta-gamma; }<200 \mathrm{nCi} / \mathrm{g} \\
\text { alpha }\end{array}$ & 317 & 16 & 9 & 13 & 9 \\
\hline$>100 \mathrm{mR} / \mathrm{h}$ beta-gamma & 1,625 & 1,731 & 1,406 & 319 & 18 \\
\hline$>200 \mathrm{nCi} / \mathrm{g}$ alpha & 66 & 77 & 77 & 77 & 77 \\
\hline
\end{tabular}

$F Y=$ fiscal year . 
HNF-SD-WM-RPT-288

Revision 0

Table 2-10. Yearly Sample Analysis Projections Summary by Analyte.

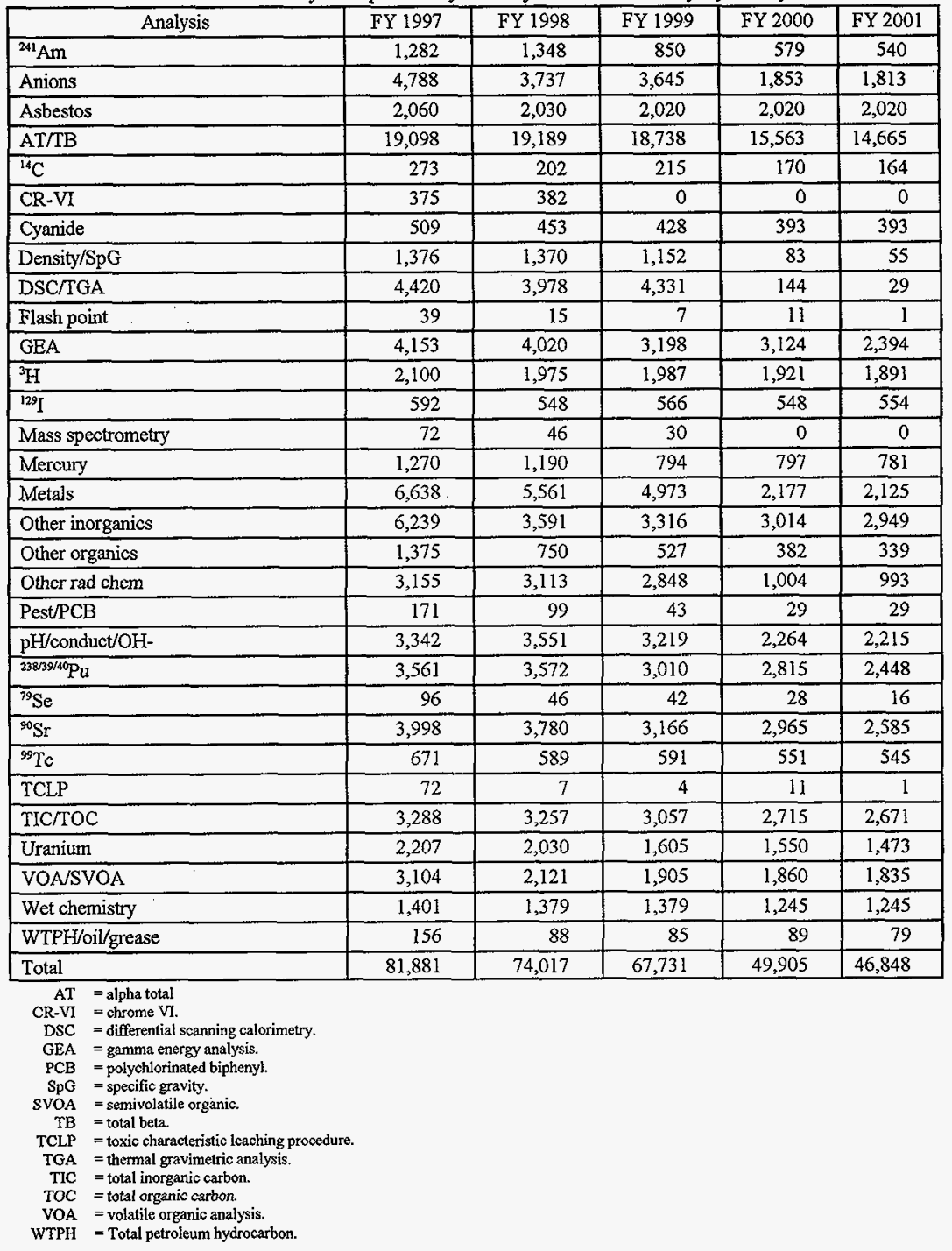


HNF-SD-WM-RPT-288

Revision 0

Table 2-11. Yearly Sample Projections by Protocol.

\begin{tabular}{|c|c|c|c|c|c|}
\hline Protocol & FY 1997 & FY 1998 & FY 1999 & FY 2000 & FY 2001 \\
\hline 10 CFR $834^{1}$ & 992 & 992 & 992 & 992 & 992 \\
\hline 10 CFR $835^{2}$ & 676 & 676 & 676 & 676 & 676 \\
\hline 216 Permit & 160 & 160 & 160 & 160 & 160 \\
\hline $40 \mathrm{CFR} 61^{3}(\mathrm{CAA})^{4}$ & 147 & 147 & 147 & 147 & 147 \\
\hline $\mathrm{CAA}^{4}$ & 600 & 600 & 600 & 600 & 600 \\
\hline CLP & 602 & 532 & 372 & 352 & 352 \\
\hline $\mathrm{CWA}^{5}$ & 223 & 223 & 223 & 223 & 223 \\
\hline IH & 2,295 & 2,200 & 2,200 & 2,000 & 2,000 \\
\hline NPDES & 4 & 4 & 4 & 4 & 4 \\
\hline Other & 150 & 150 & 150 & 150 & 150 \\
\hline Process control & 19,421 & 18,247 & 17,581 & 15,225 & 14,195 \\
\hline $\mathrm{RCRA}^{6}$ & 8,542 & 7,795 & 6,796 & 5,284 & 4,789 \\
\hline SDWA $^{7}$ & 18 & 18 & 18 & 18 & 18 \\
\hline
\end{tabular}

'10 CFR 834, "Radiation Protection of the Public and the Environment," Code of Federal Regulations, as amended.

${ }^{2} 10$ CFR 835, "Occupational Radiation Protection," Code of Federal Regulations, as amended.

${ }^{340}$ CFR 61, "National Emission Standards for Hazardous Air Pollutants," Code of Federal Regulations, as amended.

“Clean Air Act of 1955,42 USC 7401, et seq.

${ }^{5}$ Clean Water Act of 1977,33 USC 1251, et seq.

${ }^{\circ}$ Resource Conservation and Recovery Act of 1976,42 USC 6901, et seq.

'Safe Drinking Water Act of 1974, 42 USC 300f, et seq.

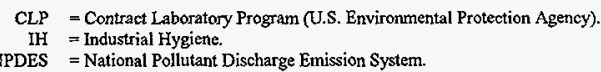

NPDES $=$ National Pollutant Discharge Emission System.

Table 2-12. Yearly Sample Projections by Matrix.

\begin{tabular}{|l|r|r|r|r|r|}
\hline \multicolumn{1}{|c|}{ Matrix } & FY 1997 & FY 1998 & FY 1999 & FY 2000 & \multicolumn{1}{c|}{ FY 2001 } \\
\hline Liquid & 9,635 & 8,333 & 8,222 & 7,792 & 6,754 \\
\hline Other & 9,783 & 9,201 & 8,867 & 8,448 & 8,266 \\
\hline Sludge & 1,619 & 1,737 & 1,396 & 361 & 56 \\
\hline Solid/soil & 3,884 & 3,572 & 2,767 & 623 & 623 \\
\hline Vapor & 8,909 & 8,901 & 8,667 & 8,607 & 8,607 \\
\hline
\end{tabular}

FY $=$ fiscal year. 
HNF-SD-WM-RPT-288

Revision 0

\subsubsection{Site-Level Functional Hierarchy}

To help integrate activities across contractors at the Hanford Site level, the Hanford Site (Systems Engineering) Integration group has formulated a Hanford Site functional hierarchy. The five top-level Site system functions are described in Table 2-13 (LMSI 1997). Figure 2-37 presents a more in-depth decomposition of these Site functions. The relationship between the Project and the Site functional hierarchies is shown in Tables 2-14 and 2-15.

Table 2-13. Site Systems Engineering Functions. (2 sheets)

\begin{tabular}{|c|c|c|}
\hline $\begin{array}{c}\text { Function } \\
\text { Number }\end{array}$ & Function title & \multicolumn{1}{|c|}{ Definition } \\
\hline 0 & Clean Up Hanford & $\begin{array}{l}\text { The waste management and environmental restoration mission is to clean up the } \\
\text { Hanford Site, protect the health and safety of the public and our workers, protect } \\
\text { the environment, and provide beneficial use of land and other resources while } \\
\text { serving as the DOE model for environmental restoration. Site cleanup will be in } \\
\text { accordance with the Hanford Federal Facility Agreement and Consent Order } \\
\text { (also known as the Tri-Party Agreement) (Ecology et al. 1996) and other } \\
\text { agreements, and will be in compliance with all applicable federal, state, and local } \\
\text { laws. The stakeholders will be active participants in the decision processes } \\
\text { including establishing priorities, determining end states, and developing a } \\
\text { consistent set of rules, regulations, and laws. The work will be leveraged with } \\
\text { providing positive, lasting economic impact in the region. Effectiveness, } \\
\text { efficiency, and discipline in all mission activities will enable us to achieve the } \\
\text { Site vision and mission in a continuous and substantive manner. }\end{array}$ \\
\hline 1 & $\begin{array}{l}\text { Maintain Safe and } \\
\text { Compliant } \\
\text { Envelope }\end{array}$ & $\begin{array}{l}\text { Facilities, waste, and materials located at the Hanford Site and newly received } \\
\text { wastes and materials will be maintained within an established safety and } \\
\text { compliant envelope while awaiting cleanup operations to begin. } \\
\text { Qualified staff and all necessary documentation will be maintained to support the } \\
\text { safe and compliant envelope. }\end{array}$ \\
\hline
\end{tabular}


HNF-SD-WM-RPT-288

Revision 0

Table 2-13. Site Systems Engineering Functions. (2 sheets)

\begin{tabular}{|c|c|c|}
\hline $\begin{array}{l}\text { Function } \\
\text { Number }\end{array}$ & Function title & Definition \\
\hline 2 & Clean Up Site & $\begin{array}{l}\text { Clean up sites for the recovery of land and other resources. For the purposes of } \\
\text { identification, the } 1,450-\mathrm{km}^{2} \text { Hanford Site is decomposed into five areas. These } \\
\text { areas are the } 100 \text { Areas which encompasses the reactors on the Columbia River, } \\
\text { the } 200 \text { Areas and Central Plateau, the South } 600 \text { Area (including the } 300,400 \text {, } \\
\text { and } 1100 \text { Areas and their adjacent lands), the Central Core, and areas along the } \\
\text { Columbia River shoreline. These areas contain approximately } 65 \text { Operable } \\
\text { Units (OU) comprised of approximately } 1,500 \text { waste management units and a } \\
\text { like number of facilities containing various waste forms from previous operations } \\
\text { at the Hanford Site. Each OU contains a unique combination of facilities, tanks, } \\
\text { solid waste, environmental contamination (both groundwater and soil sites), } \\
\text { liquid effluents, infrastructure, and nuclear materials. In general, OUs in the five } \\
\text { areas are to be cleaned up to specified standards in accordance with priority } \\
\text { determined by a risk-based cleanup strategy. Waste/materials removed from the } \\
\text { OUs are transferred to systems for treatment, interim storage, and disposition. } \\
\text { Cleanup operations begin upon transfer of waste sites and/or facilities and their } \\
\text { wastes/materials from safe and compliant maintenance state to clean up. Cleanup } \\
\text { operations for waste sites and/or facilities end when they are dispositioned to } \\
\text { their final state (i.e., closed, ready for reuse, disposed). }\end{array}$ \\
\hline 3 & $\begin{array}{c}\text { Treat Waste and } \\
\text { Material }\end{array}$ & $\begin{array}{l}\text { Treat waste/materials resulting from cleanup operations to prepare the } \\
\text { waste/material for long-term disposition ready storage, disposal, or reuse. } \\
\text { Treatment begins upon receipt of wastes/materials from cleanup operations. } \\
\text { Treatment is considered complete when the wastes/materials are made } \\
\text { disposition ready and transferred to long-term storage or the appropriate } \\
\text { disposition system. }\end{array}$ \\
\hline 4 & $\begin{array}{l}\text { Store Waste and } \\
\text { Material }\end{array}$ & $\begin{array}{l}\text { Interim storage will be provided for treated wastes and materials for which there } \\
\text { are no national policies for disposition. The treated wastes/materials will be } \\
\text { stored until such time as a national policy is determined and then disposed in } \\
\text { accordance with that policy. Other waste/material for which there is a national } \\
\text { disposal policy but for which the disposal facility is not yet in operations will be } \\
\text { stored until the disposal facility is ready to accept the waste/material. }\end{array}$ \\
\hline 5 & $\begin{array}{l}\text { Disposition Waste } \\
\text { and Material }\end{array}$ & $\begin{array}{l}\text { Disposition-ready waste and materials will be disposed of on site at a permitted } \\
\text { site or transported off site to sites identified by national policy to receive these } \\
\text { wastes/materials. Waste/material is considered to be dispositioned when the } \\
\text { waste/material is accepted at the receiving site. }\end{array}$ \\
\hline
\end{tabular}


HNF-SD-WM-RPT-288

Revision 0

This page intentionally left blank. 

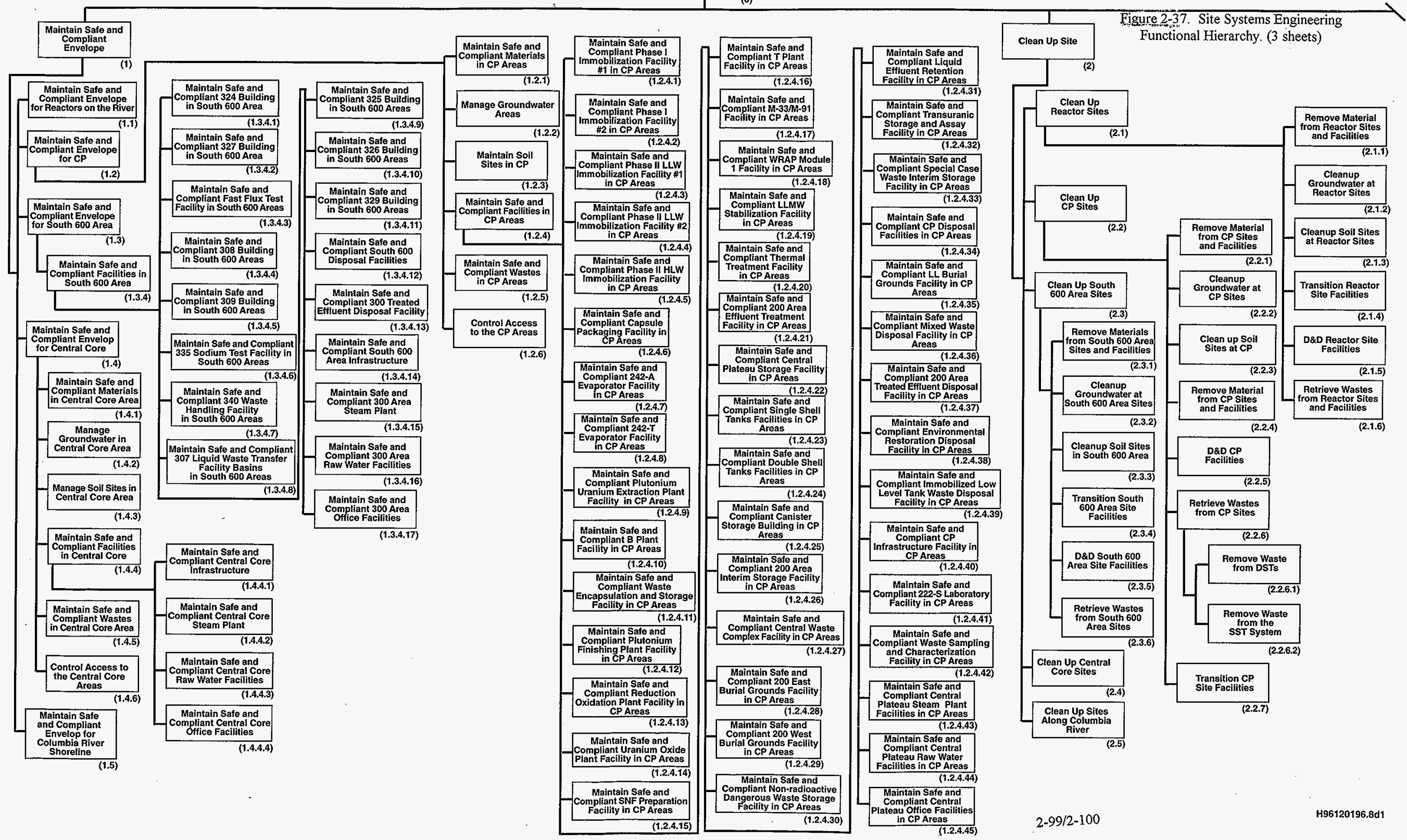

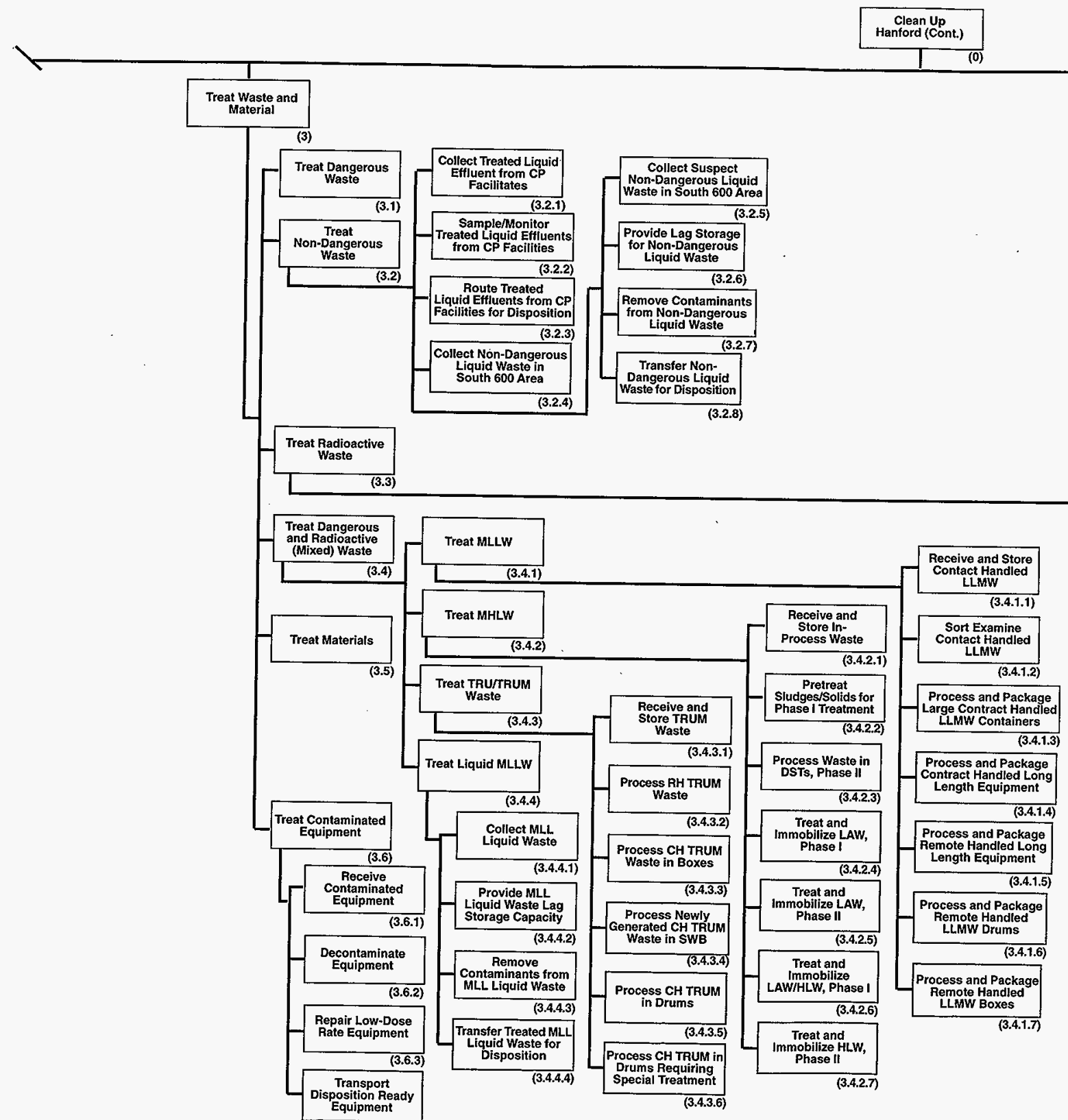

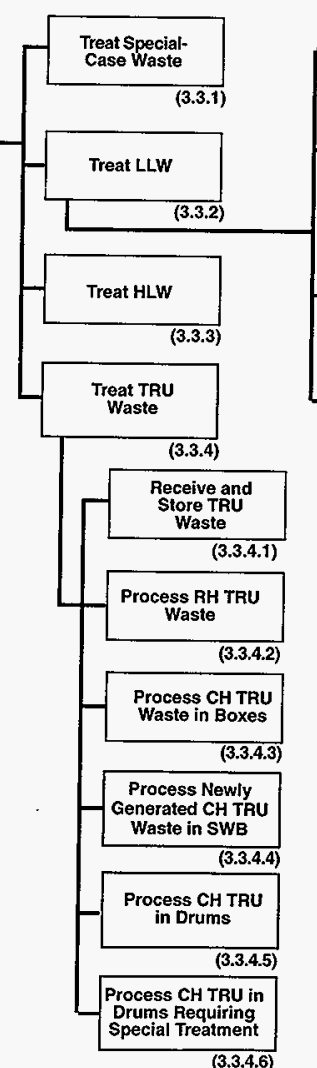

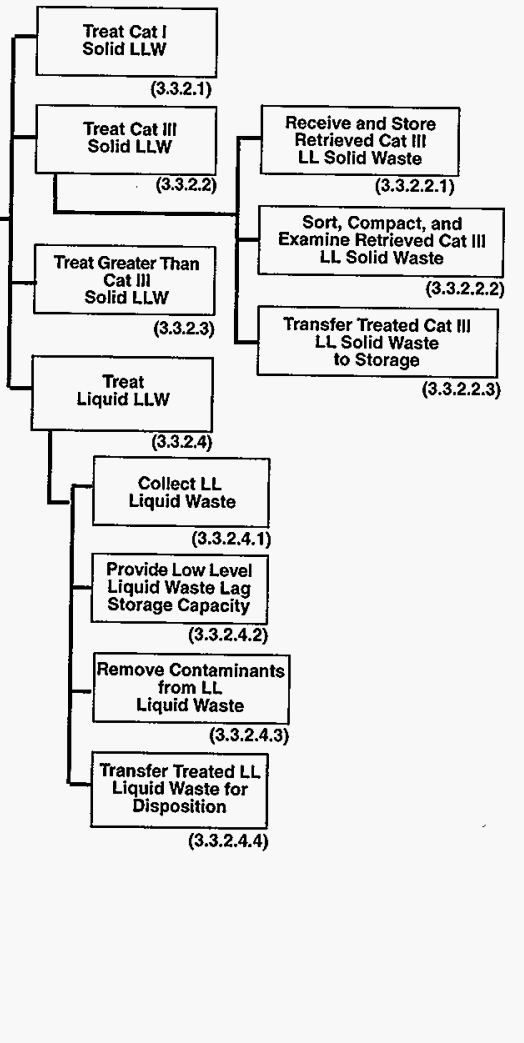




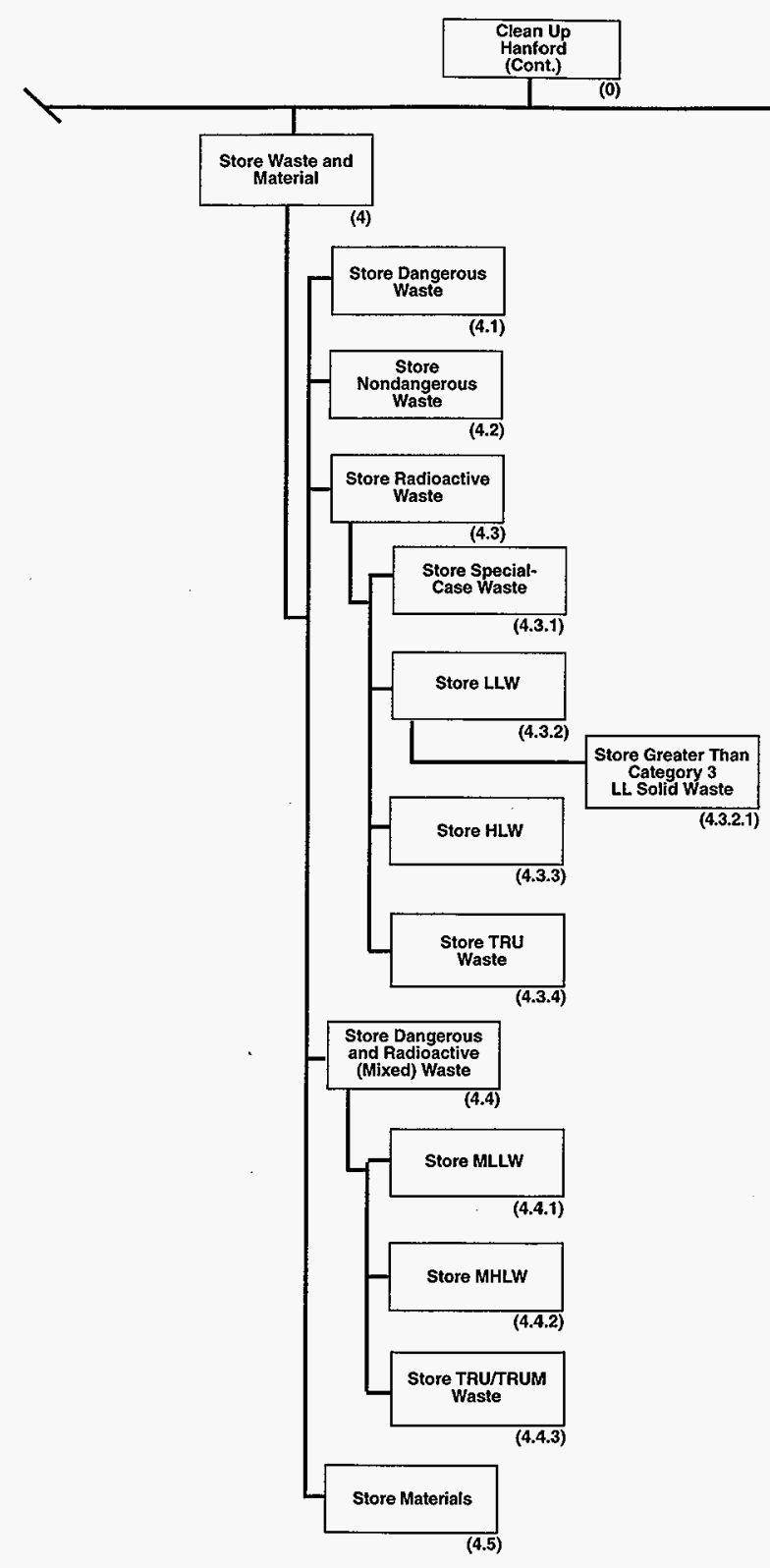

HNF-SD-WM-RPT-288

Revision 0

Figure 2-37. Site Systems Engineering Functional Hierarchy. (3 sheets)
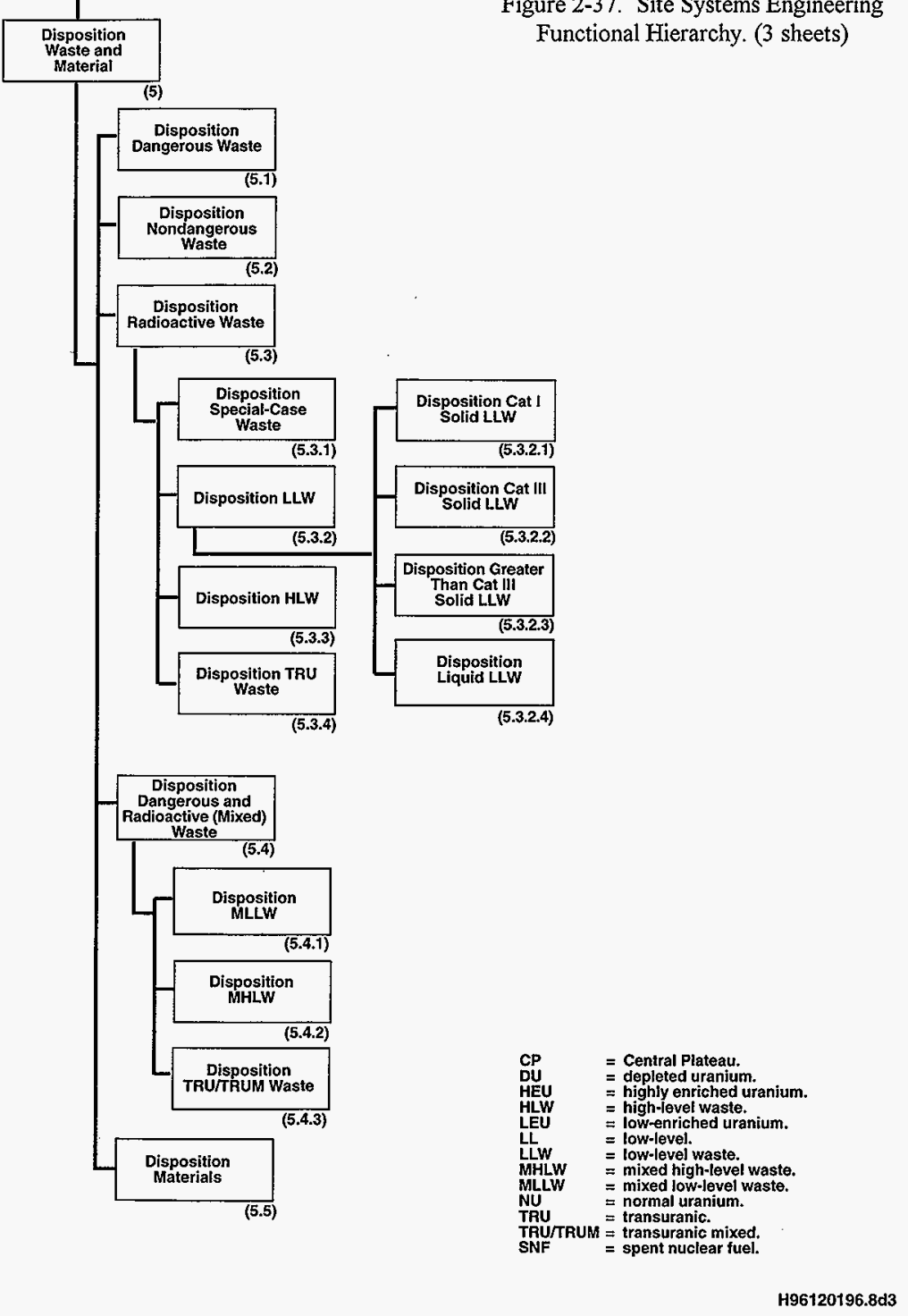

$2-103 / 2-104$ 
Table 2-14. Functional Crosswalk - Site Systems Engineering to Waste Management. (4 sheets)

\begin{tabular}{|c|c|c|}
\hline \multicolumn{2}{|r|}{ Site Systems Engineering functions } & Waste Management Project functions \\
\hline No. & Title & \\
\hline 0 & Clean Up Hanford & See tributary function(s) \\
\hline 1 & Maintain Safe and Compliant Envelope & See tributary function(s) \\
\hline 1.1 & $\begin{array}{l}\text { Maintain Safe and Compliant Envelope for Reactors on the } \\
\text { River }\end{array}$ & Not applicable \\
\hline 1.2 & Maintain Safe and Compliant Envelope for Central Plateau & See tributary function(s) \\
\hline 1.2 .1 & $\begin{array}{l}\text { Maintain Safe and Compliant Materials at Central Plateau } \\
\text { Sites }\end{array}$ & Not applicable \\
\hline 1.2 .2 & Manage Groundwrater Areas & Not applicable \\
\hline 1.2 .3 & Maintain Soil Sites in Central Plateau Areas & Not applicable \\
\hline 1.2 .4 & Maintain Safe and Compliant Waste in Central Plateau Areas & X.1.5 \\
\hline 1.2.4.1 & $\begin{array}{l}\text { Maintain Safe and Compliant Phase I Immobilization Facility } \\
\# 1 \text { in Central Plateau Areas }\end{array}$ & Not applicable \\
\hline 1.2 .4 .2 & $\begin{array}{l}\text { Maintain Safe and Compliant Phase I Immobilization Facility } \\
\text { \#2 in Central Plateau Areas }\end{array}$ & Not applicable \\
\hline 1.2 .4 .3 & $\begin{array}{l}\text { Maintain Safe and Complaint Phase II LLW Immobilization } \\
\text { Facility \#1 in Central Plateau Areas }\end{array}$ & Not applicable \\
\hline 1.2.4.4 & $\begin{array}{l}\text { Maintain Safe and Complaint Phase II LLW Immobilization } \\
\text { Facility \#2 in Central Plateau Areas }\end{array}$ & Not applicable \\
\hline 1.2 .4 .5 & $\begin{array}{l}\text { Maintain Safe and Compliant Phase II HL W Immobilization } \\
\text { Facility in Central Plateau Areas }\end{array}$ & Not applicable \\
\hline 1.2 .4 .6 & $\begin{array}{l}\text { Maintain Safe and Compliant Capsule Packaging Facility in } \\
\text { Central Plateau Areas }\end{array}$ & Not applicable \\
\hline 1.2 .4 .7 & $\begin{array}{l}\text { Maintain Safe and Compliant 242-A Evaporator Facility in } \\
\text { Central Plateau Areas }\end{array}$ & X.2.7 \\
\hline 1.2.4.8 & $\begin{array}{l}\text { Maintain Safe and Compliant 242-T Evaporator Facility in } \\
\text { Central Plateau Areas }\end{array}$ & Not applicable \\
\hline 1.2 .4 .9 & $\begin{array}{l}\text { Maintain Safe and Compliant Plutonium Uranium Extraction } \\
\text { Plant Facility in Central Plateau Areas }\end{array}$ & Not applicable \\
\hline 1.2 .4 .10 & $\begin{array}{l}\text { Maintain Safe and Compliant B Plant Facility in Central } \\
\text { Plateau Areas }\end{array}$ & Not applicable \\
\hline 1.2.4.11 & $\begin{array}{l}\text { Maintain Safe and Compliant Waste Encapsulation and } \\
\text { Storage Facility in Central Plateau Areas }\end{array}$ & Not applicable \\
\hline 1.2.4.12 & $\begin{array}{l}\text { Maintain Safe and Compliant Plutonium Finishing Plant } \\
\text { Facility in Central Plateau Areas }\end{array}$ & Not applicable \\
\hline 1.2 .4 .13 & $\begin{array}{l}\text { Maintain Safe and Compliant Reduction Oxidation Plant } \\
\text { Facility in Central Plateau Areas }\end{array}$ & Not applicable \\
\hline 1.2 .4 .14 & $\begin{array}{l}\text { Maintain Safe and Compliant Uranium Oxide Plant Facility in } \\
\text { Central Plateau Areas }\end{array}$ & Not applicable \\
\hline 1.2 .4 .15 & $\begin{array}{l}\text { Maintain Safe and Compliant SNF Preparation Facility in } \\
\text { Central Plateau Areas }\end{array}$ & Not applicable \\
\hline 1.2 .4 .16 & $\begin{array}{l}\text { Maintain Safe and Compliant T Plant Facility in Central } \\
\text { Plateau Areas }\end{array}$ & X.1.9 \\
\hline 1.2.4.17 & $\begin{array}{l}\text { Maintain Safe and Compliant M-33/M-91 Facility in Central } \\
\text { Plateau Areas }\end{array}$ & X.1.9 \\
\hline
\end{tabular}

$$
\begin{aligned}
& 2-105 \\
& 2-\mu^{4 n^{1}}
\end{aligned}
$$


HNF-SD-WM-RPT-288

Revision 0

Table 2-14. Functional Crosswalk - Site Systems Engineering to Waste Management. (4 sheets)

\begin{tabular}{|c|c|c|}
\hline \multicolumn{2}{|r|}{ Site Systems Engineering functions } & \multirow[t]{2}{*}{ Waste Management Project functions } \\
\hline No. & Title & \\
\hline 1.2.4.18 & $\begin{array}{l}\text { Maintain Safe and Compliant WRAP Module } 1 \text { Facility in } \\
\text { Central Plateau Areas }\end{array}$ & X.1.9 \\
\hline 1.2 .4 .19 & $\begin{array}{l}\text { Maintain Safe and Compliant LLMW Stabilization Facility in } \\
\text { Central Plateau Areas }\end{array}$ & X.1.9 \\
\hline 1.2 .4 .20 & $\begin{array}{l}\text { Maintain Safe and Compliant Thermal Treatment Facility in } \\
\text { Central Plateau Areas }\end{array}$ & X.1.9 \\
\hline 1.2 .4 .21 & $\begin{array}{l}\text { Maintain Safe and Compliant } 200 \text { Area Effluent Treatment } \\
\text { Facility in Central Plateau Areas }\end{array}$ & X.1.9 \\
\hline 1.2 .4 .22 & $\begin{array}{l}\text { Maintain Safe and Compliant Central Plateau Storage Facility } \\
\text { in Central Plateau Areas }\end{array}$ & X.1.9 \\
\hline 1.2 .4 .23 & $\begin{array}{l}\text { Maintain Safe and Compliant Single-Shell Tank Facilities in } \\
\text { Central Plateau Areas }\end{array}$ & Not applicable \\
\hline 1.2 .4 .24 & $\begin{array}{l}\text { Maintain Safe and Compliant Double-Shell Tank Facilities in } \\
\text { Central Plateau Areas }\end{array}$ & Not applicable \\
\hline 1.2 .4 .25 & $\begin{array}{l}\text { Maintain Safe and Compliant Canister Storage Building in } \\
\text { Central Plateau Areas }\end{array}$ & X.1.9 \\
\hline 1.2 .4 .26 & $\begin{array}{l}\text { Maintain Safe and Compliant Interim Storage Facility in } \\
\text { Central Plateau Areas }\end{array}$ & X.1.9 \\
\hline 1.2 .4 .27 & $\begin{array}{l}\text { Maintain Safe and Compliant Central Waste Complex } \\
\text { Facilities in Central Plateau Areas }\end{array}$ & X.1.9 \\
\hline 1.2 .4 .28 & $\begin{array}{l}\text { Maintain Safe and Compliant } 200 \text { East Burial Grounds Facility } \\
\text { in Central Plateau Areas }\end{array}$ & $\mathrm{X} .1 .9$ \\
\hline 1.2 .4 .29 & $\begin{array}{l}\text { Maintain Safe and Compliant } 200 \text { West Burial Grounds } \\
\text { Facility in Central Plateau Areas }\end{array}$ & X.1.9 \\
\hline 1.2 .4 .30 & $\begin{array}{l}\text { Maintain Safe and Compliant Non-radioactive Dangerous } \\
\text { Waste Storage Facility in Central Plateau Areas }\end{array}$ & $\times .1 .9$ \\
\hline 1.2 .4 .31 & $\begin{array}{l}\text { Maintain Safe and Compliant Liquid Effluent Retention } \\
\text { Facility in Central Plateau Areas }\end{array}$ & X.2.7 \\
\hline 1.2 .4 .32 & $\begin{array}{l}\text { Maintain Safe and Compliant Transuranic Storage and Assay } \\
\text { Facility in Central Plateau Areas }\end{array}$ & X.1.9 \\
\hline 1.2 .4 .33 & $\begin{array}{l}\text { Maintain Safe and Compliant Special Case Waste Interim } \\
\text { Storage Facility in Central Plateau Areas }\end{array}$ & X. 1.9 \\
\hline 1.2 .4 .34 & $\begin{array}{l}\text { Maintain Safe and Compliant Central Plateau Disposal } \\
\text { Facilities in Central Plateau Areas }\end{array}$ & $\mathrm{X} .1 .9$ \\
\hline 1.2 .4 .35 & $\begin{array}{l}\text { Maintain Safe and Compliant Low-Level Burial Grounds } \\
\text { Facility in Central Plateau Areas }\end{array}$ & X.1.9 \\
\hline 1.2 .4 .36 & $\begin{array}{l}\text { Maintain Safe and Compliant Mixed Waste Disposal Facility } \\
\text { in Central Plateau Areas }\end{array}$ & $\mathrm{X} .1 .9$ \\
\hline 1.2 .4 .37 & $\begin{array}{l}\text { Maintain Safe and Compliant } 200 \text { Area Treated Effluent } \\
\text { Disposal Facility in Central Plateau Areas }\end{array}$ & X.1.9 \\
\hline 1.2 .4 .38 & $\begin{array}{l}\text { Maintain Safe and Compliant Environmental Restoration } \\
\text { Disposal Facility in Central Plateau Areas }\end{array}$ & Not applicable \\
\hline 1.2 .4 .39 & $\begin{array}{l}\text { Maintain Safe and Compliant Immobilization Low-Level Tank } \\
\text { Waste Disposal Facility in Central Plateau Areas }\end{array}$ & Not applicable \\
\hline 1.2 .4 .40 & $\begin{array}{l}\text { Maintain Safe and Compliant Central Plateau Infrastructure } \\
\text { Facility in Central Plateau Areas }\end{array}$ & $X .1 .9, X .2 .7$, and X.4.5 \\
\hline
\end{tabular}


Table 2-14. Functional Crosswalk - Site Systems Engineering to Waste Management. (4 sheets)

\begin{tabular}{|c|c|c|}
\hline \multicolumn{2}{|r|}{ Site Systems Engineering functions } & \multirow[t]{2}{*}{ Waste Management Project functions } \\
\hline No. & Title & \\
\hline 1.2 .4 .41 & $\begin{array}{l}\text { Maintain Safe and Compliant 222-S Laboratory Facility in } \\
\text { Central Plateau Areas }\end{array}$ & $\mathrm{X} .4 .5$ \\
\hline 1.2 .4 .42 & $\begin{array}{l}\text { Maintain Safe and Compliant Waste Sampling and } \\
\text { Characterization Facility in Central Plateau Areas }\end{array}$ & $\mathrm{X} .4 .5$ \\
\hline 1.2 .4 .43 & $\begin{array}{l}\text { Maintain Safe and Compliant Central Plateau Steam Plant } \\
\text { Facilities in Central Plateau Areas }\end{array}$ & Not applicable \\
\hline 1.2 .4 .44 & $\begin{array}{l}\text { Maintain Safe and Compliant Central Plateau Raw Water } \\
\text { Facilities in Central Plateau Areas }\end{array}$ & Not applicable \\
\hline 1.2 .4 .45 & $\begin{array}{l}\text { Maintain Safe and Compliant Central Plateau Office Facilities } \\
\text { in Central Plateau Areas }\end{array}$ & Not applicable \\
\hline 1.2 .5 & Maintain Safe and Compliant Wastes in Central Plateau Areas & $\mathrm{X} .1$ and X.2 \\
\hline 1.2 .6 & Control Access to the Central Plateau Areas & Not applicable \\
\hline 1.3 & Maintain Safe and Compliant Envelope for South 600 Area & See tributary function(s) \\
\hline 1.3 .4 & Maintain Safe and Compliant Facilities in South 600 Areas & See tributary function(s) \\
\hline 1.3 .4 .1 & $\begin{array}{l}\text { Maintain Safe and Compliant } 325 \text { Building in South } \\
600 \text { Areas }\end{array}$ & Not applicable \\
\hline 1.3 .4 .2 & $\begin{array}{l}\text { Maintain Safe and Compliant } 327 \text { Building in South } \\
600 \text { Areas }\end{array}$ & Not applicable \\
\hline 1.3.4.3 & $\begin{array}{l}\text { Maintain Safe and Compliant Fast Flux Test Facility in South } \\
600 \text { Areas }\end{array}$ & Not applicable \\
\hline 1.3.4.4 & $\begin{array}{l}\text { Maintain Safe and Compliant } 308 \text { Building in South } \\
600 \text { Areas }\end{array}$ & Not applicable \\
\hline 1.3 .4 .5 & $\begin{array}{l}\text { Maintain Safe and Compliant } 309 \text { Building in South } \\
600 \text { Areas }\end{array}$ & Not applicable \\
\hline 1.3 .4 .6 & $\begin{array}{l}\text { Maintain Safe and Compliant } 335 \text { Sodium Test Facility in } \\
\text { South } 600 \text { Areas }\end{array}$ & Not applicable \\
\hline 1.3.4.7 & $\begin{array}{l}\text { Maintain Safe and Compliant } 340 \text { Waste Handling Facility in } \\
\text { South } 600 \text { Areas }\end{array}$ & $\mathrm{X} .2 .7$ \\
\hline 1.3 .4 .8 & $\begin{array}{l}\text { Maintain Safe and Compliant } 307 \text { Liquid Waste Transfer } \\
\text { Facility Basins in South } 600 \text { Areas }\end{array}$ & $\mathrm{X} .2 .7$ \\
\hline 1.3 .4 .9 & $\begin{array}{l}\text { Maintain Safe and Compliant } 325 \text { Building in South } \\
600 \text { Areas }\end{array}$ & Not applicable \\
\hline 1.3 .4 .10 & $\begin{array}{l}\text { Maintain Safe and Compliant } 326 \text { Building in South } \\
600 \text { Areas }\end{array}$ & Not applicable \\
\hline 1.3 .4 .11 & $\begin{array}{l}\text { Maintain Safe and Compliant } 329 \text { Building in South } \\
600 \text { Areas }\end{array}$ & Not applicable \\
\hline 1.3 .4 .12 & $\begin{array}{l}\text { Maintain Safe and Compliant South } 600 \text { Area Disposal } \\
\text { Facility }\end{array}$ & Not applicable \\
\hline 1.3 .4 .13 & $\begin{array}{l}\text { Maintain Safe and Compliant } 300 \text { Area Treated Effluent } \\
\text { Disposal Facility }\end{array}$ & $\mathrm{X} .2 .7$ \\
\hline 1.3 .4 .14 . & Maintain Safe and Compliant South 600 Area Infrastruture & Not applicable \\
\hline 1.3 .4 .15 & Maintain Safe and Compliant 300 Area Steam Plant & Not applicable \\
\hline 1.3 .4 .16 & Maintain Safe and Compliant 300 Area Raw Water Facilities & Not applicable \\
\hline 1.3 .4 .17 & Maintain Safe and Compliant 300 Area Office Facilities & Not applicable \\
\hline 1.4 & Maintain Safe and Compliant Envelope for Central Core & Not applicable \\
\hline
\end{tabular}


Table 2-14. Functional Crosswalk - Site Systems Engineering to Waste Management. (4 sheets)

\begin{tabular}{|c|c|c|}
\hline & Site Systems Engineering functions & Waste Management Project functions \\
\hline No. & Title & \\
\hline 1.4 .1 & Maintain Safe and Compliant Materials in Central Core Area & Not applicable \\
\hline 1.4 .2 & Maintain Safe and Compliant Facilities in Central Core & Not applicable \\
\hline 1.4 .3 & Manage Soil Sites in Central Core Area & Not applicable \\
\hline 1.4 .4 & Maintain Safe and Compliant Facilities in Central Core Area & Not applicable \\
\hline 1.4 .5 & Maintain Safe and Compliant Waste in Central Core Area & Not applicable \\
\hline 1.4 .6 & Control Access to the Central Core Area & Not applicable \\
\hline 1.5 & $\begin{array}{l}\text { Maintain Safe and Compliant Envelope for Columbia River } \\
\text { Shoreline }\end{array}$ & Not applicable \\
\hline 2 & Clean Up Site & See tributary function(s) \\
\hline 2.1 & Clean Up Reactor Sites & Not applicable \\
\hline 2.1 .1 & Remove Materials from Reactor Sites and Facilities & Not applicable \\
\hline 2.1 .2 & Clean up Groundwater at Reactor Sites & Not applicable \\
\hline 2.1 .3 & Clean up Soil Sites at Reactor Sites & Not applicable \\
\hline 2.1 .4 & Transition Reactor Site Facilities & Not applicable \\
\hline 2.1 .5 & Decontaminate and Decommission Reactor Site Facilities & Not applicable \\
\hline 2.1 .6 & Retrieve Wastes from Reactor Sites and Facilities & Not applicable \\
\hline 2.2 & Clean Up Central Plateau Sites & See tributary function(s) \\
\hline 2.2 .1 & Retrieve Material from Central Plateau Sites and Facilities & X.1.1.5.1, X.1.3.1.2, and X.1.3.2.2 \\
\hline 2.2 .2 & Clean Up Groundwater at Central Plateau Sites & Not applicable \\
\hline 2.2 .3 & Clean Up Soil at Central Plateau Sites & Not applicable \\
\hline 2.2 .4 & Remove Material from Central Plateau Sites and Facilities & $X .1 .3 .5$ and $X .1 .7$ \\
\hline 2.2 .5 & $\begin{array}{l}\text { Decontaminate and Decommission Central Plateau Site } \\
\text { Facilities }\end{array}$ & X.1.1.5.3 and X.1.2.4.3 \\
\hline 2.2 .6 & Retrieve Waste from Central Plateau Sites & Not applicable \\
\hline 2.2 .6 .1 & Remove Waste from Double-Shell Tanks & Not applicable \\
\hline 2.2 .6 .2 & Remove Waste from Single-Shell Tank System & Not applicable \\
\hline 2.2 .7 & Transition Central Plateau Site Facilities & Not applicable \\
\hline 2.3 & Clean up South 600 Area Sites & See tributary function(s) \\
\hline 2.3 .1 & Remove Materials from South 600 Area Sites and Facilities & Not applicable \\
\hline 2.3 .2 & Clean up Groundwater at South 600 Areas Sites & Not applicable \\
\hline 2.3 .3 & Clean up Soil Sites at South 600 Area Sites & Not applicable \\
\hline 2.3 .4 & Transition South 600 Area Site Facilities & Not applicable \\
\hline 2.3 .5 & $\begin{array}{l}\text { Decontaminate and Decommission South } 600 \text { Area Site } \\
\text { Facilities }\end{array}$ & Not applicable \\
\hline 2.3 .6 & Retrieve Wastes from South 600 Area Sites & Not applicable \\
\hline 2.4 & Clean Up Central Core Sites & Not applicable \\
\hline 2.5 & Clean Up Sites Along Columbia River & Not applicable \\
\hline 3 & Treat Waste and Material & See tributary function(s) \\
\hline 3.1 & Treat Dangerous Waste & Not applicable \\
\hline 3.2 & Treat Nondangerous Waste & Not applicable \\
\hline 3.2 .1 & Collect Treated Liquid Effluent from Central Plateau Facilities & $\mathrm{X} .2 .6 .1$ \\
\hline 3.2 .2 & $\begin{array}{l}\text { Sample/Monitor Treated Liquid Effluent from Central Plateau } \\
\text { Facilities }\end{array}$ & Not applicable \\
\hline
\end{tabular}


Table 2-14. Functional Crosswaik - Site Systems Engineering to Waste Management. (4 sheets)

\begin{tabular}{|c|c|c|}
\hline \multicolumn{2}{|r|}{ Site Systems Engineering functions } & \multirow[t]{2}{*}{ Waste Management Project functions } \\
\hline No. & Title & \\
\hline 3.2 .3 & $\begin{array}{l}\text { Route Treated Liquid Effluents from Central Plateau Facilities } \\
\text { to Disposition }\end{array}$ & X.2.6.3 \\
\hline 3.2 .4 & Collect Non-Dangerous Liquid Waste in South 600 Areas & $\mathrm{X} .2 .6 .1$ \\
\hline 3.2 .5 & $\begin{array}{l}\text { Collect Suspect Non-Dangerous Liquid Waste in South } \\
600 \text { Areas }\end{array}$ & $\mathrm{X} .2 .6 .1$ \\
\hline 3.2 .6 & Provide Lag Storage for Non-Dangerous Liquid Waste & $\mathrm{X} .2 .2 .2$ and X.2.3.2 \\
\hline 3.2 .7 & Remove Contaminants from Non-Dangerous Liquid Waste & $\mathrm{X} .2 .2 .3$ and $\mathrm{X} .2 .3 .3$ \\
\hline 3.2 .8 & Transfer Non-Dangerous Liquid Waste for Disposition & $\mathrm{X} .2 .5 .5$ \\
\hline 3.3 & Treat Radioactive Waste & See tributary function(s) \\
\hline 3.3 .1 & Treat Special-Case Waste & Not applicable \\
\hline 3.3 .2 & Treat Low-Level Waste & See tributary function(s) \\
\hline 3.3 .2 .1 & Treat Category I Solid Low-Level Waste & X.1.1.1 and X.1.1.3 \\
\hline 3.3 .2 .2 & Treat Category III Solid Low-Level Waste & $\mathrm{X} .1 .1 .2$ and $\mathrm{X} .1 .1 .4$ \\
\hline 3.3 .2 .3 & Treat Greater Than Category III Solid Low-Level Waste & $\mathrm{X} .1 .1 .6$ \\
\hline 3.3 .2 .4 & Treat Liquid Low-Level Waste & $\mathrm{X} .2 .1, \mathrm{X} .2 .2$, and X.2.3.3 \\
\hline 3.3.2.4.1 & Collect Low-Level Liquid Waste & Not applicable \\
\hline 3.3.2.4.2 & Provide Low-Level Liquid Waste Lag Storage Capacity & Not applicable \\
\hline 3.3.2.4.3 & Remove Contaminants from Low-Level Liquid Waste & Not applicable \\
\hline 3.3 .2 .4 .4 & Transfer Treated Low-Level Liquid Waste for Disposition & Not applicable \\
\hline 3.3 .3 & Treat High-Level Waste & Not applicable \\
\hline 3.3 .4 & Treat TRU Waste & $\mathrm{X} .1 .3 .1$ and $\mathrm{X} .1 .3 .2$ \\
\hline 3.3 .4 .1 & Receive and Store TRU Waste & Not applicable \\
\hline 3.3 .4 .2 & Process Remote-Handled TRU Waste & Not applicable \\
\hline 3.3 .4 .3 & Process Contact-Handled TRU Waste in Boxes & Not applicable \\
\hline 3.3 .4 .4 & $\begin{array}{l}\text { Process Newly Generated Contact-Handled TRU Waste in } \\
\text { SWB }\end{array}$ & Not applicable \\
\hline 3.3 .4 .5 & Process Contact-Handled TRU Waste in Drums & Not applicable \\
\hline 3.3 .4 .6 & $\begin{array}{l}\text { Process Contact-Handled TRU Waste in Drums Requiring } \\
\text { Special Treatment }\end{array}$ & Not applicable \\
\hline 3.4 & Treat Dangerous and Radioactive (Mixed) Waste & See tributary function(s) \\
\hline 3.4 .1 & Treat MLLW & $\mathrm{X} .1 .2$ \\
\hline 3.4 .1 .1 & Receive and Store Contact-Handled LLMW & Not applicable \\
\hline 3.4 .1 .2 & Sort and Examine Contact-Handled LLMW & Not applicable \\
\hline 3.4 .1 .3 & $\begin{array}{l}\text { Process and Package Large Contact-Handled LLMW } \\
\text { Containers }\end{array}$ & Not applicable \\
\hline 3.4.1.4 & $\begin{array}{l}\text { Process and Package Contact-Handled Long-Length } \\
\text { Equipment }\end{array}$ & Not applicable \\
\hline 3.4 .1 .5 & $\begin{array}{l}\text { Process and Package Remote-Handled Long-Length } \\
\text { Equipment }\end{array}$ & Not applicable \\
\hline 3.4 .1 .6 & Process and Package Remote-Handled LLMW Drums & Not applicable \\
\hline 3.4 .1 .7 & Process and Package Remote-Handled LLMW Boxes & Not applicable \\
\hline 3.4 .2 & Treat MHLW & Not applicable \\
\hline 3.4 .2 .1 & Receive and Store in-Process Waste & Not applicable \\
\hline
\end{tabular}




\section{Revision 0}

Table 2-14. Functional Crosswalk - Site Systems Engineering to Waste Management.

(4 sheets)

\begin{tabular}{|c|c|c|}
\hline \multicolumn{2}{|r|}{ Site Systems Engineering functions } & Waste Management Project functions \\
\hline No. & $\begin{array}{c}\text { Title } \\
\end{array}$ & \\
\hline 3.4 .2 .2 & Pretreat Sludges/Solids for Phase I Treatment & Not applicable \\
\hline 3.4 .2 .3 & Process Waste in Double-Shell Tanks, Phase II & Not applicable \\
\hline 3.4 .2 .4 & Treat and Immobilize LAW, Phase I & Not applicable \\
\hline 3.4 .2 .5 & Treat and Immobilize LAW, Phase II & Not applicable \\
\hline 3.4 .2 .6 & Treat and Immobilize LAW/EIL, Phase I & Not applicable \\
\hline 3.4 .2 .7 & Treat and Immobilize LAW/HLW, Phase II & Not applicable \\
\hline 3.4 .3 & Treat TRU/TRUM Waste & $\mathrm{X} .1 .3 .1$ and $\mathrm{X} .1 .3 .2$ \\
\hline 3.4 .3 .1 & Receive and Store TRUM Waste & Not applicable \\
\hline 3.4 .3 .2 & Process Remote-Handled TRUM Waste & Not applicable \\
\hline 3.4 .3 .3 & Process Contact-Handled TRUM Waste in Boxes & Not applicable \\
\hline 3.4.3.4 & $\begin{array}{l}\text { Process Newly Generated Contact-Handled TRUM Waste in } \\
\text { SWB }\end{array}$ & Not applicable \\
\hline 3.4 .3 .5 & Process Contact-Handled TRUM Waste in Drums & Not applicable \\
\hline 3.4 .3 .6 & $\begin{array}{l}\text { Process Contact-Handled TRUM Waste in Drums Requiring } \\
\text { Special Treatment }\end{array}$ & Not applicable \\
\hline 3.4 .4 & Treat Liquid MLLW & $X .2 .1$ and $X .2 .2$ \\
\hline 3.4 .4 .1 & Collect MLL Liquid Waste & Not applicable \\
\hline 3.4 .4 .2 & Provide MLL Liquid Waste Lag Storage Capacity & Not applicable \\
\hline 3.4 .4 .3 & Remove Contaminants from MLL Liquid Waste & Not applicable \\
\hline 3.4 .4 .4 & Transfer Treated MLL Liquid Waste for Disposition & Not applicable \\
\hline 3.5 & Treat Materials & $\mathrm{X} .1 .5$ \\
\hline 3.6 & Treat Contaminated Equipment & $\mathrm{X} .1 .5$ \\
\hline 3.6 .1 & Receive Contaminated Equipment & $\mathrm{X} .1 .5 .1$ \\
\hline 3.6 .2 & Decontaminate Equipment & X.1.5.2 \\
\hline 3.6 .3 & Repair Low-Dose-Rate Equipment & $\mathrm{X} .1 .5 .3$ \\
\hline 3.6 .4 & Transport Disposition-Ready Equipment & $\mathrm{X} .1 .5 .4$ \\
\hline 4 & Store Waste and Material & See tributary function(s) \\
\hline 4.1 & Store Dangerous Waste & Not applicable \\
\hline 4.2 & Store Nondangerous Waste & Not applicable \\
\hline 4.3 & Store Radioactive Waste & See tributary function(s) \\
\hline 4.3 .1 & Store Special-Case Waste & Not applicable \\
\hline 4.3 .2 & Store LLW & X.1.1.1,X.1.1.2, X.1.1.3,X.1.1.4 \\
\hline 4.3 .2 .1 & Store GTCIII Solid LLW & $\mathrm{X} .1 .1 .6$ \\
\hline 4.3 .3 & Store HLW & Not applicable \\
\hline 4.3 .4 & Store TRU Waste & X.1.3.1 and X.1.3.4 \\
\hline 4.4 & Store Dangerous and Radioactive (Mixed) Waste & Not applicable \\
\hline 4.4 .1 & Store MLLW & $\begin{array}{l}\text { X.1.2, X.1.2.5, X.2.3.2, X.2.2.1.2, and } \\
\text { X.2.2.2.2 }\end{array}$ \\
\hline 4.4 .2 & Store MHLW & Not applicable \\
\hline 4.4 .3 & Store TRU/TRUM Waste & X.1.3.1 and X.1.3.4 \\
\hline 4.5 & Store Materials & Not applicable \\
\hline 5 & Disposition Waste and Material & See tributary function(s) \\
\hline 5.1 & Disposition Dangerous Waste & Not applicable \\
\hline
\end{tabular}


Table 2-14. Functional Crosswalk - Site Systems Engineering to Waste Management. (4 sheets)

\begin{tabular}{|c|c|c|}
\hline \multicolumn{2}{|r|}{ Site Systems Engineering functions } & \multirow{2}{*}{ Waste Management Project functions } \\
\hline No. & Title & \\
\hline 5.2 & Disposition Nondangerous Waste & Not applicable \\
\hline 5.3 & Disposition Radioactive Waste & See tributary function(s) \\
\hline 5.3 .1 & Disposition Special-Case Waste & Not applicable \\
\hline 5.3 .2 & Disposition Low-Level Waste & See tributary function(s) \\
\hline 5.3 .2 .1 & Disposition Category I Solid Low-Level Waste & $\mathrm{X} .1 .1 .5 .2$ \\
\hline 5.3 .2 .2 & Disposition Category III Solid Low-Level Waste & $\mathrm{X} .1 .1 .5 .2$ \\
\hline 5.3 .2 .3 & Disposition GTCIII Solid Low-Level Waste & $\mathrm{X} .1 .1 .6$ and $\mathrm{X} .1 .2 .5 .3$ \\
\hline 5.3 .2 .4 & Disposition Liquid Low-Level Waste & $\mathrm{X} .2 .3 .3$ \\
\hline 5.3 .3 & Disposition High-Level Waste & Not applicable \\
\hline 5.3 .4 & Disposition TRU Waste & $\mathrm{X} .1 .3 .5$ \\
\hline 5.4 & Disposition Dangerous and Radioactive (Mixed) Waste & See tributary function(s) \\
\hline 5.4 .1 & Disposition MLLW & X.1.2.4.2, X.1.2.5.3, and X.2.3 \\
\hline 5.4 .2 & Disposition MHLW & Not applicable \\
\hline 5.4 .3 & Disposition TRU/TRUM Waste & $\mathrm{X} .1 .3 .5$ \\
\hline 5.5 & Disposition Materials & $\mathrm{X} .1 .5 .4$ \\
\hline TRU & $\begin{aligned} \text { TCIII } & =\text { Greater Than Category III. } \\
\text { HLW } & =\text { high-level waste. } \\
\text { LEU } & =\text { low-enriched uranium. } \\
\text { LLW } & =\text { low-level waste. } \\
\text { IHLW } & =\text { mixed high-level waste. } \\
\text { ALLW } & =\text { mixed low-level waste. } \\
\text { SNF } & =\text { spent nuclear fuel. } \\
\text { TRU } & =\text { transuranic. } \\
\text { CRUM } & =\text { transuranic and transuranic mixed. }\end{aligned}$ & \\
\hline
\end{tabular}

Table 2-15. Functional Crosswalk - Waste Management to Site Systems Engineering. (6 sheets)

\begin{tabular}{|l|l|l|}
\hline \multicolumn{1}{|c|}{ Waste Management functions } & Site Systems Engineering functions \\
\hline \multicolumn{1}{|c|}{ No. } & \multicolumn{1}{|c|}{ Title } & \\
\hline X.1 & Manage Solid Waste and Materials & To be determined \\
\hline X.1.1 & Manage LLW & To be determined \\
\hline X.1.1.1 & Manage CH Cat I LLW & To be determined \\
\hline X.1.1.1.1 & Receive CH Cat I LLW Containers & To be determined \\
\hline X.1.1.1.2 & Assess CH Cat I LLW Drum Nondestructively & To be determined \\
\hline X.1.1.1.3 & Open-Sort CH Drum Contents & To be determined \\
\hline X.1.1.1.4 & Implement RWM Handling Process & To be determined \\
\hline X.1.1.1.5 & Super-Compact Cat I LLW Contents & To be determined \\
\hline X.1.1.1.6 & Repackage CH Cat I LLW & To be determined \\
\hline X.1.1.1.7 & Transport Disposition-Ready CH LLW & To be determined \\
\hline X.1.1.2 & Manage CH Cat III LLW & To be determined \\
\hline X.1.1.2.1 & Receive CH Cat III LLW Containers & To be determined \\
\hline X.1.1.2.2 & Remove Cat III LLW Overpack & To be determined \\
\hline X.1.1.2.3 & Assess CH Cat III LLW Drum Nondestructively & To be determined \\
\hline X.1.1.2.4 & Open-Sort CH Drum Contents & To be determined \\
\hline
\end{tabular}


Table 2-15. Functional Crosswalk - Waste Management to Site Systems Engineering. (6 sheets)

\begin{tabular}{|c|c|c|}
\hline \multicolumn{2}{|r|}{ Waste Management functions } & Site Systems Engineering functions \\
\hline No. & Title & \\
\hline $\mathrm{X} .1 .1,2.5$ & Implement RWM Handling Process & To be determined \\
\hline $\mathrm{X} .1 .1 .2 .6$ & Super-Compact Cat III LLW Contents & To be determined \\
\hline $\mathrm{X} .1 .1 .2 .7$ & Repackage CH Cat III LLW & To be determined \\
\hline X.1.1.2.8 & Transport Disposition-Ready CH LLW & To be determined \\
\hline X.1.1.3 & Manage RH Cat ILIW & To be determined \\
\hline X.1.1.3.1 & Receive RH Cat I LLW Containers & To be determined \\
\hline X.1.1.3.2 & Remove RH Cat I LLW Overpack/Shielding & To be determined \\
\hline X.1.1.3.3 & Assess RH Cat I LLW Drum Nondestructively & To be determined \\
\hline X.1.1.3.4 & Open-Sort RH Drum Contents & To be determined \\
\hline X.1.1.3.5 & Implement RWM Handling Process & To be determined \\
\hline$X .1 .1 .3 .6$ & Super-Compact Cat ILLW Contents & To be determined \\
\hline X.1.1.3.7 & Repackage RH Cat ILLW & To be determined \\
\hline $\mathrm{X} .1 .1 .3 .8$ & Transport Disposition-Ready RHILW & To be determined \\
\hline X.1.1.4 & Manage RH Cat III LLW & To be determined \\
\hline X.1.1.4.1 & Receive RH Cat III LLW Containers & To be determined \\
\hline$X .1 .1 .4 .2$ & Remove Cat III LLW Overpack/Shielding & To be determined \\
\hline X.1.1.4.3 & Assess RH Cat III LLW Drum Nondestructively & To be determined \\
\hline X.1.1.4.4 & Open-Sort RH Drum Contents & To be determined \\
\hline X.1.1.4.5 & Implement RWM Handling Process & To be determined \\
\hline X.1.1.4.6 & Super-Compact Cat III LLW Contents & To be determined \\
\hline $\begin{array}{ll}X .1 .1 .4 .7 \\
\end{array}$ & Repackage RH Cat III LLWW & To be determined \\
\hline X.1.1.4.8 & Transport Disposition-Ready RH LLW & To be determined \\
\hline $\mathrm{X} .1 .1 .5$ & Manage LLW Disposal Site & To be determined \\
\hline X.1.1.5.1 & Operate LLW Burial Ground & To be determined \\
\hline $\mathrm{X} .1 .1 .5 .2$ & Disposition Cat $\mathrm{I}$ and III LLW & To be determined \\
\hline $\mathrm{X} 1.1 .5 .3$ & Deactivate LLW Burial Ground & To be determined \\
\hline X.1.1.6 & Manage GTCIII LLW & To be determined \\
\hline X.1.1.6.1 & Store Containerized GTCIII LLW & To be determined \\
\hline X.1.1.6.2 & Transport (Ship) GTCIII LLW & To be determined \\
\hline X.1.1.6.3 & TreatDisposition GTCIII LLW & To be determined \\
\hline X.1.2 & Manage MeLW & To be determined \\
\hline X.1.2.1 & Manage CH MLLW & To be determined \\
\hline X.1.2.1.1 & Receive CF Cat I and III MLLW Containers & To be determined \\
\hline $\mathrm{X} .1 .2 .1 .2$ & Store CHMLLW & To be determined \\
\hline X.1.2.1.3 & Remove CH MLLW Overpack & To be determined \\
\hline $\mathrm{X} .1 .2 .1 .4$ & Assess CH MLLW Drum Nondestructively & To be determined \\
\hline X.1.2.1.5 & Transport/Ship CHMLLW & To be determined \\
\hline X.1.2.1.6 & Conduct Thermal Treatment & To be determined \\
\hline $\mathrm{X} .1 .2 .1 .7$ & Conduct Stabilization Treatment & To be determined \\
\hline X.1.2.1.8 & Conduct Other Specialized Treatments & To. be determined \\
\hline X.1.2.1.9 & Verify PA Requirements Compliance & To be determined \\
\hline X.1.2.1.10 & Transport/Ship Disposition-Ready CHMLLW & To be determined \\
\hline X.1.2.2 & Manage RH Cat IMLLW & To be determined \\
\hline $\mathrm{X.1.2.2.1}$ & Receive RH Cat IMLLW Containers & To be determined \\
\hline $\mathrm{X} .1 .2 .2 .2$ & Store RH Cat IMLLW & To be determined \\
\hline $\mathrm{X} .1 .2 .2 .3$ & Remove RFIMLLW Overpack/Shielding & To be determined \\
\hline
\end{tabular}


Table 2-15. Functional Crosswalk - Waste Management to Site Systems Engineering. (6 sheets)

\begin{tabular}{|c|c|c|}
\hline \multicolumn{2}{|r|}{ Waste Management functions } & Site Systems Engincering functions \\
\hline No. & Title & \\
\hline $\mathrm{X} .1 .2 .2 .4$ & Assess RH MLLW Drum Nondestructively & To be determined \\
\hline X.1.2.2.5 & Open-Sort RH LLW/MLLW Contents & To be determined \\
\hline $\mathrm{X} .1 .2 .2 .6$ & Implement RWM Handling Process & To be determined \\
\hline X.1.2.2.7 & Conduct Thermal Treatment & To be determined \\
\hline X.1.2.2.8 & Stabilize RCRA ${ }^{2}$ Non-Thermal MLLW & To be determined \\
\hline X.1.2.2.9 & Repackage RH Cat IMLLW & To be determined \\
\hline $\mathrm{X} .1 .2 .2 .10$ & Transport Disposition-Ready RH Cat I MLLW & To be determined \\
\hline $\mathrm{X} .1 .2 .3$ & Manage RH Cat III MLIW & To be determined \\
\hline X.1.2.3.1 & Receive RH Cat III MLIWW Containers & To be determined \\
\hline $\mathrm{X} .1 .2 .3 .2$ & Store RH Cat III MLLW & To be determined \\
\hline X.1.2.3.3 & Remove RHMLLW Overpack/Shielding & To be determined \\
\hline X.1.2.3.4 & Assess RH MLLW Drum Nondestructively & To be determined \\
\hline $\mathrm{X} .1 .2 .3 .5$ & Open-Sort RH LLW/MLLW Contents & To be determined \\
\hline $\mathrm{X} .1 .2 .3 .6$ & Implement RWM Handling Process & To be determined \\
\hline $\mathrm{X} .1 .2 .3 .7$ & Conduct Thermal Treatment & To be determined \\
\hline X.1.2.3.8 & Stabilize RCRA ${ }^{2}$ Non-Thermal MLLW & To be determined \\
\hline X.1.2.3.9 & Repackage RH Cat III MLLW & To be determined \\
\hline $\mathrm{X} .1 .2 .3 .10$ & Transport Disposition-Ready RH Cat III MLLW & To be determined \\
\hline $\mathrm{X} .1 .2 .4$ & Manage MLLW Disposal Site & To be determined \\
\hline $\mathrm{X} .1,2.4 .1$ & Operate MLLW Disposal Trench & To be determined \\
\hline $\mathrm{X} .1 .2 .4 .2$ & Disposition Cat I and III MLLW & To be determined \\
\hline $\mathrm{X} .1 .2 .4 .3$ & Deactivate MLLW Disposal Trench & To be determined \\
\hline $\mathrm{X} .1 .2 .5$ & Manage GTCIII MLLW & To be determined \\
\hline$X .1 .2 .5 .1$ & Store Containerized GTCIII MLLW & To be determined \\
\hline $\mathrm{X} .1 .2 .5 .2$ & Transport (Ship) Disposition-Ready GTCIII MLLW & To be determined \\
\hline$X .1 .2 .5 .3$ & Treat/Disposition GTCIII MLLWW & To be determined \\
\hline $\mathrm{X} .1 .3$ & Manage TRU/TRUM & To be determined \\
\hline $\mathrm{X} .1 .3 .1$ & Manage CH TRU/TRUM & To be determined \\
\hline $\mathrm{X} .1 .3 .1 .1$ & Receive CH TRU/TRUM Containers & To be determined \\
\hline $\mathrm{X} .1 .3 .1 .2$ & Retrieve Retrievably Stored CH TRU/TRUM & To be determined \\
\hline X.1.3.1.2.1 & Excavate TRU/TRUM Drum & To be determined \\
\hline $\mathrm{X} .1 .3 .1 .2 .2$ & Inspect TRU/TRUM Drum & To be determined \\
\hline $\mathrm{X} .1 .3 .1 .2 .3$ & Assess CH Container Nondestructively & To be determined \\
\hline $\mathrm{X}, 1.3 .1,2.4$ & Package TRU/TRUM Drum in Overpack & To be determined \\
\hline$X .1 .3 .1 .3$ & Provide CH TRU/TRUM Preprocessing Storage & To be determined \\
\hline $\mathrm{X} .1 .3 .1 .3 .1$ & Transport Overpacked TRU/TRUM to Storage & To be determined \\
\hline $\mathrm{X} .1 .3 .1 .3 .2$ & Store Overpacked TRU/TRUM & To be determined \\
\hline $\mathrm{X} .1 .3 .1 .3 .3$ & Transport Overpacked TRU/TRUM to Processing & To be determined \\
\hline X.1.3.1.4 & Remove TRU/TRUM Overpack & To be determined \\
\hline $\mathrm{X} .1 .3 .1 .4 .1$ & Remove Waste from Overpack & To be determined \\
\hline $\mathrm{X} .1 .3 .1 .4 .2$ & Recycle Overpack & To be determined \\
\hline $\mathrm{X} .1 .3 .1 .5$ & Assess CH Container Nondestructively & To be determined \\
\hline $\mathrm{X} .1 .3 .1 .6$ & Open-Sort CH TRU/TRUM Contents & To be determined \\
\hline $\mathrm{X} .1 .3 .1 .7$ & Treat CH TRU & To be determined \\
\hline $\mathrm{X} .1 .3 .1 .8$ & Treat CH TRU/TRUM & To be determined \\
\hline $\mathrm{X} .1 .3 .1 .9$ & Package TRU for WIPP & To be determined \\
\hline
\end{tabular}




\section{Revision 0}

Table 2-15. Functional Crosswalk - Waste Management to Site Systems Engineering. (6 sheets)

\begin{tabular}{|c|c|c|}
\hline \multicolumn{2}{|r|}{ Waste Management functions } & \multirow[t]{2}{*}{ Site Systems Engineering functions } \\
\hline No. & Title & \\
\hline X.1.3.1.10 & Package TRU/TRUM for WIPP & To be determined \\
\hline $\mathrm{X} .1 .3 .2$ & Manage RH TRU/TRUM & To be determined \\
\hline $\mathrm{X} .1 .3 .2 .1$ & Receive RH TRU/TRUM & To be determined \\
\hline $\mathrm{X} .1 .3 .2 .2$ & Retrieve Retrievably Stored RH TRU/TRUM & To be determined \\
\hline $\mathrm{X} .1 .3 .2 .3$ & Remove TRU/TRUM Overpack/Shielding & To be determined \\
\hline X.1.3.2.4 & Assess RH Container Nondestructively & To be determined \\
\hline $\mathrm{X} .1 .3 .2 .5$ & Open-Sort RH TRU/TRUM Contents & To be determined \\
\hline $\mathrm{X} .1 .3 .2 .6$ & Treat RH TRU & To be determined \\
\hline $\mathrm{X} .1 .3 .2 .7$ & Treat RH TRU/TRUM & To be determined \\
\hline $\mathrm{X} .1 .3 .2 .8$ & Package TRU for WIPP & To be determined \\
\hline $\mathrm{X} .1 .3 .2 .9$ & Package TRU/TRUM for WIPP & To be determined \\
\hline X.1.3.3 & Transport Disposition-Ready TRU/TRUM to Onsite Storage & To be determined \\
\hline $\mathrm{X} .1 .3 .4$ & Store Disposition-Ready TRU/TRUM Containers & To be determined \\
\hline X.1.3.5 & Ship Disposition-Ready TRU/TRUM & To be determined \\
\hline $\mathrm{X} .1 .4$ & (Placeholder TBD) & To be determined \\
\hline $\mathrm{X} .1 .5$ & Manage Contaminated Equipment & To be determined \\
\hline $\mathrm{X} .1 .5 .1$ & Receive Contaminated Equipment & To be determined \\
\hline $\mathrm{X} .1 .5 .2$ & Decontaminate Equipment & To be determined \\
\hline $\mathrm{X} .1 .5 .3$ & Repair Low-Dose Rate Equipment & To be determined \\
\hline X.1.5.4 & Transport Disposition-Ready Equipment & To be determined \\
\hline $\mathrm{X} .1 .6$ & Store Radioactive Materials & To be determined \\
\hline X.1.6.1 & Store TRIGA Fuel & To be determined \\
\hline $\mathrm{X} .1 .6 .2$ & Store Sodium & To be determined \\
\hline $\mathrm{X} .1 .6 .3$ & Store Shipping port Reactor Core & To be determined \\
\hline $\mathrm{X} .1 .7$ & Ship Hazardous Waste to Offsite TSD Facility & To be determined \\
\hline X.1.8 & Maintain Inactive Solid Waste Facilities & To be determined \\
\hline $\mathrm{X} .1 .9$ & Operate and Maintain Active Solid Waste Facilities & To be determined \\
\hline$X .1 .9 .1$ & Operate and Maintain Plant Systems & To be determined \\
\hline X.1.9.2 & Operate and Maintain Facility Support Systems & To be determined \\
\hline $\mathrm{X} .1 .9 .3$ & Operate and Maintain Protection Systems & To be determined \\
\hline $\mathrm{X} .1 .9 .4$ & Maintain Information Management Systems & To be determined \\
\hline $\mathrm{X} .1 .9 .5$ & Manage Facility Wastes & To be determined \\
\hline $\mathrm{X} .1 .10$ & Provide Generator Services & To be determined \\
\hline $\mathrm{X} 2$ & Manage Liquid Waste & To be determined \\
\hline $\mathrm{X} .2 .1$ & Concentrate Liquid Tank Waste & To be determined \\
\hline $\mathrm{X} .2 .1 .1$ & Stage Tank Waste for Evaporator Campaign & To be determined \\
\hline $\mathrm{X} .2 .1 .2$ & Evaporate Liquid Tank Waste & To be determined \\
\hline X.2.1.3 & Analyze Process Streams & To be determined \\
\hline $\mathrm{X} .2 .1 .4$ & Return Concentrated Liquid Tank Waste to Tank Farms & To be determined \\
\hline $\mathrm{X} .2 .1 .5$ & Transfer Process Condensate & To be determined \\
\hline $\mathrm{X} .2 .2$ & Treat Liquid Effluent Streams & To be determined \\
\hline $\mathrm{X} .2 .2 .1$ & Treat CERCLA ${ }^{\mathrm{b}}$-Generated Liquid Effluent Streams & To be determined \\
\hline $\mathrm{X} .2 .2 .1 .1$ & Receive CERCLA ${ }^{b}$-generated Liquid Waste & To be determined \\
\hline $\mathrm{X} .2 .2 .1 .2$ & Store Liquid Waste & To be determined \\
\hline $\mathrm{X} .2 .2 .1 .3$ & Analyze Process Streams & To be determined \\
\hline $\mathrm{X} .2 .2 .1 .4$ & Treat Liquid Waste & To be determined \\
\hline
\end{tabular}


Table 2-15. Functional Crosswalk - Waste Management to Site Systems Engineering. (6 sheets)

\begin{tabular}{|c|c|c|}
\hline \multicolumn{2}{|r|}{ Waste Management functions } & Site Systems Engineering functions \\
\hline No. & Title & \\
\hline $\mathrm{X} .2 .2 .1 .5$ & Manage Solid Wastes for Disposition & To.be determined \\
\hline $\mathrm{X} .2 .2 .1 .6$ & Transfer Treated Effluent for Disposal & To be determined \\
\hline $\mathrm{X} .2 .2 .2$ & Treat Listed RCRA ${ }^{\circ} /$ Mixed Waste Liquid Effluent Streams & To be determined \\
\hline $\mathrm{X} .2 .2 .2 .1$ & Receive Effluent Streams from Generators & To be determined \\
\hline $\mathrm{X} .2 .2 .2 .2$ & Store Effluent Streams & To be determined \\
\hline $\mathrm{X} 2.2 .2 .3$ & Analyze Process Streams & To be determined \\
\hline X.2.2.2.4 & Treat Effluent Streams & To be determined \\
\hline $\mathrm{X} .2 .2 .2 .5$ & Manage Solid Wastes for Disposition & To be determined \\
\hline $\mathrm{X} .2 .2 .2 .6$ & Transfer Treated Effluent for Disposal & To be determined \\
\hline $\mathrm{X} .2 .2 .3$ & Treat Non-Listed/Industrial Effluent Streams & To be determined \\
\hline $\mathrm{X} .2 .2 .4$ & Treat LLW Effluent Streams & To be determined \\
\hline $\mathrm{X} .2 .2 .5$ & Manage Miscellaneous Streams & To be determined \\
\hline X.2.3 & Discharge Treated Liquid Effluents & To be determined \\
\hline $\mathrm{X} .2 .3 .1$ & Receive Discharge-Ready Liquid Effluents & To be determined \\
\hline $\mathrm{X} .2 .3 .2$ & Hold Pending Discharge & To be determined \\
\hline $\mathrm{X} .2 .3 .3$ & Verify Discharge Criteria Compliance & To be determined \\
\hline$X .2 .3 .4$ & Discharge at Approved Disposal Site & To be determined \\
\hline $\mathrm{X} .2 .4$ & Operate and Maintain Active Liquid Waste Facilities & To be determined \\
\hline X.2.4.1 & Operate and Maintain Plant Systems & To be determined \\
\hline $\mathrm{X} .2 .4 .2$ & Operate and Maintain Facility Support Systems & To be determined \\
\hline $\mathrm{X} .2 .4 .3$ & Operate and Maintain Protection Systems & To be determined \\
\hline $\mathrm{X} .2 .4 .4$ & Maintain Information Management Systems & To be determined \\
\hline $\mathrm{X} .2 .4 .5$ & Manage Facility Wastes & To be determined \\
\hline $\mathrm{X} .2 .5$ & Maintain Inactive Liquid Waste Facilities & To be determined \\
\hline $\mathrm{X} 4$ & Provide Analytical Services & To be determined \\
\hline X.4.1 & Provide Laboratory Services & To be determined \\
\hline$X .4 .1 .1$ & Provide HL Radioactive Sample Services & To be determined \\
\hline $\mathrm{X}, 4.1 .1 .1$ & Provide Routine HIL Sample Services & To be determined \\
\hline $\mathrm{X} .4 .1 .1 .1 .1$ & Receive HL Radioactive Sample & To be determined \\
\hline $\mathrm{X} .4 .1 .1 .1 .2$ & Prepare HL Sample for Analysis & To be determined \\
\hline $\mathrm{X} .4 .1 .1 .1 .3$ & Analyze HL Sample & To be determined \\
\hline $\mathrm{X} .4 .1 .1 .1 .4$ & Report Sample Analysis Results & To be determined \\
\hline X.4.1.1.2 & Provide HL Developmental Services & To be determined \\
\hline X.4.1.2 & Provide LL Radioactive Sample Services & To be determined \\
\hline $\mathrm{X} .4 .1 .2 .1$ & Provide Routine LL Sample Services & To be defermined \\
\hline $\mathrm{X} .4 .1 .2 .1 .1$ & Receive LL Radioactive Sample & To be determined \\
\hline $\mathrm{X} .4 .1 .2 .1 .2$ & Collect LL Radioactive Sample & To be determined \\
\hline $\mathrm{X} .4 .1 .2 .1 .3$ & Prepare LL Sample for Analysis & To be determined \\
\hline $\mathrm{X} .4 .1 .2 .1 .4$ & Analyze LL Sample & To be determined \\
\hline X.4.1.2.1.5 & Report Sample Analysis Results & To be determined \\
\hline $\mathrm{X} .4 .1 .2 .2$ & Provide LL Developmental Services & To be determined \\
\hline $\mathrm{X} .4 .2$ & Provide Mobile In-Field Analytical Services & To be determined \\
\hline $\mathrm{X} .4 .2 .1$ & Provide Routine In-Field LL Services & To be determined \\
\hline X.4.2.1.1 & Receive LL Radioactive Sample & To be determined \\
\hline $\mathrm{X} .4,2.1,2$ & Collect LL Radioactive Sample & To be determined \\
\hline $\mathrm{X.4.2.1.3}$ & Prepare LL Sample for Analysis & To be determined \\
\hline
\end{tabular}


Table 2-15. Functional Crosswalk - Waste Management to Site Systems Engineering. (6 sheets)

\begin{tabular}{|c|c|c|}
\hline \multicolumn{2}{|r|}{ Waste Management functions } & Site Systems Engineering functions \\
\hline No. & Title & \\
\hline $\mathrm{X} .4 .2 .1 .4$ & Analyze LL Sample & To be determined \\
\hline X.4.2.1.5 & Report Sample Analysis Results & To be determined \\
\hline $\mathrm{X} .4 .2 .2$ & Provide In-Field IL Developmental Services & To be determined \\
\hline $\mathrm{X} .4 .3$ & Provide Commercial Laboratory Services & To be determined \\
\hline $\mathrm{X} .4 .3 .1$ & Receive Low/Nonradioactive Sample & To be determined \\
\hline $\mathrm{X} .4 .3 .2$ & Collect Low/Nonradioactive Sample & To be determined \\
\hline $\mathrm{X} .4 .3 .3$ & Prepare Sample for Offsite Analysis & To be determined \\
\hline $\mathrm{X} .4 .3 .4$ & Ship Low/Nonradioactive Sample & To be determined \\
\hline $\mathrm{X} .4 .3 .5$ & Analyze Low/Nonradioactive Sample & To be determined \\
\hline $\mathrm{X} .4 .3 .6$ & Monitor Commercial Analysis Process & To be determined \\
\hline $\mathrm{X} .4 .3 .7$ & Report Sample Analysis Results & To be determined \\
\hline X.4.4 & Operate and Maintain Active Laboratory Facilities & To be determined \\
\hline $\mathrm{X} .4 .4 .1$ & Provide Standards Laboratory Services & To be determined \\
\hline $\mathrm{X} .4 .4 .2$ & Archive Samples & To be determined \\
\hline$X .4 .4 .2 .1$ & Archive HL Radioactive Samples & To be determined \\
\hline $\mathrm{X} .4 .4 .2 .2$ & Archive LL Radioactive Samples & To be determined \\
\hline $\mathrm{X} .4 .4 .3$ & Maintain Analytical Equipment Operational & To be determined \\
\hline $\mathrm{X} .4 .4 .4$ & Operate and Maintain Utility Systems & To be determined \\
\hline$X .4 .4 .5$ & Manage Laboratory Wastes & To be determined \\
\hline $\mathrm{X} .4 .4 .6$ & Operate and Maintain Protection Systems & To be determined \\
\hline $\mathrm{X} .4 .4 .7$ & Maintain Information Management Systems Operational & To be determined \\
\hline $\mathrm{X} .4 .5$ & Maintain Inactive Laboratory Facilities & To be determined \\
\hline $\begin{array}{r}\text { Resor } \\
\text { 'Comp } \\
\text { CH } \\
\text { GTCIII } \\
\text { HL } \\
\text { LL } \\
\text { LLW } \\
\text { MLLW } \\
\text { PA } \\
\text { RH } \\
\text { RWM } \\
\text { TRIGA } \\
\text { TRU } \\
\text { TRU/TRUM } \\
\text { TSD } \\
\text { WIPP }\end{array}$ & $\begin{array}{l}\text { Irce Conservation and Recovery Act of } 1976,42, \text { USC } 6901 \text {, et seq. } \\
\text { rehensive Environmental, Response, Compensation, and Liability Act of } \\
=\text { contact-handled. } \\
\text { = Greater Than Category III. } \\
=\text { high-level. } \\
=\text { low-level. } \\
\text { = low-level waste. } \\
\text { = mixed low-level waste. } \\
=\text { performance assessment. } \\
\text { = remote-handled. } \\
=\text { restricted waste management. } \\
\text { = Training Reactor, Isotopes, General Atomics. } \\
\text { = transuranic. } \\
=\text { transuranic and transuranic mixed. } \\
=\text { treatment, storage, and disposal. } \\
=\text { Waste Isolation Pilot Plant. }\end{array}$ & 2 USC 9601 , et seq. \\
\hline
\end{tabular}

\subsubsection{How to Use the Functions-Guidance for the Non-Systems Engineer}

The Project's functions, along with the associated requirements, etc., are under configuration control. All requirements, inputs/outputs (interfaces), and engineering documentation will be mapped to these functions, as will any facilities or other major resources used to carry out these functions. During this transition year (FY 1997), Project staff will work closely with the Project's budget group to better link (bridge) the WBS, schedule, and technical 
HNF-SD-WM-RPT-288

Revision 0

baseline. These mappings will enable management to quickly trace and assess the impact of proposed changes from either the bottom up or top down point of view as decisions and changes occur in the environment.

Some modifications to these product lines (functions) may occur in the future as changes are made to national or Hanford Site waste management policies, end-state targets, issues, or requirements, or as better solutions are developed during the systems engineering process. All recommended changes will be made through the Project's Technical Baseline group and the Project Hanford Management Contract change control process.

The following chapters help clarify the WBS.

- Chapter 3.0 identifies the requirements underlying the design and execution of these functions.

- Chapter 4.0 covers major external interfaces.

- Chapter 6.0 provides a high-level "system" level overview of the function presented in this chapter $(2.0)$.

- Chapter 8.0 helps bridge the gap between the functional view and how some of the Project functions are implemented.

\section{3 REFERENCES}

10 CFR 834, "Radiation Protection of the Public and the Environment," Code of Federal Regulations, as amended.

10 CFR 835, "Occupational Radiation Protection," Code of Federal Regulations, as amended.

40 CFR 61, "National Emission Standards for Hazardous Air Pollutants," Code of Federal Regulations, as amended.

Clean Air Act of 1995, 42 USC 7401, et seq.

Clean Water Act of 1977, 33 USC 1251, et seq.

Comprehensive Environmental, Response, Compensation, and Liability Act of 1980 , 42 USC 9601, et seq.

LMSI, 1997, Function Data Report, V41-HSTB-NEW-970121, January 21, Lockheed Martin Services, Inc., Richland, Washington.

Resource Conservation and Recovery Act of 1976, 42 USC 6901, et seq. 


\section{HNF-SD-WM-RPT-288}

Revision 0

RL, 1996, Project Hanford, U.S. Department of Energy, Richland Operations Office, Richland, Washington.

Safe Drinking Water Act of 1974, 42 USC 300f, et seq. 
HINF-SD-WM-RPT-288

Revision 0

\section{CONTENTS}

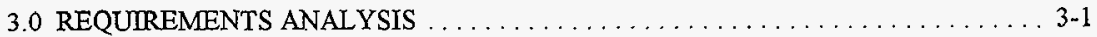

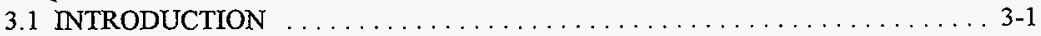

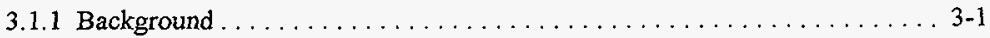

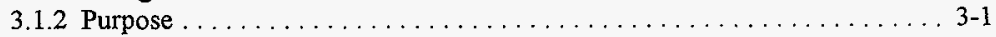

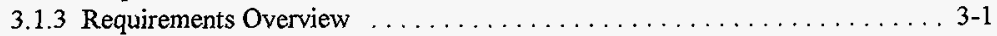

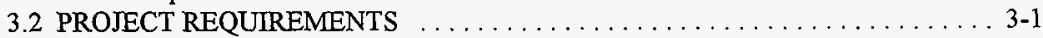

3.2.1 Common Requirements .......................... 3-2

3.2.2 Requirements Published Under Separate Cover $\ldots \ldots \ldots \ldots \ldots \ldots \ldots$ 3-2

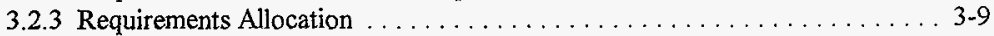

3.3 REFERENCES . . . . . . . . . . . . . . . . . . . . . . . . . . 3-9

\section{LIST OF TABLES}

3-1. Documents Used to Set the Site Systems Engineering Requirements . . . . . . . 3-2

3-2. Source Documents Used for Solid Waste Standards/Requirements Identification Document . . . . . . . . . . . . . . . . . . . . . . . . . . . . . . 3-3

3-3. Documents Req̨uired to Implement the Solid Waste Standards/Requirements Source

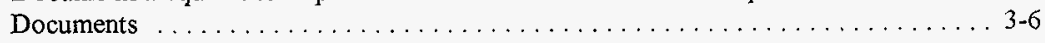




\section{HNF-SD-WM-RPT-288}

Revision 0

\section{LIST OF TERMS}

DNFSB

Project

S/RID
Defense Nuclear Facilities Safety Board

Waste Management Project

standards and requirements identification document 
HNF-SD-WM-RPT-288

Revision 0

\subsection{REQUIREMENTS ANALYSIS}

\subsection{INTRODUCTION}

The requirements analysis provides the basis for the Waste Management Project's (Project) functions, which are defined in Section 2.0. Requirements describe the need met by the functions to complete the mission identified in Section 1.0. Requirements define how well a function must perform, and set limits on functions and on the outputs from functions. Requirements include, but are not limited to, mission specifications, regulatory constraints, external policies, and internal policies.

\subsubsection{Background}

High-level requirements, which define the needs from the U.S. Department of Energy, include the Hanford Strategic Plan (RL 1996a), the Hanford Mission Direction Document (Draft) December 1995 (RL 1996b), and the Fiscal Year 1995 Hanford Mission Plan (RL 1994a).

\subsubsection{Purpose}

This section establishes the Project baseline requirements associated with each function defined in Section 2.0. Only the top-level requirements that govern the technical baseline system are presented.

\subsubsection{Requirements Overview}

The Project identifies the set of requirements necessary and sufficient to adequately protect workers, the public, and the environment. The Project incorporates federal, state, U.S. Department of Energy, and other requirements.

\subsection{PROJECT REQUIREMENTS}

Requirements are "driven down" from the highest levels. Table 3-1 presents the requirements that have been driven down to the Site systems engineering level. Table 3-2 presents the requirements that have been driven down to the waste management Solid Waste major subfunction. Table 3-3 subsequently defines implementing documents within the Solid Waste major subfunction. 
HNF-SD-WM-RPT-288

Revision 0

Table 3-1. Documents Used to Set the Site Systems Engineering Requirements.

\begin{tabular}{|c|c|}
\hline Document number & Document title \\
\hline- & Comprehensive Land Use Plan \\
\hline DOE/RL-96-92 & Hanford Strategic Plan (RL 1996a) \\
\hline- & Hanford Federal Facility Agreement and Consent Order (Ecology et. a1 1996) \\
\hline WAC $173-303$ & "Dangerous Waste Regulations" \\
\hline DOE Order $5820.2 \mathrm{~A}$ & Radioactive Waste Management (DOE 1988) \\
\hline DOE/EIS-0113 & $\begin{array}{l}\text { Final Environmental Impact Statement: Disposal of Hanford Defense High- } \\
\text { Level, Transuranic, and Tank Wastes, Hanford Site, Richland, Washingion } \\
\text { (DOE 1987) }\end{array}$ \\
\hline DOE/WIPP-069 & Waste Acceptance Criteria for the Waste Isolation Pilot Plant (WIPP 1996) \\
\hline DOE Order $6430.1 \mathrm{~A}$ & General Design Criteria (DOE 1989) \\
\hline DOE/RW-0351P & Waste Acceptance System Requirements Document (WASRD) (DOE/RW 1996) \\
\hline $10 \mathrm{CFR} 61$ & "Licensing Requirements for Land Disposal of Radioactive Waste" \\
\hline DOE Order 5400.5 & Radiation Protection of the Public and the Environment (DOE 1990) \\
\hline DOE Order 5480.4 & $\begin{array}{l}\text { Environmental Protection, Safety, and Health Protection Standards } \\
\text { (DOE 1984) }\end{array}$ \\
\hline
\end{tabular}

\subsubsection{Common Requirements}

Many of the Project requirements are common to other projects on the Hanford Site. Further work on this section is to be completed in the next revision of this document.

\subsubsection{Requirements Published Under Separate Cover}

To meet the requirements necessary and sufficient to adequately protect workers, the public, and the environment, the Project has developed WHC-IP-1120, Solid Waste Disposal Standards and Requirements Identification Document (S/RID) (Hamilton 1995) for the waste management Solid Waste major subfunction. ${ }^{1}$ This S/RID follows the structure of the Environment, Safety and Health Configuration Guide (DOE 1993); is compatible with the S/RID Development and Approval Instructions (DOE 1994); is consistent with Defense Nuclear Facilities Safety Board

${ }^{1}$ Waste Management Operations is replacing the SWD S/RID (WHC-IP-1120, Rev 4) with a new S/RD. On approval, which is tentatively set for the end of fiscal year 1997, WHC-IP-1120 and WHC-CM-5-36 will be cancelled. WHC-CM-5-34 is currently being replaced by a Waste Management Operations administration manual. 


\section{Revision 0}

(DNFSB) Recommendation 94-5 (DNFSB 1994); and meets the intent of DNFSB Recommendation 90-2 (DNFSB 1990).

Table 3-2. Source Documents Used for Solid Waste Standards/Requirements Identification Document. (3 sheets)

\begin{tabular}{|c|c|}
\hline Document number & Document title \\
\hline WAC $173-200$ & "Water Quality Standards for Groundwater of the State of Washington" \\
\hline WAC 173-216 & " "State of Washington Waste Discharge Permit Program" \\
\hline WAC 173-303 & "Dangerous Waste Regulations" \\
\hline WAC $173-307$ & "Plan Requirements" \\
\hline WAC $173-360$ & "Underground Storage Tank Regulations" \\
\hline WAC $173-400$ & "General Regulations for Air Pollution Sources" \\
\hline WAC $173-401$ & "Operating Permit Regulations" \\
\hline WAC $173-460$ & "Controls for New Sources of Toxic Air" \\
\hline WAC 197-11 & "Washington State Environmental Policy Act" \\
\hline WAC 212-80 & "Fire Sprinkler System Contractors" \\
\hline WAC $246-247$ & "Radiation Protection - Air Emissions" \\
\hline WAC $246-272$ & "On-Site Sewage System" \\
\hline WAC $246-290$ & "Public Water Supplies" \\
\hline WAC 296-24 & "General Safety and Health" \\
\hline WAC 296-62 & "Occupational Health Standards" \\
\hline $10 \mathrm{CFR} 830.120$ & "Quality Assurance" \\
\hline 10 CFR 835 & "Occupational Radiation Protection" \\
\hline 10 CFR 1008 & "Records Maintained on Individuals" \\
\hline 10 CFR 1021 & "National Environmental Policy Act Implementing Procedures" \\
\hline 29 CFR 1904 & "Recording and Reporting Occupational Injuries and Illnesses" \\
\hline 29 CFR 1910 & "Occupational Safety and Health Standards" \\
\hline 29 CFR 1926 & "Safety and Health Regulations for the Construction Industry" \\
\hline 36 CFR 79 & "Parks, Forests, and Public Property" \\
\hline 40 CFR 191 & $\begin{array}{l}\text { "Environmental Radiation Protection Standards for Management and Disposal of Spent } \\
\text { Nuclear Fuel, High-Level and Transuranic Radioactive Wastes" }\end{array}$ \\
\hline 40 CFR 26] & "Identification and Listing of Hazardous Waste" \\
\hline 40 CFR 262 & "Standards Applicable to Generators of Hazardous Waste" \\
\hline 40 CFR 265 & "Interim Status Standards for TSD Facilities" \\
\hline 40 CFR 268 & "Land Disposal Restrictions" \\
\hline 40 CFR 355 & "Emergency Planning and Notification" \\
\hline 40 CFR 370 & "Hazardous Chemical Reporting: Community Right-To-Know" \\
\hline 40 CFR 372 & "Toxic Chemical Release Reporting: Community Right-To-Know" \\
\hline
\end{tabular}


Revision 0

Table 3-2. Source Documents Used for Solid Waste Standards/Requirements Identification Document. (3 sheets)

\begin{tabular}{|c|c|}
\hline Document number & Document title \\
\hline 40 CFR 761 & $\begin{array}{l}\text { "Polychlorinated Biphenyls (PCB's) Manufacturing, Processing, Distribution in Commerce } \\
\text { and Use Prohibitions" }\end{array}$ \\
\hline 40 CFR 1501 & "National Environmental Policy Act (NEPA) Procedures" \\
\hline $49 \mathrm{CFR} 171$ & "Hazardous Materials Regulations" \\
\hline 49 CFR 172 & "Hazardous Materials Table, Special Provisions" \\
\hline 49 CFR 173 & "Shippers - General Requirements for Shipments and Packaging" \\
\hline $49 \mathrm{CFR} 174$ & "Carriage by Rail" \\
\hline $49 \mathrm{CFR} 177$ & "Carriage by Public Highway" \\
\hline 54 FR 3904 & "Safety and Health Program Management Guidelines; Issuance of Voluntary Guidelines" \\
\hline DOE Order 4700.3 & General Plant Projects (DOE 1991a) \\
\hline DOE Order 232.1 & Occurrence Reporting and Processing of Operations Information (DOE 1995a) \\
\hline DOE M 232.1-1 & Occurrence Reporting and Processing of Operations Information (DOE 1995b) \\
\hline DOE Order 5480.3 & $\begin{array}{l}\text { Safety Requirements for the Packaging and Transportation of Hazardous Materials, } \\
\text { Hazardous Substances and Hazardous Wastes (DOE 1985) }\end{array}$ \\
\hline DOE Order 5480.21 & Unreviewed Safety Questions (DOE 1991b) \\
\hline DOE Order 5480.22 & Technical Safety Requirements (DOE 1992a) \\
\hline DOE Order 5480.23 & Nuclear Safety Analysis Reports (DOE 1992b) \\
\hline DOE Order 5480.24 & Nuclear Criticality Safety (DOE 1992c) \\
\hline DOE Order 5481.1B & Safety Analysis and Review System (DOE 1986a) \\
\hline DOE Order 5482.1B & Environmental, Safety, and Health Appraisal Program (DOE 1986b) \\
\hline DOE Order 5500.1B & Emergency Management System (DOE 1991c) \\
\hline DOE Order $5500.2 \mathrm{~B}$ & $\begin{array}{l}\text { Emergency Categories, Classes, and Notification and Reporting Requirements } \\
\text { (DOE 1991d) }\end{array}$ \\
\hline DOE Order 5500.3A & Planning and Preparedness for Operational Emergencies (DOE 199le) \\
\hline RLID $5632.1 B$ & Asset Protection Requirements (RL 1994b) \\
\hline DOE Order $5820.2 \mathrm{~A}$ & Radioactive Waste Management (DOE 1988) \\
\hline DOE-STD-1027 & $\begin{array}{l}\text { Hazard Categorization and Accident Analysis Techniques for Compliance with DOE } \\
5480.23 \text { (DOE 1992d) }\end{array}$ \\
\hline NFPA & National Fire Prevention Association Codes and Standards \\
\hline RLD $1300.1 \mathrm{C}$ & Facility Representative Program (RL 1996c) \\
\hline UBC & Uniform Building Code (ICBO 1991) \\
\hline WHC-SP-1131 & WHC Quality Assurance Program and Implementation Plan (Moss 1995) \\
\hline
\end{tabular}


HNF-SD-WM-RPT-288

Revision 0

Table 3-2. Source Documents Used for Solid Waste Standards/Requirements Identification Document. (3 sheets)

\begin{tabular}{|c|c|}
\hline Document number & Document title \\
\hline WHC-CM-5-34 & $\begin{array}{l}\text { Solid Waste Disposal Operations Administration } \\
\text { Section 1.3, "Fire Protection," all except Para. 5.1.3 and Appendix A } \\
\text { Section 1.4, "Operational Readiness Activities" } \\
\text { Section 1.16, "Hazardous Material Packaging and Transportation" } \\
\text { Section 3.6, "Operations Maintenance Requirements" } \\
\text { Section 3.7, "Conduct of Operations," Chapter 2, "Shift Routines and Operating Practices" } \\
\text { Section 3.9, "Communications" } \\
\text { Section 3.10, "Conduct of Operations," Chapter 5, "On-the-Job Training" } \\
\text { Section 3.13, "Conduct of Operations," Chapter 8, "Control of Equipment and System } \\
\text { Status" } \\
\text { Section 3.14, "Lockout and Tagout" } \\
\text { Section 3.15, "Independent Verification" } \\
\text { Section 3.16, "Alarm Management" } \\
\text { Section 3.17, "Logkeeping" } \\
\text { Section 3.18, "Conduct of Operations, Chapter 12, "Operations Turnover" } \\
\text { Section 3.19, "Operations Aspects of Facility Chemistry and Unique Processes" } \\
\text { Section 3.20, "Required Reading" } \\
\text { Section 3.21, "Timely Orders to Operators" } \\
\text { Section 3.22, "Operations Procedures" } \\
\text { Section 3.23, "Operator Aid Postings" } \\
\text { Section 3.24, "Equipment and Piping Labeling" }\end{array}$ \\
\hline
\end{tabular}




\section{Revision 0}

Table 3-3. Documents Required to Implement the Solid Waste Standards/Requirements Source Documents. (3 sheets)

\begin{tabular}{|c|c|}
\hline Document number & Document title \\
\hline WHC-CM-5-36 & 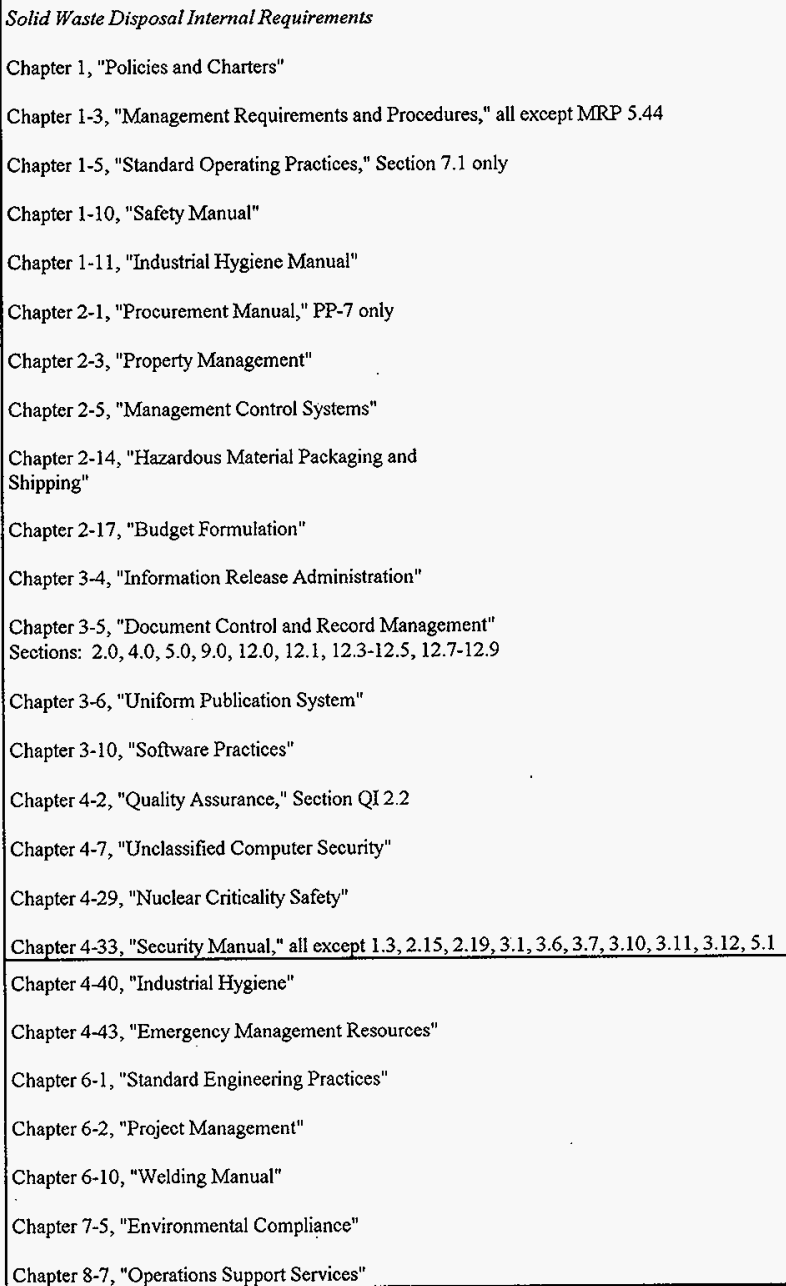 \\
\hline WHC-IP-1019 & Material Control and Accountability Plan (Engel 1994). \\
\hline
\end{tabular}


HNF-SD-WM-RPT-288

\section{Revision 0}

Table 3-3. Documents Required to Implement the Solid Waste Standards/Requirements Source Documents. (3 sheets)

\begin{tabular}{|c|c|}
\hline Document number & Document title \\
\hline DOE/RL-92-36 & Hanford Site Hoisting and Rigging Manual (RL 1993) \\
\hline WHC-SP-1145 & WHC Radiation Protection Program (Atencio 1995) \\
\hline HSRCM-1 & Hanford Site Radiation Control Manual (WHC 1994) \\
\hline WHC-SD-WM-RPT-060 & $\begin{array}{l}\text { Solid Waste Program Technical Baseline Description (Carlson and Sederburg 1994, 1995, and } \\
\text { 1996) }\end{array}$ \\
\hline WHC-CM-5-34 & $\begin{array}{l}\text { Solid Waste Disposal Operations Administration } \\
\text { Section 1.1, "External Correspondence and Technical Work Document Approvals" } \\
\text { Section 1.2, "Preparing and Maintaining the Solid Waste Disposal Manual" } \\
\text { Section 1.3, "Fire Protection," only 5.1.3 and Appendix A } \\
\text { Section 1.6, "Solid Waste Assurance Program" } \\
\text { Section 1.7, "Changes to Solid Waste Disposal Requirements" } \\
\text { Section 1.8, "Training Administration" } \\
\text { Section 1.9, "Quality Assurance Program Plan" } \\
\text { Section 1.10, "Inspections" } \\
\text { Section 1.11, "Self Assessment" } \\
\text { Section 1.12, "Hazard Communication Program" } \\
\text { Section 1.13, "Processing and Transferring Records" }\end{array}$ \\
\hline
\end{tabular}


Table 3-3. Documents Required to Implement the Solid Waste Standards/Requirements Source Documents. (3 sheets)

\begin{tabular}{|c|c|}
\hline Document number & Document title \\
\hline & $\begin{array}{l}\text { Section 1.14, "ALARA Program" } \\
\text { Section 1.15, "Safety Analysis" } \\
\text { Section 1.18, "Occurrence Reporting and Processing of Operations Information" } \\
\text { Section 1.20, "Waste Remediation Tracking System" } \\
\text { Section 1.22, "Corrective Action Management" } \\
\text { Section 1.24, "Unreviewed Safety Questions" } \\
\text { Section 1.28, "Waste Generation and Control" } \\
\text { Section 1.30, "Conducting Self Survey at Solid Waste Disposal" } \\
\text { Section 1.31, "Scheduling" } \\
\text { Section 1.32, "Change Control" } \\
\text { Section 2.1, "Configuration Change Control" } \\
\text { Section 2.2, "Solid Waste and T Plant As-Built Drawing Control" } \\
\text { Section 2.3, "Technical Notebooks" } \\
\text { Section 2.4, "Configuration Management" } \\
\text { Section 2.11, "Job Control System" } \\
\text { Section 2.17, "Criticality Safety" } \\
\text { Section 3.1, "Material Control" } \\
\text { Section 3.2, "Receipt of Submarine Reactor Compartments" } \\
\text { Section 3.3, "EPCRA } 312 \text { Chemical Inventory Reporting" } \\
\text { Section 3.4, "EPCRA 313 Chemical Release Reporting" } \\
\text { Section 3.5, "Operations Organization and Administration" }\end{array}$ \\
\hline
\end{tabular}


HNF-SD-WM-RPT-288

Revision 0

\subsubsection{Requirements Allocation}

The requirements developed for the waste management Solid Waste major subfunction under the S/RID process have yet to be allocated to the functions, inputs, and outputs defined in Section 2.0. This task will be completed in the next revision of this document. Requirements ties from other sources, such as the Hanford Site Environmental Management Specification, HNF-SD-WM-SD-024, will be added to future revisions of this documes

\subsection{REFERENCES}

10 CFR 61, "Licensing Requirements for Land Disposal of Radioactive Waste," Code of Federal Regulations, as amended.

10 CFR 830.120, "Quality Assurance," Code of Federal Regulations, as amended.

10 CFR 835, "Occupational Radiation Protection," Code of Federal Regulations, as amended.

10 CFR 1008, "Records Maintained on Individuals," Code of Federal Regulations, as amended.

10 CFR 1021, "National Environmental Policy Act Implementing Procedures," Code of Federal Regulations, as amended.

29 CFR 1904, "Recording and Reporting Occupational Injuries and Illnesses," Code of Federal Regulations, as amended.

29 CFR 1910, "Occupational Safety and Health Standards," Code of Federal Regulations, as amended.

29 CFR 1926, "Safety and Health Regulations for the Construction Industry," Code of Federal Regulations, as amended.

36 CFR 79, "Parks, Forests, and Public Property," Code of Federal Regulations, as amended.

40 CFR 191, "Environmental Radiation Protection Standards for Management and Disposal of Spent Nuclear Fuel, High-Level and Transuranic Radioactive Wastes," Code of Federal Regulations, as amended.

40 CFR 261, "Identification and Listing of Hazardous Waste," Code of Federal Regulations, as amended.

40 CFR 262, "Standards Applicable to Generators of Hazardous Waste," Code of Federal Regulations, as amended. 
HNF-SD-WM-RPT-288

Revision 0

40 CFR 265, "Interim Status Standards for TSD Facilities," Code of Federal Regulations, as amended.

40 CFR 268, "Land Use Restrictions," Code of Federal Regulations, as amended.

$40 \mathrm{CFR} 355$, "Emergency Planning and Notification," Code of Federal Regulations, as amended.

40 CFR 370, "Hazardous Chemical Reporting: Community Right-To-Know," Code of Federal Regulations, as amended.

40 CFR 372, "Toxic Chemical Release Reporting: Community Right-To-Know," Code of Federal Regulations, as amended.

40 CFR 761, "Polychlorinated Biphenyls (PCB's) Manufacturing, Processing, Distribution in Commerce and Use Prohibitions," Code of Federal Regulations, as amended.

40 CFR 1501, "National Environmental Policy Act (NEPA) Procedures," Code of Federal Regulations, as amended.

49 CFR 171, "Hazardous Materials Regulations," Code of Federal Regulations, as amended.

49 CFR 172, "Hazardous Materials Table, Special Provisions," Code of Federal Regulations, as amended.

49 CFR 173, "Shippers - General Requirements for Shipments and Packaging," Code of Federal Regulations, as amended.

49 CFR 174, "Carriage by Rail," Code of Federal Regulations, as amended.

49 CFR 177, "Carriage by Public Highway," Code of Federal Regulations, as amended.

54 FR 3904, 1989, "Safety and Health Program Management Guidelines, Issuance of Voluntary Guidelines," Federal Register, Vol. 54, No. 16, p. 3904 (January 26).

Atencio, E. M., 1995, WHC Radiation Protection Program Implementation of Title 10 Code of Federal Regulations Part 835, WHC-SP-1 145, Westinghouse Hanford Company, Richland, Washington.

Comprehensive Environmental Response, Compensation, and Liability Act of 1980 , 42 USC 9601 , et seq.

DNFSB, 1990, Standards Compliance, Recommendation 90-2, Defense Nuclear Facilities Safety Board, Washington, D.C.

DNFSB, 1994, Integration of DOE Safety Rules, Orders, and Other Requirements, Recommendation 94-5, Defense Nuclear Facilities Safety Board, Washington, D.C. 
HNF-SD-WM-RPT-288

Revision 0

DOE, 1984, Environmental Protection, Safety, and Health Protection Standards, DOE Order 5480.4, U.S. Department of Energy, Washington, D.C.

DOE, 1985, Safety Requirements for the Packaging and Transportation of Hazardous Materials, Hazardous Substances, and Hazardous Wastes, DOE Order 5480.3, U.S. Department of Energy, Washington, D.C.

DOE, 1986a, Safety Analysis and Review System, DOE Order 5481.1B, U.S. Department of Energy, Washington, D.C.

DOE, 1986b, Environmental, Safety, and Health Appraisal Program, DOE Order 5482.1B, U.S. Department of Energy, Washington, D.C.

DOE, 1987, Final Environmental Impact Statement: Disposal of Hanford Defense High-Level, Transuranic, and Tank Wastes, Hanford Site, Richland, Washington, DOE/EIS-0113, Vols. 1-5, U.S. Department of Energy, Washington, D.C.

DOE, 1988, Radioactive Waste Management, DOE Order 5820.2A, United States Department of Energy, Washington, D.C.

DOE, 1989, General Design Criteria, DOE Order 6430.1A, U.S. Department of Energy, Washington, D.C.

DOE, 1990, Radiation Protection of the Public and the Environment, DOE Order 5400.5, U.S. Department of Energy, Washington, D.C.

DOE, 1991a, General Plant Projects, DOE Order 4700.3, U.S. Department of Energy, Washington, D.C.

DOE, 1991b, Unreviewed Safety Questions, DOE Order 5480.21, U.S. Department of Energy, Washington, D.C.

DOE, 1991c, Emergency Management System, DOE Order 5500.1B, U.S. Department of Energy, Washington, D.C.

DOE, 1991d, Emergency Categories, Classes, and Notification and Reporting Requirements, DOE Order 5500.2B, U.S. Department of Energy, Washington, D.C.

DOE, 1991e, Planning and Preparedness for Operational Emergencies, DOE Order 5500.3A, U.S. Department of Energy, Washington, D.C.

DOE, 1992a, Technical Safety Requirements, DOE Order 5480.22, U.S. Department of Energy, Washington, D.C. 
HNF-SD-WM-RPT-288

Revision 0

DOE, 1992b, Nuclear Safety Analysis Reports, DOE Order 5480.23, U.S. Department of Energy, Washington, D.C.

DOE, 1992c, Nuclear Criticality Safety, DOE Order 5480.24, U.S. Department of Energy, Washington, D.C.

DOE, 1992d, Hazard Categorization and Accident Analysis Techniques for Compliance with DOE 5480.23, DOE-STD-1027, U.S. Department of Energy, Washington, D.C.

DOE, 1993, Environment, Safety and Health Configuration Guide, Rev. 0, July 30,

U.S. Department of Energy, Washington, D.C.

DOE, 1994, S/RID Development Approval Instructions, September, U.S. Department of Energy, Washington, D. C.

DOE, 1995a, Occurrence Reporting and Processing of Operations Information, DOE Order 232.1, U.S. Department of Energy, Washington, D.C.

DOE, 1995b, Occurrence Reporting and Processing of Operations Information, DOE M 232.1-1, U.S. Department of Energy, Washington, D.C.

DOE/RW, 1996, Waste Acceptance System Requirements Document (WASRD), DOE/RW-0351P, Rev. 2, U.S. Department of Energy, Office of Civilian Radioactive Waste Management, Washington, D.C.

Ecology, EPA, and DOE, 1966, Hanford Federal Facility Agreement and Consent Order, as amended, Washington State Department of Ecology, U.S. Environmental Protection Agency, and U.S. Department of Energy, Olympia, Washington.

Engel, D. W., 1994, Material Control and Accountability Plan, WHC-IP-1019, Rev. 0, Westinghouse Hanford Company, Richland, Washington.

Hamilton, W. H., 1995, Solid Waste Disposal Standards and Requirements Identification Document (S/RID), WHC-IP-I 120, Rev. 4, Westinghouse Hanford Company, Richland, Washington.

ICBO, 1991, Uniform Building Code, International Conference of Building Officials, Whittier, California.

Moss, S. S., 1995, WHC Quality Assurance Program and Implementation Plan, WHC-SP-1131, Rev. 1, Westinghouse Hanford Company, Richland, Washington.

RL, 1993, Hanford Site Hoisting and Rigging Manual, DOE/RL-92-36, Rev. 0, Westinghouse Hanford Company, Richland, Washington. 
HNF-SD-WM-RPT-288

Revision 0

RL, 1994a, Fiscal Year 1995 Hanford Mission Plan, Volume 1, "Site Guidance," DOE/RL-93-102, U.S. Department of Energy, Richland Operations Office, Richland, Washington.

RL, 1994b, Asset Protection Requirements, RLID 5632.1B, U.S. Department of Energy, Richland Operations Office, Richland, Washington.

RL, 1996a, Hanford Strategic Plan, DOE/RL-96-92, Rev. 0, U.S. Department of Energy, Richland Operations Office, Richland, Washington.

RL, 1996b, Hanford Mission Direction Document (Draft) December 1995, DOE/RL-96-14, U.S. Department of Energy, Richland Operations Office, Richland, Washington.

RL, 1996c, Richland Operations Office Facility Representative Program, RLID 1300.1C, U.S. Department of Energy, Richland Operations Office, Richland, Washington.

Sederburg, J. P., 1996, Solid Waste Program Technical Baseline Description, WHC-SD-WM-RPT-060, Rev. 2, Westinghouse Hanford Company, Richland, Washington.

WAC 173-216, "State of Washington Waste Discharge Permit Program," Washington Administrative Code, as amended.

WAC 173-200, "Water Quality Standards for Groundwater of the State of Washington," Washington Administrative Code, as amended.

WAC 173-303, "Dangerous Waste Regulations," Washington Administrative Code, as amended.

WAC 173-307, "Plan Requirements," Washington Administrative Code, as amended.

WAC 173-360, "Underground Storage Tank Regulations," Washington Administrative Code, as amended.

WAC 173-400, "General Regulations for Air Pollution Sources," Washington Administrative Code, as amended.

WAC 173-401, "Operating Permit Regulations," Washington Administrative Code, as amended.

WAC 173-460, "Controls for New Sources of Toxic Air," Washington Administrative Code, as amended.

WAC 197-11, "Washington State Environmental Policy Act," Washington Administrative Code, as amended. 
HNF-SD-WM-RPT-288

Revision 0

WAC 212-80, "Fire Sprinkler System Contractors," Washington Administrative Code, as amended.

WAC 246-247, "Radiation Protection - Air Emissions," Washington Administrative Code, as amended.

WAC 246-272, "On-Site Sewage System," Washington Administrative Code, as amended.

WAC 246-290, "Public Water Supplies," Washington Administrative Code, as amended.

WAC 296-24, "General Safety and Health," Washington Administrative Code, as amended.

WAC 296-62, "Occupational Health Standards," Washington Administrative Code, as amended.

WHC, 1994, Hanford Site Radiological Control Manual, HSRCM-1, Rev. 2, Westinghouse Hanford Company, Richland, Washington.

WHC-CM-5-34, Solid Waste Disposal Operations Administration, Westinghouse Hanford Company, Richland, Washington.

WHC-CM-5-36, Solid Waste Disposal Internal Requirements, Westinghouse Hanford Company, Richland, Washington.

WIPP, 1996, Waste Acceptance Criteria for the Waste Isolation Pilot Plant, WIPP/DOE-069, Rev. 5, Westinghouse Electric Corporation, Waste Isolation Division, Carlsbad, New Mexico. 
HNF-SD-WM-RPT-288

Revision 0

\section{CONTENTS}

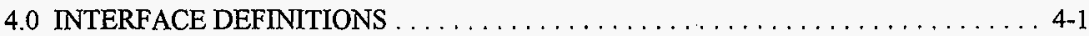

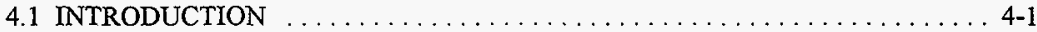

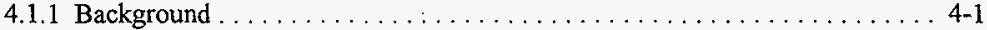

4.1 .2 Purpose and Scope .......................... 4-1

4.2 INTERNAL PROJECT INTERFACES . . . . . . . . . . . . . . . 4-2

4.2.1 Solid Waste and Liquid Waste Subprojects . . . . . . . . . . . . . 4-2

4.2.2 Liquid Waste and Analytical Services Subprojects . . . . . . . . . . . . . 4-4

4.2.3 Analytical Services and Solid Waste Subprojects . . . . . . . . . . 4-6

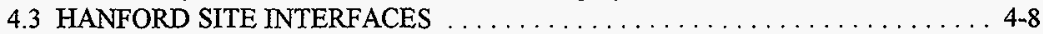

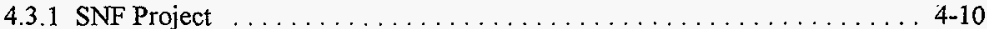

4.3 .2 TWRS . . . . . . . . . . . . . . . . . . . . . . 4-13

4.3.3 Environmental Restoration Program $\ldots \ldots \ldots \ldots \ldots \ldots \ldots \ldots \ldots . \ldots .14$

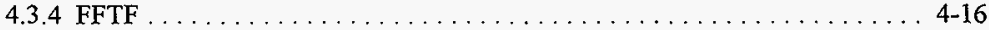

4.3 .5 PFP . . . . . . . . . . . . . . . . . . . . . . . . . . 4-18

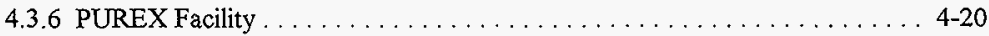

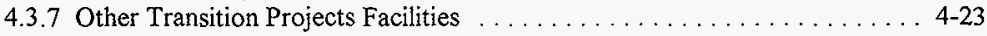

4.3 .8 PNNL . . . . . . . . . . . . . . . . . . . . . . . . . 4-24

4.3.9 B Plant/Waste Encapsulation and Storage Facility (WESF) . . . . . . . 4-25

4.3.10 Site Infrastructure Providers . . . . . . . . . . . . . . . . . . 4-26

4.3.11 TWRS Privatization-Phase I Facilities $\ldots \ldots \ldots \ldots \ldots \ldots \ldots \ldots \ldots .4 .31$

4.4 OFFSITE INTERFACES $\ldots \ldots \ldots \ldots \ldots \ldots \ldots \ldots \ldots \ldots \ldots \ldots \ldots . .4 .33$

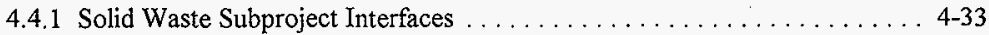

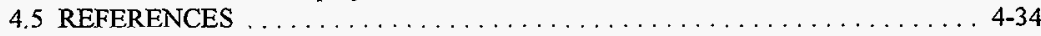


HNF-SD-WM-RPT-288

Revision 0

\section{LIST OF FIGURES}

4-1. Solid Waste and Liquid Waste

4-2. Liquid Waste and Analytical Services $\ldots \ldots \ldots \ldots \ldots \ldots \ldots \ldots \ldots \ldots$

4-3. Analytical Services and Solid Waste $\ldots \ldots \ldots \ldots \ldots \ldots \ldots \ldots \ldots \ldots \ldots$

4-4. DE\&S Hanford and Waste Management Subprojects . . . . . . . . . . . . . . 4-12

4-5. Fast Flux Test Facility Transition Programs . . . . . . . . . . . . . . . . . 4-17

4-6. Plutonium Finishing Plant Transition Project . . . . . . . . . . . . . . . . 4-19

4-7. Plutonium-Uranium Extraction Facility $\ldots \ldots \ldots \ldots \ldots \ldots \ldots \ldots \ldots \ldots \ldots$

4-8. Site Infrastructure $\ldots \ldots \ldots \ldots \ldots \ldots \ldots \ldots \ldots \ldots \ldots \ldots \ldots \ldots \ldots \ldots$

\section{LIST OF TABLES}

4-1. Contractor-Provided Instrastructure Services $\ldots \ldots \ldots \ldots \ldots \ldots \ldots \ldots \ldots \ldots$

4-2. Wastewater Streams at the 200 Area Treated Effluent Disposal Facility . . . . . . . . 4-30

4-3. Wastewater Streams at the 300 Area Treated Effluent Disposal Facility . . . . . . . . 4-32 


\section{LIST OF TERMS}

$\begin{array}{ll}\text { BWP } & \text { B\&W Protec, Inc. } \\ \text { CH } & \text { contact-handled } \\ \text { CWC } & \text { Central Waste Complex } \\ \text { D\&D } & \text { decontamination and decommissioning } \\ \text { DOE } & \text { U.S. Department of Energy } \\ \text { DynCorp } & \text { DynCorp Tri-Cities Services, Inc. } \\ \text { ERC } & \text { Environmental Restoration Contractor } \\ \text { ETF } & \text { Effluent Treatment Facility } \\ \text { FDH } & \text { Fluor Daniel Hanford, Inc. } \\ \text { FDNW } & \text { Fluor Daniel Northwest, Inc. } \\ \text { FFTF } & \text { Fast Flux Test Facility } \\ \text { FY } & \text { fiscal year } \\ \text { HEHF } & \text { Hanford Environmental Health Foundation } \\ \text { HLW } & \text { high-level waste } \\ \text { ICD } & \text { interface control document } \\ \text { INS } & \text { Interstate Nuclear Services } \\ \text { LAW } & \text { low-activity waste } \\ \text { LLW } & \text { low-level waste } \\ \text { LLWTF } & \text { Low-Level Waste Treatment Facility } \\ \text { LMHC } & \text { Lockheed Martin Hanford Corporation } \\ \text { LMSI } & \text { Lockheed Martin Services, Inc. } \\ \text { MLLW } & \text { mixed low-level waste } \\ \text { NHC } & \text { Numatec Hanford Corporation } \\ \text { NRDWSF } & \text { Nonradioactive Dangerous Waste Storage Facility } \\ \text { PFP } & \text { Plutonium Finishing Plant } \\ \text { PHMC } & \text { Project Hanford Management Contract } \\ \text { PNNL } & \text { Pacific Northwest National Laboratory } \\ \text { Project } & \text { Waste Management Project } \\ \text { PRTR } & \text { Plutonium Recycle Test Reactor } \\ \text { PUREX } & \text { Plutonim-Uranium Extraction } \\ \text { PWR } & \text { Pressurized Water Reactor } \\ \text { RCRA } & \text { Resource Conservation and Recovery Act of } 1976 \\ \text { RH } & \text { remote-handled } \\ \text { SESC } & \text { SGN Eurisys Services Corporation } \\ \text { SWIFT } & \text { Solid Waste Information Forecast Tool } \\ \text { SNF } & \text { Spent Nuclear Fuel } \\ \text { TEDF } & \text { Treated Effluent Disposal Facility } \\ \text { TRIGA } & \text { Training Reactor, Isotopes, General Atomics storage, and disposal } \\ \text { TRU } & \text { transuranic } \\ \text { TRUM } & \text { transuranic mixed } \\ \text { TRUSAF } & \\ \text { TSD } & \end{array}$


HNF-SD-WM-RPT-288

Revision 0

\section{LIST OF TERMS (Continued)}

TWRS

WIPP

WESF

WSCF
Tank Waste Remediation System

Waste Isolation Pilot Plant

Waste Encapsulation and Storage Facility

Waste Sampling and Characterization Facility 
HNF-SD-WM-RPT-288

Revision 0

\subsection{INTERFACE DEFINITIONS}

\subsection{INTRODUCTION}

The Waste Management Project (Project) is defined, in many ways, by the system interfaces among the subprojects and their respective customers and service providers. This section provides a top-level review of the internal subproject interfaces and their respective interfaces with other key onsite and offsite projects, programs, and facilities.

\subsubsection{Background}

The Project is responsible for the safe management and final disposition of legacy and futuregenerated waste and for providing analytical services associated with the disposition of these and other waste types. Successfully completing the Hanford Site's environmental management mission entails meeting mainy needs, including the need for "solid waste disposal to be consistent with national policies for management of transuranic, low-level, and low-level mixed and hazardous waste" (RL 1996). This includes receiving onsite and offsite waste for disposal in the 200 Areas. Furthermore, support services, such as analytical services capabilities, are needed to disposition hazardous and radioactive liquid waste.

\subsubsection{Purpose and Scope}

This section provides an overview of the interfaces within the Project; between the Project and other Hanford Site programs, projects, and facilities; between the Project and offsite customers; and between the Project and offsite service providers of treatment, storage, and disposal (TSD) and analytical services.

Numerous internal Project interfaces exist within the Project. The Solid Waste subproject (Solid Waste) and Analytical Services subproject (Analytical Services) rely on the Liquid Waste subproject (Liquid Waste) to provide TSD services for their liquid effluents. Both Solid Waste and Liquid Waste rely on Analytical Services to provide sampling and analysis services, while Analytical Services sends liquid and solid waste back to those respective subprojects. These internal interfaces are covered in Section 4.2.

The Project receives liquid and solid waste from most of the other programs, projects, and facilities on the Hanford Site. Analytical Services provides sampling and analysis services to many of the same onsite customers. The Project also relies on other onsite programs for meeting infrastructure needs, turning over aging facilities to the Transition Program, transferring stewardship for spent fuels, and meeting other needs for completion of its mission. The Project interfaces with other onsite projects, programs, and facilities are discussed in Section 4.3. 
Solid Waste also receives newly generated waste from offsite sources. In turn, Solid Waste and Liquid Waste use or may plan to use offsite TSD facilities to achieve their missions. Analytical Services also relies on offsite laboratories to augment its capabilities. The interface between the Project and its primary offsite customers and service providers is covered in Section 4.4.

\subsection{INTERNAL PROJECT INTERFACES}

This section defines the internal interfaces among the subprojects (Solid Waste, Liquid Waste, and Analytical Services).

\subsubsection{Solid Waste and Liquid Waste Subprojects}

The interface between Solid Waste and Liquid Waste encompasses the liquid waste generated by Solid Waste and the solid waste generated by Liquid Waste (Figure 4-1). WHC-SD-WMPICD-001, Liquid Effluent Services and Solid Waste Disposal Interface Control Document (ICD) (Greager 1996a) covers the interface between the two subprojects in more detail. In addition to describing the interface between these subprojects, the ICD provides a baseline description of this waste, including waste volumes, characteristics, and timing for use in planning the proper waste management capabilities.

4.2.1.1 Liquid Waste Generated by the Solid Waste Subproject. Liquid Waste will manage the liquid waste generated by Solid Waste over its life cycle as identified in Section 2.0 of the ICD (Greager 1996a). This waste includes approximately $120 \mathrm{~m}^{3}$ of T Plant waste water and approximately $750 \mathrm{~m}^{3}$ of leachate from the mixed low-level waste (MLLW) trenches annually. Management begins when the waste is placed into the trenches.

Liquid Waste will not provide for the collection of any liquid waste generated by Solid Waste that requires treatment other than normal lag storage at Liquid Waste-operated treatment facilities. Solid Waste will be responsible for collecting liquids at its facilities. Solid Waste will provide treatment systems to condition the waste as needed to make it compatible for treatment in Liquid Waste facilities. In addition, Solid Waste will arrange transport of liquid waste to Liquid Waste facilities. Liquid Waste will provide treatment capacity to treat the quantity of liquid waste generated by Solid Waste providing that all permit conditions are met. Liquid Waste will provide for the discharge of liquid effluents that have been treated. (See Figure 4-1.)

4.2.1.2 Solid Waste Generated by the Liquid Waste Subproject. Solid Waste will manage the solid waste generated by Liquid Waste as identified in Section 3.0 of the ICD

(Greager 1996a). Appendix A in the ICD contains the baseline waste projections for solid waste generated by Liquid Waste and the Resource Conservation and Recovery Act of 1976 (RCRA) and Operations Monitoring Program requiring TSD. The forecasted waste volumes are for streams originating from the 200 Area Effluent Treatment Facility (ETF), 300 Area Treated Effluent Disposal Facility (TEDF), and the 340 Waste Handling Facility. (See Figure 4-1.) 
HNF-SD-WM-RPT-288

Revision 0

Figure 4-1. Solid Waste and Liquid Waste.

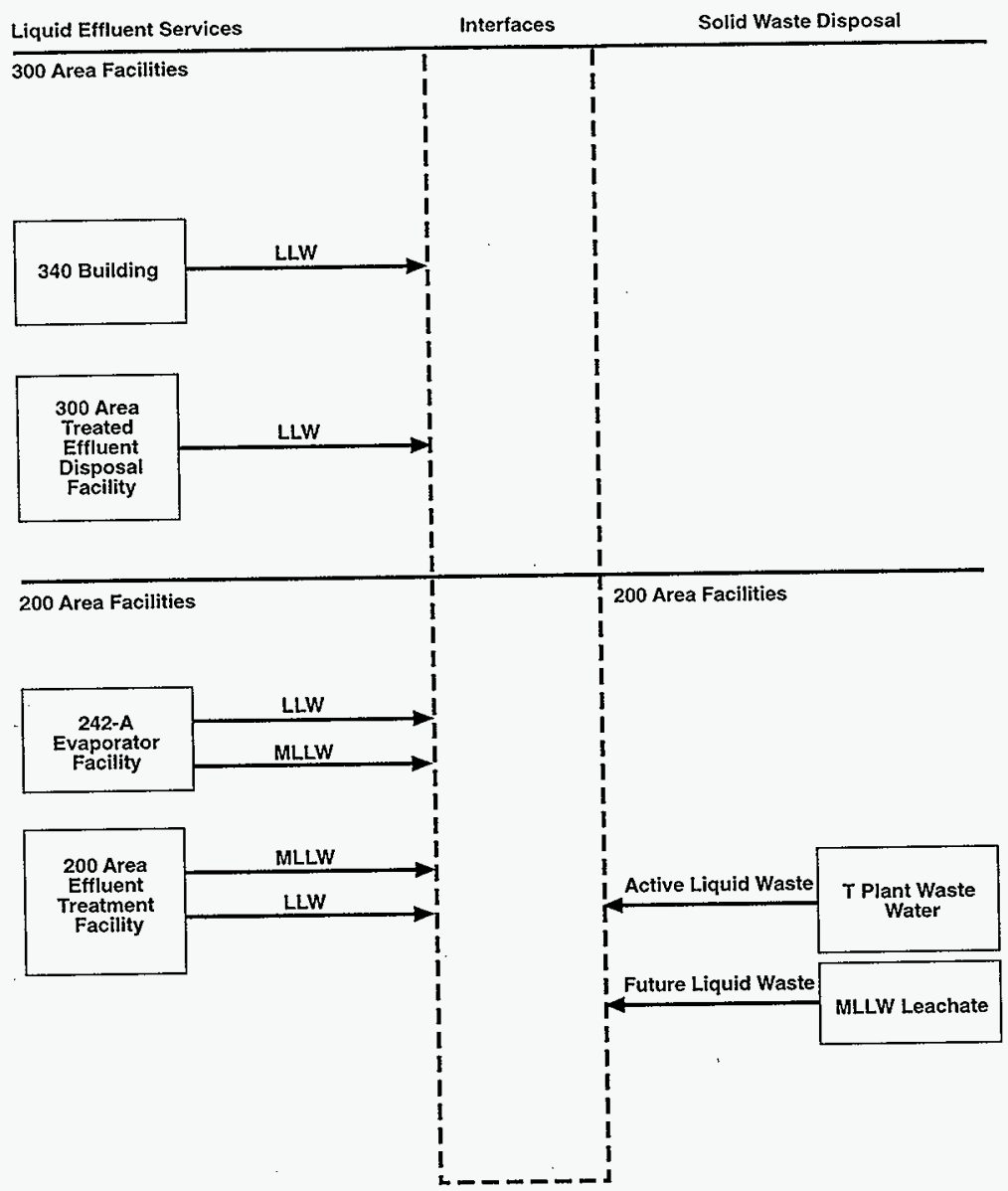

LLW = low-level waste.

H96120196.25R1

MLLW = mixed low-level waste. 
HNF-SD-WM-RPT-288

Revision 0

Solid waste generated by Liquid Waste will be accepted by Solid Waste provided the waste meets the criteria established in WHC-EP-0063-5, Hanford Site Solid Waste Acceptance Criteria (Willis 1996). Solid Waste will provide TSD as necessary for the solid waste generated by Liquid Waste.

\subsubsection{Liquid Waste and Analytical Services Subprojects}

This interface deals with the liquid waste generated by Analytical Services and the waste sampling support needed by Liquid Waste. (See Figure 4-2.)

\subsubsection{Waste Characterization Support Required by the Liquid Waste Subproject.} Analytical Services operates onsite analytical laboratories, contracts commercial services, establishes quality standards for Site analytical services, and integrates all Site analytical services through the Site Sample Management Office. Cost-effective, quality, and timely services are provided using a combination of government-contracted and commercial capabilities based on biannual Site sample projections.

Sample projections for Liquid Waste have been provided for the 200 and 300 Area liquid effluent facilities. Sample requirements for the 242-A Evaporator Project are included with the Tank Waste Remediation System (TWRS) projections and presently are not part of this interface.

The Hanford Analytical Sample Projections FY 1997 - FY 2001 (Joyce 1997) indicates the Liquid Waste fiscal year (FY) 1997 sample projection is 1,600 samples. Most of these are liquid samples; a few are sludge samples. The 222-S Laboratory, Waste Sampling and Characterization Facility (WSCF), or a commercial laboratory could characterize the samples. (See Figure 4-2.) The annual projection of 1,600 samples remains level from FYs 1997 through 2001 . Cyclic operations of treatment facilities may cause extreme peak and valley work loads for the laboratories.

4.2.2.2 Liquid Waste Generated by the Analytical Services Subproject. Liquid Waste will manage the liquid waste generated by Analytical Services during the lifetime of the generating laboratory. The Analytical Services facilities that are generating liquid waste are the 222-S Laboratory and WSCF. The 222-S Laboratory generates two waste streams. The 222-S Laboratory waste stream is forecast at approximately $120 \mathrm{~m}^{3}$ annually through 2025 . This stream is sent to the ETF. The 222-S Laboratory wastewater stream is forecast at $5,600 \mathrm{~m}^{3}$ annually through 2025 . This stream is sent to the 200 Area TEDF. The WSCF generates a laboratory waste stream that is forecast at $46 \mathrm{~m}^{3}$ annually through 2023 . This stream is sent to the ETF and the 300 Area TEDF for treatment and disposal. (See Figure 4-2.) 
HNF-SD-WM-RPT-288

Revision 0

Figure 4-2. Liquid Waste and Analytical Services.

Liquid Effluents

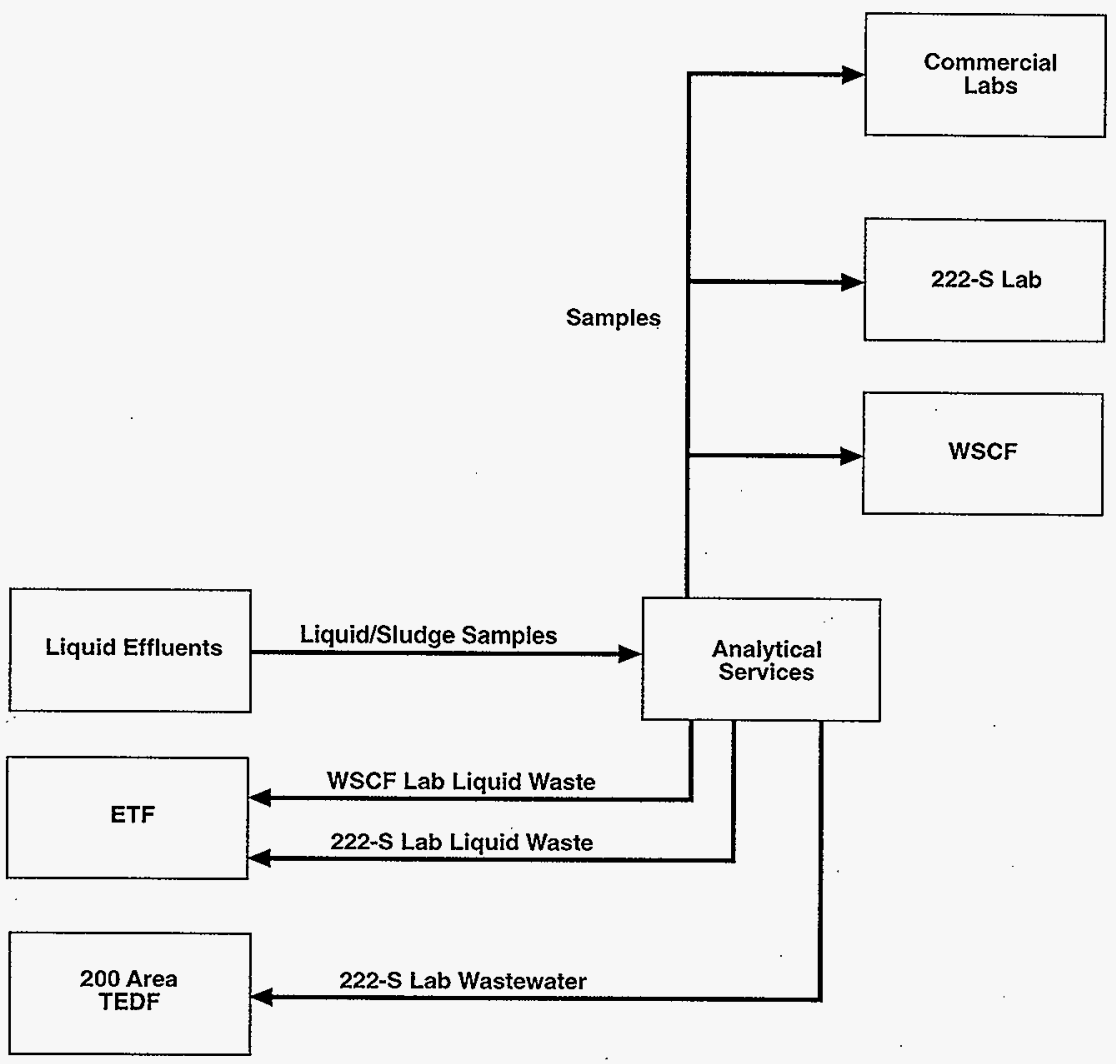

ETF = Effluent Treatment Facility.

TEDF $\quad=$ Treated Effluent Disposal Facility.

WSCF $\quad=$ Waste Sampling and Characterization Facility.

Note: Quantities and Schedules are as listed in Joyce (1997). 
The Liquid Waste subproject will not provide for the collection of any liquid waste generated by Analytical Services that requires treatment other than normal lag storage at Liquid Wasteoperated treatment facilities. Analytical Services will be responsible for collecting liquids at its facilities. Analytical Services will provide treatment systems to condition the waste as needed to make it compatible for treatment in Liquid Waste facilities. Analytical Services will arrange transportation of liquid waste to Liquid Waste facilities. The Liquid Waste subproject will provide treatment capacity to treat the quantity of liquid waste generated by Analytical Services providing all permit conditions are met. The Liquid Waste subproject will provide for the discharge of liquid effluents that have been treated.

\subsubsection{Analytical Services and Solid Waste Subprojects}

This interface encompasses the waste sampling support needed by the Solid Waste subproject and the solid waste generated by the Analytical Services subproject. Figure 4-3 describes the interface between Analytical Services and Solid Waste. The interface between these subprojects is discussed in more detail in WHC-SD-WM-PICD-005, Interface Control Document Between Analytical Services and Solid Waste Disposal Division (Greager 1996b). In addition to describing the interface between these subprojects, the ICD provides a baseline description of the waste and samples, including volumes, characteristics, and shipping schedules for use in planning the proper requirements needed to support this interface.

4.2.3.1 Solid Waste Generated by the Analytical Services. Solid Waste will manage the solid waste generated by Analytical Services as identified in Section 4.0 of the ICD (Greager 1996b). The Analytical Services facilities (within the scope of this interface) that are, or soon will be, generating solid waste are the 222-S Laboratory and WSCF.

The 222-S Laboratory generates the following waste streams: low-level waste (LLW), MLLW, and hazardous waste. The primary source of the LLW comes from laboratory waste and equipment, along with lab packs. Laboratory analysis of tank farm core samples and Sitewide sampling generates the majority of MLLW, and the hazardous waste is generated in the 222-S Standards Laboratory. The WSCF is expected to generate LLW, MLLW, and hazardous waste. These waste streams are described in the Appendix A tables in the ICD. The 1995 222-S Laboratory multi-year program plan solid waste volume forecast is in Appendix B of the ICD.

The solid waste generated by Analytical Services will be accepted by Solid Waste provided the waste meets the criteria established in WHC-EP-0063-5, Hanford Site Solid Waste Acceptance Criteria (Willis 1996). Solid Waste will provide TSD as necessary for the solid waste generated by Analytical Services.

4.2.3.2 Waste Characterization Support Required by the Solid Waste Subproject. Analytical Services is chartered to provide laboratory support to the major programs at the Hanford Site. Analytical Services provides the technical, managerial, and programmatic 
HNF-SD-WM-RPT-288

Revision 0

Figure 4-3. Analytical Services and Solid Waste.

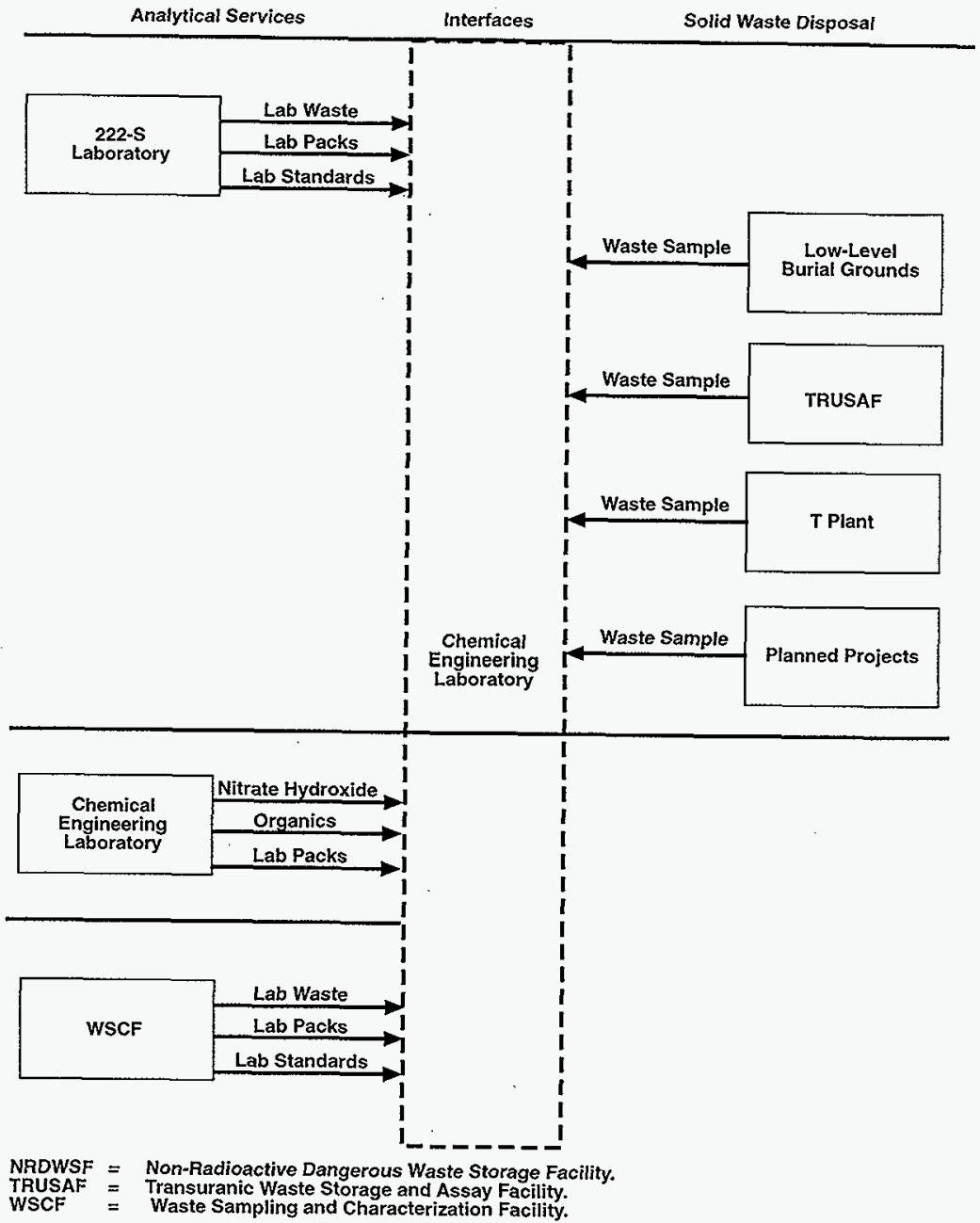


functions to complete the waste characterization process. Analytical Services will provide waste characterization of the samples taken by Solid Waste as identified in Section 3.0 of the ICD (Greager 1996b).

Characterization support will be provided by the 222-S Laboratory and WSCF. The primary mission of the 222-S Laboratory is to provide analytical support to the Project and to environmental restoration programs. Also, the laboratory prepares and characterizes radiochemical standards for waste characterization analyses completed at various laboratories on the Site. The WSCF will complete waste characterization analysis on air, water, and soil samples. Sample constituents primarily will be low-level radioactive isotopes and nonradiological hazardous materials taken from various effluent streams on the Hanford Site.

The estimated annual sample volume required by Solid Waste is summarized in Appendix C, Tables 13 through 16, of the ICD. Facility-specific analyses and precision requirements are provided in the facility sample schedules.

\subsection{HANFORD SITE INTERFACES}

Numerous interfaces exist among Solid Waste, Liquid Waste, and Analytical Services and other Hanford Site programs, projects, and facilities. This section summarizes the interfaces between the Project and each of the following:

- Spent Nuclear Fuel (SNF) Project

- TWRS

- Environmental Restoration Contractor (ERC)

- Fast Flux Test Facility (FFTF)

- Plutonium Finishing Plant (PFP)

- Plutonium-Uranium Extraction (PUREX) Facility

- Transition Facilities

- Pacific Northwest National Laboratory (PNNL)

- B Plant Transition

- Site Infrastructure.

Each subproject's generic roles and responsibilities to these other Site programs are summarized in the following paragraphs. Specific information regarding each subproject's interface with a given Site program is discussed in Sections 4.3.1 through 4.3.10.

Solid Waste is chartered to manage the centralized facilities for the receipt, containment, and TSD of solid waste at the Hanford Site. Solid Waste provides the technical, managerial, and programmatic functions to ensure safe and proper disposition of solid waste, and also provides the following:

- Storage of mixed, transuranic (TRU) and transuranic mixed (TRU/TRUM), MLLW, and Greater Than Category III LLW 
HNF-SD-WM-RPT-288

Revision 0

- Shipment for disposal of LLW

- Management of the U.S. Department of Energy, Richland Operations Office contract for treatment and disposal of non-radioactive dangerous waste

- Treatment of MLLW

- Characterization, size reduction, packaging, certification, and shipment of TRU waste to the Waste Isolation Pilot Plant (WIPP).

The responsibilities of Solid Waste in its interface with other Site programs are as follows:

- Provide the annual Solid Waste Forecast Data Request along with guidance for completing the request. The quarterly forecasts are published in HNF-EP-0918, Solid Waste Integrated Forecast Technical (SWIFT) Report: FY 1997 to FY 2070 (RFSH 1996). This report is available on the Internet at http://w3.pnl.gov:2080/swift/welcome.htm.

- Maintain and readily provide the Hanford Site Solid Waste Acceptance Criteria (Willis 1996).information to other Site organizations. Solid Waste will accept forecasted waste that meets these criteria and does not exceed baseline volumes presented in the ICDs for each program.

- Initiate changes to the appropriate ICDs to incorporate annual changes to the forecast, identify new waste streams, and document changes in responsibility.

The following sections contain estimates of the solid waste expected to be generated by onsite projects and sent to Solid Waste for TSD. These estimates are based on the most current SWIFT report (RFSH 1996). This report is routinely updated; it is therefore recommended to refer to this source for more detailed and up-to-date Solid Waste estimates. Volume information found herein is given only to provide a relative idea of the size of a given waste stream.

Liquid Waste operates the existing liquid effluent facilities and will provide local treatment or arrange for offsite treatment of liquid effluents if needed. The services that are available to other projects in cleaning up the Hanford Site are described in RFSH Letter \#9751400. Requests for liquid effluent treatment and disposal should be directed to the Generator Services organization within the project.

Liquid Waste will not provide for the collection of any liquid waste generated by Site programs that requires treatment other than normal lag storage at Liquid Waste-operated treatment facilities. Each generator is responsible for collecting liquids at its facilities. Each generator also is responsible for transportation of liquid waste to Liquid Waste facilities. Liquid Waste will provide treatment capacity to treat the quantity of liquid waste forecast and generated by interface organizations provided all permit conditions are met. Liquid Waste also provides for the discharge of liquid effluents that have been treated. 
The following sections provide current estimates of the effluent volumes expected to be received by the subproject from each onsite interface. These projections are provided to indicate the relative size of the stream only; these estimates change from time to time.

Analytical Services provides services that include waste and environmental sample analysis, process control support, field and sampling services, development services, and Site expertise in chemistry and data quality. Analytical Services operates onsite analytical laboratories, contracts commercial services, establishes Site analytical services quality standards, and integrates all Site analytical services through the Site Sample Management Office. Services are provided using a combination of government-contracted and commercial capabilities based on biannual Site sample projections. Current projections are published in WHC-SD-WM-TI-608, Hanford Analytical Sample Projections FY 1997 - FY 2001 (Joyce 1997).

Key interfaces of Analytical Services with other Site programs include projections of sampling and analytical needs, which are compiled and documented twice per year.

The following sections provide approximate numbers of samples projected by each onsite interface. These projections show the relative magnitude of the interface; for the most recent estimates, see the latest version of Hanford Analytical Sample Projections FY 1997 - FY $200 I$ (Joyce 1997).

\subsubsection{SNF Project}

The SNF Project was established to provide for the safe storage of SNF at the Hanford Site. The primary technical objectives of the SNF Project are as follows.

1. Provide safe, economical, and environmentally sound interim storage for all the Hanford Site's SNF before final disposition.

2. Rapidly remove the SNF, debris, and sludge from the pools at the $\mathrm{K}$ Basins and relocate these materials in a configuration that will allow safe, economical, and environmentally sound long-term storage.

The interface between the SNF Project and the Project is to be described in an interface control document between the SNF Project and the Project.

Figure 4-4 shows the primary interfaces between these projects, which include the following:

- Transfer of solid waste from the SNF Project to Solid Waste for TSD

- Transfer of liquid waste from the SNF Project to Liquid Waste for TSD

- Analytical services provided by Analytical Services to support the SNF Project

- Transfer of stewardship for SNF currently managed by the Project to the SNF Project. 


\section{HNF-SD-WM-RPT-288}

Revision 0

Transferring management of the 212-H canister storage building to the Project by the SNF Project will become an interface on completion of the SNF Project.

4.3.1.1 Interface with Solid Waste Subproject. Solid Waste will accept all the SNF Project waste that will be forecast and identified in the draft ICD between the Project and the SNF Project. The LLW and MLLW classified as Category I through Category III (Willis 1996) will be accepted for TSD, LLW and MLLW classified as Greater than Category III (Willis 1996) will be accepted for storage, and any TRU solid waste that the SNF Project generates will be accepted for treatment and storage until the waste is shipped to WIPP for final disposal. Unique waste will be accepted on a case-by-case basis; these quantities are expected to be minimal. Currently, the SNF Project forecasts that it will send approximately $1,800 \mathrm{~m}^{3}$ of waste to Solid Waste between 1996 and 2001. Most of this waste is forecast to be contact-handled (CH) Category I LLW, CH Category III LLW, and CH TRU. Small volumes of CH Category I MLLW, remote-handled (RH) Category III LLW, and RH TRU are also projected.

Spent nuclear fuel is maintained by Solid Waste in two primary locations:

- T Plant where the waste consists of 16 MTUM (approximately $9 \mathrm{~m}^{3}$ ) of Pressurized Water (Cooled) Reactor (PWR) Core II

- 200 Area Burial Grounds where the waste consists of heavy metal from research activities (approximately $21 \mathrm{~m}^{3}$ ) mostly as Test Reactor and Isotope Production General Atomics (TRIGA) waste.

An ICD is being developed to more fully describe these interfaces between the SNF Project and the Project.

4.3.1.2 Interface with Liquid Waste Subproject. During the pending fuel removal operations (1997-2000) at the K Basins, the ETF is expected to receive approximately $18,927 \mathrm{~L} / \mathrm{month} / \mathrm{basin}$ (5,000 gal/month/basin). This interface between Liquid Waste and the SNF Project is further defined in a memorandum of understanding (RL 1996).

Once the spent fuel, debris, and sludge are removed from the basins, the SNF Project plans to send the approximately 4.5 million L (1.2 million gal) from each basin to Liquid Waste. The time frame for this activity is $2002-03$.

4.3.1.3 Interface with Analytical Services Subproject. Sample projections for the SNF Project are provided for basin sludge characterization, liquid discharge, and the $183 \mathrm{KE}$ water laboratory in Hanford Analytical Sample Projections FY 1997 - FY 2001 (Joyce 1997). This document provides the annual SNF Project sample projections sorted by radiation level, analysis type, protocol, and matrix type, and is updated annually. 
Figure 4-4. DE\&S Hanford and Waste Management Subprojects.

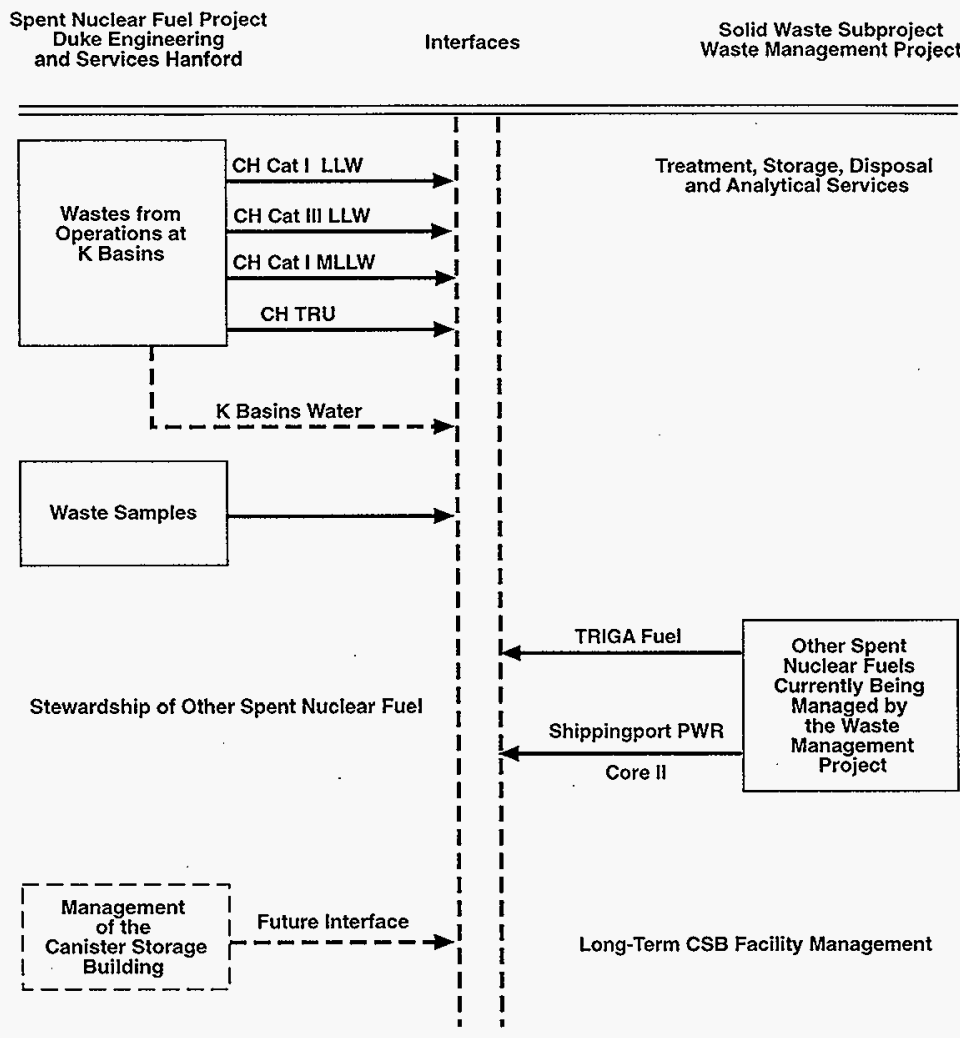
nt Nuclear Fuel Project
Duke Engineering
Interfaces
Solid Waste Subproject
Waste Management Project

$\begin{array}{ll}\text { CH } & =\text { contact-handled. } \\ \text { CSB } & =\text { Canister Storage Building. } \\ \text { LLW } & =\text { low-level waste. } \\ \text { MLLW } & =\text { mixed low-level waste. } \\ \text { PWR } & =\text { Pressurized Water Reactor. } \\ \text { TRIGA } & =\text { Training Reactor, Isotopes, General Atomics. } \\ \text { TRU } & =\text { transuranic. }\end{array}$

H96120196.21R1 
The projected number of samples to be sent to Analytical Services from the SNF Project ranges between approximately 900 and 1,100 between 1997 and 2000 before dropping to zero in 2001. Sample projections for the SNF Project indicate that water sampling with the canister sludge program will end in FY 1997. This includes support for transporting fuel to the canister storage building and any potential sludge to tank farms.

\subsubsection{TWRS}

The TWRS Division is responsible for storing, treating, and immobilizing highly radioactive Hanford Site waste in single- and double-shell tanks and associated equipment and structures. The specific roles of the TWRS Project are defined further in the Hanford Mission Plan, Vol. I, Site Guidance (RL 1993) and Tank Waste Remediation System Functions and Requirements (RL 1994).

The interface between the TWRS Project and the Project is described in WHC-SD-WM-PICD-003, Interface Control Document Between the Tank Waste Remediation Division and the Solid Waste Disposal Division (Duncan 1995). This ICD is a living document that will be updated annually to reflect changes in the forecasts of solid and liquid waste volumes and analytical support requirements.

4.3.2.1 Interface with Solid Waste Subproject. Several different types of solid waste are generated as a result of the work done in and around the tanks or their ancillary structures. This solid waste consists mostly of plastic, paper, metal, cloth, and, less frequently, includes highefficiency particulate air filters, soil, equipment, chemical products, lead, wood, and asbestos. Solid waste collected in the field is packaged, characterized, and shipped to TSD units on the Hanford Site. These units include dangerous waste storage facilities, LLW disposal sites, and mixed waste storage areas.

A unique category of TWRS solid waste is long-length contaminated equipment. This includes the instrument trees, transfer pumps, airlift circulators, and air lances that are installed in the tanks, vaults, and receivers located in the tank farms. The long-length contaminated equipment cannot be handled in the same manner as most solid waste because of size and current or recent contact with liquid tank waste, but it still must be removed for disposal.

A life-cycle forecast of all waste classes (LLW, mixed waste, TRU, and dangerous waste) pertinent to the TWRS waste generator is submitted each year to Solid Waste (RFSH 1996). This and other generator forecasts provide Solid Waste with data to establish billing rates and plan construction of new TSD units. It also provides data to the national U.S. Department of Energy (DOE) database that compiles current data on waste inventories.

Solid Waste generates liquid waste from decontamination activities. This waste is characterized and shipped to TWRS for storage in double-shell tanks. 
HNF-SD-WM-RPT-288

Revision 0

4.3.2.2 Interfaces with Liquid Waste Subproject. During FY 1997, Liquid Waste expects to begin receiving cooling water from the 241-A Tank Farm (Project W-030). The flow rate for this stream is nominally $5 \mathrm{gpm}$.

Historically, the major effluent stream sent by TWRS to Liquid Waste was from the 242-A Evaporator. Operation of this facility has now been transferred from TWRS to Liquid Waste. Therefore, the interface has moved and is now between $102-\mathrm{AW}$, the respective slurry receiver, and the 242-A Evaporator.

4.3.2.3 Interfaces with Analytical Services Subproject. Sample projections for TWRS are provided for Waste Storage and Operations and TWRS Waste Disposal in Hanford Analytical Sample Projections FY 1997 - FY 2001 (Joyce 1997). This document provides the annual TWRS Project sample projections sorted by radiation level, analysis type, protocol, and matrix type, and is updated annually.

The TWRS sample projections show: (1) that the number of core samples remains constant during the next 3 years (FY 1997 has 77 cores, 379 segments, for a total of 1,468 samples; FY 1998 has 91 cores, 345 segments, for a total of 1,362 samples; and FY 1999 has 84 cores, 300 segments, for a total of 1,208 samples); (2) that the number of core samples sharply decreases in FY 2000 to 18 cores, 73 segments, for a total of 292 samples; (3) no core needs are identified for FY 2001; and (4) TWRS Waste Disposal needs are focused based on waste characterization by the Project Hanford Management Contract (PHMC) for transfer to the Disposal Program private contractor. The out-year needs for support to Disposal Program operations are as yet undefined. The TWRS has other limited needs, which were identified for FYs 1997 through 2001.

\subsubsection{Environmental Restoration Program}

The interface between the ERC and Solid Waste regarding waste management is clarified and bounded in WHC-SD-WM-PICD-010, Interface Control Document Between the Environmental Restoration Contractor and the Solid Waste Disposal Division (Greager 1996c). This ICD will be updated to include the interface between the ERC and all the subprojects.

4.3.3.1 Interface with Solid Waste Subproject. The responsibility for work shared between the ERC and Solid Waste is clarified in the following list of interface areas.

- In waste designation, the ERC is responsible for properly designating and packaging the solid waste generated from the ERC for shipment. This includes solid LLW, MLLW, and TRU wastes.

- In waste characterization, the ERC is responsible for providing Solid Waste with detailed information supporting characterization of the waste streams. Solid Waste must verify that the solid waste received from the ERC is the same as that itemized on the shipping 
records. The ERC is subject to periodic assessments by Solid Waste to ensure consistency in the management of the shipped waste.

- Solid Waste is responsible for setting the solid waste rates, and the ERC is responsible for the rate assessments of any waste received from Solid Waste.

- Shipment schedules for waste from the ERC to Solid Waste facilities are made by the Solid Waste scheduler. The ERC generator must notify the scheduler of the estimated time of arrival of any waste shipments. Any shipments of waste from Solid Waste to the ERC are scheduled through the ERC shipping coordinator. In those cases, Solid Waste must submit information to the ERC on the planned shipment and a preferred shipment date.

- Records of all waste shipped to and dispositioned at the Solid Waste facilities must be developed and maintained by Solid Waste until the facility is closed. The ERC must maintain descriptions of the waste content for 5 years. In addition, the ERC must also maintain waste tracking data, including shipping papers.

- Specific records of dangerous waste must be maintained by the ERC and Solid Waste. The ERC must ensure proper designation and record all proper dangerous waste numbers. Solid Waste must keep an operating record of the description and quantity of dangerous waste received and the location of each quantity within the facility.

- The ERC must provide an annual waste forecast to Solid Waste to plan for future storage and disposal needs. Solid Waste establishes the reporting categories to be used in the forecast.

4.3.3.2 Interface with Liquid Waste Subproject. The primary liquid effluent stream from the ERC is the excess leachate from the Environmental Restoration Disposal Facility. The volume of this stream is expected to be nominally $75,708 \mathrm{~L} /$ year $(20,000$ gal/year) starting in 1998 . Liquid Waste has already received 4.5 million L (1.2 million gal) in FY 1997 because of excessive snowfall $(103 \mathrm{~cm})$ between November 1996 and March 1997 and equipment malfunctions.

The ERC also plans to send approximately 4 million L ( 1 million gal) of $\mathrm{N}$ Basin water to Liquid Waste during 1997.

4.3.3.3 Interface with Analytical Services Subproject. Sample projections for the ERC are provided for the 100,200,300, and 1100 Areas as well as decontamination and decommissioning (D\&D) in Hanford Analytical Sample Projections FY 1997 - FY 2001 (Joyce 1997). This document provides the annual ERC sample projections sorted by radiation level, analysis type, protocol, and matrix type. It is updated annually.

Environmental Restoration projects that 6,500 samples will be sent to Analytical Services during FY 1997. Sample projections for FY 1998 and beyond show a significant decrease in 
solid/soil samples in FYs 2000 and 2001 and a steady decrease in the number of sample analyses required from FYs 1997 to 2000.

\subsubsection{FFTF}

The Interface Control Document Between Fast Flux Test Facility Transition Project and Rust Federal Services of Hanford Waste Management Project (RFSH 1997a) documents the interface between the FFTF Transition Project, managed by Babcock and Wilcox of Hanford Company, and the Project. This interface deals with the management responsibilities and the conditions under which solid waste, liquid waste, and analytical samples will be shipped from FFTF to Solid Waste, Liquid Waste, and Analytical Services, respectively. The disposition of waste generated after FFTF is deactivated and the facility is turned over to the DOE Environmental Restoration Program (EM-40) for D\&D is not within the scope of this interface. Figure 4-5 shows the interface between the FFTF Transition Programs and the Project.

4.3.4.1 Interface with Solid Waste Subproject. Solid Waste is responsible for the following activities directly benefiting FFTF: managing receipts of newly generated solid waste from FFTF, storing solid waste in buildings that are part of the Hanford Central Waste Complex (CWC), and managing the 200 Area LLW Burial Grounds that accept LLW for disposal.

The FFTF Transition Project scope includes maintenance and surveillance of the FFTF complex and reactor defueling. Solid waste generated from D\&D activities once the facilities are turned over to the ERC are excluded from the scope of the FFTF Transition Project.

Solid Waste will manage the solid waste generated by FFTF as identified in Section 3.0 of the ICD (RFSH 1997a). The waste volume forecasts indicate a total of $85 \mathrm{~m}^{3}$ of solid waste, primarily LLW, will be sent from FFTF between 1997 and 2001. A very small percentage of this waste, $0.3 \%$, will be MLLW containing reactive metals.

Solid waste generated by FFTF will be accepted by Solid Waste provided the waste meets the established criteria as provided in WHC-EP-0063-5, Hanford Site Solid Waste Acceptance Criteria (Willis 1996). Solid Waste will provide TSD as necessary for the solid waste generated by FFTF.

4.3.4.2 Interface with Liquid Waste Subproject. The FFTF forecasts no liquid effluent waste for the remainder of the Transition Project.

4.3.4.3 Interface with Analytical Services Subproject. The characteristics of the waste generated by FFTF do not vary significantly over time. Thus, once the waste stream has been characterized, periodic sampling is generally not required. For this reason, FFTF has not sent samples to Analytical Services during the past several years and does not anticipate doing so for the remainder of the Transition Project. 
Figure 4-5. Fast Flux Test Facility Transition Programs.

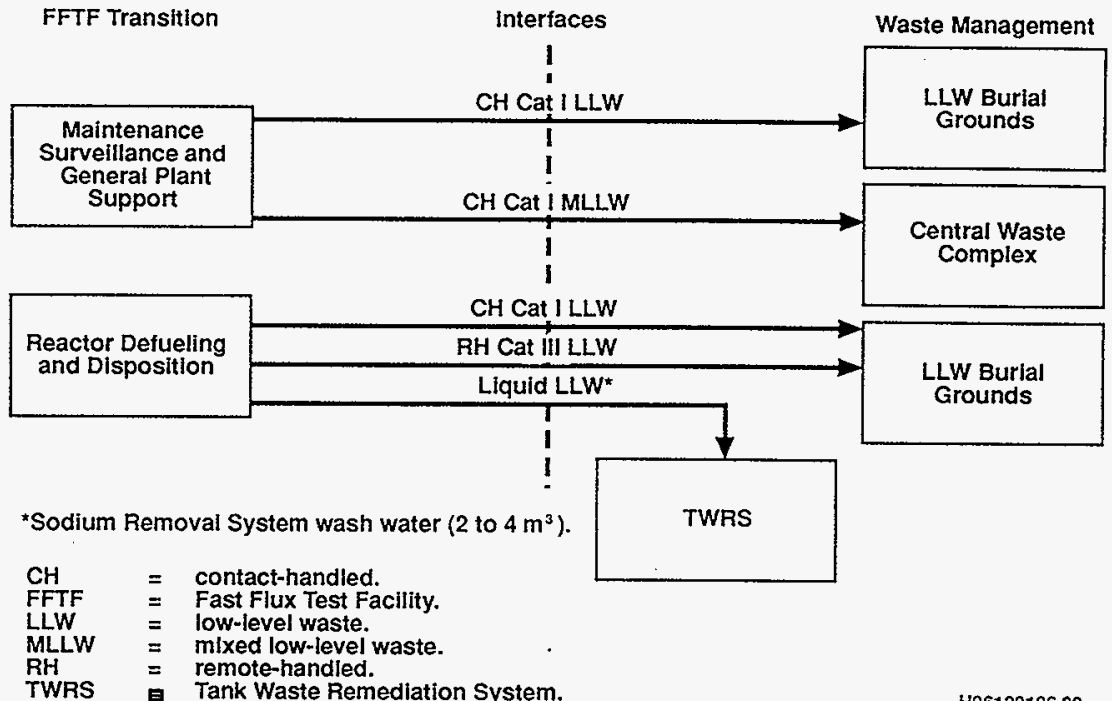

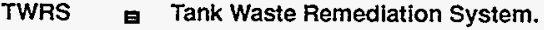


HNF-SD-WM-RPT-288

Revision 0

\subsubsection{PFP}

The Interface Control Document Between Plutonium Finishing Plant Transition Project and Rust Federal Services of Hanford Waste Management Project (RFSH 1997b) will document the interface between the PFP Transition Project, managed by Babcock and Wilcox of Hanford Company, and the Project. This interface deals with the management responsibilities and the conditions under which solid waste, liquid waste, and analytical samples will be shipped from PFP to Solid Waste, Liquid Waste, and Analytical Services, respectively. Figure 4-6 shows the interface between the PFP Transition Project and the Project.

4.3.5.1 Interface with Solid Waste Subproject. Solid Waste is responsible for multiple activities with the following activities directly benefiting PFP.

- Managing receipts of newly generated solid waste from PFP

- Storing solid waste in buildings that are part of the CWC

- Managing the 200 Area LLW Burial Grounds, which accepts LLW for disposal

- Coordinating shipments of hazardous waste to offsite commercial disposition facilities.

Solid Waste will receive $7,640 \mathrm{~m}^{3}$ of solid waste from PFP through FY 2034 (RFSH 1996). The waste streams are primarily TRU(M) waste and LLW; approximately $10 \%$ is MLLW. The PFP Transition Project scope includes stabilization and deactivation of the PFP and ancillary support structures. Solid waste generated from D\&D activities performed by the ERC is not included in the scope of the PFP Transition Project.

Solid wastes generated by FFTF will be accepted by Solid Waste provided the waste meets the criteria established in WHC-EP-0063-5, Hanford Site Solid Waste Acceptance Criteria (Willis 1996). Solid Waste will provide TSD as necessary for the solid waste generated by FFTF.

4.3.5.2 Interface with Liquid Waste Subproject. Liquid Waste provides effluent environmental monitoring services and the disposal of effluents and wastewater for PFP. According to WHC-SP-1097, Liquid Effluents Program FY 1997 Multi-Year Work Plan (Green 1996), PFP is expected to generate a volume of approximately $49,700 \mathrm{~m}^{3}$ of liquid effluent annually through FY 2003 and approximately 19,900 $\mathrm{m}^{3}$ from FYs 2004 through 2034. This waste consists of two streams: a potentially contaminated wastewater stream and an uncontaminated effluent stream. The potentially contaminated wastewater (annual volume of approximately $23,500 \mathrm{~m}^{3}$ through FY 2003) includes non-contact process cooling water, miscellaneous wastewater from laboratory activities, and steam condensate. This stream is conservatively assumed to be low-level and is treated at PFP's 243-Z Low-Level Waste Treatment Facility with granulated carbon, ion exchange, or bone char before it is discharged to the 200 Area TEDF (Crane 1996). 
HNF-SD-WM-RPT-288

Revision 0

Figure 4-6. Plutonium Finishing Plant Transition Project.

PFP Transition

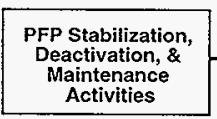

Interfaces

Solid MLLW
Waste Management

Central Waste

Complex
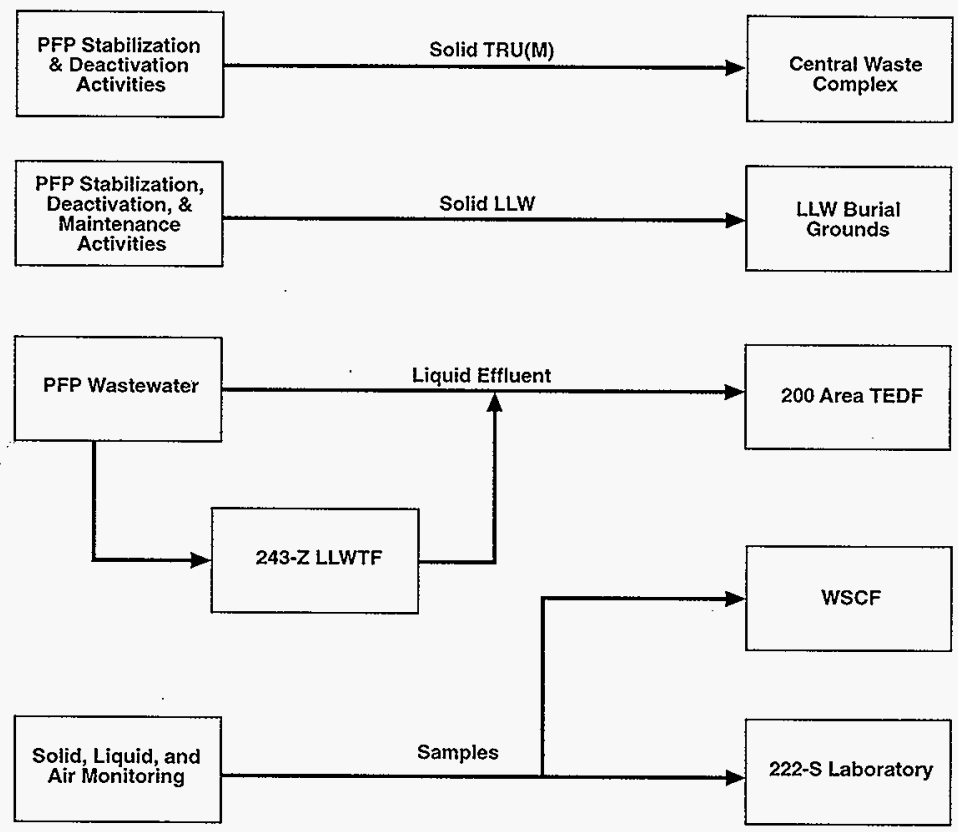

LLW $=$ low-level waste.

LLWTF = Low-Level Waste Treatment Facility.

PFP $=$ Plutonium Finishing Plant.

TEDF $\quad=$ Treated Effluent Disposal Facility

$\operatorname{TRU}(M)=$ transuranic and transuranic mixed.

WSCF $=$ Waste Sampling and Characterization Facility. 
The nonradioactive effluent stream (with an annual volume of approximately $26,200 \mathrm{~m}^{3}$ through FY 2003) is primarily roof runoff and storm drain effluents. The low-level effluent will only be generated through FY 2003. The nonradioactive effluent stream will be generated through FY 2034, although at a reduced annual volume of approximately $19,900 \mathrm{~m}^{3}$ after FY 2003. Wastewater that is known to be contaminated or contain mixed waste is collected in the $241-Z$ tanks and sent to the tank farms. These wastewater is not included in the water volumes for this interface.

Liquid Waste will not provide for the collection of any liquid waste generated by PFP requiring treatment other than normal lag storage at Liquid Waste-operated treatment facilities. The PFP will be responsible for collecting liquids at its facilities. The PFP will provide treatment systems to condition the waste as needed to make it compatible for treatment in Liquid Waste facilities. The PFP will arrange transportation of liquid waste to Liquid Waste facilities. Liquid Waste will provide treatment capacity to treat the quantity of liquid waste forecast and generated by PFP, provided that all permit conditions are met. Liquid Waste will provide for the discharge of liquid effluents that have been treated.

4.3.5.3 Interface with Analytical Services Subproject. Analytical Services provides analytical services for PFP monitoring purposes. Samples from PFP will be sent to Analytical Services for analytical characterization at the 222-S Laboratory and WSCF.

PFP is projected to send approximately 19,500 samples to Analytical Services annually during FYs 1996 through 2002. The majority of these samples $(18,800)$ fall under the "other matrix" category, but a small number of liquid, soil/solids, and sludge samples are included. The "liquid" sample category includes water, oil, and liquid solutions, and "other" includes media filters and chemicals or solutions $\left(\mathrm{PuO}_{2}\right.$ and $\left.\mathrm{HNO}_{3}\right)$. The Analytical Services Program FY 1997 Multi-Year Work Plan (Spohr 1996) indicates a majority of the "other" samples (greater than 97\%) are filter media continuous air monitors and room air samples. Although sample data are projected for only 5 years, PFP will continue to send samples to Analytical Services after FY 2002 for monitoring purposes.

\subsubsection{PUREX Facility}

The PUREX facility operated from 1956 to 1972 and from 1983 to 1988 to recover uranium and plutonium from fuel irradiated in Hanford Site reactors for the nation's defense project. The PUREX facility is one of several former processing plants at the Hanford Site that is no longer needed. Because continued operation of the plant entails costly maintenance and monitoring, the decision was made to clean out and shut down PUREX and place it in a deactivated safe storage mode, requiring minimum surveillance and maintenance. The PUREX facility is undergoing deactivation, which is expected to be completed in May 1997. Solid waste is generated from zone reduction, routine operations, maintenance activities, and housekeeping associated with the deactivation efforts; liquid effluent and wastewater will continue to be generated as drains and piping systems are drained during the final months of deactivation; and samples are collected for monitoring purposes. 
HNF-SD-WM-RPT-288

Revision 0

The draft Interface Control Document (ICD) Between Plutonium Uranium Extraction Plant Transition Project and Waste Management Project (RFSH 1997c) documents the interface between the PUREX Transition Project and the Project. This ICD describes the management responsibilities and the conditions under which waste, effluent, and samples will be shipped from PUREX to the Project. The guiding principle is that the Project will manage the TSD of the solid and liquid waste and provide analytical services in a safe and cost-effective manner.

The Project will receive and accept the solid wastes, samples, and liquid effluents identified in the ICD. The Project will accept the solid waste and liquid effluents for TSD. The Project will also provide analytical services for a number of samples. The interface between PUREX and the Project is depicted in Figure 4-7. The sources of solid waste in the figure are broadly stated as PUREX deactivation activities because the generated waste is not associated with the deactivation of a single facility, but with a number of facilities in the PUREX complex.

4.3.6.1 Interface with Solid Waste Subproject. Deactivation of PUREX facilities will be completed in May 1997; therefore, volumes are only forecasted for FY 1997. The PUREX facility will send the Project approximately $500 \mathrm{~m}^{3}$ of solid waste in FY 1997 (RFSH 1996). The volume is divided among the following three waste classes to be treated, stored, and disposed of at the Project:

- MLLW - $10 \mathrm{~m}^{3}$

- LLW - $510 \mathrm{~m}^{3}$

- Hazardous waste $-4 \mathrm{~m}^{3}$.

4.3.6.2 Interface with Liquid Waste Subproject. A flow of less than $0.38 \mathrm{~m} / \mathrm{min}$ of liquid effluent will be generated by PUREX during January 1997 (RFSH 1997c) and will be sent to the 200 Area TEDF for treatment and disposal. This equates to a maximum total volume of approximately $17,000 \mathrm{~m}^{3}$ of liquid effluent that will be sent to the Project during January 1997.

In the last months of deactivation, only intermittent effluent inputs are expected as the water and sewer systems are drained. Raw water is provided from a fire system to maintain a continuous flow for monitoring systems to remain operational. This effluent consists of nonprocess building services wastewater and non-contact, nonradioactive process heat exchange effluent. The stream has the option of being routed to the 216-A-42 Retention Basin where stream characteristics (i.e., $\mathrm{pH}$ ) need adjusting before the stream is sent to the 200 Area TEDF. Refer to the 200 Area Treated Effluent Disposal Facility Interface Control Document (Crane 1996) for further detail of the system in which the effluent is sent to 200 Area TEDF and for historical information of the PUREX effluents and wastewater. PUREX also has the option of sending other deactivation wastewater to the LERF on agreement with the Project.

4.3.6.3 Interface with Analytical Services Subproject. Sample projections for the PUREX facility are provided along with the other transition projects in Hanford Analytical Sample Projections FY 1997 - FY 2001 (Joyce 1997). This document provides the annual sample projections for all transition projects sorted by radiation level, analysis type, protocol, and matrix type. It is updated annually. 
HNF-SD-WM-RPT-288

\section{Revision 0}

Figure 4-7. Plutonium-Uranium Extraction Facility.

PUREX Transition

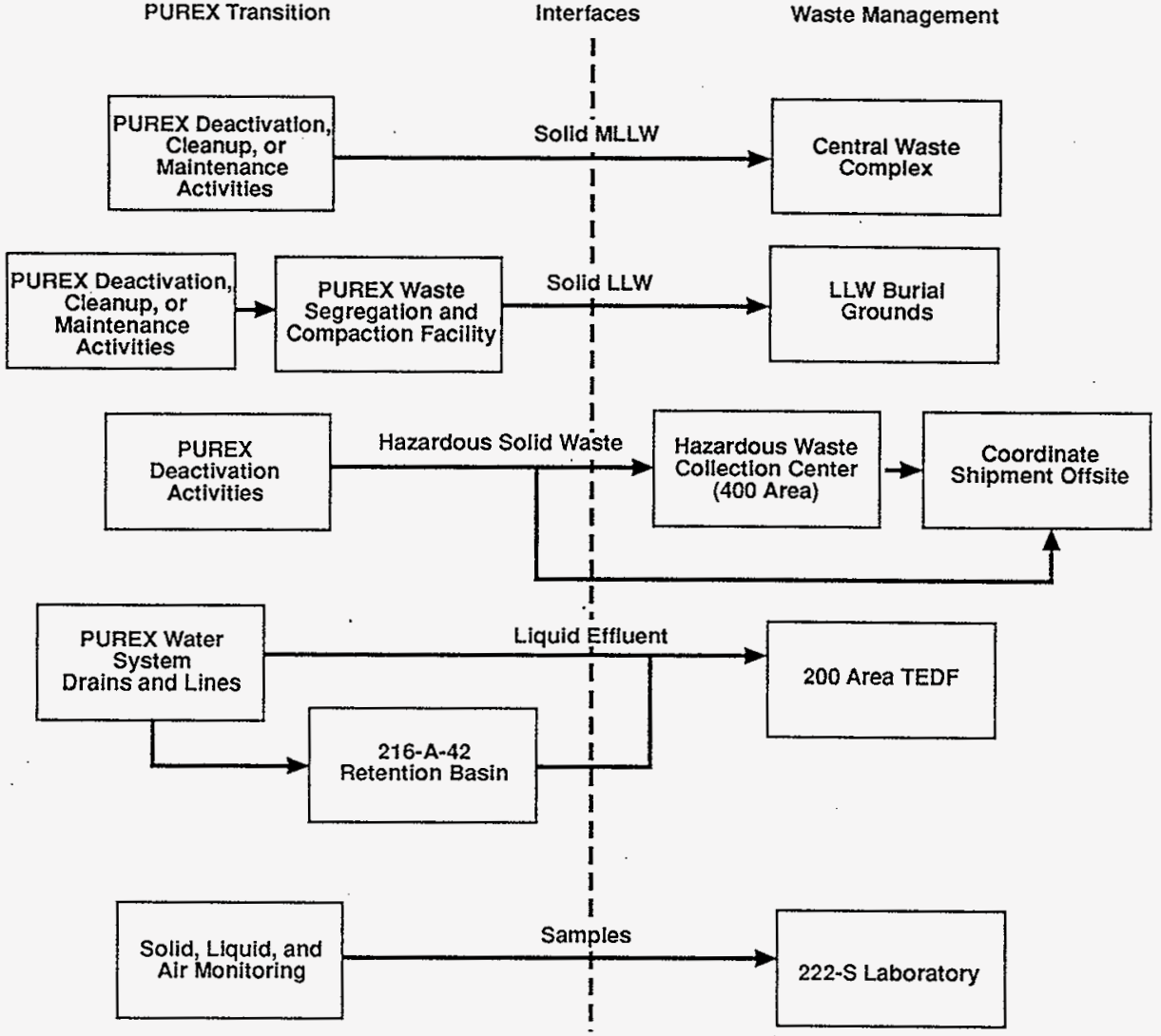

LLW = low-level waste.

PUREX a Plutonium-Uranium Extraction.

TEDF = Treated Effluent Disposal Facility. 
HNF-SD-WM-RPT-288

Revision 0

The PUREX facility is expected to send 5 liquid samples and 62 other samples to the Project for analytical characterization at the 222-S Laboratory (Joyce 1997). The liquid sample category includes water, oils, and liquid solutions. The other sample category includes filter media and chemicals or solutions. Sample data are projected for only 5 years, so this annual projection is estimated for FYs 1997 to 2001. The PUREX facility expects to send samples to the Project for monitoring purposes beyond the deactivation stage and until the facility changes status, such as the PUREX facility being transferred to EM-40 for D\&D.

\subsubsection{Other Transition Projects Facilities}

The mission of the Facility Transitions Program is to manage the deactivation activities of those facilities that are no longer in the operational phase. As stored materials and waste are removed, these facilities will be deactivated and transferred to the D\&D program. The interfaces of the Project with several of the larger transition facilities, FFTF, PFP, PUREX, and B Plant are discussed separately in previous sections. The other transition facilities covered in this section include the following:

- 303K Fuels Fabrication

- 309 Plutonium Recycle Test Reactor (PRTR) Vault

- 327 Building

- 324 Building

- 335 Sodium Test Facility.

The WESF will be discussed with B Plant.

No ICD between the Project and the Transition Program currently exists.

4.3.7.1 Interface with Solid Waste Subproject. The solid waste forecast to be sent from the transition projects listed in Section 4.3 .7 can be found in the SWIFT report (RFSH 1996). The following provides a brief summary for each facility.

- 303K Fuels Fabrication solid waste generation ends in 1998 , and $70 \mathrm{~m}^{3}$ of remote-handled MLLW are forecast.

- 309 PRTR Vault waste results from the ion-exchange module. Waste generation ends in 1998 , and $1 \mathrm{~m}^{3}$ of MLLW and TRU(M) waste is forecast.

- 327 Building forecasts that $60 \mathrm{~m}^{3}$ of solid waste, primarily contact-handled $(\mathrm{CH})$ TRU, will be generated through 2000 . 
HNF-SD-WM-RPT-288

Revision 0

- 324 Building forecasts that $40 \mathrm{~m}^{3}$ of solid waste, primarily CH MLLW, will be generated through 2001.

- 335 Sodium Test Facility generates only CH MLLW. A total of $1 \mathrm{~m}^{3}$ is forecast through 1999.

4.3.7.2 Interface with Liquid Waste Subproject. The liquid effluent from the 324 and 327 facilities is treated at the 340 treatment facility, which is operated by Liquid Waste. The 340 Facility is scheduled to be shut down late in FY 1998. The timing of the shutdown, as well as the length of time required for transition, is still unclear.

4.3.7.3 Interface with Analytical Services Subproject. Sample projections for the transition projects are forecast in Hanford Analytical Sample Projections FY 1997 - FY 2001 (Joyce 1997). This document provides the annual sample projections for all transition projects sorted by radiation level, analysis type, protocol, and matrix type, and is updated annually.

\subsubsection{PNNL}

The core mission of the PNNL is to solve legacy environmental problems by delivering technologies that remediate existing environmental hazards, address environmental needs with technologies that prevent pollution and minimize waste, and develop processes for clean energy.

This section defines the interface between PNNL and the Project. This interface encompasses the management responsibilities and the conditions under which solid waste, liquid waste, and analytical samples will be shipped from PFP to Solid Waste, Liquid Waste, and Analytical Services, respectively.

4.3.8.1 Interface with Solid Waste Subproject. The projects at PNNL that generate solid waste are involved with environmental research, analysis, and waste characterization activities. The PNNL solid waste streams are generated from 14 different facilities, mostly laboratories. This interface includes solid waste to be generated during daily operations and building clean-out activities. Any solid waste streams held at PNNL with an undefined pathway for disposal are excluded in this interface. Waste generated once the facilities have been turned over to Babcock and Wilcox of Hanford Company for transition are not the responsibility of PNNL, and are excluded from this interface.

The solid waste volume to be sent from PNNL to Solid Waste is forecast to be $8,700 \mathrm{~m}^{3}$ through 2010. The annual total waste volume is approximately $600 \mathrm{~m}^{3}$ because PNNL will generate waste at a constant rate throughout the remainder of the life cycle. The majority of the $8,700 \mathrm{~m}^{3}$ is LLW; $900 \mathrm{~m}^{3}$ are MLLW and TRU(M) waste (RFSH 1996).

4.3.8.2 Interface with Liquid Waste Subproject. The ICD between PNNL and the Project is being developed and this interface has not yet been defined. 
HNF-SD-WM-RPT-288

Revision 0

4.3.8.3 Interface with Analytical Services Subproject. The ICD between PNNL and the Project is being developed and this interface has not yet been defined.

\subsubsection{B Plant/Waste Encapsulation and Storage Facility (WESF)}

The current mission of B Plant is to transition the facility to a safe configuration for transfer to the ERC team for long-term surveillance and maintenance activities. Waste generated during this process are those associated with the reduction or removal of hazards within the facility. The waste generated will be that associated with the reduction or removal of hazards within B Plant in anticipation of deactivation and transfer to the ERC team. The waste will include minor decontamination waste and system deactivation waste. Large portions of the waste will be those associated with contamination control and personal protective equipment.

The current mission of the WESF is the continued safe and efficient storage of the cesium and strontium capsules until the final disposition has been determined. Unlike B Plant, WESF is not in transition to the ERC team.

The ICD between B Plant/WESF and the Project is under development; it will provide additional details once completed.

4.3.9.1 Interface with Solid Waste Subproject. B Plant will generate both hazardous and mixed waste. Hazardous waste is shipped directly offsite in accordance with current Site practice and will not be shipped to Solid Waste disposal facilities. Generally, hazardous constituents are segregated before mixed waste is shipped. However, this will be evaluated as situations arise and, if necessary, several hazardous constituents may be placed into a single container to reduce cost.

The B Plant interface with Solid Waste entails the projection of waste to be generated by the B Plant Transition Project. All projects associated with the deactivation of B Plant have been included in the current forecast. The Solid Waste forecast assumes that B Plant will complete its deactivation mission by the end of FY 1998. During Fys 1997 and 1998, B Plant is projected to generate approximately $140 \mathrm{~m}^{3}$ of solid waste that will require TSD by Solid Waste. Of this waste, $1 \mathrm{~m}^{3}$ is MLLW; the rest is LLW (RFSH 1996).

In the past, WESF solid waste forecasts have been included with the B Plant projections. However, this year the forecasts were reported separately. The solid waste streams from WESF are proportioned the same as B Plant; however, the volumes are an order of magnitude less. Furthermore, WESF solid waste generation is projected through 2025, rather than ending in 1998 like B Plant.

4.3.9.2 Interface with Liquid Waste Subproject. Currently, the only liquid waste stream from B Plant that is being received by Liquid Waste is a combined chemical sewer stream that evolves from B Plant and WESF operations. This stream can receive chemical spills, water flushes, and other effluents from drains in B Plant and WESF where chemicals are stored and used.

Administrative controls provide the principal deterrent to introducing chemicals into the stream. 
HNF-SD-WM-RPT-288

Revision 0

The stream can also receive steam condensate, cooling water, sanitary water, and demineralized water produced by the B Plant/WESF Ionpure Continuous Deionization unit (Lesser 1994).

Projections by B Plant personnel for the volume rate of the chemical sewer liquid waste stream were originally estimated at approximately 189 million L ( 50 million gal) per year through FY 1998 . However, the current volume rate that TEDF has been receiving is approximately 11 million L ( 3 million gal) per year.

A future liquid waste stream has been identified as the WESF cooling water stream. This stream is projected to begin at the end of FY 1997 and continue through 2025. This stream is projected at a volume flow rate of approximately 15 million $\mathrm{L}$ ( 4 million gal) per year and would also be sent to TEDF. The 200 Area TEDF ICD (WHC-D-W049H-ICD-001, Rev. 3) governs the streams and should be referred to for further detail.

4.3.9.3 Interface with Analytical Services Subproject. Analytical Services provides sample characterization for B Plant and WESF process control and RCRA monitoring.

The B Plant Transition Project analytical sample projections for FYs 1997 and 1998 are approximately 140 and 10 liquid samples, respectively. The sample projections for WESF are approximately 1150 for FY 1997 and 1100 for FYs 1998-2002. The WESF projections include some liquid and solid samples, but the majority of the samples fall in the "other" category.

\subsubsection{Site Infrastructure Providers}

DynCorp Tri-Cities Services, Inc. (DynCorp) is the primary provider of infrastructure services; however, B\&W Protec, Inc.; Benton County; Fluor Daniel Hanford, Inc.; Fluor Daniel Northwest, Inc.; Hanford Environmental Health Foundation; Interstate Nuclear Services; Jantec, Inc.; Lockheed Martin Hanford Corporation (LMHC); Lockheed Martin Services, Inc.; Numatec Hanford Company; PNNL; and SGN Eurisys Services Corporation (SESC) provide limited infrastructure services.

Some infrastructure services (laundry, law enforcement, mail, and health care) are provided by contracts directly with the DOE. Figure 4-8 describes the interface between infrastructure service providers and the Project. The infrastructure services provided to the Project and the companies that provide them are identified in Table 4-1. The ICD between infrastructure service providers and RFSH is under development; it will provide additional details once completed. 
Figure 4-8. Site Infrastructure.

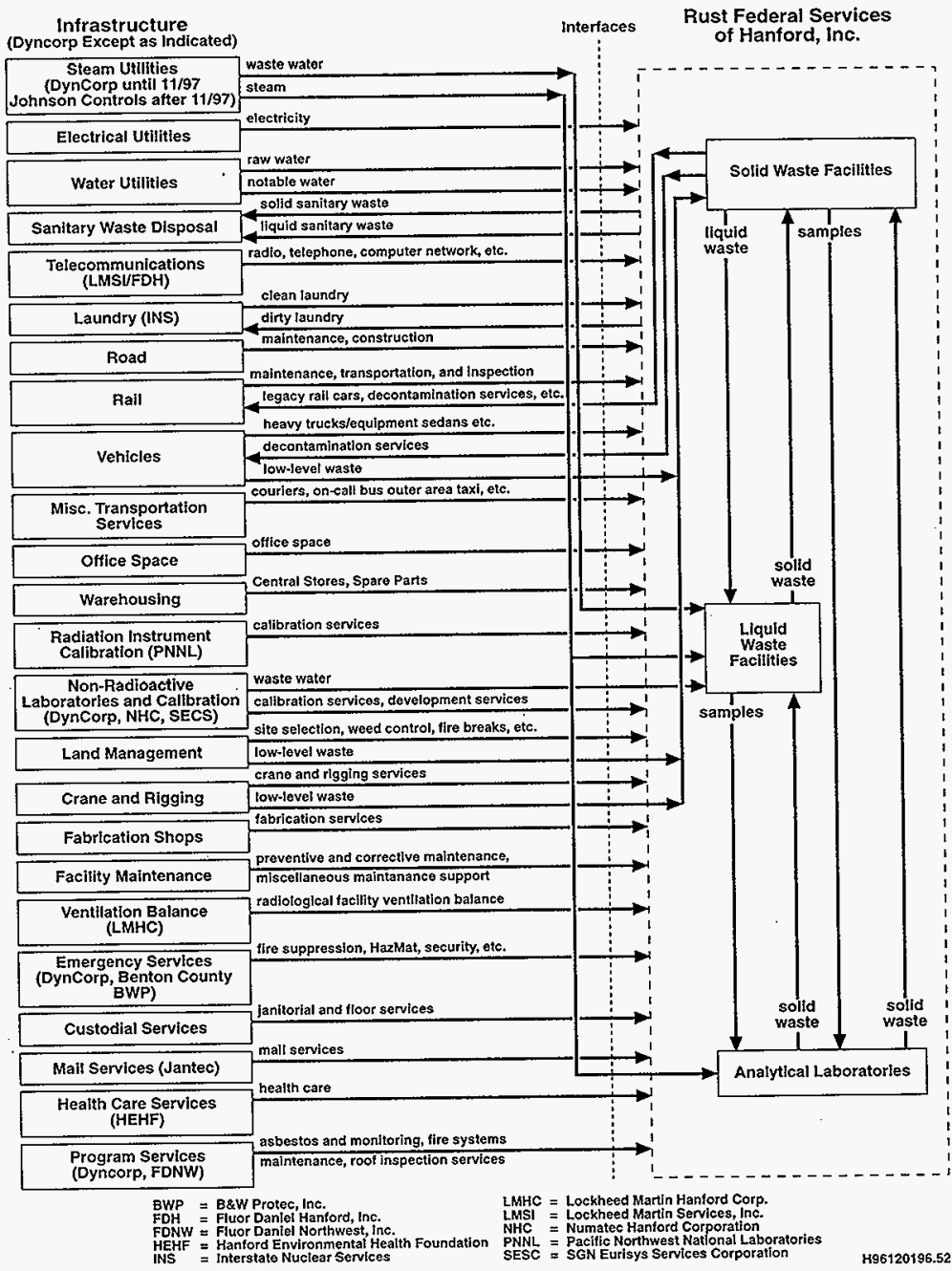


HNF-SD-WM-RPT-288

Revision 0

Table 4-1. Contractor-Provided Instrastructure Services. (2 sheets)

\begin{tabular}{|c|c|c|c|}
\hline \multicolumn{2}{|c|}{ Infrastructure Service } & DynCorp & Other \\
\hline \multirow[t]{6}{*}{ Utilities } & Steam & $\mathrm{X}^{*}$ & -- \\
\hline & Electricity & $\mathrm{x}$ & -- \\
\hline & Water & $x$ & -- \\
\hline & Sanitary waste & $\mathrm{X}$ & -. \\
\hline & $\begin{array}{l}\text { Telecommunications } \\
\text { Radio, telephone, pager, } \\
\text { computer network, } \\
\text { Cellular phone service }\end{array}$ & -- & $\begin{array}{l}\text { LMSI } \\
\text { FDH } \\
\end{array}$ \\
\hline & Laundry & -- & INS \\
\hline \multirow[t]{4}{*}{ Transportation } & Road & $\mathrm{X}$ & -- \\
\hline & Rail & $\mathrm{X}$ & -- \\
\hline & Vehicles (rolling stock) & $\mathrm{X}$ & - \\
\hline & $\begin{array}{l}\text { Miscellaneous transportation } \\
\text { services }\end{array}$ & $\mathrm{x}$ & -- \\
\hline \multirow{2}{*}{ General-Purpose Facilities } & Office space & $\mathrm{x}$ & -- \\
\hline & Warehousing & $\mathrm{x}$ & - \\
\hline \multirow{2}{*}{$\begin{array}{l}\text { Laboratory Services } \\
\text { Standards and Calibration }\end{array}$} & Radiation instrument calibration & -- & PNNL \\
\hline & $\begin{array}{l}\text { Nonradioactive laboratories and } \\
\text { calibration }\end{array}$ & $\mathrm{x}$ & $\begin{array}{l}\text { NHC } \\
\text { SESC }\end{array}$ \\
\hline
\end{tabular}


HNF-SD-WM-RPT-288

Revision 0

Table 4-1. Contractor-Provided Instrastructure Services. (2 sheets)

\begin{tabular}{|l|l|c|c|}
\hline \multicolumn{2}{|c|}{ Infrastructure Service } & DynCorp & Other \\
\hline Land Management & $\begin{array}{l}\text { Planning/site selection, weed } \\
\text { control, fire break maintenance, } \\
\text { etc. }\end{array}$ & $\mathrm{X}$ & -- \\
\hline \multirow{5}{*}{ General Services } & Crane and rigging & $\mathrm{X}$ & -- \\
\cline { 2 - 4 } & Fabrication shops & $\mathrm{X}$ & -- \\
\cline { 2 - 5 } & Facility maintenance & $\mathrm{X}$ & -- \\
\cline { 2 - 5 } & Ventilation balance & -- & LMHC \\
\cline { 2 - 5 } & $\begin{array}{l}\text { Emergency services } \\
\text { Hanford Fire Dept. } \\
\text { Safeguards and security } \\
\text { Law enforcement services }\end{array}$ & $\mathrm{X}$ & BWP \\
\hline \multirow{5}{*}{ General Services } & Custodial services & $\mathrm{X}$ & Benton County \\
\cline { 2 - 5 } & Mail services & -- & Jantec, Inc. \\
\cline { 2 - 5 } & Health care services & -- & HEHF \\
\hline \multirow{2}{*}{ Program Services } & $\begin{array}{l}\text { Asbestos/air monitoring, fire } \\
\text { systems maintenance }\end{array}$ & $\mathrm{X}$ & -- \\
\cline { 2 - 5 } & Roof inspection & -- & FDNW \\
\hline
\end{tabular}

*Steam will be provided by Johnson Controls, Inc., by November 1997.

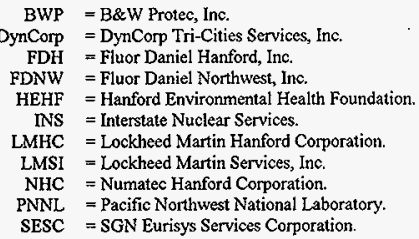

4.3.10.1 Interface with Solid Waste Subproject. Solid Waste provides disposal of small amounts of LLW that are generated by DynCorp activities, such as:

- Protective clothing disposables, (e.g., rubber gloves, tape) from operation of heavy equipment in contaminated areas at RFSH facilities 
HNF-SD-WM-RPT-288

Revision 0

- Contaminated tumbleweeds from area cleanup

- Contaminated tools and excess rail car parts

- Contaminated animal carcasses and droppings

- One burial box $\left(3.6 \mathrm{~m}^{3}\right)$ of CH Category I LLW from demolition of the 3732 Building during FY 1997.

These waste volumes are not quantified in the Hanford Site solid waste forecast (RFSH 1996).

4.3.10.2 Interface with Liquid Waste Subproject. Liquid Waste provides, or will provide, disposal of DynCorp facility wastewater streams at the 200 Area TEDF (see Table 4-2).

Table 4-2. Wastewater Streams at the 200 Area Treated Effluent Disposal Facility.

(disposal provided by liquid waste subproject)

\begin{tabular}{|l|l|}
\hline \multicolumn{1}{|c|}{ Facility } & \multicolumn{1}{c|}{ Flow rate } \\
\hline 284-E Power Plant & $\begin{array}{l}110 \text { gal per minute June 1997 - FY 2000 } \\
30 \text { gal per minute after FY 2000 }\end{array}$ \\
\hline 284-W Power Plant & 20 \\
\hline
\end{tabular}

FY = fiscal year

Liquid Waste provides treatment and disposal of DynCorp, NHC, and SESC facility wastewater streams at the 300 Area TEDF (see Table 4-3).

4.3.10.3 Interface with Analytical Services Subproject. At this time, no analytical services requirements exist for the infrastructure providers.

4.3.10.4 Other Issues. The Project also provides the following equipment decontamination services.

Legacy Rail Cars. DynCorp is responsible for dispositioning several legacy rail cars stored in various locations on the Hanford Site; this requires the Project's services.

Nonregulated Rail Cars. The Project provides storage of nonregulated rail cars on the T Plant rail spur for DynCorp. The DynCorp train crew uses these rail cars as spacer cars for moving tank cars into and out of the T Plant tunnel. 
HNF-SD-WM-RPT-288

Revision 0

Equipment Decontamination. The Project provides decontamination services for DynCorp equipment on an as-needed basis. Decontamination is performed at $T$ Plant in either the 221-T Canyon or 2706-T.

\subsubsection{TWRS Privatization-Phase I Facilities}

The DOE's strategy for privatizing the processing of TWRS waste involves a two-phased approach. Phase I is a proof-of-concept/commercial demonstration-scale effort and Phase II is a full-scale production effort.

The following operations will be implemented under Phase I (DOE and Ecology 1996).

- Transfer low-activity waste (LAW) from the feed tank to the LAW facility.

- Transfer selected waste for high-level waste (HLW) processing directly to the HLW facility.

- Perform separations to remove cesium, technetium, strontium, TRU elements, and sludge from the LAW stream.

- Store separated cesium and technetium at the treatment facilities or package and transport to the Canister Storage Building for onsite interim storage pending future $\mathrm{HLW}$ treatment.

- Return the sludge, strontium, and TRU waste separated before LAW processing to double-shell tanks for storage.

- Immobilize the LAW and vitrify the HLW.

- Place the vitrified HLW into canisters.

- Place the immobilized LAW into containers.

- Transport the immobilized waste to onsite interim storage facilities.

The two privatization contractors began working on Part A of the Phase I effort in the fall of 1996. During this 20 -month development period, the design of the processes to be used in the 10- to 14-year demonstration phase (B) will be defined. As part of the Phase IA effort, interfaces with the various Project interfaces will be identified and defined in specific ICDs.

4.3.11.1 Interface with Solid Waste Subproject. The interface between Solid Waste and each of the TWRS privatization contractors is to be defined in the radioactive solid waste and dangerous waste ICDs. These ICDs will be submitted to the DOE by each privatization contractor at the end of Phase IA. 
HNF-SD-WM-RPT-288

Revision 0

Table 4-3. Wastewater Streams at the 300 Area Treated Effluent Disposal Facility. (disposal provided by Liquid Waste Subproject)

\begin{tabular}{|l|r|r|}
\hline \multirow{2}{*}{ Facility } & \multicolumn{2}{c|}{ Flow rate (gpm) } \\
\cline { 2 - 3 } & Average & Maximum \\
\hline 305 Engineering Testing Facility (NHC) & $<1$ & 20 \\
\hline $\begin{array}{l}\text { 306-E Development, Fabrication, and Testing Laboratory (DynCorp, } \\
\text { NHC, and SESC) }\end{array}$ & 5 & 30 \\
\hline 382 Pump House (DynCorp) & 10 & 10 \\
\hline 382-B Fire Pump Station (DynCorp) & 1 & 10 \\
\hline 382-C Sanitary Water Storage (DynCorp) & 2 & 10 \\
\hline 382-D Sanitary Water Reservoir (DynCorp) & 2 & 10 \\
\hline 384 Power House (DynCorp) & 12 & 70 \\
\hline 3709 Paint Shop (DynCorp) & 5 & 10 \\
\hline 3717 Spare Parts Warehouse (DynCorp) & 2 & 2 \\
\hline 3717-B Standards Laboratory (DynCorp) & $<1$ & 3 \\
\hline
\end{tabular}

$\begin{aligned} \text { DynCorp } & =\text { DynCorp Tri-Cities Services, Inc. } \\ \text { NHC } & =\text { Numatec Hanford Corporation. } \\ \text { SESC } & =\text { SGN Eurisys Services Corporation. }\end{aligned}$

4.3.11.2 Interface with Liquid Waste Subproject. The interface between Liquid Waste and each TWRS privatization contractor will be defined in the nonradioactive, non-dangerous liquid effluents and the radioactive, dangerous liquid effluent ICDs. These ICDs are due at the end of Phase IA.

The planning assumption at this time is that approximately $40,000 \mathrm{~m}^{3} / \mathrm{yr}$ of liquid will be received at the 200 Area ETF and $100,000 \mathrm{~m}^{3} / \mathrm{yr}$ will be received at TEDF.

4.3.11.3 Interface with Analytical Services Subproject. Analytical Services support to the TWRS privatization effort will be required, although definite estimates are not available at this time. 
HNF-SD-WM-RPT-288

Revision 0

\subsection{OFFSITE INTERFACES}

In addition to the Hanford Site interfaces discussed earlier, the Project has a number of offsite system interfaces. These interfaces include the government and non-government entities for which the Project provides services as well as those that provide services to the Project.

\subsubsection{Solid Waste Subproject Interfaces}

4.4.1.1 Interfaces with Offsite Waste Generators. The Offsite Programs have various missions, including general maintenance and operations, environmental restoration, $D \& D$, and research and development. This section defines the Project's interfaces with offsite generators and offsite TSD facilities.

Twenty-three generators send waste from off site to the Project. Most of these generators are expected to send very little to no MLLW or TRU/TRUM waste. All but three of the generators completed solid waste forecasts. In the other cases, the Site treatment plans were used as the basis for the solid waste estimate. A total of $210 \mathrm{~m}^{3}$ of MLLW and TRU/TRUM waste is expected to be shipped from offsite generators to Solid Waste during the life cycle of the program (RFSH 1996). The forecasted life cycle ends in 2070. The Princeton Plasma Physics Laboratory is expected to generate the most MLLW and TRU/TRUM in this program $\left(28 \%\right.$ or $\left.60 \mathrm{~m}^{3}\right)$. The second highest generator, Rockwell Canoga Park, is expected to generate $24 \%$ or $50 \mathrm{~m}^{3}$. The following generators will provide the remainder of this waste:

- Puget Sound Naval Shipyards

- Paducah

- Knolls Atomic Power Laboratory

- Battelle Columbus Laboratory

- General Atomics

- University of Utah

- Pearl Harbor Naval Shipyard

- Lawrence Berkeley Laboratory

- Portsmouth Naval Shipyard

- Ames Laboratory - Ames, Iowa.

Furthermore, $46,500 \mathrm{~m}^{3}$ of LLW is expected to be shipped to the Project from off site during the Project's life cycle (RFSH 1996). No hazardous waste is expected from off site for management by the CWC.

4.4.1.2 Interfaces with TSD Facilities. Solid Waste relies on offsite interfaces for execution of its mission. The following are examples of these interfaces.

- TRU waste is to be disposed of off site at WIPP. 
HNF-SD-WM-RPT-288

Revision 0

- Dangerous waste is sent offsite for TSD.

- Offsite laboratories will provide a portion of the sample analysis requirements.

\subsubsection{Liquid Waste Subproject Interfaces}

Currently, Liquid Waste has limited offsite interfaces. As the enterprise companies associated with the PHMC begin to diversify into the private sector, these companies may request the services of Liquid Waste.

\subsubsection{Analytical Services Subproject Interfaces}

4.4.3.1 Interfaces with Offsite Customers. Analytical Services provides sampling, analysis, data management, and planning services to offsite customers on a case-by-case basis. Offsite customers include other DOE sites and DOE Complex-wide programs; other federal customers including the U.S. Department of Defense; and some non-government entities (such as privatization contractors). As the enterprise companies associated with the PHMC begin to diversify into the private sector, Analytical Services likely will increase its number of offsite customers.

4.4.3.2 Interfaces with Offsite Laboratories. In addition to onsite facilities, Analytical Services retains the services of a number of commercial laboratories. The commercial laboratories provide support for samples that are less than $10 \mathrm{mR} / \mathrm{h}$. Environmental monitoring, bioassay, and routine Comprehensive Environmental Response, Compensation, and Liability Act of 1980/RCRA mixed waste samples are processed by these laboratories.

\subsection{REFERENCES}

Comprehensive Environmental Response, Compensation, and Liability Act of 1980 , 42 USC 9601, et seq.

Crane, A. F., 1996, 200 Area Treated Effluent Disposal Facility Interface Control Document, WHC-SD-W049H-ICD-001, Rev. 2, Westinghouse Hanford Company, Richland, Washington.

DOE and Ecology, 1996, Final Environmental Impact Statement for the Tank Waste Remediation System, Hanford Site, Richland, Washington, DOE/EIS-0189, U.S. Department of Energy and Washington State Department of Ecology, Richland, Washington.

Duncan, D. R., 1995, Interface Control Document Between the Tank Waste Remediation Division and the Solid Waste Disposal Division, WHC-SD-WM-PICD-003, Rev. 0, Westinghouse Hanford Company, Richland, Washington. 
HNF-SD-WM-RPT-288

Revision 0

Greager, T. M., 1996a, Interface Control Document Between Liquid Effluent Services and Solid Waste Disposal Division, WHC-SD-WM-PICD-001, Rev. 1, Westinghouse Hanford Company, Richland, Washington.

Greager, T. M., 1996b, Interface Control Document Between Analytical Services and Solid Waste Disposal Division, WHC-SD-WM-PICD-005, Rev. 1, Westinghouse Hanford Company, Richland, Washington.

Greager, T. M., 1996c, Interface Control Document Between the Environmental Restoration Contractor and the Solid Waste Disposal Division, WHC-SD-WM-PICD-010, Rev. 0, Westinghouse Hanford Company, Richland, Washington.

Green, F. T., 1996, Liquid Effluents Program FY 1997 Multi-Year Work Plan, WHC-SP-1097, Rev. 2, Westinghouse Hanford Company, Richland, Washington.

Joyce, S. M., 1997, Hanford Analytical Sample Projections FY 1997 - FY 2001, WHC-SD-WM-TI-608, Rev. 3, Rust Federal Services of Hanford, Richland, Washington.

Lesser, J. E., 1994, Facility Effluent Monitoring Plan for the B Plant, WHC-EP-0467, Rev. 1, Westinghouse Hanford Company, Richland, Washington.

Resource Conservation and Recovery Act of 1976, 42 USC 6901, et seq.

RFSH, 1996, Solid Waste Integrated Forecast Technical (SWIFT) Report: FY 1997 to FY 2070, HNF-EP-0918, Rev. 1, Rust Federal Services of Hanford, Inc., Richland, Washington. (Also available on the Internet at TTP://W3.PNL.GOV:2080/SWIFT/ WELCOME.HTM)

RFSH, 1997a, Interface Control Document Between Fast Flux Test Facility Transition Project and Rust Federal Services of Hanford Waste Management Project, HNF-SD-WM-PICD004, Rev. 2, Rust Federal Services of Hanford, Inc., Richland, Washington.

RFSH, 1997b, Interface Control Document Between Plutonium Finishing Plant Transition Project and Rust Federal Services of Hanford Waste Management Project, HNF-SD-WMPICD-006, Rev. 2, Rust Federal Services of Hanford, Inc., Richland, Washington.

RFSH, 1997c, Interface Control Document Between Plutonium Uranium Extraction Project and Rust Federal Services of Hanford Waste Management Project, DRAFT, Rust Federal Services of Hanford, Inc., Richland, Washington.

RL, 1993, Hanford Mission Plan, Vol. 1, Site Guidance, DOE/RL-93-08, U.S. Department of Energy, Richland Operations Office, Richland, Washington.

RL, 1994, Tank Waste Remediation System Functions and Requirements, DOE/RL-92-60, Rev. 1, U.S. Department of Energy, Richland Operations Office, Richland, Washington. 
RL, 1996, Memorandum of Understanding: Disposition and Transport of Excess Water from 100K Basins to the 200 Area Effluent Treatment Facility, signed by T. K. Teynor and

E. D. Sellers, U.S. Department of Energy, Richland Operations Office, Richland, Washington.

Spohr, R. A., 1996, Analytical Services Program FY 1997 Multi-Year Work Plan-WBS 1.5.1, WHC-SP-1110, Rev. 2, Westinghouse Hanford Company, Richland, Washington.

Willis, N. P., 1996, Hanford Site Solid Waste Acceptance Criteria, WHC-EP-0063-5, Westinghouse Hanford Company, Richland, Washington. 
HNF-SD-WM-RPT-288

Revision 0

CONTENTS

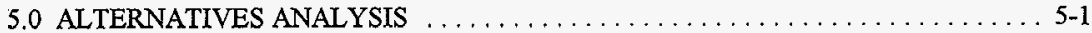

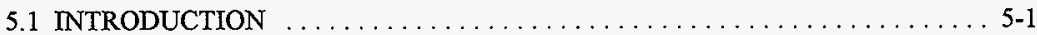

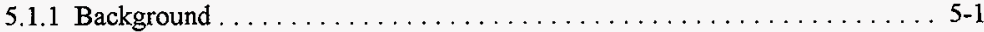

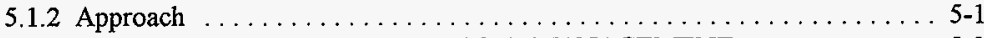

5.2 ALTERNATIVES TO IMPLEMENT WASTE MANAGEMENT $\ldots \ldots \ldots \ldots .5-2$

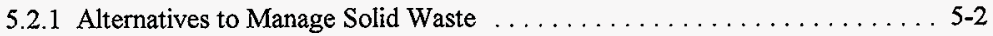

5.2 .2 Alternatives To Manage Liquid Waste ................... 5-47

5.2.3 Alternatives To Manage Analytical Services . . . . . . . . . . . . 5-48

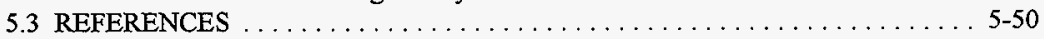


HNF-SD-WM-RPT-288

Revision 0

\section{LIST OF FIGURES}

5-1. Time Line of Solid Waste Management Events at the Hanford Site. . . . . . . . . 5-3

5-2. Alternative Analysis for Waste Categories Managed by the Solid Waste Subproject. . . 5 5-5

\section{LIST OF TABLES}

5-1. Summary of the Environmental Impacts for Each Solid Waste Alternative. . . . . 5 5-16

5-2. Summary of Onsite Nonradioactive Emissions for the Geologic Disposal Alternative 5-18

5-3. Resource Requirements for the Geologic Disposal Alternative ........... 5-18

5-4. Summary of Onsite Nonradioactive Emissions for the In-Place Stabilization and

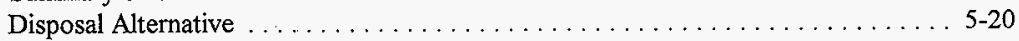

5-5. Resource Requirements for the In-Place Stabilization and Disposal Alternative . . . . 5-21

5-6. Summary of Onsite Nonradioactive Emissions for the No Disposal Action

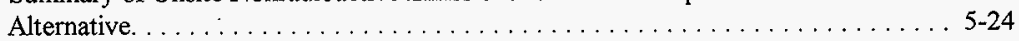

5-7. Resource Requirements for the No Disposal Action Alternative. . . . . . . . . 5-25

5-8. Alternative Evaluation Results for Pre-1970 Suspect Transuranic Solid Waste . . . . 5-30

5-9. Treatment Strategies for Mixed Waste Physical Waste Forms ............ 5-36

5-10. Estimated 30-Year Future Volume Generation Summary by Waste Class for Forecasts Requested in 1989 through 1993 . . . . . . . . . . . . . 5 5-42

5-11. Waste Stream Volumes Expected by the Solid Waste Subproject in Support of Pursuing Two Waste Receiving and Processing Modules ........... 5-43

5-12. Engineering Studies for the Liquid Effluent Facilties ............... 5-49 


\section{LIST OF TERMS}

$\begin{array}{ll}\text { ALARA } & \text { as low as reasonably achievable } \\ \text { BDAT } & \text { best demonstrated available (treatment) technology } \\ \text { CEQ } & \text { Council on Environmental Quality } \\ \text { CH } & \text { contact-handled } \\ \text { DOE } & \text { U.S. Department of Energy } \\ \text { Ecology } & \text { Washington State Department of Ecology } \\ \text { EIS } & \text { environmental impact statement } \\ \text { EPA } & \text { U.S. Environmental Protection Agency } \\ \text { ERDA } & \text { U.S. Energy Research and Development Administration } \\ \text { FFCA } & \text { Federal Facilities Compliance Act of 1992 } \\ \text { FY } & \text { fiscal year } \\ \text { HDW-EIS } & \text { Hanford Defense Waste Environmental Impact Statement } \\ \text { LDR } & \text { land disposal restriction } \\ \text { LLW } & \text { low-level waste } \\ \text { M\&I } & \text { management and integration } \\ \text { MLLW } & \text { mixed low-level waste } \\ \text { NEPA } & \text { National Environmental Policy Act of 1969 } \\ \text { NRC } & \text { U.S. Nuclear Regulatory Commission } \\ \text { PCB } & \text { polychlorinated biphenyl } \\ \text { PHMC } & \text { Project Hanford Management Contract } \\ \text { Project } & \text { Waste Management Project } \\ \text { PUREX } & \text { Plutonium-Uranium Extraction } \\ \text { RCRA } & \text { Resource Conservation and Recovery Act of } 1976 \\ \text { RH } & \text { remote-handled } \\ \text { TRU } & \text { transuranic } \\ \text { WIPP } & \text { Waste Isolation Pilot Plant } \\ \text { WRAP } & \text { Waste Receiving and Processing } \\ \text { WRAP 1 } & \text { Waste Receiving and Packaging Module 1 } \\ \text { WRAP 2 } & \text { Waste Receiving and Packaging Module 2 } \\ & \\ \end{array}$




\section{HNF-SD-WM-RPT-288}

Revision 0

This page intentionally left blank. 
HNE-SD-WM-RPT-288

Revision 0

\subsection{ALTERNATIVES ANALYSIS}

\subsection{INTRODUCTION}

This section delineates the Waste Management Project (Project) aiternatives evaluated to ensure that the complex aspects of the Project can be efficiently managed. Alternative evaluations establish decision criteria that focus decision makers on compliant and viable options for achieving the Project's mission.

The alternative evaluations have the following purposes.

- Describe alternatives examined to a sufficient level to manage the diverse aspects of the Project.

- Identify the decision criteria against which alternatives are evaluated.

- Evaluate each alternative against the decision criteria.

- Compare the alternative evaluations.

- Explain the alternative selected or decision made.

Ultimately the intent is to identify, evaluate, and select preferred alternatives to satisfy the stated objectives of the Project.

\subsubsection{Background}

Hanford Site radioactive waste has been generated since 1944 as a result of national defense activities. Since 1944, waste management guidelines and practices have changed markedly. Most recently (October 1, 1996), the U.S. Department of Energy, Richland Operations Office transitioned to a management and integration (M\&I) contractor at the Hanford Site. The Project Hanford Management Contract (PHMC) has resulted in establishment of the Project as a portion of this new M\&I structure. Many alternatives were considered before October 1, 1996, and many will undoubtedly be considered in the future. This section provides a framework to capture these alternatives, analyze them, and recommend preferred alternatives for the Project to undertake.

\subsubsection{Approach}

This section describes alternatives that support the waste management mission. The Project approach that has been identified within the boundary of the PHMC is described in Section 5.2. The remainder of Chapter 5.0 describes many of the alternatives evaluated to this point and provides a basis for the details of the Project as it now exists within the PHMC. Additional alternatives and the subsequent analyses will be examined in future revisions to this document. 
HNF-SD-WM-RPT-288

Revision 0

\subsection{ALTERNATIVES TO IMPLEMENT WASTE MANAGEMENT}

The PHMC has resulted in establishment of the Project to accomplish the following activities.

- Manage Solid Waste-This is the Solid Waste Program that existed under the previous contractor (Westinghouse Hanford Company).

- Manage Liquid Waste--This is the Liquid Effluents Program and the Waste Concentration portion of the Tank Waste Remediation System Project that existed under the previous contractor (Westinghouse Hanford Company).

- Manage Analytical Services-This is the Analytical Services portion of the Infrastructure Program/Project that existed under the former contractor (Westinghouse Hanford Company).

\subsubsection{Alternatives to Manage Solid Waste}

Figure 5-1 presents a time line depicting the major waste management guidelines and practice since 1944. These events affected the solid waste management direction and the decisions that have been or are being made to manage transuranic (TRU) waste, low-level waste (LLW), and mixed low-level waste (MLLW).

Three major categories of solid waste managed under the Project are LLW, MLLW, and TRU waste. Figure 5-1 illustrates the separate evolution of waste management strategies for these waste categories. Transuranic solid waste remediation strategies were developed and analyzed in great detail in DOE/EIS-0113, Final Environmental Impact Statement - Disposal of Hanford Defense High-Level, Transuranic, and Tank Wastes (DOE 1987a), which is commonly referred to as the Hanford Defense Waste Environmental Impact Statement (HDW-EIS). Strategies to remediate solid LLW were developed and analyzed in ERDA-1538, Final Environmental Impact Statement for Waste Management Operations - Hanford Reservation (ERDA 1975). Strategies to remediate LLW and Resource Conservation and Recovery Act of 1976 (RCRA) hazardous waste are being developed under the Federal Facilities Compliance Act of 1992 (FFCA).

The second area of alternative analysis is strategy implementation. Section 5.2.1.4 describes the implementation alternatives that have been evaluated, changes that have occurred to the Solid Waste subproject scope over the years, and the reasoning associated with various alternative evaluations. Variation in the nature of the waste (radioactive and hazardous characteristics) dictates that various alternatives be examined for each waste class. However, considerable overlap occurs in managing these waste categories, particularly incidental waste (management 
Figure 5-1. Time Line of Solid Waste Management Events at the Hanford Site.

Radioactive solid waste generated at the Hanford Site. Wastes buried in the 100,200 , and 300 Areas.

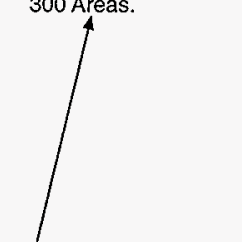

Radioactive solid waste no longer disposed in the 300 Area burial grounds. Waste transferred to 200 Areas for disposal.

Transuranic solid waste segregated for retrievable storage in grounds.

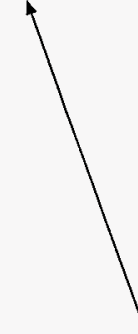
the 200 Areas' burial

Radioactive solid waste no longer disposed in the 100 Areas' burial grounds. Waste transferred to 200 Areas for disposal.

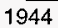
1950 1960

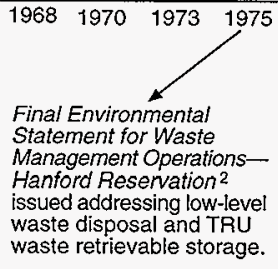

Record of Decision for the Final Environmental Impact Statement ${ }^{4}$ states geologic disposal of TRU waste at WIPP to be pursued.

\footnotetext{
DOE = U.S. Department of Energy.

TRU = transuranic.
}

WIPP $=$ Waste Isolation Pilot Plant.

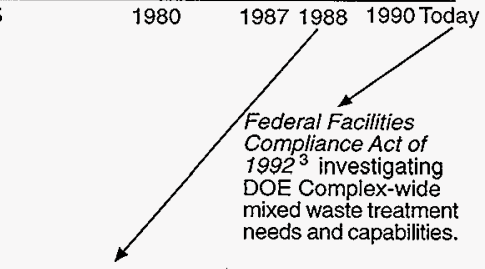

${ }^{1}$ Resource Conservation and Recovery Act of 1976, 42 USC 6901, et seq.

2 ERDA, 1975, Final Environmental Statement for Waste Management Operations - Hanford Reservation, ERDA-1538, U.S. Energy Research and Development Administration, Washington, D.C.

${ }^{3}$ DOE, 1988, Disposal of Hanford Defense High-Level, Transuranic, and Tank Wastes, Hanford Site, Richland, Washington; Record of Decision, Federal Register V.53, No. 72, pp. 12449-12453, U.S. Department of Energy, Washington, D.C.

${ }^{4}$ Federal Facility Compliance Act of 1992, 42 USC 6901, et seq. 
of LLW and MLLW associated with retrieved TRU waste overlaps with management of newly generated LLW). Because of this overlap, alternative strategies meaningful to the Project need to be integrated.

Figure 5-2 shows that alternative strategies were examined independently for the major solid waste types (TRU, LLW, and MLLW), and graphically represents integration strategies for developing Project alternatives. Environmental impact statements (EIS) have been issued comparing alternative strategies for disposing of TRU waste and LLW. The U.S. Department of Energy (DOE) strategies for managing MLLW are being examined under the auspices of the FFCA.

The alternatives examined in the HDW-EIS and their proposals are as follows.

- Geologic Disposal Alternative (Preferred Alternative) - Dispose of all TRU waste in a geologic repository such as the Waste Isolation Pilot Plant (WIPP), which is approximately $42 \mathrm{~km}$ from Carlsbad, New Mexico.

- In-Place Stabilization and Disposal Alternative-Stabilize TRU waste in place and implement a barrier and marker system to deter accidental intrusion into the near-surface disposal areas.

- No Disposal Action Alternative-Perform no disposal action, but continue the current method of solid waste storage.

The HDW-EIS addressed final disposal alternatives for several waste types, including pre-1970 suspect TRU waste. The alternatives that were evaluated in this EIS are summarized as follows.

- Geologic Disposal of Pre-1970 Suspect TRU Solid Waste-This alternative examined the option of retrieving and processing the TRU portion of the pre-1970 suspect TRU solid waste and the surrounding TRU-contaminated soil for enhanced protection in a geologic repository. This repository was assumed to be WIPP. Retrieval procedures would be similar to those proposed for use at TRU-contaminated soil sites.

- In-Place Stabilization and Disposal of Pre-1970 Suspect TRU Solid Waste-In this alternative, the HDW-EIS proposed that all pre-1970 buried suspect TRU solid waste would remain in place as disposed of. It would be covered with a protective barrier and marker system.

- Reference Alternative for Pre-1970 Suspect TRU Solid Waste - This alternative for the 200 Areas was enhanced protection identical to the in-place stabilization and disposal alternative described above. However, TRU waste in the 618-11 site near the 300 Area would be retrieved. This selective combination of in-place stabilization and geologic disposal would consolidate waste at central locations and remove TRU waste from the sites near areas of habitation and potential flooding. 
Figure 5-2. Alternative Analysis for Waste Categories Managed by the Solid Waste Subproject.

\section{Strategic Alternatives \\ Examined for Specitic \\ Radioactive Solid Wastes at the Hanford Site}

Transuranic Waste

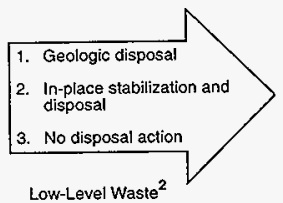

Low-Level Waste ${ }^{2}$

1. Current practice

2. Compaction

3. Disposal in deactivated plants

Mixed Low-Level Waste

t. Current practice

2. Altérnatives examined under Federal Facility Comoliance Act of $1992^{3}$ activities (ongoing)
Integrated Alternatives to

Implement Selected

Waste Type-Specific Strategles

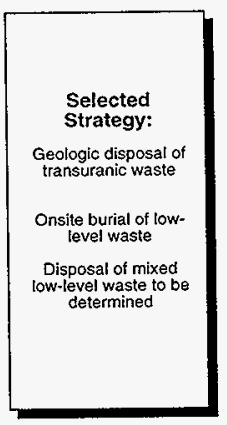

Selected Strategy:

One facility to provide all waste treatment needs

2. Two facilities to provide waste processing needs

3. Multiple facilities tailored to meet specific treatment needs
Multiple facilities tallored to meet specific waste processing needs

${ }^{1}$ DOE, 1987, Final Environmental Impact Statement - Disposal of Hanford Defonse High-Level, Transuranic and Tank Wastes, DOEJEIS-0113, U.S. Department of Energy, Washington, D.C.

2 ERDA, 1975, Final Environmental Statement for Waste Management Operations - Hanford, Reservation, ERDA-1538, U.S. Energy Research and Development Administration, Washington, D.C.

${ }^{3}$ Federal Facility Compliance Act of 1992, 42 USC 6901, et seq. 
HNF-SD-WM-RPT-288

Revision 0

- Continued Surveillance of Pre-1970 Suspect TRU Solid Waste-The HDW-EIS noted that by 2000 , all suspect TRU solid waste burial grounds from pre-1970 operations were expected to have been surface stabilized. Planned activities directed at surface stabilization through the control of deep-rooted vegetation were to be implemented and completed by 2000 .

- Preferred Alternative for Pre-1970 Suspect TRU Solid Waste-The HDW-EIS preferred alternative for pre-1970 buried suspect TRU-contaminated solid waste would postpone a decision between geologic disposal and in-place stabilization and disposal until after completion of ongoing and planned development and evaluation. In the interim, the DOE would continue the present maintenance activities for these waste sites.

5.2.1.1 Alternatives to Remediate LLW. Several alternatives were evaluated in ERDA-1538, Final Environmental Statement for Waste Management Operations - Hanford Reservation (ERDA 1975) for disposal of solid waste at the Hanford Site. The evaluation presented here pertains only to LLW and the alternatives identified to treat this waste. The continuing practice of onsite land burial, as described under "Current Practice," along with waste minimization and compaction of some site waste, forms the current strategy for managing solid LLW at the Hanford Site. The alternatives examined in ERDA-1538 were as follows.

- Current Practice (1975) - After minimal processing, solid radioactive waste is placed into the ground at several locations in the 200 Areas.

- Compaction and Disposal-Compaction of solid waste before disposal could reduce the total volume of the initial package.

- Storage in Deactivated Plants-Deactivated plants could be converted to waste disposal "vaults."

To implement the most productive disposal practice, ERDA-1538 evaluated alternatives to enhance the disposal process. These alternatives are as follows.

- Sorting and Classifying-A sorting and classifying system for solid waste handling would assist in determining waste treatment options. Developing instrumentation to nondestructively analyze the contents of packaged solid waste would allow the identification and measurement of the radioactive content of waste before determining its disposition.

- Equipment Reclamation - An equipment reclamation alternative was considered to recover all contaminated process equipment for reuse, thus eliminating the need for burial.

- Equipment Disposal-An equipment disposal alternative was considered that would involve one or more methods of consolidating large equipment items into easily handled 
forms. Items could be cut, melted, burned, disassembled, and compacted, or they could be completely converted to liquid waste.

- Burial Ground Selection-Solid waste burial alternatives were evaluated for longversus short-term burials. Criteria for long-term burial were developed and existing burial sites would be evaluated using these criteria. The evaluations were expected to determine which burial grounds required stabilization, which needed relocation, and which potential new sites were acceptable for long-term storage.

5.2.1.2 Alternatives to Remediate MLLW. Before 1987, radioactive waste was regulated solely under the Atomic Energy Act of 1954. In 1987, the DOE issued a mixed byproduct ruling (DOE 1987b) stating that the hazardous components of radioactive waste are regulated by RCRA. The RCRA land disposal restrictions ( $L D R$ ) require that established treatment requirements be met before land disposal of hazardous wastes. While treatment capacity generally exists for the nonradioactive hazardous waste subject to LDRs, treatment is currently unavailable for the radioactive mixed waste subject to LDRs.

Because a DOE Complex-wide treatment approach for MLLW is undecided, mixed waste is temporarily stored at the Hanford Site according to Washington State Department of Ecology (Ecology) storage requirements and as low as reasonably achievable (ALARA) radiation safety requirements. Remediation alternatives will be developed once the MLLW treatment capability becomes available.

In accordance with Hanford Federal Facility Agreement and Consent Order (Tri-Party Agreement) (Ecology et al. 1996) Milestone M-26-00, a Hanford Site LDR treatment and processing plan for mixed wastes is submitted annually to the U.S. Environmental Protection Agency (EPA) and Ecology. This plan describes the process for managing mixed waste subject to LDRs at the Hanford Site and identifies actions that will be taken to achieve full compliance with LDR requirements.

Treatment options have been developed based on identified technology requirements. Options are divided into two groups: mixed waste that requires thermal treatment and mixed waste that does not require thermal treatment. Waste with specified or best demonstrated available (treatment) technologies (BDAT) of "combustion" or "incineration" would be treated according to the thermal treatment option. Waste that does not require these treatment technologies would be designated for the non-thermal treatment options. Three options are under consideration for mixed waste that requires thermal treatment. The first option is to process this waste in a commercial facility. Other options include constructing an onsite facility or treating the waste at another DOE site. Under any option, additional treatment will be provided at the facility as required so that the returned waste residues are in an acceptable form for disposal. Services for thermal treatment are expected to become available in fiscal year (FY) 2001.

Some waste in the non-thermal treatment option could effectively be treated by the thermal treatment option. The treatment path decision will be made by evaluating treatment cost differences and volume reduction advantages relating to disposal costs. Waste that does not 
require thermal treatment will be processed by a commercial stabilization contract providing non-thermal mixed waste treatment capability. These services are planned to be available by September 1999.

5.2.1.3 Alternatives to Implement Remediate Solid Waste Decision. Implementation of the Geologic Disposal alternative as defined in the HDW-EIS has evolved as additional waste management requirements have emerged. The most notable of these requirements is the DOE policy that all radioactive waste classified as hazardous under RCRA would be subject to regulation under RCRA and the Atomic Energy Act of 1954. Planning has been modified for changes in the Project scope. The current option being pursued by the Project is the multiple treatment facility alternative.

- One Treatment Facility-This alternative provided one Waste Receiving and Processing (WRAP) facility to certify and ship TRU waste to WIPP. During the initial consideration of this alternative, RCRA regulations did not apply to radioactive solid waste.

- Two Treatment Facilities-This alternative, which was developed to accommodate the expanded scope of treating mixed waste in accordance with RCRA requirements, proposed two WRAP facilities for all processing needs. One facility would certify and ship TRU waste to WIPP (as originally planned in the one treatment facility alternative), and the other would perform all other solid waste processing functions.

- Multiple Treatment Facilities - This alternative, which is the preferred alternative, proposes multiple facilities, with each responsible for treating a particular portion of the solid waste. One WRAP facility would certify and ship contact-handled $(\mathrm{CH})$ and remote-handled (RH) TRU waste to WIPP (as originally planned in the one treatment facility alternative), another facility would provide non-thermal treatment of MLLW in accordance with RCRA regulations, and another would provide thermal treatment of MLLW in accordance with RCRA regulations. Facility requirements are being examined for the remaining inventory of solid waste (RH-TRU and RH MLLW, waste requiring size reduction or waste in oversized containers, and waste requiring decontamination). (Note that "facility" in this context also applies to contracting of services at a privately owned facility.)

5.2.1.4 Alternatives to Remediate TRU Waste. Alternative strategies for disposal of retrievably stored and newly generated TRU waste, including pre-1970 suspect TRU, are examined in this section. These alternatives were examined as part of the HDW-EIS.

5.2.1.4.1 Background. In early 1943, the U.S. Army Corps of Engineers selected the Hanford Site as the location for reactor and chemical separation facilities for producing and purifying plutonium. The separation and waste management facilities were and are located in the 200 Areas, on a plateau about $11 \mathrm{~km}$ from the Columbia River although, until 1966, solid waste disposal occurred in all areas of the Hanford Site. 
Original planning for the 200 Areas was directed toward a short-term operating period. Based on this philosophy, shallow land burial was used for disposal of contaminated solids. The national needs after World War II resulted in extending operations in the plants, and supported an expansion of operations in new plants. Expanding knowledge of the regional geology and hydrology, combined with understanding and observation of radionuclide behavior, provided the basis for continued use of the ground for liquid LLW disposal and burial of contaminated solids. From 1944-54, no serious segregation of different types of solid LLW occurred. Combustibles and noncombustibles were buried in the same trench. Burial records were incomplete and minimal information was available about the quantity or type of radioactive material present.

By 1953 , it was recognized that the facilities would be operated much longer than originally planned. A disposal policy was established that consisted of reviewing each source of waste and specifying conditions for disposal. Shallow land burial of solid materials contaminated with radioactivity continued to be acceptable.

From 1966-74, a program of centralization of solid waste disposal in the 200 Area was started and completed. The measures of the kinds and amounts of radioactivity in the buried waste improved, sites were marked with informative semipermanent markers, record keeping was further improved, and segregation of radioactive waste by category was initiated.

In April 1970, waste containing, or suspected of containing, TRU radionuclides greater than $10 \mathrm{nCi} / \mathrm{g}$ began to be retrievably stored in the ground. In 1982 , the definition of TRU was changed to waste containing greater than $100 \mathrm{nCi} / \mathrm{g}$ of TRU radionuclides.

In 1976, the National Academy of Sciences published a review of solid waste disposal practices at DOE sites (formerly the U.S. Energy Research and Development Administration [ERDA]), including the Hanford Site (NAS 1976). In the conclusion of its long study of solid waste handling, the National Academy of Sciences did not attempt an overall judgement but noted the following:

- ERDA's present practices "have not created a hazardous situation"

- "desert areas with a deep water table are preferable as sites for waste burial"

- Exhumation of waste is difficult and costly, and should be undertaken only if "the aiternative mode of disposal, after exhumation, is manifestly safer than leaving the material in its present burial site"

- Additional research is urgently needed on the rates and conditions of movements of radionuclides, especially plutonium, through soils and sediments.

5.2.1.4.2 Alternatives Evaluated. The HDW-EIS examined general approaches to managing and disposing of defense-related waste. This waste includes retrievably stored TRU and newly generated TRU included in the scope of the Project. Alternative descriptions include 
the objective of the alternative; the activities and/or waste processes used to meet the objective; and assumptions, such as facility information, that were used for calculation purposes.

Several disposal alternatives were discussed in the HDW-EIS but a significant number were not presented in detail. The alternatives excluded from detailed consideration in the HDW-EIS include seabed disposal, space disposal, deep-hole disposal, ice sheet disposal, and island disposal. These alternatives had been previously investigated for disposal of commercial radioactive waste and it was determined that Geologic Disposal was the alternative of choice. Therefore, these alternatives were not reexamined for disposal of defense waste.

A synopsis of the information presented in the HDW-EIS for each alternative examined is presented in the following paragraphs. The information relates only to the retrievably stored and newly generated TRU waste and does not include impacts from other waste types examined in the HDW-EIS (tank waste, cesium strontium capsules, TRU-contaminated soil, and pre-1970 TRU-contaminated buried waste). The HDW-EIS examined a geologic disposal alternative, an in-place stabilization and disposal alternative, a reference alternative, a no-disposal-action alternative, and the preferred alternative. For retrievably stored TRU waste and newly generated TRU waste, the reference and preferred alternatives are similar to the geologic disposal alternative. They will not be discussed separately.

Geologic Disposal Alternative. In the Geologic Disposal alternative, essentially all the TRU waste (to the extent practicable) would be removed from surface or near-surface storage or disposal on the Hanford Site and placed in WIPP. Retrievably stored and newly generated TRU waste would be retrieved and converted to a stabilized form meeting repository acceptance criteria. Any retrieved waste having a concentration of less than $100 \mathrm{nCi} / \mathrm{g}$ of TRU would be classified as LLW and disposed of as such on site. Some of the LLW is anticipated to be classified as MLLW. This waste would be segregated and disposed of in accordance with RCRA. Retrievable TRU waste may already be adequately stabilized or may be further stabilized by incorporation into cement. The stabilized waste form would be packaged as solid TRU waste to meet acceptance criteria, and transported to a geologic repository for disposal. For calculation purposes, the geologic repository is assumed to be WIPP.

The activities and/or waste processes considered to perform the Geologic Disposal alternative include waste package inspection, assaying, repackaging, size reduction, sorting, shredding, and waste immobilization in cement. Incineration would be implemented as an additional process step between shredding and grouting if deemed necessary.

All TRU waste would be inspected and certified to meet the WIPP waste acceptance criteria (WAC) (WIPP 1996). Accordingly, the current inventory of retrievably stored, CH TRU waste (exposure rates of less than $200 \mathrm{mrem} / \mathrm{h}$ ) would be removed and transferred to a WRAP facility. The WRAP facility would be designed to support inspection and certification of CH TRU waste for repository disposal. Processing and packaging capability for CH TRU waste in 20-year retrievable storage containers also would be provided in the facility. 
Estimates of process costs, emissions, and volumes of waste have calculated that $45 \%$ of all retrievably stored $\mathrm{CH}$ TRU waste would not be classified as TRU waste after the TRU waste content of each waste package is determined. The projected $45 \%$ of waste to be reclassified is based on engineering judgment and historical records and reflects the change in definition of TRU waste limits from 10 to $100 \mathrm{nCi} / \mathrm{g}$.

Until about 1994 (when construction of the WRAP facility was to be completed), newly generated TRU waste was to be retrievably stored on pads or in buildings. Newly generated TRU waste was planned to be retrieved and processed in the same manner as the existing retrievable TRU solid waste. After the WRAP TRU line comes on line, all CH TRU waste will be processed directly in the WRAP facility and packaged to meet the WIPP WAC.

Remote-handled TRU waste (exposure rates equal to or exceeding $200 \mathrm{mrem} / \mathrm{h}$ ) in caissons would be mechanically removed using an airtight, double-shelled metal structure installed over the caissons. The RH TRU waste would be placed in a cask and transferred by truck to a waste processing facility, where it would be processed. Tri-Party Agreement Milestones M-33 and M-91 include processing and packaging of RH TRU waste to WIPP. The schedule and funding for this project have not been identified.

Two facilities were assumed for development of the Geologic Disposal alternative: WIPP and WRAP. The WIPP facility is intended to receive and store RH and CH TRU waste volumes. The WRAP facility is intended to receive and process TRU waste in accordance with the WIPP WAC.

In-Place Stabilization and Disposal AIternative. The objective of the In-Place Stabilization and Disposal alternative is to immobilize and stabilize TRU waste at the Hanford Site and to dispose of the waste or provide enhanced protection by isolating the waste from ecosystems using a protective barrier and marker system.

Activities and/or waste processes to be performed for this alternative would be minimal. Retrievably stored and newly generated TRU waste would be disposed of near surface and covered with a protective barrier and marker system. Waste already placed in a predisposal location would not be removed and the site would be treated as necessary for subsidence control. All sites containing TRU waste would be covered with protective barriers and marker systems.

Compaction would be performed for TRU waste burial grounds with significant potential for subsidence. One technology under consideration uses a vibratory hammer interfaced with a heavy-duty crane to inject rods into the waste site, compacting the buried drums and other containers. The rods (piles) would be withdrawn for reuse unless during their withdrawal they were determined to be contaminated. If contaminated, the rods would be redriven for in-place disposal. Caissons containing TRU waste would be immobilized in place by being filled with grout or another stable filler.

Although this alternative would be a permanent disposal action, and retrieval would not be contemplated, waste having been so disposed of does not preclude future generations from 
HNF-SD-WM-RPT-288

Revision 0

intentionally removing the waste (although with some difficulty) for resource recovery or to effect enhanced disposal by some other means if either appears warranted.

No assumptions were identified for the In-Place Stabilization and Disposal alternative.

No Disposal Action. The objective of the No Disposal Action alternative is to continue with the current course of waste management, including ongoing and future plans for improved storage. This alternative is similar to the In-Place Stabilization and Disposal alternative with two important exceptions.

- Sites would not be stabilized, but if incipient subsidence were detected, those sites would be stabilized to prevent further subsidence

- TRU sites would not be covered with a protective barrier and marker system.

The No Disposal Action alternative represents the "no action" alternative required by Council on Environmental Quality (CEQ) guidelines; interpretation of the "no action" alternative as "walk away" or site abandonment is unacceptable to the DOE. Continuation of current waste management plans over the long term for waste not already disposed of would also be contrary to the DOE's mandate to provide safe, permanent disposal of the waste.

The activities and/or waste processes to be performed for the No Disposal Action alternative include continued retrievable storage for the current inventory and any future TRU solid waste for 20 years after generation. Current packaging and storage procedures would be followed (i.e., packaging in 208-L drums and storing in designated TRU waste sites or trenches). A filled waste site would then be covered with soil so that the waste could be retrieved later if desired. After 20 years of storage, the waste might be reclassified as buried waste. Monitoring, surveillance, and maintenance of TRU solid waste would continue until a decision is made to recover materials contained in the waste or to permanently dispose of the waste. Monitoring would include site surveys, groundwater analyses, atmospheric sampling, and biotic surveys. Based on monitoring results, maintenance activity would provide (as necessary) erosion and subsidence control; maintenance of observation wells, vents, etc; and control of plant and animal access.

No assumptions were identified for development of the No Disposal Action alternative.

5.2.1.4.3 Decision Criteria for Evaluation of Alternatives. The decision criteria for evaluating the alternatives in the HDW-EIS are divided into two major categories: environmental near-term impacts and long-term impacts. Different measures of radiation dose were used to assess the radiological impacts within these categories. Radiation dose is proportional to the quantity of energy deposited per unit mass of irradiated tissue. Definitions of length of time of exposure and length of time following exposure determine the format of the dose reported. There are five basic categories of public radiation dose.

- One-year dose from 1 year of exposure (external plus internal). This dose is used for comparison with occupational exposure standards and was originally used for comparison 
with public standards. This dose is used at the Hanford Site to measure the potential short-term impact from accidental releases during waste management operations.

- Committed dose from 1-year external exposure plus extended internal dose accumulated as a result of a 1-year intake (ingestion plus inhalation). Normally, a 50- or 70-year dose-commitment period is used. This dose is being used by most of those who calculate public doses, and is used for occupational record keeping by the U.S. Nuclear Regulatory Commission (NRC). The committed dose is used as a measure of the potential longer-term impact of accidents and routine releases.

- Accumulated dose from a lifetime (50 or 70 years) of external exposure plus intake via ingestion and inhalation. This includes the effects of radionuclide accumulation or decay in the environment during the exposure period. This can also be construed as the lifetime committed dose from continuous exposure. This dose relates most closely to the risk of health effects from lifetime radiation exposure. The accumulated dose is used as a measure of the total impact of any operation that results in chronic releases over a period of several years' duration, or from long-lasting, relatively constant groundwater contamination.

- Maximum annual dose during a lifetime (50 to 70 years). This dose is calculated for each year of exposure, accounting for each year's external exposure plus the internal dose from radionuclides taken in during the year of interest and all previous years. The maximum annual dose is identified by inspection for each organ. This type corresponds most closely to the existing guidelines for occupational and public exposure, which contain standards for annual radiation dose. The maximum annual dose is calculated for scenarios of human intrusion or long-term occasional exposure to waste that has been disposed of.

- Integrated or cumulative dose from very long-term population exposure (up to 10,000 years). This dose is calculated as a sum of lifetime accumulated doses to long, time-dependent release of radionuclides to the environment. The integrated population dose is used in conjunction with long-term groundwater and surface-water scenarios.

The following paragraphs define the environmental near- and long-term impacts that are used as decision criteria to evaluate the alternatives to remediate solid waste.

Environmental Near-Term Impacts. Several environmental impacts were assessed for each disposal alternative and the No Disposal Action (continued storage) alternative. The following list identifies the impacts that are included in the environmental impacts category. Specific results that pertain to each alternative are defined in the following alternative evaluation section.

- Radiological Impacts from Routine Operations-These impacts identify the estimated total-body radiation doses from routine operations and include occupational doses, maximum individual dose commitments, and population dose commitments. 
- Potential Radiological Accidents-These impacts identify the upper-bound accidents and calculated total-body radiation doses and include descriptions of the upper-bound accidents, maximum individual dose commitments, and population dose commitments.

- Nonradiological Impacts-Injuries, illnesses, and fatalities-These impacts include generation of dust from waste retrieval, site preparation, site stabilization, and handling of mined material; combustion products from operation of surface vehicles and equipment; transportation of waste; and injuries and fatalities associated with retrieval, transportation, and disposal of the waste.

- Ecological Impacts-This includes impacts to the surrounding land, plants, and wildlife from implementation of the alternative.

- Resource Commitments-This includes the estimated resource requirements, such as energy, materials, and staffing, for implementing each alternative.

- Costs-The costs associated with each alternative summarize the retrieval, processing, and transportation costs.

- Socioeconomic Impacts-These impacts consist of several components such as staffing requirements and related employment and population impacts. Socioeconomic impacts include growth-related effects and social, cultural, or psychological effects related to the hazardous nature of the materials or technology involved.

Long-Term Impacts. The primary performance objective of waste disposal systems is to provide reasonable assurance that radionuclides and inextricably intertwined chemicals in biologically significant concentrations are isolated and thus the long-term protection of public health and safety is ensured. The degree to which that objective can be expected to be met is discussed under the long-term impacts in the following sections. Long-term impacts are assessed in the following areas:

- Present Conditions Remain Unchanged-The expected performance of each alternative is presented where those systems perform as designed under present climatic conditions and without human-induced or other disruption.

- Disposal Systems are Disrupted by Postulated Natural Events-Although numerous postulated events were reviewed, only four were identified as having a reasonable expectation of occurring and being likely to have some consequences for offsite populations. These events were impact of large aircraft into a waste site, return of glaciation, a change to a wetter climate, and partial failure of a protective barrier.

- Disposal Systems are Distupted by Intruders-In accordance with EPA standards stipulating that active institutional controls are not to be relied on for environmental protection for more than 100 years after disposal, this impact presents consequences where disposal systems are disrupted by intruders. Thus, for this analysis, 100 years after 
disposal, active institutional control is assumed to no longer exist on the Hanford Site. This leaves passive institutional controls such as markers, monuments, and public records as the only mechanisms to inhibit intrusion onto the Site and into waste sites. Federal ownership and presence on the Hanford Site is planned in perpetuity, and, as long as active institutional control exists, the intrusion scenarios would be unrealistic.

This section summarizes the evaluation of alternatives provided in the HDW-EIS against decision criteria, and summarizes the alternative comparison. Radiological impacts for each alternative are discussed in Table 5-1. The alternatives are summarized in the following paragraphs.

Geologic Disposal Alternative-Near-Term Impacts. The Geologic Disposal alternative, as previously described, requires the shipment of newly generated and retrieved TRU waste to WIPP. Environmental near-term impacts of the Geologic Disposal alternative range from radiological exposures to socioeconomic effects. These impacts are discussed in the following paragraphs.

Radiological Impacts. Radiological impacts from routine operations showed occupation doses of 140 person-rem for operations and 110 person-rem for repository emplacement. Maximum individual dose commitments for a 1-year exposure are $1 \times 10^{-6} \mathrm{rem}$ and for a 70-year exposure (or lifetime accumulated dose from all operations) are $1 \times 10^{-4} \mathrm{rem}$. Population dose commitments for a 1-year exposure are $0.09 \mathrm{rem}$, for a 70 -year exposure (or lifetime accumulated dose from all operations) are $9 \mathrm{rem}$, and for transportation offsite are $40 \mathrm{rem}$.

Potential Radiological Impacts. Potential radiological accidents were reviewed for the Geologic Disposal alternative and, of these occurrences, the accident with the largest potential consequence, was determined. A pressurized release from a waste drum rupture caused by a buildup of radiolytic gases, would cause the largest radiation dose release to the public. The 1 -year maximum individual dose commitment would be $1 \times 10^{-3} \mathrm{rem}$, and the 70 -year maximum individual dose commitment would be 0.05 rem. The 1-year population dose commitment would be 3 person-rem and the 70-year population dose commitment would be 100 person-rem.

Nonradiological Impacts. Onsite nonradiological emissions for the Geologic Disposal alternative are summarized in Table 5-2. These are the totals that would be emitted over the period of years required to implement the alternative. At any given time, the emissions would be within the applicable air quality standards. The sum of all emissions is 23 tons. The total for nonradiological injuries and illnesses postulated for the Geologic Disposal alternative is 56 and for fatalities is 1 .

Ecological Impacts. Ecological impacts from the Geologic Disposal alternative would be minimal because much of the area under consideration has already been disturbed as a result of radioactive waste management and other nuclear-related activities. The onsite areas of present radioactive waste storage at the Hanford Site have already undergone some environmental modification, and the additional impact on plants and wildlife from waste retrieval and deposition 
in repositories is judged to be temporary and small. Noise, dust, and human activity associated with the implementation of the Geologic Disposal alternative would extend for about 20 years.

Resource Commitments. Resource commitments for the Geologic Disposal alternative include energy, materials, and staffing. The resource requirements for sending the TRU waste to WIPP are shown in Table 5-3. These requirements include offsite resource requirements.

Costs. The cost for shipping the TRU waste to WIPP in the Geologic Disposal alternative was estimated at $\$ 470$ million (based on 1987 dollars). This cost was estimated based on preconceptual studies of salt repositories.

Table 5-1. Summary of the Environmental Impacts for Each Solid Waste Alternative. (2 sheets)

\begin{tabular}{|c|c|c|c|c|}
\hline \multirow[b]{2}{*}{ Environmental impacts } & \multirow[b]{2}{*}{ Mersure } & \multicolumn{3}{|c|}{ Altemative } \\
\hline & & $\begin{array}{c}\text { Geological } \\
\text { Disposal }\end{array}$ & $\begin{array}{c}\text { In-Place } \\
\text { Stabilization }\end{array}$ & No Disposal Action \\
\hline $\begin{array}{l}\text { Near-term inpacts } \\
\text { Routine oprosious } \\
\text { Occupational doses } \\
\text { Maximum individual dose } \\
\text { 1-year exposure } \\
\text { 70-year exposure } \\
\text { Population dose } \\
\text { 1-year exposure } \\
\text { 70-year exposure } \\
\text { Transport offsite } \\
\text { Postulated accidents } \\
\text { Maximum individual dose } \\
\text { 1-year exposure } \\
\text { 70-year exposure } \\
\text { Population dose } \\
\text { 1-year exposure } \\
\text { 70-year exposure }\end{array}$ & $\begin{array}{l}\text { Person-tem } \\
\text { Rem } \\
\text { Rem } \\
\text { Person-rem } \\
\text { Person-rem } \\
\text { Person-rem } \\
\\
\text { Rem } \\
\text { Rem } \\
\text { Person-rem } \\
\text { Person-rem }\end{array}$ & $\begin{array}{r}250 \\
1 \times 10^{6} \\
1 \times 10^{-4} \\
9 \times 10^{-2} \\
9 \\
40 \\
\\
1 \times 10^{3} \\
5 \times 10^{2} \\
3 \\
100\end{array}$ & $\begin{array}{r}60 \\
1 \times 10^{-15} \\
2 \times 10^{-14} \\
2 \times 10^{-10} \\
1 \times 10^{9} \\
- \\
\\
2 \times 10^{3} \\
4 \times 10^{-2} \\
5 \\
80\end{array}$ & $\begin{array}{c}20 \\
-. \\
-- \\
-. \\
-- \\
-- \\
\\
5 \times 10^{-6} \\
7 \times 10^{-5} \\
\\
0.01 \\
0.20\end{array}$ \\
\hline $\begin{array}{l}\text { Long-term impacts } \\
\text { Conditions unchanged } \\
\text { Number of presumed health effects over } 10,000 \text { years } \\
\text { Postulated intrusions } \\
\text { Well drilling scenario } \\
\text { Maximum individual annual dose } \\
\text { At } 100 \text { years } \\
\text { At } 400 \text { years } \\
\text { At } 1,000 \text { years } \\
\text { At } 10,000 \text { years } \\
\text { Post- drilling scenario } \\
\text { Maximum individual annual dose } \\
\text { At } 100 \text { years } \\
\text { At } 400 \text { years } \\
\text { At } 1,000 \text { years } \\
\text { At } 10,000 \text { years }\end{array}$ & $\begin{array}{l}\text { Number } \\
\text { rem/yr (total body) } \\
\text { rem/yr (total body) } \\
\text { rem/yr (total body) } \\
\text { rem/yr (total body) } \\
\text { ren/yr (total body) } \\
\text { rem/yr (total body) } \\
\text { rem/yr (total body) } \\
\text { rem/yr (total body) }\end{array}$ & $\begin{array}{l}- \\
- \\
- \\
-\end{array}$ & $\begin{array}{r}4 \times 10^{-4} \\
5 \times 10^{-7} \\
7 \times 10^{-8} \\
5 \times 10^{-8} \\
\\
\\
1 \\
2 \times 10^{-1} \\
2 \times 10^{-1} \\
1 \times 10^{-1}\end{array}$ & $\begin{array}{r}4 \times 10^{-4} \\
5 \times 10^{-7} \\
7 \times 10^{-3} \\
5 \times 10^{*} \\
\\
1 \\
2 \times 10^{-1} \\
2 \times 10^{-1} \\
1 \times 10^{-1}\end{array}$ \\
\hline Cost summary' & Millions (in 1987 dollars) & 180 & 68 & 9 \\
\hline
\end{tabular}


Table 5-1. Summary of the Environmental Impacts for Each Solid Waste Alternative. (2 sheets)

\begin{tabular}{|c|c|c|c|c|}
\hline \multirow[b]{2}{*}{ Environmental impacts } & \multirow[b]{2}{*}{ Measure } & \multicolumn{3}{|c|}{ Alternative } \\
\hline & & $\begin{array}{c}\text { Geological } \\
\text { Disposal }\end{array}$ & $\begin{array}{c}\text { In-Place } \\
\text { Stabilization }\end{array}$ & No Disposal Action \\
\hline \multicolumn{5}{|l|}{ Resource requirementst } \\
\hline Energy & & & & \\
\hline Propane & $\mathrm{m}^{3}$ & 80 & -. & -- \\
\hline Diesel fuel & $\mathrm{m}^{3}$ & 4,700 & 11,000 & 26 \\
\hline Gasoline & $\mathrm{m}^{3}$ & 1,000 & 250 & 470 \\
\hline Electricity & GWh & 2,100 & -. & - \\
\hline Coal & & 12 & - & - \\
\hline Staffing & Worker-year & 2,600 & 120 & - \\
\hline Material & & & & \\
\hline Concrete & $\mathrm{m}^{3}$ & 12,000 & -. & -. \\
\hline Steel & $t$ & 2,200 & 6,500 & - \\
\hline Stairless steel & t & -- & -- & -. \\
\hline Copper & & 20 & ـ. & -- \\
\hline Lumber & $\mathrm{m}^{3}$ & 180 & - & .. \\
\hline Staffing & Worker-year & - & 120 & 40 \\
\hline \multicolumn{5}{|l|}{ Emissions } \\
\hline Particulates & $t$ & 1 & 2,800 & 100 \\
\hline $\mathrm{SO}_{x}$ & $t$ & 1 & 40 & 330 \\
\hline $\mathrm{co}$ & $t$ & 4 & 340 & 170 \\
\hline No & $t$ & 15 & 180 & 18 \\
\hline HC & $\mathrm{t}$ & 2 & 42 & 120 \\
\hline
\end{tabular}

NOTE: Data were obtained from DOE, 1987a, Final Environmental Impact Statement - Disposal of Hanford Defense High-Level, Transuranic, and Tank Wastes, DOE/EIS-0113, U.S. Department of Energy, Washingtor, D.C., as follows.

'Data obtained for the Geologic Disposal, In-Place Stabilization and Disposal, and No Disposal Action altematives came from Tables 5.3, 5.13, and 5.32, respectively.

Data obtained for the Geologic Disposal, In-Place Stabilization and Disposal, and No Disposal Action altematives came from Tables 5.4, 5.14, and 5.33, respectively.

Data obtained for all aiternatives came from Table 3.8 .

Data obtained for the Geologic Disposal, In-Place Stabilization and Disposal, and No Disposal Action altematives came from Tables R-51, R.52, and R.54, respectively.

'Data obtained for the Geologic Disposal, In-Place Stabilization and Disposal, and No Disposal Action altematives came from Tables R.63, R.64, and R.66, respectively.

Data obtained for all alternatives came from Table 3.7.

Data obtained for the Geologic Disposal, In-Place Stabilization and Disposal, and No Disposal Action atternatives came from Tables L.3 and L.S, L.9, and L.17, respectively.

'Data obtained for the Geologic Disposah, In-Place Stabilization and Disposal, and No Disposal Action alternatives came from Tables L.1, L.7, and L.15, respectively.

Socioeconomic Impacts. The socioeconomic considerations presented here are limited to those that might be associated with preparing the TRU waste for disposal at a geologic repository and do not include the impact of developing a geologic repository. New residents moving into the area for employment in these activities will require housing and community services that include transportation, health care, schools, police and fire, water and sewer, and recreation facilities. Because the area will be recovering from the significant employment and population losses of the early 1980s at the time of these staffing requirements, most of these services should have excess capacity to meet these needs.

The total estimated workforce requirements for the Geologic Disposal alternative from 1985 to 2020 is estimated at approximately 453 worker years. This estimate is less than the total workforce requirements because some workers will be needed in subsequent years for surveillance 


\section{Revision 0}

and maintenance. Also, workers employed in the offsite WIPP disposal facility do not contribute to socioeconomic consequences and are not included.

Table 5-2. Summary of Onsite Nonradioactive Emissions for the Geologic Disposal Alternative.

\begin{tabular}{|l|c|}
\hline \multicolumn{1}{|c|}{ Emission } & Totals $(t)$ \\
\hline Particulates & 1 \\
\hline $\mathrm{SO}_{\mathrm{x}}$ & 1 \\
\hline $\mathrm{CO}$ & 4 \\
\hline $\mathrm{NO}_{\mathrm{x}}$ & 15 \\
\hline $\mathrm{HC}$ & 2 \\
\hline
\end{tabular}

Table 5-3. Resource Requirements for the Geologic Disposal Alternative.

\begin{tabular}{|l|c|}
\hline \multicolumn{1}{|c|}{ Resource } & $\begin{array}{c}\text { Total onsite and offsite } \\
\text { requirements }\end{array}$ \\
\hline Energy & \\
Propane $\left(\mathrm{m}^{3}\right)$ & 80 \\
Diesel Fuel $\left(\mathrm{m}^{3}\right)$ & 4,700 \\
Gasoline $\left(\mathrm{m}^{3}\right)$ & 1,000 \\
Electricity $(\mathrm{GWh})$ & 2,100 \\
Coal $(\mathrm{t})$ & 12 \\
\hline Materials & \\
Concrete $\left(\mathrm{m}^{3}\right)$ & 12,000 \\
Steel $(\mathrm{t})$ & 2,200 \\
Stainless steel $(\mathrm{t})$ & -- \\
Copper $(\mathrm{t})$ & 20 \\
Lumber (m $\left.\mathrm{m}^{3}\right)$ & 180 \\
\hline Staffing (worker-year) & 2,600 \\
\hline
\end{tabular}


Social conditions refer to individual and community well-being and, in the case of the Hanford Site, include the "cultural community" of neighboring Native American tribes. The implementation of any defense waste disposal alternative is projected to result in reduced long-term impacts on the environment and somewhat reduced adverse health and safety consequences over the long term compared with the No Disposal Action alternative. Therefore, adverse social effects, if any, are also expected to be insignificant.

Geologic Disposal Alternative-Long-Term Impacts. The long-term impacts of the Geologic Disposal alternative include those that would occur when conditions remain unchanged and thosethat would occur when conditions are disrupted. The following paragraphs describe these impacts.

Conditions Remain Unchanged. It is assumed that geologic repositories (i.e., WIPP) employed in this alternative would have been sited in accordance with those applicable provisions of the Nuclear Waste Policy Act of 1982 and, as such, would meet limits prescribed for environmental protection in 40 CFR 191 with a reasonable degree of confidence. Conformance to NRC regulations as set forth in 10 CFR 60 would also be required. As a consequence of assumed conformance to EPA and NRC regulations, and because the selection of a particular geologic repository is outside the scope of this analysis, an assessment of long-term performance of geologic repositories is not presented here.

Disposal Systems are Disrupted. Impact of a large aircraft at the Hanford Site would result in a negligible maximum 70-year total-body dose to the offsite population (less than 0.03 person-rem assuming all Hanford Site defense waste was included to calculate the impact). Therefore, impacts of falling aircraft were not considered further. Other falling bodies, such as meteorites, were considered, but the low probability of a meteorite hitting a waste site and releasing some of its contents was thought to be too small to warrant further consideration as a reasonable disruptive scenario.

A climate change scenario was examined that included the return of an ice age. In previous ice ages, ice dams on upper tributaries of the Columbia River formed and, when broken through, resulted in floods unimaginably large (about $2,000 \mathrm{~km}^{3}$ within a few weeks, compared with the river's present average annual flow of $100 \mathrm{~km}^{3} / \mathrm{yr}$ ). Such floods would probably either scour out all waste not disposed of in a deep geologic repository and carry it to the ocean or would further isolate it with additional deposits of sediments. In any event, such floods would obliterate most evidence of civilization along the Columbia River. Studies suggest that recurrence of an advance and retreat of ice flows sufficient to result in catastrophic floods of this magnitude might arise 40,000 to 50,000 years from now. Because the TRU waste would be disposed of in a geologic repository, beyond the effects of such a flood, no attempt was made to quantify impacts from this scenario. In the Geologic Disposal alternative, waste placed in a geologic repository would not be expected to be significantly affected by a climate change, wherever the repository might be located. 
In-Place Stabilization and Disposal-Near-Term Impacts. The In-Place Stabilization and Disposal alternative, as previously described, requires disposing of the TRU waste in place. The following paragraphs describe the environmental and long-term impacts of this alternative.

The operational impacts for the In-Place Stabilization and Disposal alternative include radiation doses to workers and to the public from normal operations and doses to the public from operational accidents, nonradiological emissions to the environment and resulting air quality impacts, nonradiological accidents, ecological impacts, socioeconomic impacts, resource requirements, and costs.

Radiological Impacts. Implementing the In-Place Stabilization and Disposal alternative would release minor amounts of radionuclides to the atmosphere that could result in radiation doses to members of the offsite general public. The calculated total-body dose commitment in any 1 year to a maximally exposed individual is $2 \times 10^{-15} \mathrm{rem}$ and the calculated individual lifetime total-body dose is $2 \times 10^{-14} \mathrm{rem}$. The collective total-body dose to the population residing within $80 \mathrm{~km}$ in any 1 year is calculated to total $2 \times 10^{-10}$ person-rem, and the calculated 70-year total dose from all operations is about $1 \times 10^{-9}$ person-rem. At this level, no health effects are projected. For comparison, the dose to the same population $(420,000)$ during the same period from naturally occurring sources would be about $2,500,000$ person-rem.

Potential Radiological Impacts. A range of postulated accidents was analyzed for operations in the In-Place Stabilization and Disposal alternative. The 70-year population dose from the most severe accident amounts to 80 person-rem. As previously noted, that same population would receive a dose of $2,500,000$ person-rem from natural background radiation in the same period.

Nonradiological Impacts. A summary of onsite nonradioactive emissions for the In-Place Stabilization and Disposal alternative is shown in Table 5-4. Nonradiological consequences include dust generated from site preparation and site stabilization; combustion products from operation of surface vehicles and equipment; and injuries and fatalities associated with waste stabilization. The nonradiological injuries and illnesses postulated for the In-Place Stabilization and Disposal alternative total 1 ; the fatalities total 0.

Table 5-4. Summary of Onsite Nonradioactive Emissions for the In-Place Stabilization and Disposal Alternative.

\begin{tabular}{|l|c|}
\hline \multicolumn{1}{|c|}{ Emission } & Totals \\
\hline Particulates & 2,800 \\
\hline $\mathrm{SO}_{\mathrm{x}}$ & 40 \\
\hline $\mathrm{CO}$ & 340 \\
\hline $\mathrm{NO}_{\mathrm{x}}$ & 180 \\
\hline $\mathrm{HC}$ & 42 \\
\hline
\end{tabular}


HNF-SD-WM-RPT-288

Revision 0

Resource Commitments. Resource commitments for the In-Place Stabilization and Disposal alternative include energy, materials, and staffing. These resources would be expended over about 5 years. The resource requirements for this alternative are shown in Table 5-5.

Table 5-5. Resource Requirements for the In-Place Stabilization and Disposal Alternative.

\begin{tabular}{|l|c|}
\hline \multicolumn{1}{|c|}{ Resource } & Total requirements \\
\hline Energy & \\
Diesel fuel $\left(\mathrm{m}^{3}\right)$ & 11,000 \\
Gasoline $\left(\mathrm{m}^{3}\right)$ & 250 \\
Staffing (worker-year) & 120 \\
\hline Materials & \\
Steel $(\mathrm{t})$ & 6,500 \\
\hline Staffing (worker-year) & 120 \\
\hline
\end{tabular}

Costs. The cost associated with the In-Place Stabilization and Disposal alternative is approximately $\$ 68$ million (in 1987 dollars).

Socioeconomic Impacts. Socioeconomic impacts are influenced by the size and scheduling of the estimated staffing requirements for each alternative and by public perception of the hazardous nature of radioactive materials. Staffing requirements for In-Place Stabilization and Disposal are relatively low compared with those for the Geologic Disposal alternative. The peak workforce requirement would be about 15 workers from 1993 through 1995. The potential socioeconomic impacts created by the size of the workforce would be much less than those created by the Geologic Disposal alternative.

Because the Geologic Disposal alternative results in the largest number of jobs, the positive impacts to social conditions from the In-Place Stabilization and Disposal alternative would be substantially less. Even though the radiological consequences of In-Place Disposal are expected to be very small, more public concern would be likely for disposal of waste near the surface than in a geologic repository.

In-Place Stabilization and Disposal-Long-Term Impacts. Determining long-term impacts include examining the In-Place Stabilization and Disposal alternative where (1) present conditions remain unchanged, (2) disposal systems are disrupted by postulated natural events, and (3) disposal systems are disrupted by intruders. However small, the likelihood of intrusion into waste sites leading to fatal consequences is substantially greater in the In-Place Stabilization and Disposal alternative than in the Geologic Disposal alternative. 
Conditions Remain Unchanged. The expected performance of the disposal system is presented where the system performs as designed under present climatic conditions and without human-induced or other disruption. The disposal system in the in-place stabilization and disposal alternative is all "near surface" (from about 1 to about $15 \mathrm{~m}$ below grade), but with the addition of a protective barrier over all waste sites and a marker system in place.

The diffusion and transport of waste through soils was estimated to result in a dose of about 10 person-rem over 10,000 years for the population downstream from the Hanford Site. This dose would not be expected to produce any health effects.

Chemicals could similarly be transported to the river via a variety of mechanisms. Using conservative and bounding values of parameters, the concentration of nitrate ion $\left(\mathrm{NO}_{3}^{-}\right)$amounted to only $10^{-8}$ of the drinking water standard of $45 \mathrm{mg} / \mathrm{L}$ (based on nitrate).

Disposal Systems are Disrupted. As previously discussed, an analysis was made of postulated natural and human-induced events that might disrupt confinement of waste. Candidates identified for analysis as disruptive events were the impact of a large aircraft into a waste site, the return of glaciation, a change to a wetter climate, and partial failure of a protective barrier.

The consequences of an impact of a large aircraft are calculated to be a maximum 70-year total-body dose to the offsite population of 0.3 person-rem for an impact into a waste site without protective barriers, which would release the largest dose. Any type of disposal action further reduces the consequence of this scenario. Therefore, impacts of falling aircraft were not considered further. As previously stated, other falling bodies such as meteorites were considered, but the low probability of a meteorite hitting a waste site and releasing some contents appeared too small to warrant further consideration as a disruptive scenario.

In the 40,000- to 50,000-year time frame predicted for recurrence of glacial floods, the total inventory of waste will have decayed to a hazard index about one-fifth that of the uranium from which the waste was originally generated. Although radioactive decay will have reduced the hazard from this waste markedly by the time of the postulated glacial flood in the next 40,000 to 50,000 years, a study was initiated to determine whether the fate of the waste following such a flood could be estimated. Results of this study indicate that the first wave of such a flood could reasonably scour out the waste sites to a depth of several meters, then, as flood waters backed up at Wallula Gap, the water velocity would markedly decrease. Most of the sediments and waste would probably be reworked and then redeposited in the Pasco Basin. Because of low concentrations of plutonium and other radionuclides at that time, radiological consequences of a glacial flood would appear minor compared with the flood itself, whether the action on waste was scouring, reworking, or deposition.

The climate change assumed for this analysis is the same as that assumed in the Geologic Disposal alternative, a wetter climate represented by an average recharge to groundwater of $5 \mathrm{~cm} / \mathrm{yr}$ on the 200 Areas Plateau. It is reasonable to expect that the protective barrier as finally designed will remain effective; however, to assess the consequences if the barrier failed, two 
scenarios have been postulated in which partial failure of the protective barrier occurs in 2500 in conjunction with a climate change. (These scenarios were discussed in more detail under the Geologic Disposal alternative.) The diffusion and transport of waste through soils in a wetter climate was calculated to result in a cumulative population total-body dose of 12 person-rem over 10,000 years to the downstream users of the Columbia River. No health effects would be predicted for such a dose.

A disruptive failure of the barrier could result in an additional dose to the downstream population of about 300 person-rem over 10,000 years. A functional failure of the barrier could result in an additional total-body dose to the downstream population of about 280 person-rem. Thus, at most, diffusion combined with barrier failures would result in a total-body dose of about 620 person-rem over 10,000 years. Again for comparison, the dose from natural background to the downstream population over 10,000 years would be about $3,000,000,000$ person-rem. Thus, the combined scenarios do not constitute a significant impact.

The intruder scenarios analyzed for the In-Place Stabilization and Disposal alternative are the same as those discussed briefly under the Geologic Disposal alternative. They are repeated here for convenience. As in the Geologic Disposal alternative, all waste sites would be covered by a protective barrier and marker system, and the same type of warning markers would be distributed within the barrier itself. Again, drilling through a protective barrier is not believed likely; however, it cannot be precluded. By 400 years after disposal, the potential maximum annual dose to the intruder would be about $1 \mathrm{rem}$, and no health effects to the intruders would be expected.

The resettlement scenario discussed under the Geologic Disposal alternative was also analyzed for the In-Place Stabilization and Disposal alternative. Estimates of the integrated population total-body dose to and health effects among farm occupants are 2,000 person-rem and 0 to 2 health effects for the current climate, and 2,000 person-rem and 0 to 2 health effects for the wetter climate assumed in the analysis.

No Disposal Action Alternative-Near-Term Impacts. The No Disposal Action alternative is represented by continued storage of waste. It does not implement a long-term solution for permanent disposal of radioactive waste. Waste continues to be stored essentially as it is now for the indefinite future. To be consistent with other alternatives for calculation purposes, active institutional control over the stored waste is assumed to be absent after 2150 , leaving them without further protection. This is not an intended action, but it is evaluated as a no action alternative as required by the CEQ regulations. This alternative serves primarily as a basis for comparison with permanent disposal alternatives.

This section summarizes operational impacts, including public and worker radiation doses from normal operations and operational accidents, nonradiological emissions to the environment and air quality impacts, nonradiological accidents, ecological impacts, socioeconomic impacts, resource requirements, and costs. 
HNF-SD-WM-RPT-288

Revision 0

Radiological Impacts. An estimated 3,800 person-years of radiation work per 100 years will be required for continued storage of all waste classes. A total occupational total-body dose of approximately 20 person-rem per 100 years would result.

Potential Radiological Impacts. The most severe accident resulted in a 70-year population dose of 0.2 person-rem. For comparison, the dose to the same population for the same period from naturally occurring sources would amount to about $3,000,000$ person-rem.

Nonradiological Impacts. The nonradiological injuries and illnesses associated with the No Disposal Action alternative are summarized in Table 5-6. The nonradiological injuries, illnesses, and fatalities postulated for the No Disposal Action alternative total 0.

Ecological Impacts. According to the HDW-EIS, ecological impacts from the No Disposal Action (continued storage) of all waste classes would essentially be unchanged from present conditions.

Resource Commitments. Estimates of resource requirements for the first and subsequent centuries of storage are presented in Table 5-7. Resources identified include energy, materials, and staffing.

Costs. Costs for the first 100 years of continued storage are about $\$ 9.4$ million, and for each additional 100 years about $\$ 9.4$ million (in 1987 dollars).

Socioeconomic Impacts. Staffing requirements for the No Disposal Action are low compared with those of any of the alternatives considered. Between 1985 and 2020, it is estimated that only one worker is required on average per year. The potential for socioeconomic impacts would hardly be detectable.

Table 5-6. Summary of Onsite Nonradioactive

Emissions for the No Disposal Action Alternative.

\begin{tabular}{|l|c|}
\hline \multicolumn{1}{|c|}{ Emission } & Totals $(\mathrm{t})$ \\
\hline Particulates & 100 \\
\hline $\mathrm{SO}_{x}$ & 330 \\
\hline $\mathrm{CO}$ & 170 \\
\hline $\mathrm{NO}_{\mathrm{x}}$ & 18 \\
\hline $\mathrm{HC}$ & 120 \\
\hline
\end{tabular}


HNF-SD-WM-RPT-288

Revision 0

Table 5-7. Resource Requirements for the No

Disposal Action Alternative.

\begin{tabular}{|l|c|}
\hline \multicolumn{1}{|c|}{ Resource } & Total requirements \\
\hline Energy & \\
Diesel fuel $\left(\mathrm{m}^{3}\right)$ & 26 \\
Gasoline $\left(\mathrm{m}^{3}\right)$ & 470 \\
\hline Staffing (person-year) & 40 \\
\hline
\end{tabular}

No Disposal Action Alternative- Long-Term Impacts. As noted earlier, consideration of the No Disposal Action alternative is mandated by the CEQ regulations in implementing the National Environmental Policy Act of 1969 (NEPA). Continued storage in the long term is not a disposal action and is contrary to DOE policy and plans for managing defense waste at the Hanford Site. Nevertheless, a determination of long-term impacts of the No Disposal Action was made and is useful to contrast with the impacts of the disposal alternatives.

For purposes of long-term analysis, active or passive institutional control is assumed to be absent from the Hanford Site beginning in 2150 without the DOE having provided for additional protection of the waste. Although the DOE has no intention of leaving the Hanford Site in such a manner, this assumption allows an analysis parallel to that performed for the disposal alternatives.

Conditions Remain Unchanged. With conditions remaining as they are now, no significant impacts to the offsite population from continued storage would occur until the loss of institutional control in 2150 . The present population total-body dose rate of about 5 person-rem/yr to the offsite populations ( 420,000 people) would be expected to continue.

Following the time when active institutional control of the Hanford Site is assumed to be absent, natural conditions could act on the waste, causing radionuclides to be leached from the various waste forms and transported to groundwater and to the Columbia River. Impacts on the downstream population were calculated assuming the offsite population did not change when the Hanford Site was vacated. Again, this is an unlikely occurrence (whatever caused the Hanford Site to be vacated would probably result in the region being vacated) but one that permits parallel analysis.

If the average annual recharge were $0.5 \mathrm{~cm} / \mathrm{yr}$ (current climate), the cumulative total-body dose to downstream users of the Columbia River would be about 25,000 person-rem over 10,000 years. This dose would equate to between 2 and 25 health effects over 10,000 years, which can be compared with 300,000 to $3,000,000$ health effects to the downstream population from naturally occurring radioactive sources. 
Disposal Systems are Disrupted. Where waste is in a continued storage mode but without any institutional control (active or passive), the probability of inadvertent intrusion increases considerably. For waste in continued storage, the same intrusion scenarios were analyzed as for the disposal alternatives. The consequences depend greatly on the class of waste into which intrusion is made.

5.2.1.5 Summary of Alternative Evaluations. The alternative evaluations presented in the previous sections for each of the alternatives to remedy solid waste are summarized in this section and in Table 3-1. In addition to summarizing the environmental and long-term impacts, other impacts are addressed in this section including key impacts of future-generated TRU waste; the potential impacts on Native Americans and their reservation lands; and the impacts on archaeological, cultural, or historic sites.

5.2.1.5.1 Summary of Environmental Near- and Long-Term Impacts. The environmental near- and long-term impacts for each alternative are summarized in Table 5-1. The health and environmental impacts of the Geologic Disposal and In-Place Stabilization and Disposal alternatives are relatively low. Overall, the No Disposal Action alternative was estimated to have the fewest negative short-term (under 100 years) impacts, with the exception of emissions. The In-Place Stabilization and Disposal alternative had the next fewest negative near-term impacts, with the exception of emissions. The No Disposal Action had the most negative long-term (greater than 100 years) impacts followed by the In-Place Stabilization and Disposal alternative.

5.2.1.5.2 Key Impacts from Future Newly Generated TRU Waste. Impacts from future newly generated TRU waste are presented here separately to provide a measure of impacts of disposal from additional Plutonium-Uranium Extraction (PUREX) campaigns processing $\mathrm{N}$ Reactor fuel. If 12,000 metric tons of irradiated uranium are processed per campaign, the waste that results would need to be dispositioned .

It could be assumed, for example, that an extension of special nuclear materials production activities would result in reprocessing an additional 20,000 metric tons of irradiated uranium. Therefore, the impacts from this extended operation would be approximately twice those calculated for the 1985-95 campaign and compared in this section. For the 20,000 metric tons extended production of special nuclear materials beyond 1995, the exposure and health impacts stated should be multiplied by 2 and added to all tables that display total impacts.

5.2.1.5.3 Potential Impacts on Native Americans and Their Reservation Lands. The assessment of the impacts to Native Americans and their reservation lands included an evaluation of the radiological doses that could affect the people, land, and water. Potential impacts on Native Americans were assessed by calculating the doses from routine disposal operations to the total population within $80 \mathrm{~km}$ of the Site, including the eastern one-third of the Yakama Reservation (about $1 \%$ of the exposed population). In the reasonably postulated accident with the most severe consequences (the same in each of the alternatives), the calculated population dose was about $1 \%$ of the dose allowed by EPA standards during routine disposal operations. 
For each alternative, estimates also were made of the amounts of radionuclides that might be transported to the Columbia River during the next 10,000 years and the doses that downstream populations might receive. The doses calculated included contributions from drinking water, crops irrigated with river water, and consumption of fish that had lived in the river. Although the number of health effects for each alternative was small relative to that allowable, the number associated with the Geologic Disposal alternative was the smallest.

While active institutional control exists, actual physical access to the Hanford Site will be limited. However, consultation of DOE's compliance guidelines regarding the American Indian Religious Freedom Act and the National Historic Preservation Act of 1966 is planned as part of implementation of the disposal options finally chosen.

Impacts on Archaeological, Cultural, and Fistorical Resources. The principal archaeological, cultural, and historical resources on the Hanford Site relate to places or sites of previous occupancy and use by Native Americans. The sites are most often associated with the Columbia River; however, other sites have been identified, such as the Gable Mountain/Gable Butte area. None of the sites identified are within the waste disposal area; consequently, none would be affected directly, regardless of alternative. In all except the No Disposal Action alternative, large quantities of basalt riprap and soil are needed with which to build barriers over waste sites or over residuals sent to near-surface burial. As a consequence of riprap addition, any impacts on archaeological, cultural, or historical sites are expected to be essentially the same regardless of the disposal alternative. The DOE is committed to taking all reasonable steps to preserve such places and has initiated a sitewide survey for archaeological and cultural sites to aid in developing an overall plan for resource protection.

The quarry sites for obtaining the riprap will be selected in concert with the resource protection plan. Because of the distances involved, activities on the 200 Area Plateau, regardless of alternative, are not expected to have any impact on sites along the Columbia River or on the National Historic sites in Pasco and Kennewick.

5.2.1.6 Decision Made. The DOE decided to implement the Geologic Disposal Alternative. Specifically, the DOE decided that a facility will be designed, constructed, and operated at the Hanford Site to sort, process, and repackage retrievably stored and newly generated TRU solid waste for shipment to WIPP.

In compliance with NEPA, the DOE has analyzed the environmental impacts of each alternative described in the HDW-EIS. The DOE considered all comments received on the draft HDW-EIS in preparing the final HDW-EIS, which contains DOE's responses to those comments. The DOE also has considered comments received on the final HDW-EIS in making its decision.

The near- and long-term environmental impacts, DOE's commitment to provide for the safe, permanent disposal of the waste, and costs were all considered in identifying the alternative to be implemented. The Geologic Disposal alternative is judged to be the environmentally preferred alternative. The No Disposal Action alternative was not selected by the DOE because it is contrary to its commitment to provide safe, permanent disposal of the waste. 
The health and environmental impacts of the Geologic Disposal and In-Place Stabilization and Disposal alternatives are relatively low. When the short-term (operational, transportation) and long-term impacts (from final disposal) of these alternatives are compared, the Geologic Disposal alternative has greater near-term health and environmental impacts and lower long-term impacts. Existing technology can process readily retrievable and newly generated TRU wastes for final disposal. The DOE considers the impacts associated with this technology to be acceptably low.

The low short-term impacts associated with retrieval and processing of readily retrievable waste classes, together with the reduced potential for long-term impacts, provide the basis for the decision to proceed with disposal in a geologic repository. This decision is consistent with evaluations and decisions resulting from DOE/EIS-0046F, Final Environmental lmpact Statement - Management of Commercially Generated Radioactive Waste (DOE 1980a); DOE/EIS-0023, Final Environmental Impact Statement - Long Term Management of Defense High-Level Radioactive Waste, Savannah River Plant (Research and Development Program for Immobilization) (DOE 1979); DOE/EIS-0082, Final Environmental Impact Statement - Defense Waste Processing Facility, Savannah River Plant (DOE 1982); and DOE/EIS-0026, Final Environmental Impact Statement - Waste Isolation Pilot Plant (DOE 1980b).

5.2.1.7 Alternatives Evaluated in the HDW-EIS. The HDW-EIS included an evaluation of the following disposal alternatives for pre-1970 suspect TRU waste. This waste may meet LLW criteria when retrieved:

- Geologic Disposal of Pre-1970 Suspect TRU Solid Waste

- In-Place Stabilization and Disposal of Pre-1970 Suspect TRU Solid Waste

- Reference Alternative for Pre-1970 Suspect TRU Solid Waste

- Continued Surveillance of Pre-1970 Suspect TRU Solid Waste

- Preferred Alternative for Pre-1970 Suspect TRU-Contaminated Solid Waste.

The following paragraphs discuss each of these disposal alternatives in general terms.

Geologic Disposal of Pre-1970 Suspect TRU Solid Waste. Under the geologic disposal alternative in the HDW-EIS, pre-1970 buried TRU solid waste and the surrounding contaminated soil that was defined as TRU waste would be retrieved and processed for enhanced protection in a geologic repository. This repository was assumed to be WIPP for calculation purposes. Retrieval procedures would be similar to those proposed for use at TRU-contaminated soil sites. Retrieved waste (exceeding $100 \mathrm{nCi} \mathrm{TRU/g)} \mathrm{would} \mathrm{be} \mathrm{processed} \mathrm{in} \mathrm{the} \mathrm{waste} \mathrm{processing} \mathrm{facility,} \mathrm{certified} \mathrm{as}$ meeting the WIPP WAC (WIPP 1996), and sent to WIPP. The final waste form sent to WIPP was assumed to be a slag.

Residual waste containing more than $100 \mathrm{nCi} / \mathrm{g}$ of TRU would be retained in the original, excavated burial site. The site would be backfilled and stabilized in the same manner as any other LLW site. 
In-Place Stabilization and Disposal of Pre-1970 Suspect TRU Solid Waste. In this alternative, the HDW-EIS proposed that all pre-1970 buried TRU solid waste would remain as disposed and covered with a protective barrier and marker system.

Reference Alternative for Pre-1970 Suspect TRU Solid Waste. The reference alternative for pre-1970 TRU solid waste burial grounds in the 200 Areas was enhanced protection identical to the in-place stabilization and disposal alternative described earlier. However, TRU waste in the 618-11 site near the 300 Area would be retrieved. Retrieved waste would be packaged and processed the same way as newly generated TRU solid waste. This selective combination of in-place stabilization and geologic disposal would consolidate waste at central locations (either the 200 Areas or WIPP) and remove TRU waste from the sites near areas of habitation and potentially accessible to severe floods.

Continued Surveillance of Pre-1970 Suspect TRU Solid Waste. Even without other disposal actions, the HDW-EIS noted that by 2000 all TRU solid waste burial grounds from pre-1970 operations were expected to have been surface stabilized. Planned activities directed at surface stabilization through the control of deep-rooted vegetation would have been implemented and completed by 2000 . Extensive monitoring and surveillance practices as described in ERDA-1538 would continue at these sites. Monitoring would include site surveys, groundwater analyses, atmospheric sampling, and biotic surveys. Based on monitoring results, maintenance activity would provide (as necessary) erosion and subsidence control; maintenance of observation wells, vents, etc.; and control of plant and animal access.

Preferred Alternative for Pre-1970 Suspect TRU-Contaminated Solid Waste. The HDW-EIS preferred alternative for pre-1970 buried suspect TRU-contaminated solid waste was to postpone a decision between geologic disposal and in-place stabilization and disposal until after completion of ongoing and planned development and evaluation. In the interim, the DOE was to continue the present maintenance activities for these waste sites. The exception was for the TRU waste at the 618-11 site near the 300 Area. This waste would be retrieved and processed for disposal in a geologic repository (assumed to be WIPP for calculation purposes).

According to the HDW-EIS, sites with pre-1970 buried solid TRU waste were also being evaluated under the Comprehensive Environmental Response, Compensation, and Liability Act of 1980 to determine whether additional stabilization or exhumation would be needed because of their hazardous components (including radioactivity). The first stage (complete at the time of the HDW-EIS) was to identify the hazardous waste content based on existing records. The second phase was to be actual site characterization, if deemed necessary. As a minimum, because of their radioactive contamination, a protective barrier and marker system was proposed to be placed over each site that was not exhumed. Those sites active after November 1980 were to be evaluated under RCRA, if they were mixed-waste sites.

5.2.1.8 Decision Criteria for Evaluation of Alternatives. Decision criteria for alternatives for pre-1970 buried suspect TRU sites were discussed in the HDW-EIS Record of Decision (ROD) (DOE 1988). The decision was based on public comments; short- and long-term environmental impacts; DOE's commitment to provide for the safe, permanent disposal of the waste; and cost. 
The HDW-EIS ROD was used in conjunction with ERDA-1538 (ERDA 1975). ERDA-1538 provided a cost-benefit analysis that addressed all the planned waste management. This information is critical because approximately $50 \%$ of the pre-1970 suspect TRU waste will be reclassified as LLW and disposed of in the same manner.

5.2.1.9 Alternative Evaluation Results. The alternative solid waste practices examined in ERDA-1538 were not compared directly to each other. Rather, the HDW-EIS concluded that "radioactive solid waste burials in the dry soil of the 200 East and 200 West Area plateau do not and are not expected to have an offsite environmental impact. Alternatives to present practices are being studied to determine a practical plan for long-term treatment, disposal and surveillance of this solid radioactive waste."

Alternative evaluation results from the HDW-EIS specifically for pre-1970 buried suspect TRU solid waste are shown in Table 5-8. Evaluations of the HDW-EIS criteria that are not specifically identified as coming from pre-1970 buried suspect TRU waste, including resource commitments, socioeconomic impacts, resource requirements, etc., are described in Section 5.2.1.4.

Table 5-8. Alternative Evaluation Results for Pre-1970 Suspect Transuranic Solid Waste. (2 sheets)

\begin{tabular}{|l|c|c|c|c|}
\hline \multicolumn{1}{|c|}{ Impact/criterion } & $\begin{array}{c}\text { Geologic } \\
\text { Disposal }\end{array}$ & $\begin{array}{c}\text { In-Place } \\
\text { Stabilization }\end{array}$ & $\begin{array}{c}\text { Reference } \\
\text { Alternative }\end{array}$ & $\begin{array}{c}\text { No } \\
\text { Disposal } \\
\text { Action }\end{array}$ \\
\hline $\begin{array}{l}\text { Operations occupational dose } \\
\text { (person-rem) }\end{array}$ & 2,480 & 80 & 150 & 20 \\
\hline $\begin{array}{l}\text { Maximum offsite individual } \\
\text { dose, 1 year (rem) }\end{array}$ & $4 \times 10^{-4}$ & None & None & None \\
\hline $\begin{array}{l}\text { Maximum offsite individual } \\
\text { dose, 70 years (rem) }\end{array}$ & $5 \times 10^{-4}$ & None & None & None \\
\hline $\begin{array}{l}\text { Population dose, 1 year } \\
\text { (person-rem) }\end{array}$ & 30 & None & None & None \\
\hline $\begin{array}{l}\text { Population dose, 70 years } \\
\text { (person-rem) }\end{array}$ & 30 & None & None & None \\
\hline $\begin{array}{l}\text { Population dose, } \\
\text { transportation (person-rem) }\end{array}$ & 6 & None & None & None \\
\hline $\begin{array}{l}\text { Upper-bound accident max. } \\
\text { individual dose, } 1 \text { year (rem) }\end{array}$ & $5 \times 10^{-6}$ & $3 \times 10^{-7}$ & $3 \times 10^{-7}$ & $3 \times 10^{-7}$ \\
\hline $\begin{array}{l}\text { Upper-bound accident max. } \\
\text { individual dose, 70 years (rem) }\end{array}$ & $1 \times 10^{-4}$ & $7 \times 10^{-6}$ & $7 \times 10^{-6}$ & $7 \times 10^{-6}$ \\
\hline
\end{tabular}


HNF-SD-WM-RPT-288

Revision 0

Table 5-8. Alternative Evaluation Results for Pre-1970 Suspect Transuranic Solid Waste. (2 sheets)

\begin{tabular}{|l|c|c|c|c|}
\hline \multicolumn{1}{|c|}{ Impact/criterion } & $\begin{array}{c}\text { Geologic } \\
\text { Disposal }\end{array}$ & $\begin{array}{c}\text { In-Place } \\
\text { Stabilization }\end{array}$ & $\begin{array}{c}\text { Reference } \\
\text { Alternative }\end{array}$ & $\begin{array}{c}\text { No } \\
\text { Disposal } \\
\text { Action }\end{array}$ \\
\hline $\begin{array}{l}\text { Upper-bound accident, } \\
\text { population dose, 1 yr (person-rem) }\end{array}$ & 0.01 & $6 \times 10^{-4}$ & $6 \times 10^{-4}$ & $6 \times 10^{-4}$ \\
\hline $\begin{array}{l}\text { Upper-bound accident, } \\
\text { population dose, 70 years } \\
\text { (person-rem) }\end{array}$ & 0.3 & 0.02 & 0.02 & 0.02 \\
\hline Cost (millions of 1987 dollars) & 1,600 & 140 & 170 & 5.4 \\
\hline
\end{tabular}

5.2.1.10 Decision Made. The DOE has decided to conduct additional development and evaluation efforts before making decisions on final disposal of the pre-1970 buried suspect TRU-contaminated solid waste within the 200 Area Plateau (DOE 1988). These development and evaluation efforts will focus on methods to retrieve and process this waste for disposal, as well as to stabilize and isolate near-surface waste. The only pre-1970 buried suspect TRU-contaminated solid waste site outside the 200 Area Plateau will be removed from the 618-11 Burial Ground to the 200 Area Plateau to be processed for disposal as solid TRU waste.

5.2.1.11 Alternatives to Remediate LLW. Shallow land disposal of LLW has been ongoing at the Hanford Site since operations began in 1944. Although the disposal practices have changed through the years, the concept of shallow land disposal has been the principal method used.

Alternatives Evaluated. The alternatives described in this section apply to the generation and disposal of LLW. Existing LLW is disposed of in burial trenches and caissons. Some of this waste, disposed of before 1970 , is suspected to be contaminated with TRU radionuclides. Newly generated LLW is non-TRU (i.e., less than $100 \mathrm{nCi} / \mathrm{g}$ of TRU) and is disposed of in burial trenches. Some newly generated LLW is now being compacted before disposal.

Alternatives to remediate LLW at the Hanford Site have been reviewed and evaluated in the following two EISs:

- ERDA-1538, Final Environmental Statement for Waste Management Operations-Hanford Reservation (ERDA 1975)

- DOE/EIS-0113, Final Environmental Impact Statement-Disposal of Hanford Defense High Level, Transuranic, and Tank Wastes (HDW-EIS) (DOE 1987a).

Ongoing waste management operations, including LLW disposal, were evaluated in ERDA-1538. The purpose of ERDA-1538 was to reassess the program in existence at that time. 
This document examined options for continued waste management efforts, but did not specifically address final disposal. The HDW-EIS addressed final disposal of several waste types. It included pre-1970 suspect TRU waste, but did not address any other portions of LLW.

Alternatives Evaluated in ERDA-1538. The following LLW disposal alternatives were evaluated in ERDA-1538:

- Current Practice

- Compaction

- Storage in Deactivated Plants.

Enhancements to these LLW disposal alternatives were as follows:

- Sorting and Classifying

- Equipment Reclamation

- Equipment Disposal

- Burial Ground Selection.

The following paragraphs discuss these alternatives individually.

Current Practice. When ERDA-1538 was prepared, LLW was handled in several ways. The majority of beta-gamma-contaminated solid waste was disposed of in shallow trenches in the 200 Areas. Large items of process equipment, items considered too radioactive and too bulky for either transfer to the 200 West Area (for decontamination) or burial, were placed in the PUREX Facility's railroad tunnel. Ongoing emphasis was to be placed on reducing the amount of contaminated waste generated and on packing more waste into each burial package to reduce the amount of required trench space.

Compaction. Compaction of solid waste was considered to reduce the volume of initial waste packages. Use of compaction would not reduce the amount of radionuclides being disposed of, and the corresponding reduction in the size of the burial grounds did not appear to justify the cost of compaction units.

Storage in Deactivated Plants. Deactivated plants were considered for conversion to waste storage vaults. Successful conversion would have required modifying the old plants to provide fire protection, proper ventilation, and monitoring capabilities. These modifications were expected to cost many millions of dollars, and probably would not lower population dose. The benefit would have been a reduced commitment of additional land for waste storage.

Sorting and Classifying. This alternative would have included developing instrumentation to nondestructively analyze the contents of packaged solid waste to assist in sorting. Identification and measurement of the radioactive content of waste were considered essential to determining waste disposition because measurements could determine whether the package could be treated as fission product-contaminated waste or would have to be handled as TRU waste. 
This alternative specifically mentioned a central data reduction system, the Automatic Radioactive Inventory System, which could identify 34 radionuclides from one spectrum.

Equipment Reclamation. This alternative would recover, clean, and repair all contaminated process equipment for reuse, thus eliminating the need for burial. This type of work was and continues to be current practice, but ERDA-1538 considered it neither technologically nor economically feasible to recover all such equipment because in many cases, cost in time, chemicals, and radiation dose to employees would far exceed the value of the equipment and the cost of burial. Such extra cleanup would also produce significantly larger volumes of liquid waste requiring disposal.

Equipment Disposal. This alternative involved using one or more methods of consolidating large, bulky items, such as process equipment, hoods, structural members, etc., into easily handled forms. Items could be cut, melted, burned, disassembled, and compacted, or they could be completely converted to liquid waste, which could then be handled as part of the existing liquid waste inventory.

Standard practice was to place large items of failed equipment in concrete boxes for burial. This alternative was considered to reduce future waste volumes which were expected to increase significantly under the long-range facilities decommissioning program. According to ERDA-1538 a study was under way to establish the technologies for converting the large items to consolidated forms and to determine subsequent treatments. Cost estimates and schedules for possible alternatives had not been made when ERDA-1538 was issued.

Burial Ground Selection. ERDA-1538 stated that evaluation of solid waste burial alternatives for long- versus short-term burials might be considered. Criteria for long-term burial would be developed and existing burial sites would be evaluated using these criteria. The evaluations were expected to determine which burial grounds required stabilization, which needed relocation, and which potential new sites were acceptable for long-term storage. ERDA-1538 stated that should relocation of a burial ground be judged necessary, the technology or equipment would probably not be available before FY 1980.

Decision Made. The decision made in ERDA-1538 was to continue present operations and continue to strive for improvement. Continued emphasis would be placed on reducing the amount of contaminated waste generated, and on packing more waste into each burial package to reduce the amount of required trench space. Some of the alternatives mentioned in ERDA-1538 have been implemented. For example, an increasing amount of solid LLW from the tank farms is being compacted before burial. Escalating disposal costs have made compaction economically viable. Also, assays of solid waste have become common. Failed or unused process equipment that has not yet been declared waste has been stored on the unused canyon deck of $U$ Plant. Some of the canyon deck area of T Plant is also used to store contaminated equipment items. The Environmental Restoration Contractor (Bechtel Hanford, Inc.) is responsible for burial grounds that may require relocation. 
5.2.1.12 Historical Decisions for MLLW. Before 1987, radioactive waste was regulated solely under the Atomic Energy Act of 1954. In 1987, the DOE ruled that stored and newly generated mixed waste was subject to RCRA requirements, including LDRs. This section outlines the regulatory actions that affected how MLLW was managed and the treatment and processing assumptions and options currently under consideration at the Hanford Site.

Regulatory Background. Congress passed RCRA in 1976. Regulations issued by the EPA under RCRA set forth a comprehensive program to provide "cradle-to-grave" control of hazardous waste. This program required generators and transporters of hazardous waste and owners and operators of treatment, storage, and disposal facilities to meet specific standards and follow specific procedures. The RCRA also required the EPA to issue LDRs specifying concentration- and technology-based standards to treat hazardous waste. The LDRs prohibit the storage of waste that requires treatment, except to facilitate proper recovery, treatment, or disposal.

In 1987, the DOE issued a mixed byproduct ruling stating that the hazardous components of radioactive waste are regulated by RCRA (DOE 1987b). Although Site procedures were in place to address the presence of hazardous constituents in radioactive waste, before 1987 the DOE had claimed federal immunity from compliance with RCRA. In November 1987, the EPA authorized Ecology to regulate the hazardous constituents of mixed waste at the Hanford Site. As a result, the Hanford Site stopped disposing of mixed waste in unlined trenches and began to store this waste in aboveground facilities. In January 1988, an agreement with Ecology stipulated that mixed waste with a dose rate less than $200 \mathrm{mrem} / \mathrm{h}(\mathrm{CH})$ would be retrievably stored and placed in a building that met all the Ecology storage requirements. Mixed waste with greater than $200 \mathrm{mrem} / \mathrm{h}(\mathrm{RH})$ would be disposed of below ground to satisfy ALARA radiation safety requirements, assuming successful waiver applications (Carlson 1994).

The DOE established policies, guidelines, and minimum requirements by which it manages its radioactive and mixed waste and contaminated facilities. RL provides the guidelines, policies, and minimum requirements by which it manages radioactive waste, mixed waste, and contaminated facilities at the Hanford Site. The DOE Orders define the performance objectives for DOE disposal sites and dictate the certification requirements associated with waste destined for disposal. Implementation of DOE Orders was accomplished by including the requirements as part of WHC-EP-0063-04, Hanford Site Solid Waste Acceptance Criteria (Willis 1993) and plant standard operating procedures.

The FFCA waived sovereign immunity at federal facilities by allowing states to impose fines and penalties for RCRA violations. The FFCA also gave the DOE a 3-year delay of the waiver (until October 6, 1995) for DOE's violations of RCRA's LDRs for waste storage. The FFCA further required the DOE to prepare plans for developing treatment capacity for its mixed waste; however, the FFCA specifically excludes sites that have signed agreements with their host states. Because the Tri-Party Agreement was signed in 1989, the Hanford Site is exempt from the FFCA. 
Treatment and Processing. The RCRA LDRs require that established treatment requirements be met before land disposal of hazardous wastes. While treatment capability generally exists for the nonradioactive hazardous waste that is subject to LDR, treatment is unavailable for the mixed wastes subject to LDR. Thus, mixed waste is stored at the Hanford Site until LDR treatment capability is available.

In accordance with Tri-Party Agreement Milestone M-26-00, a Hanford Site LDR treatment and processing plan for mixed waste is submitted annually to EPA and Ecology (Ecology et al. 1996). This plan describes the process for managing mixed waste subject to LDR at the Hanford Site and identifies actions that will be taken to achieve full compliance with LDR requirements. The technology assumptions, treatment requirements, and treatment options under consideration by the Project are described in the following paragraphs.

LDR Technology Assumptions. The treatment and processing assumptions that will be used to prepare the $\mathrm{RL}$ data sheets for the proposed Site treatment plan options for containerized mixed LLW streams are as follows:

- Technology needs are driven by matrix and concentration of hazardous contaminants.

- Deactivation technology, when needed, as indicated by the ignitable/corrosive/reactive contaminant parameter, is achieved by thermal treatment or stabilization technologies when required because other contaminants are present.

- In cases where organics (including polychlorinated biphenyls [PCB]) are the contaminants present, thermal treatment technology will be used.

- Technology for metal-contaminated soil is stabilization (as opposed to soil washing, etc).

- Debris matrices may be treated via destruction, immobilization, or removal-type technologies. Pretreatment via sorting/separation will likely be needed.

Physical Waste Forms and Treatment Requirements. The physical forms of mixed waste at the Hanford Site include the following:

- Inorganic and organic process homogeneous solids, including particulates and sludges (hereafter referred to as "homogeneous solids")

- Contaminated soils (hereafter referred to as "soils")

- Lab packs

- Debris

- Elemental mercury 
- Elemental lead

- Lead acid and cadmium batteries.

The treatment strategy for these physical waste forms is summarized in Table 5-9. For organic waste forms, organic contaminants are characterized as matrices laden with organics, i.e., absorbed oils and lab-packed organics, solid or soil matrices contaminated with RCRA-regulated organic contaminants, and Toxic Substances Control Act of 1976-regulated levels of PCB contamination.

Treatment Options Under Consideration. Treatment options are divided into two groups: mixed waste that requires thermal treatment and mixed waste that does not require thermal treatment. Waste with specified or BDAT's of "combustion" or "incineration" would be treated in accordance with the thermal treatment option. Waste that does not require the aforementioned treatment technologies would be designated to the non-thermal treatment options.

Some waste in the non-thermal treatment option could effectively be treated by the thermal treatment option. The treatment path decision will be made by evaluating differences in treatment cost, and volume reduction advantages relating to disposal cost.

Table 5-9. Treatment Strategies for Mixed Waste Physical Waste Forms. (3 sheets)

\begin{tabular}{|l|l|}
\hline \multicolumn{1}{|c|}{ Physical waste form } & \multicolumn{1}{|c|}{ Treatment strategy } \\
\hline Lab packs containing organic solvents or oils. & Thermal treatment technology. \\
\hline $\begin{array}{l}\text { Polychlorinated biphenyls regulated under the Toxic } \\
\text { Substances Control Act of } 1976^{\text {a }}\end{array}$ & Thermal treatment technology. \\
\hline $\begin{array}{l}\text { Homogeneous solids, soils, and lab packs } \\
\text { contaminated with metals regulated under the } \\
\text { Resource Conservation and Recovery Act of } 1976^{\circ} \\
\text { and organic contaminants. }\end{array}$ & $\begin{array}{l}\text { Thermal treatment and stabilization } \\
\text { technologies. }\end{array}$ \\
\hline $\begin{array}{l}\text { Homogeneous solids, soils, and lab packs with organic } \\
\text { contaminants but without metals regulated under } \\
\text { Resource Conservation and Recovery Act of } 19766^{b}\end{array}$ & Thermal treatment technology. \\
\hline $\begin{array}{l}\text { Homogeneous solids, soils, and lab packs } \\
\text { contaminated with metals or ignitable/corrosive/ } \\
\text { reactives regulated under Resource Conservation and } \\
\text { Recovery Act of } 1976^{b} \text { codes and/or Washington State } \\
\text { Department of Ecology codes. }\end{array}$ & Stabilization technology. \\
\hline
\end{tabular}


Table 5-9. Treatment Strategies for Mixed Waste Physical Waste Forms. (3 sheets)

\begin{tabular}{|c|c|}
\hline Physical waste form & Treatment strategy \\
\hline $\begin{array}{l}\text { Inorganic homogeneous solids and soils that are } \\
\text { contaminated with mercury. }\end{array}$ & $\begin{array}{l}\text { Stabilization technology. (Additional } \\
\text { characterization of the waste will be } \\
\text { performed to verify that the } \\
\text { concentration of mercury in the } \\
\text { waste matrix is less than the } \\
\text { regulated level of } 260 \mathrm{mg} / \mathrm{L} \text {.) }\end{array}$ \\
\hline $\begin{array}{l}\text { Inorganic homogeneous solids and soils that are } \\
\text { contaminated with mercury and have been stabilized } \\
\text { but are determined to exceed } 260 \mathrm{mg} / \mathrm{L} \text { mercury. }\end{array}$ & $\begin{array}{l}\text { Retorting/roasting technology. (The } \\
\text { selection of a facility with } \\
\text { retorting/roasting capability will be } \\
\text { conducted when this waste is } \\
\text { identified and accumulated.) }\end{array}$ \\
\hline $\begin{array}{l}\text { Containerized, dewatered fuel fabrication sludge from } \\
\text { the } 183-\mathrm{H} \text { dewatering basins. (This waste is a listed } \\
\text { waste containing low concentrations of formic acid. A } \\
\text { petition to waive the formic acid incineration land } \\
\text { disposal restriction treatment standard using } \\
\text { demonstration of equivalent treatment is being } \\
\text { prepared for this waste.) }\end{array}$ & Stabilization technology. \\
\hline $\begin{array}{l}\text { Tank farm backlog soils contaminated with organic } \\
\text { solvents below land disposal restriction } \\
\text { concentration-based standards. }\end{array}$ & $\begin{array}{l}\text { Sampling and analysis of the soil are } \\
\text { planned to support a petition to the } \\
\text { Washington State Department of } \\
\text { Ecology for concurrence that the } \\
\text { waste should be considered non-land } \\
\text { disposal restricted. }\end{array}$ \\
\hline $\begin{array}{l}\text { Debris waste, including debris contaminated with low } \\
\text { concentrations of organic solvents, oils, or } \\
\text { polychlorinated biphenyls ( }<50 \mathrm{ppm}) \text {, as well as } \\
\text { backlog debris. }\end{array}$ & $\begin{array}{l}\text { Stabilization technology. The } \\
\text { planned technology is shred-grout } \\
\text { immobilization. Debris that contains } \\
\text { no or low concentrations of these } \\
\text { hazardous constituents will be } \\
\text { pretreated by screening to remove } \\
\text { particulates. }\end{array}$ \\
\hline
\end{tabular}


Table 5-9. Treatment Strategies for Mixed Waste Physical Waste Forms. (3 sheets)

\begin{tabular}{|l|l|}
\hline \multicolumn{1}{|c|}{ Physical waste form } & \multicolumn{1}{|c|}{ Treatment strategy } \\
\hline $\begin{array}{l}\text { Debris waste, including debris contaminated with low } \\
\text { concentrations of organic solvents, oils, or } \\
\text { polychlorinated biphenyls }(<50 \mathrm{ppm}) \text {, as well as } \\
\text { backlog debris. }\end{array}$ & $\begin{array}{l}\text { Alternative treatment strategy. } \\
\text { Macroencapsulation using sealed } \\
\text { polyethylene containers. This } \\
\text { strategy depends on the Washington } \\
\text { State Department of Ecology's } \\
\text { concurrence that placement of waste } \\
\text { in sealed, polyethylene containers } \\
\text { may be considered a best } \\
\text { demonstrated available technology. }\end{array}$ \\
\hline Elemental mercury waste. & $\begin{array}{l}\text { Amalgamation. Encapsulation is } \\
\text { planned after amalgamation. }\end{array}$ \\
\hline Elemental lead. & $\begin{array}{l}\text { Macroencapsulation. } \\
\text { Decontamination and recycling } \\
\text { technologies are not planned. }\end{array}$ \\
\hline Lead acid and cadmium batteries. & Encapsulated in a shred-grout form. \\
\hline
\end{tabular}

'Toxic Substances Control Act of 1976,15 USC 2601, et seq.

'Resource Conservation and Recovery Act of 1976, 42 USC 6901, et seq.

Thermal Treatment Options. Three options are under consideration for mixed waste that require thermal treatment. The first option is to process these waste in a commercial facility. The other options are to construct an onsite facility or treat the waste at another DOE site. Under any option, additional treatment will be provided at the facility as required to ensure that the returned waste residues are in an acceptable form from disposal. Services for thermal treatment are expected to become available in FY 2001.

Non-Thermal Treatment Options. Waste that does not require thermal treatment will be processed by a commercial stabilization treatment contractor providing non-thermal mixed waste treatment capability. These services are planned to be available by September 1999 .

5.2.1.13 Alternatives to Implement the Remediate Solid Waste Decision. Throughout the Project's activities to implement the strategies to manage and dispose of radioactive solid waste, several events took place that directed the development of alternative system configurations to provide treatment, storage, and disposal of solid waste at the Hanford Site. The changes that have occurred are presented in Figure 5-1. The decision to continue with the practice of LLW disposal with no significant treatment of waste before emplacement was reaffirmed in ERDA-1538 (ERDA 1975). Since that time, additional requirements have been instituted for 
disposal of LLW (Willis 1993) but the overall policy regarding onsite disposal in shallow land burial grounds has remained unchanged.

The decision to proceed with Geologic Disposal of TRU waste was made in the HDW-EIS ROD in 1988. Initial facility designs to support Geologic Disposal of TRU waste called for one WRAP facility. The scope of this single WRAP facility was to process stored and newly generated CH TRU waste. This facility's development began in 1983. At that time, TRU waste required preparation and certification for appropriate disposal in WIPP.

By the time the HDW-EIS was being made final, the policy regarding management of radioactive waste and byproduct material was being modified. On May 1, 1987, 10 CFR 962 established the policy that all DOE radioactive waste that is classified as hazardous under RCRA would be subject to regulation under RCRA and the Atomic Energy Act of 1954. With this change in policy, additional requirements would be placed on the management and disposition of radioactive waste. The HDW-EIS included discussion that treatment would be provided for RCRA-regulated waste. The emphasis, however, was on the waste from retrievable storage rather than newly generated waste. The establishment of RCRA regulation of radioactive waste that is also hazardous significantly expanded the scope of the Project at the Hanford Site. Management of solid waste other than TRU waste became necessary.

5.2.1.13.1 Wrap Needs Before RCRA Implementation. Before implementation of RCRA regulations for radioactive waste that was also hazardous, the objective of the WRAP facility was to provide receipt and processing of TRU and suspect-TRU waste for shipment to permanent disposal in WIPP. The WRAP facility provided all necessary treatment of TRU waste to meet the requirements specified by the WIPP WAC (WIPP 1996).

Waste Streams Treated. A single facility was needed to process stored and newly generated CH TRU waste in drums and boxes. However, limited volumes of oversized, unpackaged TRU-contaminated waste volumes were identified for treatment in WRAP. An example of the oversized, unpackaged items in storage is an 8-m-long, 1-m-diameter culvert. Based on a then-current engineering study (RHO 1985), the 1985 inventory and future generation projections showed $44,000 \mathrm{~m}^{3}$ of solid, $\mathrm{CH}$ TRU, and suspect $\mathrm{CH}$ TRU waste being received for management at the Hanford Site between 1970 and 2015.

Streams not requiring treatment in this alternative included mixed waste, LLW, and $\mathrm{RH}$ waste. These streams were not addressed because this waste was termed byproducts and was not subject to waste disposal regulations. The only motivation to treat LLW was to incur a cost savings by reducing the waste volume requiring storage and disposal. The RH TRU waste was a very small fraction of the total volume expected to be managed by the Project at the time of Project planning. Furthermore, technology required to manage the $\mathrm{RH}$ waste was expensive and not clearly defined.

Treatment Functions. The WIPP WAC are limits that allow waste generator and shipping sites to develop their own procedures and specifications for preparing TRU waste for shipment to WIPP. These criteria also allow sites to plan future facilities for waste preparation 
that will produce TRU waste forms compatible with WIPP waste emplacement and isolation requirements. The WIPP WAC were developed to ensure that all functions of the geologic repository can be performed safely during receipt and emplacement of the wastes. The following list defines the functions required for treating TRU waste according to the WIPP WAC.

- Receive-Initial examinations of the waste package will be made to determine surface dose rates, surface contamination levels, and waste package physical dimensions and relative condition.

- Examine-A relatively large percentage of waste packages without package opening or processing will be certified by a nondestructive assay and nondestructive examination function. This function includes activities such as package weighing, TRU assay, and visual, radiographic, and ultrasonic examinations.

- Size Reduction-The compliance requirements for CH TRU waste retrieved from storage limit the maximum container size shipped to WIPP. This function will involve opening the original box containers and removing, reducing the size of, and repacking the waste contents.

- Sort-The sorting function will include removing the drum lid, unloading the drum, crushing emptied drums, separating conforming from nonconforming waste, and repackaging waste.

- Process-Some of the processing operations that may be required include immobilizing particulates, sorping small amounts of liquids, initiating reaction of corrosives or pyrophorics, recovering plutonium-rich scrap, overpacking small amounts of sludges, and venting pressurized gas cylinders.

- Ship - Each waste package must meet U.S. Department of Transportation and WIPP labeling requirements before shipment to WIPP. In addition, data package and certification documentation will be prepared in final form and the waste packages will be banded or palletized and loaded into the TRUPACT-II* transport container for shipment to WIPP by truck or rail.

Alternative Examined. Original WRAP studies were initiated before relinquishing byproduct material exclusion, and RCRA treatment was excluded from the scope of the required facility functional capability. An engineering study completed in 1985 (RHO 1985) proposed one WRAP facility to meet the needs of TRU treatment and certification for disposal at WIPP. This system configuration was developed to perform the functions listed previously for treating the stored and newly generated TRU waste expected to be managed at the Hanford Site.

"TRUPACT-II is a trademark of Container Productions Corporation. 
Alternative Evaluation and Decision Made. Decision criteria for the one facility alternative included safety, cost, schedule, and technology availability. The magnitude of uncertainties associated with the alternative also was assessed (e.g., what was the appropriate technology to be used or what were the treatment requirements).

The original WRAP facility was proposed as a line item project to provide the necessary treatment to enable the permanent disposal of CH TRU waste stored at the Hanford Site, but it was deferred on the basis of funding priorities. Early in 1988, it became apparent that further delays would be unacceptable to the Hanford Site because stored waste containers were beginning to deteriorate to the point of being breached. This would result in increasing the cost and personnel exposure required for retrieval. In addition, the continued storage of hazardous and radioactive mixed waste in noncompliant configurations was not acceptable. It was also determined at that time that the scope of the WRAP facility should be expanded to include the treatment of other solid waste types besides the $\mathrm{CH}$ TRU included in the original WRAP, and that the expanded-scope WRAP should be accelerated as much as possible. However, the expanded scope of WRAP had not been sufficiently defined at that time to support the full scope as a line item project. The need to complete the functions identified for this facility still existed, but the added scope changed the overall needs. The change in scope required a reassessment of how to remediate solid waste. This is discussed in the following paragraphs.

WRAP Needs After RCRA Implementation. With the advent of RCRA regulation of radioactive waste that was also hazardous, the scope of waste requiring treatment dramatically increased and changed in terms of requirements. (RCRA requirements for mixed waste were added.) As in the first alternative, the objective of this alternative was to provide processing and shipping of TRU waste to WIPP. However, the addition of RCRA regulation had expanded the Project's objective. In addition to providing processing of TRU waste, the Project now had to provide processing and disposal of any LLW encountered during retrieval operations that was also found to be hazardous, provide any required RCRA treatment for TRU waste, and provide RCRA treatment of future-generated LLW that was also hazardous under RCRA regulations.

Waste Streams Treated. The waste streams treated after implementation of RCRA regulation expanded to include $C H$ and RHLLW, MLLW, and TRU waste. Streams not addressed under this alternative include Greater Than Category III waste and nonradioactive hazardous waste. Beginning in 1989 , the Project began annually compiling data of waste generators planning to generate waste in the future. Table 5-10 summarizes the solid waste volumes estimated to be generated during the next 30 years. The table shows estimates for each major category of waste for 1989 through 1993 for which forecast information has been requested. Before 1989, these forecast volumes were not obtained. The volumes listed in this table show the need for treating streams other than CH TRU.

Treatment Functions. The treatment functions required for $\mathrm{CH}$ TRU remained the same as defined for the single CH TRU treatment facility. However, with the expanded scope to treat mixed waste under RCRA regulation, new functions were required of the system configuration to implement the HDW-EIS ROD. The following list defines the functions that need to be implemented to manage the solid waste volumes not requiring WIPP WAC certification. 
- Size Reduction-Will include waste receipt, container opening, real-time dose rate measurement of unshielded waste, smear sampling, various sectioning operations, compaction, repackaging, and loadout. All containers would be reduced in size and weight to fit into appropriate waste containers for disposal in a RCRA-approved landfill.

- Decontamination-Will include spraying waste with wet chemical decontamination agents and providing size reduction for long or oversized waste volumes.

- Remote Handling-Will include waste receipt, assay, smear sampling, plasma melting, measuring unshielded total and neutron dose rates, repackaging, canister welding, and cask handling. The RH TRU will be certified for WIPP emplacement by this function.

- Mixed Waste Treatment-Will include waste receiving, pretreatment, solidification, metals treatment, liquid treatment, and treated waste shipment.

Table 5-10. Estimated 30-Year Future Volume Generation Summary by Waste Class for Forecasts Requested in 1989 through 1993 (in $\mathrm{m}^{3}$ ).

\begin{tabular}{|c|c|c|c|c|c|c|}
\hline Year & CH MLLW & CH LLW & CH TRU & RH MLLW & RH LLW & RH TRU \\
\hline 1989 & 7,980 & 131,432 & 5,608 & 1,647 & 16,985 & 509 \\
\hline 1990 & 43,229 & 273,765 & 9,306 & 2,381 & 19,839 & 4,165 \\
\hline 1991 & 61,409 & 276,571 & 13,373 & 1,967 & 8,285 & 4,089 \\
\hline 1992 & 72,319 & 273,583 & 6,186 & 1,855 & 8,070 & 4,973 \\
\hline 1993 & 61,352 & $1,310,467$ & 8,502 & 3,202 & 4,545 & 1,788 \\
\hline
\end{tabular}

\footnotetext{
$\mathrm{CH}=$ contact-handled.

LLW $=$ low-level waste.

MLLW = mixed low-level waste.

$\mathrm{RH}=$ remote-handled.

$\mathrm{TRU}=$ transuranic.
}

Alternatives Examined. Two alternative system configurations have been examined in detail to provide the additional treatment functions required by RCRA regulation. Each of these system configurations maintained the initial alternative of a $\mathrm{CH}$ TRU WRAP for certifying $\mathrm{CH}$ TRU wastes according to the WIPP WAC. The first alternative (two WRAP facilities) examined the possibility of providing one additional WRAP facility to meet all processing needs not covered in the original WRAP facility slated for CH TRU waste processing. The other alternative (multiple facilities) proposed separate facilities with more specific or limited scope. These 
facilities would include the original WRAP facility for CH TRU processing; a facility for MLLW stabilization; and a facility for waste requiring thermal treatment, with the remaining scope to be determined through additional study (facility requirements for $\mathrm{RH}$ waste, oversized waste, and waste requiring decontamination).

For these alternatives, the use of either onsite facilities or the contracting of services to provide the necessary capability has not been distinguished. Construction of a facility on site or contracting services to provide the needed treatment are considered equivalent in terms of comparing the alternatives.

Two WRAP Facilities. During the development of the two WRAP module alternatives, the waste volumes requiring treatment were expected to be those shown in Table 5-11 (Pauly 1990).

Table 5-11. Waste Stream Volumes Expected by the Solid Waste Subproject in Support of Pursuing Two Waste Receiving and Processing Modules.

\begin{tabular}{|l|c|}
\hline \multicolumn{1}{|c|}{ Waste streams } & Volume $\left(\mathrm{m}^{3}\right)$ \\
\hline Stored CH TRU & 15,400 \\
\hline Newly generated CH TRU & 6,325 \\
\hline Stored RH TRU & 363 \\
\hline Newly generated RH TRU & 2,103 \\
\hline Stored MLLW & 3,557 \\
\hline Newly generated CH MLLW & 25,338 \\
\hline Newly generated RH MLLW & 1,116 \\
\hline Newly generated CH LLW & 4,934 \\
\hline Newly generated RH LLW & 534 \\
\hline
\end{tabular}

Source: Pauly, T. R. 1990, Engineering Study for Waste Receiving and Processing (WRAP)

Facility, Module 2, WHC-SD-W100-ES-001, Westinghouse Hanford Company, Richland, Washinton.

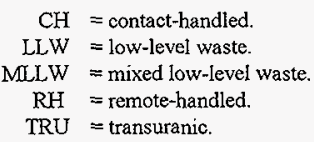

For this alternative, WRAP Module 1 (WRAP 1) would certify CH TRU and LLW as defined in the first alternative. Remaining solid waste streams would be processed in WRAP 
HNF-SD-WM-RPT-288

Revision 0

Module 2 (WRAP 2). These streams included RH TRU, suspect RH TRU, TRU waste packaged in containers unacceptable to WRAP $1, \mathrm{RH}$ and $\mathrm{CH}$ MLLW, and nonradioactive hazardous waste. The WRAP 2 would process all retrieved and newly generated CH suspect-TRU waste in boxes other than standard waste boxes and in "other" containers, as well as CH suspect-TRU waste in drums with high dose rates, contaminated soil, or security classified contents. All retrieved and newly generated RH TRU waste would be processed in WRAP 2, and all MLLW would be processed in WRAP 2. The WRAP 2 would have outputs of compliant TRU and LLW drums, compliant MLLW drums, and compliant RH TRU canisters. All TRU and LLW CH drums would be routed back to WRAP 1 for final certification and shipping to disposal. All MLLW and RH TRU would be certified in WRAP 2 and shipped directly to the disposal site.

The WRAP 1 would perform the functions required to meet the WIPP WAC in treating CH TRU waste, including assay and inspection, certification, and shipping. The WRAP 2 would provide the mixed waste, size reduction, remote handling, and decontamination functions. The mixed waste treatment function would provide all necessary capabilities to treat, characterize, and certify MLLW for disposal at the Hanford Site. The size reduction function would repackage all TRU waste from boxes and "other" containers, including certain drummed waste, into 208-L drums. All CH drums would be transferred to WRAP 1 for assay, LLW/TRU segregation, inspection, certification, and shipping. All RH drums from the size reduction function would be transferred to the remote handling function for assay, LLW/TRU segregation, inspection, packaging into RH canisters (RH TRU only), certification, and shipping via the RH TRU cask.

The WRAP 2 would decontaminate or smelt low-level contaminated lead and release the waste for conditional reuse if possible. Equipment items and retired shipping casks would be decontaminated and released for conditional reuse. Decontaminated, retired shipping casks would be transported from WRAP 2 to the Idaho National Engineering Laboratory for disassembly and recovery of the lead. Decontaminated equipment would be returned to the user, or sectioned and reduced in size for further processing as waste.

The MLLW and secondary solids from effluent treatment facilities would be characterized, treated, and repackaged pending processing in WRAP 2, with low-level liquid organic waste being characterized, repackaged, and transported to the Idaho National Engineering Laboratory for incineration at the Waste Experimental Reduction Facility. All nonorganic MLLW would be treated and certified for disposal in accordance with all regulations, including LDRs. Also within WRAP 2, the RH TRU waste would be melted into monoliths using plasma furnace technology in hot cells, characterized, and packaged into RH TRU canisters. All RH TRU canisters would be loaded into the RH TRU cask, and transported to WIPP for emplacement.

Multiple Facilities. The objective of this alternative was to operate multiple modular facilities for treatment and disposal of all streams managed by the Project. As in the first alternative, this alternative provided one module to process and ship TRU waste to WIPP and a second module to process CH MLLW. In addition, this alternative provided a separate facility (WRAP 2B) for thermally treating mixed waste containing hazardous constituents requiring thermal destruction, and a third module for $\mathrm{RH}$ waste and waste in large containers. 
As in the previous alternative, this alternative included one module for receipt and processing of $\mathrm{CH}$ TRU waste in drums and standard waste boxes. This module would perform all processing necessary to certify the $\mathrm{CH}$ TRU waste for shipment to WIPP in accordance with the WIPP WAC. Under current system planning, this module is referred to as WRAP 1 and performs the following functions: receive, examine, sort, process, immobilize, repackage, certify, and ship.

It was determined that WRAP 1 would not be designed to handle TRU waste in extremely large or oversized containers or RH waste. These waste volumes, however, would still require treatment in accordance with the WIPP WAC, as stated in the HDW-EIS ROD. Therefore, it was concluded that treatment for CH TRU waste packaged in large containers and RH TRU waste would be provided through a different module. Under current system planning, the scope of facilities for CH TRU waste in oversized containers and RH TRU waste was determined through additional study (Carlson 1995).

Mixed waste requiring non-thermal treatment before land disposal based on RCRA requirements would be handled by a separate module to prevent cross-contamination of the mixed and non-mixed waste types. The technologies used in this module will include only RCRA-approved technologies such as grout stabilization or polyethylene extrusion. Under current system planning, this is referred to as CH MLLW commercial stabilization treatment. This treatment will be provided by a contract for commercial services.

Mixed waste requiring thermal treatment before land disposal based on RCRA requirements for hazardous characteristics or specific constituents would be processed by a separate facility. This waste contains hazardous constituents such as PCBs or organics. Under current system planning, this module is a thermal treatment commercial contract for services that performs thermal destruction. The facility would return the treated waste to the Hanford Site for disposal.

It was determined that the commercial contracts for CH MLLW treatment would not handle $\mathrm{CH}$ waste in oversized containers or $\mathrm{RH}$ waste. These waste volumes, however, would still require treatment in accordance with LDRs. Therefore, it was concluded that treatment for CH MLLW packaged in oversized containers and RH MLLW would be provided through a different module. Under current system planning, the scope of facilities for CH MLLW in oversized containers and RH MLLW would be determined through additional study. That study was completed under part of Tri-Party Agreement Milestone M-33 (Carlson 1995).

Alternative Evaluation and Decision Made. The decision criteria for evaluation of these alternatives were the same as the decision criteria for the first aiternative: safety, cost, schedule, and technology availability. In addition, the magnitude of uncertainties associated with the alternative were also assessed (e.g., what is the appropriate technology to be employed, or what are the treatment requirements).

After the Project's scope increased to include RCRA-regulated waste, it became necessary to accelerate WRAP as much as possible. Therefore, it was proposed by the operating contractor (and agreed to by RL) that WRAP should be split into at least two separate projects called 
HNF-SD-WM-RPT-288

Revision 0

Module 1 and Module 2. In 1988, WRAP was split into WRAP Module 1 (1991 line item) and WRAP Module 2 (1993 line item). This strategy had the following advantages.

- The necessary technology was much better defined and available for certain parts of WRAP than others. The split scope had the simultaneous advantages of proceeding immediately with those parts for which technology was developed and available, while allowing more time for investigations in other areas.

- Early retrieval was much more urgent for certain containers than others; approximately $85 \%$ of the stored-TRU activity was in drums.

- Inventory work-off would take much longer for certain containers than others; more than 37,000 drums and fewer than 1,200 boxes and other containers were in storage.

- The capital funding requirements would be spread out over a longer time, thus reducing peak funding requests. Rather than a single $\$ 200$ million line item, two smaller line items could be proposed.

- WRAP I was validated as a 1991 line item. Had the scope not been split, the earliest a single project could have been ready would have been 1993 , which would have unnecessarily delayed work-off of stored drums.

Before 1989, 30-year forecast data were not obtained. Each year, system planners based the system's design specifications on waste volumes currently in storage and volumes expected to arrive the following year. Therefore, the alternative system configurations developed during that time were not designed with the flexibility to accommodate waste volumes that would be arriving throughout the design life of the system. The multiple module alternative provides the Project with the flexibility to address these waste volume uncertainties. Because each module in the alternative has a defined mission, where streams will be processed is clear and facility capacities can be designed and adjusted accordingly.

In 1991, a strategy assessment study was initiated to assess the proposed WRAP 2 configuration, requirements, and plans to develop a defendable position and program strategy for project validation, design, and construction (Lamberd 1991). The assessment centered on treatment techniques for the management of waste at the Hanford Site. Treatment alternatives for each waste stream identified for WRAP 2 were evaluated and selected for technical and regulatory acceptability. Two waste categories were highlighted for treatment in WRAP 2: RH waste and $\mathrm{CH}$ waste. The strategy assessment recommended that a separate module (WRAP 2A) treat $\mathrm{CH}$ MLLW and that another separate module (WRAP 2B) handle RH waste and waste that must be characterized before treatment. This second facility would have provisions for handling large heavy items, or items not accepted in either WRAP 1 or the CH MLLW treatment facility. This facility would also house hot cells for treatment of specialized waste streams. Since that time, additional work regarding this scope has been undertaken. Additional study will be required to determine the appropriate facility requirements for $\mathrm{RH}$ and oversized waste. 
The strategy assessment also recognized that some thermal treatment technology would eventually be needed to treat certain mixed waste. Los Alamos Technical Associates evaluated available thermal treatment technologies; recommended alternative thermal treatment technologies, including specific facility features; and identified a strategy to implement these technologies into WRAP 2 or a standalone facility. Because the Los Alamos Technical Associates report indicated that significant development efforts were necessary for implementing any thermal treatment processes, it was determined that the proper course of action was to delay that part of WRAP 2 until the technology had been further defined. Subsequently, a separate thermal treatment module was recommended.

In 1995, a system alternatives study (Carlson 1995) examined alternative configurations for $\mathrm{RH}$ and oversized waste. The engineering study was completed as part of Tri-Party Agreement Milestone M-33. The study assessed existing and forecast inventories, and functions and requirements to develop flowsheets for the waste (encompassing WRAP 2B waste streams). Alternative facility configurations were then explored. Facility designs and cost estimates were developed the following four alternatives.

- A single new facility for the entire scope

- Multiple new facilities each with a smaller scope

- Modification of multiple existing facilities each with a smaller scope

- Modification of a single existing facility for the entire scope.

The alternatives were evaluated against a set of values including safety, health, environmental impact, cost, schedule, manageability, socioeconomic impact, and integration. Since the system alternatives study has been issued, public involvement has been pursued to receive the public's input in the decision-making process.

The multiple facilities alternative lowered the risk of environmental impact and worker safety compared to the two WRAP facilities alternative. Risk is lowered through accelerating the retrieval, treatment, and disposal of waste with a well-defined scope. In addition, the multiple facilities alternative minimized costs compared with the other alternatives by providing more timely treatment and disposal of waste not in compliance with state and federal regulations. Under this alternative, the Project gained the flexibility to obtain funding required to expedite treatment of large volumes of waste with well-defined treatment paths. In addition, by appropriating funds for facilities with clearly defined scope and treatment technologies, the multiple module alternative was able to more quickly treat waste volumes arriving for management by the Project. Costly facilities needed to treat small volumes of waste, or facilities with undefined treatment technologies, could also be delayed under this alternative until the Project needs for final disposal criteria were better understood.

\subsubsection{Alternatives To Manage Liquid Waste}

Engineering studies were performed for each liquid effluent facility. Alternatives were first identified that could possibly meet the functional needs. These alternatives were developed to the 
extent sufficient for comparison. Feasibility of the alternatives was assessed, and their compliance with mission-driven and externally imposed requirements was verified. Selection criteria were developed and used to select a preferred alternative. The preferred alternative was then used as the basis for conceptual design. The engineering studies that have been performed for the liquid effluent facilities are listed in Table 5-12.

Further development of alternatives, and analyses of alternatives, to manage the liquid waste within the Project will be performed in future revisions to this document.

\subsubsection{Alternatives To Manage Analytical Services}

The Analytical Services subproject supports the Hanford Site mission by providing analytical services to Site programs and projects. These services include waste and environmental sample analysis, process control support, field and sampling services, development services, and Site expertise in chemistry and data quality. The Analytical Services subproject operates onsite analytical laboratories, contracts commercial services, establishes Site analytical services quality standards, and integrates all Hanford Site analytical services (Hatch 1996).

A strategy has been developed to provide timely, cost-effective, and quality services to the Hanford Site. Modifications and revisions to this strategy are expected as the demand for Site analytical services changes and the Site cleanup mission progresses. Several alternatives, including the following, have been considered in development of this strategy:

- Use of commercially provided laboratory services

- Use of onsite services

- Privatization of selected onsite services

- Consolidation of commercial services

- Consolidation of onsite services

- Integration of all Site analytical services

- Establishment and application of a Site analytical services quality standard.

The resultant strategy is based on an optimal combination of services to meet the Site needs for analytical services. The process of defining this optimal combination of services is as follows:

- Hanford Site needs for analytical services are documented twice per year (November and May) and cover a period of 5 years (Mattsson 1996).

- A catalog of all analytical services is updated annually (in February). It includes information on all Site services and commercial services used (Mattsson 1997).

- A management plan will be prepared (April 1997) and updated annually. The plan will update the current strategy (Carter 1996) and identify planned actions. The plan will be the basis for updates to the Project's Technical Baseline and the following fiscal year's budget submittal. 
HNF-SD-WM-RPT-288

Revision 0

- Consolidation of commercial contracts is performed by the Sample Management Working Group, appointed by RL and consisting of representatives of the Environmental Restoration Contractor, Pacific Northwest National Laboratory, and the Project Hanford Management Contract (Wagoner 1996a and Wagoner 1996b).

- Consolidation of onsite services are performed based on a make-or-buy policy and procedure (WHC-CM-5-4, Section 3.30). The basis of this approach is to consolidate onsite work at the 222-S Laboratory and the Waste Sampling and Characterization Facility when warranted. This will result in lower unit analysis costs because of higher business volumes and will allow closure or reuse of other Hanford Site facilities.

Table 5-12. Engineering Studies for the Liquid Effluent Facilties. (2 sheets)

\begin{tabular}{|c|c|}
\hline WHC-SD-C018H-ER-00 I & $\begin{array}{l}\text { Project C-018H Waste Water Engineering Alternatives Treatment Report } \\
\text { (McDonald 1992) }\end{array}$ \\
\hline WHC-SD-W291-ER-001 & $\begin{array}{l}\text { Project W-291, Engineering Report for } 200 \text { Areas Effluent BAT/AKART } \\
\text { Implementation (Pedersen 1992) }\end{array}$ \\
\hline & 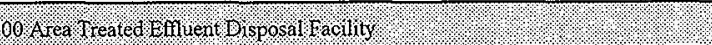 \\
\hline WHC-SD-W049F-ES-001 & $\begin{array}{l}\text { Engineering Study to Evaluate Need for Modifications to Liquid Effluent } \\
\text { Retention Facility - LERF Basin Design (Carrigan 1991a) }\end{array}$ \\
\hline WHC-SD-WO49H-ES-002 & $\begin{array}{l}\text { Final Letter Report } 200 \text { West Area Effluent Collection System } \\
\text { Project W-049H (Carrigan 1991b) }\end{array}$ \\
\hline WHC-SD-W049H-ES-003 & $\begin{array}{l}\text { Project W-049H Treated Effluent Disposal Alternatives Engineering Study } \\
\text { (Davis 1992) }\end{array}$ \\
\hline WHC-SD-W252-ER-001 & $\begin{array}{l}\text { Phase II Liquid Effluent Program (Project W-252) Wastewater Engineering } \\
\text { Report and BAT/AKART Studies (Halgren and Williams 1992) }\end{array}$ \\
\hline & 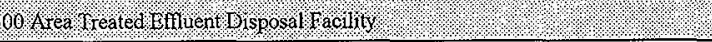 \\
\hline -- & 300 Area Sanitary and Process Wastewater Study (Beck 1990) \\
\hline-- & $\begin{array}{l}\text { Engineering Summary Report - Hanford } 300 \text { Area Process Wastewater } \\
\text { Discharge to the City of Richlond POTW (CH2M Hill 1993a) }\end{array}$ \\
\hline-- & $\begin{array}{l}\text { Hanford } 300 \text { Area-Addendum Engineering Summary Report (CH2M } \\
\text { Hill 1993b) }\end{array}$ \\
\hline WHC-SD-L045H-VES-001 & $\begin{array}{l}\text { Engineering L-045 us City of Richland Discharge Approach Final Report } \\
\text { (Olander 1993) }\end{array}$ \\
\hline WHC-SD-L070-ES-001 & $\begin{array}{l}\text { Engineering Study for } 300 \text { Area Process Sewer Replacement, Project L-070 } \\
\text { (Bare 1991) }\end{array}$ \\
\hline LLES-039 & $\begin{array}{l}\text { Engineering Study of Management Options for } 300 \text { Area Noncontact Cooling } \\
\text { Water (CH2M Hill and IT Corporation 1994) }\end{array}$ \\
\hline
\end{tabular}




\section{HNF-SD-WM-RPT-288}

\section{Revision 0}

Table 5-12. Engineering Studies for the Liquid Effluent Facilties. (2 sheets)

\begin{tabular}{|l|l|}
\hline & \multicolumn{1}{|c|}{} \\
\hline WHC-SD-WM-ER-277 & 30 racility \\
\hline & $\begin{array}{l}\text { Engineering Study of the 300 Area Process Wastewater Handling System } \\
\text { (Stordeur 1994) }\end{array}$ \\
\hline
\end{tabular}

Further development of alternatives and analyses of alternatives to manage the Analytical Services within the Project will be performed in future revisions to this document.

\subsection{REFERENCES}

10 CFR 60, "Disposal of High-Level Radioactive Wastes in Geologic Repositories," Code of Federal Regulations, as amended.

10 CFR 962, "Radioactive Waste: Byproduct Material," Code of Federal Regulations, as amended.

40 CFR 191, "Environmental Radiation Protection Standards for Management and Disposal of Spent Nuclear Fuel, High Level and Transuranic Radioactive Waste, " Code of Federal Regulations, as amended.

American Indian Religious Freedom Act, 42 USC 1996, et seq.

Atomic Energy Act of 1954, 42 USC 2011, et seq.

Bare, K. D., 1991, Engineering Study for 300 Area Process Sewer Replacement, Project L-070, WHC-SD-L070-ES-001, Rev. 0, Westinghouse Hanford Company, Richland, Washington.

Beck, R. W., 1990, 300 Area Sanitary and Process Wastewater Study, R.W. Beck and Associates for the City of Richland, Washington.

Carlson, A. B., 1994, Solid Waste Program Technical Baseline Description, WHC-SD-WM-RPT-060, Rev. 0, Westinghouse Hanford Company, Richland, Washington.

Carlson, A. B., 1995, Solid Waste and Materials System Alternatives Study, WHC-SD-WM-ES-341, Rev. 0, Vol. 1-6, Westinghouse Hanford Company, Richland, Washington. 
HNF-SD-WM-RPT-288

Revision 0

Carrigan, M. C., 1991a, Engineering Study to Evaluate Need for Modifications to Liquid Effluent Retention Facility - LERF Basin Design, WHC-SD-W049H-ES-001, Rev. 0, Westinghouse Hanford Company, Richland, Washington.

Carrigan, M. C., 1991b, Final Letter Report 200 West Area Effluent Collection System Project $W-049 H$, WHC-SD-W049H-ES-002, Rev. 0, Westinghouse Hanford Company, Richland, Washington.

Carter, R. P., 1996, Managing Analytical Services in a Changing Environment, presented to Site Management Board, June, U.S. Department of Energy, Richland Operations Office, Richland, Washington.

CH2M Hill, 1993a, Engineering Summary Report - Hanford 300 Area Process Wastewater Discharge to the City of Richland POTW, CH2M Hill, Inc., Richland, Washington.

CH2M Hill, 1993b, Hanford 300 Area--Addendum Engineering Summary Report, CH2M Hill, Inc., Richland, Washington.

CH2M Hill and IT Corporation, 1994, Engineering Study of Management Options for 300 Area Noncontact Cooling Water, LLES-039, September, CH2M Hill, Inc. and IT Corporation, Richland, Washington.

Comprehensive Environmental Response, Compensation, and Liability Act of 1980 , 42 USC 9601, et seq.

Davis, J. D., 1992, Project W-049H Treated Effluent Disposal Alternatives Engineering Study, WHC-SD-W049H-ES-003, Rev. 0A, Westinghouse Hanford Company, Richland, Washington.

DOE, 1979, Final Environmental Impact Statement - Long Term Management of Defense High-Level Radioactive Waste, Savannah River Plant (Research and Development Program for Immobilization), DOE/EIS-0023, U.S. Department of Energy, Washington, D.C.

DOE, 1980a, Final Environmental Impact Statement - Management of Commercially Generated Radioactive Waste, DOE/EIS-0046F, U.S. Department of Energy, Washington, D.C.

DOE, 1980b, Final Environmental Impact Statement - Waste Isolation Pilot Plant, DOE/EIS-0026, U.S. Department of Energy, Washington, D.C.

DOE, 1982, Final Environmental Impact Statement - Defense Waste Processing Facility, Savannah River Plant, DOE/EIS-0082, U.S. Department of Energy, Washington, D.C. 
DOE, 1987a, Final Environmental Impact Statement - Disposal of Hanford Defense High-Level, Transuranic, and Tank Wastes, DOE/EIS-0113, U.S. Department of Energy, Washington, D.C.

DOE, 1987b, Radioactive Waste, By-Products Material Final Rule, 10 CFR 962, Federal Register, 52 FR 159397-1592, U.S. Department of Energy, Washington, D.C.

DOE, 1988, Disposal of Hanford Defense High-Level, Transuranic, and Tank Wastes, Hanford Site, Richland, Washington; Record of Decision, Federal Register V.53, No. 72, pp. 12449-12453, U.S. Department of Energy, Washington, D.C.

Ecology, EPA, and DOE, 1996, Hanford Federal Facility Agreement and Consent Order, as amended, Washington State Department of Ecology, U.S. Environmental Protection Agency, and U.S. Department of Energy, Olympia, Washington.

ERDA, 1975, Final Environmental Statement for Waste Management Operations - Hanford Reservation, ERDA-1538, U.S. Energy Research and Development Administration, Washington, D.C.

Federal Facility Compliance Act of 1992, 42 USC 6901, et seq.

Halgren, D. L., and J. D. Williams, 1992, Phase II Liquid Effluent Program (Project W-252) Wastewater Engineering Report and BAT/AKART Studies, WHC-SD-W252-ER-001, Rev. 0, Westinghouse Hanford Company, Richland, Washington.

Hatch, H. J., 1996, Integration of Hanford Analytical Services (Letter to Distribution, November 21), Fluor Daniel Hanford, Inc., Richland, Washington.

Lamberd, D. L., 1991, Strategy Assessment Project W100, Waste Receiving and Processing (WRAP) Module 2, WHC-SD-W100-ES-005, Rev. 0, Westinghouse Hanford Company, Richland, Washington.

Mattsson, C. G., 1996, Update to Hanford Site Analytical Services Projections (Letter to T. K. Teynor, U.S. Department of Energy, Richland, Washington, November 21) Fluor Daniel Hanford, Inc., Richland, Washington.

Mattsson, C. G., 1997, Cataloging of Site Analytical Services (Letter to T. K. Teynor, U.S. Department of Energy, Richland Office, February 27), Fluor Daniel Hanford, Inc., Richland, Washington.

McDonald, F. N., 1992, Project C-018H Waste Water Engineering Alternatives Treatment Report, WHC-SD-C018H-ER-001, Rev. 1, Westinghouse Hanford Company, Richland, Washington.

NAS, 1976, The Shallow Land Burial of Low-Level Radioactively Contaminated Solid Waste, National Academy of Sciences, Washington, D.C. 
HNF-SD-WM-RPT-288

Revision 0

National Environmental Policy Act of 1969, 42 USC 4321, et seq.

National Historic Preservation Act of 1966, 16 USC 410, et seq.

Nuclear Waste Policy Act of 1982, 42 USC 10101, et seq.

Olander, A. R., 1993, Value Engineering L-045 vs City of Richland Discharge Approach Final Report, WHC-SD-L045H-VES-001, Rev. 0, Westinghouse Hanford Company, Richland, Washington.

Pauly, T. R., 1990, Engineering Study for Waste Receiving and Processing (WRAP) Facility, Module 2, WHC-SD-W100-ES-001, Westinghouse Hanford Company, Richland, Washington.

Pedersen, K. S., 1992, Project W-291, Engineering Report for 200 Areas Effluent BAT/AKART Implementation, WHC-SD-W291-ER-001, Rev. 0, Westinghouse Hanford Company, Richland, Washington.

Resource Conservation and Recovery Act of 1976, 42 USC 6901, et seq.

RHO, 1985, Waste Receiving and Processing (WRAP) Facility Engineering Study, SD-RE-ES-017, Rockwell Hanford Operations, Richland, Washington.

Stordeur, R. T., 1994, Engineering Study of the 300 Area Process Wastewater Handling System, WHC-SD-WM-ER-277, Rev. 0, Westinghouse Hanford Company, Richland, Washington.

Toxic Substances Control Act of 1976, 15 USC 2601, et seq.

Wagoner, J. L., 1996a, Formation of Hanford Site Analytical Services Sample Management Working Group (Letter 96-ASP-007 to Dr. W. J. Madia, Pacific Northwest National Laboratory, and Dr. A. L. Trego, Westinghouse Hanford Company, April 19), U.S. Department of Energy, Richland Operations Office, Richland, Washington.

Wagoner, J. L., 1996b, Contract DE-AC06-93RL12367; Formation of Hanford Site Analytical Services Sample Management Working Group (Letter 96-ASP-008 to Mr. J. F. Nemec, Bechtel Hanford, Inc., April 5), U.S. Department of Energy, Richland Operations Office, Richland, Washington.

WHC-CM-5-4, Laboratories Administration, Westinghouse Hanford Company, Richland, Washington.

Willis, N. P., 1993, Hanford Site Solid Waste Acceptance Criteria, WHC-EP-0063-04, Westinghouse Hanford Company, Richland, Washington. 
HNF-SD-WM-RPT-288

Revision 0

WIPP, 1966, Waste Acceptance Criteria for the Waste Isolation Pilot Plant, WIPP/DOE-069, Rev. 5, Westinghouse Electric Corporation, Waste Isolation Pilot Plant, Carlsbad, New Mexico. 
HNF-SD-WM-RPT-288

Revision 0

\section{CONTENTS}

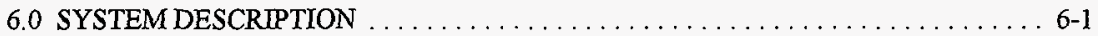

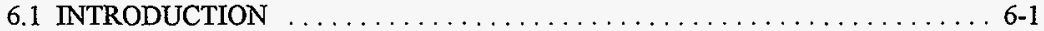

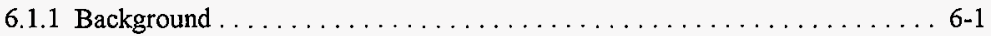

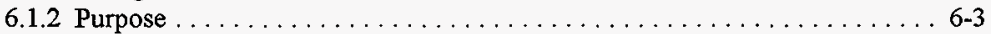

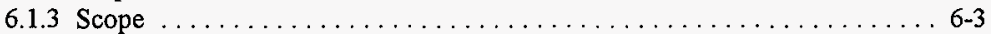

6.2 Solid Waste . . . . . . . . . . . . . . . . . . . . . . . . . . 6-4

6.2.1 Scope (Inventory and Forecasted Solid Waste Volumes) . . . . . . . . 6-4

6.2 .2 Process Flowsheet . . . . . . . . . . . . . . . . . . . . . . . . 6-9

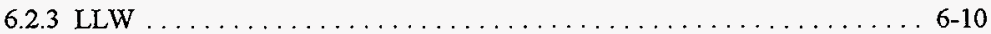

6.2 .4 MLLW . . . . . . . . . . . . . . . . . . . . . . . 6-16

6.2 .5 TRU(M) Waste . . . . . . . . . . . . . . . . . . . . . . 6-32

6.2 .6 Nonradioactive Hazardous Waste . . . . . . . . . . . . . . . . 6-45

6.2.7 Material not Categorized as Waste . . . . . . . . . . . . . . . . . 6-45

6.2 .8 Other Waste . . . . . . . . . . . . . . . . . . . . . . . . . 6-46

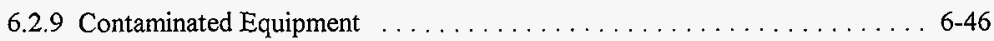

6.3 LIQUID WASTE $\ldots \ldots \ldots \ldots \ldots \ldots \ldots \ldots \ldots \ldots \ldots \ldots \ldots \ldots \ldots$

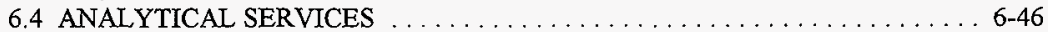

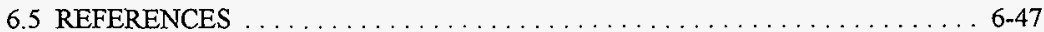


HNF-SD-WM-RPT-288

Revision 0

\section{LIST OF FIGURES}

6-1. Waste Management Project . . . . . . . . . . . . . . . . . . . . . . 6-5

6-2. Hanford Site Radioactive Solid Waste Current and Projected Inventory. . . . . . . . 6-8

6-3. Solid Waste Subproject Flow . . . . . . . . . . . . . . . . . . . . . . . . . . 6-11

6-4. Historical and Forecast Annual Solid Low-Level Waste Volumes. . . . . . . . . . . 6-15

6-5. Solid Waste Subproject LLW Flowsheet . . . . . . . . . . . . . . . . . . 6-17

6-6. Historical and Forecast Annual Solid Mixed Low-Level Waste Volumes . . . . . . . 6 6-21

6-7. Solid Waste Subproject MLLW Flowsheet .................... 6-23

6-8. Annual Capacity and Throughput of Contract-Handled Mixed Low-Level Waste for the Stabilization Treatment Program . . . . . . . . . . . . . . . . . . . 6-25

6-9. Annual Capacity and Throughput for the Future Remote-Handled/Large Container Facility . . . . . . . . . . . . . . . . . . . . . . . . . . . . . 6-27

6-10. Annual Capacity and Throughput of Contact-Handled Mixed Low-Level Waste for Commercial Thermal Treatment . . . . . . . . . . . . . . . . . . . . . . . . . . 6-29

6-11. Annual Storage Volumes and Capacities ..................... 6-31

6-12. Annual Mixed Low-Level Waste Disposal Volumes . . . . . . . . . . . . . . . . . . . . 6-33

6-13. Historical and Forecast Annual Solid Transuranic Waste Volumes . . . . . . . . . . 6-36

6-14. Solid Waste Subproject TRU Flowsheet . . . . . . . . . . . . . . . . 6-37

6-15a. Annual Waste Receiving and Processing Module 1 Transuranic Waste Throughput and Capacity ........................... 6-43

6-15b. Annual Waste Receiving and Processing Module 1 Low-Level Waste Throughput and Capacity 


\section{HNF-SD-WM-RPT-288}

Revision 0

\section{LIST OF TABLES}

6-1. Fraction of National U.S. Department of Energy Waste at the Hanford Site . . . . . . . 6-9 
HNF-SD-WM-RPT-288

Revision 0

\section{LIST OF TERMS}

CERCLA Comprehensive Environmental Response, Compensation, and Liability Act of 1980

$\mathrm{CH}$

CWC

contact-handled

DOE

Central Waste Complex

DOT

U.S. Department of Energy

U.S. Department of Transportation

Ecology

EPA

FY

GTCIII

HLW

LLW

M\&I

MLLW

PCB

Washington State Department of Ecology

U.S. Environmental Protection Agency

fiscal year

Greater Than Category III

high-level waste

low-level waste

Management and Integration

mixed low-level waste

polychlorinated biphenyl

PNNL

Project

RCRA

Pacific Northwest National Laboratory

Waste Management Project

RH

SWIFT

SWITS

SWPM

TRU

TRU(M)

Resource Conservation and Recovery Act of 1976

remote-handled

Solid Waste Information Forecast Tool

Solid Waste Information and Tracking System

Solid Waste Projection Model

transuranic

transuranic and transuranic mixed

TRUPACT

TWRS

WAC

WRAP

transuranic package transporter

Tank Waste Remediation System

waste acceptance criteria

Waste Receiving and Processing

WSCF

Waste Sampling and Characterization Facility 
HNF-SD-WM-RPT-288

Revision 0

\subsection{SYSTEM DESCRIPTION}

\subsection{INTRODUCTION}

This section describes the system the Waste Management Project (Project) has defined as its baseline approach for accomplishing its mission. The Project's system is defined in terms of the existing and forecast inventory within its scope, the facilities and projects that the Project has defined to accomplish its mission, and flowsheets that describe the flow of the various waste types through each facility and project.

\subsubsection{Background}

Before October 1, 1996, the Project existed as three separate programs independently managed at the Site: the Solid Waste Program, the Liquid Effluent Program, and the Analytical Services Program. With the transition to a Management and Integration (M\&I) Contractor at the Hanford Site, the three programs were consolidated as the Waste Management Project. In addition to these three former programs (referred to as subprojects), the management of Waste Minimization/Pollution Prevention, Environmental Monitoring, and Transportation \& Packaging also became part of the Waste Management Project. The following paragraphs will provide a brief background on each of the three major subprojects that make up the Project.

Solid Waste Subproject. The majority of the operating or planned solid waste management facilities are located in the 200 West Area, which is in the center of the Hanford Site. Radioactive and hazardous solid waste currently exists and will continue to be generated at many locations throughout the Hanford Site. Solid waste will also be generated and shipped from offsite waste generators.

The following solid waste types ${ }^{1}$ are managed by the Project at the Hanford Site:

\footnotetext{
'All categories of radioactive waste are further divided into two more categories dependent on surface dose rate of beta, gamma, and neutron radiation. These categories are "contact-handled" and "remote-handled. "Contact-handled packages are those with surface dose rates no greater than $100 \mathrm{mrem} / \mathrm{h}$ for newly generated TRU waste and stored LLW, and $200 \mathrm{mrem} / \mathrm{h}$ for directly buried LLW. Before 1992, the limits were the same for both waste types. The remote-handled category was implemented to segregate high-dose rate packages and minimize worker exposure.
} 
HNF-SD-WM-RPT-288

Revision 0

- Low-level waste (LLW) ${ }^{1}$, which is radioactive waste that has small amounts of radioactivity (less than $100 \mathrm{nCi} / \mathrm{g}$ ) from transuranic (TRU) elements and is not high-level waste $(\mathrm{HLW})$, spent nuclear fuel, or byproduct material

- TRU waste, which is radioactive waste contaminated with alpha-particle-emitting TRU radionuclides with half-life periods longer than 20 years and TRU emission rates greater than $100 \mathrm{nCi} / \mathrm{g}$

- Mixed waste, which is radioactive waste that is co-contaminated with dangerous waste as defined in Washington Administrative Code (WAC) 173-303, "Dangerous Waste Regulations." Washington is the administrator for the dangerous waste program because the state meets the requirements of the U.S. Environmental Protection Agency (EPA) hazardous waste program. Mixed waste may be either LLW or TRU waste.

- Hazardous waste, which is nonradioactive waste contaminated with dangerous constituents as defined in WAC 173-303.

These solid waste types are defined in detail in WHC-EP-0063-04, Hanford Site Solid Waste Acceptance Criteria (Willis 1994).

The Project uses solid waste databases for existing inventory and forecast waste and waste volume throughput modeling to aid in defining the Project's system.

Strict accounting requirements for radioactive and hazardous waste require tracking systems from generation to disposal. The Solid Waste Information and Tracking System (SWITS), maintained by the Project, tracks each container of waste received for storage or disposal at the Hanford Site with a unique identification number and records location, physical attributes (e.g., weight, volume), chemical characteristics (e.g., presence of dangerous constituents), radionuclides, and other information (e.g., hazard classifications). The database has more than 950,000 waste records dating from 1944 .

The Solid Waste Projection Model (SWPM) (Anderson and Konynenbelt 1995) was developed for Westinghouse Hanford Company by Pacific Northwest National Laboratory (PNNL) to provide detailed projections of future waste storage, treatment, and disposal needs. In addition, the SWPM performs process flow modeling of waste volumes (including volume changes) through future waste handling facilities. Volume forecasts, including waste type, class, and physical and chemical descriptions, are prepared annually by generators for the life cycle of

\footnotetext{
'Low-level waste is further classified according to radionuclide concentration into Category I, Category III, and Greater Than Category III. This system is similar to the U.S. Nuclear Regulatory Commission waste classification system found in 10 Code of Federal Regulations (CFR) 61, "Licensing Requirements for Land Disposal of Radioactive Waste." This categorization is adapted to fit isotopic and volume characteristics of Hanford Site waste. The higher the category number, the greater the activity and long-lived radionuclide concentration. This results in stricter disposal requirements. Small volumes of Category II waste at the Hanford Site led to an extension of the activity limits for Category III to envelope Category II.
} 
their facilities. The Solid Waste Information Forecast Tool (SWIFT) is the electronic tool that collects forecast waste information. The most recent summary of waste volume forecast data is presented in HNF-EP-0918, Solid Waste Integrated Forecast Technical (SWIFT) Report: FY 1997 to FY 2070 (Valero 1996).

Liquid Effluent Subproject. The majority of the facilities used for managing liquid waste are located in the 200 and 300 Areas. The waste types managed by the Liquid Effluent subproject include the following:

- Liquid tank waste that is concentrated and returned to the Tank Farms project

- Comprehensive Environmental Response, Compensation, and Liability Act of 1980 (CERCLA)- and Resource Conservation and Recovery Act of 1976 (RCRA)-regulated liquid effluents

- Non-listed/industrial liquid effluents

- Liquid LLW.

Analytical Services Subproject. The two primary facilities that provide analytical services to the Hanford Site include the 222-S Laboratory and the Waste Sampling and Characterization Facility (WSCF). These facilities provide $\mathrm{HLW}, \mathrm{LLW}$, and nonradioactive analytical services. Additionally, mobile in-field and commercial laboratory services are provided to the Hanford Site.

\subsubsection{Purpose}

This section provides a top-level description of the current direction of the Project in meeting its mission. This document supports planning and analysis of top-level inventory, functions, facilities, and projects within the Project that establish the baseline.

\subsubsection{Scope}

The Waste Management Project Technical Baseline Description compiles (1) the volume of existing and forecast radioactive solid waste, liquid waste, and analytical samples required at the Hanford Site; (2) Project facilities and projects identified to manage the radioactive solid waste and liquid waste and to provide analytical services; and (3) flowsheets that describe how the solid waste, liquid waste, and analytical services within the Project mission are managed. These three categories of information are combined to define the Project's technical system, which has been developed to meet its mission.

The system description aids the Project in defining its role in the overall Hanford Site cleanup mission. In addition, the flowsheets provide links between Project planning and the specific subprojects identified to meet the Project mission. 
Figure 6-1 graphically displays the interfaces of the three subprojects, or functions, that significantly make up the Project: Manage Solid Waste and Materials (Function X.1), Manage Liquid Waste (Function X.2), and Provide Analytical Services (Function X.4). Although other functions such as Minimize Waste Generation (Function X.3), Provide Transportation and Packaging (Function X.5), and Provide Environmental Monitoring (Function X.6) are considered primary functions, these functions are accomplished within the three significant functions shown in Figure 6-1.

Each of the three primary functions shown in Figure 6-1 is further developed in this document (see Sections 6.2, 6.3, and 6.4). For each primary function, the function's scope, process flowsheet, and managed product streams are discussed. Furthermore, for each product stream, the facilities that accomplish the function are described including annual throughputs, capacities, and specific facility descriptions.

\subsection{Solid Waste}

This section describes the Solid Waste system. This system has evolved to carry out the mission of the Solid Waste subproject: receive, store, treat, decontaminate, and dispose of solid radioactive and nonradioactive dangerous wastes in a safe, cost-effective, and environmentally compliant manner. The scope of the Solid Waste subproject is provided and includes the inventory and forecast solid waste that are or will be managed by the subproject. A process flowsheet is provided that specifically links the functions of the subproject to the specific facilities required to accomplish the mission of Solid Waste subproject.

This section also provides a detailed discussion of each waste type or material managed by the subproject. For each waste type or material (LLW, MLLW, TRU[M] waste, nonradioactive hazardous waste, material not categorized as waste, and contaminated equipment), the following are provided:

- Waste inventory and forecast

- A detailed process flowsheet

- The specific facilities required to manage each waste type or material.

Furthermore, annual throughputs for each of these facilities are provided.

\subsubsection{Scope (Inventory and Forecasted Solid Waste Volumes)}

This section summarizes existing and forecast life-cycle solid waste at the Hanford Site. The following waste types are included: 
Revision 0

Figure 6-1. Waste Management Project.

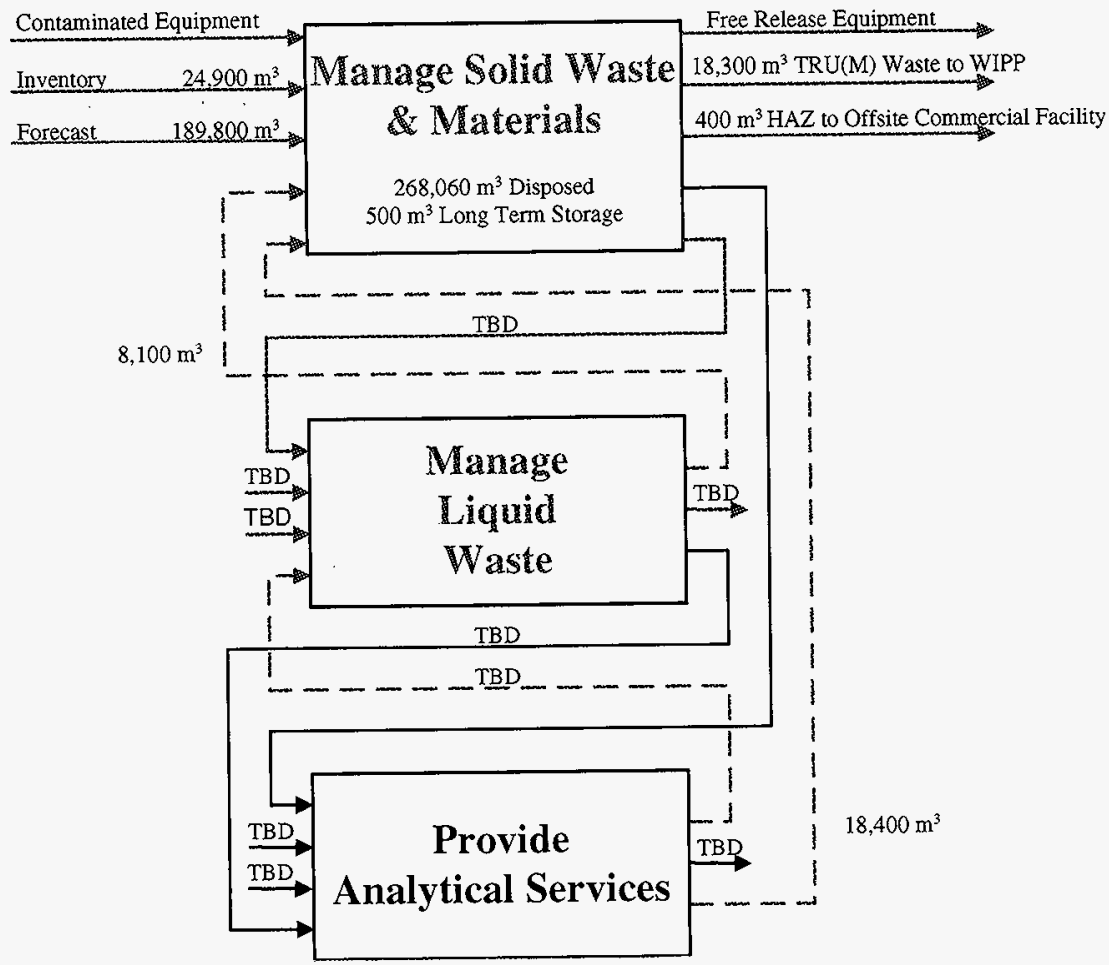


- LLW (by category depending on radionuclide activity: Category I, Category III, and Greater Than Category III [GTCIII])

- TRU waste

- Mixed low-level waste (MLLW) (mixed with hazardous components).

Hazardous solid waste is not specifically addressed in this section because of a recent change that involves the Project as the central administrator of a commercial contract for the physical collection point for hazardous waste generated by other projects on the Hanford Site. The current role allows for the Project to manage hazardous waste by contracting offsite services for the disposition of the waste and scheduling shipments of hazardous waste to the offsite vendor. The Project no longer performs verification or central site collection services for the Hanford Site. However, hazardous waste generated by the Project and hazardous liquid waste are managed by the Project.

Radioactive and hazardous waste originates from six major sources: (1) DOE-related activities, such as experimental reactors; (2) defense nuclear industry support; (3) institutions, such as universities, and research foundations; (4) industrial uses of radioisotopes; (5) mining and milling of uranium ore; and (6) the commercial fuel cycle. Hanford Site solid waste within the scope of this report is principally from the first three sources. The defense nuclear materials production and breeder reactor program produced radioactive waste from the first two sources.

The Hanford Site has always had the responsibility to manage waste produced within its boundaries. An arid climate and large land area make the Site suitable for land disposal of radioactive solid waste. Thus, since the 1950's the DOE has accepted radioactive waste from institutions with no waste disposal capabilities. Other waste sources are either not received by the Site or not considered within the scope of the Solid Waste subproject. Tank wastes, cesium and strontium capsules, production and power reactor fuel, and residual special nuclear material (e.g., enriched uranium) are not included in the scope. Solid waste from all expected sources is discussed in this report.

Figure 6-2 represents the existing inventory of solid waste at the Hanford Site. Waste in the environmental restoration mission area is included in Figure 6-2 to portray the entire inventory of existing solid waste buried at the Hanford Site.

Solid waste from environmental restoration work is included in the historical inventories. This represents the largest volume of waste encountered at the Hanford Site. A division of responsibility for handling this waste was recently established. This document assigns responsibility for characterization, retrieval, storage, treatment, and in-place disposal of environmental restoration waste to the Environmental Restoration Program. The Project will have disposal responsibility only for environmental restoration waste that is sent to the 200 Areas.

6.2.1.1 National Waste Inventories. Hanford Site wastes constitute major portions of the national DOE waste inventory. The integrated database prepared annually by Oak Ridge National 
Figure 6-2. Hanford Site Radioactive Solid Waste Current and Projected Inventory.

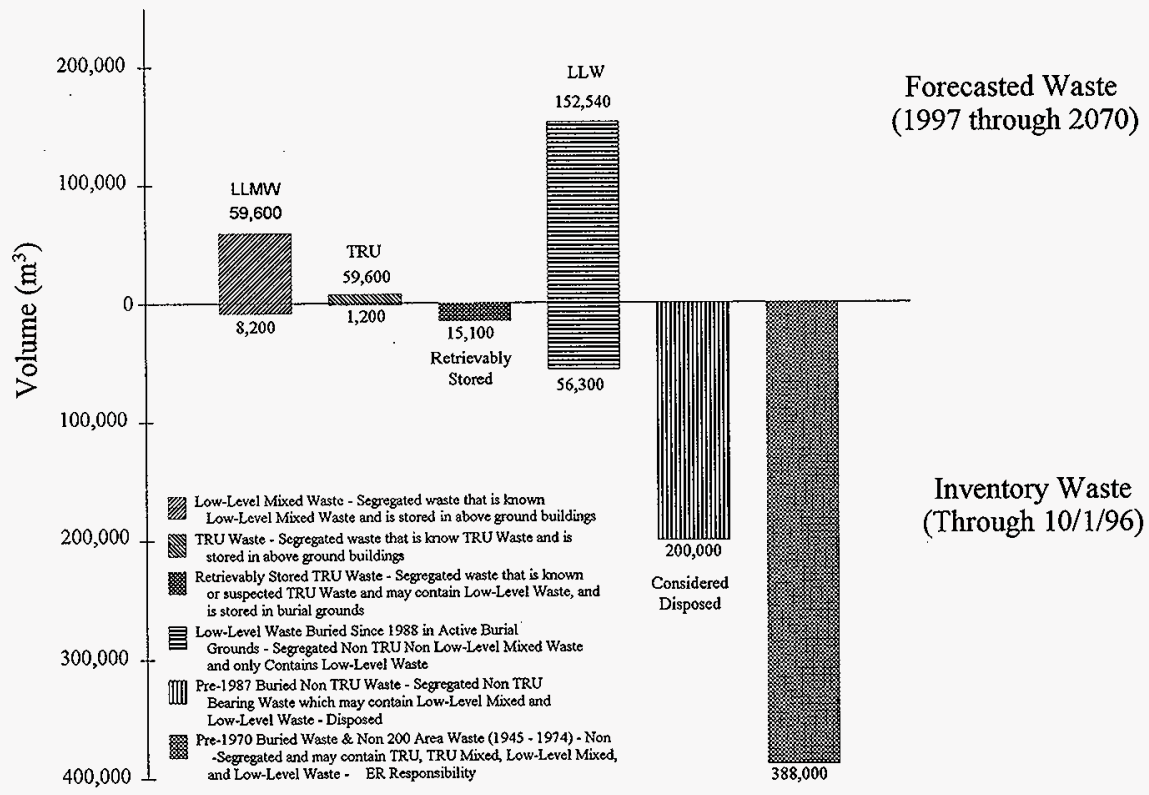


Laboratory (DOE 1996) is current only through calendar year (CY) 1995 and provides the percentages shown in Table 6-1.

The LLW in Table 6-1 is considered dispositioned. The TRU waste fraction is the stored and retrievably stored portion. No buried TRU (waste with TRU elements buried before initiation of the TRU designation in 1970) was included. The volumes in Table 6-1 do not include any environmental restoration-managed waste.

Table 6-1. Fraction of National U.S. Department of Energy Waste at the Hanford Site.

\begin{tabular}{|l|c|}
\hline \multicolumn{1}{|c|}{ Waste type } & $\begin{array}{c}\text { Nation's waste } \\
\text { onsite (\%) }\end{array}$ \\
\hline Low-level & 21 \\
\hline Transuranic & 13 \\
\hline Mixed low-level & 5 \\
\hline
\end{tabular}

Past shipments of waste to the Hanford Site have occurred from many offsite generators, including such diverse entities as the International Atomic Energy Agency in Seibersdorf, Austria, and Ceer University in Puerto Rico as well as DOE facilities such as Argonne National Laboratory.

\subsubsection{Process Flowsheet}

The flowsheet presented in Figure 6-3 identifies the projected direction of the current Solid Waste subproject. This direction is based on the current and forecast inventory of solid waste to be managed by the Project; the functions identified to properly manage this inventory; and the goals, objectives, requirements, assumptions, and definitions that govern management of this waste. The flowsheet offers a clear and concise understanding of the solid waste mission by connecting functions through waste stream paths and providing an overall volumetric flow associated with each type of waste. Thus the reader gains an appreciation for the magnitude of waste that will be handled by each function and the projected interaction of the functions.

The flowsheet is divided into four top-level program categories: waste streams, storage, treatment/processing, and disposal. The waste categories covered in the flowsheet are TRU, MLLW, and LLW. Each of these waste categories is divided into existing inventory and forecast waste for the life cycle of the Site (FYs 1997 through 2070) later in this section. The TRU waste inventory includes all contact-handled (CH) and $\mathrm{RH}$, mixed and non-mixed TRU inventory. The 
MLLW inventory includes all $\mathrm{CH}$ and $\mathrm{RH}$, Category $\mathrm{I}$, and Category III MLLW. The LLW inventory includes $\mathrm{CH}$ and $\mathrm{RH}$, Category I, and Category III LLW. Greater-Than-Category III (GTCIII) waste has not been included in the flowsheet because there is currently no defined pathway. Furthermore the waste from the 324 Building Radiochemical Engineering Cells requiring special interim storage is not included because it has no defined pathway as yet.

\subsubsection{LLW}

This waste type consists of the following:

- Trash from operating facilities

- Failed equipment

- Organic debris (e.g., tumbleweeds)

- Other materials with low levels of radioactive contamination

- Ion-exchange resins

- Asbestos

- Classified waste packages

- Contaminated heavy equipment (e.g., cranes, grade-alls)

- Various process equipment (e.g., piping, valves)

- Laboratory waste

- Hot cell waste

- Miscellaneous contaminated items (e.g., paper, rubber, plastic, and glass)

- Soil.

Packages that have been used to dispose of waste include self-contained items, plastic wrap, cardboard boxes, 208-L drums, large metal boxes, concrete casks, and composite material containers. Recent criteria preclude using waste packages that degrade and cause backfill subsidence, such as cardboard boxes. The larger packages to date include the Shippingport Pressurized Water Reactor Core II blanket fuel rod vessel and the steam generator from the nuclear power plant in Surrey, Virginia. Before CY 1992, disposed-of LLW was not divided into the categories of Category I LLW and Category III LLW because these classifications were not implemented until 1992.

Typically, LLW is buried in unlined trenches at the Hanford Site. A final strategy for Category III LLW management requires completion of a performance assessment to verify acceptability of disposal practices; currently, a performance assessment has been completed for the 200 West Area and conditionally accepted by the DOE. A draft performance assessment is near completion for the 200 East Area. Management practices (identified in the 200 West Area performance assessment) for Category III LLW include segregation and disposal in a stabilized waste form or a high-integrity container. Currently, individual containers of GTCIII LLW can be 


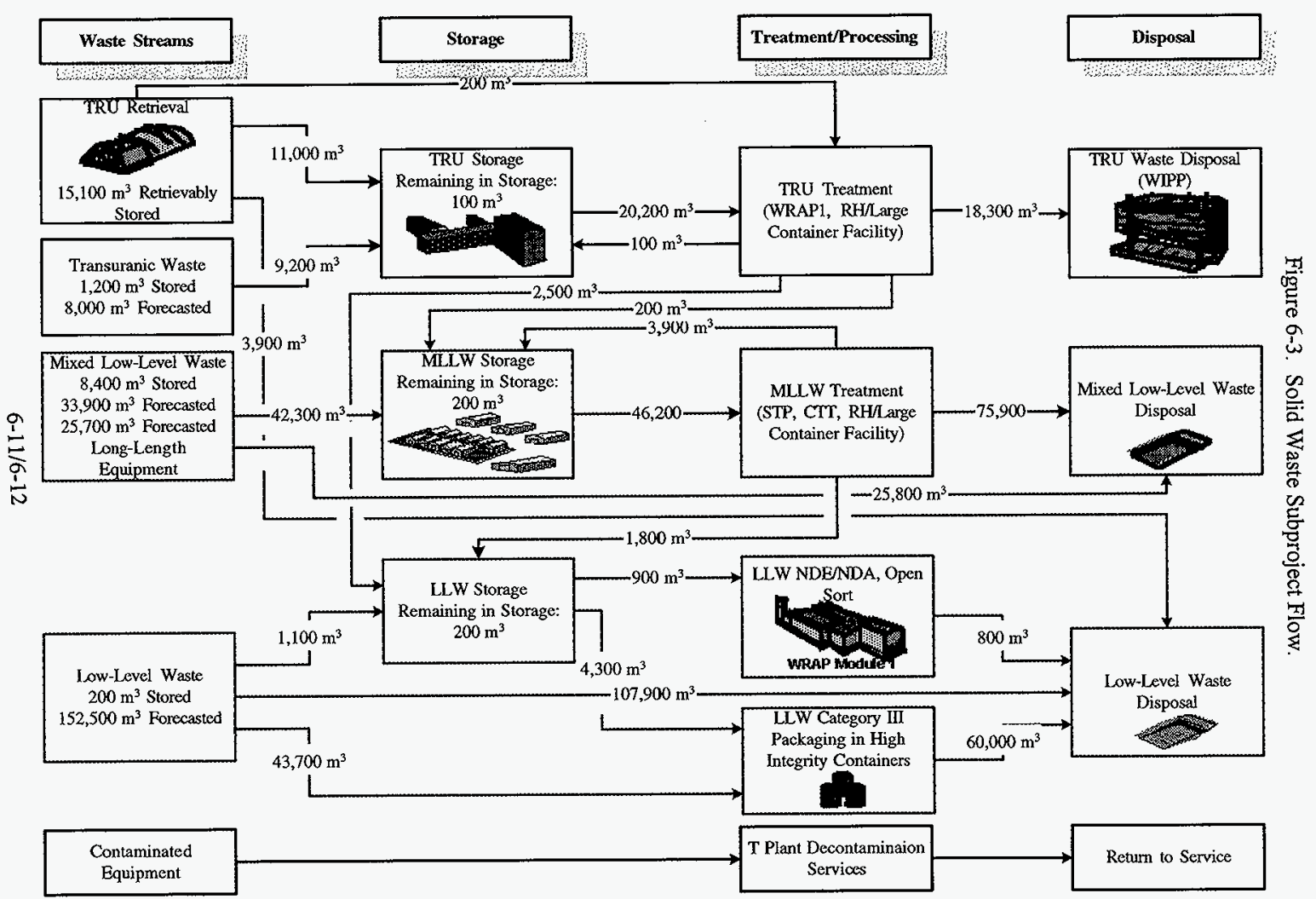


disposed of in trenches with justification. Waste that is defined as Greater Than Class C (GTCC) waste according to the calculation methods defined in 10 CFR 61 cannot be disposed of; it must be stored until an acceptable disposal method is determined and documented.

Since 1943, LLW has been disposed of in direct shallow land burial in the 100, 200,300, and 600 Areas of the Hanford Site. The 100 Area has 29 burial grounds, which have been inactive since 1973. The 200 Areas have 43 active and inactive burial grounds and buildings where LLW (including MLLW) is either disposed of or stored. The project is responsible for the disposal and management of eight active burial grounds in the 200 Area. Summary of Radioactive Solid Waste Received in the 200 Areas During Calendar Year 1994 (Anderson and Hagel 1995) summarizes all radioactive solid waste in the 200 Areas.

The LLW and TRU waste were not separated in the Hanford Site burial grounds until May 1, 1970, with the issuance of the U.S. Atomic Energy Commission Immediate Action Directive 0511-21 (AEC HQ 1970). Before that date, all solid waste was disposed of in shallow trenches. No distinction was made between LLW and MLLW before November 23, 1987, when Washington State received authorization to regulate the dangerous waste component of mixed waste. After November 23, 1987, mixed waste was stored in aboveground buildings that meet RCRA requirements. All radioactive waste buried before November 23, 1987, is considered to be properly dispositioned. Trenches containing such waste will be closed and monitored according to applicable regulations.

6.2.3.1 LLW Inventory. A total of $258,000 \mathrm{~m}^{3}$ of LLW had been buried in the active burial grounds managed by the Project from January 1988 through September 30, 1996 (218-E-10, 218-E-12B, 218-W-3A, 218-W-3AE, 218-W-4B, 218-W-4C, 218-W-5, and 218-W-6). Approximately $200,000 \mathrm{~m}^{3}$ of this LLW were buried before the November 23, 1987, designation of MLLW by the Washington State Department of Ecology (Ecology) (Anderson 1989), while the remaining $58,000 \mathrm{~m}^{3}$ of LLW have been buried since 1988 in the 8 active burial grounds. This volume does not include the following two types of waste:

- Waste consisting of defueled submarine reactor compartment sections $\left(47,873 \mathrm{~m}^{3}\right)$ containing lead as a hazardous constituent and Toxic Substances Control Act of 1976 (TSCA)-regulated polychlorinated biphenyls (PCB)-The compartments have been treated by encapsulation and are thus considered dispositioned and will not require further treatment. An exemption request from the liner/leachate collection and removal system will be approved by Ecology on issuance of the Part B permit for the disposal of reactor compartments in Trench 94 of Burial Ground 218-E-12B.

- Approximately $1 \mathrm{~m}^{3}$ of GTCIII LLW that is stored pending national decisions necessary to permanently dispose of such waste.

In addition, approximately $143,000 \mathrm{~m}^{3}$ (Anderson 1992) of unsegregated waste were buried in the 200 Area inactive burial grounds before 1970. The waste disposed in the currently inactive 
burial grounds is managed by the Environmental Restoration Contractor. The Environmental Restoration Contractor manages $245,000 \mathrm{~m}^{3}$ of unsegregated waste (Anderson 1992, DOE 1991) outside the 200 Area $(100,300$, and 600 Areas) that was buried from 1944-74.

6.2.3.2 Forecasted LLW. During the life cycle, approximately $152,540 \mathrm{~m}^{3}$ of LLW are forecast to come from onsite generators $\left(106,020 \mathrm{~m}^{3}\right)$ and offsite generators $\left(46,520 \mathrm{~m}^{3}\right)$. This waste falls into the following categories.

- $71 \%$ is CH LLW (Category I).

- $23 \%$ is CH LLW (Category III).

- $6 \%$ is distributed among other LLW classes (RH LLW [Category I], RH LLW [Category III]).

The physical waste forms that are forecast for the LLW are as follows:

- $93 \%$ debris

- $4 \%$ inorganic homogeneous solids

- $3 \%$ other physical characteristics.

A waste stream that has not been included in the preceding forecast volumes is a product of TRU retrieval operations. Retrieval of the stored TRU waste will result in redesignation of suspect-TRU waste as LLW. Approximately $50 \%$ of the suspected TRU waste in drums is expected to become LLW after an assay of the suspected containers. Processing of the suspectTRU waste in boxes is expected to result in a volume of LLW approximately $25 \%$ of the processed waste. This is mainly because of the change in the activity limit for TRU waste from $10 \mathrm{nCi} / \mathrm{g}$ to $100 \mathrm{nCi} / \mathrm{g}$ for segregating TRU waste from LLW after 12 years of accumulation at the lower limit and the lack early on of accurate assay equipment to determine the TRU content of the containers.

The types of containers forecast for shipment of the LLW are as follows:

- $52 \%$ in Metal Box V (MB-V)

- $12 \%$ in $208-\mathrm{L}$ drums

- $12 \%$ in small boxes

- $24 \%$ in other containers.

Figure 6-4 displays the annual receipts of LLW from 1945 through 1996 at the Hanford Site obtained from the SWITS database. The LLW disposal began in 1943. The LLW volume shows a significant spike in 1969. This corresponds to the addition of the 300 Area burial grounds as a unit to the database. Figure 6-4 also shows the forecast volumes from 1997 through 2070 obtained from HNF-EP-0918, Solid Waste Integrated Forecast Technical (SWIFT) Report: FY 1997 to FY 2070 (Valero 1996). 
Revision 0

Figure 6-4. Historical and Forecast Annual Solid Low-Level Waste Volumes.

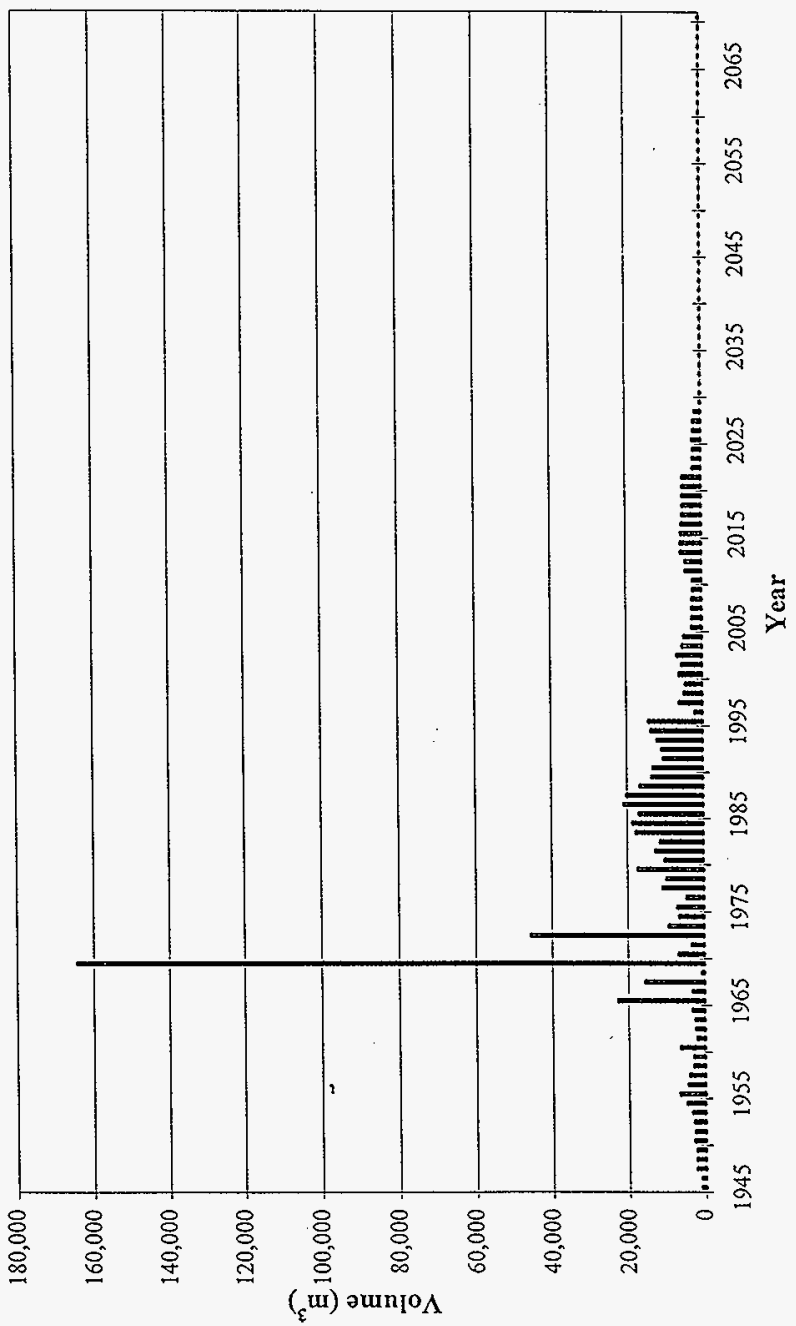


6.2.3.3 LLW Process Flowsheet. Figure 6-5 displays the flow of LLW through the Solid Waste subproject. The existing inventory of LLW is $200 \mathrm{~m}^{3}$ of stored waste that are not in a form suitable for disposal. The forecasted $152,540 \mathrm{~m}^{3}$ of LLW include $108,900 \mathrm{~m}^{3}$ of Category I and $43,700 \mathrm{~m}^{3}$ of Category III. No GTCIII LLW is currently forecast from FYs 1997 to 2070 . Five percent of CH LLW Category I receipts in drums $\left(900 \mathrm{~m}^{3}\right)$ will be shipped to Waste Receiving and Processing Module 1 (WRAP 1) for certification. WRAP 1 will process and verify this waste. Processing will reduce the waste volume to $800 \mathrm{~m}^{3}$. After processing and verification, waste will be sent to the LLW burial grounds for disposal. The remaining $107,900 \mathrm{~m}^{3}$ of Category I LLW will be directly disposed of in the LLW burial grounds.

The $43,700 \mathrm{~m}^{3}$ of forecasted Category III waste will be disposed of as LLW on the Hanford Site. In addition, $4,300 \mathrm{~m}^{3}$ of Category III waste from M-33/M-91 processing will require disposal. Category III LLW is placed in high-integrity containers for stabilization before disposal. Placement in the high-integrity containers is assumed to result in a net increase in volume of $25 \%$. This will result in $60,000 \mathrm{~m}^{3}$ of Category III waste being disposed in the LLW burial grounds. In addition, reclassification of suspect-TRU CH waste in drums is expected to result in $3,900 \mathrm{~m}^{3}$ of disposed-of CH Category III LLW.

The $200 \mathrm{~m}^{3}$ of $\mathrm{LLW}$ in storage will remain in long-term storage until direction regarding its disposition is determined.

6.2.3.4 Facilities and Projects to Accomplish LLW Disposition. The primary facility required for disposition of solid LLW is the LLW burial ground. Although a minimal amount of LLW will be in storage at CWC and some will need to be verified in WRAP. The WRAP facility is discussed with the TRU(M) waste in Section 6.2.5.

6.2.4.3.1 LLW Burial Grounds. The LLW burial grounds provide disposal capability for Category I and Category III LLW.

The following design assumptions are specific to the LLW burial grounds.

- The Program currently disposes of Category I and Category III LLW in burial grounds in the 200 Areas.

- The capacity of the disposal system can accommodate all forecast Category I and Category III LLW.

\subsubsection{MLLW}

On May 18, 1987, the DOE issued a rule under the Atomic Energy Act of 1954 clarifying the DOE's obligations under RCRA. As a result, all DOE radioactive waste contaminated with hazardous waste under RCRA is termed mixed waste and is subject to regulation by the DOE and the WAC. This created categories of waste that require separate waste management disposition and segregation. WAC 173-303-070 outlines the procedure for determining if a radioactive solid 


\section{Revision 0}

Figure 6-5. Solid Waste Subproject LLW Flowsheet.

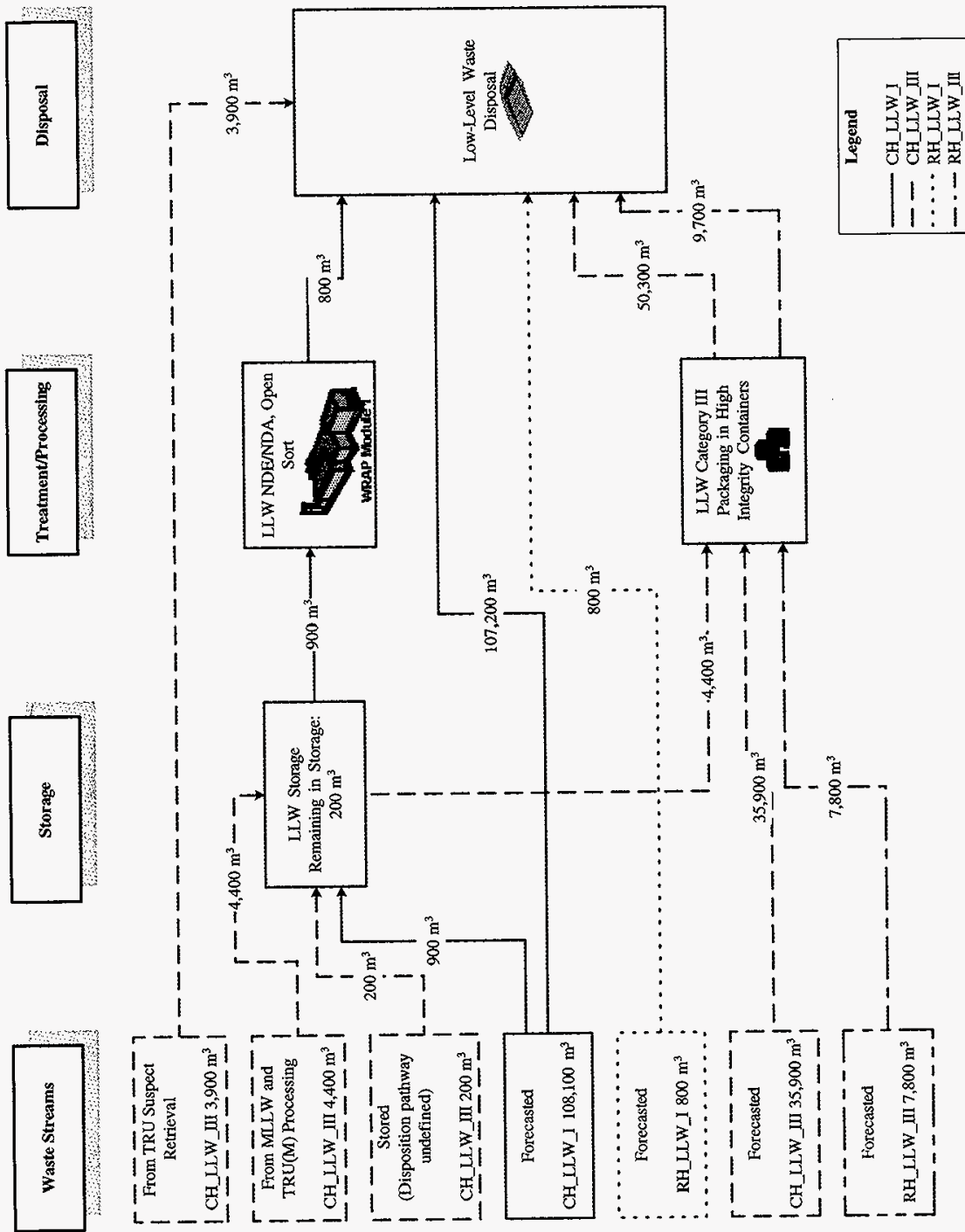


waste is a mixed waste. Briefly, waste is designated mixed if constituent(s) from one or more "Dangerous Waste" lists are present above a specific concentration threshold or if the waste exhibits certain characteristics, such as ignitability or corrosivity.

In 1987 , the Hanford Site began to store waste that exhibited both radioactive and hazardous characteristics in aboveground facilities. In January 1988, an agreement with Ecology stipulated that mixed waste with a dose rate of less than $200 \mathrm{mrem} / \mathrm{h}$ would be stored in a building that meets all the Washington State storage requirements. Mixed waste with greater than $200 \mathrm{mrem} / \mathrm{h}$ (RH) would be disposed of below ground to satisfy as low as reasonably achievable radiation safety requirements, assuming successful waiver applications.

6.2.4.1 MLLW Inventory. As of September 30, 1996, the inventory of stored MLLW is $8,430 \mathrm{~m}^{3}$. The MLLW is stored primarily in aboveground buildings and modules in the Central Waste Complex (CWC) in the 200 Areas.

A large portion of the stored MLLW, approximately $3,400 \mathrm{~m}^{3}$, is cleanup waste received from the 183-H Basin. The four 183-H basins were used from 1973 through 1985 for solar evaporation of neutralized acid etch solutions from $\mathrm{N}$ Reactor fuel fabrication activities. The waste includes solidified 183-H Basin liquids, crystalline 183-H Basin solids, 183-H Basin sludge waste, and miscellaneous $183-\mathrm{H}$ Basin waste. The waste contains primarily salts with some heavy metals. In general, the radionuclides that contaminate the waste are technetium, neptunium, and uranium.

6.2.4.2 Forecasted MLLW. Approximately $59,660 \mathrm{~m}^{3}$ of MLLW are expected to be received at the Project from onsite generators $\left(59,460 \mathrm{~m}^{3}\right)$ and offsite generators $\left(200 \mathrm{~m}^{3}\right)$ during the life cycle of the Hanford Site. The MLLW is expected to fall into the following categories:

- $51 \% \mathrm{CH}$ MLLW (Categories I and III)

- $49 \%$ RH MLLW (Categories I and III).

The forecast MLLW physical waste forms are as follows:

- $89 \%$ debris waste

- $11 \%$ other physical waste forms.

The containers forecast for shipping MLLW are as follows:

- $43 \%$ in long-length equipment containers

- $37 \%$ in $208-\mathrm{L}$ drums

- $20 \%$ in other container types.

The long-length equipment containers are forecast by the tank farms. The exact use and specific dimensions for these containers are currently unresolved. Engineering studies are being conducted to determine the unique dimensions required to safely package the retrieved tank farm 
long-length equipment. It is assumed that once the long-length equipment containers are received by the Project, they will be directly disposed of in the MLLW trenches because treatment will be handled by the Tank Waste Remediation System (TWRS) Project.

Approximately $58 \%$ of the MLLW is expected to be contaminated with Ecology-coded contaminants. Twenty-two percent of the hazardous constituents are expected to be organics. The remaining $20 \%$ of the MLLW will be contaminated with other hazardous constituents that may include combinations of the previously mentioned hazardous constituents.

Figure 6-6 displays the annual receipts of MLLW from 1987 through 1996. Figure 6-6 also includes the forecast volumes from 1997 through 2070 (Valero 1996). The peak in 1994 is the result of unexpected backlog waste receipts from the TWRS Project.

6.2.4.3 MLLW Flowsheet. Figure 6-7 shows the flow of MLLW through the Solid Waste subproject. The existing inventory of MLLW consists of $8,430 \mathrm{~m}^{3}$ of waste exhibiting one or more characteristics and/or containing one or more listed constituents of dangerous waste. In addition, 59,660 $\mathrm{m}^{3}$ of MLLW are forecast to be generated from FY 1997 through FY 2070.

Existing and forecast CH MLLW to be treated via the MLLW stabilization treatment program is $33,900 \mathrm{~m}^{3}$, which includes $240 \mathrm{~m}^{3}$ resulting from processing of retrievably stored TRU waste and lead shielding. Treatment via stabilization will result in a doubling of the waste volumes to be disposed of to $67,800 \mathrm{~m}^{3}$.

Combined existing and forecast CH MLLW to be thermally treated is $3,300 \mathrm{~m}^{3}$. Of this volume, $3,200 \mathrm{~m}^{3}$ will be sent directly to thermal treatment from storage and $100 \mathrm{~m}^{3}$ will come from processing retrievably stored TRU waste in the M-91 facility (formerly M-33 facility) and WRAP 1. Waste treated under the Commercial Thermal Treatment contract will have the same volume as before treatment because of the immobilization medium used to stabilize the ash for final disposal. The immobilized material $\left(3,700 \mathrm{~m}^{3}\right)$ from thermal treatment will be sent directly to the MLLW disposal site.

The M-33/M-91 Facility will process $5,500 \mathrm{~m}^{3}$ of $\mathrm{CH}$ waste in large boxes and $3,500 \mathrm{~m}^{3}$ of RH waste. The $\mathrm{CH}$ waste results in $3,800 \mathrm{~m}^{3}$ of MLLW that is sent to the stabilization treatment program and $1,100 \mathrm{~m}^{3}$ of LLW. The $3,500 \mathrm{~m}^{3}$ of RH waste will produce $4,600 \mathrm{~m}^{3}$ of RH MLLW and $700 \mathrm{~m}^{3}$ of LLW after size reduction and processing.

Long-length contaminated equipment $\left(25,700 \mathrm{~m}^{3}\right)$ received from the tank farms will be disposed of directly in the mixed waste trench because it is assumed to be treated by the TWRS Project.

The total volume of MLLW requiring disposal is $101,600 \mathrm{~m}^{3}$, consisting of $67,800 \mathrm{~m}^{3}$ from CH MLLW stabilization, $3,300 \mathrm{~m}^{3}$ from $\mathrm{CH}$ thermal treatment, $25,800 \mathrm{~m}^{3}$ from directly disposed-of long-length equipment and disposal-ready waste, and $4,600 \mathrm{~m}^{3}$ of RH waste from the M-33/M-91 Facility. 


\section{HNF-SD-WM-RPT-288 \\ Revision 0}

Figure 6-6. Historical and Forecast Annual Solid Mixed Low-Level Waste Volumes.

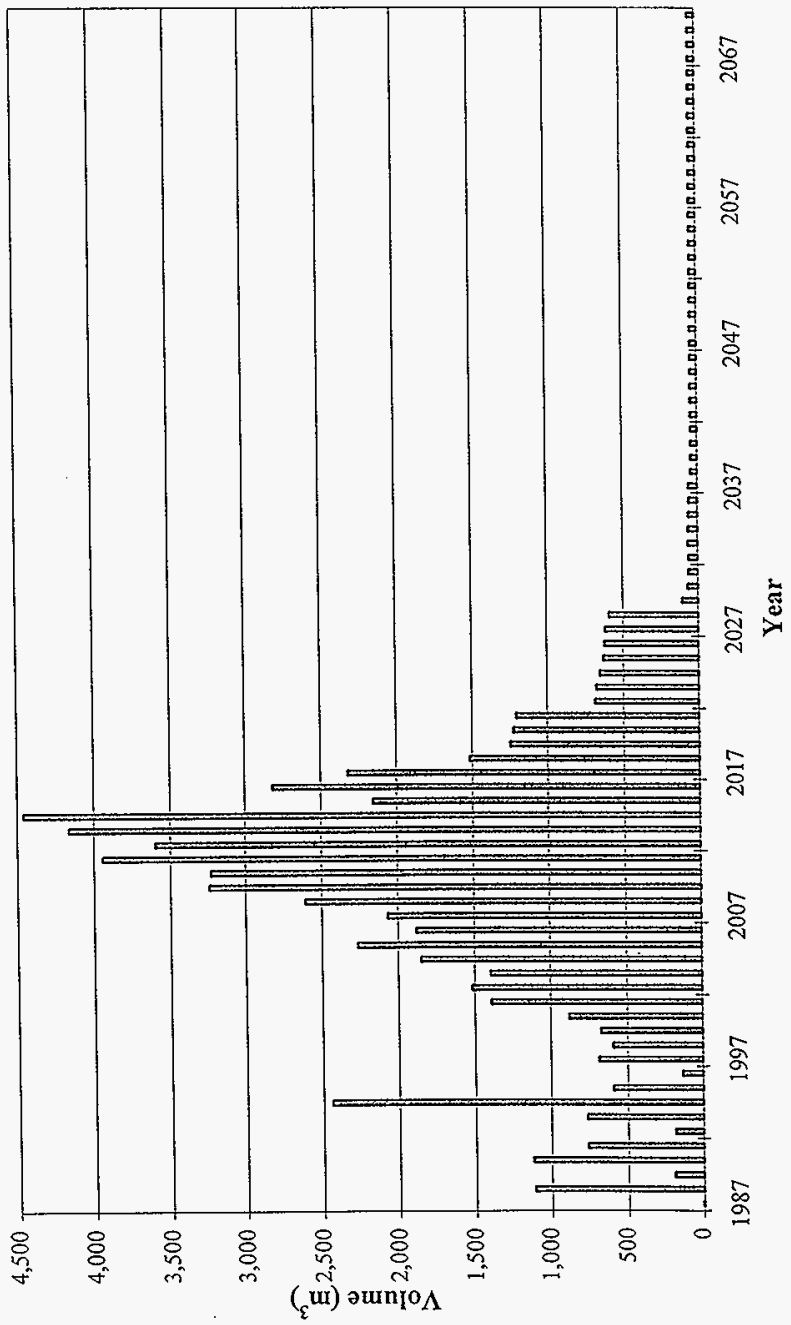


6.2.4.4 Facilities and Projects to Accomplish MLLW Disposition. The Solid Waste subproject has several existing and planned facilities that will be used for final disposition of MLLW. These facilities include storage operations in the CWC; treatment in the MLLW Stabilization Treatment Program (STP), the M-33/M-91 Facility, and in the Commercial Thermal Treatment (CTT) Facility; and disposal in the mixed-waste trenches. The following sections briefly describe, and provide an annual throughput for, each facility.

\subsection{MLLW Stabilization Treatment Program (Formerly Project W-100,} WRAP Module 2A). On May 18, 1987, the DOE issued an interpretive rule under the Atomic Energy Act of 1954 clarifying DOE obligations under RCRA, which is promulgated in Washington State by WAC 173-303, "Dangerous Waste Regulations." As a result, all LLW contaminated with dangerous waste under the Washington Administrative Code is termed MLLW and subject to regulation by the $\mathrm{DOE}$ and Washington State. This MLLW requires separate waste management, disposition, and segregation (Duncan 1991).

The MLLW Stabilization Treatment Program has been put into place to provide treatment for existing and future-generated CH MLLW that does not require thermal treatment. This program replaces treatment activities originally designated for the WRAP 2A Facility, which was terminated during Title I design in December 1994. Termination was justified mostly because the DOE was looking for less expensive alternatives to treating the waste, mainly reducing up-front capital expenditures. The following design assumptions are specific to the MLLW Stabilization Treatment Program.

- The treated waste will meet the waste acceptance criteria (WAC) for disposal of mixed waste.

- The program will provide treatment for Hanford Site RCRA-defined solid wastes determined to be $\mathrm{CH}$ non-thermally treatable MLLW.

- Operations are assumed to begin by FY 1999.

- Waste forms expected for treatment include ion-exchange resin, sludges, soils, dry particulate, debris, dry active waste, metals, glass, and materials absorbed in an immobilization matrix (Kruger 1994).

- A total of $33,900 \mathrm{~m}^{3}$ of MLLW are expected to be treated under the program through FY 2070. Figure 6-8 displays the annual throughputs of MLLW and the annual capacity.

- The program will have three treatment options: direct disposal, onsite treatment, and commercial treatment.

Direct Disposal. Pursue regulatory strategies/positions allowing for direct disposal of some mixed waste that was previously identified as requiring treatment. This is to be done through 
HNF-SD-WM-RPT-288

Revision 0

Figure 6-7. Solid Waste Subproject MLLW Flowsheet.

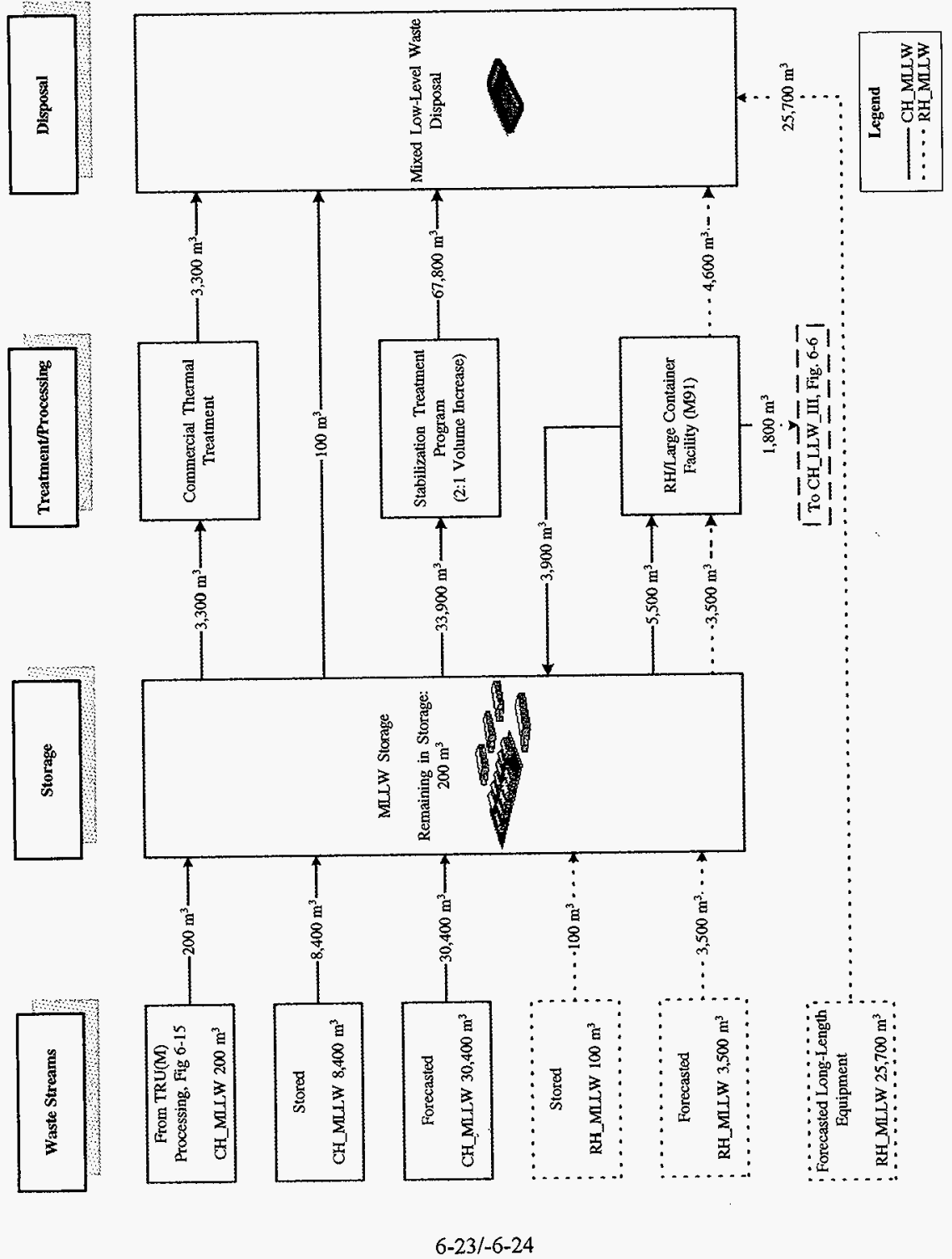




\section{HNF-SD-WM-RPT-288 \\ Revision 0}

Figure 6-8. Annual Capacity and Throughput of Contract-Handled Mixed Low-Level Waste for the Stabilization Treatment Program.

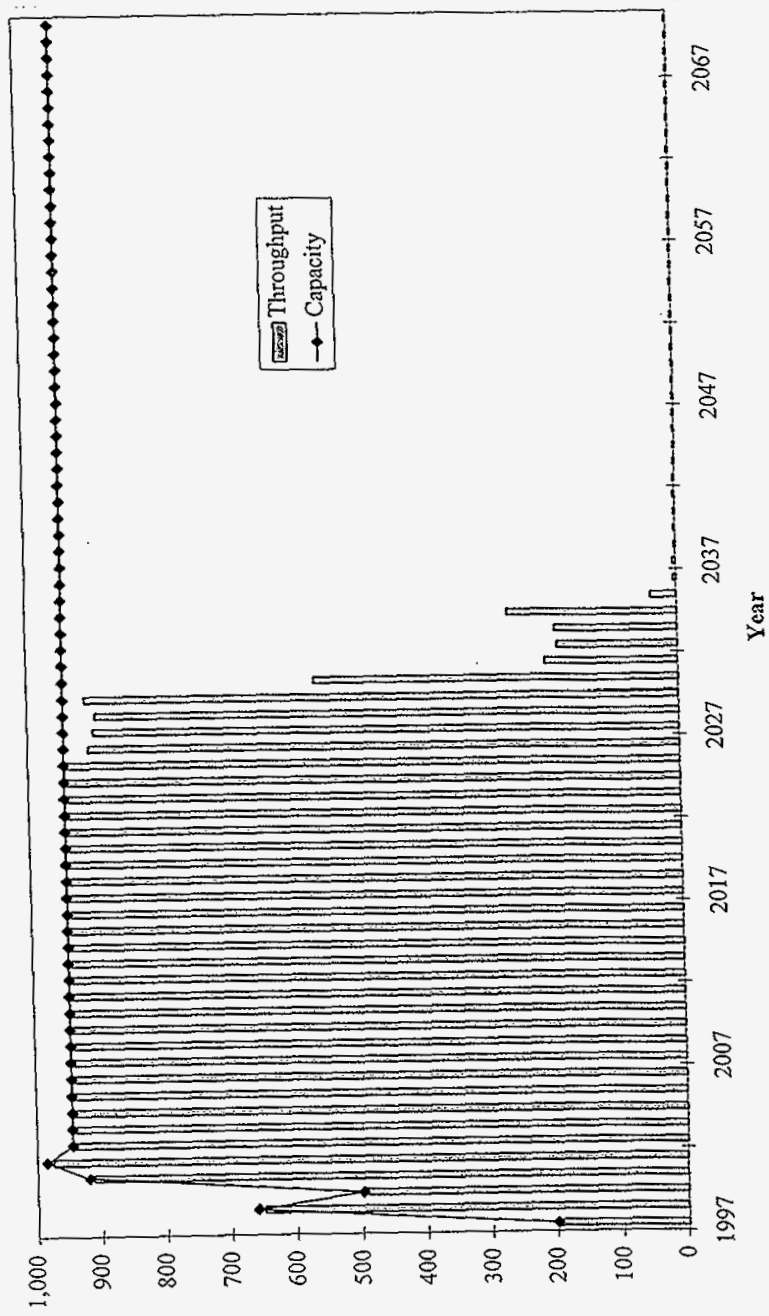

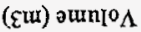


treatment variances/equivalent treatment, verifying waste currently meets land disposal restrictions, and/or petition acceptance of existing treatment performed on some waste (RL 1995).

Onsite Treatment. Provide the capability to treat some mixed waste at the Hanford Site facility. Logic for selecting the type of treatment and the waste streams to be treated on site is as follows: waste requiring substantial further characterization or treatment-lot sorting should be considered for onsite treatment (e.g., lab packs); capital expenditures for treatment should be minimal (e.g., debris macroencapsulation); and/or small-volume waste streams should be treated on site (Baker 1995).

Commercial Treatment. Procure commercial stabilization treatment services to treat mixed waste in accordance with RCRA, Washington Administrative Code, and the Hanford Site's performance assessment disposal requirements. Treatment is to begin no later than September 30,1999 , and have a minimum capability to treat up to $820 \mathrm{~m}^{3} /$ year (original WRAP 2A throughput). Current planning assumptions call for treatment beginning in FY 1998 at a rate of $1,475 \mathrm{~m}^{3} /$ year.

6.2.4.4.2 Tri-Party Agreement Milestones M-33 and M-91. The fourth amendment to the Tri-Party Agreement (Ecology et al. 1994) defined a new milestone, M-33-00. Milestone M-33 looks at the integration of storage, treatment, and disposal needs for a wide range of solid waste and materials. Milestone M-91 was established in 1996 to deal specifically with solid waste issues. Currently, a transition from Milestone M-33 to Milestone M-91 is taking place; the transition is noted as M-33/M-91 in this document. These waste and materials were generated from past operations on the Hanford Site as well as from ongoing and planned activities, mostly associated with the cleanup of the Hanford Site. Of particular interest bas been the management of highly radioactive $(\mathrm{RH})$ waste and oversize radioactive solid waste because such materials have special handling requirements. Previous Site planning for disposition of RH waste and other solid waste and materials that are difficult to handle was based on the design and construction of a new facility known as WRAP 2B. The facilities defined through Milestone M-33/M-91 replace the WRAP 2B Facility by looking at integrated storage and treatment needs at the Hanford Site. Additional milestones defining facilities and schedules will be defined in the future.

For planning purposes, the following design assumptions are specific to the Tri-Party Agreement Milestone M-33/M-91-defined processing facilities.

- TRU processing will take place in a separate train or in separate campaigns from MLLW processing to avoid cross-contamination of waste. Figure 6-9 shows the annual throughputs and capacity restraints currently assumed. MLLW processing is assumed to begin in FY 2003, followed by TRU in FY 2005. 


\section{HNF-SD-WM-RPT-288}

Revision 0

Figure 6-9. Annual Capacity and Throughput for the Future Remote-Handled/Large Container Facility.

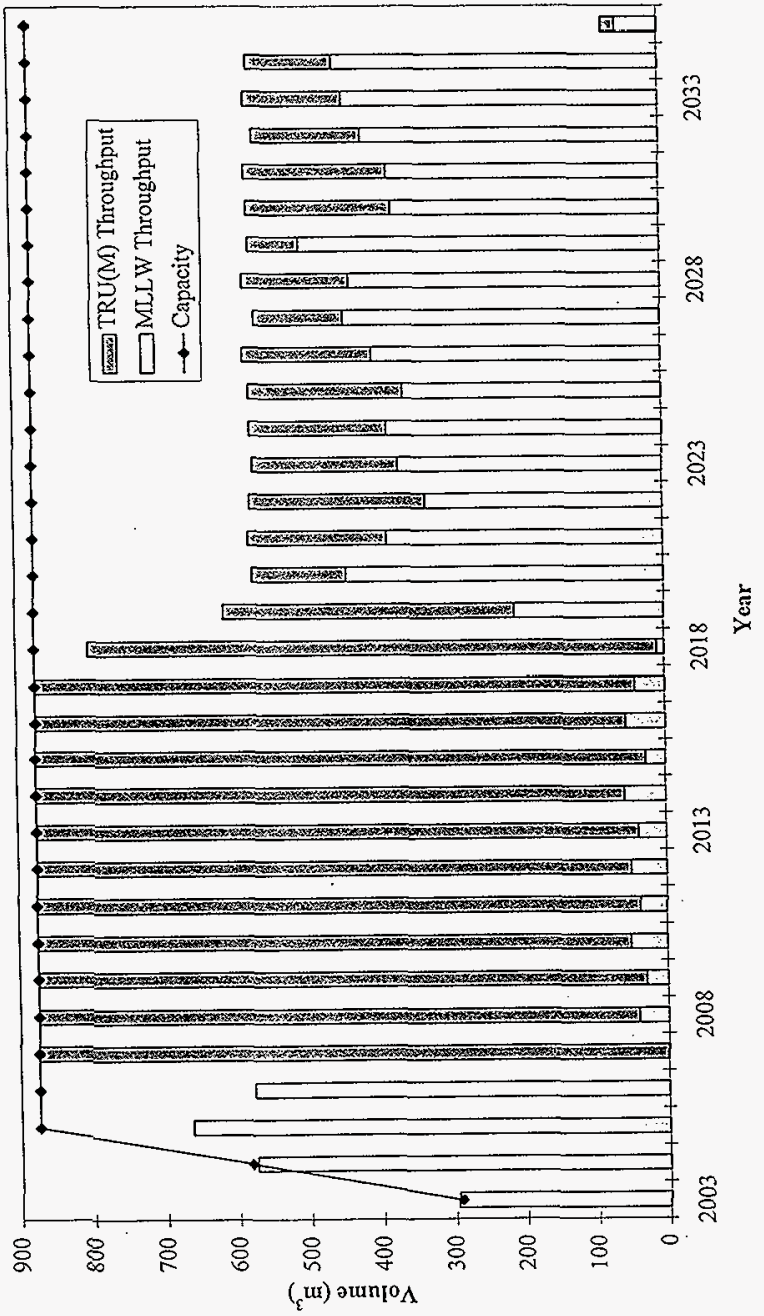


- The Milestone M-33/M-91-defined processing facility(ies) will treat solid waste at the Hanford Site determined to be RH MLLW, oversize (larger than 2.4 by 2.4 by $3.4 \mathrm{~m}$ ) CH low-level hazardous radioactive mixed waste, RH TRU waste, oversize (larger than a standard waste box) $\mathrm{CH}$ TRU waste, and $\mathrm{CH}$ TRU waste that requires processing that cannot be provided by WRAP 1 .

- The low-level hazardous radioactive mixed waste will be treated to meet the WAC for disposal of MLLW.

- TRU(M) waste processed will meet transuranic package transporter (TRUPACT II) shipping requirements and the WAC for disposal at WIPP.

- WIPP will receive TRU waste from the Milestone M-33/M-91-defined facility.

6.2.4.4.3 Commercial Thermal Treatment. The Commercial Thermal Treatment contract provides treatment for $\mathrm{CH}$ MLLW that will require thermal treatment either as the required technology-based standard or as the best demonstrated available technology of choice for concentration-based land disposal restriction standards. The thermal treatment alternative currently being emphasized is a thermal treatment service performed by an offsite contractor for any or all of the $\mathrm{CH} \mathrm{MLLW} \mathrm{requiring} \mathrm{thermal} \mathrm{treatment.} \mathrm{A} \mathrm{service} \mathrm{contract} \mathrm{was} \mathrm{awarded} \mathrm{in} \mathrm{late}$ FY 1995. The Commercial Thermal Treatment contract will generate a stabilized final waste form suitable for disposal at the Hanford Site. Figure 6-10 provides the expected throughput of MLLW and the annual capacity for this facility.

6.2.4.4.4 CWC. The CWC consists of a number of buildings, storage modules, and projects. These facilities include 12 small mixed waste storage buildings (2402-W, 2402-WB, 2402-WC, 2402-WD, 2402-WE, 2402-WF, 2402-WG, 2402-WH, 2402-WI, 2402-WJ, 2402-WK, and 2402-WL), Low-flashpoint mixed waste storage modules, one plutonium/polychlorinated biphenyl mixed waste storage building (2401-W), Large mixed waste storage buildings (2403-WA, 2403-WB, 2403-WC, and 2403-WD), and a mixed waste storage pad. These facilities provide interim storage of mixed waste awaiting appropriate treatment and disposal methods being developed for waste disposition. The Mixed Waste Storage Facility has the following capabilities.

- The 2401-W, 2402-W series, 2403-W series, low-flashpoint mixed waste storage modules, alkali metal waste storage modules, and south alkali metal storage modules are currently operational.

- The 2401-W storage building has the design capacity to store 1,072 208-L drum equivalents of waste.

- Each of the 2402-W series buildings has the design capacity to store 1,072 208-L drum equivalents of waste. 
HNF-SD-WM-RPT-288

\section{Revision 0}

Figure 6-10. Annual Capacity and Throughput of Contact-Handled Mixed Low-Level Waste for Commercial Thermal Treatment.

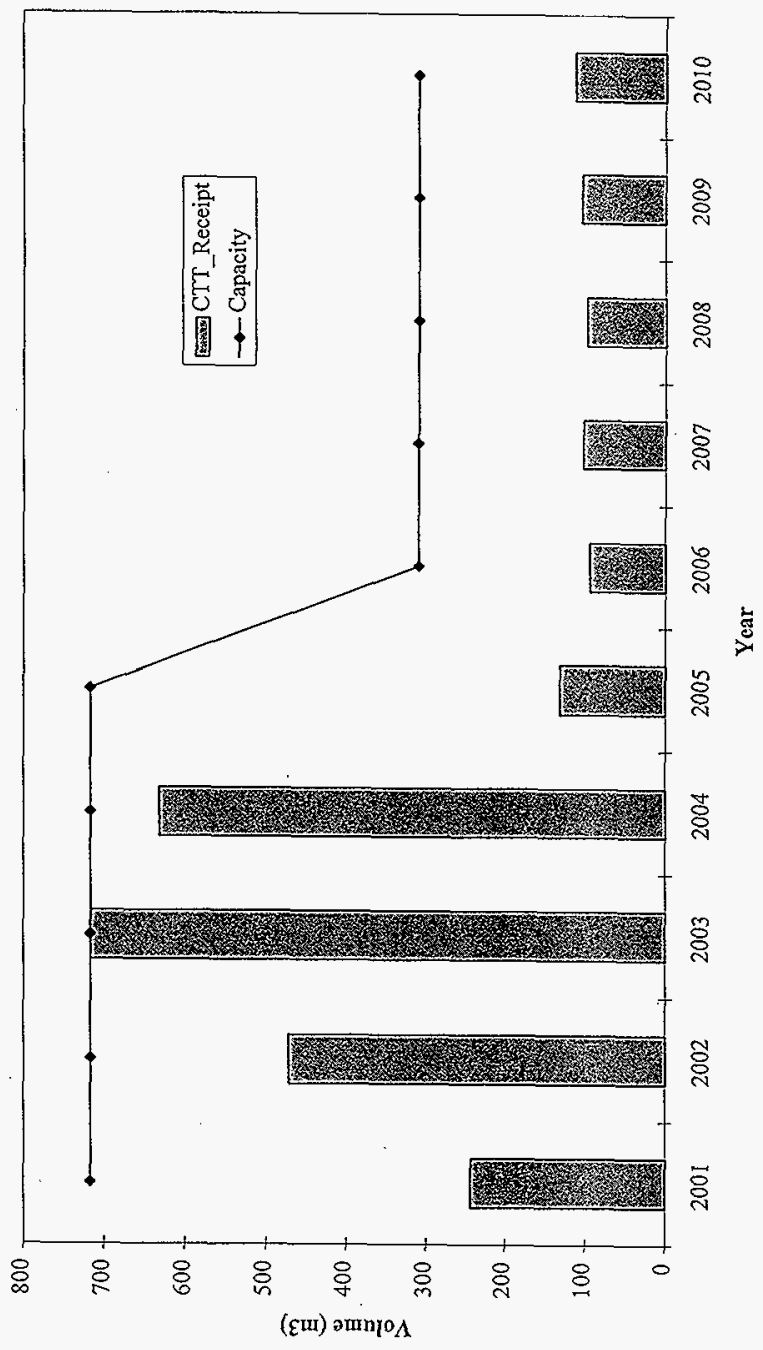


- The 2403-W series buildings have a combined capacity of 52,300 208-L drum equivalents. Buildings 2403-WA, -WB, and -WC have a design capacity to accommodate 11,600 208-L drum equivalents each, and 2403-WD has a design capacity to accommodate 17,500208 - $\mathrm{L}$ drum equivalents.

- There are 19 low-flashpoint mixed waste storage modules with a total design capacity to store $436208-\mathrm{L}$ drum equivalents of waste.

- There are 4 alkali metal waste storage modules with a total design capacity to store 84 208-L drum equivalents of waste.

- There are 8 south alkali metal storage modules with a total design capacity to store 168 208-L drum equivalents of material.

- Waste types are segregated according to hazardous characteristics.

- The characteristic types of MLLW/TRU(M) stored will include acids, caustics, oxidizers, and toxicity characteristic leaching procedure toxic waste.

6.2.4.4.5 Enhanced Radioactive and Mixed Waste Storage Module. The Enhanced Radioactive and Mixed Waste Storage Module will provide interim and long-term storage for waste (Buildings 2404-WA, 2404-WB, and 2404-WC). Construction of these facilities was recently completed, but no waste had been emplaced as yet. Project W-112 also provided general office (Building 2740W) and maintenance (Building 2620W) space for the WRAP 1 and future facilities. The following design assumptions are specific to storage provided by these facilities:

- They will store CH solid waste received from offsite and onsite generators (Nester 1995).

- Storage will be provided for 13,300 322-L overpack equivalents of $\mathrm{CH}$ waste (Nester 1995).

- Storage will be able to accommodate GTCIII LLW, Category I MLLW, Category III MLLW, GTCIII MLLW, suspect TRU, and TRU(M) waste (Nester 1995).

- Classified waste will not be stored in these facilities.

Figure 6-11 compares the annual storage requirements to annual capacity for both $\mathrm{CWC}$ and the Enhanced Radioactive and Mixed Waste Storage Module. The volumes provided in this figure do not include retrievably stored suspect-TRU waste.

6.2.4.4.6 Radioactive Mixed Waste Disposal. The Radioactive Mixed Waste Disposal Facility will provide permanent disposal capability for MLLW. The following design assumptions are specific to the Radioactive Mixed Waste Disposal Facility. 
HNF-SD-WM-RPT-288

Revision 0

Figure 6-11. Annual Storage Volumes and Capacities.

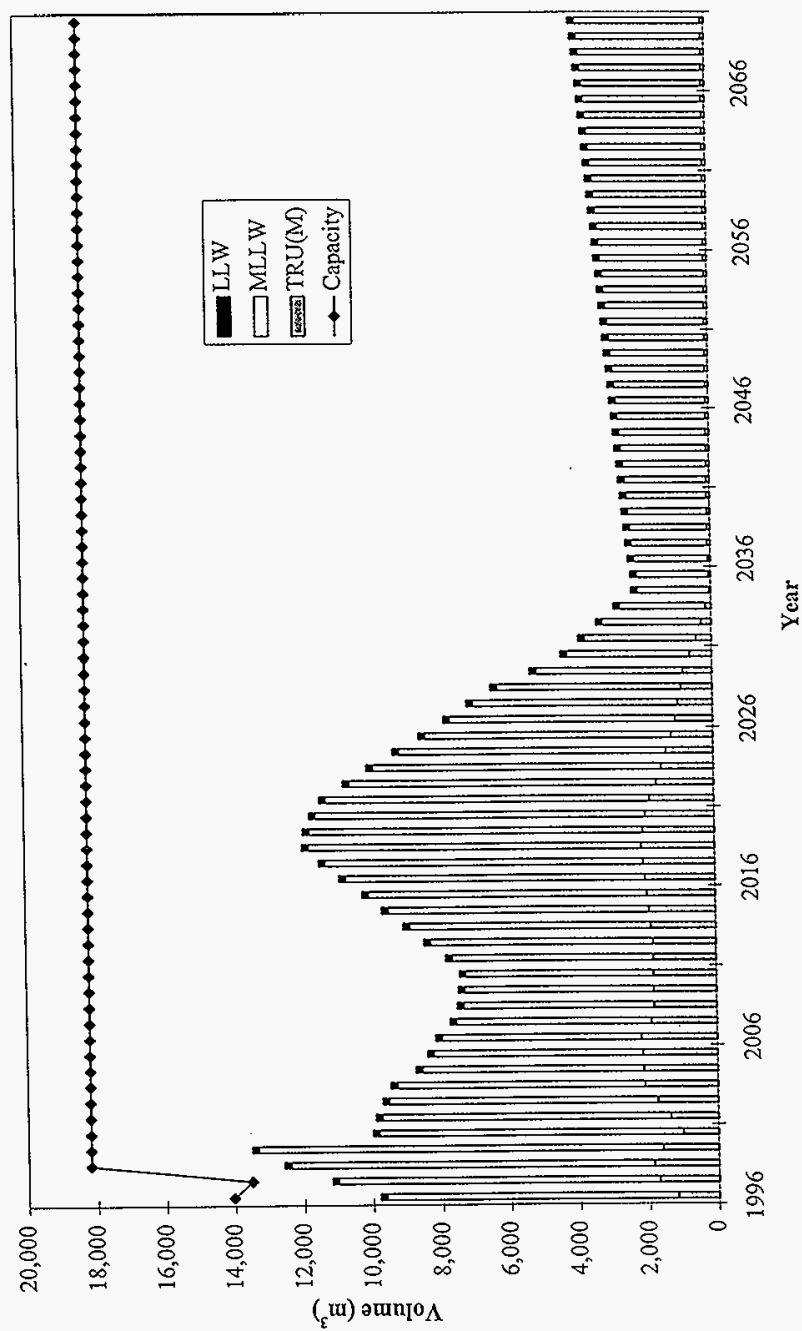


Revision 0

- Two disposal trenches have been constructed in Burial Ground 218-W-5 for radioactive mixed waste disposal.

- Each disposal system will have a design life of 50 years minimum; 20 years are required for the operational phase and 30 years for post-closure monitoring (Johnson 1992).

- The capacity of each of the two radioactive mixed waste trenches is a minimum of $7,600 \mathrm{~m}^{3}$ of waste. Additional disposal capacity will be built as demand requires. Figure 6-12 provides the annual amount of MLLW to be disposed of in current and future trenches.

- The Radioactive Mixed Waste Disposal system will meet the minimum functional standards for a dangerous waste landfill as required by WAC 173-303, "Dangerous Waste Regulations."

- The trenches will provide permanent disposal capacity for MLLW that has been treated. to meet the land disposal restriction.

\subsubsection{TRU(M) Waste}

The Atomic Energy Commission directed in Immediate Action Directive 0511-21 (AEC HQ 1970) on March 20, 1970, that after April 30, 1970, all Atomic Energy Commission sites would segregate "waste with known or detectable contamination of transuranium nuclides" from other types of waste. Such waste was to be segregated, packaged, and stored in readily retrievable, contamination-free packages for up to 20 years. After 20 years, retrievability was to continue to be possible. This policy was implemented because of the high toxicity and long half-lives of TRU isotopes. The 20-year interim storage period was to allow time to determine the best disposal alternative. Immediate Action Directive 0511-21 did not provide a detailed definition of TRU waste. Contractors to the Atomic Energy Commission implemented the policy as well as possible based on analytical data, calculations, and process knowledge.

In 1973, the segregation limit for TRU waste was given a value of $10 \mathrm{nCi} / \mathrm{g}$. This did not change waste handling practices because the amount of TRU was based on calculations and/or estimates. In 1982, the segregation limits were changed again, to $100 \mathrm{nCi} / \mathrm{g}$, reducing the volume of newly generated waste designated as TRU waste.

Retrievably stored TRU waste has been placed in several different storage configurations at the Hanford Site. Initially, waste was placed horizontally in trenches with direct soil cover. Then, from 1972-73, drums of TRU waste were placed in a concrete $V$ trench with a metal cover. After 1974, drums and boxes of CH TRU waste were stored upright in trenches with either asphalt or plywood bottoms, plywood and plastic tarps covering the containers, and at least $1.2 \mathrm{~m}$ of earth over the tarp cover. In 1985, an aboveground building, the Transuranic Waste Storage and Assay Facility (TRUSAF), was opened to store newly generated TRU waste and currently houses TRU waste with some containers having hazardous components. However, until 1989, some newly 
HNF-SD-WM-RPT-288

Revision 0

Figure 6-12. Annual Mixed Low-Level Waste Disposal Volumes.

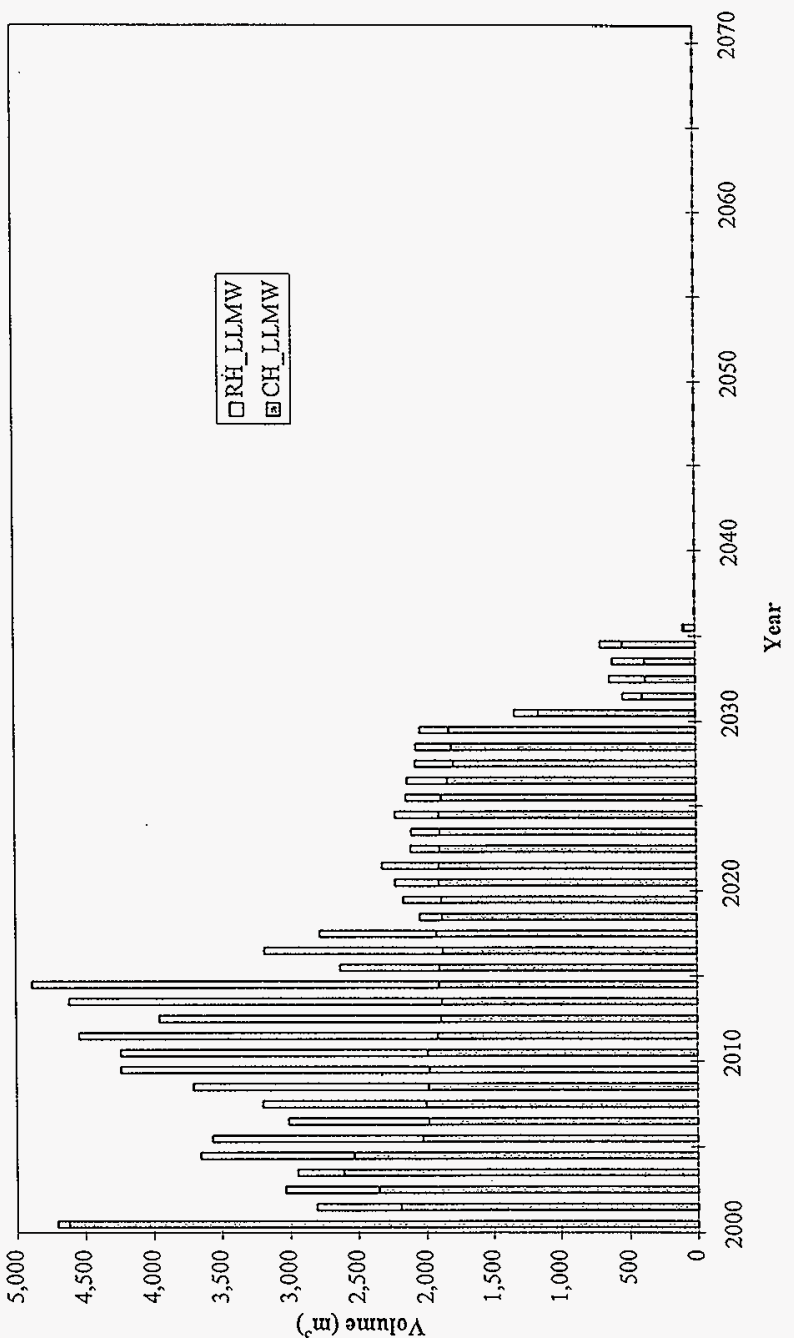


generated TRU was placed in trenches. In the summer of 1994, 23 drums of retrievably stored TRU waste were retrieved from Burial Ground $218-W-4 B$ and stored at the TRUSAF.

6.2.5.1 TRU(M) Waste Inventory. As of October 1, 1996, 16,300 $\mathrm{m}^{3}$ of TRU waste were stored in burial grounds and aboveground buildings. Contact-handled TRU waste in burial grounds and aboveground buildings amounts to $16,100 \mathrm{~m}^{3}\left(1,200 \mathrm{~m}^{3}\right.$ in aboveground buildings and $14,900 \mathrm{~m}^{3}$ in burial grounds). Because TRU definitions have changed since 1970 , approximately $50 \%$ of the waste in drums now designated as stored TRU is expected to be LLW when retrieved and assayed. The waste in boxes and other containers is expected to result in approximately $50 \%$ of the original volume of TRU waste after processing. Remote-handled TRU waste amounts to approximately $200 \mathrm{~m}^{3}$ in 2 trenches and 4 cylindrical underground vaults, called caissons.

Approximately $97 \%$ of the retrievably stored TRU waste packages are 208-L drums; the remainder are concrete, metal, plywood, or fiberglass-coated plywood boxes. Because of their large size, however, the boxes contain nearly $50 \%$ of the stored TRU by volume.

The physical composition of the stored TRU is estimated to be as follows:

- $48 \%$ glass, metal, or similar solid noncombustibles

- $43 \%$ combustible

- $3 \%$ dirt, gravel, or asphalt

- $1 \%$ absorbed liquids or sludges

- $1 \%$ filters or filter media

- $4 \%$ all other materials.

Before about 1978, essentially no records were kept of the waste form's physical composition; data recording has improved steadily since 1978.

Because of the retrievability requirements, more data are available on the nature of the TRU waste than the LLW. The waste characteristics are described in WHC-EP-0225, Contact-Handled Transuranic Waste Characterization Based on Existing Records (Anderson 1991).

No requirement existed for listing hazardous components on waste disposal records before 1986; thus, all waste designated as TRUM waste is recent. Recent studies have shown that approximately $30 \%$ of all TRU waste generated since 1986 is mixed waste. It would be reasonable to assume that waste generated before 1986 is of similar composition, although it is not currently designated mixed.

6.2.5.2 Forecast TRU(M) Waste. Approximately $7,900 \mathrm{~m}^{3}$ of forecast solid TRU waste is expected at the Hanford Site. This includes $1,070 \mathrm{~m}^{3}$ of long-length equipment and $2 \mathrm{~m}^{3}$ of offsite waste. A total of $54 \%\left(4,300 \mathrm{~m}^{3}\right)$ of this volume is TRU waste; $46 \%\left(3,600 \mathrm{~m}^{3}\right)$ is TRU(M) waste. Most (79\%) of the TRU(M) waste is $\mathrm{CH}$. 
The TRU(M) waste is expected to have the following physical waste forms:

- $93 \%$ debris waste

- $3 \%$ inorganic homogenous solids

- $4 \%$ other physical characteristics.

The forecast TRU(M) containers are as follows:

- $65 \%$ in 208-L drums

- $20 \%$ standard waste boxes

- $13 \%$ in long-length equipment containers

- $2 \%$ other miscellaneous containers.

Figure 6-13 displays the inventory of TRU(M) waste from 1970 through 1996 and the forecast volumes from 1997 through 2070 (Valero 1996). The spike in 1975 is mostly gloveboxes and equipment from the cleanout of a plutonium production line (the Division of Military Applications line) in the Plutonium Finishing Plant.

The smaller spike in 1980 is mostly boxed waste from the $231-Z$ Building, at that time a PNNL plutonium metallurgy laboratory. The spike in 1981 was not caused by any single generator or event. The decrease from 1985 to 1986 results from greater accuracy in assay techniques when TRUSAF became operational. Previously, the inability to accurately assay to the $100 \mathrm{nCi} / \mathrm{g}$ TRU limit led to conservatism in assigning waste to the TRU category.

6.2.5.3 TRU(M) Waste Flowsheet. The TRU waste inventory, for both current and forecast waste, is $24,200 \mathrm{~m}^{3}$. The flow of this waste through the Solid Waste subproject system is displayed in Figure 6-14. This waste consists of the following:

- $15,100 \mathrm{~m}^{3}$ of waste that will require retrieval $\left(200 \mathrm{~m}^{3}\right.$ of $\mathrm{RH}$ and $14,900 \mathrm{~m}^{3}$ of $\left.\mathrm{CH}\right)$

- $1,200 \mathrm{~m}^{3}$ of $\mathrm{CH}$ waste that are stored awaiting treatment and/or certification

- $7,900 \mathrm{~m}^{3}$ of forecast waste during the life cycle from onsite operations, waste management, and facility transition-related activities.

The $200 \mathrm{~m}^{3}$ of existing RH waste will go directly to the M-91 treatment function (formerly M-33) on retrieval without going to storage. The only planned storage function for retrieved RH waste is lag storage incidental to the treatment function. The $14,900 \mathrm{~m}^{3}$ of retrievably stored waste, $1,200 \mathrm{~m}^{3}$ of CH TRU waste stored in buildings, and $7,900 \mathrm{~m}^{3}$ of forecast TRU waste are sent to storage awaiting treatment and certification. Excluding the $200 \mathrm{~m}^{3}$ of RH TRU, $24,000 \mathrm{~m}^{3}$ of TRU waste will be sent to storage during the life cycle at the Hanford Site. Note that required storage capacity depends on the expected quantity of waste requiring storage at any particular point in time. 
Revision 0

Figure 6-13. Historical and Forecast Annual Solid Transuranic Waste Volumes.

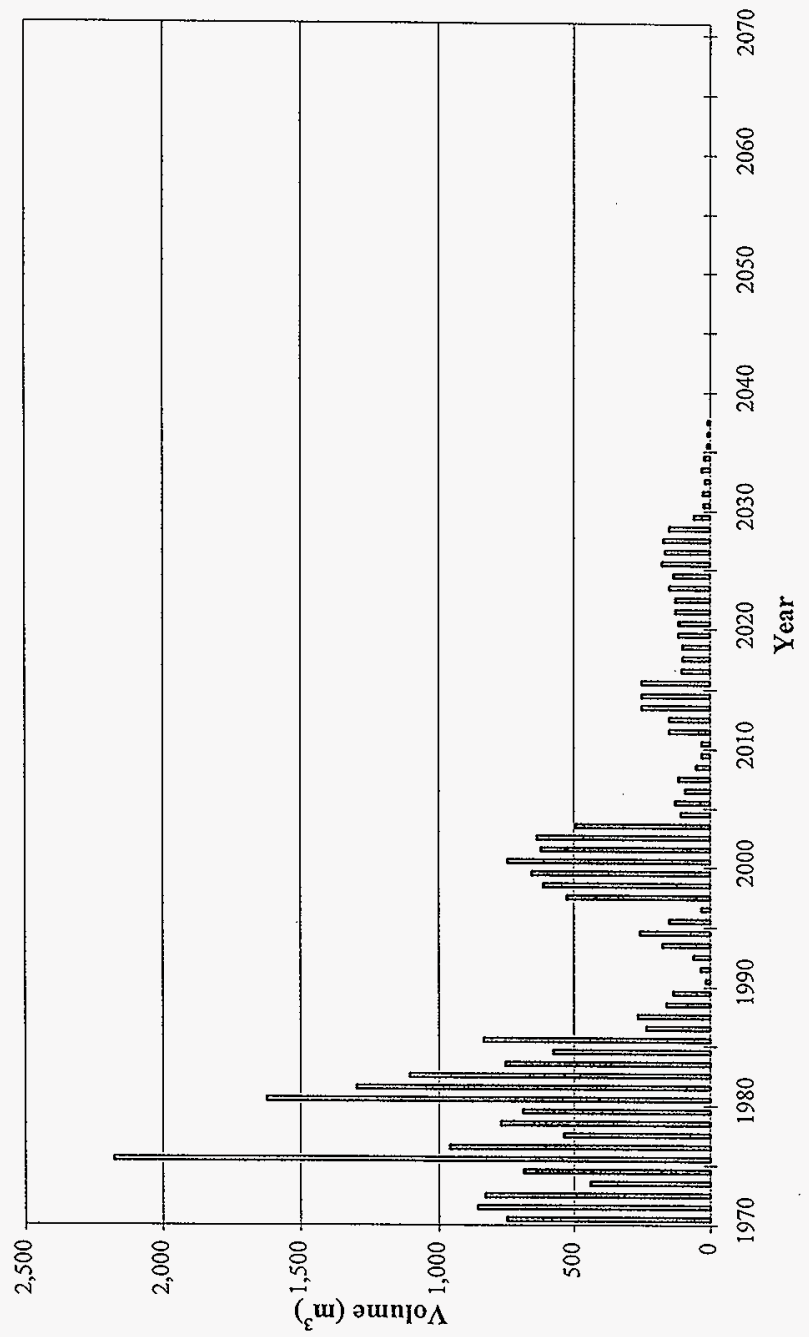


HNF-SD-WM-RPT-288

Revision 0

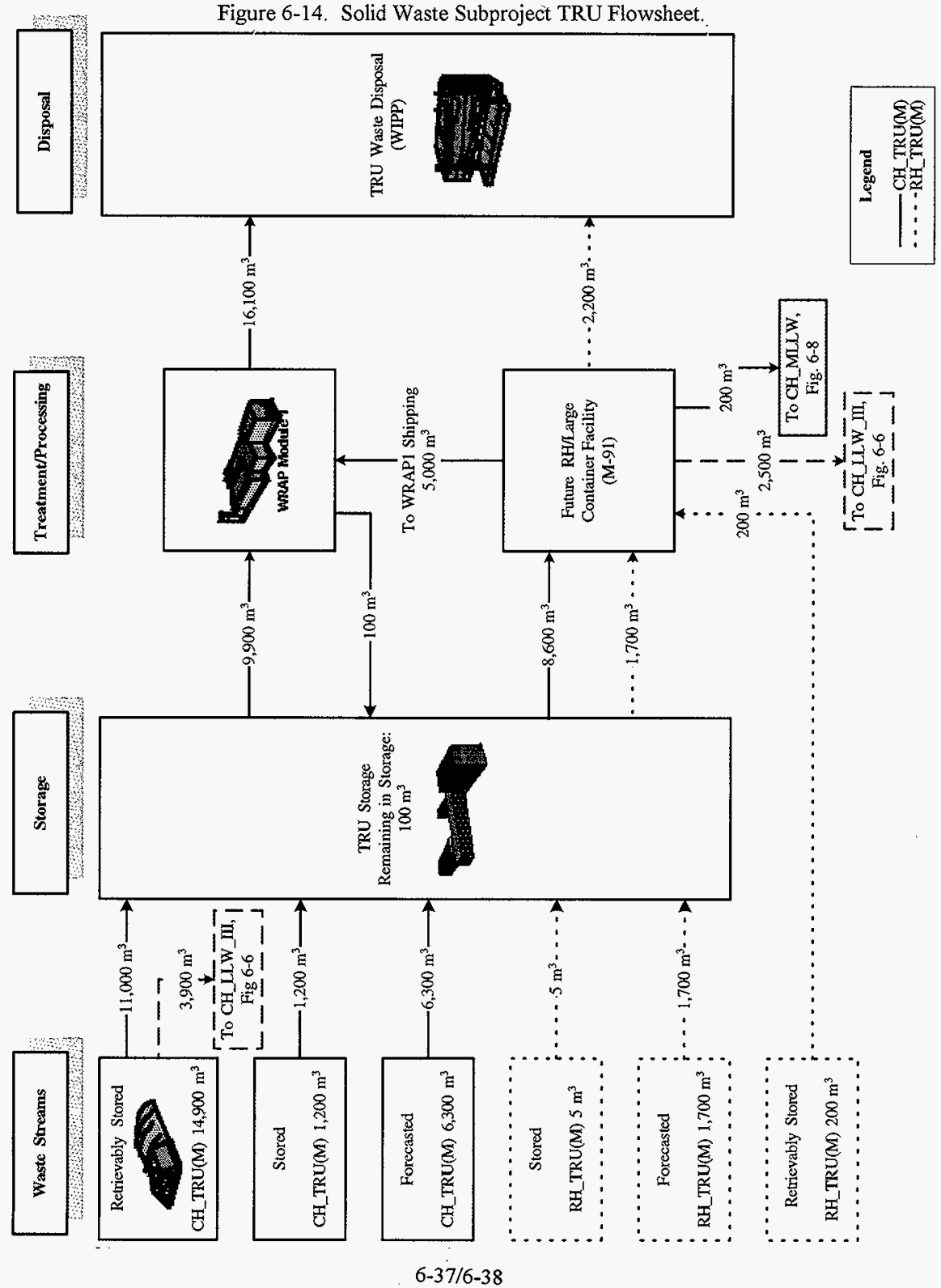


A total of $14,900 \mathrm{~m}^{3}$ of retrievably stored and forecast $\mathrm{CH}$ TRU waste are processed and certified in the WRAP 1 treatment function. The $3,700 \mathrm{~m}^{3}$ of retrievably stored waste drums processed in WRAP 1 become $5,100 \mathrm{~m}^{3}$ of TRU waste for disposal at WIPP. Of the $600 \mathrm{~m}^{3}$ of $\mathrm{CH}$ waste in drums stored in buildings and the $5,100 \mathrm{~m}^{3}$ of forecast $\mathrm{CH}$ waste in drums, $5,500 \mathrm{~m}^{3}$ are sent to WRAP 1 where the waste is assumed to increase slightly in volume to $5,700 \mathrm{~m}^{3}$ after processing and certification. The remaining $400 \mathrm{~m}^{3}$ of stored and forecast $\mathrm{CH}$ waste in drums are either sent to the M-33/M-91 treatment facility or remain in long-term storage because no treatment is identified for their disposal. The $700 \mathrm{~m}^{3}$ of forecast $\mathrm{CH}$ waste in standard waste boxes are assumed to remain the same volume after certification in WRAP 1 . WRAP 1 also will ship to WIPP $5000 \mathrm{~m}^{3}$ of CH TRU waste processed in the M-33/M-91 facility. Total TRU waste shipments from WRAP I to WIPP for disposal are $16,000 \mathrm{~m}^{3}$.

The M-33/M-91 treatment function will receive $7,300 \mathrm{~m}^{3}$ from retrieval and $1,300 \mathrm{~m}^{3}$ from storage) of stored and forecast $\mathrm{CH}$ waste in boxes and other containers for treatment and/or certification. The 7,300 $\mathrm{m}^{3}$ of retrievably stored waste sent to $\mathrm{M}-33 / \mathrm{M}-91$ for size reduction, repackaging, and sorting will segregate into TRU and LLW, resulting in an estimated $4,000 \mathrm{~m}^{3}$ of TRU waste, $400 \mathrm{~m}^{3}$ of MLLW, and $1,900 \mathrm{~m}^{3}$ of LLW. A total of $5,000 \mathrm{~m}^{3}$ of CH TRU waste (existing and newly generated) will be sent from the M-33/M-91 facility to WRAP 1 for shipment.

The M-33/M-91 treatment function will receive $200 \mathrm{~m}^{3}$ of existing and $1,700 \mathrm{~m}^{3}$ of forecast $\mathrm{RH}$ waste for treatment and certification. The $200 \mathrm{~m}^{3}$ of existing and $1,700 \mathrm{~m}^{3}$ of forecast $\mathrm{RH}$ waste sent to the M-33/M-91 facility for treatment and repackaging will result in $2,000 \mathrm{~m}^{3}$ of $\mathrm{RH}$ TRU waste prepared for WIPP disposal. Because the waste is RH, the shipping will be handled at the M-33/M-91 facility rather than through WRAP 1.

\subsubsection{Facilities and Projects to Accomplish TRU(M) Waste Disposition. The Solid} Waste subproject has several existing and planned facilities that will be used for final disposition of TRU(M) waste. These facilities include retrieval projects; storage operations in the CWC, TRUSAF ${ }^{1}$; and treatment in the WRAP Facility and the M-33/M-91 facility. The project will not provide a disposal facility for TRU waste. Disposal of TRU waste will be provided by a DOE Complex-wide disposal facility. Certified TRU waste will be shipped to WIPP through 2033. Any TRU waste at the Hanford Site after 2033 is assumed to be placed in storage. When a decision is made about how TRU waste will be disposed of after 2033, this assumption will be updated.

The following briefly describes each facility required for disposition of TRU(M) waste (except for WIPP) and provides an annual throughput for each facility if applicable.

6.2.5.4.1 Retrieval Projects. The project must plan for and implement the retrieval of TRU waste stored in burial ground trenches and caissons since May 1, 1970. Since that date, waste suspected or known to contain TRU constituents has been segregated and retrievably stored pending a decision on management of the waste (AEC RL 1970). This waste was to be stored as

\footnotetext{
${ }^{1}$ TRUSAF will be cleaned out by end of FY97.
} 


\section{HNF-SD-WM-RPT-288}

Revision 0

"retrievable waste." The waste was to be placed in contamination-free packages and retrieved within 20 years. The HDW-EIS ROD states that retrievably stored and newly generated TRUcontaminated solid waste will be retrieved, processed as necessary, and sent to WIPP for disposal.

The retrieval function will be divided into two activities for TRU waste: retrieval of waste from burial ground trenches and retrieval of waste from burial ground alpha caissons. The trench waste retrieval function will provide for the retrieval of $\mathrm{CH}$ suspect-TRU waste in a variety of containers, mostly $208-\mathrm{L}$ drums. The caisson waste retrieval function will provide for the retrieval of RH TRU waste stored in the dry waste alpha caissons. Remote-handled material, whether in caissons or trenches, will be retrieved only when treatment is directly available; no storage will be provided for retrieved $\mathrm{RH}$ waste.

The project provides retrieval of the retrievably stored TRU waste in the 200 Areas of the Hanford Site. The retrieval function has been separated into three distinct projects. General assumptions regarding retrieval are presented in the following sections. Assumptions specific to a particular retrieval project are provided in the appropriate section. The assumption of retrieval for radioactive solid waste under the project is as follows:

- TRU waste retrievably stored since May 1, 1970, will be retrieved (53 FR 12449).

Project W-113, Solid Waste Retrieval Phase 1. Solid Waste Retrieval Phase 1 will retrieve the TRU waste from Trench 4 of Burial Ground 218-W-4C.

The following design assumptions are specific to the Solid Waste Retrieval Phase 1 Project.

- Phase 1 retrieval operations will last approximately 2 years

- The total number of waste containers to be retrieved is 9,989 (Johnson 1993).

- The total waste volume to be retrieved is $2,397 \mathrm{~m}^{3}$, approximately $1,200 \mathrm{~m}^{3}$ of waste per year.

- The waste containers are expected to be intact with no significant risk of questionable structural integrity causing contamination release to the environment (Johnson 1993).

- Facilities and equipment are not included for cleanup, disposal, treatment, or storage of contaminated soil (Johnson 1993).

- Waste containers will be overpacked as part of the retrieval process (Johnson 1993).

- Fifty percent of suspect-TRU waste in drums will be assayed in the trenches as LLW.

Project W-156, Alpha Caisson Retrieval. The Alpha Caisson Retrieval Project will involve removing RH TRU waste stored in the dry waste caissons located in Burial Ground 218-W-4B. 
HNF-SD-WM-RPT-288

Revision 0

Waste will be retrieved, packaged, surveyed, and transferred to the appropriate treatment function for treatment before disposal.

The following design assumptions are specific to the Alpha Caisson Retrieval Project.

- Retrieval operations will last 3 years.

- The total number of containers to be retrieved is 5,534 .

- The total volume of waste placed in the alpha caissons and to be retrieved is $23.4 \mathrm{~m}^{3}$ (Deichelbohrer 1990).

- All containers retrieved will be non-contact (RH) sources (Deichelbohrer 1992).

- Waste will be loaded into a transportable cask and transported to an undefined treatment facility (Tri-Party Agreement [Ecology et al. 1996] under negotiation), currently assumed to be the M-33/M-91 facility.

- All waste in caissons is considered TRU (Deichelbohrer 1992).

- Miscellaneous debris (plastic sheeting, wrapping, etc.) waste volume is estimated at $5.7 \mathrm{~m}^{3}$.

Project W-221, Solid Waste Retrieval Phase 2. The retrieval project for retrievably stored TRU waste, known as Phase 2 retrieval, will involve retrieving the entire inventory of retrievably stored TRU waste (less that retrieved in Phase 1 and Alpha Caisson Retrieval) located in trenches in the burial grounds. The integrity of the retrieved waste containers is expected to range from completely sound to totally degraded.

The following design assumptions are specific to the full-scale retrieval, Phase 2 retrieval project. As with Phase I Retrieval, these assumptions were developed in conjunction with the Project Baseline Schedule goals.

- The scope of Phase 2 retrieval is the entire inventory of retrievably stored TRU waste less the waste retrieved in Phase 1 and Alpha Caisson Retrieval.

- Containers retrieved intact will be overpacked.

- Retrieved waste in breached containers will be repackaged.

- Waste that was repackaged will not be overpacked.

- Drums will be retrieved before other containers

- Retrieval operations will last 10 years, starting in FY 2003. 


\section{HNF-SD-WM-RPT-288}

Revision 0

- Fifty percent of suspect-TRU waste in drums will be assayed as LLW in the trenches.

6.2.5.4.2 TRUSAF (224-T). The 224-T TRUSAF primarily stores TRU waste that meets the Hanford Site WAC (Willis 1994) for solid waste. In addition, other properly characterized and packaged MLLW could be accepted for storage.

The following assumptions are specific to the TRUSAF.

- TRUSAF has the capacity to store 2,000 208-L drums.

- In 1985, the 224-T Building modifications were complete to initiate storing TRU(M); the 224-T Building was redesignated as 224-T TRUSAF (RL 1992).

- Waste is received primarily in U.S. Department of Transportation (DOT)-approved or equivalent $17 \mathrm{C}$ or $17 \mathrm{H}$ UN1A2 208-L containers or other DOT-approved packages and overpacks (RL 1992).

- TRUSAF is planned to be emptied out by the end of FY97.

Other TRU storage facilities, the CWC, are discussed in Sections 6.2.4.4.4 and 6.2.4.4.5.

6.2.5.4.3 Project W-026, WRAP 1 (Building 2336-W). The HDW-EIS ROD states that "A facility will be designed, constructed and operated at Hanford to sort, process and repackage retrievably stored and newly generated TRU solid waste for shipment to the Waste Isolation Pilot Plant (WIPP)... The only pre-1970 buried suspect TRU-contaminated solid waste site outside the central (200 Area) plateau [Burial Ground 618-11] will be removed to the 200 Area plateau for processing for disposal as solid TRU waste." It also states that "retrievably stored and newly generated TRU solid waste would be sent to WIPP. The waste would first be processed and packaged...The waste processing facility...would not... be sized for treatment of... remotely handled TRU waste." This waste processing facility is known as WRAP 1. WRAP I will receive retrieved and newly generated solid $\mathrm{CH}$ radioactive wastes in 208-L drums (some overpacked in salvage drums). Drums will be inspected, assayed, and opened if necessary. Waste contents can be sorted and segregated, empty drums and waste compacted as appropriate, and repackaged, certified, and shipped to final disposal.

The following design assumptions are specific to the WRAP 1 treatment project.

- WRAP 1 will have a design operating life extending from FY 1998 to FY 2070. Figure 6-15a compares the annual throughput of TRU(M) waste to the annual capacity. Figure 6-15b compares the annual throughput of $\mathrm{CH}_{-} \mathrm{LLW} \_$III to the annual capacity.

- WRAP 1 will operate on a one-shift per day basis.

- A total of 6,825 drums of $\mathrm{CH}$ waste can be received annually. This includes 2,100 drums of newly generated TRU(M) waste, 2,625 drums of retrieved suspect TRU, and 
HNF-SD-WM-RPT-288

Revision 0

Figure 6-15a. Annual Waste Receiving and Processing Module 1 Transuranic Waste Throughput and Capacity.

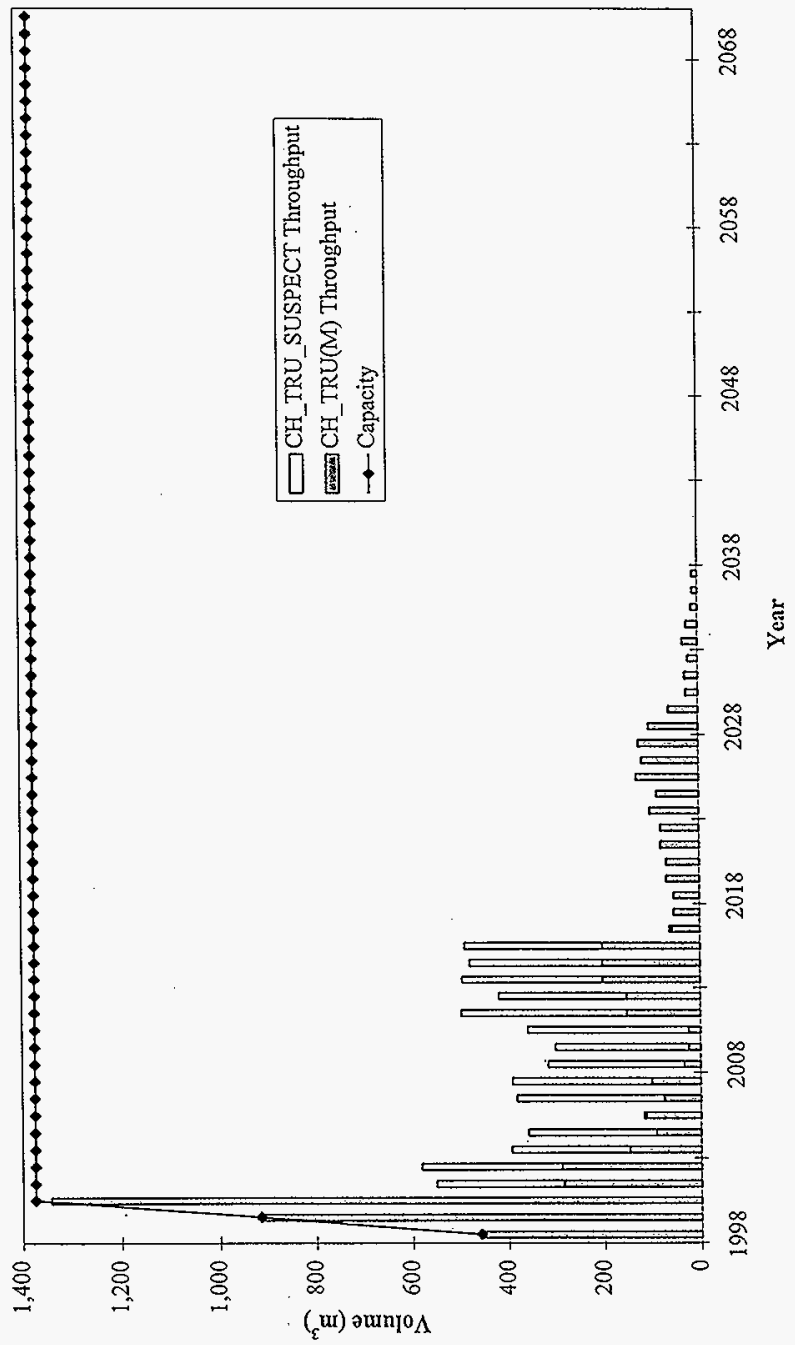




\section{HNF-SD-WM-RPT-288}

\section{Revision 0}

Figure 6-15b. Annual Waste Receiving and Processing Module 1 Low-Level Waste Throughput and Capacity.

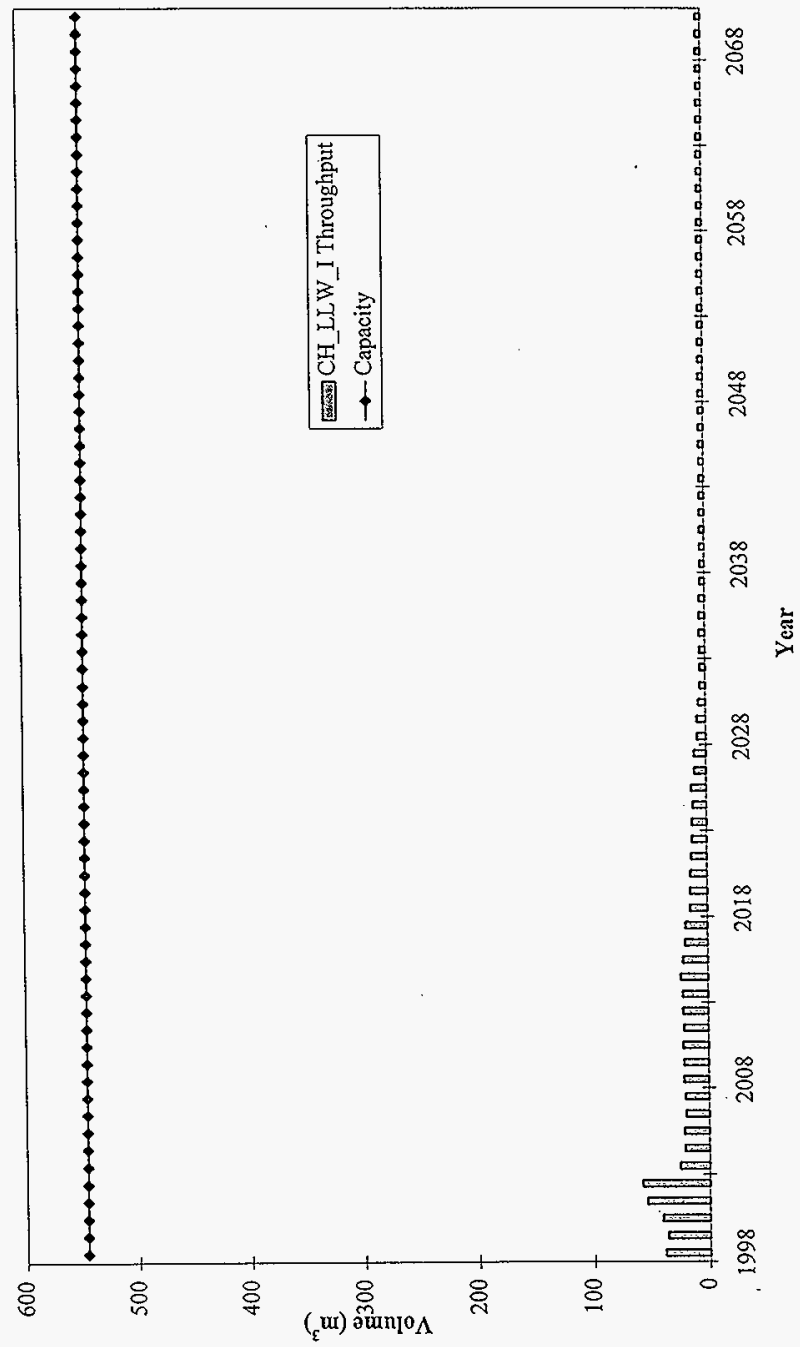


HNF-SD-WM-RPT-288

Revision 0

2,100 drums of newly generated LLW/MLLW. The facility shall also be able to receive, certify, and ship 70 standard waste boxes of CH TRU annually (Mayancsik 1994). If fewer than 2,625 drums of suspect-TRU waste are received in a given year, additional newly generated TRU waste can be processed up to a total of 4,725 drums of TRU waste.

- The newly generated TRU(M) waste received annually will consist entirely of TRU(M) waste (Mayancsik 1994).

- The of newly generated LLW/MLLW received annually will consist entirely of LLW/MLLW (Mayancsik 1994).

- WRAP 1 shall be designed to be able to accommodate the minimum required annual waste throughput in no more than 175 total operating days per year, with no more than 5 operating days per week. This is equivalent to $70 \%$, or 35 weeks, of the total 50 weeks in a normal operating year (Mayancsik 1994).

- TRU(M) waste processed will meet TRUPACT II shipping requirements and the WAC for disposal at WIPP (Mayancsik 1994).

- WIPP will receive waste from WRAP 1 until 2033.

\subsubsection{Nonradioactive Hazardous Waste}

Hazardous waste that is not radioactive is accumulated at the source of generation and shipped directly offsite. Waste containing PCBs with no other hazardous contaminants is stored in the 212-P Building before offsite shipment. Typically, hazardous waste consists of soils and debris. The 616 Nonradioactive Dangerous Waste Storage Facility is available for storing hazardous waste, but is currently in a standby mode. Hazardous waste inventory data are not collected because central management by the Project no longer occurs. Currently, the Project manages hazardous waste by contracting offsite services for the disposition of the waste and scheduling shipments of hazardous waste to the offsite vendor. The Project no longer performs verification or central site collection services for the Hanford Site; thus, additional information such as waste flowsheets, inventory, and forecast waste is not provided for hazardous waste.

\subsubsection{Material not Categorized as Waste}

Materials exist on the Hanford Site that are not currently designated as solid waste, but may eventually be so designated and thus require waste management activities. A report was prepared to summarize these materials (Jacobsen 1993). 
Many of these materials will probably be designated as HLW. Management of this waste could become a source for solid LLW or TRU waste, however, which would be expected to appear in solid waste volume forecasts.

Lead bricks and alkali metals would most likely become solid waste, although a beneficial use or customer may yet be found for the alkali metals. Approximately $10 \mathrm{~m}^{3}$ of the alkali metals was declared waste.

\subsubsection{Other Waste}

In the past, a category called "special-case waste" was used because the waste had no identified path forward. Approximately $15 \mathrm{~m}^{3}$ of this waste, PNNL's inventories within the 324 Building Radiochemical Engineering Cells, could possibly be stored on the Hanford Site. The Project may provide this storage until a decision is made on the interim storage location or the waste is reclassified into another of the standard waste categories.

\subsubsection{Contaminated Equipment}

Currently, contaminated equipment is treated for free release at the $T$ Plant on an as-needed basis for the Hanford Site. This equipment is received by $\mathrm{T}$ Plant for decontamination services and then shipped to the customer for free-release reuse or disposal if treatment capabilities are inadequate. No substantial inventory currently exists of contaminated equipment; however, three cranes, six boxes ( 2 by 4 by 8 ) of lead bricks, and one truck-mounted cable tool drilling rig are forecast to be decontaminated at $\mathrm{T}$ Plant during the next 4 years.

\subsection{LIQUD WASTE}

TBD

\subsection{ANALYTICAL SERVICES}

TBD 
HNF-SD-WM-RPT-288

Revision 0

\subsection{REFERENCES}

10 CFR 61, "Licensing Requirements for Land Disposal of Radioactive Waste," Code of Federal Regulations, as amended.

53 FR 12449, 1988, "Final Environmental Impact Statement for the Disposal of Hanford Defense High-Level, Transuranic and Tank Wastes, Hanford Site, Richland, Washington; Record of Decision," Federal Register, Vol. 53, No. 72, pp. 12449-12453, (April 14).

AEC HQ, 1970, Policy Statement Regarding Solid Waste Burial, Immediate Action Directive No. 0511-21, U.S. Atomic Energy Commission, Richland, Washington.

Anderson, B. C., 1991, Contact-Handled Transuranic Waste Characterization Based on Existing Records, WHC-EP-0225, Rev. 1, Westinghouse Hanford Company, Richland, Washington.

Anderson, G. A. and H. J. Konynenbelt, 1995, 1995 Baseline Solid Waste Management System Description, PNL-10743, Pacific Northwest Laboratory, Richland, Washington.

Anderson, J. D., 1989, Radioactive Solid Waste Received in the 200 Areas During CY 1988, WHC-EP-0125-1, Westinghouse Hanford Company, Richland, Washington.

Anderson, J. D., 1992, Radioactive Solid Waste Received in the 200 Areas, WHC-EP-0125-4, Westinghouse Hanford Company, Richland, Washington.

Anderson, J. D., and D. L. Hagel, 1995, Summary of Radioactive Solid Waste Received in the 200 Areas During Calendar Year 1994, WHC-EP-0125, Rev. 6, Westinghouse Hanford Company, Richland, Washington.

Atomic Energy Act of 1954, 42 USC 2011, et seq.

Baker, T. L., 1995, Response to Additional Guidance for Management for the Solid Waste Program (Internal Memo 9501610B R1, May 8), Westinghouse Hanford Company, Richland, Washington.

Craig, P. A., 1991, Westinghouse Hanford Company Waste Minimization and Pollution Prevention Awareness Program Plan, WHC-EP-0496, Westinghouse Hanford Company, Richland, Washington.

Deichelbohrer, P. R., 1990, Alpha Caisson Data and Evaluation, WHC-SD-WM-RPT-008, Rev. 0, Westinghouse Hanford Company.

Deichelbohrer, P. R., 1992, Retrieval of Waste from Alpha Caissons, WHC-SD-WM-ES-181, Rev. 0, Westinghouse Hanford Company, Richland, Washington. 
HNF-SD-WM-RPT-288

Revision 0

DOE, 1996, Integrated Data Base-1995: U.S. Spent Nuclear Fuel and Radioactive Waste Inventories, Projections, and Characteristics, DOE/RW-0006, Rev. 12, U.S. Department of Energy, Washington, D.C.

Duncan, D. R., 1991, Solid Waste Program Plan, WHC-EP-0363, Rev. 1, Westinghouse Hanford Company, Richland, Washington.

Ecology, EPA, and DOE, 1994, Hanford Federal Facility Agreement and Consent Order, as amended, Washington State Department of Ecology, U.S. Environmental Protection Agency, and U.S. Department of Energy, Olympia, Washington.

Ecology, EPA, and DOE, 1996, Hanford Federal Facility Agreement and Consent Order, as amended, Washington State Department of Ecology, U.S. Environmental Protection Agency, and U.S. Department of Energy, Olympia, Washington.

Floyd, B. C., 1994, Westinghouse Hanford Company Waste Minimization and Pollution Prevention and Awareness Program Plan, WHC-EP-0496, Rev. 1, Westinghouse Hanford Company, Richland, Washington.

Holmes, J. J., 1994, Systems Engineering Functions and Requirements for the Hanford Cleanup Mission: First Issue, WHC-EP-0722, Addendum 2, Rev. 0, Westinghouse Hanford Company, Richland, Washington.

Jacobsen, P. H., 1993, Material-Not-Categorized-As-Waste Survey for 1992, WHC-EP-0626, Westinghouse Hanford Company, Richland, Washington.

Johnson, D. M., 1993, Functional Design Criteria Solid Waste Retrieval Facility Phase 1, Project W-113, WHC-SD-W113-FDC-001, Rev. 2, Westinghouse Hanford Company, Richland, Washington.

Johnson, K. D., 1992, Functional Design Criteria Interim RMW Disposal Facility, WHC-SD-W025-FDC-001, Rev. 1, Westinghouse Hanford Company, Richland, Washington.

Knuger, O. L., 1994, Waste Receiving and Processing, Module 2A, Feed Specification, WHC-SD-W100-RD-001, Rev. 1, Westinghouse Hanford Company, Richland, Washington.

Mayancsik, B. A., 1994, Functional Design Criteria Waste Receiving and Processing (WRAP) Facility Module 1, WHC-SD-FDC-W026-001, Rev. 2, Westinghouse Hanford Company, Richland, Washington.

Nester, D. E., 1995, Functional Design Criteria For Enhanced Radioactive and Mixed Waste Storage Phase V, Project W-112, WHC-SD-W112-FDC-001, Rev. 3, Westinghouse Hanford Company, Richland, Washington. 
Resource Conservation and Recovery Act of 1976, 42 USC 6901, et seq.

RL, 1992, Transuranic Storage and Assay Facility (TRUSAF), Part B Permit Application, DOE/RL-91-51, Rev. 0, U.S. Department of Energy, Richland Operations Office, Richland, Washington.

RL, 1995, Direct Disposal Team Report - Options for Treating and Disposing of Current and Future Mixed Waste Streams on the Hanford Facility, DOE/RL-95-35, Rev. 0, U.S. Department of Energy, Richland, Washington.

Toxic Substances Control Act of 1976, 15 USC 2601, et seq.

Valero, O. J., 1996, Solid Waste Integrated Forecast Technical (SWIFT) Report: FY 1997 to FY 2070, HNF-EP-0918, Rev. 1, Rust Federal Services of Hanford, Richland, Washington.

WAC 173-303, "Dangerous Waste Regulations," Washington Administrative Code, as amended.

WHC, 1995, Solid Waste Program Fiscal Year 1996 Multi-Year Program Plan WBS 1.2.1, WHC-SP-1161, Westinghouse Hanford Company, Richland, Washington.

Willis, N. P., 1994, WHC-EP-0063, Rev. 4, Hanford Site Solid Waste Acceptance Criteria, Westinghouse Hanford Company, Richland, Washington. 
HNE-SD-WM-RPT-288

Revision 0

This page intentionally left blank. 
HNF-SD-WM-RPT-288

Revision 0

CONTENTS

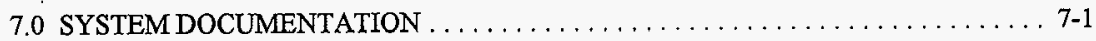

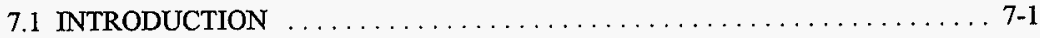

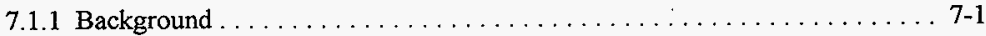

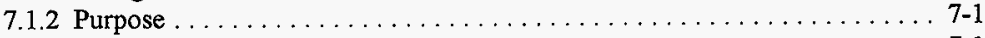

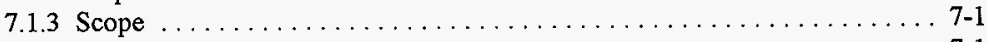

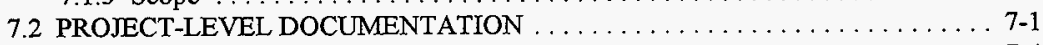

7.3 FACILITY CONTRACTS AND PROJECT DOCUMENTATION ........ 7-4

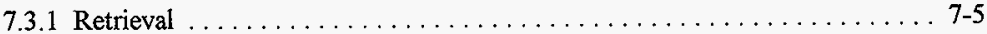

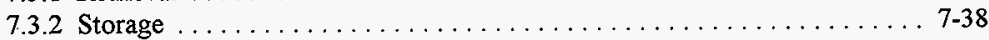

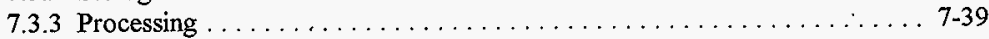

7.3.4 Disposal . . . . . . . . . . . . . . . . . . . . . . . . . . . 7-40

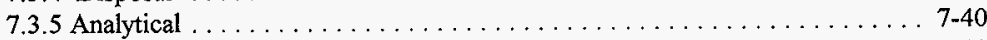

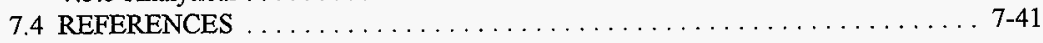

\section{LIST OF FIGURES}

7-1. Waste Management Project Document Hierarchy 
HNF-SD-WM-RPT-288

Revision 0

\section{LIST OF TABLES}

7-1. Current Documentation for Waste Management Project

7-2. Current Documentation for Project W-113, Solid Waste Retrieval,

Phase 1. . . . . . . . . . . . . . . . . . . . . . . . . . . . . . 7-9

7-3. Current Documentation for Project W-221, Solid Waste Retrieval, Phase 2. . . . . 7-10

7-4. Current Documentation for Project W-156, Alpha Caisson Retrieval. . . . . . . . 7-10

7-5. Current Documentation for the Hanford Central

Waste Complex . . . . . . . . . . . . . . . . . . . . . . . 7-11

7-6. Current Documentation for Transuranic Waste Storage and Assay Facility . . . . . 7-12

7-7. Current Documentation for Project W-112, Enhanced Radioactive Mixed Waste

Storage Facility $\ldots \ldots \ldots \ldots \ldots \ldots \ldots \ldots \ldots \ldots \ldots \ldots \ldots \ldots \ldots$

7-8. Documentation for Project W-272, Special-Case.Solid Waste Temporary Storage

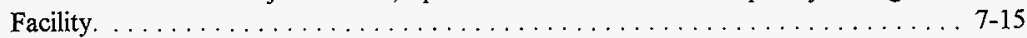

7-9. Current Documentation for the Nonradioactive Dangerous Waste Storage Facility .. 7-16

7-10. Current Documentation for Project W-026, Waste Receiving and Processing

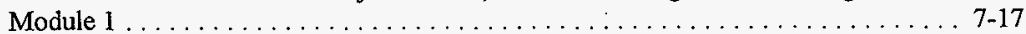

7-11. Current Documentation for Contact-Handled Mixed Low-Level Waste Commercial

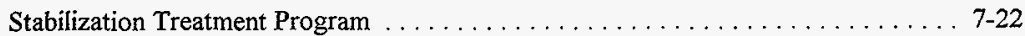

7-12. Current Documentation for the Thermal Treatment Facility . . . . . . . . . 7-22

7-13. Current Documentation for the T Plant Facility . . . . . . . . . . . . 7-23

7-14. Current Documentation for Project W-259, Secondary Containment and

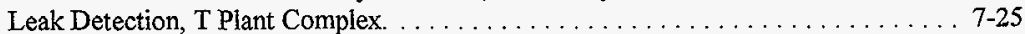

7-15. Current Documentation for Project B-459, T Plant Ventilation Upgrade. . . . . . . . 7-26

7-16. Current Documentation for Tri-Party Agreement Milestone M-33/M-91

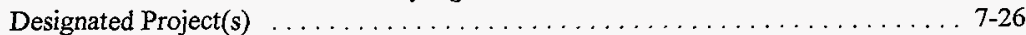

7-17. Current Documentation for the Waste Neutralization Facility . . . . . . . . . . . 7-27

7-18. Current Documentation for the 200 Area Liquid Waste Processing Facility

Complex . . . . . . . . . . . . . . . . . . . . . . . . . 7-29

7-19. Current Documentation for Project W-252, Phase II Liquid Effluent Treatment

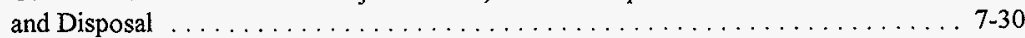

7-20. Current Documentation for the 300 Area Effluent Treatment Facility Complex . . . 7 7-30

7-21. Current Documentation for Project W-353, 300 Area Diverter Stations Upgrades . . 7-33

7-22. Current Documentation for Project W-345, 307 Basin Maintenance Upgrades . . . . 7-34

7-23. Current Documentation for Project L070, 300 Area Process Sewer Piping

System Upgrade $\ldots \ldots \ldots \ldots \ldots \ldots \ldots \ldots \ldots \ldots \ldots \ldots \ldots \ldots \ldots \ldots \ldots$

7-24. Current Documentation for the 242-A Evaporator Complex . . . . . . . . . . 7-35

7-25. Current Documentation for Low-Level Waste Burial Grounds . . . . . . . . . . . . 7-35

7-26. Current Documentation for Mixed Low-Level Waste Disposal

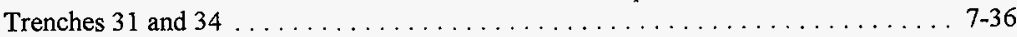

7-27. Current Documentation for the 222-S Laboratory Complex. . . . . . . . . . . . 7-37

7-28. Project W-087, 222-S Radioactive Liquid Waste Line Replacement . . . . . . . . . 7-37

7-29. Project W-187, 219-S Secondary Containment Upgrade . . . . . . . . . . . 7-37

7-30. Current Documentation for K Area Facilities $\ldots \ldots \ldots \ldots \ldots \ldots \ldots \ldots \ldots$ 7-37 


\section{HNF-SD-WM-RPT-288}

\section{Revision 0}

7-31. Current Documentation for the Waste Sampling and Characterization Facility Complex. 


\section{LIST OF TERMS}

$\begin{array}{ll}\text { ATP } & \text { acceptance test procedure } \\ \text { AWC } & \text { award of contract } \\ \text { CDR } & \text { conceptual design report } \\ \text { CPS } & \text { criticality prevention specification } \\ \text { CSER } & \text { criticality safety evaluation report } \\ \text { CVI } & \text { certified vendor information } \\ \text { DDR } & \text { detailed design report } \\ \text { DOE } & \text { U.S. Department of Energy } \\ \text { FDC } & \text { functional design criteria } \\ \text { ISB } & \text { interim safety basis } \\ \text { LEF } & \text { Liquid Effluent Facility } \\ \text { LERF } & \text { Liquid Effluent Retention Facility } \\ \text { LWPF } & \text { Liquid Waste Processing Facility } \\ \text { MEL } & \text { master equipment list } \\ \text { MP } & \text { Management Plan; maintenance procedure } \\ \text { N/A } & \text { not applicable } \\ \text { NEPA } & \text { National Environmental Policy Act of } 1969 \\ \text { ORR } & \text { operational readiness review } \\ \text { OTP } & \text { operational test procedure } \\ \text { PDR } & \text { preliminary design report } \\ \text { PMM } & \text { procurement and materials management } \\ \text { POP } & \text { plant operating procedure } \\ \text { Project } & \text { Waste Management Project } \\ \text { PSAR } & \text { preliminary safety analysis report } \\ \text { PSE } & \text { preliminary safety evaluation } \\ \text { RCRA } & \text { Resource Conservation and Recovery Act of } 1976 \\ \text { RWP } & \text { radiation work procedure } \\ \text { SAR } & \text { safety analysis report } \\ \text { SEL } & \text { safety equipment list } \\ \text { TRUSAF } & \text { Transuranic Waste Storage and Assay Facility } \\ \text { TSR } & \text { technical safety requirement } \\ \text { WRAP } & \text { Waste Receiving and Processing } \\ \text { WSCF } & \text { Waste Sampling and Characterization Facility } \\ & \end{array}$


HNF-SD-WM-RPT-288

Revision 0

This page intentionally left blank. 
HNF-SD-WM-RPT-288

Revision 0

\subsection{SYSTEM DOCUMENTATION}

\subsection{INTRODUCTION}

Within the Waste Management Project (Project), each project and facility must develop and maintain a number of documents to satisfy a wide variety of requirements. Listings and cross referencing of most of these documents are provided in this section.

\subsubsection{Background}

Documentation of the vast amount of analysis, study, design, evaluation, and planning done by the Project is necessary to meet requirements placed on the Project and to substantiate its technical baseline. External requirements are placed on the Project by regulatory considerations such as federal regulations and the Washington Administrative Code. In addition, the Project must fulfill the requirements of the Hanford Federal Facility Agreement and Consent Order (Tri-Party Agreement) (Ecology et al. 1996), applicable U.S. Department of Energy (DOE) orders, and Project-controlled manuals.

\subsubsection{Purpose}

This section lists the documentation necessary to establish the technical basis for the Project. This list includes documents required at the programmatic, project, and facility levels.

\subsubsection{Scope}

This section covers the high-level documentation necessary to establish the technical basis for the Project. In most cases, detailed procedures, drawings, etc., are not listed in their entirety, but are inferred.

\subsection{PROJECT-LEVEL DOCUMENTATION}

A number of programmatic documents must be developed to satisfy the requirements placed on the Project. These documents cover strategic planning, budgets, interface control, technical baselines, and general support. The baseline documentation for the Project is listed in Table 7-1. The documents listed in this table are categorized according to the purpose of the document. 
HNF-SD-WM-RPT-288

Revision 0

Table 7-1. Current Documentation for Waste Management Project. (2 sheets)

\begin{tabular}{|c|c|}
\hline Document number & Title \\
\hline \multicolumn{2}{|r|}{ Strategic planning and budgetary } \\
\hline DOE/RL-96-14 & Hanford Mission Direction Document (Draft) December 1995 (RL 1996) \\
\hline WHC-SP-1161 & $\begin{array}{l}\text { Solid Waste Program Fiscal Year } 1997 \text { Multi-Year Work Plon, WBS 1.2.1 } \\
\text { (Riddelle 1996) }\end{array}$ \\
\hline WHC-SP-1110 & $\begin{array}{l}\text { Analytical Services Program Fiscal Year 1997 Multi-Year Work Plan, WBS 1.5.I } \\
\text { (Spohr 1996) }\end{array}$ \\
\hline WHC-SP-1097 & $\begin{array}{l}\text { Liquid Effluents Program Fiscal Year 1997 Multi-Year Work Plan, WBS } 1.2 .2 \\
\text { (Green 1996) }\end{array}$ \\
\hline WHC-SP-1101 & $\begin{array}{l}\text { Tank Waste Remediation System Fiscal Year 1997 Multi-Year Work Plan, WBS 1.1 } \\
\text { (Wilson 1996) }\end{array}$ \\
\hline \multicolumn{2}{|r|}{ Interface controls } \\
\hline WHC-SD-ER-EE-002 & $\begin{array}{l}\text { Hanford Restoration Baseline Approach - Interface Control Document } \\
\text { (Dronen 1993) }\end{array}$ \\
\hline WHC-SD-WM-PICD-001 & $\begin{array}{l}\text { Interface Control Document Between Liquid Effuent Services and Solid Waste } \\
\text { Disposal Division (Greager 1996a) }\end{array}$ \\
\hline WHC-SD-WM-PICD-002 & $\begin{array}{l}\text { Interface Control Document Between PUREX/UO }{ }_{3} \text { Plant Transition and Solid Waste } \\
\text { Disposal Division (A.B. Carlson 1995a) }\end{array}$ \\
\hline WHC-SD-WM-PICD-003 & $\begin{array}{l}\text { Interface Control Document Between Tank Waste Remediation System and Solid } \\
\text { Waste Disposal Division (Duncan 1994) }\end{array}$ \\
\hline WHC-SD-WM-PICD-004 & $\begin{array}{l}\text { Interface Control Document Between FFTF Transition Project and Solid Waste } \\
\text { Disposal Division (Greager 1996b) }\end{array}$ \\
\hline WHC-SD-WM-PICD-005 & $\begin{array}{l}\text { Interface Control Document Between Analytical Services and Solid Waste Disposal } \\
\text { Division (Greager 1996c) }\end{array}$ \\
\hline WHC-SD-WM-PICD-006 & $\begin{array}{l}\text { Interface Control Document Between PFP Transition Project and Solid Waste } \\
\text { Disposal Division (Venetz 1995) }\end{array}$ \\
\hline WHC-SD-WM-PICD-009 & $\begin{array}{l}\text { Interface Control Document Between Spent Nuclear Fuel Operations and Solid } \\
\text { Waste Disposal Division (Greager 1996d) }\end{array}$ \\
\hline WHC-SD-WM-ICD-038 & $\begin{array}{l}\text { Interface Control Document for Untreated Liquid Effluents (Graves 1996a) (Tank } \\
\text { Waste Remediation System Project Phase I privatization contractor liquid effluents to } \\
\text { Effluent Treatment Facility) }\end{array}$ \\
\hline WHC-SD-WM-ICD-039 & Interface Control Document for Treated Liquid Effluents (Graves 1996b) \\
\hline WHC-SD-W049H-ICD-001 & $\begin{array}{l}200 \text { Area Treated Effluent Disposal Facility Interface Control Document } \\
\text { (Crane 1996) }\end{array}$ \\
\hline \multicolumn{2}{|r|}{ Technical baseline } \\
\hline WHC-SD-WM-RPT-060 & Solid Waste Program Technical Baseline Description (Sederburg 1996) \\
\hline 87330-93-WPG-026 & $\begin{array}{l}\text { Solid Waste Projects Nondestructive Assay/Nondestructive Examination Review } \\
\text { (Riddelle 1993) }\end{array}$ \\
\hline
\end{tabular}


HNF-SD-WM-RPT-288

Revision 0

Table 7-1. Current Documentation for Waste Management Project. (2 sheets)

\begin{tabular}{|c|c|}
\hline Document number & Title \\
\hline $87330-93-J B M-021$ & $\begin{array}{l}\text { Results of Solid Waste Operations Complex (SWOC) Office Administrative Space } \\
\text { Study (Myers 1993) }\end{array}$ \\
\hline PNL-8990 & 1993 Baseline Solid Waste Management System Description (PNL 1994) \\
\hline \multicolumn{2}{|r|}{ General support } \\
\hline $\mathrm{WHC}-\mathrm{CM}-5-34$ & Solid Waste Disposal Operations Aaministration Manual \\
\hline WHC-CM-5-36 & Solid Waste Disposal S/RID's Implementation \\
\hline WHC-SD-WM-ES-324 & $\begin{array}{l}\text { Treatment Options for Tank Famms Long-Length Contaminated Equipment } \\
\text { (Josephson 1995) }\end{array}$ \\
\hline WHC-EP-0063-05 & Hanford Site Solid Waste Acceptance Criteria (Willis 1996) \\
\hline WHC-EP-0918 & $\begin{array}{l}\text { Solid Waste Integrated Forecast Technical (SWIFT) Report: FY } 1997 \text { to FY } 2070 \\
\text { (Valero 1996) }\end{array}$ \\
\hline WHC-SD-RE-SAP-013 & $\begin{array}{l}\text { Safety Report for Packaging On-site Railroad Liquid Waste Tank Cars } \\
\text { (Smyth 1996a) }\end{array}$ \\
\hline WHC-SD-WM-EV-053 & Double-Shell Tank System Waste Analysis Plan (Mulkey 1995) \\
\hline WHC-IP-1026 & Engineering Practice Guidelines (Theo 1994) \\
\hline WHC-EP-0137 & $\begin{array}{l}\text { Best Available Technology (Economically Achievable) Guidance Document for the } \\
\text { Hanford Site Waste Management Systems Engineering (Flyckt 1988) }\end{array}$ \\
\hline WHC-EP-0438-1 & $\begin{array}{l}\text { A Guide for Preparing Hanford Site Facility Effluent Monitoring Plans } \\
\text { (Nickels 1992) }\end{array}$ \\
\hline WHC-IP-1043 & WHC Occupational ALARA Program (Berglund 1995) \\
\hline DOE/RL-93-94 & $\begin{array}{l}\text { Plan and Schedule for Disposition and Regulatory Compliance for Miscellaneous } \\
\text { Streams (RL 1995a) }\end{array}$ \\
\hline
\end{tabular}




\subsection{FACILITY CONTRACTS AND PROJECT DOCUMENTATION}

A procedure is in place to provide a method for managing the technical baseline of facilities and projects controlled by the Solid Waste Disposal Division through WHC-CM-5-34, Solid Waste Disposal Operations Administration Manual, Section 2.4, "Configuration Management." The procedure provides guidelines for the establishment and subsequent management of a facility technical baseline. The procedure also provides instructions for integrating the varying document control systems for the different types of technical baseline documents and helps to ensure that consistency among baseline documents is maintained.

The technical baseline for planned facilities and projects in development evolves along with the facility or project. Documents that should be included in the technical baseline for a project follow in the general order in which they are developed:

- Engineering study

- Functional design criteria

- Hazard classification

- Conceptual design report

- Preliminary safety evaluation

- Quality assurance project plan

- Preliminary design review

- Definitive design review

- Preliminary safety analysis report

- Fire hazards analysis

- Safety analysis report

- Permits (including applications, Interim Permit, Notices of Deficiency, etc., for Resource Conservation and Recovery Act of 1976 [RCRA] permit, air permits, and other required permits)

- National Environmental Policy Act of 1969 (NEPA) documentation

- Startup plan

- Acceptance test plans/reports 
Revision 0

- Operability test plans/reports

- Readiness review documentation

- Technical (H-series) drawings.

The project documentation requirements are determined primarily by the size, importance, and cost of the project. The larger, more important, and costlier the project, the greater the level of documentation required.

In addition to any project-related documentation, the technical baseline for those facilities that are operating also should include the following:

- Plant operating procedures

- Maintenance procedures

- Radiological work permits

- Field verified (as-built) drawings

- Certified vendor information

- Specifications

- Project files

- Master equipment lists

- Safety equipment lists

- Criticality safety evaluation reports

- Criticality prevention specifications

- Calibration procẹdures

- Operating specification documents

- Interim safety basis (in lieu of a safety analysis report)

- Technical safety requirements

- Training qualification packages.

The documentation associated with each project or facility under the Project is summarized in Figure 7-1. Coding is provided to illustrate the status of each document (completed, in-process, not started, or not required). The level of completion of this documentation depends on the status and schedule of each project or facility.

A complete list of documents that the Project has developed or is developing is tabulated for each project and facility in Tables 7-2 through 7-30. The list of baseline documentation provided in each of these tables follows the list of requirements previously mentioned for either new facilities or projects or currently operating facilities.

\subsubsection{Retrieval}

This section presents a list of documents that the Project has developed or is developing in support of each retrieval project. 


\section{HNF-SD-WM-RPT-288}

Revision 0

This page intentionally left blank. 


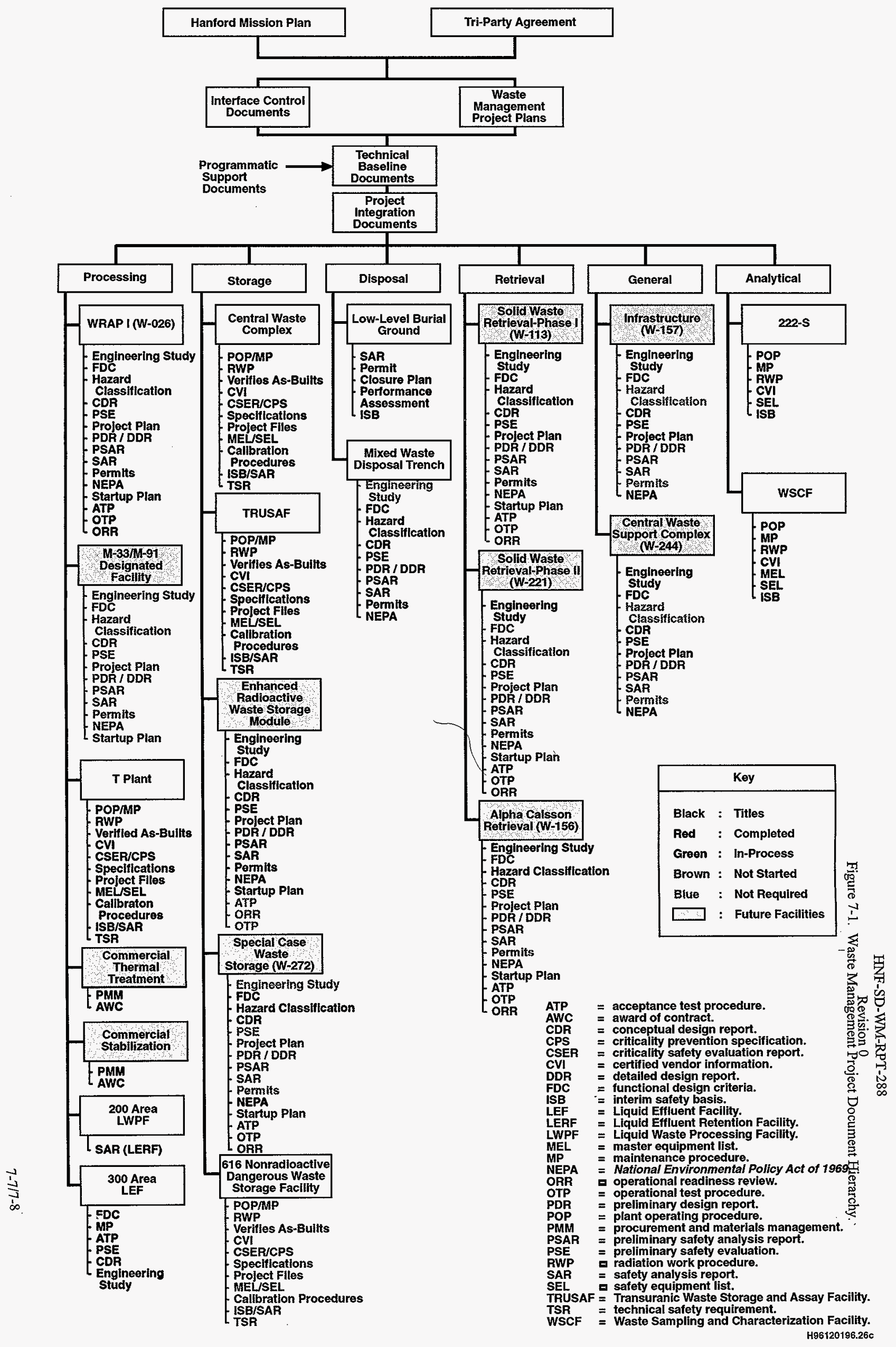


HNF-SD-WM-RPT-288

Revision 0

Table 7-2. Current Documentation for Project W-113, Solid Waste Retrieval, Phase 1. (2 sheets)

\begin{tabular}{|c|c|c|}
\hline Required document & Document number & Title \\
\hline \multirow[t]{2}{*}{ Engineering design } & WHC-SD-W113-ES-001 & $\begin{array}{l}\text { Engineering Study for the Solid Waste Retrieval } \\
\text { (Johnson 1994a) }\end{array}$ \\
\hline & WHC-SD-W113-ES-002 & $\begin{array}{l}\text { Engineering Safety Study for Project W-113 } \\
\text { (Harker 1991a) }\end{array}$ \\
\hline \multirow{2}{*}{$\begin{array}{l}\text { Functional design } \\
\text { criteria }\end{array}$} & WHC-SD-W113-RD-001 & W-113 FDC Technical Basis (Johnson 1994b) \\
\hline & WHC-SD-W113-FDC-001 & $\begin{array}{l}\text { Functional Design Criteria Solid Waste Retrieval } \\
\text { Phase I (Johnson 1994c) }\end{array}$ \\
\hline Hazard classification & WHC-SD-W113-HC-002 & $\begin{array}{l}\text { Solid Waste Retrieval Phase I Hazard Classification } \\
\text { (Harker 1991b) }\end{array}$ \\
\hline \multirow[t]{3}{*}{ Conceptual design report } & WHC-SD-W113-WP-001 & $\begin{array}{l}\text { Advanced Conceptual Design Work Plan, Project } \\
\text { W-113 Solid Waste Retrieval Facility, Phase I } \\
\text { (Smith 1992) }\end{array}$ \\
\hline & WHC-SD-W113-CDR-002 & $\begin{array}{l}\text { Conceptual Design Report, Solid Waste Retrieval } \\
\text { Facility Phase I, Project W-113 (Smith 1993) }\end{array}$ \\
\hline & WHC-SD-W113-ACDR-001 & $\begin{array}{l}\text { Advanced Conceptual Design Report, Solid Waste } \\
\text { Retrieval Facility Phase 1, Project W-113 } \\
\text { (Smith 1994) }\end{array}$ \\
\hline $\begin{array}{l}\begin{array}{l}\text { Preliminary safety } \\
\text { evaluation }\end{array} \\
\end{array}$ & WHC-SD-W113-PSE-001 & $\begin{array}{l}\text { Solid Waste Retrieval Phase I Preliminary Safety } \\
\text { Evaluation (PSE) (Harker 1993) }\end{array}$ \\
\hline $\begin{array}{l}\begin{array}{l}\text { Preliminary design } \\
\text { report }\end{array} \\
\end{array}$ & WHC-SD-W113-SPRD-001 & Preliminary Design Report (Smith 1995a) \\
\hline Definitive design review & WHC-SD-W113-SDRD-001 & $\begin{array}{l}\text { Supplemental Design Requirements Document, } \\
\text { Enhanced Radioactive and Mixed Waste Storage } \\
\text { Phase V, Project W-113 (Smith 1995b) }\end{array}$ \\
\hline Safety assessment & $\begin{array}{l}\text { WHC-SD-WM-SARR-028, } \\
\text { App. G }\end{array}$ & $\begin{array}{l}\text { Solid Waste Burial Grounds Interim Safety Analysis } \\
\text { (Estrellado 1995) }\end{array}$ \\
\hline Fire hazards analysis & WHC-SD-W113-FHA-001 & $\begin{array}{l}\text { Preliminary Fire Hazards Analysis for the Solid } \\
\text { Waste Retrieval Facility Phase 1-Project W-113 } \\
\text { (Louie 1995) }\end{array}$ \\
\hline $\begin{array}{l}\text { National Environmental } \\
\text { Policy Act of } 1969 \\
\text { documentation }\end{array}$ & DOE/EA-0981 & $\begin{array}{l}\text { Solid Waste Retrieval Complex, Enhanced } \\
\text { Radioactive and Mixed Waste Storage Facility, } \\
\text { Infrastructure Upgrades, and Central Waste Support } \\
\text { Complex (DOE 1995a) }\end{array}$ \\
\hline Project plan & - & $\begin{array}{l}\text { U.S. Department of Energy, Solid Waste Operations } \\
\text { Complex (SWOC), Phase 1 Project 94-D-411 Project } \\
\text { Plan (DOE 1994a) }\end{array}$ \\
\hline \multirow[t]{4}{*}{$\begin{array}{l}\text { Other supporting } \\
\text { documents }\end{array}$} & WHC-SD-W306-TI-001 & $\begin{array}{l}\text { Radiological and Chemical Source Terms for Solid } \\
\text { Waste Operations Complex (Booth 1994) }\end{array}$ \\
\hline & WHC-SD-WM-TPP-028 & $\begin{array}{l}\text { Technology Program Plan (TPP) for Contact Handled } \\
\text { Transuranic (CH-TRU) Waste Retrieval } \\
\text { (Winterhalder 1986) }\end{array}$ \\
\hline & WHC-SD-WM-TRP-002 & $\begin{array}{l}\text { Inspection of Retrievably Stored Transuranic Waste } \\
\text { Containers (Demiter 1991) }\end{array}$ \\
\hline & WHC-SD-W113-ES-003 & $\begin{array}{l}\text { Project W-113 Drum Venting and Head Gas Sampling } \\
\text { System Equipment (Ocampo 1993) }\end{array}$ \\
\hline
\end{tabular}


Table 7-2. Current Documentation for Project W-113, Solid Waste Retrieval, Phase 1. (2 sheets)

\begin{tabular}{|l|l|l|}
\hline \multicolumn{1}{|c|}{ Required document } & \multicolumn{1}{|c|}{ Document number } & \multicolumn{1}{|c|}{ Title } \\
\hline $\begin{array}{l}\text { Other supporting } \\
\text { documents (cont) }\end{array}$ & WHC-SD-W026-PAP-001 & $\begin{array}{l}\text { Waste Receiving and Processing/Solid Waste } \\
\text { (WRAP/SW) Engineering Development Program Plan } \\
\text { (LeClair 1993) }\end{array}$ \\
\cline { 2 - 3 } & WHC-SD-W113-OCD-001 & $\begin{array}{l}\text { Solid Waste Retrieval Phase I Operational Basis } \\
\text { (Johnson 1994d) }\end{array}$ \\
\cline { 2 - 4 } & WHC-SD-W113-ER-001 & $\begin{array}{l}\text { Preliminary Evaluation of Retrieval Systems Required } \\
\text { for Phase I Suspect TRU Solid Waste (Kelly 1991) }\end{array}$ \\
\cline { 2 - 3 } & WHC-SD-W113-ER-002 & $\begin{array}{l}\text { Equipment Design for NDE/NDA \& Gas Sampling for } \\
\text { Phase I Retrieval (Robles 1992) }\end{array}$ \\
\cline { 2 - 3 } & WHC-SD-W113-EV-001 & $\begin{array}{l}\text { Estimated Offsite and Onsite Population Health } \\
\text { Effects from Drum Explosion Out of Enclosure } \\
\text { Accident for Project W-113 (Savino 1993a) }\end{array}$ \\
\hline
\end{tabular}

Table 7-3. Current Documentation for Project W-221, Solid Waste Retrieval, Phase 2.

\begin{tabular}{|l|l|l|}
\hline \multicolumn{1}{|c|}{ Required document } & \multicolumn{1}{|c|}{ Document number } & \multicolumn{1}{|c|}{ Title } \\
\hline Engineering design & WHC-SD-W221-ES-001 & $\begin{array}{l}\text { Preliminary Engineering Study for Solid Waste } \\
\text { Retrieval, Phase 2 Project 96L-GFW-221 } \\
\text { (Robles 1993) }\end{array}$ \\
\cline { 2 - 4 } & WHC-SD-W221-ES-002 & $\begin{array}{l}\text { Phase 2 Solid Waste Retrieval Strategy } \\
\text { (Johnson 1994e) }\end{array}$ \\
\hline $\begin{array}{l}\text { Other supporting } \\
\text { documents }\end{array}$ & WHC-SD-W221-DP-001 & $\begin{array}{l}\text { Phase 2 Solid Waste Retrieval Trench } \\
\text { Characterizations (Johnson 1994f) }\end{array}$ \\
\hline
\end{tabular}

Table 7-4. Current Documentation for Project W-156, Alpha Caisson Retrieval. (2 sheets)

\begin{tabular}{|l|l|l|}
\hline \multicolumn{1}{|c|}{ Required document } & \multicolumn{1}{|c|}{ Document number } & \multicolumn{1}{c|}{ Title } \\
\hline Engineering design & WHC-SD-WM-ES-191 & $\begin{array}{l}\text { Alpha Caisson Retrieval Cask Engineering Study } \\
\text { (Monthey 1992) }\end{array}$ \\
\cline { 2 - 3 } & WHC-SD-WM-ES-181 & $\begin{array}{l}\text { Engineering Study, Retrieval of Waste from Alpha } \\
\text { Caissons (Deichelbohrer 1992a) }\end{array}$ \\
\cline { 2 - 3 } & WHC-SD-W156-ES-001 & $\begin{array}{l}\text { Engineering Safety Study for Project W-156 } \\
\text { (Medsker 1992) }\end{array}$ \\
\hline $\begin{array}{l}\text { Functional design } \\
\text { criteria }\end{array}$ & None & None \\
\hline Hazard classification & WHC-SD-W156-HC-001 & $\begin{array}{l}\text { Hazard Classification for Project W-156 Retrieval of } \\
\text { Remote-Handled Transuranic Waste from Alpha } \\
\text { Caissons (Medsker 1994) }\end{array}$ \\
\hline
\end{tabular}


Table 7-4. Current Documentation for Project W-156, Alpha Caisson Retrieval. (2 sheets)

\begin{tabular}{|l|l|l|}
\hline \multicolumn{1}{|c|}{ Required document } & \multicolumn{1}{|c|}{ Document number } & \multicolumn{1}{|c|}{ Title } \\
\hline (cont) & WHC-SD-TP-PDC-005 & $\begin{array}{l}\text { Packaging Design Criteria for the Alpha Caisson } \\
\text { Packaging System (McCormick 1992) }\end{array}$ \\
\cline { 2 - 3 } & WHC-SD-WM-ES-102 & $\begin{array}{l}\text { Remote Handling of Transuranic and Low Level } \\
\text { Waste in the Waste Receiving and Processing Facility } \\
\text { (Wyer 1992) }\end{array}$ \\
\cline { 2 - 4 } & WHC-SD-WM-PAP-041 & $\begin{array}{l}\text { Solid Waste Burial Caisson Plan for Transuranic } \\
\text { (TRU) Wastes ("Alpha" Caissons) (Garvey 1995) }\end{array}$ \\
\cline { 2 - 4 } & WHC-SD-WM-ROB-002 & $\begin{array}{l}\text { Status at Termination, Alpha Caisson Recovery } \\
\text { Demonstration (Deichelbohrer 1985a) }\end{array}$ \\
\cline { 2 - 4 } & WHC-SD-WM-ROB-003 & $\begin{array}{l}\text { Plan for Removing Remote Handled Transuranic } \\
\text { Waste from Alpha Caissons (Deichelbohrer 1985b) }\end{array}$ \\
\cline { 2 - 4 } & WHC-SD-WM-ROB-005 & $\begin{array}{l}\text { Retrieval of Waste from Alpha Caissons } \\
\text { (Deichelbohrer 1992b) }\end{array}$ \\
\cline { 2 - 4 } & WHC-SD-WM-RPT-008 & $\begin{array}{l}\text { Alpha Caisson Data and Evaluation } \\
\text { (Deichelbohrer 1992c) }\end{array}$ \\
\cline { 2 - 3 } & WhC-SD-WM-RPT-051 & Alpha Caisson Air Sampling Report (Johnson 1992) \\
\hline
\end{tabular}

Table 7-5. Current Documentation for the Hanford Central Waste Complex. (2 sheets)

\begin{tabular}{|c|c|c|}
\hline Required document & Document number & Title \\
\hline \multirow[t]{6}{*}{ Plant operating procedures } & SW-001-310 & $\begin{array}{l}\text { Respond to Radioactive Mixed Waste or Highly } \\
\text { Toxic Waste Spills-Emergency (WHC 1995a) }\end{array}$ \\
\hline & SW-040-005 & $\begin{array}{l}\text { Inspect Solid Waste Storage/Disposal Facilities } \\
\text { (WHC 1995b) }\end{array}$ \\
\hline & SW-040-020 & $\begin{array}{l}\text { Perform Surveillance of Alkali Material Storage at } \\
\text { 2727-W Building and at South Alkali Metal } \\
\text { Storage Modules (WHC 1995c) }\end{array}$ \\
\hline & SW-040-040 & $\begin{array}{l}\text { Inspect SWO Facilities and Equipment } \\
\text { (WHC 1995d) }\end{array}$ \\
\hline & SW-100-095 & Overpack Drums (WHC 1995e) \\
\hline & SW-100-110 & $\begin{array}{l}\text { Receive Radioactive Solid Waste at the Central } \\
\text { Waste Complex (WHC 1996a) }\end{array}$ \\
\hline Maintenance procedures (MP) & N/A & 45 applicable MPs \\
\hline Radiological work permits & Various & \begin{tabular}{|l|} 
Various \\
\end{tabular} \\
\hline $\begin{array}{l}\text { Field verified (as-built) } \\
\text { drawings } \\
\end{array}$ & Applicable drawings & Various \\
\hline Certified Vendor Information & N/A & 182 files \\
\hline Master Equipment Lists & WHC-SD-WM-EL-002 & $\begin{array}{l}\text { Solid Waste Monagement Facilities Master } \\
\text { Equipment List (Busching 1995) }\end{array}$ \\
\hline Safety equipment lists & WHC-SD-WM-SEL-009 & $\begin{array}{l}\text { Central Waste Complex Equipment List } \\
\text { (Renard 1995) }\end{array}$ \\
\hline
\end{tabular}


Table 7-5. Current Documentation for the Hanford Central Waste Complex. (2 sheets)

\begin{tabular}{|l|l|l|}
\hline \multicolumn{1}{|c|}{ Required document } & \multicolumn{1}{|c|}{ Document number } & \multicolumn{1}{|c|}{ Title } \\
\hline $\begin{array}{l}\text { Criticality safety evaluation } \\
\text { reports }\end{array}$ & WHC-SD-SQA-CSA-20123 & $\begin{array}{l}\text { CSAR 80-021, Addendum 2, Packaging, Storage } \\
\text { and Disposal of Solid Waste (55-Gallon Drums, } \\
\text { Unrestricted H/Pu Only) (Friar 1989a) }\end{array}$ \\
\cline { 2 - 3 } & WHC-SD-SQA-CSA-20129 & $\begin{array}{l}\text { CSAR 82-001, Transportation Burial of PUREX } \\
\text { Burial Box (Friar 1989b) }\end{array}$ \\
\cline { 2 - 3 } & WHC-SD-SQA-CSA-20130 & $\begin{array}{l}\text { CSAR 82-003, Packaging, Storage and/or Disposal } \\
\text { of Solid Wastes (Burial Containers and Uranic } \\
\text { Burial) (Friar 1989c) }\end{array}$ \\
\cline { 2 - 3 } & WHC-SD-SQA-CSA-20132 & $\begin{array}{l}\text { CSAR 85-004, Disposal of Department of } \\
\text { Transportation and Certificate of Compliance } \\
\text { Approved Contciners (Friar 1989d) }\end{array}$ \\
\cline { 2 - 3 } & WHC-SD-SQA-CSA-20204 & $\begin{array}{l}\text { CSAR 79-038, Out of Hood Plutonium Storage } \\
\text { (Friar 1990a) }\end{array}$ \\
\hline $\begin{array}{l}\text { Criticality prevention } \\
\text { specifications }\end{array}$ & CPS-SW-149-00002 & $\begin{array}{l}\text { Waste Storage Central Waste Complex } \\
\text { (WHC 1996b) }\end{array}$ \\
\hline $\begin{array}{l}\text { Interim safety basis (in lieu of } \\
\text { a safety analysis report) }\end{array}$ & HNF-SD-WM-ISB-007 & $\begin{array}{l}\text { Central Waste Complex-Interim Safety Basis } \\
\text { (Bushon 1997) }\end{array}$ \\
\hline Calibration procedures & N/A & Part of maintenance procedures \\
\hline Technical safety requirements & N/A & $\begin{array}{l}\text { N/A } \\
\text { Manford Central Waste Complex - Radioactive } \\
\text { Permit Application - Vol. 1 and 2 (Bowman 1991a) }\end{array}$ \\
\hline Permit & DOE/RL-91-17 & \\
\hline
\end{tabular}

$\mathrm{N} / \mathrm{A}=$ not applicable.

Table 7-6. Current Documentation for Transuranic Waste Storage and Assay Facility (224T Building). (2 sheets)

\begin{tabular}{|l|l|l|}
\hline \multicolumn{1}{|c|}{ Required documents } & \multicolumn{1}{|c|}{ Document number } & \multicolumn{1}{c|}{ Title } \\
\hline Plant Operating Procedures & SW-080-011 & $\begin{array}{l}\text { B-2, Non Destructive Exannination of Solid Waste } \\
\text { Drums at 224-T for Verification (WHC 1996c) }\end{array}$ \\
\cline { 2 - 3 } & SW-040-040 & $\begin{array}{l}\text { Inspect SWO Facilities and Equipment } \\
\text { (WHC 1995d) }\end{array}$ \\
\cline { 2 - 3 } & SW-040-005 & $\begin{array}{l}\text { Inspect Solid Waste Storage/Disposal Facilities } \\
\text { (WHC 1995b) }\end{array}$ \\
\cline { 2 - 3 } & SW-001-310 & $\begin{array}{l}\text { Respond to Radioactive Mixed Waste or Highly } \\
\text { Toxic Waste Spills-Emergency (WHC 1995a) }\end{array}$ \\
\hline Maintenance procedures (MP) & Various & 46 MPs \\
\hline Field verified (as-built) & Applicable drawings & Various \\
\hline Certified vendor information & Various & 93 files \\
\hline Master equipment lists & WHC-SD-WM-EL-002 & $\begin{array}{l}\text { Solid Waste Management Facilities Master } \\
\text { Equipment List (Busching 1995) }\end{array}$ \\
\hline Safety equipment lists & WHC-SD-WM-SEL-011 & $\begin{array}{l}\text { Transuranic Waste Storage and Assay Facility } \\
\text { Safety Equipment List (Irwin 1996a) }\end{array}$ \\
\hline
\end{tabular}


Table 7-6. Current Documentation for Transuranic Waste Storage and Assay Facility (224T Building). ( 2 sheets)

\begin{tabular}{|l|l|l|}
\hline \multicolumn{1}{|c|}{ Required documents } & \multicolumn{1}{|c|}{ Document number } & \multicolumn{1}{c|}{ Title } \\
\hline $\begin{array}{l}\text { Criticality safety evaluation } \\
\text { reports }\end{array}$ & WHC-SD-SQA-CSA-20123 & $\begin{array}{l}\text { CSAR 80-021, Addendum 2, Packaging, Storage } \\
\text { and Disposal of Solid Waste (55-Gallon Drums, } \\
\text { Unrestricted H/Pu Only) (Friar 1989a) }\end{array}$ \\
\hline $\begin{array}{l}\text { Criticality prevention } \\
\text { specifications }\end{array}$ & CPS-SW-149-00001 & $\begin{array}{l}\text { TRUSAF Criticality Prevention Specifications } \\
\text { (WHC 1994a) }\end{array}$ \\
\hline Calibration procedures & N/A & Part of maintenance procedures \\
\hline Safety analysis & WHC-SD-WM-SAR-025 & $\begin{array}{l}\text { Transuranic Waste Storage and Assay Facility } \\
\text { Hazard Identification and Evaluation (Pines 1992) }\end{array}$ \\
\cline { 2 - 4 } & HNF-SD-WM-ISB-004 & $\begin{array}{l}\text { Transuranic Storage and Assay Facility (TRUSAF) } \\
\text { Interim Safety Basis (Porten 1997) }\end{array}$ \\
\hline Technical safety requirements & HNF-SD-WM-TSR-002 & $\begin{array}{l}\text { Transuranic Storage and Assay Facility Interim } \\
\text { Operational Safety Requirements (Gibson 1997) }\end{array}$ \\
\hline Permit & DOE/RL-91-51 & $\begin{array}{l}\text { 224-T Transuranic Waste Storage and Assay } \\
\text { Facility Dangerous Waste Permit Application } \\
\text { (Saueressig 1992) }\end{array}$ \\
\hline
\end{tabular}

$\mathrm{MP}=$ Management Plan.

N/A = not applicable.

Table 7-7. Current Documentation for Project W-112, Enhanced Radioactive Mixed Waste Storage Facility (Phase V). (3 sheets)

\begin{tabular}{|l|l|l|}
\hline \multicolumn{1}{|c|}{ Required documents } & \multicolumn{1}{|c|}{ Document number } & \multicolumn{1}{|c|}{ Title } \\
\hline Engineering design & WHC-SD-W112-ER-001 & $\begin{array}{l}\text { Material Flow Simulation Study for the Initial Phase } \\
\text { of Phase V Storage Operations Project W-112 } \\
\text { (Kelly 1992) }\end{array}$ \\
\cline { 2 - 3 } & WHC-SD-W112-ER-002 & Witness Simulation for Project W-112 (Kooiker 1992) \\
\cline { 2 - 3 } & WHC-SD-W112-ES-002 & $\begin{array}{l}\text { Engineering Safety Study for Project W-112 } \\
\text { (Cain 1991a) }\end{array}$ \\
\hline $\begin{array}{l}\text { Functional design } \\
\text { criteria }\end{array}$ & WHC-SD-W112-FDC-001 & $\begin{array}{l}\text { Functional Design Criteria for Enhanced Radioactive } \\
\text { and Mixed Waste Storage Phase V, Project W-112 } \\
\text { (Erickson 1995) }\end{array}$ \\
\hline \multirow{2}{*}{ Hazard classification } & WHC-SD-W112-HC-002 & $\begin{array}{l}\text { Hazard Classification for the Enhanced Radioactive } \\
\text { and Mixed Waste Storage Facility Phase V, } \\
\text { Project W-112 (Cain 1991b) }\end{array}$ \\
\hline Conceptual design report & WHC-SD-W112-CDR-001 & $\begin{array}{l}\text { Enhonced Radioactive and Mixed Waste Storage } \\
\text { Phase V (Barnes 1992) }\end{array}$ \\
\cline { 2 - 3 } & WHC-SD-W112-ACDR-001 & $\begin{array}{l}\text { Project W-112, Enhanced Radioactive and Mixed } \\
\text { Waste Storage, Phase V(Greager 1994a) }\end{array}$ \\
\hline $\begin{array}{l}\text { Preliminary safety } \\
\text { evaluation }\end{array}$ & WHC-SD-W112-PSE-001 & $\begin{array}{l}\text { Preliminary Safety Evaluation for Enhanced } \\
\text { Radioactive and Mixed Waste Storage Phase V } \\
\text { Infrastructure Upgrades and Support Complex } \\
\text { Project W-112 (Cain 1993) }\end{array}$ \\
\hline
\end{tabular}


Table 7-7. Current Documentation for Project W-112, Enhanced Radioactive Mixed Waste Storage Facility (Phase V). (3 sheets)

\begin{tabular}{|c|c|c|}
\hline Required documents & Document number & Title \\
\hline $\begin{array}{l}\text { Quality assurance } \\
\text { project plan }\end{array}$ & WHC-SD-W306-QAPP-001 & $\begin{array}{l}\text { Quality Assurance Project Plan, Solid Waste } \\
\text { Operations Complex (McGee 1995) }\end{array}$ \\
\hline Definitive design review & WHC-SD-W112-SDRD-001 & $\begin{array}{l}\text { Supplemental Design Requirements Document } \\
\text { Radioactive and Mixed Waste Storage Phase V, } \\
\text { Project W-112 (Ocampo 1994) }\end{array}$ \\
\hline $\begin{array}{l}\text { Preliminary safety } \\
\text { analysis report }\end{array}$ & WHC-SD-W112-PSAR-001 & $\begin{array}{l}\text { Enhanced Radioactive \& Mixed Waste Storage Phase } \\
\text { VPreliminary Safety Analysis Report (Gibson 1996) }\end{array}$ \\
\hline Fire hazards analysis & WHC-SD-W112-EHA-001 & $\begin{array}{l}\text { Preliminary Fire Hazards Analysis for the Enhanced } \\
\text { Radioactive and Mixed Waste Storage Phase V, } \\
\text { Project W-112 (Louie 1994) }\end{array}$ \\
\hline $\begin{array}{l}\text { National Environmental } \\
\text { Policy Act of } 1969 \\
\text { documentation }\end{array}$ & DOE/EA-0981 & $\begin{array}{l}\text { Solid Waste Retrieval Complex, Enhanced } \\
\text { Radioactive and Mixed Waste Storage Facility, } \\
\text { Infrastructure Upgrades, and Central Waste Support } \\
\text { Complex (DOE 1995a) }\end{array}$ \\
\hline Project plan & Draft & $\begin{array}{l}\text { U.S. Department of Energy Solid Waste Operations } \\
\text { Complex (SWOC), Phase 1 Project 94-D-411 Project } \\
\text { Plan (DOE 1994a) }\end{array}$ \\
\hline Safety Analysis Report & WHC-SD-W112-SAD-001 & $\begin{array}{l}\text { Enhanced Radioactive and Mixed Waste Storage } \\
\text { Facility Phase V (Project W112) Safety Assessment } \\
\text { (Bonner 1995a) }\end{array}$ \\
\hline Startup plan & Draft & Draft W-112 Start Up Plan (Irwin 1996b) \\
\hline $\begin{array}{l}\text { Acceptance test } \\
\text { plans/reports }\end{array}$ & N/A & N/A \\
\hline $\begin{array}{l}\text { Operability test } \\
\text { plans/reports }\end{array}$ & N/A & N/A \\
\hline $\begin{array}{l}\text { Operational readiness } \\
\text { review }\end{array}$ & N/A & N/A \\
\hline $\begin{array}{l}\text { Criticality safety } \\
\text { evaluation report }\end{array}$ & WHC-SD-W112-CSER-001 & $\begin{array}{l}\text { Criticality Classification of Enhanced Radioactive } \\
\text { and Mixed Waste Storage (Erpenbeck 1995) }\end{array}$ \\
\hline \multirow[t]{4}{*}{$\begin{array}{l}\text { Other supporting } \\
\text { documents }\end{array}$} & WHC-SD-W026-PAP-001 & $\begin{array}{l}\text { Waste Receiving and Processing/Solid Waste } \\
\text { (WRAP/SW) Engineering Development Program Plan } \\
\text { (LeClair 1993) }\end{array}$ \\
\hline & WHC-SD-W112-ES-003 & $\begin{array}{l}\text { Project W-112, Enhanced Radioactive and Mixed } \\
\text { Waste - Phase V, Additional Studies for Project W-112 } \\
\text { (Greager 1993a) }\end{array}$ \\
\hline & WHC-SD-W112-ES-001 & $\begin{array}{l}\text { Project W-112, Enhanced Radioactive and Mixed } \\
\text { Waste Storage Phase V Engineering Study } \\
\text { (Biebesheimer 1992) }\end{array}$ \\
\hline & WHC-SD-W1 12-ES-004 & $\begin{array}{l}\text { Hanford Waste Vitrification Plant Project Interim } \\
\text { Storage Facility for Hanford Waste Vitrification Plane } \\
\text { Canister Evaluation of Alternatives (Sabin 1993) } \\
\end{array}$ \\
\hline
\end{tabular}


HNF-SD-WM-RPT-288

Revision 0

Table 7-7. Current Documentation for Project W-112, Enhanced Radioactive Mixed Waste Storage Facility (Phase V). ( 3 sheets)

\begin{tabular}{|l|l|l|}
\hline \multicolumn{1}{|c|}{ Required documents } & \multicolumn{1}{|c|}{ Document number } & \multicolumn{1}{|c|}{ Title } \\
\hline $\begin{array}{l}\text { Other supporting } \\
\text { documents (cont) }\end{array}$ & WHC-SD-W112-ES-005 & $\begin{array}{l}\text { Hanford Central Waste Complex Maintenance Study } \\
\text { (Greager 1993b) }\end{array}$ \\
\cline { 2 - 3 } & WHC-SD-W112-ES-006 & $\begin{array}{l}\text { Solid Waste Management Complex Site Development } \\
\text { Plan (Greager 1994b) }\end{array}$ \\
\cline { 2 - 3 } & WHC-SD-W112-EV-001 & $\begin{array}{l}\text { Estimated Offsite and Onsite Population Health } \\
\text { Effects Design Basis Earthquake Accident for Project } \\
\text { W-112 (Savino 1993b) }\end{array}$ \\
\cline { 2 - 3 } & WHC-SD-W112-RPT-001 & $\begin{array}{l}\text { Solid Waste Operations Complex Site Characteristics } \\
\text { Description (Bonner 1993) }\end{array}$ \\
\cline { 2 - 3 } & DOE/RL-95-79 & $\begin{array}{l}\text { Notice of Construction for Project W-112 } \\
\text { (DOE 1995b) }\end{array}$ \\
\cline { 2 - 3 } DOE/RL-91-17 & $\begin{array}{l}\text { Hanford Central Waste Complex - Radioactive Mixed } \\
\text { Waste Storage Facility Waste Permit Application - } \\
\text { Vol. 1 and 2 (Bowman 1991a) }\end{array}$ \\
\cline { 2 - 3 } & $\begin{array}{l}\text { Statistical Analysis of Total Transuranic (TRU) Waste } \\
\text { in Two Through Thirty Drums for the Proposed 4000 } \\
\text { Drum Storage Area (Stong 1994) }\end{array}$ \\
\hline
\end{tabular}

Table 7-8. Documentation for Project W-272, Special-Case Solid Waste Temporary Storage Facility.* (2 sheets)

\begin{tabular}{|l|l|l|}
\hline \multicolumn{1}{|c|}{ Required documents } & \multicolumn{1}{|c|}{ Document number } & \multicolumn{1}{|c|}{ Title } \\
\hline $\begin{array}{l}\text { Functional design } \\
\text { criteria }\end{array}$ & WHHC-SD-W272-FDC-001 & $\begin{array}{l}\text { Functional Design Criteria for the Special Case Solid } \\
\text { Waste Temporary Storage Facility (Cejka 1993) }\end{array}$ \\
\hline Hazard classification & WHC-SD-W272-HC-001 & $\begin{array}{l}\text { Special Case Waste Hazard Classification } \\
\text { (Bonner 19956) }\end{array}$ \\
\hline $\begin{array}{l}\text { Conceptual design report } \\
\text { (procurement } \\
\text { specification**) }\end{array}$ & $\begin{array}{l}\text { MDR-SVV-061460 (project } \\
\text { cancelled; document not issued) }\end{array}$ & $\begin{array}{l}\text { "Pre-Conceptual Design Considerations for a } \\
\text { Dedicated Storage Facility for 300 Area Remote } \\
\text { Handled Materials and Waste" }\end{array}$ \\
\hline Specifications & W.272-P2 & $\begin{array}{l}\text { "Procurement Specifications for Special Case Solid } \\
\text { Waste Transportation, Storage System, and Related } \\
\text { Services" }\end{array}$ \\
\hline Safety evaluation & N/A & $\begin{array}{l}\text { Vendor will provide related documentation according } \\
\text { to 10 CFR 71, "Additional Requirements for Type B } \\
\text { Packages," and 10 CFR 72, "Licensing Requirements } \\
\text { for the Independent Storage of Spent Nuclear Fuel and } \\
\text { High-Level Radioactive Waste." }\end{array}$ \\
\hline $\begin{array}{l}\text { National Environmental } \\
\text { Policy Act of 1969 } \\
\text { documentation }\end{array}$ & Draft & $\begin{array}{l}\text { Environmental Assessment for a Special Case Waste } \\
\text { Storage Unit (W-272) }\end{array}$ \\
\hline
\end{tabular}

*This project (W-272) is no longer funded. This table is included for historical purposes only.

**Conceptual design report is replaced with procurement specifications for this planned facility only. 


\section{Revision 0}

Table 7-9. Current Documentation for the Nonradioactive Dangerous Waste Storage Facility (616 Building).

\begin{tabular}{|c|c|c|}
\hline Required documents & Document number & Title \\
\hline $\begin{array}{l}\text { Plant operating } \\
\text { procedures }\end{array}$ & Various & Multiple plant operating procedures \\
\hline Maintenance procedures & Various & 18 applicable maintenance procedures \\
\hline $\begin{array}{l}\text { Radiological work } \\
\text { permits }\end{array}$ & N/A & $\mathrm{N} / \mathrm{A}$ \\
\hline $\begin{array}{l}\text { Field verified (as-built) } \\
\text { drawings }\end{array}$ & Applicable drawings & Various \\
\hline $\begin{array}{l}\text { Certified vendor } \\
\text { information }\end{array}$ & $\mathrm{N} / \mathrm{A}$ & 26 files \\
\hline Specifications & $\begin{array}{l}\text { Construction Spec: B-526-CI, } \\
\text { WHC-S-0277 }\end{array}$ & 616 Walk-In Fume Hood (WHC 1995f) \\
\hline Master equipment lists & WHC-SD-WM-EL-002 & $\begin{array}{l}\text { Solid Waste Management Facilities Master Equipment } \\
\text { List (Busching 1995) }\end{array}$ \\
\hline Safety equipment lists & WHC-SD-WM-SEL-014 & 616 Building Safety Equipment List (Bodily 1993a) \\
\hline $\begin{array}{l}\text { Interim safety basis (in } \\
\text { lieu of a safety analysis } \\
\text { report) }\end{array}$ & WHC-SD-WM-SAR-019 & $\begin{array}{l}\text { Nonradioactive Dangerous Waste Storage Facility } \\
\text { (Bodily 1993b) }\end{array}$ \\
\hline Permit & DOE/RL-89-03 & $\begin{array}{l}\text { Hanford Facility Dangerous Waste Permit, } 616 \\
\text { Nonradioactive Dangerous Waste Storage Facility } \\
\text { (Bowman 1994) }\end{array}$ \\
\hline
\end{tabular}

N/A = not applicable. 


\section{HNF-SD-WM-RPT-288}

\section{Revision 0}

Table 7-10. Current Documentation for Project W-026, Waste Receiving and Processing Module 1. (5 sheets)

\begin{tabular}{|c|c|c|}
\hline Required documents & Document number & Title \\
\hline \multirow[t]{3}{*}{ Engineering design } & WHC-SD-RE-ES-017 & $\begin{array}{l}\text { Waste Receiving and Processing (WRAP) Facility } \\
\text { Engineering Study (Cammann 1985) }\end{array}$ \\
\hline & WHC-SD-W026-ES-001 & $\begin{array}{l}\text { Technical Evaluation of the Conceptual Design for } \\
\text { the WRAP 1 Open/Sort/Package Enclosure } \\
\text { (Kelley 1990) }\end{array}$ \\
\hline & WHC-SD-W026-ES-009 & $\begin{array}{l}\text { WRAP Module 1, Characterization and Process } \\
\text { Alternatives Study (Sexton 1993) }\end{array}$ \\
\hline \multirow[t]{2}{*}{$\begin{array}{l}\text { Functional design } \\
\text { criteria }\end{array}$} & WHC-SD-W026-FDC-001 & $\begin{array}{l}\text { Waste Receiving and Processing (WRAP) Facility } \\
\text { Module I Functional Design Criteria } \\
\text { (Mayancsik 1994) }\end{array}$ \\
\hline & WHC-SD-WM-TI-291 & $\begin{array}{l}\text { Waste Receiving and Processing (WRAP) Facility } \\
\text { Draft Functional Design Criteria (Christie 1987a) }\end{array}$ \\
\hline Hazard classification & WHC-SD-WM-RPT-056 & $\begin{array}{l}\text { Solid Waste Stream Hazardous and Dangerous } \\
\text { Components (Olson 1993) }\end{array}$ \\
\hline \multirow[t]{2}{*}{ Conceptual design report } & WHC-SD-WM-TI-263 & $\begin{array}{l}\text { Waste Receiving Processing (WRAP) Facility } \\
\text { Conceptual Design Report (CDR) (Christie 1986a) }\end{array}$ \\
\hline & WHC-SD-W026-CDR-001 & $\begin{array}{l}\text { Conceptual Design Report for Project W-026 Waste } \\
\text { Receiving and Processing Facility Module } 1 \text { (Rieck } \\
\text { 1990) }\end{array}$ \\
\hline $\begin{array}{l}\text { Preliminary safety } \\
\text { evaluation }\end{array}$ & WHC-SD-W026-PSE-001 & $\begin{array}{l}\text { Preliminary Safety Evaluation for Waste Receiving } \\
\text { and Processing Facility Module } 1 \text { Project W-026 } \\
\text { (Joyce 1993) }\end{array}$ \\
\hline \multirow[t]{7}{*}{$\begin{array}{l}\text { Preliminary design } \\
\text { review }\end{array}$} & $\begin{array}{l}\text { UE\&C Preliminary Design } \\
\text { Report }\end{array}$ & 85 Gallon Drum Overpack Study (UE\&C 1991a) \\
\hline & $\begin{array}{l}\text { UE\&C Preliminary Design } \\
\text { Report }\end{array}$ & $\begin{array}{l}\text { Waste Receiving and Processing Facility Module I } \\
\text { Preliminary Design Report (UE\&C 1992) }\end{array}$ \\
\hline & $\begin{array}{l}\text { UE\&C Preliminary Design } \\
\text { Report }\end{array}$ & ALARA Assessment Study (UE\&C 1991b) \\
\hline & $\begin{array}{l}\text { UE\&C Preliminary Design } \\
\text { Report }\end{array}$ & Bagless Transfer System (UE\&C 1991c) \\
\hline & $\begin{array}{l}\text { UE\&C Preliminary Design } \\
\text { Report }\end{array}$ & CDR Technical Assessment (UE\&C 1991d) \\
\hline & $\begin{array}{l}\text { UE\&C Preliminary Design } \\
\text { Report }\end{array}$ & Compaction Optimization Study (UE\&C 1991e) \\
\hline & $\begin{array}{l}\text { UE\&C Preliminary Design } \\
\text { Report }\end{array}$ & $\begin{array}{l}\text { Degree of Automation Within Containment Study } \\
\text { (UE\&C 1991f) }\end{array}$ \\
\hline
\end{tabular}


Table 7-10. Current Documentation for Project W-026, Waste Receiving and Processing Module 1. ( 5 sheets)

\begin{tabular}{|c|c|c|}
\hline Required documents & Document number & Title \\
\hline \multirow[t]{7}{*}{$\begin{array}{l}\text { Preliminary design } \\
\text { review (cont) }\end{array}$} & $\begin{array}{l}\text { UE\&C Preliminary Design } \\
\text { Report }\end{array}$ & Drum and Box Lag Storage Study (UE\&C 1991g) \\
\hline & $\begin{array}{l}\text { UE\&C Preliminary Design } \\
\text { Report }\end{array}$ & $\begin{array}{l}\text { Hardware for Characterization of Waste Study } \\
\text { (UE\&C 1991h) }\end{array}$ \\
\hline & $\begin{array}{l}\text { UE\&C Preliminary Design } \\
\text { Report }\end{array}$ & HVAC Confinement Study (UE\&C 1991i) \\
\hline & $\begin{array}{l}\text { UE\&C Preliminary Design } \\
\text { Report }\end{array}$ & Material Handling Optimization Study (UE\&C 1991j) \\
\hline & $\begin{array}{l}\text { UE\&C Preliminary Design } \\
\text { Report }\end{array}$ & $\begin{array}{l}\text { Methods of Waste Entry Into Containment } \\
\text { (UE\&C 1991k) }\end{array}$ \\
\hline & $\begin{array}{l}\text { UE\&C Preliminary Design } \\
\text { Report }\end{array}$ & Waste Minimization Study (UE\&C 19911) \\
\hline & $\begin{array}{l}\text { UE\&C Preliminary Design } \\
\text { Report }\end{array}$ & $\begin{array}{l}\text { Waste Processing Systems Layout \& Configuration } \\
\text { Study (UE\&C 1991m) }\end{array}$ \\
\hline $\begin{array}{l}\text { Preliminary safety } \\
\text { analysis report }\end{array}$ & WHC-SD-W026-SAR-001 & $\begin{array}{l}\text { Waste Receiving and Processing Facility Module } 1 \\
\text { (WRAP) Preliminary Safety Analysis Report } \\
\text { (Olson 1994) }\end{array}$ \\
\hline Permit & DOE/RL-91-16 & $\begin{array}{l}\text { Hanford Central Waste Complex - Waste Receiving } \\
\text { and Processing Facility Dangerous Waste Permit } \\
\text { Application (Bowman 1991b) }\end{array}$ \\
\hline $\begin{array}{l}\text { National Environmental } \\
\text { Policy Act of } 1969 \\
\text { documentation }\end{array}$ & DOE/EIS-01133-FS/SA2 & $\begin{array}{l}\text { Supplement Analysis of the Environmental Effects of } \\
\text { Changes in DOE's Proposed Action to Construct and } \\
\text { Operate the Waste Receiving and Processing Facility } \\
\text { Module I (DOE 1992) }\end{array}$ \\
\hline Startup plan & $\begin{array}{l}\text { Draft, WHC-SD-W026-PLN- } \\
\text { 004, Rev. } 1\end{array}$ & $\begin{array}{l}\text { Implementation Plan (IP) for the Waste Receiving and } \\
\text { Processing Facility Module 1 (WRAP 1) Operational } \\
\text { Readiness Review (WHC 1996d) }\end{array}$ \\
\hline $\begin{array}{l}\text { Acceptance test } \\
\text { plans/reports }\end{array}$ & N/A & N/A \\
\hline \multirow[t]{4}{*}{$\begin{array}{l}\text { Operability test } \\
\text { plans/reports }\end{array}$} & WHC-SD-WM-IP-027 & $\begin{array}{l}\text { Test Plan for Optimizing Grout Formulation and } \\
\text { Mixing Techmiques for Immobilization of CH-TRU } \\
\text { Waste at the WRAP Facility (Keith 1994a) }\end{array}$ \\
\hline & WHC-SD-WM-TRP-017 & $\begin{array}{l}\text { Waste Form Development for the Waste Receiving } \\
\text { and Processing (WRAP) Facility (Naser 1985) }\end{array}$ \\
\hline & WHC-SD-WM-TRP-023 & $\begin{array}{l}\text { Test Report from Grout Formulation and Mixing } \\
\text { Techniques for Immobilization of Solid Shredded } \\
\text { CH-TRU Waste at the WRAP Facility (Keith 1994b) }\end{array}$ \\
\hline & WHC-SD-W026-DTP-001 & $\begin{array}{l}\text { Development Test Plan for Drum Cutting for WRAP } \\
\text { Module } 1 \text { (Kanjilal 1991) }\end{array}$ \\
\hline
\end{tabular}




\section{Revision 0}

Table 7-10. Current Documentation for Project W-026, Waste Receiving and Processing Module 1. (5 sheets)

\begin{tabular}{|c|c|c|}
\hline Required documents & Document number & Title \\
\hline \multirow{9}{*}{$\begin{array}{l}\text { Operability test } \\
\text { plans/reports (cont) }\end{array}$} & WHC-SD-W026-DTP-002 & Relidding 55 Gallon Waste Drums (Griffen 1992) \\
\hline & WHC-SD-W026-DTP-003 & $\begin{array}{l}\text { Waste Drum Relidding, C-Clip Installation, and Feed } \\
\text { Mechanism Development Plan (Webb 1993) }\end{array}$ \\
\hline & WHC-SD-W026-DTP-001 & $\begin{array}{l}\text { Drum Waste Non-Destructive Examination Interim } \\
\text { Status Report (Weber 1992a) }\end{array}$ \\
\hline & WHC-SD-W026-TP-001 & $\begin{array}{l}\text { Nondestructive Examination Development and } \\
\text { Demonstration Plan (Weber 1994) }\end{array}$ \\
\hline & WHC-SD-W026-TP-002 & Test Plan for Sphincter Seal Testing (Pauly 1990a) \\
\hline & WHC-SD-W026-TP-005 & Entry/Exit Port Testing Test Plan (Winkelman 1993) \\
\hline & WHC-SD-W026-TRP-002 & $\begin{array}{l}\text { Test Report for Compacted Waste Drum Sampling } \\
\text { (Hull 1992) }\end{array}$ \\
\hline & WHC-SD-W026-TRP-003 & $\begin{array}{l}\text { Test Report for Vacuum Lift Drum De-Lidding } \\
\text { (Ruff 1992a) }\end{array}$ \\
\hline & WHC-SD-W026-TRP-00S & $\begin{array}{l}\text { C-Clip Drum Re-Lidding Test Report Implementation } \\
\text { Plan (Ruff 1992b) }\end{array}$ \\
\hline $\begin{array}{l}\text { Operational readiness } \\
\text { review }\end{array}$ & See Startup Plan & See Startup Plan \\
\hline Project plan & N/A & $\begin{array}{l}\text { U.S. Department of Energy Waste Receiving and } \\
\text { Processing Module } 1 \mathrm{~W}-026 \text { Project Plan } \\
\text { (Sullivan 1992) }\end{array}$ \\
\hline \multirow[t]{6}{*}{$\begin{array}{l}\text { Other supporting } \\
\text { documents }\end{array}$} & WHC-SD-W026-PAP-001 & $\begin{array}{l}\text { Waste Receiving and Processing/Solid Waste } \\
\text { (WRAP/SW) Facility Engineering Development } \\
\text { Program Plan (LeClair 1993) }\end{array}$ \\
\hline & DOE/RL-93-15 & $\begin{array}{l}\text { Radioactive Air Emissions Notice of Construction for } \\
\text { the Waste Receiving and Processing Facility - } \\
\text { WRAP I (Coenenberg 1993a) }\end{array}$ \\
\hline & DOE/RL-93-16 & $\begin{array}{l}\text { Application for Approval to Construct the Waste } \\
\text { Receiving and Processing Facility } \\
\text { (Coenenberg 1993b) }\end{array}$ \\
\hline & DOE/RL-93-18 & $\begin{array}{l}\text { Nonradioactive Air Emissions Notice of Construction } \\
\text { for the Waste Receiving and Processing Facility } \\
\text { (Coenenberg 1993c) }\end{array}$ \\
\hline & WHC-SD-W026-SE-001 & $\begin{array}{l}\text { The Honford Central Waste Complex Site Evaluation } \\
\text { Report (Havens 1988) }\end{array}$ \\
\hline & WHC-SD-W100-ES-001 & $\begin{array}{l}\text { Engineering Study for Waste Receiving and } \\
\text { Processing (WRAP) Facility Module } 2 \text { (Pauly 1990b) }\end{array}$ \\
\hline
\end{tabular}


Table 7-10. Current Documentation for Project W-026, Waste Receiving and Processing Module 1. ( 5 sheets)

\begin{tabular}{|c|c|c|}
\hline \multirow[t]{2}{*}{ Required documents } & Document number & Title \\
\hline & WHC-SD-WM-PE-021 & $\begin{array}{l}\text { Waste Receiving and Processing (WRAP) Facility } \\
\text { Performance Evaluation Plon for Shredded, } \\
\text { Simulated TRU Waste Immobilization in Cement } \\
\text { Grout (Christie 1985) }\end{array}$ \\
\hline \multirow[t]{14}{*}{$\begin{array}{l}\text { Other supporting } \\
\text { documents (cont) }\end{array}$} & WHC-SD-WM-II-128 & $\begin{array}{l}\text { Design of Drum Calibration Standards for the } \\
\text { Transuranic Assay Unit (Cunningham 1985) }\end{array}$ \\
\hline & WHC-SD-PRP-HA-027 & $\begin{array}{l}\text { Waste Receiving and Processing (WRAP) Module } 1 \\
\text { Hazards Analysis (Sutton 1996) }\end{array}$ \\
\hline & WHC-SD-WM-TI-221 & $\begin{array}{l}\text { Operating and Product Criteria for the Shred/Grout } \\
\text { Process Planned for Use in the Woste Receiving and } \\
\text { Processing (WRAP) Facility (Keith 1994c) }\end{array}$ \\
\hline & WHC-SD-WM-TI-243 & $\begin{array}{l}\text { Practical Considerations for the Design and } \\
\text { Operation of the Waste Receiving and Processing } \\
\text { (WRAP) Size Reduction Facility (Christie 1987b) }\end{array}$ \\
\hline & WHC-SD-WM-TI-262 & $\begin{array}{l}\text { Waste Receiving and Processing Facility (WRAP) } \\
\text { Preliminary System Operating Logic Diagram } \\
\text { (SOLD) (Christie 1986b) }\end{array}$ \\
\hline & WHC-SD-WM-TI-264 & $\begin{array}{l}\text { Performance Evaluation of Simulated TRU Waste } \\
\text { Shredded and Immobilized in Cement Grout (Phase I), } \\
\text { Vol. I of } 2 \text { (Christie 1986c) }\end{array}$ \\
\hline & WHC-SD-WM-TI-265 & $\begin{array}{l}\text { Performance Evaluation of Simulated TRU Shredded } \\
\text { and Immobilized in Cement Grout (Phase II), Vol. } 2 \text { of } \\
2 \text { (Christie 1986d) }\end{array}$ \\
\hline & WHC-SD-WM-TI-268 & $\begin{array}{l}\text { Practical Considerations of High-Density } \\
\text { Compaction Systems for Use in the Waste Receiving } \\
\text { and Processing (WRAP) Facility (Christie 1987c) }\end{array}$ \\
\hline & WHC-S-0033 & Boxed Waste Assoy System (WHC 1994b) \\
\hline & WHC-SD-W026-DP-001 & $\begin{array}{l}\text { Nondestructive Assay (NDA) Data from Transuranic } \\
\text { Storage and Asscy Facility (TRUSAF) Oct } 1985 \text { - } \\
\text { Oct } 1990 \text { (Lunsford 1991) }\end{array}$ \\
\hline & WHC-SD-W026-ES-004 & $\begin{array}{l}\text { Evaluation of Alternatives for Nondestructive Assay } \\
\text { and Examination of Drums and Boxed Waste in } \\
\text { WRAP } 1 \text { (Weber 1995) }\end{array}$ \\
\hline & UE\&C & $\begin{array}{l}\text { Waste Receiving and Processing Facility Module I } \\
\text { Detailed Design Report (UE\&C 1993) }\end{array}$ \\
\hline & WHC-SD-W026-SDRD-001 & $\begin{array}{l}\text { Supplemental Design Requirements Document, } \\
\text { Project W-026 (Weidert 1993) }\end{array}$ \\
\hline & WHC-SD-W026-TI-003 & $\begin{array}{l}\text { WRAP Module } 1 \text { Air Emissions Source Term } \\
\text { (Pauly 1992) }\end{array}$ \\
\hline
\end{tabular}


Table 7-10. Current Documentation for Project W-026, Waste Receiving and Processing Module 1. (5 sheets)

\begin{tabular}{|c|c|c|}
\hline \multirow{13}{*}{$\begin{array}{l}\text { Required documents } \\
\text { Other supporting } \\
\text { documents (cont) }\end{array}$} & Document number & Title \\
\hline & WHC-SD-W026-TY-004 & $\begin{array}{l}\text { Waste Receiving and Processing Module l Best } \\
\text { Available Radionuclide Control Technology } \\
\text { Assessment (Coenenberg 1993d) }\end{array}$ \\
\hline & WHC-SD-W026-TI-005 & $\begin{array}{l}\text { Hanford Waste Receiving and Processing Facility } \\
\text { Module } 1 \text { Technical Background Document for Best } \\
\text { Available Control Technology for Toxic } \\
\text { Demonstration (Coenenberg 1993e) }\end{array}$ \\
\hline & WHC-SD-W026-WP-001 & $\begin{array}{l}\text { WRAP Module 1 NSE/NDA Area Development Work } \\
\text { Plon (Weber 1992b) }\end{array}$ \\
\hline & WHC-SD-W026-WP-002 & $\begin{array}{l}\text { Work Plan for Design Verification and Acceptance } \\
\text { Testing of a Box Waste Assay System (Shaw 1992) }\end{array}$ \\
\hline & WHC-SD-W026-CSRS-001 & $\begin{array}{l}\text { WRAP I Module I DataManagement System } \\
\text { Software Requirements Specification (Rosnick 1994) }\end{array}$ \\
\hline & WHC-SD-W026-CSWD-001 & $\begin{array}{l}\text { WRAP I Plant DMS/PCS Interface Definition } \\
\text { (Weidert 1994) }\end{array}$ \\
\hline & WHC-SD-W026-PMP-002 & $\begin{array}{l}\text { Project Management Plan, Waste Receiving and } \\
\text { Processing Facility, Project W-026 (Starkey 1994) }\end{array}$ \\
\hline & WHC-SD-W026-TRP-002 & $\begin{array}{l}\text { Test Report for Compacted Waste Drum Sampling } \\
\text { (Hull 1992) }\end{array}$ \\
\hline & WHC-SD-WM-TRP-001 & $\begin{array}{l}\text { Test Report on the Siudy of Drum Cutting } \\
\text { (Sprouse 1982) }\end{array}$ \\
\hline & WHC-SD-W026-TA-001 & $\begin{array}{l}\text { Technical Assessment: WRAP I-HVAC Passive } \\
\text { Shutdown (Stroup 1993) }\end{array}$ \\
\hline & WHC-SD-W026-TI-006 & $\begin{array}{l}\text { Project W-026, Waste Receiving and Processing } \\
\text { (WRAP) Facility Module 1: Maximum Possible Fire } \\
\text { Loss (MPFL) Decontamination and Cleanup } \\
\text { Estimates (Hinkle 1994) }\end{array}$ \\
\hline & WHC-SD-W026-TI-007 & $\begin{array}{l}\text { Probability of an Explosion in WRAP-1 Gloveboxes } \\
\text { (Siemer 1993) }\end{array}$ \\
\hline
\end{tabular}




\section{Revision 0}

Table 7-11. Current Documentation for Contact-Handled Mixed Low-Level Waste Commercial Stabilization Treatment Program.

\begin{tabular}{|l|l|l|}
\hline \multicolumn{1}{|c|}{ Required documents } & \multicolumn{1}{|c|}{ Document number } & \multicolumn{1}{c|}{ Title } \\
\hline $\begin{array}{l}\text { Procurement and } \\
\text { materials management }\end{array}$ & $\begin{array}{l}\text { Purchase Order } \\
\text { M6K-SFW-452759 }\end{array}$ & $\begin{array}{l}\text { Mixed Waste Stabilization Treatment Program } \\
\text { Purchase Order }\end{array}$ \\
\hline Award of Contract & $\begin{array}{l}\text { Purchase Order } \\
\text { M6K-SFW-452759 }\end{array}$ & $\begin{array}{l}\text { Mixed Waste Stabilization Treatment Program } \\
\text { Purchase Order }\end{array}$ \\
\hline Request for Proposal & No. W-452759-GK & $\begin{array}{l}\text { Mixed Waste Stabilization Treatment Program } \\
\text { Request for Proposal (WHC 1995g) }\end{array}$ \\
\hline Close-out report & WHC-SD-W100-RPT-001 & $\begin{array}{l}\text { Waste Receiving and Processing Module 2A } \\
\text { Termination of Design Closeout Report } \\
\text { (T. A. Carlson 1995a) }\end{array}$ \\
\hline
\end{tabular}

Table 7-12. Current Documentation for the Thermal Treatment Facility.

\begin{tabular}{|l|l|l|}
\hline \multicolumn{1}{|c|}{ Required documents } & \multicolumn{1}{|c|}{ Document number } & \multicolumn{1}{|c|}{ Title } \\
\hline Request for Proposal & No. W-357079-JW* & $\begin{array}{l}\text { Low-Level Mixed Waste Thermal Treatment Service } \\
\text { (WHC 1994c) }\end{array}$ \\
\hline $\begin{array}{l}\text { Procurement and } \\
\text { materials management }\end{array}$ & $\begin{array}{l}\text { Purchase Order } \\
\text { MW6-SBV-357079* }\end{array}$ & $\begin{array}{l}\text { Low-Level Mixed Waste Thermal Treatment Service } \\
\text { Purchase Order }\end{array}$ \\
\hline Award of Contract & $\begin{array}{l}\text { Purchase Order } \\
\text { MW6-5BV-357079 }\end{array}$ & $\begin{array}{l}\text { Low-Level Mixed Waste Thermal Treatment Service } \\
\text { Purchase Order }\end{array}$ \\
\hline Hazard classification & WHC-SD-W242-HC-001* & $\begin{array}{l}\text { Hazard Classification for the Thermal Treatment } \\
\text { Facility, Project W-242 (Cillan 1993) }\end{array}$ \\
\hline \multirow{2}{*}{ Other supporting } & SAIC-91/1278* & $\begin{array}{l}\text { Assessment of High-Temperature Thermal Treatment } \\
\text { Alternatives for Inclusion into the Scope of the } \\
\text { Hanford Waste Receiving and Processing (WRAP) } \\
\text { Facility (SAIC 1991) }\end{array}$ \\
\cline { 2 - 4 } & WHC-SD-W242-ES-002* & $\begin{array}{l}\text { W242 Thermal Treatment Facility Technical Basis } \\
\text { Document (Place 1993) }\end{array}$ \\
\cline { 2 - 3 } & WHC-SD-W242-ES-003* & $\begin{array}{l}\text { Low-Level Mixed Waste Thermal Treatment Technical } \\
\text { Basis Report (Place 1994) }\end{array}$ \\
\hline
\end{tabular}

*Historical documentation to show process from request for proposals to contract award. 


\section{Revision 0}

Table 7-13. Current Documentation for the T Plant Facility. (3 sheets)

\begin{tabular}{|c|c|c|}
\hline Required documents & Document number & Title \\
\hline $\begin{array}{l}\text { Plant operating } \\
\text { procedures }\end{array}$ & $\begin{array}{l}40 \text { applicable plant operating } \\
\text { procedures }\end{array}$ & Various \\
\hline Maintenance procedures & $\begin{array}{l}131 \text { applicable maintenance } \\
\text { procedures }\end{array}$ & Various \\
\hline Calibration procedures & $\begin{array}{l}59 \text { applicable calibration } \\
\text { procedures }\end{array}$ & Various \\
\hline $\begin{array}{l}\text { Field verified (as-built) } \\
\text { drawings }\end{array}$ & Applicable drawings & Various \\
\hline $\begin{array}{l}\text { Certified vendor } \\
\text { information }\end{array}$ & 451 files & Various \\
\hline $\begin{array}{l}\text { Radiological work } \\
\text { permits }\end{array}$ & $\begin{array}{l}46 \text { applicable radiological work } \\
\text { permits }\end{array}$ & Various \\
\hline \multirow[t]{2}{*}{$\begin{array}{l}\text { Criticality prevention } \\
\text { specifications }\end{array}$} & CPS-T-149-00015 & $\begin{array}{l}\text { Liquid Waste Transport-20000 Gallon Railroad Tank } \\
\text { (WHC 1991) }\end{array}$ \\
\hline & CPS-D-149-00001 & TPlant Canyon Operations (WHC 1995h) \\
\hline \multirow[t]{2}{*}{$\begin{array}{l}\text { Criticality safety } \\
\text { analysis }\end{array}$} & WHC-SD-SQA-CSA-20104 & $\begin{array}{l}\text { T Plant Decontamination and Repair Facilities } \\
\text { (Johnson 1993a) }\end{array}$ \\
\hline & WHC-SD-SQA-CSA-20153 & $\begin{array}{l}\text { CSAR 78-001, PWR CORE } 2 \text { Blanket Fuel Storage } \\
\text { Cell 4/221T Building (Friar 1990b) }\end{array}$ \\
\hline Fire hazard analysis & WHC-SD-WM-FHA-OOI & Fire Hazards Analysis for T Plant (Oar 1995) \\
\hline $\begin{array}{l}\text { Operating specification } \\
\text { documents }\end{array}$ & OSD-D-187-00008 & $\begin{array}{l}\text { Operating Specifications for T Plant Facility } \\
\text { (WHC 1996e) }\end{array}$ \\
\hline \multirow[t]{2}{*}{ Safety analysis } & WHC-SD-WM-SA-023 & $\begin{array}{l}\text { PWR CORE II Storage Pool Structural/Seismic } \\
\text { Qualification-T Plont (Barlow 1994a) }\end{array}$ \\
\hline & WHC-SD-WM-SA-024 & T Plant Roof Seismic Qualification (Jorisson 1993) \\
\hline Support drawings & WHC-SD-WM-EDL-001 & TPlant Support Drowing List (Winslow 1995) \\
\hline Interim safety basis & HNF-SD-WM-ISB-006 & $\begin{array}{l}\text { Interim Safety Basis for Solid Waste Facilities } \\
\text { (T Plant) (Meyer 1997) }\end{array}$ \\
\hline Safety equipment list & WHC-SD-WM-SEL-013 & Interim T Plant Safety Equipment List (Ortega 1993) \\
\hline \multirow[t]{2}{*}{ Engineering studies } & WHC-SD-WM-TI-550 & $\begin{array}{l}\text { Fault and Coordination Study for 221T/27IT/2706T } \\
\text { (Whattam 1993) }\end{array}$ \\
\hline & WHC-SD-WM-ES-315 & $\begin{array}{l}\text { T Plant Canyon Deck-Level Allowable Floor Load } \\
\text { Study (Barlow 1994b) }\end{array}$ \\
\hline Interim permit & DOE/RL-95-36 & $\begin{array}{l}\text { Hanford Facility Dangerous Waste Permit } \\
\text { Application, T Plant Complex (RL 1995b) }\end{array}$ \\
\hline $\begin{array}{l}\text { Resource Conservation } \\
\text { and Recovery Act of } \\
1976 \text { permit }\end{array}$ & N/A & $\begin{array}{l}\text { Hanford Facility Dangerous Waste Part A Permit } \\
\text { Application, Form } 3 \text { Revision } 4 \text { for } T \text { Plant Complex } \\
\text { (TSD: T-2-7) }\end{array}$ \\
\hline Air permit & DOE/RL-95-07 & $\begin{array}{l}\text { Hanford Site Air Operating Permit Application } \\
\text { (Moon 1995) }\end{array}$ \\
\hline
\end{tabular}


Revision 0

Table 7-13. Current Documentation for the T Plant Facility. (3 sheets)

\begin{tabular}{|c|c|c|}
\hline Required documents & Document number & Title \\
\hline $\begin{array}{l}\text { National Environmental } \\
\text { Policy Act of } 1969 \\
\text { (NEPA) documentation } \\
\text { for projects at T Plant }\end{array}$ & N/A & $\begin{array}{l}\text { Files on NEPA documentation are kept by the } \mathrm{T} \text { Plant } \\
\text { Environmental Compliance Officer }\end{array}$ \\
\hline $\begin{array}{l}\text { Functional design } \\
\text { criteria }\end{array}$ & WHC-SD-W291H-FDC-001 & $\begin{array}{l}\text { Functional Design Criteria for } 200 \text { Area Effluent } \\
\text { BAT/AKART Implementation Project W-291 } \\
\text { (Brown 1994) }\end{array}$ \\
\hline Conceptual design report & WHC-SD-W291-CDR-001 & $\begin{array}{l}\text { Conceptual Design Report } 200 \text { Area Effluent } \\
\text { BAT/AKART Implementation Project W-291 } \\
\text { (Peterson 1993) }\end{array}$ \\
\hline Quality assurance plan & WHC-SD-W291-QAPP-001 & Project-Specific Quality Assurance Plan (Finch 1995) \\
\hline $\begin{array}{l}\text { Preliminary safety } \\
\text { evaluation }\end{array}$ & WHC-SD-W291-PSE-001 & $\begin{array}{l}\text { Preliminary Safety Evaiuation for Project W-291, } 200 \\
\text { Areas Effluent BAT/AKART Implementation } \\
\text { (Lavender 1993) }\end{array}$ \\
\hline $\begin{array}{l}\text { Preliminary safety } \\
\text { analysis report }\end{array}$ & WHC-SD-W291H-PSAR-001 & $\begin{array}{l}200 \text { Area Effluent BAT/AKART Implementation } \\
\text { Preliminary Safety Analysis Report (Bendixsen 1994) }\end{array}$ \\
\hline $\begin{array}{l}\text { Acceptance test } \\
\text { procedure }\end{array}$ & WHC-SD-W291H-ATP-001 & $\begin{array}{l}\text { TPlant Instrumentation and Electrical Acceptance } \\
\text { Test Procedure (Ocampo 1995) }\end{array}$ \\
\hline $\begin{array}{l}\text { Functional design } \\
\text { criteria }\end{array}$ & SD-630-FDC-00I & $\begin{array}{l}\text { Project B-630, Building 221-T Life Safety Upgrade } \\
\text { Functional Design Criteria (Romano 1986a) }\end{array}$ \\
\hline Conceptual design report & SD-630-CDR-001 & $\begin{array}{l}\text { Conceptual Design Report Building 221-T Life Safety } \\
\text { Upgrade Project B-630 (Romano 1986b) }\end{array}$ \\
\hline $\begin{array}{l}\text { Technical (H-series) } \\
\text { drawings }\end{array}$ & Applicable drawings & Various \\
\hline \multirow[t]{2}{*}{$\begin{array}{l}\text { Acceptance test } \\
\text { procedure }\end{array}$} & B630-ATP-01 & $\begin{array}{l}\text { Acceptance Test Procedure for Project B-630 } \\
221-T \text { Building Life Safety Upgrade (Palmros 1987) }\end{array}$ \\
\hline & SD-C181-ATP-00I & $\begin{array}{l}\text { Acceptance Test Procedure for Project C-181-2706- } \\
\text { T Building Upgrade (Buckles 1992a) }\end{array}$ \\
\hline \multirow[t]{4}{*}{$\begin{array}{l}\text { Other supporting } \\
\text { documents }\end{array}$} & SD-630-CDP-001 & $\begin{array}{l}\text { Conceptual Design Plon Project B-630, 221-T Life } \\
\text { Safety Upgrade (Romano 1986c) }\end{array}$ \\
\hline & SD-630-DRR-001 & $\begin{array}{l}\text { Design Document Review Report Functional Design } \\
\text { Criteria Building 22I-T Life Safety Upgrade Project } \\
\text { B-630 (Romano 1986d) }\end{array}$ \\
\hline & SD-630-DRR-002 & $\begin{array}{l}\text { Design Document Review Report Conceptual Design } \\
\text { Report Building 221-T Life Safety Upgrade Project } \\
\text { B-630 (Romano 1986e) }\end{array}$ \\
\hline & SD-C181-PMP-001 & $\begin{array}{l}\text { Project C-181, Project-Specific Project Management } \\
\text { Plan (Buckles 1992b) }\end{array}$ \\
\hline Acceptance test record & SD-C181-ATR-001 & $\begin{array}{l}\text { Acceptance Test Record For Project C181 2706-T } \\
\text { Building Upgrade (Buckles 1993) }\end{array}$ \\
\hline $\begin{array}{l}\text { Interface control } \\
\text { documents }\end{array}$ & WHC-SD-W049H-ICD-001 & $\begin{array}{l}\text { 200 Area Treated Effluent Disposal Facility Interface } \\
\text { Control Document (Crane 1996) }\end{array}$ \\
\hline
\end{tabular}


Table 7-13. Current Documentation for the T Plant Facility. (3 sheets)

\begin{tabular}{|c|c|c|}
\hline Required documents & Document number & Title \\
\hline \multirow{7}{*}{$\begin{array}{l}\text { Training qualification } \\
\text { packages }\end{array}$} & Course no. 450020 & T Plant Surveillance Operator Training Qualification \\
\hline & Course no. 450010 & Canyon Decontamination Operator Qualification \\
\hline & Course no. 450030 & 2706-T Decontamination \\
\hline & Course no. 450040 & Waste Handler \\
\hline & Course no. 000390 & On the Job Training \\
\hline & Course no. 000397 & On the Job Evaluation \\
\hline & Course no. 451420 & $\begin{array}{l}\text { T Plant Training Manager Technical Staff Facility } \\
\text { Overview }\end{array}$ \\
\hline \multicolumn{3}{|c|}{$\begin{array}{l}\text { Documentation for projects at } \mathrm{T} \text { Plant in preliminary stage } \\
\text { (construction not started) }\end{array}$} \\
\hline $\begin{array}{l}\text { Functional design } \\
\text { criteria for Project C- } 157\end{array}$ & WHC-SD-C157-FDC-001 & $\begin{array}{l}\text { Functional Design Criteria, T Plant Electrical } \\
\text { Upgrade (Winslow 1994) }\end{array}$ \\
\hline $\begin{array}{l}\text { Conceptual design report } \\
\text { for Project C-157 }\end{array}$ & WHC-SD-C157-CDR-001 & $\begin{array}{l}\text { Conceptual Design Report "T Plant Electrical } \\
\text { Upgrade" Project C-157 (Hoofkin 1995) }\end{array}$ \\
\hline
\end{tabular}

$\mathrm{N} / \mathrm{A}=$ not applicable.

Table 7-14. Current Documentation for Project W-259, Secondary Containment and Leak Detection, T Plant Complex.

\begin{tabular}{|c|c|c|}
\hline Required documents & Document number & Title \\
\hline $\begin{array}{l}\text { Functional design } \\
\text { criteria for } \\
\text { Project W-259 }\end{array}$ & WHC-SD-W259-FDC-001 & $\begin{array}{l}\text { Functional Design Criteria T Plant Secondary } \\
\text { Containment and Leak Detection Upgrades } \\
\text { Project } W-259 \text { (Belcher 1993) }\end{array}$ \\
\hline $\begin{array}{l}\text { Conceptual design report } \\
\text { for Project W-259 }\end{array}$ & WHC-SD-W259-CDR-001 & $\begin{array}{l}\text { Conceptual Design Report T Plant Secondary } \\
\text { Containment and Leak Detection Upgrades } \\
\text { Project W-259 (Hoofkin 1994) }\end{array}$ \\
\hline Engineering study & WHC-SD-W259-ER-001 & $\begin{array}{l}\text { T Plant Secondary Containment and Leak Detection } \\
\text { Upgrades (T. A. Carlson 1995b) }\end{array}$ \\
\hline $\begin{array}{l}\text { Quality assurance } \\
\text { project plan }\end{array}$ & WHC-SD-W259-QAPP-001 & $\begin{array}{l}\text { Project W-259, T-Plant Secondary Containment and } \\
\text { Leak Detection Upgrades (Carlson 1996) }\end{array}$ \\
\hline $\begin{array}{l}\text { Preliminary design } \\
\text { review }\end{array}$ & $\mathrm{N} / \mathrm{A}$ & N/A \\
\hline Definitive design review & N/A & $\mathrm{N} / \mathrm{A}$ \\
\hline Permits & $\mathrm{N} / \mathrm{A}$ & $\mathrm{N} / \mathrm{A}$ \\
\hline $\begin{array}{l}\text { National Environmental } \\
\text { Policy Act of } 1969 \\
\text { documentation for } \\
\text { Project W-259 }\end{array}$ & $\mathrm{N} / \mathrm{A}$ & $\begin{array}{l}\text { Categorical Exclusion for Project W259 Secondary } \\
\text { Containment and Leak Detection Upgrades, T Plant } \\
\text { Complex, } 200 \text { West Area, Hanford Site, Richland, } \\
\text { Washington (DOE 1994b) }\end{array}$ \\
\hline
\end{tabular}

N/A $=$ not applicable. 
Table 7-15. Current Documentation for Project B-459, T Plant Ventilation Upgrade.

\begin{tabular}{|c|c|c|}
\hline Required documents & Document number & Title \\
\hline Engineering study & SD-459-ES-001 & $\begin{array}{l}\text { T Plant Ventilation Upgrade, Engineering Study } \\
\text { (Hedengren 1986) }\end{array}$ \\
\hline Functional design criteria & SD-459-FDC-001 & $\begin{array}{l}\text { T Plant Exhaust System Upgrade Functional Design } \\
\text { Criteria (Bath 1986a) }\end{array}$ \\
\hline Conceptual design report & SD-459-CDR-001 & $\begin{array}{l}\text { T Plant Exhaust System Upgrade Project B-459 } \\
\text { (Bath 1986b) }\end{array}$ \\
\hline $\begin{array}{l}\text { Technical (H-series) } \\
\text { drawings }\end{array}$ & Applicable drawings & Various \\
\hline $\begin{array}{l}\text { Construction } \\
\text { specification }\end{array}$ & $\mathrm{B}-459-\mathrm{Cl}$ & $\begin{array}{l}\text { Construction Specification Project B-459 T Plant } \\
\text { Exhaust System Upgrade (SMC 1988) }\end{array}$ \\
\hline Acceptance test report & SD-459-ATR-001 & $\begin{array}{l}\text { Project B459 Acceptance Test Report } \\
\text { (Johnston 1991a) }\end{array}$ \\
\hline $\begin{array}{l}\text { Acceptance test } \\
\text { procedure }\end{array}$ & SD-459-ATP-001 & $\begin{array}{l}\text { Acceptance Test Procedure Project B-459 } \\
\text { (Bath 1988a) }\end{array}$ \\
\hline Operability test report & WHC-SD-459-OTR-001 & $\begin{array}{l}\text { Operability Test Report for the T Plant Permanent } \\
\text { HEPA Filtration System Project B-459 (Ortega 1992) }\end{array}$ \\
\hline $\begin{array}{l}\text { Operability test } \\
\text { procedure }\end{array}$ & WHC-SD-459-OTP-001 & $\begin{array}{l}\text { Operability Test Procedure T Plant Permanent HEPA } \\
\text { Filtration System Project B-459 (Entrop 1990) }\end{array}$ \\
\hline \multirow[t]{2}{*}{$\begin{array}{l}\text { Other supporting } \\
\text { documents }\end{array}$} & SD-459-PMP-001 & $\begin{array}{l}\text { Project Management Plan T Plant Exhaust System } \\
\text { Upgrade Project B-459 (Filip 1987) }\end{array}$ \\
\hline & SD-459-P-001 & $\begin{array}{l}\text { T Plant Ventilation System Upgrade - Inspection Plan } \\
\text { (Bath 1988b) }\end{array}$ \\
\hline & SD-459-VI-001 & $\begin{array}{l}\text { Vendor Information Master List of Submittal for } \\
\text { Project B-459 (Johnston 1989) } \\
\end{array}$ \\
\hline & SD-459-ER-001 & $\begin{array}{l}\text { Project B459 Compliance to Safety Related Criteria } \\
\text { from DOE Order } 6430.1 A \text { (Johnston 1991b) }\end{array}$ \\
\hline & SD-459-DRR-001 & Project B459 Design Review Report (Johnston 1991c) \\
\hline & SD-459-CDP-001 & $\begin{array}{l}\text { T-Plant Exhaust Filler System Upgrade, Project B-459 } \\
\text { (Bath 1986c) }\end{array}$ \\
\hline
\end{tabular}

Table 7-16. Current Documentation for Tri-Party Agreement Milestone M-33/M-91Designated Project(s).

\begin{tabular}{|l|l|l|}
\hline \multicolumn{1}{|c|}{ Required documents } & \multicolumn{1}{|c|}{ Document number } & \multicolumn{1}{c|}{ Title } \\
\hline Engineering study & WHC-SD-WM-ES-341 & $\begin{array}{l}\text { Solid Waste and Materials System Alternatives Study } \\
\text { (Carlson 1995b) }\end{array}$ \\
\hline
\end{tabular}


Table 7-17. Current Documentation for the Waste Neutralization Facility (340 Facility). (2 sheets)

\begin{tabular}{|c|c|c|}
\hline Required documents & Document number & Title \\
\hline $\begin{array}{l}\text { Interim Safety Basis } \\
\text { (ISB) }\end{array}$ & WHC-SD-WM-ISB-003 & $\begin{array}{l}340 \text { Waste Handling Facility Interim Safety Basis } \\
\text { (Stordeur 1996) }\end{array}$ \\
\hline \multirow[t]{2}{*}{$\begin{array}{l}\text { Other Supporting } \\
\text { Documents }\end{array}$} & WHC-SD-LEF-SSP-001 & $\begin{array}{l}340 \text { Waste Handling Facility Deactivation Plan } \\
\text { (Stordeur and Berneski 1996) }\end{array}$ \\
\hline & WHC-SD-WM-SAD-027 & $\begin{array}{l}\text { Hanford } 300 \text { Area Retention Process Sewer Inventory } \\
\text { at Risk Calculations and Safety Analysis } \\
\text { (Berneski 1995a) }\end{array}$ \\
\hline $\begin{array}{l}\text { Criticality Safety } \\
\text { Evaluation Report }\end{array}$ & WHC-SD-SQA-CSA-20379 & $\begin{array}{l}\text { CSER 94-012: Criticality Safety Evaluation Report } \\
\text { for the 340 Facility (Miller 1996) }\end{array}$ \\
\hline $\begin{array}{l}\text { Other Supporting } \\
\text { Documents }\end{array}$ & WHC-IP-0263-340 & 340 Facility Building Emergency Plan (Deline 1994) \\
\hline Engineering Study & WHC-SD-WM-ER-546 & $\begin{array}{l}340 \text { Facility Waste Tank System Integrity Assessment } \\
\text { Report (Walter 1996) }\end{array}$ \\
\hline Fire Hazard Analysis & WHC-SD-WM-FHA-011 & $\begin{array}{l}340 \text { Complex Fire Hazard Analysis } \\
\text { (Schermerhom 1996) }\end{array}$ \\
\hline $\begin{array}{l}\text { Other Supporting } \\
\text { Documents }\end{array}$ & WHC-EP-0469-02 & $\begin{array}{l}\text { Facility Effluent Monitoring Plan for the } 340 \text { Waste } \\
\text { Handling Facility (Berneski 1996a) }\end{array}$ \\
\hline $\begin{array}{l}\text { Maintenance procedures } \\
\text { for } 340 \text { Building }\end{array}$ & Applicable Mps & Various \\
\hline \multirow[t]{2}{*}{$\begin{array}{l}\text { Other Supporting } \\
\text { Documents }\end{array}$} & WHC-SP-1154 & $\begin{array}{l}340 \text { Facility Maintenance Implementation Plan } \\
\text { (Wagner 1995) }\end{array}$ \\
\hline & WHC-SD-LEF-TI-001 & $\begin{array}{l}\text { Facility Liquid Waste Certification Plan for } 340 \text { Waste } \\
\text { Handling Facility \& } 3718 \text { F Sodium Storage } \\
\text { (Berneski 1995b) }\end{array}$ \\
\hline Safety Equipment List & WHC-SD-WM-SEL-016 & 340 SEL - Safety Equipment List (Berneski 1993a) \\
\hline $\begin{array}{l}\text { Operability Test } \\
\text { Plans/Reports } \\
\text { (OTP/OTR) }\end{array}$ & WHC-SD-W337-OTP-001 & $\begin{array}{l}\text { Operability Test Procedure for the 340-NT-EX Stack } \\
\text { Upgrades - Project W-337 (Hagerty 1994a) }\end{array}$ \\
\hline $\begin{array}{l}\text { Acceptance Test } \\
\text { Plans/Reports } \\
\text { (ATP/ATR) } \\
\end{array}$ & WHC-SD-W337-ATP-001 & $\begin{array}{l}\text { Acceptance Test Procedure for the 340-NT-EX Stack } \\
\text { Upgrades - Project W-337 (Hagerty 1994b) }\end{array}$ \\
\hline Hazard Classification & WHC-SD-PRP-HA-021 & 340 Building Hazards Assessment (Campbell 1995) \\
\hline Engineering Study & WHC-SD-WM-WP-250 & $\begin{array}{l}340 \text { Facility Waste Tank System Integrity Assessment } \\
\text { Plan (Walter 1994) }\end{array}$ \\
\hline Engineering Study & WHC-EP-0544 & $\begin{array}{l}\text { 340 Waste Hondling Facility Comparison with } \\
40 \text { CFR } 61 \text { Subpart H, and other Referenced } \\
\text { Guidelines for Stack 340-NT-EX (Halgren 1995) }\end{array}$ \\
\hline $\begin{array}{l}\text { Conceptual Design } \\
\text { Report }\end{array}$ & WHC-SD-W302-CDR-001 & $\begin{array}{l}\text { Conceptual Design Report for } 340 \text { Facility Secondary } \\
\text { Containment and Leak Detection Project W-302 } \\
\text { (Gilkeson 1995a) }\end{array}$ \\
\hline
\end{tabular}


Table 7-17. Current Documentation for the Waste Neutralization Facility ( 340 Facility). (2 sheets)

\begin{tabular}{|c|c|c|}
\hline Required documents & Document number & Title \\
\hline Engineering Study & WHC-SD-LEF-ES-001 & $\begin{array}{l}\text { Engineering Study } 340 \text { Facility Upgrade Supporting } \\
\text { Project } W-302 \text { Facility Secondary Containment and } \\
\text { Leak Detection (Gilkenson } 1995 \mathrm{~b} \text { ) }\end{array}$ \\
\hline $\begin{array}{l}\text { Functional Design } \\
\text { Criteria }\end{array}$ & WHC-SD-W302-FDC-001 & $\begin{array}{l}\text { Functional Design Criteria for the } 340 \text { Radioactive } \\
\text { Liquid Waste Storage Facility Upgrades: Project } \\
\text { W-302 (Stordeur 1994a) }\end{array}$ \\
\hline $\begin{array}{l}\text { Other Supporting } \\
\text { Documents }\end{array}$ & WHC-EP-0857 & $\begin{array}{l}\text { Statement of Work for Analytical Services Provided to } \\
\text { Westinghouse Hanford Company by the Pacific } \\
\text { Northwest National Laboratory Analytical Chemistry } \\
\text { Laboratory (Perry 1995) }\end{array}$ \\
\hline Interim Safety Basis & WHC-SD-WM-PLN-074 & $\begin{array}{l}\text { Preparation Plan for } 340 \text { Waste Handling Facility } \\
\text { Interim Safety Basis (Bendixsen 1994) }\end{array}$ \\
\hline $\begin{array}{l}\text { Other Supporting } \\
\text { Documents }\end{array}$ & WHC-SD-WM-EV-089 & $\begin{array}{l}300 \text { Area Liquid Effluent Facilities Waste } \\
\text { Minimization Plan (Berneski 1994) }\end{array}$ \\
\hline Engineering Study & WHC-SD-WM-TI-418 & $\begin{array}{l}\text { Ventilation and Monitoring Study of } 340 \text { Waste } \\
\text { Handling Facility (Chamock 1990) }\end{array}$ \\
\hline $\begin{array}{l}\text { Safety Analysis Report } \\
\text { (SAR) }\end{array}$ & WHC-SD-RE-SAP-013 & $\begin{array}{l}\text { Safety Analysis Report for Packaging Railroad Liquid } \\
\text { Waste Tank Cars (Smyth 1996) }\end{array}$ \\
\hline \multirow[t]{5}{*}{ Engineering Study } & WHC-SD-WM-DA-052 & 340-A Storage Tank Integrity Study (Dearing 1989) \\
\hline & WHC-SD-W032-PSE-001 & $\begin{array}{l}\text { Preliminary Safety Evaluation for Project W-302, } 340 \\
\text { Waste Handling Facility Secondary Containment \& } \\
\text { Leak Detection (Bendixsen 1995) }\end{array}$ \\
\hline & WHC-SD-WM-ER-277 & $\begin{array}{l}\text { Engineering Study of the } 300 \text { Area Process Waste } \\
\text { Water Handling System Engineering Study } \\
\text { (Stordeur 1994b) }\end{array}$ \\
\hline & $\begin{array}{l}\text { WHC-SD-WM-TI-412 } \\
\text { WHC-SD-W353-CDR-001 }\end{array}$ & $\begin{array}{l}\text { Project W-353 - } 300 \text { Area Diverter Station Upgrade } \\
\text { Conceptual Design Report (Jancely 1995) }\end{array}$ \\
\hline & WHC-S-0381 & $\begin{array}{l}\text { Specification for Retention Process Sewer } \\
\text { Monitoring/Diversion Radiation Detection } \\
\text { (Olander 1995a) }\end{array}$ \\
\hline $\begin{array}{l}\text { Technical (H-Series) } \\
\text { Drawings }\end{array}$ & WHC-SD-WM-TI-412 & $\begin{array}{l}\text { 340 Waste Handling Facility Drawing List } \\
\text { (Berneski 1996b) }\end{array}$ \\
\hline
\end{tabular}


Table 7-18. Current Documentation for the 200 Area Liquid Waste Processing Facility Complex (2025E, 2025EA, 2025EC, 2025EC71, 242AL42, 242AL43, and 242AL44 Facilities).

\begin{tabular}{|c|c|c|}
\hline Required documents & Document number & Title \\
\hline- & WHC-IP-0931 & $\begin{array}{l}200 \text { Area Liquid Effluent Facilities Administration } \\
\text { Policies (Bimey 1994a) }\end{array}$ \\
\hline-- & WHC-IP-0932 & $\begin{array}{l}\text { 200 Area Liquid Effuent Facilities Conduct of } \\
\text { Operations (Birney 1994b) }\end{array}$ \\
\hline- & WHC-SD-ETF-ASA-001 & $\begin{array}{l}200 \text { Area Effluent Treatment Facility Auditable Safety } \\
\text { Analysis (Flyckt 1995) }\end{array}$ \\
\hline- & & $\begin{array}{l}\text { Environmental Regulatory Guide for Radiological } \\
\text { Effluent Monitoring and Environmental Surveillance } \\
\text { (DOE 1991) }\end{array}$ \\
\hline- & WHC-SD-C018H-HC-002 & $\begin{array}{l}\text { Hazard Categorization Report for the } 200 \text { Area } \\
\text { Effluent Treatment Facility (Koetner 1995) }\end{array}$ \\
\hline- & WHC-SD-ETF-WAC-001 & $\begin{array}{l}\text { Acceptance of Feedstreams for Treatment at the } \\
\text { LERF/ETF Complex (MCDonald 1994) }\end{array}$ \\
\hline-- & WHC-SD-W105-SAR-001 & $\begin{array}{l}\text { Safety Analysis Report 242-A Evaporator Liquid } \\
\text { Effluent Retention Facility (Aguirre 1994) }\end{array}$ \\
\hline- & -- & $\begin{array}{l}\text { State Waste Discharge Permit for the } 200 \text { Area TEDF, } \\
\text { ST- } 4502\end{array}$ \\
\hline- & - & $\begin{array}{l}\text { State Waste Discharge Permit for the } 200 \text { Area TEDF, } \\
\text { ST- } 4500\end{array}$ \\
\hline- & DOE/RL-92-72 & $\begin{array}{l}200 \text { Area Effluent Treatment Facility Delisting } \\
\text { Petition (RL 1993a) }\end{array}$ \\
\hline- & DOE/RL-93-03 & $\begin{array}{l}\text { Hanford Facility Permit Application } 200 \text { Area } \\
\text { Effluent Treatment Facility (RCRA Part A\&B) } \\
\text { (RL 1993b) }\end{array}$ \\
\hline -. & -- & $\begin{array}{l}\text { Liquid Effluent Retention Facility Dangerous Waste } \\
\text { Permit Application (RCRA Part A\&B) }\end{array}$ \\
\hline-- & -- & $\begin{array}{l}\text { Memorandum of Understanding--Disposition and } \\
\text { Transport of Excess Water from 100-K Basins to the } \\
200 \text { Area ETF }\end{array}$ \\
\hline- & -- & $\begin{array}{l}\text { Memorandum of Understanding--Storage and } \\
\text { Treatment of Water from N Reactor Fuel Storage Basin } \\
\text { and } 1300-N \text { Emergency Dump Basin }\end{array}$ \\
\hline- & -- & $\begin{array}{l}\text { Memorandum of Understanding--Treatment of } \\
\text { Groundwater from 200-UP-1 Operable Unit at the } 200 \\
\text { Area ETF }\end{array}$ \\
\hline-- & -- & $\begin{array}{l}\text { Liquid Effluent Retention Facility Interim } \\
\text { Memorandum of Understanding }\end{array}$ \\
\hline
\end{tabular}


Table 7-19. Current Documentation for Project W-252, Phase II Liquid Effluent Treatment and Disposal.

\begin{tabular}{|l|l|l|}
\hline \multicolumn{1}{|c|}{ Required documents } & \multicolumn{1}{|c|}{ Document number } & \multicolumn{1}{c|}{ Title } \\
\hline $\begin{array}{l}\text { Functional Design } \\
\text { Criteria }\end{array}$ & WHC-SD-W252-FDC-001 & $\begin{array}{l}\text { Functional Design Criteria for Project W252 Phase II } \\
\text { Liquid Effuent Treatment and Disposal (Hatch 1995) }\end{array}$ \\
\hline
\end{tabular}

Table 7-20. Current Documentation for the 300 Area Effluent Treatment Facility Complex (310, M0036, M0433, M0741, M0744, and M0745 Facilities). (4 sheets)

\begin{tabular}{|c|c|c|}
\hline Required documents & Document number & Title \\
\hline Safety Analysis & WHC-SD-WM-SAD-025 & $\begin{array}{l}\text { Honford } 300 \text { Area Treated Effluent Disposal Facility } \\
\text { Inventory at Rist Calculations and Safety Analysis } \\
\text { (Olander 1995b) }\end{array}$ \\
\hline $\begin{array}{l}\text { Other Supporting } \\
\text { Documents }\end{array}$ & HNF-IP-1000 & $\begin{array}{l}300 \text { Area Liquid Effluent Facilities Administration } \\
\text { (Poole 1997) }\end{array}$ \\
\hline Permits & WA-002591-7 & $\begin{array}{l}\text { National Discharge Elimination System Permit for the } \\
300 \text { Area TEDF }\end{array}$ \\
\hline Engineering Study & WHC-SD-L045H-ER-002 & $\begin{array}{l}\text { Engineering Summary Report, Hanford } 300 \text { Area } \\
\text { Treated Effuent Disposal Facility, Project L-045H } \\
\text { (Stordeur 1992) }\end{array}$ \\
\hline Safety Analysis & WHC-SD-TP-SARP-015 & $\begin{array}{l}\text { Safety Analysis Report for Packaging (Onsite) } \\
\text { Double-Shell Tank Car (Smyth 19966) }\end{array}$ \\
\hline \multirow[t]{2}{*}{$\begin{array}{l}\text { Other Supporting } \\
\text { Documents }\end{array}$} & WHC-SP-0610 & $\begin{array}{l}300 \text { Area Spill Prevention, Control, and } \\
\text { Countermeasures Plan (Duffield 1993) }\end{array}$ \\
\hline & WHC-SD-L045H-TM-001 & $\begin{array}{l}\text { Facility Description Manual: Hanford 300 Area } \\
\text { Treated Effuent Disposal Facility (Berneski 1993b) }\end{array}$ \\
\hline Permits & & $\begin{array}{l}\text { National Pollutant Discharge Elimination System } \\
\text { permit for the } 300 \text { Area Treated Effluent Disposal } \\
\text { Facility, NPDES Permit No. WA-002591-7 (1994) }\end{array}$ \\
\hline \multirow[t]{2}{*}{$\begin{array}{l}\text { Other Supporting } \\
\text { Documents }\end{array}$} & WHC-SD-L045H-PLN-004 & $\begin{array}{l}300 \text { Area TEDF NPDES Permit Compliance } \\
\text { Monitoring Plan (Loll 1995) }\end{array}$ \\
\hline & & $\begin{array}{l}\text { Aquatic Lands Sewer Outfall Lease for the } 300 \text { Area } \\
\text { Treated Effluent Disposal Facility, DNR Lease } \\
\text { No. 20-013357 (1994) }\end{array}$ \\
\hline $\begin{array}{l}\text { Operating Specification } \\
\text { Document }\end{array}$ & WHC-SD-L045H-PC-00 1 & $\begin{array}{l}300 \text { Area Treated Effluent Disposal Facility } \\
\text { Operating Specifications Document (Olander 1994) }\end{array}$ \\
\hline Hazard Classification & WHC-SD-PRP-EAA-026 & $\begin{array}{l}\text { 300 Area Treated Effluent Disposal Facility Hazards } \\
\text { Assessment (Campbell 1996) }\end{array}$ \\
\hline \multirow[t]{2}{*}{ Specifications } & WHC-SD-L045H-TI-005 & $\begin{array}{l}\text { 300 Area Treated Effuent Disposal Facility Essential } \\
\text { Material Specification (Hagerty 1994c) }\end{array}$ \\
\hline & & $\begin{array}{l}\text { Specifications for the Treated Effluent Disposal } \\
\text { Facility: Hanford } 300 \text { Area, V-L04SH-0001 (1993) }\end{array}$ \\
\hline
\end{tabular}


Revision 0

Table 7-20. Current Documentation for the 300 Area Effluent Treatment Facility Complex (310, M0036, M0433, M0741, M0744, and M0745 Facilities). (4 sheets)

\begin{tabular}{|c|c|c|}
\hline Required documents & Document number & Title \\
\hline $\begin{array}{l}\text { Functional Design } \\
\text { Criteria }\end{array}$ & WHC-SD-L045H-FDC-001 & $\begin{array}{l}\text { Functional Design Criteria for the } 300 \text { Area Treated } \\
\text { Effluent Disposal Facility Project L-045H-Draft } \\
\text { (Muller 1990) }\end{array}$ \\
\hline $\begin{array}{l}\text { Maintenance Procedures } \\
\text { for } 310 \text { Building }\end{array}$ & Applicable MPs & Various \\
\hline \multirow[t]{14}{*}{$\begin{array}{l}\text { Other Supporting } \\
\text { Documents }\end{array}$} & WHC-IP-0263-310 & $\begin{array}{l}\text { Building Emergency Plan for the Treated Effluent } \\
\text { Disposal Facility (Roberts 1995a) }\end{array}$ \\
\hline & WHC-IP-0732-LEF & $\begin{array}{l}300 \text { Area Liquid Effluent Facility Emergency } \\
\text { Organization Listing (Roberts 1995b) }\end{array}$ \\
\hline & WHC-SD-L045H-OTR-00 1 & $\begin{array}{l}\text { Operability Test Report for the } 300 \text { Area Treated } \\
\text { Effluent Disposal Facility (Schermerhorn 1994a) }\end{array}$ \\
\hline & WHC-SD-LEF-PLN-OOI & $\begin{array}{l}\text { 300 Area Treated Effluent Disposal Facility Permit } \\
\text { Reopener Run Plan (Olander 1995c) }\end{array}$ \\
\hline & WHC-SD-L04SH-SM-001 & $\begin{array}{l}300 \text { Area Treated Effluent Disposal Facility Sampling } \\
\text { Schedule (Loll 1994) }\end{array}$ \\
\hline & WHC-SD-L045H-PLN-004 & $\begin{array}{l}300 \text { Area Treated Effluent Disposal Facility National } \\
\text { Pollutant Discharge Elimination System Permit } \\
\text { Compliance Monitoring Plan (Loll 1995) }\end{array}$ \\
\hline & WHC-SD-L045H-RPT-001 & $\begin{array}{l}300 \text { Area Treated Effluent Disposal Facility } \\
\text { Department of Energy Order of Compliance } \\
\text { Applicable Assessment (Eacker 1994a) }\end{array}$ \\
\hline & WHC-SD-L045H-TRP-001 & $\begin{array}{l}300 \text { Area Treated Effluent Disposal Facility } \\
\text { Operational and National Pollutant Discharge } \\
\text { Elimination System Analytical Testing Report } \\
\text { (Eacker 1994b) }\end{array}$ \\
\hline & WHC-SD-L045H-FHA-001 & $\begin{array}{l}\text { Fire Hazard Analysis for the } 300 \text { Area Treated } \\
\text { Effuent Disposal Facility (Sadanga 1994) }\end{array}$ \\
\hline & WHC-SD-WM-ES-308 & $\begin{array}{l}300 \text { Area Treated Effluent Disposal Facility Sludge } \\
\text { Minimization Study (Thrasher 1995) }\end{array}$ \\
\hline & WHC-SD-L045H-ATR-002 & $\begin{array}{l}\text { Acceptance Test Procedure for the } 300 \text { Area Treated } \\
\text { Effluent Disposal Facility Process Control System } \\
\text { (Sohermerhom 1994b) }\end{array}$ \\
\hline & WHC-SD-L045H-ER-003 & $\begin{array}{l}\text { Verification of Best Available Technology for the } 300 \\
\text { Area Treated Effuent Disposal Facility (310 Facility) } \\
\text { (Wagner 1994) }\end{array}$ \\
\hline & WHC-SD-ETF-PCP-001 & $\begin{array}{l}\text { Control System Troubleshooting Guide for the } 300 \\
\text { Area Treated Effluent Disposal Facility } \\
\text { (McCarthy 1995) }\end{array}$ \\
\hline & WHC-SD-L045H-CSWD-002 & $\begin{array}{l}\text { 300 Area Treated Effluent Disposal Facility } \\
\text { Computer Software Release Cover Sheet and Revision } \\
\text { Record (McCarthy 1994) }\end{array}$ \\
\hline
\end{tabular}


Table 7-20. Current Documentation for the 300 Area Effluent Treatment Facility Complex (310, M0036, M0433, M0741, M0744, and M0745 Facilities). (4 sheets)

\begin{tabular}{|c|c|c|}
\hline Required documents & Document number & Title \\
\hline \multirow[t]{15}{*}{$\begin{array}{l}\text { Other supporting } \\
\text { documents }\end{array}$} & WHC-SD-L045H-CSCM-001 & $\begin{array}{l}\text { Treated Effluent Disposal Facility Operator Training } \\
\text { Station (OTS) Configuration Management Plan } \\
\text { (Carter 1994a) }\end{array}$ \\
\hline & WHC-SD-L045H-CSD-001 & $\begin{array}{l}\text { Computer Software Design Description for the } \\
\text { Treated Effluent Disposal Facility Project L-045H } \\
\text { Operator Training Station (OTS) (Carter 1994b) }\end{array}$ \\
\hline & WHC-SD-LO45H-CSUD-002 & $\begin{array}{l}\text { Treated Effluent Disposal Facility Operator Training } \\
\text { Station } 307 \text { Retention Basin Computer Software User } \\
\text { Documentation (Carter 1995) }\end{array}$ \\
\hline & WHC-SD-ER-SE-001 & $\begin{array}{l}\text { Site Evaluation Report Project L045H } 300 \text { Area } \\
\text { Treated Effluent Disposal Facility (Daly 1992) }\end{array}$ \\
\hline & WHC-SD-L045H-PSE-00 I & $\begin{array}{l}\text { Preliminary Safety Evaluation for the } 300 \text { Area } \\
\text { Treated Effluent Disposal Facility Project L045H } \\
\text { (Carrigan 1990a) }\end{array}$ \\
\hline & WHC-SD-L045H-SAD-001 & $\begin{array}{l}300 \text { Area Treated Effluent Disposal Facility } \\
\text { Preliminary Safety Analysis Document } \\
\text { (Bendixen 1993) }\end{array}$ \\
\hline & WHC-SD-L045H-CDR-001 & $\begin{array}{l}\text { Conceptual Design Report } 300 \text { Area Treated Effluent } \\
\text { Disposal Facility Project } 92 L-G F L-045 H \text { DRAFT } \\
\text { (Carrigan 1990b) }\end{array}$ \\
\hline & WHC-SD-L045H-PLN-001 & $\begin{array}{l}\text { Preparation Plan for the } 300 \text { Area Treated Effluent } \\
\text { Disposal Facility Final Safety Analysis Report } \\
\text { (Mears 1993) }\end{array}$ \\
\hline & WHC-SD-L045H-QAPP-001 & $\begin{array}{l}\text { Project Specific Quality Assurance Plan L045H } 300 \\
\text { Area Treated Effluent Disposal Facility (Muller 1993) }\end{array}$ \\
\hline & WHC-SD-XE07-ES-003 & $\begin{array}{l}300 \text { Area Process Sewer Study to Identify Flow and } \\
\text { Constituent Reduction (Muller 1992) }\end{array}$ \\
\hline & WHC-SD-L045H-ATR-004 & $\begin{array}{l}\text { Treated Effluent Disposal Facility Phone Acceptance } \\
\text { Test Procedure (Roberts 1994) }\end{array}$ \\
\hline & WHC-SD-L045H-RRR-001 & $\begin{array}{l}\text { Readiness Plan Hanford } 300 \text { Area Treated Effluent } \\
\text { Disposal Facility (Storm 1994) }\end{array}$ \\
\hline & WHC-SD-L045H-ER-002 & $\begin{array}{l}\text { Engineering Summary Report Hanford } 300 \text { Area } \\
\text { Treated effluent Disposal Facility Project L045H } \\
\text { (Stordeur 1992) }\end{array}$ \\
\hline & & $\begin{array}{l}\text { Hanford } 300 \text { Area Treated Effluent Disposal Facility } \\
\text { Operational and National Pollutant Discharge } \\
\text { Elimination System Analytical Testing Report, MJK- } \\
\text { SVV-296951, CH2M HILL TASK ORDER } 06 \\
\text { (CH2M 1995) }\end{array}$ \\
\hline & & $\begin{array}{l}\text { Engineering Review of } 300 \text { Area Effluent Treatment } \\
\text { Facility Concept, MMLW-SVV-037106, EBASCO } \\
\text { TASK E-90-03 (Ebasco 1990) }\end{array}$ \\
\hline
\end{tabular}


Table 7-20. Current Documentation for the 300 Area Effluent Treatment Facility Complex (310, M0036, M0433, M0741, M0744, and M0745 Facilities). (4 sheets)

\begin{tabular}{|l|l|l|}
\hline \multicolumn{1}{|c|}{ Required documents } & \multicolumn{1}{|c|}{ Document number } & \multicolumn{1}{|c|}{ Title } \\
\hline $\begin{array}{l}\text { Other supporting } \\
\text { documents }\end{array}$ & WHC-SD-XE07-PSH-001 & $\begin{array}{l}\text { Preliminary Safety Evaluation for the Cessation of } \\
\text { Discharge into the 300 Area Process Trench } \\
\text { (Carrigan }\end{array}$ \\
\cline { 2 - 3 } & $\begin{array}{l}\text { Engineering Study 300 Area Process Sewer Treatment } \\
\text { and Disposal System, Project X-E07, XEO7ES, } \\
\text { ER8344 C }\end{array}$ \\
\cline { 2 - 3 } & WHC-SD-L045H-DP-001 & $\begin{array}{l}\text { Hanford 300 Area Process Wastewater } \\
\text { Characterization Data Report (Soler 1992) }\end{array}$ \\
\hline
\end{tabular}

Table 7-21. Current Documentation for Project W-353, 300 Area Diverter Stations Upgrades.

\begin{tabular}{|c|c|c|}
\hline Required documents & Document number & Title \\
\hline \multirow[t]{8}{*}{$\begin{array}{l}\text { Acceptance Test } \\
\text { Plans/Acceptance Test } \\
\text { Reports (ATP/ATR) }\end{array}$} & WHC-SD-W353-ATP-001 & $\begin{array}{l}\text { Acceptance and Operability Test Procedure for the } \\
327 \text { Butlding Retention Process Sewer Diverter } \\
\text { Station (Olander 1996d) }\end{array}$ \\
\hline & WHC-SD-W353-ATP-002 & $\begin{array}{l}\text { Acceptance and Operability Test Procedure for the } \\
325 \text { Building Retention Process Sewer Diverter } \\
\text { Station (Olander 1996e) }\end{array}$ \\
\hline & WHC-SD-W353-ATP-003 & $\begin{array}{l}\text { Acceptance and Operability Test Procedure for the } \\
325 \text { Building Retention Process Sewer Diverter } \\
\text { Station (Olander } 1996 \mathrm{f}\end{array}$ \\
\hline & WHC-SD-W353-ATP-004 & $\begin{array}{l}\text { Acceptance and Operability Test Procedure for the } \\
326 \text { Building Retention Process Sewer Diverter } \\
\text { Station (Olander 1996g) }\end{array}$ \\
\hline & WHC-SD-W353-ATR-001 & $\begin{array}{l}\text { Acceptance and Operability Test Report for the } \\
325 \text { Building Retention Process Sewer Diverter } \\
\text { Station (Olander 1996a) }\end{array}$ \\
\hline & WHC-SD-W353-ATR-002 & $\begin{array}{l}\text { Acceptance and Operability Test Report for the } \\
325 \text { Building Retention Process Sewer Diverter } \\
\text { Station (Olander 1996b) }\end{array}$ \\
\hline & WHC-SD-W353-ATR-003 & $\begin{array}{l}\text { Acceptance \& Operability Test Report for the } \\
324 \text { Building Retention Process Sewer Diverter } \\
\text { Station (Olander 1996c) }\end{array}$ \\
\hline & WHC-SD-W353-ATR-004 & $\begin{array}{l}\text { Acceptance and Operability Test Report for the } \\
326 \text { Building Retention Process Sewer Diverter } \\
\text { Station (Berneski 1996c) }\end{array}$ \\
\hline
\end{tabular}


Revision 0

Table 7-22. Current Documentation for Project W-345, 307 Basin Maintenance Upgrades.

\begin{tabular}{|c|l|l|}
\hline Required documents & \multicolumn{1}{|c|}{ Document number } & \multicolumn{1}{c|}{ Title } \\
\hline Quality assurance plan & WHC-SD-W345-QAPP-001 & $\begin{array}{l}\text { Project Specific Quality Assurance Plan, } \\
\text { Project W345, Basin Maintenance Upgrades } \\
\text { (Hydzik 1994) }\end{array}$ \\
\hline
\end{tabular}

Table 7-23. Current Documentation for Project L070, 300 Area Process Sewer Piping System Upgrade.

\begin{tabular}{|c|c|c|}
\hline Required documents & Document number & Title \\
\hline-- & WHC-SD-L070-ACDR-001 & $\begin{array}{l}\text { Project L-070, } 300 \text { Area Process Sewer System } \\
\text { Upgrade, Advanced Conceptual Design Report } \\
\text { (Dragseth 1994a) }\end{array}$ \\
\hline- & WHC-SD-L070-ATP-001 & $\begin{array}{l}\text { Acceptance Test Procedure for the L-070 Project } \\
\text { Mechanical Equipment and Instrumentation } \\
\text { (Loll 1996a) }\end{array}$ \\
\hline- & WHC-SD-L070-ATR-001 & $\begin{array}{l}\text { Acceptance Test Report for the L-070 Project } \\
\text { (Loll 1996b) }\end{array}$ \\
\hline-- & WHC-SD-L070-CDR-001 & $\begin{array}{l}\text { Project L-070, } 300 \text { Area Proces Sewer System Piping - } \\
\text { Conceptual Design Report (Cline 1996) }\end{array}$ \\
\hline- & WHC-SD-L070-ES-001 & $\begin{array}{l}\text { Engineering Study } 300 \text { Area Process Sewer } \\
\text { Replacement, Project L070 (Hayden 1993) }\end{array}$ \\
\hline-- & WHC-SD-L070-FDC-001 & $\begin{array}{l}300 \text { Area Process Sewer Piping Upgrade - Project } \\
\text { 94LEWL070 - Functional Design Criteria Revision } \\
\text { (Brandt 1994) }\end{array}$ \\
\hline$-\cdots$ & WHC-SD-L070-FDC-001 & $\begin{array}{l}\text { 300 Area Process Sewer Piping Upgrade, Project } \\
\text { 94L-EWL-070, Functional Design Criteria Revision } \\
\text { (Brandt 1995) }\end{array}$ \\
\hline-- & WHC-SD-L070-HC-001 & $\begin{array}{l}\text { Hazard Classification for the } 300 \text { Area Process Sewer } \\
\text { Upgrade, Project LO70 (WHC 1993) }\end{array}$ \\
\hline-- & WHC-SD-L070-PMP-001 & $\begin{array}{l}\text { Project L-70, } 300 \text { Area Process Sewer Piping System } \\
\text { Upgrade, Project Management Plon (Wellsfy 1994) }\end{array}$ \\
\hline- & WHC-SD-L070-PMP-001 & $\begin{array}{l}\text { Project L-070, "300 Area Process Sewer Piping } \\
\text { SystemUpgrade Project Management Plan" } \\
\text { (Wellsfry 1996) } \\
\end{array}$ \\
\hline-- & WHC-SD-L070-QAPP-001 & $\begin{array}{l}\text { Project Specific Quality Assurance Plan, L-070, } 300 \\
\text { Area Process Sewer Piping Upgrade } \\
\text { (Dragseth 1994b) }\end{array}$ \\
\hline- & WHC-SD-L070-QAPP-001 & $\begin{array}{l}\text { Project Specific Quality Assurance Plon, Project } \\
\text { L-070, 300 Area Process Sewer Piping Upgrade } \\
\text { (Amtzen 1995) }\end{array}$ \\
\hline- & WHC-SD-L070-QAPP-001 & $\begin{array}{l}\text { 300 Area Process Sewer Piping Upgrade, L-070 } \\
\text { Project (Jones 1995) }\end{array}$ \\
\hline
\end{tabular}


Table 7-24. Current Documentation for the 242-A Evaporator Complex.

This table is being developed.

Table 7-25. Current Documentation for Low-Level Waste Burial Grounds. (2 sheets)

\begin{tabular}{|c|c|c|}
\hline Required documents & Document number & Title \\
\hline $\begin{array}{l}\text { Plant operating } \\
\text { procedures }\end{array}$ & $\begin{array}{l}28 \text { applicable plant operating } \\
\text { procedures }\end{array}$ & Various \\
\hline $\begin{array}{l}\text { Maintenance } \\
\text { procedures }\end{array}$ & $\begin{array}{l}3 \text { applicable maintenance } \\
\text { procedures }\end{array}$ & Various \\
\hline $\begin{array}{l}\text { Field verified } \\
\text { (as-built) drawings }\end{array}$ & Ápplicable drawings & Various \\
\hline $\begin{array}{l}\text { Certified vendor } \\
\text { information }\end{array}$ & Various & 4 certified vendor information files, on file \\
\hline Master equipment lists & WHC-SD-WM-EL-002 & $\begin{array}{l}\text { Solid Waste Management Facilities Master Equipment } \\
\text { List (Busching 1995) }\end{array}$ \\
\hline Safety equipment lists & WHC-SD-WM-SEL-012 & Burial Grounds Safety Equipment List (Rosser 1996) \\
\hline \multirow[t]{7}{*}{$\begin{array}{l}\text { Criticality safety } \\
\text { evaluation reports }\end{array}$} & WHC-SD-SQA-CSA-20123 & $\begin{array}{l}\text { CSAR 80-021, Addendum 2, Packaging, Storage and } \\
\text { Disposal of Solid Waste (55-Gallon Drums, } \\
\text { Unrestricted H/Pu Only) (Friar 1989a) }\end{array}$ \\
\hline & WHC-SD-SQA-CSA-20129 & $\begin{array}{l}\text { CSAR 82-001, Transportation Burial of PUREX } \\
\text { Burial Box (Friar 1989b) }\end{array}$ \\
\hline & WHC-SD-SQA-CSA-20130 & $\begin{array}{l}\text { CSAR 82-003, Packaging, Storage and/or Disposal of } \\
\text { Solid Wastes (Burial Containers and Uranic Burial) } \\
\text { (Friar 19890) }\end{array}$ \\
\hline & WHC-SD-SQA-CSA-20132 & $\begin{array}{l}\text { CSAR 85-004, Disposal of Department of } \\
\text { Transportation and Certificate of Compliance } \\
\text { Approved Containers (Friar 1989d) }\end{array}$ \\
\hline & WHC-SD-SQA-CSA-20204 & $\begin{array}{l}\text { CSAR 79-038, Out of Hood Plutonitu Storage } \\
\text { (Friar 1990a) }\end{array}$ \\
\hline & WHC-SD-SQA-CSA-20324 & $\begin{array}{l}\text { CSER 90-007, Retrieval of CH-TRU Waste from } \\
200 \text { Area Burial Ground (Hess 1990) }\end{array}$ \\
\hline & WHC-SD-SQA-CSA-20377 & CSER 91-003, Addendum I (Bhatia 1994) \\
\hline $\begin{array}{l}\text { Criticality prevention } \\
\text { specifications }\end{array}$ & CPS-SW-149-00003, C-1 & $\begin{array}{l}\text { Waste Storage - } 200 \text { Area Low-Level Burial Grounds } \\
\text { (WHC 1994d) }\end{array}$ \\
\hline \multirow{2}{*}{$\begin{array}{l}\text { Interim safety basis (in } \\
\text { lieu of a safety } \\
\text { analysis report }\end{array}$} & WHC-SD-WM-ISB-002 & $\begin{array}{l}\text { Solid Waste Burial Grounds Interim Safety Basis } \\
\text { (Pratt 1996) }\end{array}$ \\
\hline & WHC-SD-WM-SAR-058 & $\begin{array}{l}\text { Final Safety Analysis for Contact-Handled } \\
\text { Transuranic Waste Drums In Situ Inspection and } \\
\text { Vented Drum Retrieval (Joyce and Harken 1994) }\end{array}$ \\
\hline $\begin{array}{l}\text { Technical safety } \\
\text { requirements }\end{array}$ & WHC-SD-WM-TSR-001 & $\begin{array}{l}\text { Solid Waste Burial Grounds Interim Operational } \\
\text { Safety Requirements (Pratt 1996) }\end{array}$ \\
\hline
\end{tabular}


Table 7-25. Current Documentation for Low-Level Waste Burial Grounds. (2 sheets)

\begin{tabular}{|l|l|l|}
\hline Required documents & \multicolumn{1}{|c|}{ Document number } & \multicolumn{1}{|c|}{ Title } \\
\hline Permit & DOE/RL-88-20 & $\begin{array}{l}\text { Low-Level Burial Grounds Dangerous Waste Permit } \\
\text { Application (Evans 1990) }\end{array}$ \\
\hline
\end{tabular}

Table 7-26. Current Documentation for Mixed Low-Level Waste Disposal Trenches 31 and 34 .

\begin{tabular}{|l|l|l|}
\hline \multicolumn{1}{|c|}{ Required documents } & \multicolumn{1}{|c|}{ Document number } & \multicolumn{1}{|c|}{ Title } \\
\hline $\begin{array}{l}\text { Plant operating } \\
\text { procedures }\end{array}$ & $\begin{array}{l}\text { Applicable plant operating } \\
\text { procedures }\end{array}$ & Various \\
\hline Maintenance procedures & $\begin{array}{l}\text { Applicable maintenance } \\
\text { procedures }\end{array}$ & Various \\
\hline $\begin{array}{l}\text { Field verified (as-built) } \\
\text { drawings }\end{array}$ & Applicable drawings & Various \\
\hline $\begin{array}{l}\text { Certified vendor } \\
\text { information }\end{array}$ & Applicable files & Various \\
\hline Master equipment lists & WHC-SD-WM-EL-002 & $\begin{array}{l}\text { Solid Waste Management Facilities Master Equipment } \\
\text { List (Busching 1995) }\end{array}$ \\
\hline Safety equipment lists & WHC-SD-WM-SEL-012 & Burial Grounds Safety Equipment List (Rosser 1996) \\
\hline $\begin{array}{l}\text { Criticality safety } \\
\text { evaluation reports }\end{array}$ & N/A & N/A \\
\hline $\begin{array}{l}\text { Criticality prevention } \\
\text { specifications }\end{array}$ & N/A & N/A \\
\hline $\begin{array}{l}\text { Interim safety basis (in } \\
\text { lieu of a safety analysis } \\
\text { report) }\end{array}$ & WHC-SD-WM-ISB-002 & $\begin{array}{l}\text { Solid Waste Burial Grounds Interim Safety Basis } \\
\text { (Bendixsen 1995) }\end{array}$ \\
\hline $\begin{array}{l}\text { Technical safety } \\
\text { requirements }\end{array}$ & WHC-SD-WM-TSR-001 & $\begin{array}{l}\text { Solid Waste Burial Grounds Interim Operational } \\
\text { Safety Requirements (Pratt 1996) }\end{array}$ \\
\hline $\begin{array}{l}\text { Permit } \\
\text { Low-Level Burial Grounds Dangerous Waste Permit } \\
\text { Application (Evans 1990) }\end{array}$ \\
\hline
\end{tabular}

$N / A=$ not applicable. 
Table 7-27. Current Documentation for the 222-S Laboratory Complex.

\begin{tabular}{|l|l|l|}
\hline \multicolumn{1}{|c|}{ Required document } & \multicolumn{1}{|c|}{ Document number } & \multicolumn{1}{c|}{ Title } \\
\hline Plant operating procedures & Various & Various \\
\hline Maintenance procedures (MP) & Various & Various \\
\hline Radiological work permits & Various & Various \\
\hline Essential drawings & WHC-SD-CP-TI-137 & 222-S Essential Drawings (Weaver 1994) \\
\hline Certified vendor information & N/A & Various \\
\hline Master equipment lists & N/A & N/A \\
\hline Safety equipment lists & WHC-SD-CP-SEL-001 & $\begin{array}{l}222-S \text { Laboratory Facility Safety Equipment List } \\
\text { (Weaver 1996) }\end{array}$ \\
\hline $\begin{array}{l}\text { Criticality safety evaluation } \\
\text { reports }\end{array}$ & N/A & N/A \\
\hline $\begin{array}{l}\text { Criticality prevention } \\
\text { specifications }\end{array}$ & N/A & N/A \\
\hline Calibration procedures & N/A & Part of maintenance procedures \\
\hline $\begin{array}{l}\text { Interim safety basis (in lieu of } \\
\text { a safety analysis report) }\end{array}$ & WHC-SD-CP-ISB-007 & $\begin{array}{l}\text { 222-S Laboratory-Interim Safety Basis } \\
\text { Weaver 1996) }\end{array}$ \\
\hline Technical safety requirements & N/A & N/A \\
\hline \begin{tabular}{l} 
Permit \\
\hline
\end{tabular} & DOE/RL-9I-27 & $\begin{array}{l}\text { 222-S Laboratory Complex - Dangerous Waste } \\
\text { Permit Application Part A (Bowman 1991a) }\end{array}$ \\
\hline
\end{tabular}

$\mathrm{N} / \mathrm{A}=$ not applicable

Table 7-28. Project W-087, 222-S Radioactive Liquid Waste Line Replacement.

Table 7-28 is being developed.

Table 7-29. Project W-187, 219-S Secondary Containment Upgrade.

Table 7-29 is being developed.

Table 7-30. Current Documentation for $\mathrm{K}$ Area Facilities (1706KE, 1706KEL, 1706KER).

Table 7-30 is being developed. 
HNF-SD-WM-RPT-288

Revision 0

Table 7-31. Current Documentation for the Waste Sampling and Characterization Facility Complex.

\begin{tabular}{|l|l|l|}
\hline Required document & \multicolumn{1}{|c|}{ Document number } & \multicolumn{1}{|c|}{ Title } \\
\hline Plant operating procedures & Various & Various \\
\hline Maintenance procedures (MP) & Various & Various \\
\hline Radiological work permits & Various & Various \\
\hline Essential drawings & WHC-SD-CP-EDL-001 & WSCF Essential Drowings (Flaherty 1996) \\
\hline Certified vendor Information & N/A & Various \\
\hline Master equipment Lists & JCS SYSTEM & N/A \\
\hline Safety equipment lists & WHC-SD-WM-SEL-036 & WSCF Safety Equipment List (Meloy 1996) \\
\hline $\begin{array}{l}\text { Criticality safety evaluation } \\
\text { reports }\end{array}$ & N/A & N/A \\
\hline $\begin{array}{l}\text { Criticality prevention } \\
\text { specifications }\end{array}$ & N/A & N/A \\
\hline Calibration procedures & N/A & Part of maintenance procedures \\
\hline $\begin{array}{l}\text { Interim safety basis (in lieu of } \\
\text { a safety analysis report) }\end{array}$ & WHC-SD-WM-ASA-001 & WSCF Complex Safety Analysis (Meloy 1996) \\
\hline Technical safety requirements & N/A & N/A \\
\hline Permit & N/A & N/A \\
\hline
\end{tabular}

$\mathrm{N} / \mathrm{A}=$ not applicable.

7.3.1.1 Solid Waste Retrieval, Phase 1 (Project W-113). Table 7-2 presents the baseline documentation for Project W-113, Solid Waste Retrieval, Phase 1.

7.3.1.2 Solid Waste Retrieval, Phase 2 (Project W-221). Table 7-3 presents the baseline documentation for Project W-221, Solid Waste Retrieval, Phase 2.

7.3.1.3 Alpha Caisson Retrieval (Project W-156). Table 7-4 presents the baseline documentation for Project W-156, Alpha Caisson Retrieval.

\subsubsection{Storage}

This section presents a list of documents that the Project has developed or is developing in support of its storage facilities and projects.

7.3.2.1 Central Waste Complex. Table 7-5 presents the baseline documentation for the Central Waste Complex.

7.3.2.2 Transuranic Waste Storage and Assay Facility (224T Building). Table 7-6 presents the baseline documentation for the Transuranic Waste Storage and Assay Facility. 
HNF-SD-WM-RPT-288

Revision 0

7.3.2.3 Project W-112, Enhanced Radioactive Mixed Waste Storage Facility. Table 7-7 presents the baseline documentation for Project W-112, Enhanced Radioactive Mixed Waste Storage Facility (Phase V).

7.3.2.4 Project W-272, Special-Case Solid Waste Temporary Storage Facility. Table 7-8 presents the baseline documentation for Project W-272, Special-Case Solid Waste Temporary Storage Facility.

7.3.2.5 Nonradioactive Dangerous Waste Storage Facility (616 Building). Table 7-9 presents the baseline documentation for the Nonradioactive Dangerous Waste Storage Facility (616 Building).

\subsubsection{Processing}

This section presents a list of documents that the Project has developed or is developing in support of waste processing projects.

7.3.3.1 Project W-026, Waste Receiving and Processing Module 1 (WRAP 1). Table 7-10 presents the baseline documentation for Project W-026, WRAP 1.

7.3.3.2 Commercial Stabilization Treatment Program (Formerly WRAP Module 2A). Table 7-11 presents the baseline documentation for the Commercial Stabilization Treatment Program.

7.3.3.3 Thermal Treatment Facility. Table 7-12 presents the baseline documentation for the Thermal Treatment Facility.

7.3.3.4 T Plant Facility. Table 7-13 presents the baseline documentation for the $T$ Plant Facility, which includes the $221 \mathrm{~T}, 271 \mathrm{~T}, 291 \mathrm{~T}, 211 \mathrm{~T}, 214 \mathrm{~T}$, and $2706 \mathrm{~T}$ Facilities. Table 7-13 also includes current documentation for projects at $\mathrm{T}$ Plant in the preliminary stage (not work completed).

Table 7-14 presents the baseline documentation for Project W-259, Secondary Containment and Leak Detection, T Plant Complex. Table 7-15 presents the baseline documentation for Project B-459, T Plant Ventilation Upgrade.

7.3.3.5 Tri-Party Agreement Milestone M-33/M-91-Designated Project(s). Table 7-16 presents the baseline documentation for future projects defined under Tri-Party Agreement Milestones M-33/M-91.

7.3.3.6 Waste Neutralization Facility (340 Facility). Table 7-17 presents the baseline documentation for the Waste Neutralization Facility. 
7.3.3.7 200 Area Liquid Waste Processing Facility Complex. Table 7-18 presents the baseline documentation for the 200 Area Liquid Waste Processing Facility Complex which includes the 2025E, 2025EA, 2025EC, 2025EC71, 242AL42, 242AL43, and 242AL44 Facilities.

7.3.3.8 Project W-252. Table 7-19 presents the baseline documentation for Project W-252, Phase II Liquid Effluent Treatment and Disposal.

7.3.3.9 300 Area Effluent Treatment Facility Complex. Table 7-20 presents the baseline documentation for the 300 Area Effluent Treatment Facility Complex which includes the 310, M0036, M0433, M0741, M0744, and M0745 Facilities.

7.3.3.10 Project W-353. Table 7-21 presents the baseline documentation for Project W-353, 300 Area Diverter Stations Upgrades.

7.3.3.11 Project W-345. Table 7-22 presents the baseline documentation for Project W-345, 307 Basin Maintenance Upgrades.

7.3.3.12 Project L070. Table 7-23 presents the baseline documentation for Project L070, 300 Area Process Sewer Piping System Upgrade.

7.3.3.13 242-A Evaporator Complex. Table 7-24 presents the baseline documentation for the 242-A Evaporator Complex which includes the TBD facilities.

\subsubsection{Disposal}

This section presents a list of documents that the Project has developed or is developing in support of its disposal facilities and projects.

7.3.4.1 Low-Level Waste Burial Grounds. Table 7-25 presents the baseline documentation for the Low-Level Waste Burial Grounds.

7.3.4.2 Mixed Low-Level Waste Disposal. Table 7-26 presents the baseline documentation for mixed low-level waste disposal Trenches 31 and 34 .

\subsubsection{Analytical}

This section presents a list of documents that the Project has developed or is developing in support of its analytical facilities and projects.

7.3.5.1 222-S Laboratory Complex. Table 7-27 presents the baseline documentation for the 222-S Laboratory Complex which includes the 207SL, 212S, 219S, 222S, 222SA, 222SB, 222SC, 2222SD, 222SE, 222SF, 222SG, 222SH, 225WB, 2704S, 2716S, and 2734S Facilities. 
7.3.5.2 Project W-087. Table 7-28 presents the baseline documentation for Project W-087, 222-S Radioactive Liquid Waste Line Replacement

7.3.5.3 Project W-187. Table 7-29 presents the baseline documentation for Project W-187, 219S Secondary Containment Upgrade.

7.3.5.4 K Area Facilities. Table 7-30 presents the baseline documentation for $\mathrm{K}$ Area Facilities which include the 1706KEL and 1706KER facilities.

7.3.5.5 Waste Sampling and Characterization Facility Complex. Table 7-31 presents the baseline documentation for the Waste Sampling and Characterization Facility Complex which includes the $6265,6266,6266 \mathrm{~A}, 6266 \mathrm{~B}, 6267,6268,6269$, and 6270 Facilities.

\subsection{REFERENCES}

10 CFR 71, "Additional Requirements for Type B Packages," Code of Federal Regulations, as amended.

10 CFR 72, "Licensing Requirements for the Independent Storage of Spent Nuclear Fuel and High-Level Radioactive Waste," Code of Federal Regulations, as amended.

Aguirre, H., 1994, Safety Analysis Report 242-A Evaporator Liquid Effluent Retention Facility, WHC-SD-W105-SAR-001, Rev. OD, Westinghouse Hanford Company, Richland, Washington.

Arntzen, M. C., 1995, Project Specific Quality Assurance Plan, Project L-070, 300 Area Process Sewer Piping Upgrade, WHC-SD-L070-QAPP-001, Rev. 2, Westinghouse Hanford Company, Richland, Washington.

Barlow, D. E., 1994a, PWR CORE II Storage Pool Structural/Seismic Qualification-T Plant, WHC-SD-WM-SA-023, Rev. 0, Westinghouse Hanford Company, Richland, Washington.

Barlow, D. W., 1994b, T Plant Canyon Deck-Level Allowable Floor Load Study, WHC-SD-WM-ES-315, Rev. 0, Westinghouse Hanford Company, Richland, Washington.

Barnes, B. M., 1992, Enhanced Radioactive and Mixed Waste Storage Phase V, WHC-SD-W112-CDR-001, Rev. OA, Westinghouse Hanford Company, Richland, Washington.

Bath, S. S., 1986a, T Plant Exhaust System Upgrade Functional Design Criteria, SD-459-FDC-001, Rev. 0, Westinghouse Hanford Company, Richland, Washington.

Bath, S. S., 1986b, T Plant Exhaust System Upgrade Project B-459, SD-459-CDR-001, Rev. 0, Westinghouse Hanford Company, Richland, Washington. 
Bath, S. S., 1986c, T-Plant Exhaust Filter System Upgrade, Project B-459, SD-459-CDP-001, Rev. 0, Westinghouse Hanford Company, Richland, Washington.

Bath, S. S., 1988a, Acceptance Test Procedure Project B-459, SD-459-ATP-001, Rev. 0, Westinghouse Hanford Company, Richland, Washington.

Bath, S. S., 1988b, T Plant Ventilation System Upgrade - Inspection Plan, SD-459-IP-001, Rev. 0, Westinghouse Hanford Company, Richland, Washington.

Belcher, J. D., 1993, Functional Design Criteria T Plant Secondary Containment and Leak Detection Upgrades Project W-259, WHC-SD-W259-FDC-001, Rev. 0, Westinghouse Hanford Company, Richland, Washington.

Bendixsen, R. B., 1993, 300 Area Treated Effluent Disposal Facility Preliminary Safety Analysis Document, WHC-SD-L045H-SAD-001, Rev. 0, Westinghouse Hanford Company, Richland, Washington.

Bendixsen, R. B., 1994, Preparation Plan for 340 Waste Handling Facility Interim SafetyBasis, WHC-SD-WM-PLN-074, Rev. 0, Westinghouse Hanford Company, Richland, Washington.

Bendixsen, R. B., 1994, 200 Area Effluent BAT/AKART Implementation Preliminary Safety Analysis Report, WHC-SD-W291H-PSAR-001, Rev. 0, Westinghouse Hanford Company, Richland, Washington.

Bendixsen, R. B., 1995, Preliminary Safety Evaluation for Project W-302, 340 Waste Handling Facility Secondary Containment \& Leak Detection, WHC-SD-W032-PSE-001, Westinghouse Hanford Company, Richland, Washington.

Bendixsen, R. B., 1995a, Solid Wasie Burial Grounds Interim Safety Basis, WHC-SD-WM-ISB-002, Rev. 0, Westinghouse Hanford Company, Richland, Washington.

Bendixsen, R. B., 1995b, Solid Waste Burial Grounds Interim Operational Safety Requirements, WHC-SD-WM-TSR-001, Rev. 0, Westinghouse Hanford Company, Richland, Washington.

Berglund, O. D., 1995, WHC Occupational ALARA Program, WHC-IP-1043, Rev. 0, Westinghouse Fanford Company, Richland, Washington.

Berneski, L. D., 1993a, 340 SEL - Safety Equipment List, WHC-SD-WM-SEL-016, Rev. 1, Westinghouse Hanford Company, Richland, Washington.

Berneski, L. D., 1993b, Facility Description Manual: Hanford 300 Area Treated Effluent Disposal Facility, WHC-SD-L045H-TM-001, Rev. 0, Westinghouse Hanford Company, Richland, Washington. 
HNF-SD-WM-RPT-288

Revision 0

Berneski, L. D., 1994, 300 Area Liquid Effluent Facilities Waste Minimization Plan, WHC-SDWM-EV-089, Rev. 0, Westinghouse Hanford Company, Richland, Washington.

Berneski, L. D., 1995a, Hanford 300 Area Retention Process Sewer - Inventory at Risk Calculations and Safety Analysis, WHC-SD-WM-SAD-027, Rev. 0, Westinghouse Hanford Company, Richland, Washington.

Berneski, L. D., 1995b, Facility Liquid Waste Certification Plan for 340 Waste Handling Facility and 3718F Sodium Storage, WHC-SD-LEF-TI-001, Rev. 0, Westinghouse Hanford Company, Richland, Washington.

Berneski, L. D., 1996a, Facility Effluent Monitoring Plan for the 340 Waste Handling Facility, WHC-EP-0469-02, Westinghouse Hanford Company, Richland, Washington.

Berneski, L. D., 1996b, 340 Waste Handling Facility Drawing List, WHC-SD-WM-TI-412, Westinghouse Hanford Company, Richland, Washington.

Berneski, L. D., 1996c, Acceptance and Operability Test Report for the 326 Building Retention Process Sewer Diverter Station, WHC-SD-W353-ATR-004, Rev. 0, Westinghouse Hanford Company, Richland, Washington.

Bhatia, S. L., 1994, CSER 91-003, Addendum 1, WHC-SD-SQA-CSA-20377, Westinghouse Hanford Company, Richland, Washington.

Biebesheimer, E., 1992, Project W-112, Enhanced Radioactive and Mixed Waste Storage Phase V Engineering Study, WHC-SD-W112-ES-001, Rev. 0, Westinghouse Hanford Company, Richland, Washington.

Birney, R. E., 1994a, 200 Area Liquid Effluent Facilities Administration Policies, WHC-IP0931, Westinghouse Hanford Company, Richland, Washington.

Birney, R. E., 1994b, 200 Area Liquid Effluent Facilities Conduct of Operations, WHC-IP-0932, Westinghouse Hanford Company, Richland, Washington.

Bodily, D. B., 1993a, 616 Building Safety Equipment List, WHC-SD-WM-SEL-014, Rev. 2, Westinghouse Hanford Company, Richland, Washington.

Bodily, D. B., 1993b, Nonradioactive Dangerous Waste Storage Facility, WHC-SD-WM-SAR-019, Rev. OA, Westinghouse Hanford Company, Richland, Washington.

Bonner, A. L., 1993, Solid Waste Operations Complex Site Characteristics Description, WHC-SD-W1 12-RPT-001, Rev. 0, Westinghouse Hanford Company, Richland, Washington. 
Bonner, A. L., 1995a, Enhanced Radioactive and Mixed Waste Storage Facility Phase $V$ (Project W-112) Safety Assessment, WHC-SD-W112-SAD-001, Rev, 0, Westinghouse Hanford Company, Richland, Washington.

Bonner, A. L., 1995b, Special Case Waste Hazard Classification, WHC-SD-W272-HC-001, Rev. 1, Westinghouse Hanford Company, Richland, Washington.

Boothe, G. F., 1994, Radiological and Chemical Source Terms for Solid Waste Operations Complex, WHC-SD-W306-TI-001, Rev. 1, Westinghouse Hanford Company, Richland, Washington.

Bowman, R. C., 1991a, Hanford Central Waste Complex - Radioactive Mixed Waste Storage Facility Dangerous Waste Permit Application - Vol. 1 and 2, DOE/RL-91-17, Rev. 0, U.S. Department of Energy, Richland Operations Office, Richland, Washington.

Bowman, R. C., 1991b, Hanford Central Waste Complex - Waste Receiving and Processing Facility Dangerous Waste Permit Application, DOE/RL-91-16, Rev. 0, U.S. Department of Energy, Richland Operations Office, Richland, Washington.

Bowman, R. C., 1994, Hanford Facility Dangerous Waste Permit, 616 Nonradioactive Dangerous Waste Storage Facility, DOE/RL-89-03, Rev. 2A, U.S. Department of Energy, Richland Operations Office, Richland, Washington.

Brandt, O. H., 1994, 300 Area Process Sewer Piping Upgrade - Project 94LEWL070 Functional Design Criteria Revision, WHC-SD-L070-FDC-001, Rev. 1, Westinghouse Hanford Company, Richland, Washington.

Brandt, O. H., 1995, 300 Area Process Sewer Piping Upgrade, Project 94L-EWL-070, Functional Design Criteria Revision, WHC-SD-L070-FDC-001, Rev. 3, Westinghouse Hanford Company, Richland, Washington.

Brown, M. J., 1994, Functional Design Criteria for 200 Area Effluent BAT/AKART Implementation Project W-291, WHC-SD-W291H-FDC-001, Rev. 1, Westinghouse Hanford Company, Richland, Washington.

Buckles, D. I., 1992a, Acceptance Test Procedure for Project C-181-2706-T Building Upgrade, SD-C181-ATP-001, Rev. 0, Westinghouse Hanford Company, Richland, Washington.

Buckles, D. I., 1992b, Project C-181, Project-Specific Project Management Plan, SD-C181-PMP-001, Rev. 0, Westinghouse Hanford Company, Richland, Washington.

Buckles, D. I., 1993, Acceptance Test Record For Project C181 2706-T Building Upgrade, SD-C181-ATR-001, Rev. 0, Westinghouse Hanford Company, Richland, Washington. 
HNF-SD-WM-RPT-288

Revision 0

Busching, K. R., 1995, Solid Waste Management Facilities Master Equipment List, WHC-SD-WM-EL-002, Rev. 1, Westinghouse Hanford Company, Richland, Washington.

Bushore, R. P. 1997, Central Waste Complex-Interim Safety Basis, HNF-SD-WM-ISB-007, Rust Federal Services, Inc., Richland, Washington.

Cain, F. G., 1991 a, Engineering Safety Study for Project W-112, WHC-SD-W112-ES-002, Rev. 0, Westinghouse Hanford Company, Richland, Washington.

Cain, F. G., 1991b, Hazard Classification for the Enhanced Radioactive and Mixed Waste Storage Facility Phase V, Project W-112, WHC-SD-W112-HC-002, Rev. 0, Westinghouse Hanford Company, Richland, Washington.

Cain, F. G., 1993, Preliminary Safety Evaluation for Enhanced Radioactive and Mixed Waste Storage Phase V Infrastructure Upgrades and Support Complex Project $W-112$, WHC-SD-W112-PSE-001, Rev. 0, Westinghouse Hanford Company, Richland, Washington.

Cain, F. G., 1995, Central Waste Complex - Interim Safety Basis, WHC-SD-WM-ISB-007, Rev. 0, Westinghouse Hanford Company, Richland, Washington.

Cammann, J. W., 1985, Waste Receiving and Processing (WRAP) Facility Engineering Study, WHC-SD-RE-ES-017, Rev. 0, Westinghouse Hanford Company, Richland, Washington.

Campbell, L. R., 1995, 340 Building Hazards Assessment, WHC-SD-PRP-HA-021, Rev. 0, Westinghouse Hanford Company, Richland, Washington.

Campbell, L. R., 1996, 300 Area Treated Effluent Disposal Facility Hazards Assessment, WHC-SD-PRP-HA-026, Westinghouse Hanford Company, Richland, Washington.

Carlson, A. B., 1995a, Interface Control Document Between PUREX/UO ${ }_{3}$ Plant Transition and Solid Waste Disposal Division, WHC-SD-WM-PICD-002, Rev. 1, Westinghouse Hanford Company, Richland, Washington.

Carlson, A. B., 1995b, Solid Waste and Materials System Alternatives Study, WHC-SD-WM-ES-341, Rev. 0, Vol. 1-6, Westinghouse Hanford Company, Richland, Washington.

Carlson, T. A., 1995a, Waste Receiving and Processing Module $2 A$ Termination of Design Closeout Report, WHC-SD-W100-RPT-001, Rev. 0, Westinghouse Hanford Company, Richland, Washington.

Carlson, T. A., 1995b, T Plant Secondary Containment and Leak Detection Upgrades, WHC-SD-W259-ER-001, Rev. 0, Westinghouse Hanford Company, Richland, Washington. 
Carlson, T. A., 1996, Project W-259, T-Plant Secondary Containment and Leak Detection Upgrades, WHC-SD-W259-QAPP-001, Rev. 0, Westinghouse Hanford Company, Richland, Washington.

Carrigan, M. C., 1990a, Preliminary Safety Evaluation for the 300 Area Treated Effluent Disposal Facility L045H, WHC-SD-L045H-PSE-001, Rev. 0, Westinghouse Hanford Company, Richland, Washington.

Carter, R. L., 1994a, Treated Effluent Disposal Facility Operator Training Station (OTS) Configuration Management Plan, WHC-SD-L045H-CSCM-001, Rev. 0, Westinghouse Hanford Company, Richland, Washington.

Carter, R. L., 1994b, Computer Software Design Description for the Treated Effluent Disposal Facility Project L-045H Operator Training Station (OTS), WHC-SD-L045H-CSD-001, Rev. 0, Westinghouse Hanford Company, Richland, Washington.

Carter, R. L., 1995, Treated Effluent Disposal Facility Operator Training Station 307 Retention Basin Computer Software User Documentation, WHC-SD-L045H-CSUD-002, Rev. 0, Westinghouse Hanford Company, Richland, Washington.

Cejka, C. C., 1993, Functional Design Criteria for the Special Case Solid Waste Temporary Storage Facility, WHC-SD-W272-FDC-001, Rev. 0, Westinghouse Hanford Company, Richland, Washington.

CH2M Hill, 1995, Hanford 300 Area Treated Effluent Disposal Facility Operational and National Pollutant Discharge Elimination System Analytical Testing Report, MJK-SVV296951, CH2M Hill Task Order 06, CH2M Hill, Richland, Washington.

Charnock, H. O., 1995, Ventilation and Monitoring Study of 340 Waste Handling Facility, WHC-SD-WM-TI-418, Rev. 0, Westinghouse Hanford Company, Richland, Washington.

Christie, M. A., 1985, Waste Receiving and Processing (WRAP) Facility Performance Evaluation Plan for Shredded, Simulated TRU Waste Immobilization in Cement Grout, WHC-SD-WM-PE-021, Rev. 0, Westinghouse Hanford Company, Richland, Washington.

Christie, M. A., 1986a, Waste Receiving Processing (WRAP) Facility Conceptual Design Report (CDR), WHC-SD-WM-TI-263, Rev, 0, Westinghouse Hanford Company, Richland, Washington.

Christie, M. A., 1986b, Waste Receiving and Processing Facility (WRAP) Preliminary System Operating Logic Diagram (SOLD), WHC-SD-WM-TI-262, Rev. 0, Westinghouse Hanford Company, Richland, Washington. 
HNF-SD-WM-RPT-288

Revision 0

Christie, M. A., 1986c, Performance Evaluation of Simulated TRU Waste Shredded and Immobilized in Cement Grout (Phase I), WHC-SD-WM-TI-264, Rev. 0, Vol. 1 of 2, Westinghouse Hanford Company, Richland, Washington.

Christie, M. A., 1986d, Performance Evaluation of Simulated TRU Shredded and Immobilized in Cement Grout (Phase II), WHC-SD-WM-TI-265, Rev. 0, Vol. 2 of 2, Westinghouse Hanford Company, Richland, Washington.

Christie, M. A., 1987a, Waste Receiving and Processing (WRAP) Facility Draft Functional Design Criteria, WHC-SD-WM-TI-291, Rev. 0, Westinghouse Hanford Company, Richland, Washington.

Christie, M. A., 1987b, Practical Considerations for the Design and Operation of the Waste Receiving and Processing (WRAP) Size Reduction Facility, WHC-SD-WM-TI-243, Rev. 0, Westinghouse Hanford Company, Richland, Washington.

Christie, M. A., 1987c, Practical Considerations of High-Density Compaction Systems for Use in the Waste Receiving and Processing (WRAP) Facility, WHC-SD-WM-TI-268, Rev. 0, Westinghouse Hanford Company, Richland, Washington.

Cillan, M. R., 1993, Hazard Classification for the Thermal Treatment Facility, Project W-242, WHC-SD-W242-HC-001, Rev. 0, Westinghouse Hanford Company, Richland, Washington.

Cline, D. E., 1996, Project L-070, 300 Area Process Sewer System Piping - Conceptual Design Report, WHC-SD-L070-CDR-001, Rev. 0, Westinghouse Hanford Company, Richland, Washington.

Coenenberg, E. T., 1993a, Radioactive Air Emissions Notice of Construction for the Waste Receiving and Processing Facility, DOE/RL-93-15, Rev. 0, U.S. Department of Energy, Richland Operations Office, Richland, Washington.

Coenenberg, E. T., 1993b, Application for Approval to Construct the Waste Receiving and Processing Facility, DOE/RL-93-16, Rev. 0, U.S. Department of Energy, Richland Operations Office, Richland, Washington.

Coenenberg, E. T., 1993c, Nonradioactive Air Emissions Notice of Construction for the Waste Receiving and Processing Facility - WRAP 1, DOE/RL-93-18, Rev. 0, U.S. Department of Energy, Richland Operations Office, Richland, Washington.

Coenenberg, E. T., 1993d, Waste Receiving and Processing Module I Best Available Radionuclide Control Technology Assessment, WHC-SD-W026-TI-004, Rev. 0, Westinghouse Hanford Company, Richland, Washington. 
Coenenberg, E. T., 1993e, Hanford Waste Receiving and Processing Facility Module 1 Technical Background Document for Best Available Control Technology for Toxic Demonstration, WHC-SD-W026-TI-005, Rev. 0, Westinghouse Hanford Company, Richland, Washington.

Crane, A. F., 1996, 200 Area Treated Effluent Disposal Facility Interface Control Document, WHC-SD-W049H-ICD-001, Rev. 2, Westinghouse Hanford Company, Richland, Washington.

Cunningham, J. P., 1985, Design of Drum Catibration Standards for the Transuranic Assay Unit, WHC-SD-WM-TI-128, Rev. 0, Westinghouse Hanford Company, Richland, Washington.

Daly, K. S., 1992, Site Evaluation Report Project L045H 300 Area Treated Effluent Disposal Facility, WHC-SD-ER-SE-001, Rev. 2, Westinghouse Hanford Company, Richland, Washington.

Dearing, J. I., 340-A Storage Tank Integrity Study, WHC-SD-WM-DA-052, Rev. 0, Westinghouse Hanford Company, Richland, Washington.

Deichelbohrer, P. R., 1985a, Status at Termination, Alpha Caisson Recovery Demonstration, WHC-SD-WM-ROB-002, Rev. 0, Westinghouse Hanford Company, Richland, Washington.

Deichelbohrer, P. R., 1985b, Plan for Removing Remote Handled Transuranic Waste from Alpha Caissons, WHC-SD-WM-ROB-003, Rev. 0, Westinghouse Hanford Company, Richland, Washington.

Deichelbohrer, P. R., 1992a, Engineering Study, Retrieval of Waste from Alpha Caissons, WHC-SD-WM-ES-181, Rev. 0, Westinghouse Hanford Company, Richland, Washington.

Deichelbohrer, P. R., 1992b, Retrieval of Waste Alpha Caissons, WHC-SD-WM-ROB-005, Rev. 0, Westinghouse Hanford Company, Richland, Washington.

Deichelbohrer, P. R., 1992c, Alpha Caisson Data and Evaluation, WHC-SD-WM-RPT-008, Rev. 0, Westinghouse Hanford Company, Richland, Washington.

Deline, J. W., 1994, 340 Facility Building Emergency Plan, WHC-IP-0263-340, Rev. 3, Westinghouse Hanford Company, Richland, Washington.

Demiter, J. A., 1991, Inspection of Retrievably Stored Transuranic Waste Containers, WHC-SD-WM-TRP-002, Rev. 0, Westinghouse Hanford Company, Richland, Washington.

DOE, 1991, Environmental Regulatory Guide for Radiological Effluent Monitoring and Environmental Surveillance, U.S. Department of Energy, Washington, D.C. 
HNF-SD-WM-RPT-288

Revision 0

DOE, 1992, Supplement Analysis of the Environmental Effects of Changes in DOE's Proposed Action to Construct and Operate the Waste Receiving and Processing Facility Module I, DOE/EIS-0113-FS/SA2, U.S. Department of Energy, Washington, D.C.

DOE, 1994a, U.S. Department of Energy Solid Waste Operations Complex (SWOC), Phase 1 Project 94-D-411 Project Plan, U.S. Department of Energy, Richland Operations Office, Richland, Washington.

DOE, 1994b, Categorical Exclusion for Project W259 Secondary Containment and Leak Detection Upgrades, $T$ Plant Complex, 200 West Area, Hanford Site Richland, Washington, Letter 94-SWT-465, U.S. Department of Energy, Washington, D.C.

DOE, 1995a, Solid Waste Retrieval Complex, Enhanced Radioactive and Mixed Waste Storage Facility, Infrastructure Upgrades, and Central Waste Support Complex, DOE/EA-0981, U.S. Department of Energy, Washington, D.C.

DOE, 1995b, Notice of Construction for Project W-112, DOE/RL-95-79, U.S. Department of Energy, Richland Operations Office, Richland, Washington.

Dragseth, G., 1994a, Project L-070, 300 Area Process Sewer System Upgrade, Advanced Conceptual Design Report, WHC-SD-L070-ACDR-001, Rev. 1, Westinghouse Hanford Company, Richland, Washington.

Dragseth, G., 1994b, Project Specific Quality Assurance Plan, L-070, 300 Area Process Sewer Piping Upgrade, WHC-SD-L070-QAPP-001, Rev. 1, Westinghouse Hanford Company, Richland, Washington.

Dronen, V. R., 1993, Hanford Restoration Baseline Approach - Interface Control Document, WHC-SD-ER-EE-002, Rev. 0, Westinghouse Hanford Company, Richland, Washington.

Duffield, G. W., 1993, 300 Area Spill Prevention, Control, and Countermeasures Plan, WHC-SP-0610, Westinghouse Hanford Company, Richland, Washington.

Duncan, D. R., 1994, Interface Control Document Between Tank Waste Remediation System and Solid Waste Disposal Division, WHC-SD-WM-PICD-003, Rev. 0, Westinghouse Hanford Company, Richland, Washington.

Eacker, J. A., 1994a, 300 Area Treated Effluent Disposal Facility Department of Energy Order of Compliance Applicable Assessment, WHC-SD-L045H-RPT-001, Rev. 0, Westinghouse Hanford Company, Richland, Washington.

Eacker, J. A., 1994b, 300 Area Treated Effluent Disposal Facility Operational and National Pollutant Discharge Elimination System Analytical Testing Report, WHC-SD-L045H-TRP-001, Rev. 0, Westinghouse Hanford Company, Richland, Washington. 
Ebasco, 1990 Engineering Review of 300 Area Effluent Treatment Facility Concept, MMLW-SVV- 037106, Ebasco Task E-90-03, Ebasco, Richland, Washington.

Ecology, EPA, and DOE, 1996, Hanford Federal Facility Agreement and Consent Order, as amended, Washington State Department of Ecology, U.S. Environmental Protection Agency, and U.S. Department of Energy, Olympia, Washington.

Entrop, G. E., 1990, Operability Test Procedure T Plant Permanent HEPA Filtration System Project $B-459$, WHC-SD-459-OTP-001, Rev. 0, Westinghouse Hanford Company, Richland, Washington.

Erpenbeck, E. G., 1995, Criticality Classification of Enhanced Radioactive and Mixed Waste Storage, WHC-SD-W112-CSER-001, Rev. 0, Westinghouse Hanford Company, Richland, Washington.

Erickson, T. L., 1995, Functional Design Criteria for Enhanced Radioactive and Mixed Waste Storage Phase V, Project W-112, WHC-SD-W112-FDC-001, Rev. 3, Westinghouse Hanford Company, Richland, Washington.

Estrellado, J. P., 1995, Solid Waste Burial Grounds Interim Safety Analysis, WHC-SD-WM-SARR-028, Rev. 1, Westinghouse Hanford Company, Richland, Washington.

Evans, G. C., 1990, Low-Level Burial Grounds Dangerous Waste Permit Application, DOE/RL-88-20, U.S. Department of Energy, Richland Operations Office, Richland, Washington.

Filip, J. E., 1987, Project Management Plan T Plant Exhaust System Upgrade Project B-459, SD-459-PMP-001, Rev. 0, Westinghouse Hanford Company, Richland, Washington.

Finch, B. G., 1995, Project-Specific Quality Assurance Plan, WHC-SD-W291-QAPP-001, Rev. 0, Westinghouse Hanford Company, Richland, Washington.

Flyckt, D. L., 1988, Best Available Technology (Economically Achievable) Guidance Document for the Hanford Site Waste Management Systems Engineering, WHC-EP-0137, Westinghouse Hanford Company, Richland, Washington.

Flyckt, D. L., 1995, 200 Area Effluent Treatment Facility Auditable Safety Analysis, WHC-SDETF-ASA-001, Rev. 0, Westinghouse Hanford Company, Richland, Washington.

Friar, D. E., 1989a, CSAR 80-021, Addendum 2, Packaging, Storage and Disposal of Solid Waste (55-Gallon Drums, Unrestricted H/Pu Only), WHC-SD-SQA-CSA-20123, Rev. 0, Westinghouse Hanford Company, Richland, Washington. 
Friar, D. E., 1989b, CSAR 82-001, Transportation and Burial of PUREX Burial Box, WHC-SD-SQA-CSA-20129, Rev. 0, Westinghouse Hanford Company, Richland, Washington.

Friar, D. E., 1989c, CSAR 82-003, Packaging, Storage and/or Disposal of Solid Wastes (Burial Containers and Uranic Burial), WHC-SD-SQA-CSA-20130, Rev. 0, Westinghouse Hanford Company, Richland, Washington.

Friar, D. E., 1989d, CSAR 85-004, Disposal of Department of Transportation and Certificate of Compliance Approved Containers, WHC-SD-SQA-CSA-20132, Rev. 0, Westinghouse Hanford Company, Richland, Washington.

Friar, D. E., 1990a, CSAR 79-038, Out of Hood Plutonium Storage, WHC-SD-SQA-CSA-20204, Rev. 0, Westinghouse Hanford Company, Richland, Washington.

Friar, D. E., 1990b, CSAR 78-001, PWR CORE 2 Blanket Fuel Storage Cell 4/221T Building, WHC-SD-SQA-CSA-20153, Rev. 0, Westinghouse Hanford Company, Richland, Washington.

Gibson, B. C., 1997, Transuranic Storage and Assay Facility Interim Operational Safety Requirements, HNF-SD-WM-TSR-002, Rust Federal Services, Inc., Richland, Washington.

Gilkenson, B. A., 1995a, Conceptual Design Report for 340 Secondary Containment and Leak Detection Project W-302, WHC-SD-W302-CDR-001, Rev. 0, Westinghouse Hanford Company, Richland, Washington.

Gilkenson, B. A., 1995b, Engineering Study 340 Waste Handling Facility Upgrade Supporting Project W-302 Facility Secondary Containment and Leak Detection, WHC-SD-LEF-ES001, Rev. 0, Westinghouse Hanford Company, Richland, Washington.

Graves, C. E., 1996a, Interface Control Document for Untreated Liquid Effluents, WHC-SDWM-ICD-038, Rev. 0, Westinghouse Hanford Company, Richland, Washington.

Graves, C. E., 1996b, Interface Control Document for Treated Liquid Effluents, WHC-SD-WMICD-039, Rev. 0, Westinghouse Hanford Company, Richland, Washington.

Garvey, L. J., 1985, Solid Waste Burial Caisson Plan for Transuranic (TRU) Wastes ("Alpha" Caissons), WHC-SD-WM-PAP-041, Rev. 0, Westinghouse Hanford Company, Richland, Washington.

Gibson, K. D., 1995, Transuranic Waste Storage and Assay Facility (TRUSAF) Interim Safety Basis, WHC-SD-WM-ISB-004, Rev. 0, Westinghouse Hanford Company, Richland, Washington. 
Gibson, K. D., 1996, Enhanced Radioactive \& Mixed Waste Storage Phase V Preliminary Safety Analysis Report, WHC-SD-W112-PSAR-001, Rev. 0A, Westinghouse Hanford Company, Richland, Washington.

Gilbert, B. H., 1996, Transuranic Storage and Assay Facility Interim Basis, WHC-SD-WM-TSR-004, Rev. OA, Westinghouse Hanford Company, Richland, Washington.

Greager, T. M., 1993a, Project W-112, Enhanced Radioactive and Mixed Waste - Phase V, Additional Studies for Project $W-112$, WHC-SD-W112-ES-003, Rev. 0, Westinghouse Hanford Company, Richland, Washington.

Greager, T. M., 1993b, Hanford Central Waste Complex Maintenance Study, WHC-SD-W112-ES-005, Rev. 0, Westinghouse Hanford Company, Richland, Washington.

Greager, T. M., 1994a, Project W-112, Enhanced Radioactive and Mixed Waste Storage, Phase $V$, WHC-SD-W112-ACDR-001, Rev. 0, Westinghouse Hanford Company, Richland, Washington.

Greager, T. M., 1994b, Solid Waste Management Complex Site Development Plan, WHC-SD-W112-ES-006, Rev. 0, Westinghouse Hanford Company, Richland, Washington.

Greager, T. M., 1996a, Interface Control Document Between Liquid Effluent Services and Solid Waste Disposal Division, WHC-SD-WM-PICD-001, Rev. 1, Westinghouse Hanford Company, Richland, Washington.

Greager, T. M., 1996b, Interface Control Document Between FFTF Transition Project and Solid Waste Disposal Division, WHC-SD-WM-PICD-004, Rev. 1, Westinghouse Hanford Company, Richland, Washington.

Greager, T. M., 1996c, Interface Control Document Between Analytical Services and Solid Waste Disposal Division, WHC-SD-WM-PICD-005, Rev. 1, Westinghouse Hanford Company, Richland, Washington.

Greager, T. M., 1996d, Interface Control Document Between Spent Nuclear Fuel Operations and Solid Waste Disposal Division, WHC-SD-WM-PICD-009, Rev. 0, Westinghouse Hanford Company, Richland, Washington.

Green, F. T., 1996, Liquid Effluents Program FY 1997 Multi-Year Work Plan, WBS 1.2.2, WHC-SP-1097, Rev. 2, Westinghouse Hanford Company, Richland, Washington.

Griffen, T. E., 1992, Relidding 55 Gallon Waste Drums, WHC-SD-W026-DTP-002, Rev. 0, Westinghouse Hanford Company, Richland, Washington. 
Hagerty, K. J., 1994a, Operability Test Procedure for the 340-NT-EX Stack Upgrades Project W-337, WHC-SD-W337-OTP-001, Westinghouse Hanford Company, Richland, Washington.

Hagerty, K. J., 1994b, Acceptance Test Procedure for the 340-NT-EX Stack Upgrades Project $W$-337, WHC-SD-W337-ATP-001, Rev. 0, Westinghouse Hanford Company, Richland, Washington.

Hagerty, K. J., 1994c, 300 Area Treated Effluent Disposal Facility Essential Material Specification, WHC-SD-L045H-TI-005, Rev. 1, Westinghouse Hanford Company, Richland, Washington.

Halgren, D. L., 1995, 340 Waste Handling Facility Comparison with 40 CFR 61, Subpart H, and other Referenced Guidelines for Stack 340-NT-EX, WHC-EP-0544, Westinghouse Hanford Company, Richland, Washington.

Harker, M. R., 1991a, Engineering Safety Study for Project W-113, WHC-SD-W113-ES-002, Rev. 1, Westinghouse Hanford Company, Richland, Washington.

Harker, M. R., 1991b, Solid Waste Retrieval Phase I Hazard Classification, WHC-SD-W113-HC-002, Rev. 0A, Westinghouse Hanford Company, Richland, Washington.

Harker, M. E., 1993, Solid Waste Retrieval Phase I Preliminary Safety Evaluation (PSE), WHC-SD-W113-PSE-001, Rev. 0, Westinghouse Hanford Company, Richland, Washington.

Hatch, C. E., 1995, Functional Design Criteria for Project W252 Phase II Liquid Effluent Treatment and Disposal, WHC-SD-W252-FDC-001, Rev. 2, Westinghouse Hanford Company, Richland, Washington.

Havens, D. E., 1988, The Hanford Central Waste Complex Site Evaluation Report, WHC-SD-W026-SE-001, Rev. 0, Westinghouse Hanford Company, Richland, Washington.

Hayden, K. D., 1993, Engineering Study 300 Area Process Sewer Replacement, Project L070, WHC-SD-L070-ES-001, Rev. OA, Westinghouse Hanford Company, Richland, Washington.

Hedengren, D. C., 1986, T Plant Ventilation Upgrade, Engineering Study, SD-459-ES-001, Rev. 0, Westinghouse Hanford Company, Richland, Washington.

Hess, A. L., 1990, CSER 90-007, Retrieval of CH-TRU Waste from 200 Area Burial Ground, WHC-SD-SQA-CSA-20324, Rev. 0, Westinghouse Hanford Company, Richland, Washington. 
Hinkle, A. W., 1994, Project W-026, Waste Receiving and Processing (WRAP) Facility Module 1: Maximum Possible Fire Loss (MPFL) Decontamination and Cleanup Estimates, WHC-SD-W026-TI-006, Rev. 1, Westinghouse Hanford Company, Richland, Washington.

Hoofkin, J. D., 1994, Conceptual Design Report T Plant Secondary Containment and Leak Detection Upgrades Project W-259, WHC-SD-W259-CDR-001, Rev. 0, Westinghouse Hanford Company, Richland, Washington.

Hoofkin, J. D., 1995, Conceptual Design Report, "T Plant Electrical Upgrade" Project C-157, WHC-SD-C157-CDR-001, Rev. 0, Westinghouse Hanford Company, Richland, Washington.

Hull, K. J., 1992, Test Report for Compacted Waste Drum Sampling, WHC-SD-W026-TRP-002, Rev. 0, Westinghouse Hanford Company, Richland, Washington.

Irwin, R. M., 1996a, Transuranic Waste Storage and Assay Facility Safety Equipment List, WHC-SD-WM-SEL-011, Rev. 4, Westinghouse Hanford Company, Richland, Washington.

Irwin, R. M., 1996b, Draft W-112 Start Up Plan, Westinghouse Hanford Company, Richland, Washington.

Johnson, D. M., 1992, Alpha Caisson Air Sampling Report, WHC-SD-WM-RPT-051, Rev. 0, Westinghouse Hanford Company, Richland, Washington.

Johnson, D. M., 1994a, Engineering Study for the Solid Waste Retrieval, WHC-SD-W113-ES-001, Rev. 2, Westinghouse Hanford Company, Richland, Washington.

Johnson, D. M., 1994b, W-113 FDC Technical Basis, WHC-SD-W113-RD-001, Rev. 0, Westinghouse Hanford Company, Richland, Washington.

Johnson, D. M., 1994c, Functional Design Criteria Solid Waste Retrieval Phase 1, WHC-SD-W113-FDC-001, Rev. 2, Westinghouse Hanford Company, Richland; Washington.

Johnson, D. M., 1994d, Solid Waste Retrieval Phase I Operational Basis, WHC-SD-W113-OCD-001, Rev. 0, Westinghouse Hanford Company, Richland, Washington.

Johnson, D. M., 1994e, Phase 2 Solid Waste Retrieval Strategy, WHC-SD-W221-ES-002, Rev. 0, Westinghouse Hanford Company, Richland, Washington.

Johnson, D. M., 1994f, Phase 2 Solid Waste Retrieval Trench Characterizations, WHC-SD-W221-DP-001, Rev. 0, Westinghouse Hanford Company, Richland, Washington. 
Johnson, H. E., 1993a, T Plant Decontamination and Repair Facilities, WHC-SD-SQA-CSA-20104, Rev. 0, Westinghouse Hanford Company, Richland, Washington.

Johnson, H. E., 1993b, T Plant Safety Analysis Report, WHC-SD-CP-SAR-007, Rev. 1, Westinghouse Hanford Company, Richland, Washington.

Johnston, G. A., 1989, Vendor Information Master List of Submittal for Project B-459, SD-459-VI-001, Rev. 0, Westinghouse Hanford Company, Richland, Washington.

Johnston, G. A., 1991a, Project 8459 Acceptance Test Report, SD-459-ATR-001, Rev. 0, Westinghouse Hanford Company, Richland, Washington.

Johnston, G. A:, 1991b, Project B459 Compliance to Safety Related Criteria from DOE Order 6430.1A, SD-459-ER-001, Rev. 0, Westinghouse Hanford Company, Richland, Washington.

Johnston, G. A., 1991c, Project B459 Design Review Report, SD-459-DRR-001, Rev. 0, Westinghouse Hanford Company, Richland, Washington.

Jones, K. L., 1995, 300 Area Process Sewer Piping Upgrade, L-070 Project, WHC-SD-L070-QAPP-001, Rev. 3, Westinghouse Hanford Company, Richland, Washington.

Jorisson, R. L., 1993, T Plant Roof Seismic Qualification, WHC-SD-WM-SA-024, Rev. 0, Westinghouse Hanford Company, Richland, Washington.

Josephson, W. S., 1995, Treatment Options for Tank Farms Long-Length Contaminated Equipment, WHC-SD-WM-ES-324, Rev. 0, Westinghouse Hanford Company, Richland, Washington.

Joyce, J. P., 1993, Preliminary Safety Evaluation for Waste Receiving and Processing Facility Module 1 Project W-026, WHC-SD-W026-PSE-001, Rev. OB, Westinghouse Hanford Company, Richland, Washington.

Joyce, J. P., and M. R. Harken, 1993, Final Safety Analysis for Contact-Handled Transuranic Waste Drums In-Situ Inspection and Vented Drum Retrieval, WHC-SD-WM-SAR-058, Rev. 0, Westinghouse Hanford Company, Richland, Washington.

Kanjilal, S., 1991, Development Test Plan for Drum Cutting for WRAP Module I, WHC-SD-W026-DTP-001, Rev. 0, Westinghouse Hanford Company, Richland, Washington.

Keith, L. M., 1994a, Test Plan for Optimizing Grout Formulation and Mixing Techniques for Immobilization of CH-TRU Waste at the WRAP Facility, WHC-SD-WM-TP-027, Rev. 0, Westinghouse Hanford Company, Richland, Washington. 
HNF-SD-WM-RPT-288

Revision 0

Keith, L. M., 1994b, Test Report from Grout Formulation and Mixing Techniques for Immobilization of Solid Shredded CH-TRU Waste at the WRAP Facility, WHC-SD-WM-TRP-023, Rev. 0, Westinghouse Hanford Company, Richland, Washington.

Keith, L. M., 1994c, Operating and Product Criteria for the Shred/Grout Process Planned for Use in the Waste Receiving and Processing (WRAP) Facility, WHC-SD-WM-TI-221, Rev. 0, Westinghouse Hanford Company, Richland, Washington.

Kelley, R. S., 1990, Technical Evaluation of the Conceptual Design for the WRAP I Open/Sort/Package Enclosure, WHC-SD-W026-ES-001, Rev. 0, Westinghouse Hanford Company, Richland, Washington.

Kelley, R. S., 1991, Preliminary Evaluation of Retrieval Systems Required for Phase I Suspect TRU Solid Waste, WHC-SD-W113-ER-001, Rev. 0, Westinghouse Hanford Company, Richland, Washington.

Kelley, R. S., 1992, Material Flow Simulation Study for the Initial Phase of Phase V Storage Operations Project W-112, WHC-SD-W112-ER-001, Rev. 0, Westinghouse Hanford Company, Richland, Washington.

Koerner, J. A., 1995, Hazard Categorization Report for the 200 Area Effluent Treatment Facility, WHC-SD-C018H-HC-002, Rev. 1, Westinghouse Hanford Company, Richland, Washington.

Kooiker, S. L., 1992, Witness Simulation for Project W-112, WHC-SD-W112-ER-002, Rev. 0, Westinghouse Hanford Company, Richland, Washington.

Lavender, J. C., 1993, Preliminary Safety Evaluation for Project W-291, 200 Areas Effluent $B A T / A K A R T$ Implementation, WHC-SD-W291-PSE-001, Rev. 0, Westinghouse Hanford Company, Richland, Washington.

LeClair, M. D., 1993, Waste Receiving and Processing/Solid Waste (WRAP/SW) Facility Engineering Development Program Plan, WHC-SD-W026-PAP-001, Rev. 1, Westinghouse Hanford Company, Richland, Washington.

Loll, C. M., 1994, 300 Area Treated Effluent Disposal Facility Sampling Schedule, WHC-SDL045H-SM-001, Rev. 1, Westinghouse Hanford Company, Richland, Washington.

Loll, C. M., 1995, 300 Area TEDF NPDES Permit Compliance Monitoring Plan, WHC-SD-L045H-PLN-004, Rev. 1, Westinghouse Hanford Company, Richland, Washington.

Loll, C. M., 1996a, Acceptance Test Procedure for the L-070 Project Mechanical Equipment and Instrumentation, WHC-SD-L070-ATP-001, Rev. 0, Westinghouse Hanford Company, Richland, Washington. 
Loll, C. M., 1996b, Acceptance Test Report for the L-070 Project, WHC-SD-L070-ATR-001, Rev. 0, Westinghouse Hanford Company, Richland, Washington.

Louie, R. L., 1994, Preliminary Fire Hazards Analysis for the Enhanced Radioactive and Mixed Waste Storage Phase V, Project W-112, WHC-SD-W112-FHA-001, Rev. 0, Westinghouse Hanford Company, Richland, Washington.

Louie, R. L., 1995, Preliminary Fire Hazards Analysis for the Solid Waste Retrieval Facility Phase 1 - Project W-113, WHC-SD-W113-FHA-001, Rev. 0, Westinghouse Hanford Company, Richland, Washington.

Lunsford, T. R., 1991, Nondestructive Assay (NDA) Data from Transuranic Storage and Assay Facility (TRUSAF) Oct 1985 - Oct 1990, WHC-SD-W026-DP-001, Rev. 0, Westinghouse Hanford Company, Richland, Washington.

Mayancsik, B. A., 1994, Waste Receiving and Processing (WRAP) Facility Module I Functional Design Criteria, WHC-SD-W026-FDC-001, Rev. 2, Westinghouse Hanford Company, Richland, Washington.

McCarthy, R. J., 1994, 300 Area Treated Effluent Disposal Facility Computer Software Release Cover Sheet and Revision Record, WHC-SD-L045H-CSWD-002, Rev. 0, Westinghouse Hanford Company, Richland, Washington.

McCarthy, R. J., 1995, Control System Troubleshooting Guide for the 300 Area Treated Effluent Disposal Facility, WHC-SD-ETF-PCP-001, Rev. 0, Westinghouse Hanford Company, Richland, Washington.

McCormick, W. A., 1992, Packaging Design Criteria for the Alpha Caisson Packaging System, WHC-SD-TP-PDC-005, Rev. 0, Westinghouse Hanford Company, Richland, Washington.

McDonald, F. N., 1994, Acceptance of Feedstreams for Treatment at the LERF/ETF Complex, WHC-SD-ETF-WAC-001, Rev. 0, Westinghouse Hanford Company, Richland, Washington.

McGee, J. R., 1995, Quality Assurance Project Plan, Solid Waste Operations Complex, WHC-SD-W306-QAPP-001, Rev. 0, Westinghouse Hanford Company, Richland, Washington.

Mears, D. L., 1993, Preparation Plan for the 300 Area Treated Effluent Disposal Facility Final Safety Analysis Report, WHC-SD-L045H-PLN-001, Rev. 0, Westinghouse Hanford Company, Richland, Washington.

Medsker, M. A., 1992, Engineering Safety Study for Project W-156, WHC-SD-W156-ES-001, Rev. 0, Westinghouse Hanford Company, Richland, Washington. 
HNF-SD-WM-RPT-288

Revision 0

Medsker, M. A., 1994, Hazard Classification for Project W-156 Retrieval of Remote-Handled Transuranic Waste from Alpha Caissons, WHC-SD-W156-ES-001, Rev. 0, Westinghouse Hanford Company, Richland, Washington.

Meyer, M. F., 1997, Interim Safety Basis for Solid Waste Facilities (T Plant), HNF-SD-WM-ISB-006, Rust Federal Services Hanford, Inc., Richland, Washington.

Miller, E. M., 1996, CSER 94-012: Criticality Safety Evaluation Report for 340 Facility, WHC-SD-SQA-CSA-20379, Rev. 1, Westinghouse Hanford Company, Richland, Washington.

Monthey, M. J., 1992, Alpha Caisson Retrieval Cask Engineering Study, WHC-SD-WM-ES-191, Rev. 0, Westinghouse Hanford Company, Richland, Washington.

Moon, T. W., 1995, Hanford Site Air Operating Permit Application, DOE/RL-95-07, U.S. Department of Energy, Richland Operations Office, Richland, Washington.

Mulkey, C. H., 1996, Double-Shell Tank System Waste Analysis Plan, WHC-SD-WM-EV-053, Rev. 4, Westinghouse Hanford Company, Richland, Washington.

Muller, F. J., 1990, Functional Design Criteria for the 300 Area Treated Effluent Disposal Facility Project $L-045 \mathrm{H}$, WHC-SD-L045H-FDC-001, Rev. 0, Westinghouse Hanford Company, Richland, Washington.

Muller, F. J., 1992, 300 Area Process Sewer Study to Identify Flow and Constituent Reduction, WHC-SD-XE07-ES-003, Rev. 0, Westinghouse Hanford Company, Richland, Washington.

Muller, F. J., 1993, Project Specific Quality Assurance Plan L045H 300 Area Treated Effluent Disposal Facility, WHC-SD-L045H-QAPP-001, Rev. 0, Westinghouse Hanford Company, Richland, Washington.

Myers, J. B., 1993, Results of Solid Waste Operations Complex (SWOC) Office Administrative Space Study (Letter 87330-93-JBM-021 to J. G. Riddelle, March 29), Westinghouse Hanford Company, Richland, Washington.

Naser, A. J., 1985, Waste Form Development for the Waste Receiving and Processing (WRAP) Facility, WHC-SD-WM-TRP-017, Rev. 0, Westinghouse Hanford Company, Richland, Washington.

Nickels, J. M., 1992, A Guide for Preparing Hanford Site Facility Effluent Monitoring Plans, WHC-EP-0438-1, Westinghouse Hanford Company, Richland, Washington.

National Environmental Policy Act of 1969, 42 USC 4321, et seq. 
HNF-SD-WM-RPT-288

Revision 0

Oar, D. L., 1995, Fire Hazards Analysis for T Plant, WHC-SD-WM-FHA-OO1, Rev. 0, Westinghouse Hanford Company, Richland, Washington.

Ocampo, V. P., 1993, Project W-113 Drum Venting and Head Gas Sampling System Equipment, WHC-SD-W113-ES-003, Rev. 0, Westinghouse Hanford Company, Richland, Washington.

Ocampo, V. P., 1994, Supplemental Design Requirements Document Radioactive and Mixed Waste Storage Phase V, Project W-112, WHC-SD-W112-SDRD-001, Rev. 0, Westinghouse Hanford Company, Richland, Washington.

Ocampo, V. P., 1995, T Plant Instrumentation and Electrical Acceptance Test Procedure, WHC-SD-W291H-ATP-001, Rev. 0, Westinghouse Hanford Company, Richland, Washington.

Olander, A. R., 1994, 300 Area Treated Effluent Disposal Facility Operating Specifications Document, WHC-SD-L045H-PC-001, Rev. 0, Westinghouse Hanford Company, Richland, Washington.

Olander, A. R., 1995a, Specification for Retention Process Sewer Monitoring/Diversion Radiation Detection, WHC-S-0381, Westinghouse Hanford Company, Richland, Washington.

Olander, A. R., 1995b, Hanford 300 Area Treated Effluent Disposal Facility Inventory at Risk Calculations and Safety Analysis, WHC-SD-WM-SAD-025, Westinghouse Hanford Company, Richland, Washington.

Olander, A. R., 1995c, 300 Area Treated Effluent Disposal Facility Permit Reopener Run Plan, WHC-SD-LEF-PLN-001, Rev. 0, Westinghouse Hanford Company, Richland, Washington.

Olander, A. R., 1996a, Acceptance and Operability Test Report for the 325 Building Retention Process Sewer Diverter Station, WHC-SD-W353-ATR-001, Rev. 0, Westinghouse Hanford Company, Richland, Washington.

Olander, A. R., 1996b, Acceptance and Operability Test Report for the 325 Building Retention Process Sewer Diverter Station, WHC-SD-W353-ATR-002, Rev. 0, Westinghouse Hanford Company, Richland, Washington.

Olander, A. R., 1996c, Acceptance \& Operability Test Report for the 324 Building Retention Process Sewer Diverter Station, WHC-SD-W353-ATR-003, Rev. 0, Westinghouse Hanford Company, Richland, Washington.

Olander, A. R., 1996d, Acceptance and Operability Test Procedure for the 327 Building Retention Process Sewer Diverter Station, WHC-SD-W353-ATP-001, Rev. 0, Westinghouse Hanford Company, Richland, Washington. 
Olander, A. R., 1996e, Acceptance and Operability Test Procedure for the 325 Building Retention Process Sewer Diverter, WHC-SD-W353-ATP-002, Rev. 0, Westinghouse Hanford Company, Richland, Washington.

Olander, A. R., 1996f, Acceptance and Operability Test Procedure for the 325 Building Retention Process Sewer Diverter Station, WHC-SD-W353-ATP-003, Rev. 0, Westinghouse Hanford Company, Richland, Washington.

Olander, A. R., 1996g, Acceptance and Operability Test Procedure for the 326 Building Retention Process Sewer Diverter Station, WHC-SD-W353-ATP-004, Rev. 0, Westinghouse Hanford Company, Richland, Washington.

Olson, W. W., 1993, Solid Waste Stream Hazardous and Dangerous Components, WHC-SD-WM-RPT-056, Rev. 0, Westinghouse Hanford Company, Richland, Washington.

Olson, W. W., 1994, Waste Receiving and Processing Facility Module 1 (WRAP) Preliminary Safety Analysis Report, WHC-SD-W026-SAR-001, Rev. 1, Westinghouse Hanford Company, Richland, Washington.

Ortega, M. A., 1992, Operability Test Report for the T Plant Permanent HEPA Filtration System Project B-459, WHC-SD-459-OTR-001, Rev. 0, Westinghouse Hanford Company, Richland, Washington.

Ortega, M. A., 1993, Interim T Plant Safety Equipment List, WHC-SD-WM-SEL-013, Rev. 0, Westinghouse Hanford Company, Richland, Washington.

Palmros, S. V., 1987, Acceptance Test Procedure for Project B-630 221-T Building Life Safety Upgrade, B630-ATP-01, Meir Associates, Kennewick, Washington.

Pauly, T. R., 1990a, Test Plan for Sphincter Seal Testing, WHC-SD-W026-TP-002, Rev. 0, Westinghouse Hanford Company, Richland, Washington.

Pauly, T. R., 1990b, Engineering Study for Waste Receiving and Processing (WRAP) Facility Module 2, WHC-SD-W100-ES-001, Rev. 0, Westinghouse Hanford Company, Richland, Washington.

Pauly, T. R., 1992, WRAP Module I Air Emissions Source Term, WHC-SD-W026-TI-003, Rev. 0, Westinghouse Hanford Company, Richland, Washington.

Perry, J. K., 1995, Statement of Work for Analytical Services Provided to Westinghouse Hanford Company by the Pacific Northwest National Laboratory Analytical Chemistry Laboratory, WHC-EP-0857, Westinghouse Hanford Company, Richland, Washington. 
Peterson, K. S., 1993, Conceptual Design Report 200 Area Effluent BAT/AKART Implementation Project W-291, WHC-SD-W291-CDR-001, Rev. 0, Westinghouse Hanford Company, Richland, Washington.

Pines, A. G., 1992, Transuranic Waste Storage and Assay Facility Hazard Identification and Evaluation, WHC-SD-WM-SAR-025, Rev. 0, Westinghouse Hanford Company, Richland, Washington.

Place, B. G., 1993, W242 Thermal Treatment Facility Technical Basis Document, WHC-SD-W242-ES-002, Rev. 0, Westinghouse Hanford Company, Richland, Washington.

Place, B. G., 1994, Low-Level Mixed Waste Thermal Treatment Technical Basis Report, WHC-SD-W242-ES-003, Rev. 0, Westinghouse Hanford Company, Richland, Washington.

PNL, 1994, 1993 Baseline Solid Waste Management System Description, PNL-8990, Pacific Northwest Laboratory, Richland, Washington.

Poole, M. E., 1997, 300 Area Liquid Effluent Facilities Administration, HNF-IP-1000, Rust Federal Services Hanford, Inc., Richland, Washington.

Porten, D. R. 1997, Transuranic Storage and Assay Facility (TRUSAF) Interim Safety Basis, HNF-SD-WM-ISB-004, Fluor Daniel Northwest, Richland, Washington.

Pratt, D. A., 1996, Solid Waste Burial Grounds Interim Operational Safety Requirements, WHC-SD-WM-TSR-001, Westinghouse Hanford Company, Richland, Washington.

Renard, V. E., 1995, Central Waste Complex Equipment List, WHC-WM-SEL-009, Rev. 4, Westinghouse Hanford Company, Richland, Washington.

Resource Conservation and Recovery Act of 1976, 42 USC 6901, et seq.

Riddelle, J. G., 1993, Solid Waste Projects Nondestructive Assay/Nondestructive Examination Review (Internal memo 87330-93-WPG-026 to W. P. Gilles, July 28) Westinghouse Hanford Company, Richland, Washington.

Riddelle, J. G., 1996, Solid Waste Program Fiscal Year 1997 Multi-Year Work Plan, WBS 1.2.1, WHC-SP-1161, Westinghouse Hanford Company, Richland, Washington.

Rieck, C. A., 1990, Conceptual Design Report for Project W-026 Waste Receiving and Processing Facility Module I, WHC-SD-W026-CDR-001, Rev. 0, Westinghouse Hanford Company, Richland, Washington.

RL, 1993a, 200 Area Effluent Treatment Facility Delisting Petition, DOE/RL-92-72, Rev. 1, U.S. Department of Energy, Washington, D.C. 
HNF-SD-WM-RPT-288

Revision 0

RL, 1993b, Hanford Facility Permit Application 200 Area Effluent Treatment Facility (RCRA Part $A \& B)$, DOE/RL-93-03, Rev. 0, U.S. Department of Energy, Washington, D.C.

RL, 1995a, Plan and Schedule for Disposition and Regulatory Compliance for Miscellaneous Streams, DOE/RL-93-94, U.S. Department of Energy, Richland Operations Office, Richland, Washington.

RL, 1995b, Hanford Facility Dangerous Waste Permit Application, T Plant Complex, DOE/RL-95-36, Rev. 0, U.S. Department of Energy, Richland Operations Office, Richland, Washington.

RL, 1996, Hanford Mission Direction Document (Draft), December 1995, DOE/RL-96-14, U.S. Department of Energy, Richland Operations Office, Richland, Washington.

Roberts, L. W., 1995a, Building Emergency Plan for the Treated Effluent Disposal Facility, WHC-IP-0263-310, Rev. 1, Westinghouse Hanford Company, Richland, Washington.

Roberts, L. W., 1995b, 300 Area Liquid Effluent Facility Emergency Organization Listing, WHC-IP-0732-LEF, Rev. 1, Westinghouse Hanford Company, Richland, Washington.

Roberts, S. L., 1994, Treated Effluent Disposal Facility Phone System Acceptance Test Procedure, WHC-SD-L045H-ATR-004, Rev. 0, Westinghouse Hanford Company, Richland, Washington.

Robles, M. H., 1992, Equipment Design for NDE/NDA \& Gas Sampling for Phase I Retrieval, WHC-SD-W113-ER-002, Rev. 0, Westinghouse Hanford Company, Richland, Washington.

Robles, M. H., 1993, Preliminary Engineering Study for Solid Waste Retrieval, Phase 2 Project 96L-GFW-221, WHC-SD-W221-ES-001, Rev. 0, Westinghouse Hanford Company, Richland, Washington.

Romano, T., 1986a, Project B-630, Building 221-T Life Safety Upgrade Functional Design Criteria, SD-630-FDC-001, Rev. 0, Westinghouse Hanford Company, Richland, Washington.

Romano, R., 1986b, Conceptual Design Report Building 221-T Life Safety Upgrade Project B-630, SD-630-CDR-001, Rev. 0, Westinghouse Hanford Company, Richland, Washington.

Romano, T., 1986c, Conceptual Design Plan Project B-630, 221-T Life Safety Upgrade, SD-630-CDP-001, Rev. 0, Westinghouse Hanford Company, Richland, Washington.

Romano, T., 1986d, Design Document Review Report Functional Design Criteria Building 221-T Life Safety Upgrade Project B-630, SD-630-DRR-001, Rev. 0, Westinghouse Hanford Company, Richland, Washington. 
HNF-SD-WM-RPT-288

Revision 0

Romano, T., 1986e, Design Document Review Report Conceptual Design Report Building 221-T Life Safety Upgrade Project B-630, SD-630-DRR-002, Rev. 0, Westinghouse Hanford Company, Richland, Washington.

Rosnick, C. K., 1994, WRAP I Module 1 Data Management System Software Requirements Specification, WHC-SD-W026-CSRS-001, Rev. 0, Westinghouse Hanford Company, Richland, Washington.

Rosser, J. R., 1996, Burial Grounds Safety Equipment List, WHC-SD-WM-SEL-012, Rev. 6, Westinghouse Hanford Company, Richland, Washington.

Ruff, D. T., 1992a, Test Report for Vacuum Lift Drum De-Lidding, WHC-SD-W026-TRP-003, Rev. 0, Westinghouse Hanford Company, Richland, Washington.

Ruff, D. T., 1992b, C-Clip Drum Re-Lidding Test Report Implementation Plan, WHC-SD-W026-TRP-005, Rev. 0, Westinghouse Hanford Company, Richland, Washington.

Sabin, J. C., 1993, Hanford Waste Vitrification Plant Project Interim Storage Facility for Hanford Waste Vitrification Plant Canister Evaluation of Alternatives, WHC-SD-W112-ES-004, Rev. 0, Westinghouse Hanford Company, Richland, Washington.

Sadanga, C. T., 1994, Fire Hazard Analysis for the 300 Area Treated Effluent Disposal Facility, WHC-SD-L045H-FHA-001, Rev. 0, Westinghouse Hanford Company, Richland, Washington.

SAIC, 1991, Assessment of High-Temperature Thermal Treatment Alternatives for Inclusion into the Scope of the Hanford Waste Receiving and Processing (WRAP) Facility, SAIC-91/1278, Science Applications International Corporation, Idaho Falls, Idaho.

Saueressig, D. G., 1992, 224-T Transuranic Waste Storage and Assay Facility Dangerous Waste Permit Application, DOE/RL-91-51, Rev. 0, U.S. Department of Energy, Richland Operations Office, Richland, Washington.

Savino, A. V., 1993a, Estimated Offsite and Onsite Population Health Effects from Drum Explosion Out of Enclosure Accident for Project W-113, WHC-SD-W113-EV-001, Rev. 0, Westinghouse Hanford Company, Richland, Washington.

Savino, A. V., 1993b, Estimated Offsite and Onsite Population Health Effects Design Basis Earthquake Accident for Project W-112, WHC-SD-W112-EV-001, Rev. 0, Westinghouse Hanford Company, Richland, Washington.

Schermerhorn, D. S., 1994a, Operability Test Report for the 300 Area Treated Effluent Disposal Facility, WHC-SD-L045H-OTR-001, Rev. 0, Westinghouse Hanford Company, Richland, Washington. 
HNF-SD-WM-RPT-288

Revision 0

Schermerhorn, D. S., 1994b, Acceptance Test Procedure for the 300 Area Treated Effluent Disposal Facility Process Control System, WHC-SD-L045H-ATR-002, Rev. 0, Westinghouse Hanford Company, Richland, Washington.

Schermerhorn, D. S., 1996, 340 Complex Fire Hazard Analysis, WHC-SD-WM-FHA-011, Rev. 1, Westinghouse Hanford Company, Richland, Washington.

Sederburg, J. P., 1996, Solid Waste Program Technical Baseline Description, WHC-SD-WM-RPT-060, Rev. 2, Westinghouse Hanford Company, Richland, Washington.

Semmers, L. S., 1995, Interim Safety Basis for Solid Waste Facilities (T Plant), WHC-SD-WM-ISB-006, Rev. 0, Westinghouse Hanford Company, Richland, Washington.

Sexton, R. A., 1993, WRAP Module I, Characterization and Process Alternatives Study, WHC-SD-W026-ES-009, Rev. 0, Westinghouse Hanford Company, Richland, Washington.

Shaw, S. W., 1992, Work Plan for Design Verification and Acceptance Testing of a Box Waste Assay System, WHC-SD-W026-WP-002, Rev. 0, Westinghouse Hanford Company, Richland, Washington.

Siemer, J. M., 1993, Probability of an Explosion in WRAP-I Gloveboxes, WHC-SD-W026-TI-007, Rev. 0, Westinghouse Hanford Company, Richland, Washington.

SMC, 1988, Construction Specification Project B-459 T Plant Exhaust System Upgrade, Construction Specification B-459-C1, SMC Consultants, Kennewick, Washington.

Smith, K. E., 1992, Advanced Conceptual Design Work Plan, Project W-113 Solid Waste Retrieval Facility, Phase I, WHC-SD-W113-WP-001, Rev. 0, Westinghouse Hanford Company, Richland, Washington.

Smith, K. E., 1993, Conceptual Design Report, Solid Waste Retrieval Facility Phase I, Project W-113, WHC-SD-W113-CDR-002, Rev. 0, Westinghouse Hanford Company, Richland, Washington.

Smith, K. E., 1994, Advanced Conceptual Design Report, Solid Waste Retrieval Facility Phase 1, Project W-113, WHC-SD-W113-ACDR-001, Rev. 0, Westinghouse Hanford Company, Richland, Washington.

Smith, K. E., 1995a, Preliminary Design Report, WHC-SD-W113-SPRD-001, Rev. 0, Westinghouse Hanford Company, Richland, Washington.

Smith, K. E., 1995b, Supplemental Design Requirements Document, Enhanced Radioactive and Mixed Waste Storage Phase V, Project W-113, WHC-SD-W113-SDRD-001, Rev. 1, Westinghouse Hanford Company, Richland, Washington. 
Smyth, W. W., 1996a, Safety Report for Packaging On-Site Railroad Liquid Waste Tank Cars, WHC-SD-RE-SAP-013, Rev. 6E, Westinghouse Hanford Company, Richland, Washington.

Smyth, W. W., 1996b, Safety Analysis Report for Packaging (Onsite) Double-Shell Tank Car, WHC-SD-TP-SARP-015, Rev. 0, Westinghouse Hanford Company, Richland, Washington.

Soler, L., 1992, Hanford 300 Area Process Wastewater Characterization Data Report, WHCSD-L045H-DP-001, Rev. 0, Westinghouse Hanford Company, Richland, Washington.

Spohr, R. A., 1996, Analytical Services Program Fiscal Year 1997 Multi-Year Work Plan, WBS 1.51, WHC-SP-1110, Rev. 2, Westinghouse Hanford Company, Richland, Washington.

Sprouse, J. S., 1982, Test Report on the Study of Drum Cutting, WHC-SD-WM-TRP-001, Rev. 0, Westinghouse Hanford Company, Richland, Washington.

Starkey, J. G., 1994, Project Management Plan, Waste Receiving and Processing Facility, Project W-026, WHC-SD-W026-PMP-002, Rev. 0, Westinghouse Hanford Company, Richland, Washington.

Stong, A. C., 1994, Statistical Analysis of Total Transuranic (TRU) Waste in Two Through Thirty Drums for the Proposed 4000 Drum Storage Area, WHC-SD-W112-TI-001, Rev. 0, Westinghouse Hanford Company, Richland, Washington.

Stordeur, R. T., 1992, Engineering Summary Report, Hanford 300 Area Treated Effluent Disposal Facility, Project L-045H, WHC-SD-L045H-ER-002, Rev. 0, Westinghouse Hanford Company, Richland, Washington.

Stordeur, R. T., 1994a, Functional Design Criteria for the 340 Radioactive Liquid Waste Storage Facility Upgrades: Project W-302, WHC-SD-W302-FDC-001, Rev. 0, Westinghouse Hanford Company, Richland, Washington.

Stordeur, R. T., 1994b, Engineering Study of the 300 Area Process Waste Handling System, WHC-SD-WM-ER-277, Westinghouse Hanford Company, Richland, Washington.

Stordeur, R. T., 1996, 340 Waste Handling Facility Interim Safety Basis, WHC-SD-WM-ISB003, Rev. 1, Westinghouse Hanford Company, Richland, Washington.

Stordeur, R. T., and L. D. Berneski, 1996, 340 Waste Handling Facility Deactivation Plan, WHC-SD-LEF-SSP-001, Rev. 0, Westinghouse Hanford Company, Richland, Washington.

Storm, S. J., 1994, Readiness Plan Hanford 300 Area Treated Effluent Disposal Facility, WHCSD-L045H-RRR-001, Rev. 1, Westinghouse Hanford Company, Richland, Washington.

Stroup, J. L., 1993, Technical Assessment: WRAP I - HVAC Passive Shutdown, WHC-SD-W026-TA-001, Rev. 0, Westinghouse Hanford Company, Richland, Washington. 
HNF-SD-WM-RPT-288

Revision 0

Sullivan, J. B., 1992, U.S. Department of Energy Waste Receiving and Processing Module 1 W-026 Project Plan (Attachment to Letter 9207102/92-WPO-025 to President, Westinghouse Hanford Company, Richland, Washington, September 29), U.S. Department of Energy, Richland Field Office, Richland, Washington.

Sutton, L. N., 1996, Waste Receiving and Processing (WRAP) Module 1 Hazards Analysis, WHC-SD-PRP-HA-027, Rev. 0, Westinghouse Hanford Company, Richland, Washington.

Theo, M. G., 1994, Engineering Practice Guidelines, WHC-IP-1026, Rev. 0, Westinghouse Hanford Company, Richland, Washington.

Thorne, S. D., 1994, Preliminary Fire Hazards Analysis for Special Case Solid Waste Temporary Storage Facility, Project W-272, WHC-SD-WM-FHA-XXX, Rev. OA, Westinghouse Hanford Company, Richland, Washington.

Thrasher, G. L., 1995, 300 Area Treated Effluent Disposal Facility Sludge Minimization Study, WHC-SD-WM-ES-308, Rev. 0, Westinghouse Hanford Company, Richland, Washington.

UE\&C, 1991a, 85 Gallon Drum Overpack Study, UE\&C, Englewood, Colorado.

UE\&C, 1991b, ALARA Assessment Study, UE\&C, Englewood, Colorado.

UE\&C, 1991c, Bagless Transfer System, UE\&C, Englewood, Colorado.

UE\&C, 1991d, CDR Technical Assessment, UE\&C, Englewood, Colorado.

UE\&C, 1991e, Compaction Optimization Study, UE\&C, Englewood, Colorado.

UE\&C, 1991f, Degree of Automation Within Containment Study, UE\&C, Englewood, Colorado.

UE\&C, 1991g, Drum and Box Lag Storage Study, UE\&C, Englewood, Colorado.

UE\&C, 1991h, Hardware for Characterization of Waste Study, UE\&C, Englewood, Colorado.

UE\&C, 1991i, HVAC Confinement Study, UE\&C, Englewood, Colorado.

UE\&C, 1991j, Material Handling Optimization Study, UE\&C, Englewood, Colorado.

UE\&C, 1991k, Methods of Waste Entry Into Containment, UE\&C, Englewood, Colorado.

UE\&C, 19911, Waste Minimization Study, UE\&C, Englewood, Colorado.

UE\&C, 1991m, Waste Processing Systems Layout \& Configuration Study, UE\&C, Englewood, Colorado. 
HNF-SD-WM-RPT-288

Revision 0

UE\&C, 1992, Waste Receiving and Processing Facility Module 1 Preliminary Design Report, UE\&C, Englewood, Colorado.

UE\&C, 1993, Waste Receiving and Processing Facility Module 1 Detailed Design Report, UE\&C, Englewood, Colorado.

Valero, O. J., 1996, Solid Waste Integrated Forecast Technical (SWIFT) Report: FY 1997 to FY 2070, WHC-EP-0918, Westinghouse Hanford Company, Richland, Washington.

Venetz, T. J., 1995, Interface Control Document Between PFP Transition Project and Solid Waste Disposal Division, WHC-SD-WM-PICD-006, Rev. 0, Westinghouse Hanford Company, Richland, Washington.

Wagner, R. N., 1994, Verification of Best Available Technology for the 300 Area Treated Effluent Disposal Facility (310 Facility), WHC-SD-L045H-ER-003, Rev. 0, Westinghouse Hanford Company, Richland, Washington.

Wagner, R. N., 1995, 340 Facility Maintenance Implementation Plan, WHC-SP-1154, Westinghouse Hanford Company, Richland, Washington.

Walter, E. J., 1994, 340 Facility Waste Tank System Integrity Assessment Plan, WHC-SD-WMWP-250, Rev. 0, Westinghouse Hanford Company, Richland, Washington.

Walter, E. J., 1996, 340 Facility Waste Tank System Integrity Assessment Report, WHC-SDWM-ER-546, Rev. 0, Westinghouse Hanford Company, Richland, Washington.

Webb, J. R., 1993, Waste Drum Relidding, C-Clip Installation, and Feed Mechanism Development Plan, WHC-SD-W026-DTP-003, Rev. 0, Westinghouse Hanford Company, Richland, Washington.

Weber, J. R., 1992a, Drum Waste Non-Destructive Examination Interim Status Report, WHC-SD-W026-DTP-001, Rev. 0, Westinghouse Hanford Company, Richland, Washington.

Weber, J. R., 1992b, WRAP Module I NSE/NDA Area Development Work Plan, WHC-SD-W026-WP-001, Rev. 0, Westinghouse Hanford Company, Richland, Washington.

Weber, J. R., 1994, Nondestructive Examination. Development and Demonstration Plan, WHC-SD-W026-TP-001, Rev. 0, Westinghouse Hanford Company, Richland, Washington.

Weber, J. R., 1995, Evaluation of Alternatives for Nondestructive Assay and Examination of Drums and Boxed Waste in WRAP 1, WHC-SD-W026-ES-004, Rev. 0, Westinghouse Hanford Company, Richland, Washington. 
HNF-SD-WM-RPT-288

Revision 0

Weidert, J. R., 1993, Supplemental Design Requirements Document, Project W-026, WHC-SD-W026-SDRD-001, Rev. 3, Westinghouse Hanford Company, Richland, Washington.

Weidert, J. R., 1994, WRAP I Plant DMS/PCS Interface Definition, WHC-SD-W026-CSWD-001, Rev. 0, Westinghouse Hanford Company, Richland, Washington.

Wellsfry, H. E., 1994, Project L-70, 300 Area Process Sewer Piping System Upgrade, Project Management Plan, WHC-SD-L070-PMP-001, Rev. 0, Westinghouse Hanford Company, Richland, Washington.

Wellsfry, H. E., 1996, Project L-070, "300 Area Process Sewer Piping System Upgrade Project Management Plan," WHC-SD-L070-PMP-001, Rev. 1, Westinghouse Hanford Company, Richland, Washington.

Whattam, J. W., 1993, Fault and Coordination Study for 2217/271T/2706T, WHC-SD-WM-TI-550, Rev. 0, Westinghouse Hanford Company, Richland, Washington.

WHC-CM-5-34, Solid Waste Disposal Operations Administration Manual, Westinghouse Hanford Company, Richland, Washington.

WHC-CM-5-36, Solid Waste Disposal S/RID's Implementation, Westinghouse Hanford Company, Richland, Washington.

WHC, 1991, Liquid Waste Transport-20000 Gallon Railroad Tank Car, CPS-T-149-00015, Rev. A-0, Westinghouse Hanford Company, Richland, Washington.

WHC, 1993, Hazard Classification for the 300 Area Process Sewer Upgrade, Project L070, WHC-SD-L070-HC-001, Rev. 0, Westinghouse Hanford Company, Richland, Washington.

WHC, 1994a, TRUSAF Criticality Prevention Specifications, CPS-SW-149-00001, Rev. B-1, Westinghouse Hanford Company, Richland, Washington.

WHC, 1994b, Boxed Waste Assay System, WHC-S-0033, Rev. 5, Westinghouse Hanford Company, Richland, Washington.

WHC, 1994c, Low-Level Mixed Waste Thermal Treatment Service, RFP No. W-357079-JW, Westinghouse Hanford Company, Richland, Washington.

WHC, 1994d, Waste Storage - 200 Area Low-Level Burial Grounds, CPS-SW-149-00003, Rev. C-1, Westinghouse Hanford Company, Richland, Washington.

WHC, 1995a, Respond to Radioactive Mixed Waste or Highly Toxic Waste Spills-Emergency, SW-001-310, Rev. C-0, Westinghouse Hanford Company, Richland, Washington. 
WHC, 1995b, Inspect Solid Waste Storage/Disposal Facilities, SW-040-005, Rev. B-0, Westinghouse Hanford Company, Richland, Washington.

WHC, 1995c, Perform Surveillance of Alkali Material Storage at 2727-WW Building and at South Alkali Metal Storage Modules, SW-040-020, Rev. C-0, Westinghouse Hanford Company, Richland, Washington.

WHC, 1995d, Inspect SWO Facilities and Equipment, SW-040-040, Rev. C-0, Westinghouse Hanford Company, Richland, Washington.

WHC, 1995e, Overpack Drums, SW-100-095, Rev. B-0, Westinghouse Hanford Company, Richland, Washington.

WHC, 1995f, 616 Walk-In Fume Hood, B-526-CI, WHC-S-0277, Rev. 5, Westinghouse Hanford Company, Richland, Washington.

WHC, 1995g, Mixed Waste Stabilization Treatment Program Request for Proposal, RFP No. W-452759-GK, Westinghouse Hanford Company, Richland, Washington.

WHC, 1995h, T Plant Canyon Operations, CPS-D-149-00001, Rev. A-1, Westinghouse Hanford Company, Richland, Washington.

WHC, 1996a, Receive Radioactive Solid Waste at the Central Waste Complex, SW-100-110, Rev. E-1, Westinghouse Hanford Company, Richland, Washington.

WHC, 1996b, Waste Storage Central Waste Complex, CPS-SW-149-00002, Rev. B-3, Westinghouse Hanford Company, Richland, Washington.

WHC, 1996c, B-2, Non-Destructive Examination of Solid Waste Drums at 224-T for Verification, SW-080-011, Westinghouse Hanford Company, Richland, Washington.

WHC, 1996d, Implementation Plan (IP) for the Waste Receiving and Processing Facility Module 1 (WRAP 1) Operational Readiness Review, WHC-SD-S026-PLN-004), Westinghouse Hanford Company, Richland, Washington.

WHC, 1996e, Operating Specifications for T Plant Facility, OSD-D-187-00008, Rev. B-5, Westinghouse Hanford Company, Richland, Washington.

Willis, N. P., 1996, Hanford Site Solid Waste Acceptance Criteria, WHC-EP-0063-05, Westinghouse Hanford Company, Richland, Washington.

Winkelman, R. H., 1993, Entry/Exit Port Testing Test Plan, WHC-SD-W026-TP-005, Rev. 0, Westinghouse Hanford Company, Richland, Washington. 
Wilson, C. E., 1996, Tank Waste Remediation System Fiscal Year 1997 Multi-Year Work Plan, WBS 1.1, WHC-SP-1101, Rev. 2, Westinghouse Hanford Company, Richland, Washington.

Winslow, C. J., 1994, Functional Design Criteria, T Plant Electrical Upgrade, WHC-SD-C157-FDC-001, Rev. 2, Westinghouse Hanford Company, Richland, Washington.

Winslow, C. J., 1995, $T$ Plant Support Drawing List, WHC-SD-WM-EDL-001, Rev. 1, Westinghouse Hanford Company, Richland, Washington.

Winterhalder, J. A., 1986, Technology Program Plan (TPP) for Contact Handled Transuranic (CH-TRU) Waste Retrieval, WHC-SD-WM-TPP-028, Rev. 0, Westinghouse Hanford Company, Richland, Washington.

Wyer, R. R., 1992, Remote Handling of Transuranic and Low Level Waste in the Waste Receiving and Processing Facility, WHC-SD-WM-ES-102, Rev. 0, Westinghouse Hanford Company, Richland, Washington. 
HNF-SD-WM-RPT-288

Revision 0

\section{CONTENTS}

8.0 IMPLEMENTATION $\ldots \ldots \ldots \ldots \ldots \ldots \ldots \ldots \ldots \ldots \ldots \ldots \ldots, \ldots \ldots \ldots, 1$

8.1 INTRODUCTION . . . . . . . . . . . . . . . . . . . . . .

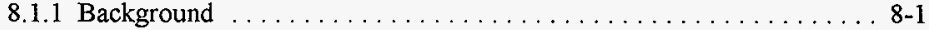

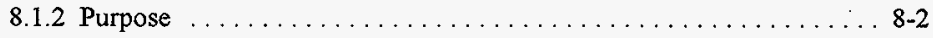

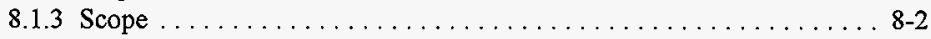

8.1.4 How to Use this Section . . . . . . . . . . . . . . . . . 8 .

8.2 FUNCTIONAL ALLOCATION $\ldots \ldots \ldots \ldots \ldots \ldots \ldots \ldots \ldots \ldots \ldots$ 8-16

8.2 .2 Facilities . . . . . . . . . . . .

8.2.3 Tri-Party Agreement Milestone M-91 Designated Scope . . . . . . . . 8 8-77

8.2.4 Disposal Facilities and Projects . . . . . . . . . . . . . . . . 8-84

8.3 REFERENCES $\ldots \ldots \ldots \ldots \ldots \ldots \ldots \ldots \ldots \ldots \ldots \ldots \ldots \ldots \ldots \ldots$ 
FNF-SD-WM-RPT-288

Revision 0

LIST OF TABLES

8-1. Functional Allocation Crosswalk . . . . . . . . . . . . . . . . . .

8-2. Waste Management Project Facility Allocation Crosswalk ............. . 8-17

8-3. Waste Receiving and Processing Module 1 Interfaces - Facilities . . . . . . . . . 8-35

8-4. Waste Receiving and Processing Module 1 Interfaces - Containers $\ldots \ldots \ldots \ldots .8$ 8-35

8-5. Waste Receiving and Processing Module 1 Interfaces - Vehicles . . . . . . . . . 8 8-36

8-6. Building System Historical Overview $\ldots \ldots \ldots \ldots \ldots \ldots \ldots \ldots \ldots \ldots \ldots .6 \ldots \ldots$

8-7. Waste Receiving and Processing Module 1 Annual Throughput Historical Overview . . 8-39

8-8. Facility Expansion Historical Overview $\ldots \ldots \ldots \ldots \ldots \ldots \ldots \ldots \ldots \ldots . . .4 .41$

8-9. Waste Receiving and Processing Module 1 Waste Sorting Historical Overview . . . . 8 8-42

8-10. Waste Receiving and Processing Module 1 Waste Treatment Historical Overview . . 8-45

8-11. Waste Receiving and Processing Module 1 Waste Characterization Historical Overview $\ldots \ldots \ldots \ldots \ldots \ldots \ldots \ldots \ldots \ldots \ldots \ldots \ldots \ldots . \ldots . \ldots . \ldots \ldots 1$

8-12. Waste Receiving and Processing Module 1 Liquid Waste Historical Overview . . . . 8 8-54

8-13. Waste Receiving and Processing Module 1 Nondestructive Examination/Nondestructive Assay Historical Overview . . . . . . . . . . . . . . . . . . . . 8-55

8-14. Contact-Handled Low-Level Mixed Waste Stabilization Treatment Program Options.

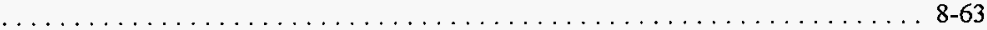

8-15. Summary Information of Active Burial Grounds $\ldots \ldots \ldots \ldots \ldots \ldots \ldots \ldots$ 8-85

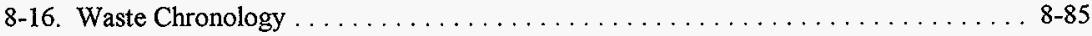


HNF-SD-WM-RPT-288

Revision 0

\section{LIST OF TERMS}

$\begin{array}{ll}\text { CH } & \text { contact-handled } \\ \text { CWC } & \text { Central Waste Complex } \\ \text { DOE } & \text { U.S. Department of Energy } \\ \text { FY } & \text { fiscal year } \\ \text { HVAC } & \text { heating, ventilation, and air conditioning } \\ \text { LLW } & \text { low-level waste } \\ \text { MLLW } & \text { mixed low-level waste } \\ \text { PHMC } & \text { Project Hanford Management Contract } \\ \text { Project } & \text { Waste Management Project } \\ \text { RFSH } & \text { Rust Federal Services of Hanford, Inc. } \\ \text { TRU } & \text { transuranic } \\ \text { TRUM } & \text { transuranic mixed } \\ \text { TRUSAF } & \text { Transuranic Waste Storage and Assay Facility } \\ \text { WIPP } & \text { Waste Isolation Pilot Plant }\end{array}$


HNF-SD-WM-RPT-288

Revision 0

\subsection{IMPLEMENTATION}

\subsection{INTRODUCTION}

Chapter 8.0 links the functions of the Waste Management Project to the key resources used to implement them. This section also provides descriptive information about these facilities, contracts, and project resources.

\subsubsection{Background}

Chapter 2.0 described the Project in terms of the functions, or primary activities and processes, needed to carry out its mission. It further described how these functions are interrelated. Subsequent sections identified the following:

- The underlying requirements for what must be done by these functions and how well their activities must be performed

- Highlighted the interfaces through which the Project interacts technically with its external environment

- Summarized the Project as a whole (system description) with an overview.

The components of the Project that are presented in this document are at different stages of maturity in their life cycles. Some functions and their component elements are operational; others are in a conceptual, preliminary study, detailed design, or construction phase. Some functions are even less mature and cannot be readily defined until major programmatic or regulatory processes progress.

Building new specialized facilities using government funds has become the least preferred alternative for conducting activities at the Hanford Site. Privatization approaches and commercial contracts have become attractive mechanisms for implementing functions. Several solid waste and analytical service functions already use service contracts or are in the process of emplacing them.

Because of this "privatization" shift, the perspective that views the Site cleanup mission as being a series of facilities is becoming obsolete. Facilities are only one way to carry out functions and the purpose of a facility may change as the functions change. Analogously, assets or services that historically have been part of facilities are likely to change as well.

Many elements of this Project need to stay cognizant of the bigger picture because "what" the Project is responsible for carrying out and "how" it fulfills these activities will be under continuous change long into the future. Organizational elements may be realigned to most costeffectively carry out the functions and provide the necessary support activities not presently described in this technical baseline. Furthermore, changing the definition or associated timing of a 
HNF-SD-WM-RPT-288

Revision 0

function or its inputs, outputs, or implementation mechanisms can easily ripple outward, affecting multiple other activities within or outside the Project.

The transition to the Project Hanford Management Contract (PHMC) approach at the Hanford Site has formed new organizational boundaries. It is essential that the boundaries defined by each contracting organization and the associated scope be sufficiently defined and understood. Contractor elements need to be certain which assets are under their direct management. They also need to identify, understand, and manage the many interfaces that exist through the sharing of assets, or transferring and receiving inputs, outputs - or even responsibility- as a particular problem progresses through its life cycle. The systems models in this baseline description are tools for documenting, highlighting, and managing these relationships.

\subsubsection{Purpose}

This section provides a bridge between "what" technically must be done (i.e., the Project functions) and "how" it is or intended to be implemented in terms of specific facilities, commercial contracts, projects, or natural systems. Further, this section provides a summary of these "hows." It does not provide the engineering bases or other rationale underlying the implementation decisions. The sources for the underling rationale are summarized in Chapters 5.0 and 7.0.

\subsubsection{Scope}

This section is limited to the Project and the technical functions for "Conducting Waste Management" as assigned by the PHMC.

\subsubsection{How to Use this Section}

This section is used to rapidly determine the logical connection between any function defined for the Project and the specific facilities, commercial contracts, projects, or natural systems that enable the function to be implemented.

Section 8.2.1 provides two mappings (or crosswalks) are provided in tabular form. They are indexed by function and by facility.

- Table 8-1 is used to determine the "how" or the implementation mechanism for a function. Use of this table assumes that the reader has read Chapter 2.0, and has identified the functions of interest.

- Table 8-2 is used to determine which functions are or will be affected by a facility issue, either technical or programmatic. Use of this table assumes that the reader is interested in a particular facility and is trying to determine which Project functions are related. 
Table 8-1. Functional Allocation Crosswalk. (13 sheets)

\begin{tabular}{|c|c|c|}
\hline Function no. & Function title & Implementing mechanisms \\
\hline $\mathrm{X} .1$ & Manage Solid Waste and Materials & $\begin{array}{l}\text { WRAP 1 (2336-W Waste Receiving and Processing Module 1) (2404-WA, - } \\
\text { WB, and -WC Drum Storage; 2620-W Maintenance, 2740-W Administration); } \\
\text { Central Waste Complex (CWC) (2401-W and 2402-W Series [B-L], 2403-W } \\
\text { Series [A-D], Low-Flashpoint Mixed Waste Storage Modules, Alkali Metal } \\
\text { Waste Storage Modules, South Alkali Metal Storage Modules, Waste Receiving } \\
\text { and Staging Area, Mixed Waste Storage Pad, 2727-W Product Sodium Storage } \\
\text { Building'); T Plant (221-T Canyon, 2706-T Building, 211-T52 Instrument, } \\
\text { 214-T Chem. Storage, 221-TA and -TB Vent Fan Houses, 2706-T Equipment } \\
\text { Decon, 2712-T Electrical Instrumentation, 2715-T Paint Storage, 271-T } \\
\text { Office/Service, 277-T Blow Down, 291-T Exhaust Fan Control House and Sand } \\
\text { Filter, 292-T Fission Products Release Lab, 296-T Gaseous Effluent Release } \\
\text { Point; MO-371, -433, -739, -892-, and -909; Tunnel Trailer Bldgs.); 224-T } \\
\text { TRUSAF; 616 Nonradiological Hazardous Waste Facility; LLW Burial } \\
\text { Ground (218-E-10, 218-E-12B, 218-W-3A, 218-W-3AE, 218-W-4B, 218-W- } \\
\text { 4C, 218-W-5, and 218-W-6 and its transportation assets); MLLW Disposal } \\
\text { Facility (Burial Ground 218-W-5, Trenches 31 and 34); Alpha Caisson in } \\
\text { Burial Ground 218-W-4B. Commercial Hazardous Waste TSD Facilities: } \\
\text { Environsafe, Easton Smelting, Landlan, USPCI Laddlaw LCNE Mountain } \\
\text { Facility, Envirotroc, USPCI Grassy Mountain Facility, Philip Environmental } \\
\text { (Georgetown \& Kent). Commercial transportation services: MP } \\
\text { Environmental Svcs., Tri-State Motor Transit, ATTUM Industries, Triad } \\
\text { Transport, Gresham Transfer, U.S. Pollution Control, Tidewater Barge Lines, } \\
\text { Ross Maritime, Burlington Environmental. Also (but unverified) MO-278, - } \\
\text { 279, -437, -438, -535,-720,-720,-721, -743, and -941; and TBD facilities or } \\
\text { commercial contracts. }\end{array}$ \\
\hline $\mathrm{X} .1 .1$ & Manage LLW & WRAP 1, LLW Burial Ground and its transportation assets \\
\hline $\mathrm{X} .1 .1 .1$ & Manage CH Cat I LLW & WRAP 1 for drums; LLW Burial Ground transportation assets \\
\hline X.1.1.1.1 & Receive CH Cat I LLW Containers & WRAP 1 \\
\hline X.1.1.1.2 & Assess CH Cat I LLW Drum Nondestructively & WRAP 1 \\
\hline $\mathrm{X} .1 .1 .1 .3$ & Open-Sort CF Drum Contents & WRAP 1 \\
\hline $\mathrm{X} .1 .1 .1 .4$ & Implement RWM Handling Process & WRAP 1 \\
\hline $\mathrm{X} .1 .1 .1 .5$ & Super-Compact Cat I LLW Contents & WRAP 1 \\
\hline
\end{tabular}


Table 8-1. Functional Allocation Crosswalk. (13 sheets)

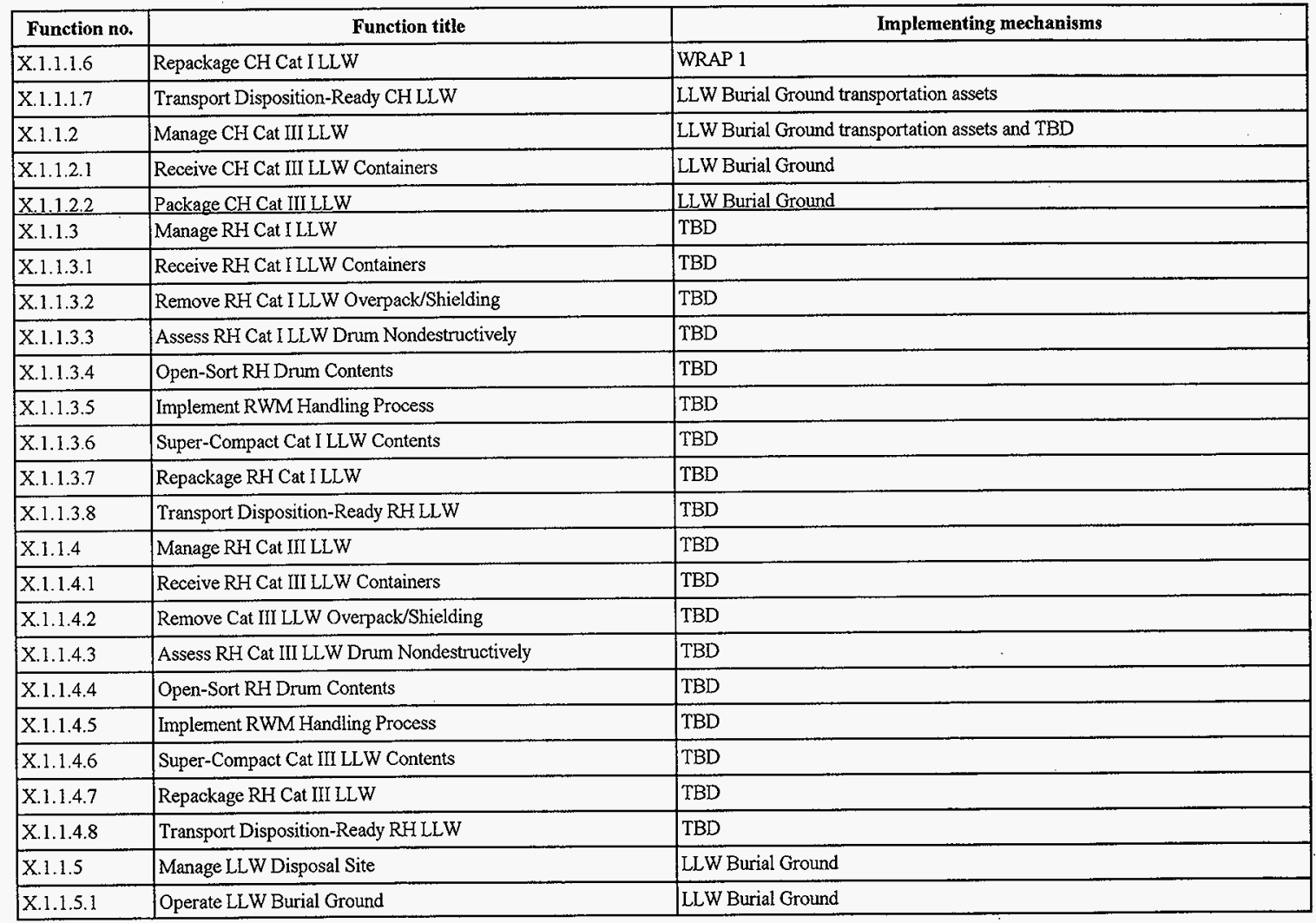


Table 8-1. Functional Allocation Crosswalk. (13 sheets)

\begin{tabular}{|c|c|c|}
\hline Function no. & Function title & Implementing mechanisms \\
\hline X.1.1.5.2 & Disposition Cat I and III LLW & LLW Burial Ground \\
\hline $\mathrm{X} .1 .1 .5 .3$ & Deactivate LLW Burial Ground & LLW Burial Ground \\
\hline $\mathrm{X} .1 .1 .6$ & Manage GTCIII LLW & TBD \\
\hline X.1.1.6.1 & Store Containerized GTCIII LLW & TBD \\
\hline $\mathrm{X} .1 .1 .6 .2$ & Transport (Ship) GTCIII LLW & TBD \\
\hline $\mathrm{X} .1 .1 .6 .3$ & Treat/Disposition GTCIII LLW & TBD \\
\hline $\mathrm{X} .1 .2$ & Manage MLLW & $\begin{array}{l}\text { CWC, WRAP 1, T Plant, Commercial Contract (vendor TBD), Mixed Waste } \\
\text { Disposal Facility, and TBD }\end{array}$ \\
\hline $\mathrm{X} .1 .2 .1$ & Manage CH MLLW & $\begin{array}{l}\text { CWC, WRAP 1, T Plant, MLLW Disposal Facility, Commercial Contract } \\
\text { (vendor TBD) }\end{array}$ \\
\hline X.1.2.1.1 & Receive $\mathrm{CH}$ Cat I and III MLLW Containers & $\begin{array}{l}\text { CWC (Waste Receiving and Staging Area), WRAP 1, T Plant, and Commercial } \\
\text { Contract (vendor TBD) }\end{array}$ \\
\hline X.1.2.1.2 & Store CH MLLW & CWC (2401-W and 2402-W Series) \\
\hline $\mathrm{X} .1 .2 .1 .3$ & Remove CH MLLW Overpack & Commercial Contract (vendor TBD) \\
\hline X.1.2.1.4 & Assess CH MLLW Drum Nondestructively & CWC (Waste Receiving and Staging Area) and WRAP 1 \\
\hline $\mathrm{X} .1 .2 .1 .5$ & Transport/Ship CH MLLW & Commercial Contract (vendor TBD) \\
\hline X.1.2.1.6 & Conduct Stabilization Treatment & Commercial Contract (vendor TBD) \\
\hline X.1.2.1.7 & Conduct Thermal Treatment & Commercial Contract (vendor TBD) \\
\hline X.1.2.1.8 & Conduct Other Specialized Treatments & WRAP 1 \\
\hline X.1.2.1.9 & Verify PA Requirements Compliance & Any, all, or none of the MLLW Treatment Facilities \\
\hline X.1.2.1.10 & Transport/Ship Disposition-Ready CH MLLW & $\begin{array}{l}\text { Commercial Contract (vendor TBD) and MLLW Disposal Facility transportation } \\
\text { assets }\end{array}$ \\
\hline $\mathrm{X} .1 .2 .2$ & Manage RH Cat I MLLW & TBD \\
\hline $\mathrm{X} .1 .2 .2 .1$ & Receive RH Cat I MLLW Containers & TBD \\
\hline $\mathrm{X} .1 .2 .2 .2$ & Store RH Cat I MLLW & TBD \\
\hline $\mathrm{X} \cdot 1.2 .2 .3$ & Remove RH MLLW Overpack/Shielding & TBD \\
\hline $\mathrm{X} .1 .2 .2 .4$ & Assess RH MLLW Drum Nondestructively & TBD \\
\hline
\end{tabular}


Table 8-1. Functional Allocation Crosswalk. (13 sheets)

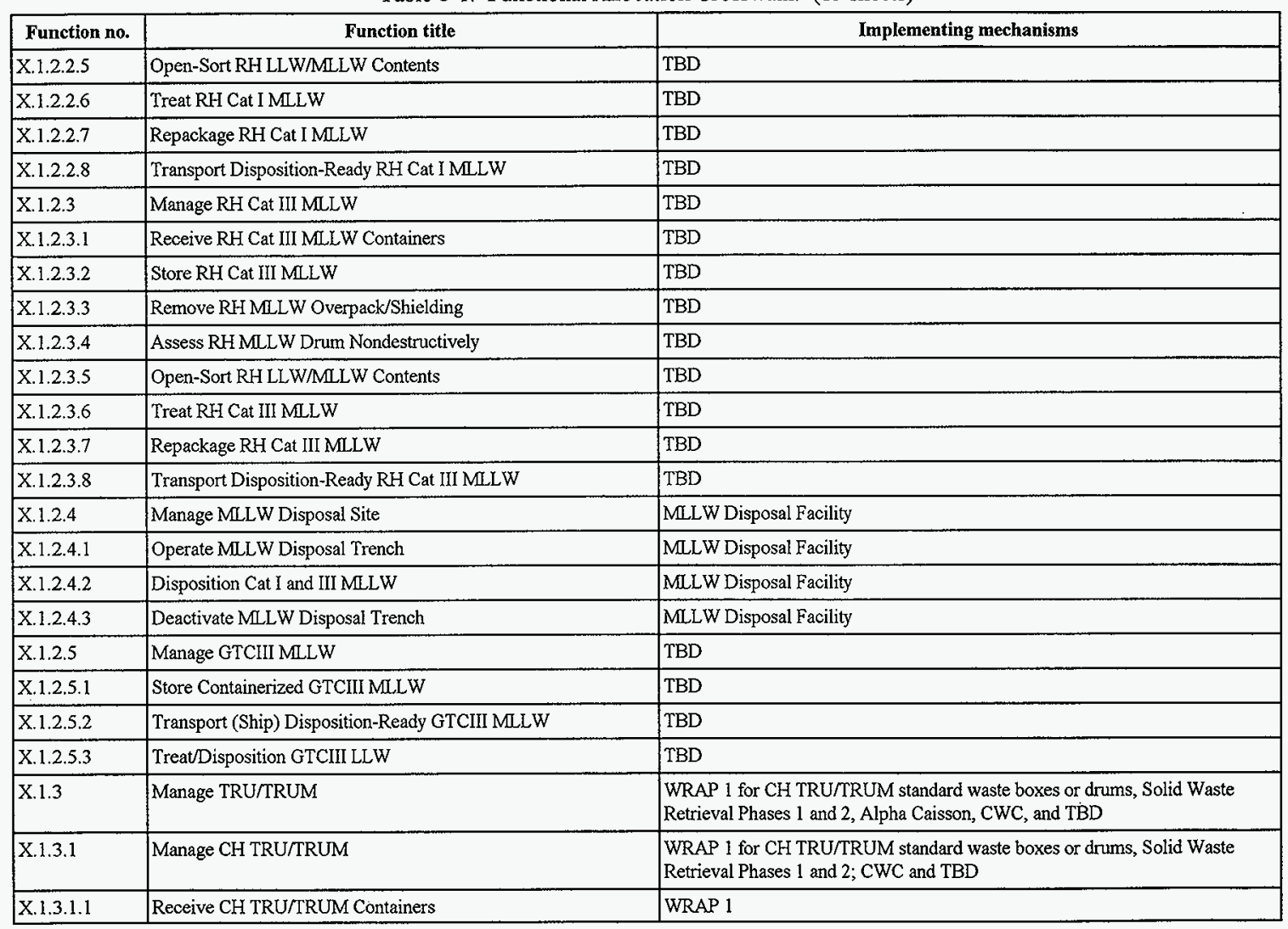


Table 8-1. Functional Allocation Crosswalk. (13 sheets)

\begin{tabular}{|c|c|c|}
\hline Function no. & Function title & Implementing mechanisms \\
\hline $\mathrm{X} .1 .3 .1 .2$ & Retrieve Retrievably Stored CH TRU/TRUM & Solid Waste Retrieval Phases 1 and 2 \\
\hline $\mathrm{X} .1 .3 .1 .2 .1$ & Excavate TRU/TRUM Drum & Solid Waste Retrieval \\
\hline $\mathrm{X} .1 .3 .1 .2 .2$ & Inspect TRU/TRUM Drum & Solid Waste Retrieval: trench enclosure and NDE/NDA mobile unit \\
\hline $\mathrm{X} .1 .3 .1 .2 .3$ & Assess $\mathrm{CH}$ Container Nondestructively & Solid Waste Retrieval: NDE/NDA mobile unit \\
\hline $\mathrm{X} .1 .3 .1 .2 .4$ & Package TRU/TRUM Drum in Overpack & Solid Waste Retrieval \\
\hline $\mathrm{X} .1 .3 .1 .3$ & Provide CH TRU/TRUM Preprocessing Storage & TBD \\
\hline$X .1 .3 .1 .3 .1$ & Transport Overpacked TRU/TRUM to Storage & TBD \\
\hline $\mathrm{X} .1 .3 .1 .3 .2$ & Store Overpacked TRU/TRUM & TBD \\
\hline $\mathrm{X} .1 .3 .1 .3 .3$ & Transport Overpacked TRU/TRUM to Processing & TBD \\
\hline $\mathrm{X} .1 .3 .1 .4$ & Remove TRU/TRUM Overpack & WRAP 1 \\
\hline $\mathrm{X} .1 .3 .1 .4 .1$ & Remove Waste from Overpack & WRAP 1 \\
\hline $\mathrm{X} .1 .3 .1 .4 .2$ & Recycle Overpack & WRAP 1 \\
\hline $\mathrm{X} .1 .3 .1 .5$ & Assess CH Container Nondestructively & WRAP 1 \\
\hline X.1.3.1.6 & Open-Sort CH TRU/TRUM Contents & WRAP 1 \\
\hline $\mathrm{X} .1 .3 .1 .7$ & Treat $\mathrm{CH}$ TRU & WRAP 1 \\
\hline $\mathrm{X} .1 .3 .1 .8$ & Treat CH TRUM & WRAP I and TBD \\
\hline $\mathrm{X} .1 .3 .1 .9$ & Package TRU for WIPP & WRAP 1 \\
\hline $\mathrm{X} .1 .3 .1 .10$ & Package TRUM for WIPP & WRAP 1 and TBD \\
\hline $\mathrm{X} .1 .3 .2$ & Manage RH TRU/TRUM & Alpha Caisson and TBD \\
\hline X.1.3.2.1 & Receive RH TRU/TRUM & TBD \\
\hline X.1.3.2.2 & Retrieve Retrievably Stored RH TRU/TRUM & Alpha Caisson \\
\hline $\mathrm{X} .1 .3 .2 .3$ & Remove TRU/TRUM Overpack/Shielding & $\mathrm{TBD}$ \\
\hline X.1.3.2.4 & Assess RH Container Nondestructively & TBD \\
\hline $\mathrm{X} .1 .3 .2 .5$ & Open-Sort RH TRU/TRUM Contents & TBD \\
\hline $\mathrm{X} .1 .3 .2 .6$ & Treat RH TRU & TBD \\
\hline $\mathrm{X} .1 .3 .2 .7$ & Treat RH TRUM & TBD \\
\hline
\end{tabular}


Table 8-1. Functional Allocation Crosswalk. (13 sheets)

\begin{tabular}{|c|c|c|}
\hline Function no. & Function title & Implementing mechanisms \\
\hline $\mathrm{X} .1 .3 .2 .8$ & Package TRU for WIPP & TBD \\
\hline X.1.3.2.9 & Package TRUM for TWIPP & TBD \\
\hline $\mathrm{X} .1 .3 .3$ & Transport Disposition-Ready TRU/TRUM to Onsite Storage & TBD \\
\hline $\mathrm{X} .1 .3 .4$ & Store Disposition-Ready TRU/TRUM Containers & CWC \\
\hline $\mathrm{X} .1 .3 .5$ & Ship Disposition-Ready TRU/TRUM & TBD \\
\hline X.1.4 & (Placeholder - TBD) & TBD \\
\hline $\mathrm{X} .1 .5$ & Manage Contaminated Equipment & T Plant (under review), MLLW Disposal Facility, and TBD \\
\hline $\mathrm{X} .1 .5 .1$ & Receive Contaminated Equipment & T Plant \\
\hline $\mathrm{X} .1 .5 .2$ & Decontaminate Equipment & T Plant \\
\hline X.1.5.3 & Repair Low-Dose Rate Equipment & T Plant \\
\hline $\mathrm{X} .1 .5 .4$ & Transport Disposition-Ready Equipment & MLLW Disposal Facility and TBD \\
\hline $\mathrm{X} .1 .6$ & Store Radioactive Materials & CWC, T Plant, and LLBG \\
\hline $\mathrm{X} .1 .6 .1$ & Store TRIGA Fuel & LLBG \\
\hline $\mathrm{X} .1 .6 .2$ & Store Sodium & CWC: $2727-$ W Product Sodium Storage Building' \\
\hline X.1.6.3 & Store Shippingport Reactor Core II Blanket Fuel Rods & T Plant \\
\hline $\mathrm{X} .1 .7$ & Ship Hazardous Waste to Offsite TSD Facility & $\begin{array}{l}\text { Commercial TSD Facilities: Environsafe, Easton Smelting, Landlan, USPCI } \\
\text { Laddlaw LCNE Mountain Facility, Envirotroc, USPCI Grassy Mountain Facility, } \\
\text { Philip Environmental (Georgetown \& Kent). } \\
\text { Commercial transportation services: MP Environmental Svcs., Tri-State } \\
\text { Motor Transit, ATTUM Industries, Triad Transport, Gresham Transfer, U.S. } \\
\text { Pollution Control, Tidewater Barge Lines, Ross Maritime, Burlington } \\
\text { Environmental. }\end{array}$ \\
\hline $\mathrm{X} .1 .8$ & Maintain Inactive Solid Waste Facilities & TRUSAF (as of late FY1997) \\
\hline
\end{tabular}


Table 8-1. Functional Allocation Crosswalk. (13 sheets)

\begin{tabular}{|c|c|c|}
\hline Function no. & Function title & Implementing mechanisms \\
\hline $\mathrm{X} .1 .9$ & Operate and Maintain Active Solid Waste Facilities & \multirow{6}{*}{$\begin{array}{l}\text { WRAP } 1 \text { (2336-W Waste Receiving and Processing Module 1) (2404-WA, - } \\
\text { WB, and -WC Drum Storage; 2620-W Maintenance, 2740-W Administration); } \\
\text { Central Waste Complex (CWC) (2401-W and 2402-W Series [B-L], 2403-W } \\
\text { Series [A-D], Low-Flashpoint Mixed Waste Storage Modules, Alkali Metal } \\
\text { Waste Storage Modules, South Alkali Metal Storage Modules, Waste Receiving } \\
\text { and Staging Area, Mixed Waste Storage Pad, 2727-W Product Sodium Storage } \\
\text { Building'); T Plant (221-T Canyon, 2706-T Building, 211-T52 Instrument, } \\
\text { 214-T Chem. Storage, 221-TA and -TB Vent Fan Houses, 2706-T Equipment } \\
\text { Decon, 2712-T Electrical Instrumentation, 2715-T Paint Storage, 271-T } \\
\text { Office/Service, 277-T Blow Down, 291-T Exhaust Fan Control House and Sand } \\
\text { Filter, 292-T Fission Products Release Lab, 296-T Gaseous Effluent Release } \\
\text { Point; MO-371, -433, -739, -892-, and -909; Tunnel Trailer Bldgs.); LLW } \\
\text { Burial Ground [218-E-10, 218-E-12B, 218-W-3A, 218-W-3AE, 218-W-4B, } \\
\text { 218-W-4C, 218-W-5, and 218-W-6 and its transportation assets]; MLLW } \\
\text { Disposal Facility [Burial Ground 218-W-5, Trenches 31 and 34]; Alpha } \\
\text { Caisson in Burial Ground 218-W-4B, 616 Nonradiological Hazardous Waste } \\
\text { Facility [standby mode]. Also (but unverified) MO-278, -279, -437, -438, - } \\
\text { 535, -720, -720, -721, -743, and -941. }\end{array}$} \\
\hline $\mathrm{X} .1 .9 .1$ & Operate and Maintain Plant Systems & \\
\hline $\mathrm{X} .1 .9 .2$ & Operate and Maintain Facility Support Systems & \\
\hline $\mathrm{X} .1 .9 .3$ & Operate and Maintain Protection Systems & \\
\hline X.1.9.4 & Maintain Information Management Systems & \\
\hline X.1.9.5 & Manage Facility Wastes & \\
\hline $\mathrm{X} .1 .10$ & Provide Generator Services & None. \\
\hline $\mathrm{X} 2$ & Manage Liquid Waste & $\begin{array}{l}340 \text { Waste Handling Facility (340-A, 340-B, MO-036, MO-741); 300 Area } \\
\text { TEDF (310 Treated Effluent Disposal Facility) (342 Waste Collection Sump, } \\
\text { MO-744, MO-745, MO-433); } 307 \text { Basins (3707-F); 3906 Lift Station, 300 } \\
\text { Area Process Sewer, Radioactive Liquid Waste System (RLWS), Retention } \\
\text { Process System (RPS), and Columbia River (permitted). } \\
\text { Effluent Treatment Facility (ETF) (2025-E) (2025-EA Administration, 225- } \\
\text { E and -W Pump Stations, 225-WA Effluent Monitoring, MO-269, Laundry } \\
\text { Shed, HS-010, HS-01 I, Oil Storage Shed); 200 Area TEDF (6653 Treated } \\
\text { Effluent Disposal Facility); Liquid Effluent Retention Facility (LERF) } \\
\text { (basins 242-AL42, -AL43, and -AL44); 242-A Evaporator (242-A702, 242- } \\
\text { A207, 242-AE); SALDS (200 Area East and West State Approved Land } \\
\text { Disposal Sites) (216-E43A and216-E43B). } \\
\text { Inactive Facilities: "Z-Cribs" (awaiting transfer) 216-Z,216Z3, 216-Z9. }\end{array}$ \\
\hline $\mathrm{X} .2 .1$ & Concentrate Liquid Tank Waste & 242-A Evaporator (242-A702, 242-A207, 242-AE). \\
\hline $\mathrm{X} .2 .1 .1$ & Receive Liquid Tank Waste for Evapor & 242-A Evaporator and Lockheed Martin Hanford, Inc-managed Tank 102-AW \\
\hline $\mathrm{X} .2 .1 .2$ & Evaporate Liquid from Tank Waste & 242-A Evaporator \\
\hline $\mathrm{X} .2 .1 .3$ & Analyze Process Streams & $\begin{array}{l}\text { 242-A Evaporator, and 222-S Analytical Laboratory (RFSH Analytical } \\
\text { Services). }\end{array}$ \\
\hline
\end{tabular}


Table 8-1. Functional Allocation Crosswalk. (13 sheets)

\begin{tabular}{|c|c|c|}
\hline Function no. & Function title & Implementing mechanisms \\
\hline $\mathrm{X} .2 .1 .4$ & Return Concentrated Liquid Tank Waste to Tank Farm & 242-A Evaporator and Lockheed Martin Hanford, Inc.-managed AW tank farm. \\
\hline $\mathrm{X} .2 .1 .5$ & Transfer Process Condensate & 242-A Evaporator, LERF basins 242-AL43, and -AL44. \\
\hline $\mathrm{X} .2 .2$ & Manage CERCLA ${ }^{2}$-Generated Liquid Effluent Streams & $\begin{array}{l}300 \text { Area TEDF ( } 10 \text { Treated Effluent Disposal Facility) (342 Waste } \\
\text { Collection Sump, MO-744, MO-745, MO-433); } 307 \text { Basins (3707-F); } 3906 \text { Lift } \\
\text { Station, } 300 \text { Area Process Sewer, Radioactive Liquid Waste System (RLWS), } \\
\text { Retention Process System (RPS). } \\
\text { ETF (2025-E) (2025-EA Administration, 225-E and -W Pump Stations, MO- } \\
\text { 269, Laundry Shed, HS-010, HS-011, Oil Storage Shed); LERF basins 242- } \\
\text { AL42, -AL43, and -AL44. } \\
6266 \text { Waste Sample Characterization Facility (WSCF) (RFSH Analytical } \\
\text { Services managed). }\end{array}$ \\
\hline $\mathrm{X} .2 .2 .1$ & Receive CERCLA $A^{2}$-generated Liquid Waste & $\begin{array}{l}300 \text { Area TEDF (310 Treated Effluent Disposal Facility) (342 Waste Collection } \\
\text { Sump, MO-744, MO-745, MO-433); 307 Basins (3707-F); 3906 Lift Station, } \\
300 \text { Area Process Sewer, Radioactive Liquid Waste System (RLWS), Retention } \\
\text { Process System (RPS). } \\
\text { LERF basins 242-AL43, and -AL44; ETF (2025-E). }\end{array}$ \\
\hline $\mathrm{X} .2 .2 .2$ & Store Liquid Waste & $\begin{array}{l}\text { LERF basins } 242 \text {-AL43, and -AL44. } \\
\text { Process streams analyzed using lab facilities at LERF, 2025-E ETF; and at } 310 \\
\text { TEDF; } 6266 \text { Waste Sample Characterization Facility (WSCF) (RFSH Analytical } \\
\text { Services managed). }\end{array}$ \\
\hline $\mathrm{X} .2 .2 .3$ & Treat Liquid Waste & 310 TEDF; 2025-E ETF. \\
\hline $\mathrm{X} .2 .2 .4$ & Prepare Solid Wastes for Disposition & 310 TEDF; 2025-E ETF. \\
\hline $\mathrm{X} .2 .2 .5$ & Transfer Treated Effluent for Disposal & 310 TEDF; 2025-E ETF. \\
\hline $\mathrm{X} .2 .3$ & Manage Listed RCRA ${ }^{\mathrm{b}}$ Mixed Waste Liquid Effluent Streams & $\begin{array}{l}300 \text { Area TEDF (310 Treated Effluent Disposal Facility) (342 Waste } \\
\text { Collection Sump, MO-744, MO-745, MO-433); } 307 \text { Basins (3707-F); 3906 Lift } \\
\text { Station, } 300 \text { Area Process Sewer, Radioactive Liquid Waste System (RLWS), } \\
\text { Retention Process System (RPS); 340 Waste Handling Facility (340-A, 340- } \\
\text { B, MO-036, MO-741). } \\
\text { LERF basins 242-AL42; ETF (2025-E). }\end{array}$ \\
\hline $\mathrm{X} .2 .3 .1$ & Receive Effluent Streams from Generators & $\begin{array}{l}307 \text { Basins, Radioactive Liquid Waste System (RLWS), Retention Process } \\
\text { System (RPS); } 340 \text { Waste Handling Facility. } \\
\text { LERF basins 242-Al42; ETF (2025-E). }\end{array}$ \\
\hline $\mathrm{X} .2 .3 .2$ & Store Effluent Streams & $\begin{array}{l}307 \text { Basins, } 340 \text { Waste Handling Facility. } \\
\text { LERF basins } 242 \text {-AL42. } \\
\text { Process streams analyzed using lab facilities at } 307 \text { Basins, } 340 \text { Waste Handling } \\
\text { Facility; and at LERF and } 2025 \text {-E ETF; } 6266 \text { Waste Sample Characterization } \\
\text { Facility (WSCF) (RFSH Analytical Services managed). }\end{array}$ \\
\hline
\end{tabular}


Table 8-1. Functional Allocation Crosswalk. (13 sheets)

\begin{tabular}{|c|c|c|}
\hline Function no. & Function title & Implementing mechanisms \\
\hline $\mathrm{X.2.3.3}$ & Treat Effluent Streams & LERF and 2025-E ETF. \\
\hline $\mathrm{X} .2 .3 .4$ & Prepare Solid Wastes for Disposition & 340 Waste Handling Facility; 2025-E ETF. \\
\hline $\mathrm{X} .2 .3 .5$ & Transfer Effluent for Disposal & 340 Waste Handling Facility; 2025-E ETF. \\
\hline $\mathrm{X} .2 .3 .6$ & Transfer Effluent to TWRS & $\begin{array}{l}340 \text { Waste Handling Facility and railroad tank car; transfer is completed by } \\
\text { Numatec for Lockheed Martin Hanford, Inc. using railroad tank car managed by } \\
\text { T Plant (RFSH solid waste). }\end{array}$ \\
\hline $\mathrm{X} .2 .4$ & Manage Non-Listed/Industrial Effluent Streams & 300 Area TEDF ( 310 Treated Effluent Disposal Facility). \\
\hline $\mathrm{X} .2 .5$ & Manage LLW Effluent Streams & $\begin{array}{l}300 \text { Area TEDF ( } 310 \text { Treated Effluent Disposal Facility). } \\
\text { ETF (2025-E). }\end{array}$ \\
\hline $\mathrm{X} .2 .5 .1$ & Receive LLW Effluent Stream & 310 TEDF; ETF (2025-E). \\
\hline $\mathrm{X} .2 .5 .2$ & Store LL Effluent Stream & 310 TEDF; ETF (2025-E). \\
\hline $\mathrm{X} .2 .5 .3$ & Treat Effluent Stream & 310 TEDF; ETF (2025-E). \\
\hline $\mathrm{X} .2 .5 .4$ & Prepare Solid Waste for Disposition & 310 TEDF; ETF (2025-E). \\
\hline $\mathrm{X} 2.5 .5$ & Transfer Treated Effluent for Disposal & 310 TEDF; ETF (2025-E). \\
\hline $\mathrm{X} .2 .6$ & Discharge Treated Liquid Effluents & $\begin{array}{l}\text { 310 TEDF. Columbia River (permitted discharge). } \\
\text { ETF (2025-E) and 200 Area TEDF. } \\
\text { SALDS (200 Area East and West State-Approved Land Disposal Sites) (216- } \\
\text { E43A and } 216-\text {-E43B). }\end{array}$ \\
\hline $\mathrm{X} .2 .6 .1$ & Receive Discharge-Ready Liquid Effluents & 310 TEDF; ETF (2025-E) and 200 Area TEDF. \\
\hline $\mathrm{X} .2 .6 .2$ & Hold Pending Discharge & 310 TEDF; ETF (2025-E). \\
\hline $\mathrm{X} .2 .6 .3$ & Discharge at Approved Disposal Site & $\begin{array}{l}\text { Columbia River (penmitted discharge). } \\
\text { SALDS (200 Area East and West State Approved Land Disposal Sites) } \\
\text { (216-E43A and216-E43B). }\end{array}$ \\
\hline $\mathrm{X} .2 .7$ & Operate and Maintain Active Liquid Waste Facilities & \multirow{6}{*}{$\begin{array}{l}340 \text { Waste Handling Facility (340-A, 340-B, MO-036, MO-741); } 300 \text { Area } \\
\text { TEDF ( } 310 \text { Treated Effluent Disposal Facility) (342 Waste Collection Sump, } \\
\text { MO-744, MO-745, MO-433); } 307 \text { Basins (3707-F); 3906 Lift Station, } 300 \\
\text { Area Process Sewer, Radioactive Liquid Waste System (RLWS), Retention } \\
\text { Process System (RPS). } \\
\text { Effluent Treatment Facility (ETF) (2025-E) (2025-EA Administration, 225- } \\
\text { E and -W Pump Stations, MO-269, Laundry Shed, HS-010, HS-011, Oil } \\
\text { Storage Shed); 200 Area TEDF (6653 Treated Effluent Disposal Facility } \\
\text { 6653); Liquid Effluent Retention Facility (LERF) basins 242-AL42,-AL43, and } \\
\text {-AL44; 242-A Evaporator (242-A702, 242-A207, 242-AE); SALDS (200 } \\
\text { Area East and West State-Approved Land Disposal Sites) (216-E43A and216- } \\
\text { E43B). }\end{array}$} \\
\hline $\mathrm{X} .2 .7 .1$ & Operate and Maintain Plant Systems & \\
\hline $\mathrm{X} .2 .7 .2$ & Operate and Maintain Facility Support Systems & \\
\hline $\mathrm{X} .2 .7 .3$ & Operate and Maintain Protection Systems & \\
\hline $\mathrm{X} .2 .7 .4$ & Maintain Information Management Systems & \\
\hline $\mathrm{X} .2 .7 .5$ & Manage Facility Waste & \\
\hline $\mathrm{X} .2 .8$ & Maintain Inactive Liquid Waste Facilities & "Z-Cribs" (inactive and awaiting ownership transfer) $216-Z, 216 Z 3,216-Z 9$. \\
\hline
\end{tabular}


Table 8-1. Functional Allocation Crosswalk. (13 sheets)

\begin{tabular}{|c|c|c|}
\hline Function no. & Function title & Implementing mechanisms \\
\hline$\overline{X .4}$ & Provide Analytical Services & $\begin{array}{l}\text { 222-S Analytical Laboratory (222-SA Chemical Standards/Process } \\
\text { Development Laboratory, 222-SB HVAC South Filter, 222-SC HVAC North } \\
\text { Filter, 222-SD Solid Waste Storage, 222-SE Diesel Exhaust and Filtering, 222- } \\
\text { SF Equipment Service and Storage, 222-SG Gas Bottle Storage, 222-SH Office } \\
\text { and Changing Area, 207-SL Water Retention Basin, 212-S Compressed Gas } \\
\text { Storage, 219-S Waste Handling and Treatment, 2704-S Office, 2716-S } \\
\text { Storage). } \\
\text { WSCF (Waste Sampling and Characterization Facility) (6266) (6266-A } \\
\text { Contaminated Liquid Waste Storage, 6266-B VAS Pump Building, 6267 } \\
\text { Sample Archiving [LL rad only], 6268 Sample Equipment Cleaning, } 6269 \\
\text { Mobile Laboratory Vehicle Storage, 6270 Environmental Data Facility). } \\
\text { Field Service Assets: RFSH-managed (Solid Waste) Mobile Field Services (2 } \\
\text { vehicles, l cart). Following assets used are non-RFSH managed: SESC- } \\
\text { managed Special Analytical Support (5 trucks, 14 trailers); RFSN-managed } \\
\text { Near Field Monitoring (5 vehicles); RFSN-managed Geophysics (3 vehicles); } \\
\text { RFSN-managed Sampling and Mobile Laboratories (8 trucks, 1 trailer). } \\
\text { Commercial Labs via contract (FY 1997): Quanterra, TMA/Weston, CH2M } \\
\text { Hill, Clayton Environmental Consultants, Data Chem Laboratories, Inland } \\
\text { Environmental, LAS Laboratory, Laucks Testing Laboratory, NATLSCO, North } \\
\text { Creek Analytical, Soil Technologies, Sound Analytical. } \\
\text { Inactive Facilities: } 3714 \text { Geotechnical Engineering Laboratory. }\end{array}$ \\
\hline $\mathrm{X} .4 .1$ & Provide HL Radioactive Sample Services & $\begin{array}{l}\text { 222-S Analytical Laboratory (222-SA Chemical Standards/Process } \\
\text { Development Laboratory, 222-SB HVAC South Filter, 222-SC HVAC North } \\
\text { Filter, 222-SD Solid Waste Storage, 222-SE Diesel Exhaust and Filtering, 222- } \\
\text { SF Equipment Service and Storage, 222-SG Gas Bottle Storage, 222-SH Office } \\
\text { and Changing Area, 207-SL Water Retention Basin, 212-S Compressed Gas } \\
\text { Storage, 219-S Waste Handling and Treatment, 2704-S Office, 2716-S } \\
\text { Storage). }\end{array}$ \\
\hline X.4.1.1 & Provide Routine HL Sample Services & 222-S Analytical Laboratory \\
\hline X.4.1.1.1 & Receive HL Radioactive Sample & 222-S Analytical Laboratory \\
\hline $\mathrm{X} .4 .1 .1 .2$ & Prepare HL Sample for Analysis & 222-S Analytical Laboratory \\
\hline $\mathrm{X} .4 .1 .1 .3$ & Analyze HL Sample & 222-S Analytical Laboratory \\
\hline X.4.1.1.4 & Report Sample Analysis Results & 222-S Analytical Laboratory \\
\hline $\mathrm{X} .4 .1 .2$ & Provide FL Developmental Services & 222-S Analytical Laboratory \\
\hline $\mathrm{X} .4 .2$ & Provide LL Radioactive Sample Services & \begin{tabular}{|l|} 
WSCF (Waste Sampling and Characterization Facility) (6266) (6266-A \\
Contaminated Liquid Waste Storage, 6266-B VAS Pump Building, 6267 \\
Sample Archiving [LL rad only], 6268 Sample Equipment Cleaning, 6269 \\
Mobile Laboratory Vehicle Storage, 6270 Environmental Data Facility).
\end{tabular} \\
\hline
\end{tabular}


Table 8-1. Functional Allocation Crosswalk. (13 sheets)

\begin{tabular}{|c|c|c|}
\hline Function no. & Function title & Implementing mechanisms \\
\hline $\mathrm{X} .4 .2 .1$ & Provide Routine LL Sample Services & WSCF (Waste Sampling and Characterization Facility) (6266) \\
\hline $\mathrm{X} .4 .2 .1 .1$ & Receive LI, Radioactive Sample & WSCF (Waste Sampling and Characterization Facility) (6266) \\
\hline$X .4 .2 .1 .2$ & Collect LL Radioactive Sample & WSCF (Waste Sampling and Characterization Facility) (6266) \\
\hline $\mathrm{X} .4 .2 .1 .3$ & Prepare LL Sample for Analysis & WSCF (Waste Sampling and Characterization Facility) (6266) \\
\hline$X .4 .2 .1 .4$ & Analyze LL Sample & WSCF (Waste Sampling and Characterization Facility) (6266) \\
\hline $\mathrm{X} .4 .2 .1 .5$ & Report Sample Analysis Results & WSCF (Waste Sampling and Characterization Facility) (6266) \\
\hline$X .4 .2 .2$ & Provide LL Developmental Services & WSCF (Waste Sampling and Characterization Facility) (6266) \\
\hline $\mathrm{X} .4 .3$ & Provide Mobile In-Field Analytical Services & $\begin{array}{l}\text { Field Service Assets: RFSH-managed (Solid Waste) Mobile Field Services } \\
\text { ( } 2 \text { vehicles, } 1 \text { cart). Following assets used are non-RFSH managed: SESC- } \\
\text { managed Special Analytical-Support ( } 5 \text { trucks, } 14 \text { trailers); RFSN-managed } \\
\text { Near Field Monitoring ( } 5 \text { vehicles); RFSN-managed Geophysics ( } 3 \text { vehicles); } \\
\text { RFSN-managed Sampling and Mobile Laboratories ( } 8 \text { trucks, } 1 \text { trailer). }\end{array}$ \\
\hline $\mathrm{X} .4 .3 .1$ & Provide Routine In-Field LL Services & Field Service Assets (see above) \\
\hline$X .4 .3 .1 .1$ & Receive LL Radioactive Sample & Field Service Assets (see above) \\
\hline$X .4 .3 .1 .2$ & Collect LL Radioactive Sample & Field Service Assets (see above) \\
\hline$X .4 .3 .1 .3$ & Prepare LL Sample for Analysis & Field Service Assets (see above) \\
\hline$X .4 .3 .1 .4$ & Analyze LL Sample & Field Service Assets (see above) \\
\hline $\mathrm{X} .4 .3 .1 .5$ & Report Sample Analysis Results & Field Service Assets (see above) \\
\hline $\mathrm{X} .4 .3 .2$ & Provide In-Field LL Developmental Services & Field Service Assets (see above) \\
\hline
\end{tabular}


Table 8-1. Functional Allocation Crosswalk. (13 sheets)

\begin{tabular}{|c|c|c|}
\hline Function no. & Function title & Implementing mechanisms \\
\hline$\overline{X .4 .4}$ & Provide Commercial Laboratory Services & $\begin{array}{l}\text { WSCF (Waste Sampling and Characterization Facility) (6266) (6266-A } \\
\text { Contaminated Liquid Waste Storage, 6266-B VAS Pump Building, 6267 } \\
\text { Sample Archiving [LL rad only], 6268 Sample Equipment Cleaning, 6269 } \\
\text { Mobile Laboratory Vehicle Storage, 6270 Environmental Data Facility). 222-S } \\
\text { Analytical Laboratory (222-SA Chemical Standards/Process Development } \\
\text { Laboratory, 222-SB HVAC South Filter, 222-SC HVAC North Filter, 222-SD } \\
\text { Solid Waste Storage, 222-SE Diesel Exhaust and Filtering, 222-SF Equipment } \\
\text { Service and Storage, 222-SG Gas Bottle Storage, 222-SH Office and Changing } \\
\text { Area, 207-SL Water Retention Basin, 212-S Compressed Gas Storage, 219-S } \\
\text { Waste Handling and Treatment, 2704-S Office, 2716-S Storage). } \\
\text { Field Service Assets: RFSH-managed (Solid Waste) Mobile Field Services (2 } \\
\text { vehicles, I cart). Following assets used are non-RFSH managed: SESC- } \\
\text { managed Special Analytical Support (5 trucks, 14 trailers); RFSN-managed } \\
\text { Near Field Monitoring (5 vehicles); RFSN-managed Geophysics (3 vehicles); } \\
\text { RFSN-managed Sampling and Mobile Laboratories (8 trucks, 1 trailer). } \\
\text { Commercial Labs via contact (FY 1997): Quanterra, TMA/Weston, CH2M } \\
\text { Hill, Clayton Environmental Consultants, Data Chem Laboratories, Inland } \\
\text { Environmental, LAS Laboratory, Laucks Testing Laboratory, NATLSCO, North } \\
\text { Creek Analytical, Soil Technologies, Sound Analytical. }\end{array}$ \\
\hline $\mathrm{X} .4 .4 .1$ & Receive Low/Nonradioactive Sample & $\begin{array}{l}\text { WSCF (Waste Sampling and Characterization Facility) (6266), } \\
222-\text { S Analytical Laboratory. }\end{array}$ \\
\hline $\mathrm{X} .4 .4 .2$ & Collect Low/Nonradioactive Sample & $\begin{array}{l}\text { Field Service Assets: RFSH-managed (Solid Waste) Mobile Field Services (2 } \\
\text { vehicles, } 1 \text { cart). Following assets used are non-RFSH managed: SESC- } \\
\text { managed Special Analytical Support ( } 5 \text { trucks, } 14 \text { trailers); RFSN-managed } \\
\text { Near Field Monitoring ( } 5 \text { vehicles); RFSN-managed Geophysics ( } 3 \text { vehicles); } \\
\text { RFSN-managed Sampling and Mobile Laboratories ( } 8 \text { trucks, } 1 \text { trailer). }\end{array}$ \\
\hline $\mathrm{X} .4 .4 .3$ & Prepare Sample for Offsite Analysis & $\begin{array}{l}\text { WSCF (Waste Sampling and Characterization Facility) (6266), } \\
222-\text { S Analytical Laboratory. }\end{array}$ \\
\hline $\mathrm{X} .4 .4 .4$ & Ship Low/Nonradioactive Sample & $\begin{array}{l}\text { WSCF (Waste Sampling and Characterization Facility) (6266), } \\
\text { 222-S Analytical Laboratory. }\end{array}$ \\
\hline X.4.4.5 & Analyze Low/Nonradioactive Sample & $\begin{array}{l}\text { Commercial Labs via contract (FY 1997): Quanterra, TMA/Weston, CH2M } \\
\text { Hill, Clayton Environmental Consultants, Data Chem Laboratories, Inland } \\
\text { Environmental, LAS Laboratory, Laucks Testing Laboratory, NATLSCO, North } \\
\text { Creek Analytical, Soil Technologies, Sound Analytical. }\end{array}$ \\
\hline $\mathrm{X} .4 .4 .6$ & Monitor Commercial Analysis Process & None. \\
\hline $\mathrm{X} .4 .4 .7$ & Report Sample Analysis Results & None. \\
\hline
\end{tabular}


Table 8-1. Functional Allocation Crosswalk. (13 sheets)

\begin{tabular}{|c|c|c|}
\hline Function no. & Function title & Implementing mechanisms \\
\hline $\mathrm{X} .4 .5$ & Operate and Maintain Active Laboratory Facilities & $\begin{array}{l}\text { 222-S Analytical Laboratory (222-SA Chemical Standards/Process } \\
\text { Development Laboratory, 222-SB HVAC South Filter, 222-SC HVAC North } \\
\text { Filter, 222-SD Solid Waste Storage, 222-SE Diesel Exhaust and Filtering, 222- } \\
\text { SF Equipment Service and Storage, 222-SG Gas Bottle Storage, 222-SH Office } \\
\text { and Changing Area, 207-SL Water Retention Basin, 212-S Compressed Gas } \\
\text { Storage, 219-S Waste Handling and Treatment, 2704-S Office, 2716-S } \\
\text { Storage). } \\
\text { WSCF (Waste Sampling and Characterization Facility) (6266) (6266-A } \\
\text { Contaminated Liquid Waste Storage, 6266-B VAS Pump Building, 6267 } \\
\text { Sample Archiving [LL rad only], 6268 Sample Equipment Cleaning, } 6269 \\
\text { Mobile Laboratory Vehicle Storage, 6270 Environmental Data Facility). }\end{array}$ \\
\hline $\mathrm{X} .4 .5 .1$ & Provide Standards Laboratory Services & $\begin{array}{l}\text { 222-S Analytical Laboratory, WSCF (Waste Sampling and Characterization } \\
\text { Facility) (6266) }\end{array}$ \\
\hline $\mathrm{X} .4 .5 .2$ & Archive Samples & $\begin{array}{l}6267 \text { Sample Archive facility within WSCF (Waste Sampling and } \\
\text { Characterization Facility) (6266), 222-S Analytical Laboratory. }\end{array}$ \\
\hline $\mathrm{X} .4 .5 .2 .1$ & Archive HL Radioactive Samples & 222-S Analytical Laboratory \\
\hline $\mathrm{X} .4 .5 .2 .2$ & Archive LL Radioactive Samples & $\begin{array}{l}6267 \text { Sample Archive facility within WSCF (Waste Sampling and } \\
\text { Characterization Facility) (6266) }\end{array}$ \\
\hline $\mathrm{X} .4 .5 .3$ & Maintain Analytical Equipment Operational & $\begin{array}{l}\text { 222-S Analytical Laboratory, WSCF (Waste Sampling and Characterization } \\
\text { Facility) (6266) }\end{array}$ \\
\hline $\mathrm{X} .4 .5 .4$ & Operate and Maintain Utility Systems & $\begin{array}{l}\text { 222-S Analytical Laboratory, WSCF (Waste Sampling and Characterization } \\
\text { Facility) (6266) }\end{array}$ \\
\hline X.4.5.5 & Manage Laboratory Wastes & $\begin{array}{l}\text { 222-S Analytical Laboratory, WSCF (Waste Sampling and Characterization } \\
\text { Facility) (6266) }\end{array}$ \\
\hline $\mathrm{X} .4 .5 .6$ & Operate and Maintain Protection Systems & $\begin{array}{l}\text { 222-S Analytical Laboratory, WSCF (Waste Sampling and Characterization } \\
\text { Facility) }(6266)\end{array}$ \\
\hline$X 4.5 .7$ & Maintain Information Management Systems Operational & $\begin{array}{l}\text { 222-S Analytical Laboratory, WSCF (Waste Sampling and Characterization } \\
\text { Facility) (6266) }\end{array}$ \\
\hline $\mathrm{X} .4 .6$ & Maintain Inactive Laboratory Facilities & 3714 Geotechnical Engineering Laboratory \\
\hline
\end{tabular}

12727-W Building is owned by TWRS and the sodium is owned by FFTF, RFSH only provides administrative support.

$\mathrm{MO}=$ mobile office.

$\mathrm{NDE}=$ nondestructive examination

$\mathrm{TBD}=$ to be determined 
The user also can quickly acquire a summary-level understanding of each facility, major commercial contract, and formally recognized project within the Project by referring to the text in Sections 8.2.2, 8.2.3, and 8.2.4 that follow the crosswalk tables. In some cases, the facility of interest can be the object of the function (i.e., the remediation problem), can enable implementation, or can serve both the means and the end. A project may help establish the capability to carry out a function (e.g., construction), but not address the execution of the function itself (i.e., operations). In other cases, the scope of a project may be entirely operational, or evolve from emplacing a capability to operations.

Information on facilities is organized by major facilities. The minor or supporting facilities that are generally needed to operate the larger facility are listed in the subsequent text. (For brevity in the crosswalk tables, the minor facilities are not listed for the lower-level functions except when the function is known to specifically require the particular minor facility.) As mentioned in Section 8.1.1, the purpose and title of existing Hanford Site facilities are expected to change, but the building numbers will not change. Therefore, the facility building numbers are provided in the tables to ensure future traceability.

By starting with the facility crosswalk tables, readers can identify the corresponding functions, then use Chapters $2.0,3.0,4.0$, and 7.0 to establish an understanding of the inputs, outputs, external interfaces, requirements, and documentation for which they need to be concerned. Chapter 6.0 provides a system-level overview of the Project.

\subsection{FUNCTIONAL ALLOCATION}

Table $8-1$ is used to determine the primary mechanisms for implementing the functions. The mechanisms in the table include facilities, commercial contracts, projects, and natural systems. Table 8-2 is used to determine which functions are or will be affected by a facility issue, whether technical or programmatic. 
Table 8-2. Waste Management Project Facility Allocation Crosswalk. (8 sheets)

\begin{tabular}{|c|c|c|}
\hline Facility for implementing function & Function number(s) & Function title \\
\hline $\begin{array}{l}\text { WRAP I (2336-W Waste Receiving and } \\
\text { Processing Module 1) [2404-WA, -WB, } \\
\text { and -WC Drum Storage; 2620-W } \\
\text { Maintenance, 2740-W Administration] }\end{array}$ & $\begin{array}{l}\text { X.1.1 } \\
\text { X.1.1.1 } \\
\text { X.1.1.1.1 } \\
\text { X.1.1.1.2 } \\
\text { X.1.1.1.3 } \\
\text { X.1.1.1.4 } \\
\text { X.1.1.1.5 } \\
\text { X.1.1.1.6 } \\
\text { X.1.2 } \\
\text { X.1.2.1 } \\
\text { X.1.2.1.1 } \\
\text { X.1.2.1.4 } \\
\text { X.1.2.1.8 } \\
\text { X.1.3 } \\
\text { X.1.3.1 } \\
\text { X.1.3.1.1 } \\
\text { X.1.3.1.4 } \\
\text { X.1.3.1.4.1 } \\
\text { X.1.3.1.4.2 } \\
\text { X.1.3.1.5 } \\
\text { X.1.3.1.6 } \\
\text { X.1.3.1.7 } \\
\text { X.1.3.1.8 } \\
\text { X.1.3.1.9 } \\
\text { X.1.3.1.10 } \\
\text { X.1.9 } \\
\text { X.1.9.1 } \\
\text { X.1.9.2 } \\
\text { X.1.9.3 } \\
\text { X.1.9.4 } \\
\text { X.1.9.5 }\end{array}$ & $\begin{array}{l}\text { Manage LLW } \\
\text { Manage CH Cat ILLW } \\
\text { Receive CH Cat I LLW Containers } \\
\text { Assess CH Cat I LLW Drum Nondestructively } \\
\text { Open-Sort CH Drum Contents } \\
\text { Implement RWM Handling Process } \\
\text { Super-Compact Cat I LLW Contents } \\
\text { Repackage CH Cat ILLW } \\
\text { Manage MLLW } \\
\text { Manage CHMLLW } \\
\text { Receive CH Cat I and III MLLW Containers } \\
\text { Assess CH MLLW Drum Nondestructively } \\
\text { Conduct Other Specialized Treatments } \\
\text { Manage TRU/TRUM } \\
\text { Manage CH TRU/TRUM } \\
\text { Receive CH TRU/TRUM Containers } \\
\text { Remove TRU/TRUM Overpack } \\
\text { Remove Waste from Overpack } \\
\text { Recycle Overpack } \\
\text { Assess CH Container Nondestructively } \\
\text { Open-Sort CH TRU/TRUM Contents } \\
\text { Treat CH TRU } \\
\text { Treat CH TRUM } \\
\text { Package TRU for WIPP } \\
\text { Package TRUM for WIPP } \\
\text { Operate and Maintain Active Solid Waste Facilities } \\
\text { Operate and Maintain Plant Systems } \\
\text { Operate and Maintain Facility Support Systems } \\
\text { Operate and Maintain Protection Systems } \\
\text { Maintain Information Management Systems } \\
\text { Manage Facility Wastes } \\
\end{array}$ \\
\hline
\end{tabular}


HNF-SD-WM-RPT-288

Revision 0

Table 8-2. Waste Management Project Facility Allocation Crosswalk. (8 sheets)

\begin{tabular}{|c|c|c|}
\hline Facility for implementing function & Function number(s) & Function title \\
\hline $\begin{array}{l}\text { CWC (Central Waste Complex) (2401-W } \\
\text { and 2402-W Series [B-L], 2403-W Series } \\
\text { [A-D], Low-Flashpoint Mixed Waste } \\
\text { Storage Modules, Alkali Metal Waste } \\
\text { Storage Modules, South Alkali Metal } \\
\text { Storage Modules, Waste Receiving and } \\
\text { Staging Area, Mixed Waste Storage Pad, } \\
\text { 2727-W Product Sodium Storage } \\
\text { Building) }\end{array}$ & $\begin{array}{r}\text { X.1.2 } \\
\text { X.1.2.1 } \\
\text { X.1.2.1.1 } \\
\text { X.1.2.1.2 } \\
\text { X.1.3 } \\
\text { X.1.3.1 } \\
\text { X.1.3.4 } \\
\text { X.1.6 } \\
\text { X.1.6.1 } \\
\text { X.1.6.2 } \\
\text { X.1.6.3 } \\
\\
\\
\text { X.1.9 } \\
\text { X.1.9.1 } \\
\text { X.1.9.2 } \\
\text { X.1.9.3 } \\
\text { X.1.9.4 } \\
\text { X.1.9.5 } \\
\end{array}$ & $\begin{array}{l}\text { Manage MLLW } \\
\text { Manage CH MLLW } \\
\text { Receive CH Cat I and III MLLW Containers } \\
\text { Store CH MLLW } \\
\text { Manage TRU/TRUM } \\
\text { Manage CH TRU/TRUM } \\
\text { Store Disposition-Ready TRU/TRUM Containers } \\
\text { Store Radioactive Materials } \\
\text { Store TRIGA Fuel } \\
\text { Store Sodium } \\
\text { Store Shippingport Pressurized Water Reactor Core II Blanket } \\
\text { Fuel Rods } \\
\text { Operate and Maintain Active Solid Waste Facilities } \\
\text { Operate and Maintain Plant Systems } \\
\text { Operate and Maintain Facility Support Systems } \\
\text { Operate and Maintain Protection Systems } \\
\text { Maintain Information Management Systems } \\
\text { Manage Facility Wastes }\end{array}$ \\
\hline $\begin{array}{l}\text { T Plant (221-T Canyon, 2706-T Building, } \\
\text { 211-T52 Instrument, 214-T Chem. } \\
\text { Storage, 221-TA and -TB Vent Fan } \\
\text { Houses, 2706-T Equipment Decon, 2712- } \\
\text { T Electrical Instrumentation, 2715-T Paint } \\
\text { Storage, 271-T Office/Service, 277-T } \\
\text { Blow Down, 291-T Exhaust Fan Control } \\
\text { House and Sand Filter, 292-T Fission } \\
\text { Products Release Lab, 296-T Gaseous } \\
\text { Effluent Release Point; MO-371, -433, - } \\
739,-892-\text {, and -909; Tunnel Trailer } \\
\text { Bldgs.) }\end{array}$ & $\begin{array}{l}\text { X.1.2 } \\
\text { X.1.2.1 } \\
\text { X.1.2.1.1 } \\
\text { X.1.5 } \\
\text { X.1.5.1 } \\
\text { X.1.5.2 } \\
\text { X.1.5.3 } \\
\text { X.1.9 } \\
\text { X.1.9.1 } \\
\text { X.1.9.2 } \\
\text { X.1.9.3 } \\
\text { X.1.9.4 } \\
\text { X.1.9.5 }\end{array}$ & $\begin{array}{l}\text { Manage MLLW } \\
\text { Manage CHMLLW } \\
\text { Receive CH Cat I and III MLLW Containers } \\
\text { Manage Contaminated Equipment } \\
\text { Receive Contaminated Equipment } \\
\text { Decontaminate Equipment } \\
\text { Repair Low-Dose Rate Equipment } \\
\text { Operate and Maintain Active Solid Waste Facilities } \\
\text { Operate and Maintain Plant Systems } \\
\text { Operate and Maintain Facility Support Systems } \\
\text { Operate and Maintain Protection Systems } \\
\text { Maintain Information Management Systems } \\
\text { Manage Facility Wastes }\end{array}$ \\
\hline TRUSAF (224-T) & $\mathrm{X} .1 .8$ & Maintain Inactive Solid Waste Facilities \\
\hline $\begin{array}{l}\text { Nonradiological Hazardous Waste } \\
\text { Facility (616) }\end{array}$ & $\mathrm{NA}$ & (In standby mode only) \\
\hline
\end{tabular}


HNF-SD-WM-RPT-288

Revision 0

Table 8-2. Waste Management Project Facility Allocation Crosswalk. (8 sheets)

\begin{tabular}{|c|c|c|}
\hline Facility for implementing function & Function number(s) & Function title \\
\hline $\begin{array}{l}\text { LLW Burial Ground (Burial Ground } \\
218-\mathrm{E}-10,218-\mathrm{E}-12 \mathrm{~B}, 218-\mathrm{W}-3 \mathrm{~A}, 218- \\
\mathrm{W}-3 \mathrm{AE}, 218-\mathrm{W}-4 \mathrm{~B}, 218-\mathrm{W}-4 \mathrm{C}, 218-\mathrm{W}-5, \\
\text { and } 218-\mathrm{W}-6 \text {, and its transportation assets) }\end{array}$ & $\begin{array}{l}\text { X.1.1 } \\
\text { X.1.1.1 } \\
\text { X.1.1.1.7 } \\
\text { X.1.1.2 } \\
\text { X.1.1.2.1 } \\
\text { X.1.1.2.2 } \\
\text { X.1.1.5 } \\
\text { X.1.1.5.1 } \\
\text { X.1.9 } \\
\text { X.1.9.1 } \\
\text { X.1.9.2 } \\
\text { X.1.9.3 } \\
\text { X.1.9.4 } \\
\text { X.1.9.5 }\end{array}$ & $\begin{array}{l}\text { Manage LLW } \\
\text { Manage CH Cat I LLW } \\
\text { Transport Disposition-Ready CH LLW } \\
\text { Manage CH Cat III LLW } \\
\text { Receive CH Cat III LLW Containers } \\
\text { Package CH Cat III LLW } \\
\text { Manage LLW Disposal Site } \\
\text { Operate LLW Burial Ground } \\
\text { Operate and Maintain Active Solid Waste Facilities } \\
\text { Operate and Maintain Plant Systems } \\
\text { Operate and Maintain Facility Support Systems } \\
\text { Operate and Maintain Protection Systems } \\
\text { Maintain Information Management Systems } \\
\text { Manage Facility Wastes }\end{array}$ \\
\hline $\begin{array}{l}\text { MLLW Disposal Facility (Burial Ground } \\
218-W-5 \text {, Trenches } 31 \text { and } 34 \text {, and } \\
\text { associated transportation assets) }\end{array}$ & $\begin{array}{l}\text { X.1.2 } \\
\text { X.1.2.1 } \\
\text { X.1.2.1.10 } \\
\text { X.1.2.4 } \\
\text { X.1.2.4.1 } \\
\text { X.1.2.4.2 } \\
\text { X.1.2.4.3 } \\
\text { X.1.5 } \\
\text { X.1.5.4 } \\
\text { X.1.9 } \\
\text { X.1.9.1 } \\
\text { X.1.9.2 } \\
\text { X.1.9.3 } \\
\text { X.1.9.4 } \\
\text { X.1.9.5 }\end{array}$ & $\begin{array}{l}\text { Manage MLLW } \\
\text { Manage CH MLLW } \\
\text { Transport/Ship Disposition-Ready CH MLLW } \\
\text { Manage MLLW Disposal Site } \\
\text { Operate MLLW Disposal Trench } \\
\text { Disposition Cat I and III MLLW } \\
\text { Deactivate MLLW Disposal Trench } \\
\text { Manage Contaminated Equipment } \\
\text { Transport Disposition-Ready Equipment } \\
\text { Operate and Maintain Active Solid Waste Facilities } \\
\text { Operate and Maintain Plant Systems } \\
\text { Operate and Maintain Facility Support Systems } \\
\text { Operate and Maintain Protection Systems } \\
\text { Maintain Information Management Systems } \\
\text { Manage Facility Wastes }\end{array}$ \\
\hline \begin{tabular}{|l|} 
Commercial Hazardous Waste TSD \\
Facilities: Environsafe, Easton Smelting, \\
Landlan, USPCI Laddlaw LCNE Mountain \\
Facility, Envirotroc, USPCI Grassy \\
Mountain Facility, Philip Environmental \\
(Georgetown \& Kent).
\end{tabular} & $\mathrm{X} .1 .7$ & Ship Hazardous Waste to Offsite TSD Facility \\
\hline $\begin{array}{l}\text { Commercial transportation services: } \\
\text { MP Environmental Svcs., Tri-State Motor } \\
\text { Transit, ATTUM Industries, Triad } \\
\text { Transport, Gresham Transfer, U.S. } \\
\text { Pollution Control, Tidewater Barge Lines, } \\
\text { Ross Maritime, Burlington Environmental. }\end{array}$ & $\mathrm{X} .1 .7$ & Ship Hazardous Waste to Offsite TSD Facility \\
\hline
\end{tabular}


Table 8-2. Waste Management Project Facility Allocation Crosswalk. (8 sheets)

\begin{tabular}{|c|c|c|}
\hline Facility for implementing function & Function number(s) & Function title \\
\hline $\begin{array}{l}\text { Other Mobile Offices: MO-278, }-279,- \\
437,-438,-535,-720,-720,-721,-743 \text {, } \\
\text { and }-941\end{array}$ & $\begin{array}{r}\text { X.1.9 } \\
\text { X.1.9.1 } \\
\text { X.1.9.2 } \\
\text { X.1.9.3 } \\
\text { X.1.9.4 } \\
\text { X.1.9.5 }\end{array}$ & $\begin{array}{l}\text { Operate and Maintain Active Solid Waste Facilities } \\
\text { Operate and Maintain Plant Systems } \\
\text { Operate and Maintain Facility Support Systems } \\
\text { Operate and Maintain Protection Systems } \\
\text { Maintain Information Management Systems } \\
\text { Manage Facility Wastes } \\
\text { (unverified as to which other functions these mobile offices are } \\
\text { related) }\end{array}$ \\
\hline $\begin{array}{l}\text { 340 Waste Handling Facility (340-A, } \\
\text { 340-B, MO-036, MO-741) }\end{array}$ & $\begin{array}{r}\text { X.2.3 } \\
\text { X.2.3.1 } \\
\text { X.2.3.2 } \\
\text { X.2.3.4 } \\
\text { X.2.3.5 } \\
\text { X.2.3.6 } \\
\text { X.2.7 } \\
\text { X.2.7.1 } \\
\text { X.2.7.2 } \\
\text { X.2.7.3 } \\
\text { X.2.7.4 } \\
\text { X.2.7.5 }\end{array}$ & $\begin{array}{l}\text { Manage Listed RCRAMixed Waste Liquid Effluent Streams } \\
\text { Receive Effluent Streams from Generators } \\
\text { Store Effluent Streams } \\
\text { Prepare Solid Wastes for Disposition } \\
\text { Transfer Effluent for Disposal } \\
\text { Transfer Effluent to TWRS } \\
\text { Operate and Maintain Active Liquid Waste Facilities } \\
\text { Operate and Maintain Plant Systems } \\
\text { Operate and Maintain Facility Support Systems } \\
\text { Operate and Maintain Protection Systems } \\
\text { Maintain Information Management Systems } \\
\text { Manage Facility Wastes }\end{array}$ \\
\hline $\begin{array}{l}300 \text { Area TEDF (310 Treated Effluent } \\
\text { Disposal Facility) (342 Waste Collection } \\
\text { Sump, MO-744, MO-745, MO-433); 307 } \\
\text { Basins (3707-F); 3906 Lift Station, 300 } \\
\text { Area Process Sewer, Radioactive Liquid } \\
\text { Waste System (RIWS), Retention Process } \\
\text { System (RPS), and Columbia River } \\
\text { (permitted) }\end{array}$ & $\begin{array}{l}\text { X.2.2 } \\
\text { X.2.2.2 } \\
\text { X.2.2.3 } \\
\text { X.2.2.4 } \\
\text { X.2.2.5 } \\
\text { X.2.3 } \\
\text { X.2.5 } \\
\text { X.2.5.1 } \\
\text { X.2.5.2 } \\
\text { X.2.5.3 } \\
\text { X.2.5.4 } \\
\text { X.2.5.5 } \\
\text { X.2.6 } \\
\text { X.2.6.1 } \\
\text { X.2.6.2 } \\
\\
\text { X.2.7 } \\
\text { X.2.7.1 } \\
\text { X.2.7.2 } \\
\text { X.2.7.3 } \\
\text { X.2.7.4 } \\
\text { X.2.7.5 }\end{array}$ & $\begin{array}{l}\text { Manage CERCLA-Generated Liquid Effluent Streams } \\
\text { Store Liquid Waste } \\
\text { Treat Liquid Waste } \\
\text { Prepare Solid Wastes for Disposition } \\
\text { Transfer Treated Effluent for Disposal } \\
\text { Manage Listed RCRA/Mixed Waste Liquid Effluent Streams } \\
\text { Manage LLW Effluent Streams } \\
\text { Receive LLW Effluent Stream } \\
\text { Store LL Effluent Stream } \\
\text { Treat Effluent Stream } \\
\text { Prepare Solid Waste for Disposition } \\
\text { Transfer Treated Effluent for Disposal } \\
\text { Discharge Treated Liquid Effluents } \\
\text { Receive Discharge-Ready Liquid Effluents } \\
\text { Hold Pending Discharge } \\
\text { Operate and Maintain Active Liquid Waste Facilities } \\
\text { Operate and Maintain Plant Systems } \\
\text { Operate and Maintain Facility Support Systems } \\
\text { Operate and Maintain Protection Systems } \\
\text { Maintain Information Management Systems } \\
\text { Manage Facility Wastes }\end{array}$ \\
\hline
\end{tabular}




\section{Revision 0}

Table 8-2. Waste Management Project Facility Allocation Crosswalk. (8 sheets)

\begin{tabular}{|c|c|c|}
\hline Facility for implementing function & Function number(s) & Function title \\
\hline $\begin{array}{l}\text { Effluent Treatment Facility (ETF) } \\
\text { (2025-E) (2025-EA Administration, 225-E } \\
\text { and -W Pump Stations, 225-WA Effluent } \\
\text { Monitoring, MO-269, Laundry Shed, HS- } \\
\text { 010, HS-011, Oil Storage Shed) }\end{array}$ & $\begin{array}{l}\text { X.2.2 } \\
\text { X.2.2.1 } \\
\text { X.2.2.2 } \\
\text { X.2.2.3 } \\
\text { X.2.2.4 } \\
\text { X.2.2.5 } \\
\text { X.2.3 } \\
\text { X.2.3.1 } \\
\text { X.2.3.2 } \\
\text { X.2.3.3 } \\
\text { X.2.3.4 } \\
\text { X.2.3.5 } \\
\\
\text { X.2.5 } \\
\text { X.2.5.1 } \\
\text { X.2.5.2 } \\
\text { X.2.5.3 } \\
\text { X.2.5.4 } \\
\text { X.2.5.5 } \\
\\
\text { X.2.6 } \\
\text { X.2.6.1 } \\
\text { X.2.6.2 } \\
\text { X.2.7 } \\
\text { X.2.7.1 } \\
\text { X.2.7.2 } \\
\text { X.2.7.3 } \\
\text { X.2.7.4 } \\
\text { X.2.7.5 }\end{array}$ & $\begin{array}{l}\text { Manage CERCLA-Generated Liquid Effluent Streams } \\
\text { Receive CERCLA-Generated Liquid Waste } \\
\text { Store Liquid Waste } \\
\text { Treat Liquid Waste } \\
\text { Prepare Solid Wastes for Disposition } \\
\text { Transfer Treated Effluent for Disposal } \\
\text { Manage Listed RCRA/Mixed Waste Liquid Effluent Streams } \\
\text { Receive Effluent Streams from Generators } \\
\text { Store Effluent Streams } \\
\text { Treat Effluent Streams } \\
\text { Prepare Solid Wastes for Disposition } \\
\text { Transfer Effluent for Disposal } \\
\text { Manage LLW Effluent Streams } \\
\text { Receive LLW Effluent Stream } \\
\text { Store LL Effluent Stream } \\
\text { Treat Effluent Stream } \\
\text { Prepare Solid Waste for Disposition } \\
\text { Transfer Treated Effluent for Disposal } \\
\text { Discharge Treated Liquid Effluents } \\
\text { Receive Discharge-Ready Liquid Effluents } \\
\text { Hold Pending Discharge } \\
\text { Operate and Maintain Active Liquid Waste Facilities } \\
\text { Operate and Maintain Plant Systems } \\
\text { Operate and Maintain Facility Support Systems } \\
\text { Operate and Maintain Protection Systems } \\
\text { Maintain Information Management Systems } \\
\text { Manage Facility Wastes }\end{array}$ \\
\hline $\begin{array}{l}\text { 200 Area TEDF ( } 6653 \text { Treated Effluent } \\
\text { Disposal Facility) }\end{array}$ & $\begin{array}{l}\text { X.2.6 } \\
X .2 .6 .1 \\
\\
\text { X.2.7 } \\
\text { X.2.7.1 } \\
\text { X.2.7.2 } \\
\text { X.2.7.3 } \\
\text { X.2.7.4 } \\
\text { X.2.7.5 }\end{array}$ & $\begin{array}{l}\text { Discharge Treated Liquid Effluents } \\
\text { Receive Discharge-Ready Liquid Effluents } \\
\text { Operate and Maintain Active Liquid Waste Facilities } \\
\text { Operate and Maintain Plant Systems } \\
\text { Operate and Maintain Facility Support Systems } \\
\text { Operate and Maintain Protection Systems } \\
\text { Maintain Information Management Systems } \\
\text { Manage Facility Wastes }\end{array}$ \\
\hline
\end{tabular}


Table 8-2. Waste Management Project Facility Allocation Crosswalk. (8 sheets)

\begin{tabular}{|c|c|c|}
\hline Facility for implementing function & Function number(s) & Function title \\
\hline $\begin{array}{l}\text { Liquid Effluent Retention Facility } \\
\text { (CERF) (basins 242-AL42,-AL43, and } \\
\text {-AL44) }\end{array}$ & $\begin{array}{l}\text { X.2.1 } \\
\text { X.2.1.5 } \\
\text { X.2.2 } \\
\text { X.2.2.1 } \\
\text { X.2.2.2 } \\
\text { X.2.3 } \\
\text { X.2.3.1 } \\
\text { X.2.3.2 } \\
\text { X.2.7 } \\
\text { X.2.7.1 } \\
\text { X.2.7.2 } \\
\text { X.2.7.3 } \\
\text { X.2.7.4 } \\
\text { X.2.7.5 }\end{array}$ & $\begin{array}{l}\text { Concentrate Liquid Tank Waste } \\
\text { Transfer Process Condensate } \\
\text { Manage CERCLA-Generated Liquid Effluent Streams } \\
\text { Receive CERCLA-generated Liquid Waste } \\
\text { Store Liquid Waste } \\
\text { Manage Listed RCRA/Mixed Waste Liquid Effluent Streams } \\
\text { Receive Effluent Streams from Generators } \\
\text { Store Effluent Streams } \\
\text { Operate and Maintain Active Liquid Waste Facilities } \\
\text { Operate and Maintain Plant Systems } \\
\text { Operate and Maintain Facility Support Systems } \\
\text { Operate and Maintain Protection Systems } \\
\text { Maintain Information Management Systems } \\
\text { Manage Facility Wastes }\end{array}$ \\
\hline $\begin{array}{l}\text { 242-A Evaporator (242-A.702, 242- } \\
\mathrm{A} 207 \text {, and } 242-\mathrm{AE})\end{array}$ & \begin{tabular}{|l|} 
X.2.1 \\
$X .2 .1 .1$ \\
$X .2 .1 .2$ \\
$X .2 .1 .3$ \\
$X .2 .1 .4$ \\
$X .2 .1 .5$ \\
$X .2 .7$ \\
$X .2 .7 .1$ \\
$X .2 .7 .2$ \\
$X .2 .7 .3$ \\
$X .2 .7 .4$ \\
$X .2 .7 .5$ \\
\end{tabular} & $\begin{array}{l}\text { Concentrate Liquid Tank Waste } \\
\text { Receive Liquid Tank Waste for Evaporation } \\
\text { Evaporate Liquid from Tank Waste } \\
\text { Analyze Process Streams } \\
\text { Retum Concentrated Liquid Tank Waste to Tank Farm } \\
\text { Transfer Process Condensate } \\
\text { Operate and Maintain Active Liquid Waste Facilities } \\
\text { Operate and Maintain Plant Systems } \\
\text { Operate and Maintain Facility Support Systems } \\
\text { Operate and Maintain Protection Systems } \\
\text { Maintain Information Management Systems } \\
\text { Manage Facility Wastes }\end{array}$ \\
\hline $\begin{array}{l}\text { SALDS (200 Area East and West State } \\
\text { Approved Land Disposal Sites) } \\
\text { (216-E43A and 216-E43B). }\end{array}$ & \begin{tabular}{|l|}
$X .2 .6$ \\
$X .2 .6 .3$ \\
X.2.7 \\
X.2.7.1 \\
X.2.7.2 \\
X.2.7.3 \\
X.2.7.4 \\
X.2.7.5
\end{tabular} & $\begin{array}{l}\text { Discharge Treated Liquid Effluents } \\
\text { Discharge at Approved Disposal Site } \\
\text { Operate and Maintain Active Liquid Waste Facilities } \\
\text { Operate and Maintain Plant Systems } \\
\text { Operate and Maintain Facility Support Systems } \\
\text { Operate and Maintain Protection Systems } \\
\text { Maintain Information Management Systems } \\
\text { Manage Facility Wastes }\end{array}$ \\
\hline
\end{tabular}


HNF-SD-WM-RPT-288

Revision 0

Table 8-2. Waste Management Project Facility Allocation Crosswalk. (8 sheets)

\begin{tabular}{|c|c|c|}
\hline Facility for implementing function & Function number(s) & Function title \\
\hline $\begin{array}{l}\text { 222-S Analytical Laboratory } \\
\text { (222-SA Chemical Standards/Process } \\
\text { Development Laboratory, 222-SB HVAC } \\
\text { South Filter, 222-SC HVAC North Filter, } \\
\text { 222-SD Solid Waste Storage, 222-SE } \\
\text { Diesel Exhaust and Filtering, 222-SF } \\
\text { Equipment Service and Storage, 222-SG } \\
\text { Gas Bottle Storage, 222-SH Office and } \\
\text { Changing Area, 207-SL Water Retention } \\
\text { Basin, 212-S Compressed Gas Storage, } \\
\text { 219-S Waste Handling and Treatment, } \\
\text { 2704-S Office, 2716-S Storage). }\end{array}$ & $\begin{array}{l}\text { X.4.1 } \\
\text { X.4.1.1 } \\
\text { X.4.1.1.1 } \\
\text { X.4.1.1.2 } \\
\text { X.4.1.1.3 } \\
\text { X.4.1.1.4 } \\
\text { X.4.4 } \\
\text { X.4.4.1 } \\
\text { X.4.4.3 } \\
\text { X.4.4.4 } \\
\text { X.4.5 } \\
\text { X.4.5.1 } \\
\text { X.4.5.2 } \\
\text { X.4.5.2.1 } \\
\text { X.4.5.3 } \\
\text { X.4.5.4 } \\
\text { X.4.5.5 } \\
\text { X.4.5.6 } \\
\text { X.4.5.7 }\end{array}$ & $\begin{array}{l}\text { Provide HL Radioactive Sample Services } \\
\text { Provide Routine HL Sample Services } \\
\text { Receive HL Radioactive Sample } \\
\text { Prepare HL Sample for Analysis } \\
\text { Analyze HI Sample } \\
\text { Report Sample Analysis Results } \\
\text { Provide Commercial Laboratory Services } \\
\text { Receive Low/Nonradioactive Sample } \\
\text { Prepare Sample for Offsite Analysis } \\
\text { Ship Low/Nonradioactive Sample } \\
\text { Operate and Maintain Active Laboratory Facilities } \\
\text { Provide Standards Laboratory Services } \\
\text { Archive Samples } \\
\text { Archive HL Radioactive Samples } \\
\text { Maintain Analytical Equipment Operational } \\
\text { Operate and Maintain Utility Systems } \\
\text { Manage Laboratory Wastes } \\
\text { Operate and Maintain Protection Systems } \\
\text { Maintain Information Management Systems Operational }\end{array}$ \\
\hline $\begin{array}{l}\text { WSCF (Waste Sampling and } \\
\text { Characterization Facility) (6266) (6266- } \\
\text { A Contaminated Liquid Waste Storage, } \\
\text { 6266-B VAS Pump Building, } 6267 \\
\text { Sample Archiving (LL rad only), } 6268 \\
\text { Sample Equipment Cleaning, } 6269 \text { Mobile } \\
\text { Laboratory Vehicle Storage, } 6270 \\
\text { Environmental Data Facility). }\end{array}$ & $\begin{array}{l}\text { X.4.2 } \\
\text { X.4.2.1 } \\
\text { X.4.2.1.1 } \\
\text { X.4.2.1.2 } \\
\text { X.4.2.1.3 } \\
\text { X.4.2.1.4 } \\
\text { X.4.2.1.5 } \\
\text { X.4.2.2 } \\
\text { X.4.4 } \\
\text { X.4.4.1 } \\
\text { X.4.4.3 } \\
\text { X.4.4.4 } \\
\\
\text { X.4.5 } \\
\text { X.4.5.1 } \\
\text { X.4.5.2 } \\
\text { X.4.5.2.2 } \\
\text { X.4.5.3 } \\
\text { X.4.5.4 } \\
\text { X.4.5.5 } \\
\text { X.4.5.6 } \\
\text { X.4.5.7 }\end{array}$ & $\begin{array}{l}\text { Provide LL Radioactive Sample Services } \\
\text { Provide Routine LL Sample Services } \\
\text { Receive LL Radioactive Sample } \\
\text { Collect LL Radioactive Sample } \\
\text { Prepare LL Sample for Analysis } \\
\text { Analyze LL Sample } \\
\text { Report Sample Analysis Results } \\
\text { Provide LL Developmental Services } \\
\text { Provide Commercial Laboratory Services } \\
\text { Receive Low/Nonradioactive Sample } \\
\text { Prepare Sample for Offsite Analysis } \\
\text { Ship Low/Nonradioactive Sample } \\
\\
\text { Operate and Maintain Active Laboratory Facilities } \\
\text { Provide Standards Laboratory Services } \\
\text { Archive Samples } \\
\text { Archive LL Radioactive Samples } \\
\text { Maintain Analytical Equipment Operational } \\
\text { Operate and Maintain Utility Systems } \\
\text { Manage Laboratory Wastes } \\
\text { Operate and Maintain Protection Systems } \\
\text { Maintain Information Management Systems Operational }\end{array}$ \\
\hline
\end{tabular}


HNF-SD-WM-RPT-288

Revision 0

Table 8-2. Waste Management Project Facility Allocation Crosswalk. (8 sheets)

\begin{tabular}{|l|c|l|}
\hline \multicolumn{1}{|c|}{ Facility for implementing function } & Function number(s) & \multicolumn{1}{|c|}{ Function title } \\
\hline Field Service Assets: RFSH-managed & X.4.3 & Provide Mobile In-Field Analytical Services \\
(Solid Waste) Mobile Field Services & X.4.3.1 & Provide Routine In-Field LL Services \\
(2 vehicies, 1 cart). Following assets used & X.4.3.1.1 & Receive LL Radioactive Sample \\
are non-RFSH managed: SESC-managed & X.4.3.1.2 & Collect LL Radioactive Sample \\
Special Analytical Support (5 trucks, & X.4.3.1.3 & Prepare LL Sample for Analysis \\
14 trailers); RFSN-managed Near Field & X.4.3.1.4 & Analyze LL Sample \\
Monitoring (5 vehicles); RFSH-managed & X.4.3.1.5 & Report Sample Analysis Results \\
Geophysics (3 vehicles); RFSH-managed & X.4.3.2 & Provide In-Field LL Developmental Services \\
Sampling and Mobile Laboratories & & \\
(8 trucks, 1 trailer). & X.4.4 & Provide Commercial Laboratory Services \\
& X.4.4.2 & Collect Low/Nonradioactive Sample \\
\hline Commercial Labs via contract & X.4.4 & Provide Commercial Laboratory Services \\
(FY 1997): Quanterra, MMA/Weston, & X.4.4.5 & Analyze Low/Nonradioactive Sample \\
CH2M Hill, Clayton Environmental & & \\
Consultants, Data Chem Laboratories, & & \\
Inland Environmental, LAS Laboratory, & & \\
Laucks Testing Laboratory, NATLSCO, & & \\
North Creek Analytical, Soil Technologies, & & \\
Sound Analytical. & & \\
\hline Inactive Facilities: 3714 Geotechnical & X.4.6 & \\
Engineering Laboratory & & \\
\hline
\end{tabular}

\subsubsection{Facilities}

\subsubsection{Central Waste Complex-Enhanced Radioactive Mixed Waste Storage, Phase V (Project W-112)}

Project Background. The Project is continuing to develop the Cetral Waste Complex (CWC) to compliantly store newly generated and existing radioactive and mixed solid waste. The Project has established a long-range strategy to ensure solid waste management at the Hanford Site protects human heaith and the environment compliant with state, federal, and DOE regulations. The strategy includes phased construction of storage and support facilities to meet solid waste inventories as projected from the responses to solicitation for information from the waste generators. Information on the Project W-112 facility was obtained from the following documents: WHC-SD-W112-ES-001, Project W-112, Enhanced Radioactive and Mixed Waste Storage Phase V Engineering Study (Biebesheimer 1992); WHC-SD-W112-CDR-001, Enhanced Radioactive and Mixed Waste Storage Phase V (Barnes 1992); WHC-EP-0918, Solid Waste Integrated Forecast Technical (SWIFT) Report: FY 1997 to FY 2070 (Valero 1996); PNL 8990, 1993 Baseline Solid Waste Management System Description (PNL 1994); WHC-EP-0063-4, Hanford Site Solid Waste Acceptance Criteria (Willis 1993); WHC-SD-W112-FDC-001, Functional Design Criteria for Enhanced Radioactive and Mixed Waste Storage Phase V, Project W-112, Appendix 2 (Nester 1995); the Resource Conservation and Recovery Act of 1976 (RCRA); and Washington Administrative Code (WAC) 173-303. 
Waste generation is projected to exceed the existing storage capacity, and additional storage buildings will be required to achieve compliance with the U.S. Environmental Protection Agency (EPA), U.S. Department of Energy (DOE), and WAC storage requirements. The Phase V Storage Facility will provide the required confinement and temporary storage appropriate for the inventoried radiological and mixed hazardous waste, while awaiting the final disposition of the waste.

Fiscal year 1996 is the sixth year for implementing additional radioactive and mixed solid waste storage at the Hanford Site. The present scope of the Project's Phase V Storage activity is represented in WHC-SD-W112-FDC-001, Functional Design Criteria For Enhanced Radioactive and Mixed Waste Storage Phase V, Project W-112 (Nester 1995).

Project W-112 is also providing support facilities for CWC, WRAP 1, and mixed waste Trenches 31 and 34. The support buildings will house Operations support staff and Maintenance support staff for the startup and operation of WRAP 1 and future facilities.

Originally, Project W-112 had significantly more scope than what is presented in Revision 3 of WHC-SD-W112-FDC-001. For example, there existed automated storage, transporting, inspection and loading capabilities; ignitable and boxed waste dedicated storage areas; WIPP head gas sampling capability; fully functional and integrated maintenance facility; 300 person office complex; and complete infrastructure upgrades to support existing and planned facilities. This scope was necessary to enhance the waste storage function, reduce worker exposure, and inherently improve worker safety. However, because of programmatic changes to the solid waste treatment, storage, and disposal mission at the Hanford Site (TRU retrieval suspended, Project W-100 [WRAP 2A] terminated) and changes and delays in the WIPP program, the Project's work scope was reduced to provide only the minimal essentials for solid waste storage and WRAP 1 startup support. The Project's original full work scope has been archived in WHC-SD-W112-FDC-001, Functional Design Criteria For Enhanced Radioactive and Mixed Waste Storage Phase V, Project W-112, Appendix A (Nester 1995).

\section{Project Scope}

Waste Types. Project W-112 provides additional storage for radioactive and mixed solid waste. The waste is generated from onsite and offsite sources. Waste to be stored will be $\mathrm{CH}$ LLW GTCIII, LLMW Category I/III/GTCIII, TRU, TRUM waste, and RH waste shielded down to $\mathrm{CH}$ packages. Storage of ignitable waste is not part of the Project W-112 work scope. Waste classifications are defined in WHC-EP-0063-4, Hanford Site Solid Waste Acceptance Criteria (Willis 1993).

Waste Quantity. The waste storage capacity to be provided by Project W-112 is set at 13,300 drum equivalents (DE). " The storage areas will be capable of receiving and accommodating 208- or 322-L palletized drums stacked up to three drums high. Small boxes

- Drum equivalent storage capacity is defined as the area required to appropriately store a U.S. Department of Transporation Standard UN1A2 208-L drum. 
containing waste types noted can also be stored in the facilities. With this additional storage capacity, the CWC will be able to store approximately 67,300 drum equivalents of solid waste.

The design has expansion provisions to accommodate an additional 13,700 drum equivalents of future manual storage capacity. Additional storage facilities will be provided by future projects on an as-needed basis. This additional storage is projected to be required by FY 2000 .

Storage capacity was based on short-term storage projections (e.g., through FY 2002) as determined from the SWPM Scenario 73R2-7-3-18 described in PNL-10743 (Anderson and Konynenbelt 1995), and the actual storage inventory existing through FY 1994 (as queried from the SWITS database). This scenario evaluated the data by assuming a planning basis at $60 \%$ of the forecasted amount, $100 \%$ of the stored waste volume, 3-year delay in TRU retrieval operations (beginning in FY 2002), WIPP shipments beginning in FY 2002, WRAP 1 operations beginning in March 1997, radioactive mixed waste stabilization treatment beginning in FY 1999, and commercial thermal treatment beginning in FY 1996. Existing inventory includes waste stored at the CWC and TRUSAF.

SWOC Support Facilities. The occupancy sizing for the support facilities was determined from the startup and operational needs of the WRAP 1 Facility. Office type occupancy space for 65 personnel and maintenance shop space for 15 craftspersons is necessary. The office and maintenance facilities will be separate buildings that are functionally located near the WRAP 1 Facility. The maintenance facility accommodates electrical, instrumentation, and pipefitter/millwright vocations.

Project Schedule. Project W-112 has completed definitive design (August 1995) and is procuring contractor services to construct the facilities. The general contract is scheduled to be let by October 1995, and construction will begin shortly afterwards. The Startup Facility is to service WRAP 1 Facility startup needs. Phase V Storage and maintenance facilities are scheduled to be in service by February 1997.

\section{Project Interfaces}

Facilities. Project W-112 will indirectly interface with WRAP 1 and existing CWC storage facilities. Facilities under the project's scope will be connected into existing Hanford Site infrastructure systems (i.e., water, power, telecommunications).

Operations. The physical design and placement of the storage facilities integrate directly with existing CWC operations. Minimal impacts to existing operational and maintenance procedures are required; furthermore, the readiness review process can be streamlined due to the previous precedents set by the existing storage facilities. Wastes stored in Phase V Storage facilities will augment waste container queuing for the WRAP I Facility and waste destined for offsite treatment (commercial treatment). Forklifts will be used to transfer drums, boxes, and pallets in all Phase V Storage facilities. 
Project Functions. The function of Project W-112 is to provide compliant storage for radioactive and mixed waste on the Hanford Site. Stored containers will reside inside enclosed noncontainment (nonfiltered ventilation)-type buildings built on top of RCRA-compliant floors (sealed concrete). Manual storage methods are employed similar to existing CWC storage facilities. Drummed containers will be palletized, banded, and stacked up to three high in the facilities. Aisles are provided to gain access to the drums for required visual inspections.

\section{Project Requirements}

Functional Requirements. Project functional requirements are defined in WHC-SD-W112-FDC-001, Functional Design Criteria for Enhanced Radioactive and Mixed Waste Storage Phase V, Project W-112 (Nester 1995). This document is the primary requirements and contractual document between the Design Authority (WHC/Project) and the Design Agency (Project's Architect-Engineer).

Regulatory Compliance Requirements. Waste management operations at the Hanford Site are regulated by a number of agencies through a variety of regulations and administrative orders. The principal regulatory authorities associated with Project W-112 include the DOE, Ecology, EPA, Washington State Department of Health), and the DOT. Consideration of these regulatory authorities is essential in maintaining compliant radioactive and mixed waste storage at the Hanford Site.

The radioactive constituents in the waste are regulated by DOE Order 5820.2A, Radioactive Waste Management (DOE 1988a), which pertains to the management of LLW, TRU, and TRUM waste. The hazardous components in the waste are regulated by RCRA and the RCRA implementing regulations contained in $40 \mathrm{CFR}$. The storage criteria specified in $40 \mathrm{CFR} 265$ must be achieved. To be accepted into Phase V Storage, the waste must be fully characterized for radioactive and hazardous material content.

Project W-1 12 will be included in the CWC RCRA Part B permit application; furthermore, air emissions and sewage permits are required.

NEPA. The NEPA regulations were developed to assess the impacts to the environment associated with given proposed actions. The environmental assessment for the CWC was completed in early FY 1996.

\subsubsection{Transuranic Waste Storage and Assay Facility}

Facility Identification. The TRUSAF, designated as the 224-T Facility, was designed and built in the mid 1940's as a chemical processing unit for plutonium purification. The facility was authorized as part of the Manhattan Project by the U.S. Army Corps of Engineers. In 1984, the DOE designated the facility for storing and assaying newly generated TRU wastes. After plutonium cleanout and an Operational Readiness Review (McIntosh 1985), the facility began storage and assay operations in 1985. 
The TRUSAF is located in the 200 West Area of the Hanford Site slightly south and east of the 221-T (T Plant) Facility. Functions performed at the TRUSAF include the exterior container inspection, real-time radiography inspection, neutron assay for fissile material content, and interim storage in facility storage modules.

Facility Scope. The TRUSAF scope includes TRU waste storage and assay operations. Since 1970, TRU was determined to be a special waste because of its long half-life and the relatively hazardous characteristics of most TRU isotopes. Because of its potential hazards, the DOE requires that TRU be segregated from other radioactive waste during disposal (AEC-RL 1970). The storage of TRU waste at the TRUSAF provides this segregation and maintains any existing package certification pending eventual transport to WIPP. The facility also provides for nondestructive testing assay, which is used as an overview for sealed, certified, CH TRU solid waste packages.

Waste Types. Waste approved for storage either temporarily or on an interim basis at TRUSAF is limited to packaged CH TRU wastes. Contact-handled TRU waste is waste consisting of TRU isotopes with half-lives greater than 20 years in a concentration greater than $100 \mathrm{nCi} / \mathrm{g}$ and radiation dose rate of less than $200 \mathrm{mrem} / \mathrm{h}$. Transuranic waste reading higher than $200 \mathrm{mrem} / \mathrm{h}$ is defined as $\mathrm{RH}$ waste. Remote-handled waste and radioactive waste not meeting the TRU concentration level are transported to other facilities for storage/disposal.

Interfaces. The following sections describe facility, vehicle, and container interfaces.

Facilities. Transuranic waste is received from facilities generating TRU waste. The TRUSAF sorts waste for the PFP. Containers determined by assay to be LLW (less than $100 \mathrm{nCi} / \mathrm{g}$ ) are transferred to the LLW burial trenches for disposal. The containers that are deficient are returned to the initial PFP generator for correction or are stored in the 200 West Area for future certification. TRU waste containers generated from a wide variety of facilities will be accepted for storage at TRUSAF.

Waste determined by assay to be LLW and not CH TRU is sent to the LLW burial grounds for final disposal. Contact-handled TRU waste certified for shipment will be transported to WIPP when the facility is operational.

Vehicles. The TRUSAF has no special vehicular needs except for transporting waste containers to and from the facility. The facility has a waste container load/unload bay where waste containers are accepted and loaded for offsite shipment.

Containers. The TRUSAF has no special container needs. Waste is not repackaged in this facility and out-of-specification containers are returned to the generating facility for correction. 
Facility Size. The TRUSAF provides approximately $1,068 \mathrm{~m}^{2}$ of floor storage space on three levels. The outside dimensions are $60 \mathrm{~m}$ long by $18 \mathrm{~m}$ wide. Floor loading limits dictate that 208-L drums may be stacked a maximum of two drums high for storage, as long as the following limits are not exceeded:

- First floor $-1,100 \mathrm{~kg} /$ single stack

- Second floor $-270 \mathrm{~kg} /$ single stack

- Third floor $-363 \mathrm{~kg} /$ single stack

- Elevator $-3,600$ capacity.

The first floor contains a control room and offices, a heating, ventilating, and air conditioning (HVAC) mechanical room, an assayer room, a real-time radiography room, and storage space. The storage area totals about $177 \mathrm{~m}^{2}$ of temporary storage area.

The remaining floors are dedicated primarily to waste storage. The second floor contains about $490 \mathrm{~m}^{2}$ of interim storage space, and the third floor contains about $400 \mathrm{~m}^{2}$ of interim storage space.

Facility Functions. The TRUSAF is used for inspection, shipping/receiving, waste handling, storage, and waste segregation, which are described in the following paragraphs.

Inspection. Container integrity is verified in accordance with the requirements of Title 49 Code of Federal Regulations (CFR) Part 173. The approved container for newly generated waste in TRUSAF is the DOT $17 \mathrm{C}$ or its equivalent, the UN1A2, 208-L galvanized drum. Waste retrieved for characterization may be contained in carbon steel or galvanized steel $208-\mathrm{L}$ drum DOT Type A containers. The wall thickness of the container will be measured in situ at the retrieval site to verify that the wall thickness is not less than $0.11 \mathrm{~cm}$ (the minimum wall thickness of a $17 \mathrm{H}$ Type A $208-\mathrm{L}$ drum) and that the drum shows no evidence of a breach. If a container has less than the required wall thickness, it will be left at the burial ground retrieval site in accordance with the RCRA permit. Additional assessment at the trench retrieval site will include an evaluation for signs of drum compromise such as bulges, dents, leakage, and weather deterioration. The retrieved containers may be placed in poly bags to minimize the spread of dirt clinging to the container.

Shipping/Receiving. A shipment is received at TRUSAF and checked for acceptability before it is unloaded. For newly generated waste, this includes examining the documentation to ensure that it is proper and complete. The required documents include a radioactive shipment record, a TRU waste storage record, a WIPP certification checklist, and a contents inventory sheet. Hazardous waste manifests also are required if hazardous constituents are present in the containers. Retrieved waste drums must be accompanied by radioactive shipment records, including a copy of the original burial record, a drum inspection form, and a preshipment checklist. If existing records indicate that the drum contains hazardous waste, a hazardous waste manifest also must accompany the drum. The documentation will be used to initially characterize the containers and to provide a comparison during the nondestructive examination (NDE). or nondestructive assay (NDA). The examinations will be used to assess the accuracy of the 
historical assay data and to estimate waste material contents. Retrieved waste data forms from $\mathrm{NDE}$ and visual inspections performed to approved solid waste burial grounds retrieval work plans or procedures must be sent to TRUSAF to verify that the waste meets TRUSAF entry requirements.

During the unloading process, care is taken to avoid damaging the containers. Lift tailgates are used to lower the containers from the transport vehicle, and weight limits of material handling equipment are not exceeded. Handcarts and forklifts are used to move the containers to the initial staging area. Signs and barricades are posted around the area to communicate the potential radiation hazard. The drum identification numbers and the dates of receipt are recorded in the receipt and storage log book. A data package that accompanies the container throughout the process is prepared for each container.

Waste Handling. The drums are weighed using a digital weighmeter. The drums are lifted using either a hand-operated forklift with a drum-handling attachment or electric crane equipment with a drum-handling attachment, or they are rolled by hand and slowly lowered onto the scale. A printer produces a label showing the drum's weight in kilograms, and the label is applied to the container. The forklift or crane is used to raise the drum off the scale and lower it to the floor.

A hand-operated forklift is used to move the container to the real-time radiography operating room where it is $\mathrm{x}$-rayed. The real-time radiography provides a visual overview of the waste to ensure that it generally agrees with the documentation, and that the waste meets WIPP criteria. The real-time radiography will be used to help identify and characterize the contents of retrieved waste containers.

The container is loaded into the radiography system using a hand-operated forklift with a drum-handling attachment. During the examination, the drum can be raised and turned using the manipulator controls. A video cassette recorder provides real-time imaging during the examination. The tape is then labeled with the drum identification number, date, and time.

A hand-operated forklift with a drum-handling attachment is used to load the drums into the assayer. The drums are then assayed to determine the extent TRU activity. All waste containers that assay greater than $100 \mathrm{nCi} / \mathrm{g}$ are considered to be TRU waste.

Results from the assay and real-time radiography determine where drums are temporarily stored. The temporary storage area is located on the first floor and is divided into the following areas:

- Certified for TRUSAF storage (drums to be moved to the interim storage areas on the upper floors)

- Noncertifiable WTPP (drums that are not certifiable and are to be sent to the TRU retrievable storage) 
- Low level (drums that assayed less than $100 \mathrm{nCi} / \mathrm{g}$ TRU activity and are to be relabeled and buried as LLW. All existing TRU labels on these drums are destroyed to avoid confusion.)

- Hold (drums that have one or more hold points checked on the traveler form and that are being held for further analysis). The retrieved drums that exceed $100 \mathrm{nCi} / \mathrm{g}$ will be placed on hold pending further examination or treatment in WRAP.

- Return to generator (drums that have been designated to be returned by the TRUSAF manager).

Storage. All TRUSAF waste packages that successfully meet the requirements are placed in interim storage pending shipment to WIPP. Interim storage areas are located on the second and third floors. Retrieved drums will be stored in separate zones from certified drums.

A hand-operated forklift with a drum-handling device is used to position the drums. A limit switch restricts the height that the forks can be raised. The operator inspects the area for overhead obstructions before before overriding the limit switch. The drums are stored in modules and stacked no more than two high. Each tier of drums is separated by a sheet of $0.6-\mathrm{cm}$ (minimum) fire retardant plywood or equivalent. Each module is labeled to ensure that the drums can be traced. Each drum's module location is recorded in the receipt and storage log book under the heading of final disposition.

Segregation. The drums are arranged with aisles around the modules to allow for easy access through the storage areas. Drums with thermal wattage in excess of $35 \mathrm{~W} / \mathrm{m}^{3}$ are segregated and stored in single tiers at least $0.9 \mathrm{~m}$ away from other stored drums.

Facility Requirements. The TRUSAF operates under WHC-SD-WM-ISB-004, Transuranic Waste Storage and Assay Facility Interim Safety Basis (Gibson 1995).

Permits. The TRUSAF operates under DOE/RL-91-51, 224-T Transuranic Waste Storage and Assay Facility Dangerous Waste Permit Application (DOE/RL 1992).

\subsubsection{Waste Receiving and Processing Module 1}

Project Identification. The Hanford Defense Waste Environmental Impact Statement (HDW-EIS) record of decision (ROD) (DOE 1988a) promulgates the U.S. Department of Energy's (DOE) decision to implement the "preferred alternative" as discussed in HDW-EIS. As part of the preferred alternative, the DOE decided that "A facility will be designed, constructed and operated at Hanford to sort process and repackage retrievably stored and newly generated TRU solid waste for shipment to WIPP located approximately 26 miles from Carlsbad, New Mexico" (DOE 1987). 
The Waste Receiving and Processing Module I (WRAP 1) facilities provide verification, characterization, treatment, and repackaging of radioactive solid waste at the Hanford Site. WRAP 1 will process CH LLW, LLMW, TRU, and TRUM waste. WRAP 1 was a 1992 Line Item. Definitive design began in January 1992 and was completed in 1993. Construction began in 1994 and was completed in 1996. Operation is planned for 1997.

Over the years, some operations at the Hanford Site produced waste containing small amounts of plutonium (TRU waste). This waste was kept separate from other waste and for the most part was put in steel drums. Some pieces of broken equipment were put into larger boxes. All TRU waste produced since 1970 has been stored on asphalt pads and covered with dirt. The HDW-EIS describes plans for this waste to be removed and shipped to New Mexico for burial deep in salt formations. The WRAP facilities provide the means to safely prepare the waste for disposal.

\section{Project Scope}

Waste Types. Solid waste that is a candidate for treatment in the WRAP Facility includes waste now in storage, waste added to storage before WRAP startup, and waste to be generated after WRAP startup.

Beginning in 1970, TRU waste was segregated from other waste types and placed into retrievably stored units. The AEC issued Immediate Action Directive No. 0511-21 (AEC-RL 1970) that directed the Hanford Site (and other sites) to begin temporarily storing all suspect TRU solid waste. The waste was to be stored "in such a fashion that it can be retrievable as contamination-free packages within an interim period of 20 years." Special provisions were made at the Hanford Site for retrievable storage of high-activity TRU waste. Thus, not only has the TRU waste been segregated from other types, but $\mathrm{CH}$ TRU has been kept separate from RH TRU. DOE Order 5820.2A (DOE 1988b) defines TRU waste, LLW, and HLW.

Transuranic waste is defined as waste containing plutonium or other "TRU" materials. This waste is given a special category by the DOE primarily because it is an "alpha emitter." That is, its radioactivity is derived primarily from alpha particles. This type of radiation is easily stopped by the skin or even a piece of newspaper. It is much more dangerous if it gets inside the body. Although handling this type of waste without shielding from radiation is usually, some precautions are needed to keep from breathing small particles of the radioactive material. Much of the material that contains TRU waste also has waste that emits gamma and beta radiation.

Records maintained on the TRU waste at the Hanford Site show more than 38,700 containers (more than 37,600 208-L drums) in CH retrievable storage. More than $485 \mathrm{~kg}$ of plutonium are on record in these containers. About $34 \mathrm{~m}^{3}$ of RH TRU waste are in retrievable storage. The waste that was retrievably stored does not meet disposal packaging criteria and must be repackaged.

The waste forecast shows that between 1997 and 2018, approximately $15,900 \mathrm{~m}^{3}$ of $\mathrm{CH}$ TRU waste will be received for treatment in WRAP 1. 
The HDW-EIS outlined the DOE plan for disposing of the Hanford Site's TRU waste. Several alternatives were considered: geologic disposal, in-place stabilization and disposal, reference alternative, and no disposal action.

The geologic disposal alternative included, for the TRU solid waste as well as the other waste classifications, retrieval, processing and packaging, and shipment of the waste to WIPP for disposal. The in-place stabilization and disposal alternative involved near-surface disposal of the solid TRU waste, including in-place compaction of waste containers to preclude future subsidence. The waste would be covered with a protective barrier and marker system. The reference alternative included retrieval, processing and packaging, and shipment to WIPP of only retrievably stored TRU waste. The no disposal action alternative (continued storage) for the TRU solid waste included monitoring, surveillance, and maintenance of the existing storage locations.

The preferred alternative for TRU waste is retrieval, processing and packaging, and shipment to WIPP for disposal. Both $\mathrm{CH}$ and RH TRU wastes are identified in this action.

Because definitions of what constitutes TRU waste have changed between 1970 and today, many of the retrievably stored TRU containers are now classified as LLW. Low-level waste was not included in the HDW-EIS evaluations. Disposal of LLW can be accomplished in accordance with the requirements of RCRA or CERCLA. WRAP 1 will segregate the LLW from TRU in the retrieved packages before disposition. Known LLW at the Hanford Site that has been put into trenches is now, by definition, disposed of.

Low-level mixed waste contains hazardous constituents, as defined by RCRA. Treatment requirements for the large number of hazardous waste categories are also given by RCRA. Generally, these treatment requirements for disposal are more extensive than those required by the WIPP waste acceptance criteria (WTPP 1996) for TRU waste. Incorporating the RCRA LLMW technologies with WRAP 1 was evaluated. The evaluation determined that a separate LLMW facility would be more effective in managing that specific class of waste, although limited treatment of small waste streams could be performed in WRAP 1 .

The RH TRU solid waste at the Hanford Site includes two general types that represent different handling and processing considerations. One type includes physically large waste items (e.g., containers up to $57 \mathrm{~m}^{3}$ in volume and failed equipment up to $18 \mathrm{~m}$ long) with moderate dose rates (greater than $200 \mathrm{mrem} / \mathrm{h}$ ). The other type includes those containers and items with very high (up to 2,000 rem $/ \mathrm{h}$ ) dose rates. The RH TRU solid waste and $\mathrm{CH}$ containers require decidedly different techniques and technologies.

The WRAP 2 Engineering Study (Pauly 1990) evaluated the feasibility of including waste other than CH TRU in the WRAP scope. The results of the evaluation concluded that WRAP should not be designed and constructed as one facility but rather should be built in modules. The portions of the processes that were well understood and well defined would be placed into WRAP 1: assay and inspection and certification and shipping for CH TRU and LLW in drums. 
Future WRAP modules would provide capabilities for size reduction, remote handling of $\mathrm{HLW}$, treatment of mixed waste, and decontamination facilities. The sampling requirements and specific analyses for mixed waste characterization were not well defined; WRAP throughput and storage needs could not be established well enough to provide a basis for design at the time of the evaluation. Requirements for potentially processing RH TRU in existing facilities, and transportation requirements, such as fissile material allowances, also were insufficient to allow for design configurations at the time. The capability to assay large containers currently in storage did not exist. All these items could affect facility sizing, lag storage, and throughput requirements.

Thus, the scope of the WRAP 1 Facility, CH TRU solid waste, was established on the basis of the HDW-EIS preferred alternative, the unique characteristics of TRU solid waste, the ability to shallow-land dispose of LLW solid waste, the technology development requirements for RH TRU solid waste, and the relative large quantity of CH TRU solid waste at the Hanford Site.

Interfaces. Although WRAP 1 is a "standalone" facility, it is planned to interface with several currently unfunded facilities. These are summarized in Table 8-3. Waste will be received in either drums or small boxes from the CWC Phase I through IV Buildings by transport motor vehicle or forklift-type vehicle. Phase V Storage will be connected with WRAP 1 to permit the use of automated vehicles to transport drummed waste. Other containers, small boxes, or standard waste boxes from Phase V Storage will be received by forklift vehicles. WRAP 1 container interfaces are presented in Table 8-4. Waste in drums from other locations may be received by motor vehicle.

WRAP 1 also will interface with other WRAP modules for transporting drummed waste requiring additional processing and for receipt of waste in drums requiring certification for shipping.

Waste for treatment or disposal off site will be shipped from WRAP 1. Transuranic waste for disposal at WIPP will be shipped in TRUPACT II* containers; this motor vehicle transport system has been specially designed for shipment of TRU waste. Drums and standard waste boxes may be shipped in TRUPACT II containers. Shipment of LLW will be accomplished by motor vehicle. No rail transportation facilities are provided at WRAP 1. Shipment of shielded casks is not part of WRAP 1. The WRAP I vehicle interfaces are shown in Table 8-5.

\footnotetext{
TRUPACT II is a trademark of Container Products Corporation.
} 


\section{Revision 0}

Table 8-3. Waste Receiving and Processing Module 1 Interfaces - Facilities.

\begin{tabular}{|c|c|c|c|c|c|c|}
\hline & $\begin{array}{c}\text { Program Plan } \\
\text { (WHC-EP-03 } \\
63)\end{array}$ & $\begin{array}{l}\text { WRAP } 1 \text { Eng } \\
\text { Study } \\
\text { (RHO 1985) }\end{array}$ & $\begin{array}{c}\text { CDR } \\
\text { (Rieck 1990) }\end{array}$ & $\begin{array}{l}\text { WRAP } 2 \text { Eng } \\
\text { Study } \\
\text { (Pauly 1990) }\end{array}$ & Title 1 design & Final design \\
\hline $\begin{array}{l}\text { Centra! Waste Complex } \\
\text { storage }\end{array}$ & - & $\ldots$ & $X$ & $X$ & -- & 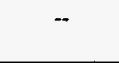 \\
\hline Retrieval trench & $X$ & - & -- & -- & -- & -- \\
\hline Phase V Storage & & - & - & - & $X$ & $X$ \\
\hline WRAP 2 & - & - & $X$ & $\mathrm{X}$ & -- & - \\
\hline WIPP & $x$ & $\mathrm{X}$ & $X$ & $\mathrm{X}$ & $\mathrm{X}$ & $\mathrm{X}$ \\
\hline TRUSAF & $\mathrm{X}$ & $\mathrm{X}$ & - & - & - & - \\
\hline Disposal trench & - & $X$ & $X$ & $\mathrm{X}$ & $\mathrm{X}$ & $X$ \\
\hline
\end{tabular}

NOTES: $\quad$ 1. The WRAP Facility interface with disposal activities--either the Hanford Site burial grounds for LLW or WIPP for TRU waste has not changed over the conceptual life of the facility.

2. The interface with TRUSAF, CWC storage, the retrieval trenches, and other WRAP modules was replaced with a single facility--the Phase V Storage Facility--as the Program strategy developed over the years.

$\begin{array}{ll}\text { CDR } & =\text { Conceptual design report } \\ \text { CWC } & =\text { Central Waste Complex } \\ \text { LLW } & =\text { Low-level waste } \\ \text { TRU } & =\text { Transuranic } \\ \text { TRUSAF } & \text { Transuranic Storage and Assay Facility } \\ \text { WIPP } & =\text { Waste Isolation Pilot Plant }\end{array}$

Table 8-4. Waste Receiving and Processing Module 1 Interfaces - Containers.

\begin{tabular}{|l|c|c|c|c|c|c|}
\hline & $\begin{array}{c}\text { Program Plan } \\
\text { (Duncan 1991) }\end{array}$ & $\begin{array}{c}\text { WRAP 1 Eng } \\
\text { Study } \\
\text { (RHO 1985) }\end{array}$ & $\begin{array}{c}\text { CDR } \\
\text { (Rieck 1990) }\end{array}$ & $\begin{array}{c}\text { WRAP 2 Eng } \\
\text { Study } \\
\text { (Pauly 1990) }\end{array}$ & Title 1 design & Final design \\
\hline 208-L drums & $\mathrm{X}$ & $\mathrm{X}$ & $\mathrm{X}$ & $\mathrm{X}$ & $\mathrm{X}$ & $\mathrm{X}$ \\
\hline 322-L drums & $\mathrm{X}$ & $\mathrm{X}$ & $\mathrm{X}$ & $\mathrm{X}$ & $\mathrm{X}$ & $\mathrm{X}$ \\
\hline Standard waste boxes & $\mathrm{X}$ & $\mathrm{X}$ & $\mathrm{X}$ & $\mathrm{X}$ & $\mathrm{X}$ & $\mathrm{X}$ \\
\hline Waste box - other & $\mathrm{X}$ & $\mathrm{X}$ & -- & - & - & $\mathrm{X}$ \\
\hline 208-L drum, four/pallet & -- & -- & $\mathrm{X}$ & $\mathrm{X}$ & $\mathrm{X}$ & $\mathrm{X}$ \\
\hline 314-L drum, four/pallet & -- & -- & $\mathrm{X}$ & $\mathrm{X}$ & $\mathrm{X}$ & $\mathrm{X}$ \\
\hline 114-L drum & $\mathrm{X}$ & $\mathrm{X}$ & -- & -- & - & - \\
\hline TRUPACT & $\mathrm{X}$ & $\mathrm{X}$ & -- & -- & - & - \\
\hline TRUPACT II & -- & -- & $\mathrm{X}$ & $\mathrm{X}$ & $\mathrm{X}$ & $\mathrm{X}$ \\
\hline
\end{tabular}

TRUPACT = Transuranic package transporter.

'TRUPACT and TRUPACT II are trademarks of Container Products Corporation. 
Table 8-5. Waste Receiving and Processing Module 1 Interfaces - Vehicles.

\begin{tabular}{|l|c|c|c|c|c|c|}
\hline & $\begin{array}{c}\text { Program } \\
\text { Plan (Duncan } \\
1991)\end{array}$ & $\begin{array}{c}\text { WRAP 1 Eng } \\
\text { Study } \\
\text { (RHO 1985) }\end{array}$ & $\begin{array}{c}\text { CDR (Rieck } \\
1990)\end{array}$ & $\begin{array}{c}\text { WRAP 2 Eng } \\
\text { Study (Pauly } \\
\text { 1990) }\end{array}$ & $\begin{array}{c}\text { Title 1 } \\
\text { design }\end{array}$ & $\begin{array}{c}\text { Final } \\
\text { design }\end{array}$ \\
\hline Truck & $\mathrm{X}$ & $\mathrm{X}$ & $\mathrm{X}$ & $\mathrm{X}$ & $\mathrm{X}$ & $\mathrm{X}$ \\
\hline Forklift & $\mathrm{X}$ & -- & $\mathrm{X}$ & $\mathrm{X}$ & $\mathrm{X}$ & $\mathrm{X}$ \\
\hline Train & $\mathrm{X}$ & $\mathrm{X}$ & -- & -- & -- & -- \\
\hline Automated guided vehicle & -- & -- & -- & -- & $\mathrm{X}$ & $\mathrm{X}$ \\
\hline
\end{tabular}

$\mathrm{CDR}=$ Conceptual design report

The Conceptual Design Report Waste Receiving and Processing Module 1, Project W-026 (Rieck 1990) stated that WRAP 1 would provide shipping functions for other WRAP modules for CH TRU and CH LLW drums and standard waste boxes. Rail access was identified in this report as "likely" to be provided by later modules.

In the CDR, WRAP 1 was not planned to have storage capability other than what might be required for direct process support. The storage function was described as being provided by existing or new facilities.

WRAP 1 also will interface with communications systems for transfer of information regarding waste processing, sampling, certification, etc. (Mayancsik 1994). Some of these interfaces are as follows.

Hanford Local Area Network and SWITS. WHC-SD-WM-TI-291, Waste Receiving and Processing (WRAP) Functional Design Criteria, Section 3.6, "Process Control and Data Acquisition" (Christie 1987).

Shipping and Receiving. WHC-SD-WM-TI-291, Waste Receiving and Processing (WRAP) Functional Design Criteria, Section 3.5 (Christie 1987).

Automated Guided Vehicles. No information available before Title 1 design (Preliminary CDR).

Box Assay System. WHC-SD-WM-TI-291, Waste Receiving and Processing (WRAP) Functional Design Criteria, Section 3.2.1 (Christie 1987).

Telecommunications. WHC-SD-WM-TI-291, Waste Receiving and Processing (WRAP) Functional Design Criteria, Section 4.10.1, "Telecommunications" (Christie 1987).

Video/Audio Archive of NDE/NDA Data. Information available in Title 1 design (Preliminary CDR). 
Portable Bar Code Reader and Transmission of Data to Control Room. WRAP Engineering Studies, Vol. V (UE\&C 1991), Waste Processing System Functional Analysis Study, p. 9, 5.2.1, "The code is read again so that a cross check. . .and the computer concurs with the tracking of that drum."

Process Control Annunciation. WHC-SD-WM-TI-291, Waste Receiving and Processing (WRAP) Functional Design Criteria, Section 3.6, "Process Control and Data Acquisition" (Christie 1987).

HVAC. WHC-SD-WM-TI-291, Waste Receiving and Processing (WRAP) Functional Design Criteria, Section 4.3 (Christie 1987).

Uninterruptable Power Supply Systems. WHC-SD-WM-TI-291, Waste Receiving and Processing (WRAP) Functional Design Criteria, Section 3.6, "Process Control and Data Acquisition" (Christie 1987).

WHC-SD-W026-CDR-001, Conceptual Design Report Waste Receiving and Processing Module 1, Project W-026, p. 41 (Rieck 1990).

Project Size. WRAP 1 is located about $244 \mathrm{~m}$ northwest of the intersection of Dayton Avenue and 23 rd Street in the 200 West Area. Natural grasses and sagebrush are the prevalent vegetation. The site development includes construction of two new access roads, parking area for 60 automobiles, and a paved area for truck maneuvering. Two roads for truck access are separate from the automobile and bus route to the facility.

The building is designed as a $4,806 \mathrm{~m}^{2}$ structure with $4,115 \mathrm{~m}^{2}$ of space on the first floor and $691 \mathrm{~m}^{2}$ on the second. The building contains four primary areas: shipping and receiving, NDA/NDE, process, and administrative. The second floor contains the plant control room, computer room, and some of the HVAC equipment. Two zones of HVAC confinement in the processing areas are provided with progressive negative pressures to ensure that air flows from potentially lower contamination locations to potentially higher contamination locations.

The design life of the facility is 30 years. It is designated as a radioactive solid waste facility classified as non-safety class in accordance with DOE Order 6430.1A (DOE 1989).

The building enclosure is of the beam-and-column type that is typically supplied by preengineered metal building manufacturers. The exterior skin of the building consists of preinsulated, prefinished metal, interlocking roof and wall sandwich panels. Some special structural design is required as a result of the second-floor loads and the bridge crane in the Shipping and Receiving Area.

The building system is not required to contribute to the mitigation of accident conditions. Analyses of credible accidents, including the maximum credible accident, show that the effects of the accidents are within the risk acceptance guidelines without consequence reduction from the building structure. 


\section{Revision 0}

Table 8-6 presents a historical overview of the building system for WRAP 1.

Table 8-6. Building System Historical Overview.

\begin{tabular}{|l|c|c|c|c|c|c|}
\hline & $\begin{array}{c}\text { Program Plan } \\
\text { (Duncan } \\
1991)\end{array}$ & $\begin{array}{c}\text { WRAP 1 Eng } \\
\text { Study } \\
\text { (RHO 1985) }\end{array}$ & $\begin{array}{c}\text { CDR (Rieck } \\
1990)\end{array}$ & $\begin{array}{c}\text { WRAP 2 Eng } \\
\text { Study (Pauly) }\end{array}$ & $\begin{array}{c}\text { Title 1 } \\
\text { design }\end{array}$ & $\begin{array}{c}\text { Final } \\
\text { design }\end{array}$ \\
\hline Preengineered structure & -- & -- & - & -- & $\mathrm{X}$ & $\mathrm{X}$ \\
\hline Secondary containment & - & $\mathrm{X}$ & -- & -- & -- & $\mathrm{X}$ \\
\hline Safety class & -- & -- & -- & -- & $\begin{array}{c}\text { Non-safety } \\
\text { class }\end{array}$ & -- \\
\hline Building size & -- & $2,600 \mathrm{~m}^{2}$ & -- & $4,800 \mathrm{~m}^{2}$ & $4,800 \mathrm{~m}^{2}$ & $4,200 \mathrm{~m}^{2}$ \\
\hline Location & - & $\begin{array}{c}200 \mathrm{West}^{2} \\
\text { Area }\end{array}$ & -- & -- & $\begin{array}{c}\text { Central } \\
\text { Waste } \\
\text { Complex } \\
200 \text { West } \\
\text { Area }\end{array}$ & $\begin{array}{c}\text { Central } \\
\text { Waste } \\
\text { Complex } \\
200 \text { West } \\
\text { Area }\end{array}$ \\
\hline Number of functional areas & 6 & -- & -- & -- & 7 & 7 \\
\hline $\begin{array}{l}\text { Heating, ventilating, and } \\
\text { air conditioning zones }\end{array}$ & -- & -- & -- & 3 & 2 & 2 \\
\hline
\end{tabular}

Project Schedule. A plan was prepared for disposing of the TRU solid waste stored at the Hanford Site. The HDW-EIS presents the outline of this plan, which includes the WRAP modules to the public. The HDW-EIS ROD states that the TRU waste at the Hanford Site would be disposed of in WIPP.

The Tri-Party Agreement committed the WRAP 1 Facility to be operational in 1997 (Milestone M-18-00). The design, environmental permitting, safety documentation, and technology/equipment development schedules all support this Tri-Party Agreement milestone.

The WIPP is designed to accept TRU waste for disposal for approximately 20 years. The earliest that WIPP could accept waste from the Hanford Site would be 2003. The WIPP operation is scheduled to stop receiving waste in 2033, leaving a maximum of 30 years for shipment from the Site.

Throughput. The DOE made a commitment to New Mexico that Hanford Site TRU waste would be shipped to meet the WIPP schedule. WRAP 1 must have the capacity to process the TRU waste in accordance with these plans. Preparing all the TRU waste stored at the Hanford Site for processing in WRAP will take several years. Stored waste will be retrieved over several years and new waste will be sent in for many years. The WRAP operation must be integrated with the waste forecasts and retrieval as well as with WIPP plans. 
Contact-handled TRU waste is retrievably stored on site and more will be received from off site generators. The DOE has established WIPP as the repository for TRU waste from all DOE sites. The WRAP 1 is to prepare Hanford Site CH TRU waste for shipment to WIPP.

The HDW-EIS designates disposal in WIPP as the preferred alternative for TRU waste disposal. The HDW-EIS ROD supported this alternative. The current closure date for WIPP is established as 2033. All TRU waste that is retrievably stored and planned for receipt must be processed and shipped before the WIPP closure date.

The entire WRAP schedule, including throughput rates for WRAP 1, supports the WIPP closure date for the currently estimated TRU waste volume. Running one processing shift per day, WRAP 1 will initially handle the TRU waste stored above ground and the newly generated TRU waste. As the retrievably stored TRU waste is retrieved, it will be processed in WRAP 1.

The planned one-shift operation for the WRAP 1 Facility allows operating flexibility in dealing with unforseen circumstances without sacrificing design and construction efficiencies. The facility size, configuration, processing lines, shipping and receiving, and administrative areas all are needed to support the basic WRAP 1 operation. Multiple shift operations can be supported by the existing facility design.

Table 8-7 is an annual throughput historical overview for WRAP 1.

Table 8-7. Waste Receiving and Processing Module 1 Annual Throughput Historical Overview.

\begin{tabular}{|l|c|c|c|c|c|c|}
\hline & $\begin{array}{c}\text { Program Plan } \\
\text { (Duncan 1991) }\end{array}$ & $\begin{array}{c}\text { WRAP 1 Eng } \\
\text { Study } \\
\text { (RHO 1985) }\end{array}$ & $\begin{array}{c}\text { CDR } \\
\text { (Rieck 1990) }\end{array}$ & $\begin{array}{c}\text { WRAP 2 Eng } \\
\text { Study } \\
\text { (Pauly 1990) }\end{array}$ & Title 1 design & Final design \\
\hline Drums & -- & 5,381 & 6,200 & 4,743 & 6,825 & 6,825 \\
\hline Standard waste boxes & -- & $\begin{array}{c}\text { Quantity } \\
\text { not } \\
\text { given }\end{array}$ & 875 & 59 & 70 & 70 \\
\hline $\mathrm{m}^{3}$ & 12,800 & 2,095 & 3,866 & 1,157 & 1,747 & 1,747 \\
\hline
\end{tabular}

NOTES: 1. The Program Plan included only retrievably stored TRU waste. No estimate was given for newly generated TRU to be received or processed.

2. The WRAP 1 CDR included nondestructively examinating, assaying, and certifying approximately 875 boxes annually. Included were 118 newly generated $2-\mathrm{m}^{3} \mathrm{CH}$ TRU boxes and 455 newly generated 3.6 $-\mathrm{m}^{3} \mathrm{CHLLW}$ boxes. Following WRAP 2 startup, an additional 262 standard waste boxes of CH TRU waste and 40 boxes of CH LLW would be processed annually. Thus, about $1,317 \mathrm{~m}^{3}$ of boxed CH TRU waste are planned for processing each year.

$\mathrm{CDR}=$ Conceptual design report

$\mathrm{CH}=$ Contact-handled

LLW = Low-level waste

TRU $=$ Transuranic

WRAP $=$ Waste Receiving and Processing 
Between 1970 and 1988 , about $15,860 \mathrm{~m}^{3}$ of suspect-TRU waste were placed in retrievable storage. In 1989, the required WRAP throughput of CH TRU was estimated based on the following information.

- Of the $15,860 \mathrm{~m}^{3}$ of suspect-TRU waste placed in storage, $7,930 \mathrm{~m}^{3}$ were $\mathrm{CH}$ waste in boxes and $7,930 \mathrm{~m}^{3}$ were $\mathrm{CH}$ wast in drums $(38,000 \mathrm{drums})$. About 18 years of operation of WRAP 1 (startup was scheduled for CY 1995) would be available before closure of WIPP in 2013.

- Given 18 years of WRAP operation, about 2,000 drums of retrievably stored TRU waste would need to be processed annually to meet the WIPP schedule.

- The 1987 waste volume forecast identified about $8,496 \mathrm{~m}^{3} / \mathrm{yr}$ of LLW to be stored. Quality verification checks of about $5 \%$ of the newly generated waste are assumed to be required. However, about one-half of the forecast LLW was soils not requiring examination or verification of the drum contents. Thus, about $425 \mathrm{~m}^{3}$, or about 2,000 drums per year, would be verified in WRAP 1 .

- The Waste Volume Forecast (Anderson 1990) (Revision 0) also identified about $7,930 \mathrm{~m}^{3}$, or roughly 38,000 drums, of newly generated $\mathrm{CH}$ TRU waste to be received by WRAP. Processing at an annual rate of 2,100 drums would work off this projected inventory before WIPP closure.

- Annual throughput requirements for WRAP were estimated in 1988 at about 6,000 drums of waste per year.

Current waste volume forecasts show that about $7,703 \mathrm{~m}^{3}$ of retrievably stored TRU in drums will be designated for WRAP 1, about $4,815 \mathrm{~m}^{3}$ of newly generated TRU drums will be received, and about 1,850 newly generated TRU boxes will be received. About 7,646 $\mathrm{m}^{3}$ of LLW will be overchecked in WRAP 1 .

- Retrievably stored TRU-35,700 drums or about 1,985 per year

- Newly generated TRU-22,300 drums or about 1,250 per year

- LLW verification-35,500 drums or about 1,970 per year

- TRU in standard waste boxes $-1,850$ boxes or about 100 per year.

The conversion from cubic meter to number of containers in the forcast assumes that each drum contains $0.26 \mathrm{~m}^{3}$ of waste and each standard waste box contains $1.9 \mathrm{~m}^{3}$. If waste is not efficiently loaded into the containers, the total number of containers received by WRAP 1 could be higher.

WRAP 1 will process 2,625 drums of retrieved wastes and 4,200 drums of newly generated waste per year, with a $50 \%$ split on LLW and TRU waste, for a total of 6,825 drums total per year. An NDE/NDA assay of 70 newly generated TRU standard waste boxes (no other processing activity for boxes is included in WRAP 1) is performed annually. WRAP 1 Shipping and Receiving can receive 6,825 drums and 70 boxes per year, or 40 drums per day and 2 boxes per week (Mayancsik 1994, DOE 1987, Roberts 1993, Lerch 1993). 
Facility Expansion. WRAP I is the first WRAP facility. Its design and construction will be able to accommodate either expansion of the basic building or connection to future modules or waste storage and handling buildings. The design will permit using WRAP 1 in shared operations, such as examination, certification, and shipping (Weidert 1993).

As the additional treatment and storage facilities become better defined, and as technologies evolve, WRAP 1 will be flexible enough that its process functional areas can be modified to expand and/or accept different equipment. The outer wall adjacent to the process lines adjoins outside space, not other equipment or necessary operating areas. Thus, the facility structure and primary processing areas could be modified with a minimum of expansion costs and schedule impacts. A facility expansion historical overview for WRAP 1 is presented in Table 8-8 (Pauly 1990).

\section{Project Functions}

Waste Sorting. Requirements placed on the disposal of TRU waste at WIPP ensure that the waste will be safely disposed of for at least 10,000 years (RCRA). These requirements are specified in the WIPP waste acceptance criteria (WIPP 1996), which have not been finalized. On the basis of existing documentation, at least 16 criteria must be met before waste will be accepted for disposal (DOE/WIPP 1989, Mayancsik 1994). At least four of the criteria define the need to sort the TRU waste:

- No free liquids are allowed

- $\quad$ Pyrophorics must be stabilized

- Explosives or compressed gases are not allowed

- Ignitables and corrosives must be deactivated or neutralized.

WRAP 1 has sorting tables within the waste processing enclosures to sort the TRU waste. The drum will be transferred to the sorting table after its lid has been removed. The drum contents then will be emptied onto the sorting table. Items identified as unsuitable for WIPP disposal during NDE will be removed. The separated items will be sent to the restricted waste management (RWM) processing line. The remaining contents will be packaged for shipment to WIPP. Table 8-9 is a waste sorting historical overview for WRAP 1 .

Table 8-8. Facility Expansion Historical Overview.

\begin{tabular}{|l|c|c|c|c|c|c|}
\hline & $\begin{array}{c}\text { Program Plan } \\
\text { (Duncan } \\
\text { 1991) }\end{array}$ & $\begin{array}{c}\text { WRAP I Eng } \\
\text { Study } \\
\text { (RHO 1985) }\end{array}$ & $\begin{array}{c}\text { CDR } \\
\text { (Rieck 1990) }\end{array}$ & $\begin{array}{c}\text { WRAP 2 Eng } \\
\text { Study (Pauly } \\
\text { 1990) }\end{array}$ & $\begin{array}{c}\text { Title 1 } \\
\text { design }\end{array}$ & $\begin{array}{c}\text { Final } \\
\text { design }\end{array}$ \\
\hline Expansion & -- & -- & - & - & $X$ & $X$ \\
\hline Connection & -- & -- & -- & $X$ & $X$ & $X$ \\
\hline
\end{tabular}

$\mathrm{CDR}=$ Conceptual design report 
Table 8-9. Waste Receiving and Processing Module 1 Waste Sorting Historical Overview.

\begin{tabular}{|l|c|c|c|c|c|c|}
\hline & $\begin{array}{c}\text { Program } \\
\text { Plan } \\
\text { (Duncan 1991) }\end{array}$ & $\begin{array}{c}\text { WRAP 1 Eng } \\
\text { Study } \\
\text { (RHO 1985) }\end{array}$ & $\begin{array}{c}\text { CDR } \\
\text { (Rieck 1990) }\end{array}$ & $\begin{array}{c}\text { WRAP 2 Eng } \\
\text { Study } \\
\text { (Pauly 1990) }\end{array}$ & Title 1 design & Final design \\
\hline Hazardous & $\mathrm{X}$ & $\mathrm{X}$ & -- & $\mathrm{X}$ & $\mathrm{X}$ & $\mathrm{X}$ \\
\hline Hard/Soft & $\mathrm{X}$ & $\mathrm{X}$ & -- & $\mathrm{X}$ & -- & -- \\
\hline Metals & $\mathrm{X}$ & $\mathrm{X}$ & -- & $\mathrm{X}$ & -- & -- \\
\hline Undefined & -- & -- & $\mathrm{X}$ & -- & -- & -- \\
\hline
\end{tabular}

CDR: $\quad$ WHC-SD-W026-CDR-001, Conceptual Design Report Waste Receiving and Processing Module 1, Project W-026 (Rieck 1990).

ENG STY: WHC-SD-W100-ES-001, Engineering Study for Waste Receiving and Processing (WRAP) Facility, Module 2 (Pauly 1990).

TITLE I: $\quad$ Waste Receiving and Processing Facility Module 1 Preliminary Design Report (UE\&C 1992).

\section{Comments:}

1. In-drum compaction of TRU waste as envisioned in the CDR (Rieck 1990) and Engineering Study (Pauly 1990) was deleted in the Title 1 design.

2. Treatment of pyrophoric material was anticipated in the CDR (Rieck 1990), but in the Title 1 design, such material would be removed from WRAP 1.

3. Aerosol can liquids were to be treated in the CDR (Rieck 1990) but are removed to storage in the Title 1 design.

4. Lead decontamination was eliminated in the Title 1 design in favor of storage and treatment in WRAP $2 \mathrm{~A}$.

5. No mention of treatment of reactive materials by a liquid reagent was given in the CDR (Rieck 1990).

6. A shred/grout alternative was considered in the WRAP 2 Engineering Study (Pauly 1990) but was not chosen for WRAP 1 implementation due to higher costs, added waste material, and added mechanical complexity.

7. Limited treatment capabilities are specified in the FDC (Mayancsik 1994).

8. The WRAP Module I Treatment Plan (Mayancsik 1995) further identifies the limited treatments provided in WRAP 1. 


\section{HNF-SD-WM-RPT-288 \\ Revision 0}

The FDC (Mayancsik 1994) states:

"The following provisions shall be provided for restricted waste management: immobilization of particulates, sorption of liquids, deactivation of reactive materials, chemical reactions of corrosive or pyrophoric materials, solidification and/or overpacking of corrosive materials, and venting of pressurized vessels (e.g., aerosol cans)."

The CDR (Rieck 1990) states:

"208- and 314-L drums; lifted by power grapple; tilted, contents spread on table; liquids collected in holding tank; manually sorted; TRU to clean 208-L drum for compaction; LLW to refilled drum for supercompaction and placement in 314-L drums.

Capacity - 6.9 TRU and 8.7 LLW drums opened per shift."

The Engineering Study (Pauly 1990) states:

"Separate enclosures for TRU and LLW drums; drums deheaded and tipped on vibratory table; manually sorted; TRU to 208-L drum for compaction, $228 \mathrm{~kg}$ pounds limit; LLW supercompacted and loaded in 314-L drums, $450 \mathrm{~kg}$ limit."

Capacity - 8.1 TRU and 7.2 LLW drums opened per day.

Title 1 design states:

"208-L or 314-L drums; lifted; by scissor lift; drums lids cut off, drum placed on tipper and contents dumped on table; TRU back to drum for supercompaction; LLW to radioactive mixed waste glovebox."

Capacity - 8 TRU and 8 LLW drums per day.

Final design states:

"208-L or 314-L drums; lifted; by scissor lift; drums' lids cut off, drum placed on tipper and contents dumped on table; LLW to radioactive mixed waste glovebox.

Capacity - 8 TRU and 8 LLW drums per day

References: $\quad$ WHC-SD-W026-CDR-001, Conceptual Design Report Waste Receiving and Processing Module 1, Project W-026 (Rieck 1990); WHC-SD-W100-ES-001, Engineering Study for Waste Receiving and Processing (WRAP) Module 2 (Pauly 1990); Waste Receiving and Processing Facility Module 1 Preliminary Design Report (UE\&C 1992); WHC-SD-FDC-W026-001, Functional Design Criteria Waste Receiving and Processing (WRAP) Facility Module 1, Section 2.2.7 
HNF-SD-WM-RPT-288

Revision 0

(Mayancsik 1994); WHC-SD-W026-PLN-007, WRAP Module 1

Treatment Plan (Mayancsik 1995).

\section{Waste Treatment.}

Bases: RCRA; WAC 173-303, "Dangerous Waste Regulations;" WIPP waste acceptance criteria (WIPP 1996); TRUPACT-II (DOE/WIPP 1989).

Source: $\quad$ WHC-SD-FDC-W026-001, Functional Design Criteria Waste Receiving and Processing (WRAP) Facility Module 1, Sections 2.0, 2.2, and 2.2.7 (Mayancsik 1994).

The WIPP waste acceptance criteria establish requirements for how the waste must be treated before it can be buried. The waste must be processed to a form that ensures that problems will not develop during 10,000 years.

The TRU waste will be shipped by truck from the Hanford Site to Carlsbad, New Mexico. Shipping requirements for the waste relate to its treatment. These requirements are specified in the TRUPACT-II Transportation Criteria (DOE/WIPP 1989). The treatments are identified to ensure that the waste can be shipped safely under all foreseeable circumstances.

The WRAP 1 waste treatment processes currently include sorting, volume reduction, deactivation (neutralization, cementing, absorption, and controlled reaction with water), stabilization (cementing, absorption, and encapsulation), and amalgamation. Other treatments can be used in WRAP 1 if they are found to be acceptable for in-glovebox treatment or if they fall within the guidance specified in the WRAP Part B Permit Application (Lerch 1993). Sorting is identified as a separate key project item in this report. Waste treatments have been reviewed during the design evolution of WRAP 1 . A waste treatment historical overview for WRAP 1 is presented in Table 8-10.

Following is a WRAP 1 review of treatment processes.

\section{TRU Compaction}

CDR All TRU loaded in 208-L drums; liquid collection tanks beneath compactor; drums weighed.

Capacity: 1.55 TRU drums per shift.

ENG STUDY All TRU loaded in 208-L drums; no liquid collection tanks beneath compactor; drums weighed.

Capacity: 5.5 TRU drums per day. 
Table 8-10. Waste Receiving and Processing Module 1 Waste Treatment Historical Overview.

\begin{tabular}{|l|c|c|c|c|c|c|c|}
\hline & $\begin{array}{c}\text { Program Plan } \\
\text { (Duncan 1991) }\end{array}$ & $\begin{array}{c}\text { WRAP 1 FDC } \\
\text { (Mayancsik } \\
\text { 1994) }\end{array}$ & $\begin{array}{c}\text { WRAP 1 } \\
\text { Eng Study } \\
\text { (RHO 1985) }\end{array}$ & $\begin{array}{c}\text { CDR } \\
\text { (Rieck 1990) }\end{array}$ & $\begin{array}{c}\text { WRAP 2 } \\
\text { Eng Study } \\
\text { (Pauly 1990) }\end{array}$ & $\begin{array}{c}\text { Title 1 } \\
\text { design }\end{array}$ & $\begin{array}{c}\text { Final } \\
\text { design }\end{array}$ \\
\hline Shred-grout & $\mathrm{X}$ & -- & $\mathrm{X}$ & -- & -- & -- & $\mathrm{X}$ \\
\hline Compaction (LLW) & -- & $\mathrm{X}$ & -- & $\mathrm{X}$ & $\mathrm{X}$ & -- & $\mathrm{X}$ \\
\hline Supercompaction & -- & $\mathrm{X}$ & -- & $\mathrm{X}$ & $\mathrm{X}$ & $\mathrm{X}$ & -- \\
\hline Size reduction & $\mathrm{X}$ & -- & $\mathrm{X}$ & -- & -- & - & -- \\
\hline Thermal treatment & -- & -- & $\mathrm{X}$ & -- & -- & -- & -- \\
\hline Immobilization & $\mathrm{X}$ & $\mathrm{X}$ & $\mathrm{X}$ & $\mathrm{X}$ & $\mathrm{X}$ & $\mathrm{X}$ & $\mathrm{X}$ \\
\hline Absorption of liquids & $\mathrm{X}$ & $\mathrm{X}$ & -- & $\mathrm{X}$ & $\mathrm{X}$ & $\mathrm{X}$ & $\mathrm{X}$ \\
\hline HEPA filter \\
immobilization
\end{tabular}

FDC $=$ Functional design criteria

HEPA $=$ High-efficiency particulate air

LLW $=$ Low-level waste

WRAP $=$ Waste Receiving and Processing

TITLE 1 TRU loaded in 208-L drums and supercompacted into "hockey pucks;" puck core sampled and weighed; pucks loaded in 208-L drums.

FINAL

TRU loaded in 208-L drums; waste is not supercompacted.

\section{LLW COMPACTION}

CDR LLW loaded into 208-L drums and supercompacted; liquid collection tanks beneath compactor; loaded into 314-L drums; drums weighed.

ENG STUDY LLW supercompacted and loaded into 314-L drums; liquid collection tank beneath compactor; drums weighed.

TITLE 1 LLW loaded into 208-L drums and supercompacted; drums weighed.

FINAL LLW loaded into 314-L drums and supercompacted; drums weighed.

\section{Particulate Immobilization}


CDR Particles sampled and characterized; mixed with solidification agent (e.g., Portland cement) in small container; cured; packaged in 208-L drum. Capability: Particles below 10 micrometers and more than $1 \%$ of waste or if below 200 micrometers and more than $15 \%$ of waste; two containers per shift.

ENG STUDY Particles sampled and characterized; mixed with immobilization agent (e.g., cement, Envirostone) in 1- to 2-L container; cured; packaged in 208-L drum.

Capability: Glovebox sweepings or soil; two containers per day.

TITLE 1. Particles mixed with cement additives and immobilized in sealed container. Capability: Not given.

FINAL Particles mixed with cement additives and immobilized in sealed container.

Capability: Not given.

\section{Liquid Neutralization/Absorption/Solidification}

CDR Small amounts (less than 3.8-L) of corrosive liquids and sludges neutralized with soda ash or sulfamic acid; mixed to provide blending; neutralized aqueous or organics absorbed with solidification agent (e.g., cement or Envirostone); cured; packaged in 208-L drum.

Capability: Amount not given; neutralizing agents chosen to minimize overheating and fume generation.

ENG STUDY Small amounts (less than 3.8-L) of corrosive liquids neutralized with soda ash or sulfamic acid; mixed; placed in 1- to 2-L container; neutralized aqueous or organics absorbed with solidification agent (e.g., cement or Envirostone); cured; packaged in 208-L drum.

Capability: Up to eight 2-L containers per day; maximum volume ratio of 2:1 solidification agent to liquid.

TITLE 1 Liquids neutralized; mixed with cement additives; sealed in small container; rotated using jar mill; cured; packaged in 208-L drum. Capability: Not given.

FINAL Liquids neutralized; mixed with cement additives; sealed in small container; rotated using jar mill; cured; packaged in 208-L drum.

Capability: Not given. 
High-Efficiency Particulate Air (HEPA) Filter Immobilization

CDR Immerse in plasticizer; cure.

Capability: Filters less than $0.03 \mathrm{~m}^{3} ; 1$ filter per shift.

ENG STUDY Only shred/grout was considered for immobilization even though the shred/grout process was not chosen for WRAP 1 use.

Capability: Filters less than $0.03 \mathrm{~m}^{3}$; no rate given.

TITLE 1 Immobilized using a fixative and disposed as TRU or TRUM waste.

Capability: None given.

\section{Pyrophoric Material Treatment}

FDC Requires treatment of pyrophoric materials if possible.

CDR Combine material with cement in small mixer; store until cured.

ENG STUDY No consideration given to pyrophoric material handling.

TITLE 1 Pyrophoric material is to be removed from WRAP 1 without processing.

\section{Aerosol Can Handling}

CDR Puncture to depressurize; collect liquid in polyethylene container; treat in liquid sorption process described above; drained cans treated as other waste.

ENG STUDY Puncture to depressurize; treat in liquid sorption process described above; drained cans treated as other waste.

TITLE 1 Puncture and drain; send collected liquids and gases for storage outside WRAP 1; drained cans treated as other waste.

\section{Lead Decontamination}

CDR Lead bricks or small sheets transferred in a 208-L drum with a handling basket; cleaned in washdown chamber.

ENG STUDY Small items of lead transferred via a "French can" into decontamination area for cleaning with high-pressure water, steam, chemicals, and wiping materials.

TITLE 1 Lead decontamination was eliminated in design in favor of storage and treatment in WRAP 2A. 
HNF-SD-WM-RPT-288

Revision 0

\section{Reactive Materials}

CDR Not mentioned.

ENG STUDY Not mentioned.

TITLE 1 Reactive materials rendered nonreactive by a reaction with a liquid reagent. Neutralized liquid handled the same as other liquids described above.

\section{Shred-Grout}

CDR Not mentioned.

ENG STUDY Considered as an alternative but not chosen for WRAP 1 due to higher costs, added waste material, and added mechanical complexity.

The WIPP will accept only TRU waste. Any container that does not contain at least $100 \mathrm{nCi} / \mathrm{g}$ TRU will not be accepted. About $45 \%$ of the retrievably stored containers are suspected to contain less than $100 \mathrm{nCi} / \mathrm{g}$. The waste in these containers becomes a candidate for LLW disposal on the Hanford Site. Waste acceptance criteria also exist for this disposal.

Free liquids are not allowed for disposal in LLW at the Hanford Site. LLW containing hazardous components is categorized as mixed waste and subject to mixed waste requirements.

Waste drums processed in WRAP 1 determined to contain restricted, regulated, or unknown waste will be opened. The unacceptable waste will be removed and sampled as required. Depending on the nature of the waste, it may be managed in WRAP 1 on a limited basis or repackaged for storage pending availability of treatment or disposal facilities.

Any treatment used in WRAP I will be performed in the restricted waste management (RWM) glovebox. These treatments consist of small-scale liquid and corrosive material neutralization, liquid absorption or solidification, particulate immobilization, HEPA filter encapsulation, and deactivation. Standard techniques that will be used in these processes in WRAP 1 include the following operations.

Acidic or alkaline liquids and corrosive materials, as determined by prior sampling and analysis, will be transferred to the RWM glovebox. A predetermined amount of neutralizing reagent will be added to the container and mixed with the liquid or corrosive material to neutralize it. The attainment of a neutral $\mathrm{pH}$ will be verified inside the glovebox.

Neutralized aqueous liquids and dry cement will be added to a plastic container in predetermined proportions for solidification. After mixing, the plastic containers will be allowed to stand while the solidified waste cures. After curing, selected containers will be physically inspected to verify that the liquid has solidified. The treated waste product then will be loaded out of the glovebox and routed directly to NDANDE as part of certification before shipment. 
If the aqueous liquid is determined from laboratory analysis not to be amenable to solidification using cement, it will be mixed with a solid absorbent using the same process equipment and materials used for absorbing organic liquids. The product then will be shipped to continued storage until treatment capabilities exist.

Organic liquids will be mixed with absorbent solids, such as vermiculite, diatomaceous earth, or conwed pads. The treated waste product will be loaded out of the glovebox and shipped to continued storage until a treatment process exists.

Particulates such as diatomaceous earth, ash, and soil will be received in the RWM glovebox and mixed with water and dry cement. The treated waste product will be loaded out and routed directly to NDA/NDE as part of certification before shipment.

The HEPA filters will be macro-encapsulated in the RWM gloveboxes. After the encapsulation agent cures, the treated waste product will be loaded out and routed directly to NDA/NDE as part of certification before shipment.

Any reactive materials will be routed to the RWM glovebox and reacted using the appropriate technique. After the material has been reacted, it will be loaded out of the glovebox and routed directly to NDA/NDE as part of certification before shipment.

References: WHC-SD-W026-FDC-001, Waste Receiving and Processing (WRAP) Facility Module 1 Functional Design Criteria (Mayancsik 1994); Waste Receiving and Processing Facility Module 1 Preliminary Design Report (UE\&C 1992); WHC-SD-W026-SDRD-001, Supplemental Design Requirements Document, Project W026 (Weidert 1993); WHC-SD-W026-SAR-001, Waste Receiving and Processing (WRAP) Module 1 Preliminary Safety Analysis Report (Olson 1994); WHC-SD-W026-PLN-007, WRAP Module 1 Treatment Plan (Mayancsik 1995); WRAP Part B Permit Application (Lerch 1993).

\section{Packaging.}

Bases: TRUPACT-II (DOE/WIPP 1989); 49 CFR 173, "Shippers--General Requirements for Shipments and Packagings;" WIPP WAC (WIPP 1996).

Source: $\quad$ WHC-SD-W026-FDC-001, Waste Receiving and Processing (WRAP) Facility Module 1 Functional Design Criteria, Sections 2.0, 2.2.1, and 2.2.8 (Mayancsik 1994).

The WRAP 1 Facility will be capable of handling 208-L drums, drum overpacks, standard waste boxes, and small waste boxes (such as a B-25 burial box). The containers will be shipped meeting the requirements of the TRUPACT II Safety Analysis Report for Packaging (Nupac 1989) and transportation requirements specified in 49 CFR, "Transportation" requirements. The facility will be able to load and unload TRUPACT II trailers, trucks, and vans. 
The certified TRU 208-L waste drums will be assembled into seven packs and loaded into a TRUPACT II cask, two packs per cask. The standard waste boxes will be loaded into TRUPACT II casks, two standard waste boxes per cask. The LLW/LLMW waste drums and boxes will be loaded onto trucks and sent to long-term storage eisewhere or for onsite disposal.

References: $\quad$ TRUPACT II Safety Analysis Report for Packaging (Nupac 1989); 49 CFR 173; WHC-SD-W026-FDC-001, Waste Receiving and Processing (WRAP) Facility Module 1 Functional Design Criteria (Mayancsik 1994); WHC-SD-W026-SDRD-001, Supplemental Design Requirements Document, Project W026 (Weidert 1993); WIPP WAC (WIPP 1996).

\section{Waste Characterization.}

Bases: WIPP waste acceptance criteria (WTPP 1996); TRUPACT-II (DOE/WIPP 1989); RCRA.

Source: $\quad$ WHC-SD-W026-FDC-001, Waste Receiving and Processing (WRAP) Facility Module 1 Functional Design Criteria, Section 2.2.7 (Mayancsik 1994); WHC-SD-W026-SDRD-001, Supplemental Design Requirements Document, Project W026, Section 3.3 (Weidert 1993).

Before the waste will be accepted for shipment, the shipper requires that it be carefully identified. The TRUPACT-II Transportation Criteria (DOE/WIPP 1989) are specific about how the waste is to be described and identified. Before the WIPP will bury waste, every precaution must be taken to ensure that the waste meets established requirements. The WIPP waste acceptance criteria are specific about identifying the waste before shipment.

Characterization is the process of obtaining enough information about the waste to properly classify, certify, and transport it. The primary methods of characterization are as follows:

1. Process history (existing records)

2. Non-destructive assay (random sample)

3. Non-destructive examination (radiography, again, random sample) This stage will also provide data to justify extending the time that $\mathrm{CH}$ TRU waste can be stored.

4. Head space gas analysis

5. Remote detection (raman spectroscopy and laser ablation techniques are proposed). 


\section{Revision 0}

6. Physical sampling and laboratory analysis. Contents are opened in a glovebox (if required). The examination would include segregation, weighing, chemical analysis, and inspections required to further quantify the waste attributes.

Certification has been an integral part of WRAP 1 since its inception. By definition, certification incorporates procedures and criteria to document waste type, labeling, and packaging before disposal (or long-term storage-20 years-until a disposal site is available). Table 8-11 presents a waste characterization historical overview for WRAP 1.

Table 8-11. Waste Receiving and Processing Module 1 Waste Characterization Historical Overview.

\begin{tabular}{|l|c|c|c|c|c|c|}
\hline & $\begin{array}{c}\text { Program Plan } \\
\text { (Duncan } \\
\text { 1991) }\end{array}$ & $\begin{array}{c}\text { WRAP 1 Eng } \\
\text { Study } \\
\text { (RHO 1985) }\end{array}$ & $\begin{array}{c}\text { CDR (Rieck } \\
1990\end{array}$ & $\begin{array}{c}\text { WRAP 2 Eng } \\
\text { Study (Pauly } \\
1990)\end{array}$ & Title 1 design & Final design \\
\hline Assay & -- & $\mathrm{X}$ & $\mathrm{X}$ & $\mathrm{X}$ & $\mathrm{X}$ & - \\
\hline NDE/NDA & -- & $\mathrm{X}$ & $\mathrm{X}$ & $\mathrm{X}$ & $\mathrm{X}$ & $\mathrm{X}$ \\
\hline Dose rates & $\mathrm{X}$ & -- & -- & -- & $\mathrm{X}$ & - \\
\hline Quantitics & $\mathrm{X}$ & - & -- & -- & - & -- \\
\hline Fissile materials & $\mathrm{X}$ & -- & -- & -- & -- & -- \\
\hline Hazardous materials & $\mathrm{X}$ & -- & -- & -- & -- & - \\
\hline Swipe & -- & - & $\mathrm{X}$ & -- & -- & - \\
\hline Core drill sample & -- & -- & -- & -- & $\mathrm{X}$ & - \\
\hline Visual & -- & -- & -- & $\mathrm{X}$ & $\mathrm{X}$ & $\mathrm{X}$ \\
\hline Open/sort & -- & -- & -- & $\mathrm{X}$ & $\mathrm{X}$ & $\mathrm{X}$ \\
\hline Radiological verification & -- & -- & -- & $\mathrm{X}$ & $\mathrm{X}$ & -- \\
\hline
\end{tabular}

NDE $/ N D A=$ Nondestructive examination/nondestructive assay

WRAP $=$ Waste Receiving and Processing

Waste will be sampled in accordance with EPA SW-846 (EPA 1995). Deviations may be made to this method if the radioactive nature of the waste dictates or difficulty is encountered during sampling. The objective of the WRAP 1 is to certify $\mathrm{CH}$ drums and boxes to the applicable waste acceptance criteria for transport and disposal (CH TRU at WIPP and LLW at the Hanford Site). Incoming drums that cannot be certified to each criterion will be opened in WRAP 1 and the contents sorted, characterized, and repackaged into new drums. Incoming standard waste boxes that cannot be certified will be returned to the generator for storage until WRAP $2 \mathrm{~A}$ (or $2 \mathrm{~B}$ ) is operational.

Physical sampling purpose: 
1. Provide statistical confirmation of the capabilities of other characterization methods, especially remote sensing. This should be accomplished through random sampling of the first 100 drums processed by WRAP 1, and maintained by random sampling of an estimated $1 \%$ of remaining drums.

2. Provide quantitative analysis of "authoritative" samples where remote methods leave unanswered questions. An authoritative sample, as defined by EPA SW-846 (EPA 1995), is not a random sample. In this case, it is a sample from a specifically identified package about which more information is needed. Samples of this type should be anticipated for fewer than one-half of $1 \%$ of all drums processed.

References: WTPP/DOE-069, Waste Acceptance Criteria for the Waste Isolation Plant (WIPP 1996); WAC 173-303, "Dangerous Waste Regulations;" Nupac TRUPACT II-SAR (Nupac 1989); WHC-EP-0223, Characterization Plan for Stored Contact Handled Transuranic Waste (Anderson 1989).

\section{Storage}

Basis: WHC-EP-0363, Solid Waste Program Plan (Duncan 1991).

Sources: $\quad$ WHC-SD-W026-FDC-001, Waste Receiving and Processing (WRAP) Facility Module I Functional Design Criteria, Sections 2.2.1 and 2.2.8 (Mayancsik 1994).

Storage is provided in the WRAP 1 Facility for incoming and outgoing containers in the Receiving/Shipping Area. Provisions are made for 210 drums (either 208-L or overpacked in salvage drum) and 8 boxes (no larger than $2.4 \mathrm{~m}$ long by $1.5 \mathrm{~m}$ wide by $1.5 \mathrm{~m}$ high. A further breakdown of this total shows 100 incoming drums and 42 incoming boxes and 110 outgoing drums and 6 outgoing standard waste boxes.

The expected incoming (receiving) load size is 18 drums or two boxes. The outgoing (shipping) load size for TRU is 42 drums ( 6 seven-packs) or 6 standard waste boxes. The outgoing load size for LLW is 18 drums or 2 boxes. Storage capacity is then provided for 4 loads of incoming drums plus a cushion of 28 drums, 2 loads of incoming boxes, 1 load of TRU drums, plus a cushion of $1 / 2$ load, 1 load of TRU standard waste boxes plus one-third of a load, $22 / 3$ loads of LLW drums, and 1 load of LLW boxes.

References: $\quad$ Nupac TRUPACT II-SAR, TRUPACT II Safety Analysis Report for Packaging (Nupac 1989); WHC-EP-0063-4, Hanford Site Solid Waste Acceptance Criteria (Willis 1993); WHC-SD-W026-FDC-001, Waste Receiving and Processing (WRAP) Facility Module 1 Functional Design Criteria (Mayancsik 1994).

\section{Liquid Waste}


Bases: HDW-EIS (DOE 1987); WHC-SD-W026-CDR-001, Conceptual Design Report, Waste Receiving and Processing Facility Module 1, Project W-026 (Rieck 1990).

Source: $\quad$ WHC-SD-W026-FDC-001, Waste Receiving and Processing (WRAP) Facility Module 1 Functional Design Criteria, Section 2.2.9 (Mayancsik 1994).

The WRAP 1 Facility is designed to handle solid TRU waste; therefore, no liquids are expected to be part of the input waste stream. However, liquids could be introduced to the process system through equipment maintenance, equipment leaks that may contain liquids, decontamination agents, fire protection systems, etc. Many of these sources were considered in WHC-SD-W026-CDR-001, Conceptual Design Report, Waste Receiving and Processing Facility Module 1, Project W-026 (Rieck 1990) and subsequent preliminary design activities. During preliminary design efforts, a waste minimization study was included as part of the assessment process. This study examined the various potential liquid waste streams and made the following recommendations.

1. Eliminate the decontamination process enclosure in favor of using manual decontamination methods that "obviate the need for many services including process steam, a large quantity of process water, decontamination chemicals, waste water treatment chemicals and the collection, storage and treatment systems that they demand."

2. Eliminate the floor drain collection system used for fire protection and cleaning water in favor of "mopping up" in case of inadvertent water from sprinklers, roof leaks, or facility cleaning efforts.

The design criteria have been altered to consider these recommendations.

The basis for eliminating or minimizing liquid waste is given in state and federal laws requiring or requesting waste minimization, and the need for this approach is given in WHC-SD-W026-CDR-001, Conceptual Design Report, Waste Receiving and Processing Facility Module 1, Project W-026 (Rieck 1990); WHC-SD-W026-FDC-001, Waste Receiving and Processing (WRAP) Facility Module 1 Functional Design Criteria (Mayancsik 1994), and Supplemental design requirements. Table 8-12 presents a liquid waste historical overview for WRAP 1.

References: WHC-SD-W-026-PSE-001, Preliminary Safety Evaluation for Waste Receiving and Processing Facility Module 1 Project W-026 (Joyce 1993); DOE Order 6430.1A, General Design Criteria (DOE 1989); WHC-SD-W026-FDC-001, Waste Receiving and Processing (WRAP) Facility Module 1 Functional Design Criteria, Sections 2.2.1 and 2.2.8 (Mayancsik 1994); WRAP 1 Title 1 Design Report (UE\&C 1992); Engineering Study for Waste Receiving and Processing (WRAP) Facility (Pauly 1990); Internal memo to J. A. Swenson (Roberts 1991). 


\section{Revision 0}

Because the WRAP 1 design will not include processing capability for large volumes of liquid waste, action plans for any such waste generated (or discovered in the waste stream) are as follows (in order of preference).

1. Collect and dispose of waste into the tank farms liquid waste system.

2. Collect and store for processing in the WRAP 2 modules.

3. Solidify and dispose of through the WRAP 1 module.

\section{NDA/NDE Systems}
Bases: DOE Order 5820.2A, Radioactive Waste Management (DOE 1988a); WIPP WAC (WIPP 1996).

Source: $\quad$ WHC-SD-W026-FDC-001, Waste Receiving and Processing (WRAP) Facility Module I Functional Design Criteria, Sections 2.2.3 and 2.2.4 (Mayancsik 1994).

Table 8-12. Waste Receiving and Processing Module 1 Liquid Waste Historical Overview.

\begin{tabular}{|l|c|c|c|c|c|c|}
\hline & $\begin{array}{c}\text { Program Plan } \\
\text { (Duncan } \\
1991)\end{array}$ & $\begin{array}{c}\text { WRAP 1 Eng } \\
\text { Study } \\
\text { (RHO 1985) }\end{array}$ & $\begin{array}{c}\text { CDR (Rieck } \\
1990)\end{array}$ & $\begin{array}{c}\text { WRAP 2 Eng } \\
\text { Study (Pauly } \\
1990)\end{array}$ & $\begin{array}{c}\text { Title I } \\
\text { design }\end{array}$ & $\begin{array}{c}\text { Final } \\
\text { design }\end{array}$ \\
\hline Process & $\mathrm{X}$ & $\mathrm{X}$ & $\mathrm{X}$ & $\mathrm{X}$ & $\mathrm{X}$ & $\mathrm{X}$ \\
\hline Generate & -- & - & $\mathrm{X}$ & $\mathrm{X}$ & - & - \\
\hline Ship & -- & -- & $\mathrm{X}$ & -- & $\mathrm{X}$ & $\mathrm{X}$ \\
\hline
\end{tabular}

WRAP $=$ Waste Receiving and Processing

A prime mission of the WRAP Facility is to characterize and certify waste. This work will be accomplished primarily through NDE/NDA techniques. The original study for the use of such equipment was done in 1988 by WHC (Gilles 1993), and the equipment was specified during the design phase by United Engineers and Constructors (UE\&C). UE\&C also completed an NDE/NDA technology assessment on the chosen equipment. The assessment examined uncertainties and alternatives as summarized in the following paragraphs.

TRU waste is defined as waste containing certain alpha emitters that require special disposal techniques. The only practical method of determining the amount of such materials in the waste is nondestructive analyses. The requirements for such determinations are based on DOE Order 5820.2A, Radioactive Waste Management (DOE 1988a) and WIPP/DOE-069, Waste Acceptance Criteria for the Waste Isolation Pilot Plant (WIPP 1996).

All drums and boxes will be scanned through both NDE and NDA systems. For drum assays, an automated guided vehicle is used to guide the drum from receiving or storage through the automated NDE and two-phase NDA scanning to either waste processing or back to storage. For box scanning, boxes are transferred from receiving or storage to the NDE unit, between NDE 
and NDA units, and from the NDA unit to waste processing or back to storage manually using a forklift.

Drum and box NDE will use real-time radiography to ascertain the material contents of the waste. Also, a linear array will be used in the drum system to provide an image of the entire drum. The drum units will handle 208-L and 314-L drums. The box unit is for boxes up to 1.5 by 1.5 by $2.4 \mathrm{~m}$. The real-time radiography system consists of an $\mathrm{x}$-ray generation unit and a high-resolution imaging system, manipulation system, radiation shielded enclosure, transport system, and control console, which is interfaced for remote operation from the plant control room. This system will be used to ascertain noncompliant waste such as free liquids and compressed gas cylinders. Video and audio records are made during the NDE.

Drum and box NDA consists of two measurement elements. First, the drum will be measured on a passive active neutron counter where passive neutron counting is used to detect and measure the quantities of uranium, plutonium, cerium, and californium isotopes. Second, the assay station uses gamma energy analysis to match the gamma ray energies. High-resolution germanium detectors measure the gamma ray attenuations for determining ${ }^{233} \mathrm{U},{ }^{238} \mathrm{Pu},{ }^{237} \mathrm{~Np}$, ${ }^{241} \mathrm{Am},{ }^{243} \mathrm{Am}$, and fission activation products. Counting data are automatically stored using bar code scanning for identification. An NDE/NDA historical overview for WRAP 1 is presented in Table 8-13.

Table 8-13. Waste Receiving and Processing Module 1 Nondestructive Examination/Nondestructive Assay Historical Overview.

\begin{tabular}{|l|c|c|c|c|c|c|}
\hline & $\begin{array}{c}\text { Program Plan } \\
\text { (Duncan } \\
\text { 1991) }\end{array}$ & $\begin{array}{c}\text { WRAP 1 Eng } \\
\text { Study } \\
\text { (RHO 1985) }\end{array}$ & $\begin{array}{c}\text { CDR (Rieck } \\
\text { 1990) }\end{array}$ & $\begin{array}{c}\text { WRAP 2 Eng } \\
\text { Study (Pauly } \\
1990)\end{array}$ & Title I design & Final design \\
\hline Passive/active neutron & $\mathrm{X}$ & $\mathrm{X}$ & $\mathrm{X}$ & $\mathrm{X}$ & $\mathrm{X}$ & $\mathrm{X}$ \\
\hline Gamma energy analysis & -- & $\mathrm{X}$ & -- & - & $\mathrm{X}$ & $\mathrm{X}$ \\
\hline $\begin{array}{l}\text { Real time } \\
\text { radiography/radioscopy }\end{array}$ & $\mathrm{X}$ & $\mathrm{X}$ & $\mathrm{X}$ & $\mathrm{X}$ & $\mathrm{X}$ & $\mathrm{X}$ \\
\hline Segmented gamma scanner & $\mathrm{X}$ & -- & $\mathrm{X}$ & $\mathrm{X}$ & $\mathrm{X}$ & $\mathrm{X}$ \\
\hline Fission products activation & -- & -- & $\mathrm{X}$ & $\mathrm{X}$ & $\mathrm{X}$ & $\mathrm{X}$ \\
\hline Eddy current & $\mathrm{X}$ & $\mathrm{X}$ & -- & - & -- & -- \\
\hline Ultrasonic & $\mathrm{X}$ & $\mathrm{X}$ & -- & - & -- & -- \\
\hline
\end{tabular}

WRAP $=$ Waste Receiving and Processing

References: WHC-SD-W026-CDR-001, Conceptual Design Report, Waste Receiving and Processing Facility Module 1, Project W-026 (Rieck 1990); DOE Order 5820.2A, Radioactive Waste Management (DOE 1988a); WIPP-DOE-069, Waste Acceptance Criteria for the Waste Isolation Pilot Plant (WIPP 1996).

Data Systems. 
HNF-SD-WM-RPT-288

Revision 0

Source: $\quad$ WHC-SD-W026-FDC-001, Waste Receiving and Processing (WRAP) Facility Module I Functional Design Criteria, Section 2.2.10 (Mayancsik 1994).

Distributed Control Computer System

WHC-SD-WM-TI-291, Waste Receiving and Processing (WRAP) Functional Design Criteria, Section 3.6, "Process Control and Data Acquisition" (Christie 1987)

WHC-SD-W026-CDR-001, Conceptual Design Report Waste Receiving and Processing Module 1, Project W-026, pp. 54-58 and Appendix C (Rieck 1990).

Instrumentation and Central Control Area

WHC-SD-WM-TI-291, Waste Receiving and Processing (WRAP) Functional Design Criteria, Section 3.6, "Process Control and Data Acquisition"

(Christie 1987)

WHC-SD-W026-CDR-001, Conceptual Design Report Waste Receiving and Processing Module 1, Project W-026, pp. 54-58 and Appendix C (Rieck 1990)

\section{NDE/NDA}

WHC-SD-WM-TI-291, Waste Receiving and Processing (WRAP) Functional Design Criteria, Section 3.2 (Christie 1987)

WHC-SD-W026-CDR-001, Conceptual Design Report Waste Receiving and Processing Module 1, Project W-026, pp. 52-53 and Appendix C (Rieck 1990).

Data Logging and Acquisition, Bar Code Reader/Labeler

WHC-SD-WM-TI-291, Waste Receiving and Processing (WRAP) Functional Design Criteria, Sections 3.1 and 3.2 (Christie 1987)

WHC-SD-W026-CDR-001, Conceptual Design Report Waste Receiving and Processing Module 1, Project W-026, pp. 54-58 and Appendix C (Rieck 1990).

\section{Characterization Data Control and Validation}

WHC-SD-WM-TI-291, Waste Receiving and Processing (WRAP) Functional Design Criteria, Section 3.6, "Process Control and Data Acquisition" (Christie 1987)

WHC-SD-W026-CDR-001, Conceptual Design Report Waste Receiving and Processing Module 1, Project W-026, pp. 54-58 (Rieck 1990). 
HNF-SD-WM-RPT-288

Revision 0

Automated Stacker/Retriever

See Specification.

Computerized Supervisory Process Control (Process Automation) Process Management System

WRAP Engineering Studies, Vol. V, Waste Processing System Functional Analysis Study (UE\&C 1991), p. 9, 5.1.16 "Appropriate information may be electronically transferred"

WHC-SD-WM-TI-291, Waste Receiving and Processing (WRAP) Functional Design Criteria, Section 3.6, "Process Control and Data Acquisition," and Section 2, "Proposed Changes to FDC" (Chriștie 1987)

WHC-SD-W026-CDR-001, Conceptual Design Report Waste Receiving and Processing Module 1, Project W-026, p. 54-58 and Appendix C (Rieck 1990).

\section{Project Requirements.}

\section{Permits}

Bases: RCRA; WAC 173-303, "Dangerous Waste Regulations;" 40 CFR 61, "National Emission Standards for Hazardous Air Pollutants;" WAC 246-247, "Radiation Protection - Air Emissions;" WAC 173-400, "General Regulations for Air Pollution Sources;" WAC 173-460, "Controls for New Sources of Toxic Air Pollutants."

Source: $\quad$ WHC-SD-W026-FDC-001, Waste Receiving and Processing (WRAP) Facility Module 1 Functional Design Criteria, Sections 2.0, 2.1.3, 2.2.7, and 3.10 (Mayancsik 1994).

TRU solid waste is a category of waste not included in the jurisdiction of RCRA or WAC 173-303. Ecology does not define specific requirements for the disposal of TRU solid waste; DOE Order 5820.2A (DOE 1988a) defines disposal requirements for this waste.

The WRAP 1 Facility will provide capabilities to perform NDE/NDA, drum opening and contents sorting, waste volume reduction via compaction, processing, and limited treatment to meet regulatory requirements for waste disposal. To operate, the WRAP 1 Facility must comply with the treatment regulations of RCRA and WAC 173-303 and environmental impacts or air emissions regulations in accordance with WAC 246-247, WAC 173-400, WAC 173-460, and 40 CFR 61. The currently planned TRU waste feed for WRAP 1 was retrievably stored and not dispositioned. Thus, handling of the waste is not under the jurisdiction of CERCLA requirements. 
All retrieved waste received at WRAP 1 will be characterized for dangerous and radionuclide constituents in accordance with RCRA and WAC 173-303 regulations. Limited treatment will be provided for noncompliant or regulated waste in the RWM glovebox. The treatment will be conducted in accordance with the WRAP 1 Part B Permit (Lerch 1993).

Because drums are only opened in gloveboxes, all airborne contaminants produced in WRAP 1 are expected to be contained in the process gloveboxes. Four gloveboxes are located in the process area and consist of TRU and LLW process lines, and TRU and LLW RWM gloveboxes. Because the RWM gloveboxes are the only place where individual waste packages will be opened and waste items treated, most of the toxic air emissions are expected to be generated in the RWM enclosures. Radioactive air emissions are expected in all gloveboxes.

The glovebox structures and penetrations are designed to confine the contaminants within Zone 1. Zone 1 and Zone 2 exhausts are ducted to their own HEPA filtration banks, each consisting of two stages of HEPA filters, before being combined and subsequently discharged to the atmosphere through the exhaust stack. Exhaust air from the gloveboxes also will flow through push-pull filters before passing through the two-stage HEPA filters.

The exhaust stack will be the emission point for ventilation Zone 1 (gloveboxes) and Zone 2 (process area room). All the ventilation air with the potential to contain contaminants will be exhausted through the exhaust stack.

References: WHC-SD-W026-FDC-001, Waste Receiving and Processing (WRAP) Facility Module I Functional Design Criteria (Mayancsik 1994); WHC-SD-W026-SDRD-001, Supplemental Design Requirements Document, Project W026 (Weidert 1993); WRAP Module I NESHAPS Notice of Construction; WRAP I Title I Design Report (UE\&C 1992).

\section{Nuclear Safety}

Bases: DOE Order 6430.1A, General Design Criteria (DOE 1989).

Source: $\quad$ WHC-SD-W026-FDC-001, Waste Receiving and Processing (WRAP) Facility Module 1 Functional Design Criteria, Section 5.0 (Mayancsik 1994).

The WRAP 1 Facility will contain radioactive, including fissile, material. Protection of the public, onsite personnel, and facility workers from the consequences of system or component failures is required. Unacceptable safety consequences for the facility include nuclear criticality, instantaneous release of radioactivity in excess of limits, and exposure of personnel to ionizing radiation in excess of limits.

DOE Orders establish limits for individual and population exposure limits for credible accident conditions. 


\section{HNF-SD-WM-RPT-288 \\ Revision 0}

Analyses of postulated WRAP 1 accidents with inventory, location, meteorology, and population considerations show worker exposure limits, established by WHC-CM-4-46, are bounding.

Analysis of the WRAP 1 design and operation shows inadvertent criticality is unacceptable. Analysis of the WRAP 1 design and operation shows that the potential for such an event is acceptably low, falling well within the risk acceptance criteria. WRAP 1 .

The following is a reference collection for the Project bases information presented for

WRAP 1 Project Bases Reference List

WHC-SD-W-026-PSE-001, Preliminary Safety Evaluation for Waste Receiving and Processing Facility Module I Project W-026 (Joyce 1993)

DOE Order 6430.1A, General Design Criteria (DOE 1989)

Internal memo to J. A. Swenson (Roberts 1991)

WHC-SD-W-100-ES-001, Engineering Study for Waste Receiving and Processing (WRAP) Facility, Module 2 (Pauly 1990)

WHC-SD-W026-FDC-001, Waste Receiving and Processing (WRAP) Facility Module 1 Functional Design Criteria (Mayancsik 1994)

WHC-SD-W026-SDRD-001, Supplemental Design Requirements Document, Project W026 (Weidert 1993)

Nupac TRUPACT II-SAR, TRUPACT II Safety Analysis Report for Packaging (Nupac 1989)

WIPP/DOE-069, Waste Acceptance Criteria for the Waste Isolation Pilot Plant (WIPP 1996)

WAC 173-303, "Dangerous Waste Regulations"

WHC-EP-0223, Characterization Plan for Stored Contact Handled Transuranic Waste (Anderson 1989)

DOE/EIS-0113, Final Environmental Impact Statement, Disposal of Hanford Defense High-Level, Transuranic and Tank Wastes (HDW-EIS) (DOE 1987)

WHC-EP-0063-2, Hanford Site Radioactive Solid Waste Acceptance Criteria (Willis 1991) 
HNF-SD-WM-RPT-288

Revision 0

Hanford Federal Facility Agreement and Consent Order (Ecology et al. 1989)

DOE Order 5820.2A, Radioactive Waste Management (DOE 1988a)

WHC-EP-0225, Contact-Handled Transuranic Waste Characterization Based on Existing Records (Anderson 1991)

WHC-SD-W026-SAR-001, Waste Receiving and Processing (WRAP) Module 1 Preliminary Safety Analysis Report (Olson 1994)

DOE/DP-0015, Defense Waste Management Plan (DOE 1983)

HDW-EIS ROD (DOE 1988b)

WHC-EP-0363, Solid Waste Management Program Plan (Duncan 1991)

WHC-SD-W026-PLN-007, WRAP Module I Treatment Plan (Mayancsik 1995).

\subsubsection{LLMW Stabilization Treatment Program (Formerly WRAP 2A, Project W-100)}

Bases: WHC-SD-W100-RPT-001, Waste Receiving and Processing Module $2 A$ Termination of Design Closeout Report (Carlson 1995); WHC-EP-0063-4, Hanford Site Solid Waste Acceptance Criteria (Willis 1993); WHC-SD-W100-RD-001, Waste Receiving and Processing Module 2A Feed Specification (Kruger 1994); DOE/RL-95-35, Direct Disposal Team Report - Options for Treating and Disposing of Current and Future Mixed Waste Streams on the Hanford Facility (DOE-RL 1995).

Project/Program Background. The HDW-EIS (DOE 1987) was issued by the U.S. Department of Energy-Richland Field Office in December 1987. The purpose of the HDW-EIS was "to provide environmental input into the selection and implementation of final disposal actions for high-level, transuranic, and tank wastes located at the Hanford Site, Richland Washington, and into the construction, operation, and decommissioning of waste treatment facilities that may be required in implementing waste disposal alternatives".

To comply with the Council on Environmental Quality guidance, the HDW-EIS was written early in the decision-making process and before completion of detailed design for the WRAP Facility. The decision, documented in the HDW-EIS ROD (DOE 1988b), was to implement the preferred alternative discussed in the HDW-EIS. That alternative included design, construction, and operation of a facility to sort, process, and repackage retrievably stored and newly generated CH TRU solid waste for shipment to WIPP (DOE 1987). In addition to constructing the CH TRU WRAP Facility, the HDW-EIS also recommended a separate facility for the handling, processing, and certification of RH TRU waste (DOE 1987). 
The DOE, Ecology, and EPA reached an agreement in 1989 that established milestones for completion of certain activities addressed in the HDW-EIS (Ecology 1989a). This agreement, commonly referred to as the Tri-Party Agreement, includes a modular approach for the WRAP Facility. Planning was to construct the WRAP Facility in two principle modules. WRAP 1 is a validated 1991 Line Item under Project W-026 and is scheduled to become operational in 1997. It is administered under Tri-Party Agreement Milestone M-18-00. WRAP 2 was a validated 1994 Line Item under Project W-100. It is administered under Tri-Party Agreement Milestone M-19-00.

On May 18, 1987, the DOE issued an interpretive rule under the Atomic Energy Act of 1954, clarifying DOE obligations under RCRA, which is promulgated in Washington State by WAC 173-303. As a result, all low-level radioactive waste contaminated with dangerous waste under WAC is termed LLMW and subject to regulation by the DOE and Ecology. This LLMW requires separate waste management, disposition, and segregation. The WRAP 2A facility was to accommodate the requirements of RCRA and WAC for the treatment of LLMW.

While the combined WRAP 1 and 2 facilities are intended to be the functional equivalent of the CH TRU WRAP Facility and RH TRU Waste Processing Facility described in the HDW-EIS, the WRAP 2 concept has undergone several changes since the publication of the HDW-EIS because of changes in the Hanford Site waste management mission. All retrieved TRU waste is suspect TRU waste, which is likely to contain some LLW, which must be segregated as part of the processing. Similarly, newly generated waste will be a combination of TRU and LLW. In both cases, the LLW could be mixed with RCRA hazardous constituents to classify them as LLMW.

The Strategy Assessment Project W100, Waste Receiving and Processing (WRAP) Module 2, WHC-SD-W100-ES-005 (Lamberd 1991) recommended that the WRAP 2 Facility be divided into smaller functional projects, so it was split into WRAP $2 A$ and WRAP $2 B$. The primary functions of WRAP $2 A$ include processing, packaging, and certification of retrieved and newly generated CH LLMW using nonthermal treatment technologies. The primary functions of WRAP 2B include processing, packaging, and certification of retrieved and newly generated RH TRU wastes; retrieved and newly generated RH radioactive mixed waste; and handling, processing, repackaging, and certification for retrieved and newly generated $\mathrm{CH}$ TRU waste that cannot be processed in WRAP 1. A change request to Tri-Party Agreement Milestone M-19-00 was submitted in October 1991 (M-19-91-1) to charter the separation of WRAP 2 into 2A and 2B. However, this request was later deleted due to commercialization of WRAP $2 \mathrm{~A}$ waste treatment functions.

The WRAP 2A (Project W-100) proceeded to the 90\% Title 1 Definitive Design phase before it was terminated in December 1994. Justification for termination was primarily based on the DOE looking for less expensive alternatives for treating the waste (i.e., reducing or eliminating up-front capital obligations). The $90 \%$ Title 1 Definitive Design report was delivered to WHC by the contracted Architect-Engineer (Raytheon) during March 1995. A project closeout report was issued by the Projects Office during August 1995 (Carison 1995). Project design documentation is archived under the Project W-100 design file. 


\section{Revision 0}

The LLMW Stabilization Treatment Program was put into place to replace the treatment void created by WRAP $2 A$ design termination. The program delineates how and where the waste will be treated to meet Tri-Party Agreement Milestone M-19-00 obligations. A Tri-Party Agreement milestone change is needed to clarify the new direction for treating subject waste; thus, Change Request M-19-95-01 was submitted to regulatory agencies which will allow for alternative treatment methods or direct disposal options other than the WRAP 2 Facility.

Project/Program Scope. The Program is divided into three treatment option categories: direct disposal, onsite treatment, and commercial treatment. Each treatment option is described below and depicted in Table 8-14. A main element of the program is that each waste stream under an option shall have a contingency plan (e.g., fall-back option). This contingency plan is presented for each waste stream in Table 8-14.

Direct Disposal. This option category pursues the regulatory strategies/positions allowing for direct disposal of some mixed waste that was previously identified as requiring treatment. This is to be done through treatment variances, verifying that waste currently meets LDRs or petition acceptance of existing treatment performed on some waste.

Waste streams identified for direct disposal were determined from an intensive review of the existing mixed waste residing in the CWC. This review is documented in DOE/RL-95-35 (RL 1995). The major focus area was on waste streams: tank farms backlog soils, tank farm backlog debris, 183-H Basin solidified liquid, $183-\mathrm{H}$ crystalline solids, $183-\mathrm{H}$ sludge, and the 183-H miscellaneous waste. Several other miscellaneous waste streams were reviewed but only on a cursory level. The conclusion from the Direct Disposal Team Report (DOE-RL 1995) is as follows.

- Tank farms backlog soil waste ( $\approx 900$ drum equivalents)--Demonstrate to Ecology that waste meets LDRs. 
Table 8-14. Contact-Handled Low-Level Mixed Waste Stabilization Treatment Program Options. (2 sheets)

\begin{tabular}{|c|c|c|c|c|}
\hline $\begin{array}{l}\text { Treatment } \\
\text { option }\end{array}$ & Waste stream & What has to be done to treat the waste & Where would it be performed & $\begin{array}{l}\text { Contingency plan If primary option } \\
\text { fails }\end{array}$ \\
\hline \multirow[t]{3}{*}{$\begin{array}{l}\text { Direct } \\
\text { disposal }\end{array}$} & 1A $183 \mathrm{H}$ solidified liquid & $\begin{array}{l}\text { Obtain Ecology/EPA treatment } \\
\text { variance for formic acid (U123) and } \\
\text { acceptance of existing solidification } \\
\text { treatment. Dispose in radioactive } \\
\text { mixed waste landfill. }\end{array}$ & $\begin{array}{l}\text { CWC and radioactive mixed waste } \\
\text { landfill }\end{array}$ & $\begin{array}{l}\text { Default to } \mathrm{CT} \text { contract under the } \\
183-\mathrm{H} \text { Basin waste category. }\end{array}$ \\
\hline & $\begin{array}{l}\text { Backlog soils ( } 770 \text { dnums, } 5 \text { boxes); } \\
\text { tank farm soil; } 2 \mathrm{~A} \text { ETF } \mathrm{NH}, \mathrm{Na} \\
\text { sulfate powder ( } 50 \% \text { ), ( (ank } \\
\text { dependent, F001-5 on'y); } \\
\text { investigation-derived waste }\end{array}$ & $\begin{array}{l}\text { Demonstrate to Ecology/EPA subject } \\
\text { waste meets LDR treatment standards } \\
\text { and dispose in radioactive mixed waste } \\
\text { landfill. }\end{array}$ & $\begin{array}{l}\text { ETF and radioactive mixed waste } \\
\text { landfill }\end{array}$ & $\begin{array}{l}\text { Default to CT contract under the } \\
\text { 9A Particulate/Sludge category. }\end{array}$ \\
\hline & State-orly waste & $\begin{array}{l}\text { Verify waste designation and dispose } \\
\text { per applicable regulations. }\end{array}$ & Radioactive mixed waste landfill & $\begin{array}{l}\text { Default to CT contract under } \\
\text { applicable waste stream. }\end{array}$ \\
\hline \multirow[t]{4}{*}{$\begin{array}{l}\text { Onsite } \\
\text { Treatment }\end{array}$} & $\begin{array}{l}\text { 5A1 elemental mercury } \\
5 \mathrm{~A} 2 \text { mercury particulate } \\
\text { (90\%) (less than } 260 \mathrm{mg} / \mathrm{kg} \mathrm{Hg}) \\
\text { SC2 lead chemicals/solutions } \\
\text { 9C contained liquids }\end{array}$ & $\begin{array}{l}\text { Treat waste using RCRA/WAC } \\
\text { specified or BDAT treatments } \\
\text { (amalgamation, chemical precip., } \\
\text { deactivation), grout stabilize residues } \\
\text { to meet other RCRA/WAC/PA } \\
\text { requirements (as applicable) and } \\
\text { dispose in radioactive mixed waste } \\
\text { landfill. Minimal capital investment } \\
\text { and can be performed using standard } \\
\text { laboratory scale equipment. }\end{array}$ & $\begin{array}{l}\text { WRAP } 1 \text { would be best option, or } \\
\text { other permitted TSD facility. These } \\
\text { are laboratory-scale treatments and } \\
\text { volumes. }\end{array}$ & $\begin{array}{l}\text { Default to storing waste until enough } \\
\text { volume is accumulated making it } \\
\text { practical for future CT (see CT SA2 } \\
\text { category). Some of this waste may } \\
\text { need repackaging before CT. }\end{array}$ \\
\hline & $\begin{array}{l}\text { 5Cl radioactive elemental lead } \\
\text { (majority in boxes from Shippingport) }\end{array}$ & $\begin{array}{l}\text { Obtain Ecology/EPA concurrence for } \\
\text { macro-encapstlation of lead using } \\
\text { sealed polyethylene containers. } \\
\text { Encapsulate waste and dispose in } \\
\text { radioactive mixed waste landfill } \\
\text { (NOTE: PA rot an issue). }\end{array}$ & $\begin{array}{l}2706 \mathrm{~T} \text { would be best option, or other } \\
\text { permitted TSD facility. }\end{array}$ & $\begin{array}{l}\text { Default to CT contract under a } \\
\text { Radiosctive Elemental } \mathrm{Pb} \text { Treatment } \\
\text { option. }\end{array}$ \\
\hline & $\begin{array}{l}\text { Backlog debris }(1,200 \text { drums, } \\
200 \text { boxes) } \\
\text { 1D } 183 \mathrm{H} \text { misc. waste (debris) } \\
\text { 9B heterogeneous debris } \\
\text { (many boxes, } 5 \text { by } 5 \text { by } 9 \text { ft, was } \\
\text { bounding case) } \\
5 \mathrm{~A} 3 \mathrm{Hg} \text { cont. debris } \\
5 \mathrm{C} 3 \text { lead cout. debris }\end{array}$ & $\begin{array}{l}\text { Obtain Ecology/EPA concurrence for } \\
\text { macro-encapsulation of debris using } \\
\text { sealed polyethylene containers. NDA } \\
\text { waste to verify for mobile } \\
\text { radionuclides content with respect to } \\
\text { the PA. Waste without PA issues, } \\
\text { encapsulate the waste and dispose in } \\
\text { radioactive mixed waste landfill. } \\
\text { Waste with PA isstes, add encapsulate } \\
\text { with grout addition (teased capability) } \\
\text { and dispose in radioactive mixed waste } \\
\text { landfill, or encapsulate without grout } \\
\text { and dispose in GIF vaults. }\end{array}$ & $\begin{array}{l}\text { WRAP } 1 \text { to NDA and } 2706 \mathrm{~T} \text { to } \\
\text { perform treatment. Some large items } \\
\text { would need to be processed. }\end{array}$ & $\begin{array}{l}\text { Default to CT contract under a Debris } \\
\text { Treatment option. }\end{array}$ \\
\hline & 1D $183 \mathrm{H}$ misc. waste, (sandblast grit) & $\begin{array}{l}\text { Obtain Ecology/EPA treatment } \\
\text { variance for formic acid (U123). } \\
\text { Procure leased stabilization treatment } \\
\text { capability to treat waste to } \\
\text { RCRA/WAC/PA requirements. } \\
\text { Disposc trated waste in radioactive } \\
\text { mixed waste landfill. }\end{array}$ & $\begin{array}{l}\text { 2706T would be best option, or other } \\
\text { permitted TSD facility. }\end{array}$ & $\begin{array}{l}\text { Default to CT contract under the } 9 \mathrm{~A} \\
\text { Particulate/Sludge category. }\end{array}$ \\
\hline \multirow[t]{2}{*}{$\begin{array}{l}\text { Compmercial } \\
\text { freatment }\end{array}$} & $\begin{array}{l}\text { SA2 mercury chemical/particulate } \\
\text { (10\%), ( } 2260 \mathrm{mg} / \mathrm{kg} \text { Hg) } \\
\text { NOTE: This waste was removed } \\
\text { from WRAP } 2 \text { A scope. }\end{array}$ & $\begin{array}{l}\text { Procure commercial treatment services } \\
\text { to treat waste to RCRA/WAC/PA } \\
\text { requirements (i.e., retorting/roasting } \\
\text { and stabilization). Dispose treated } \\
\text { waste in radioactive mixed waste } \\
\text { landfill. }\end{array}$ & $\begin{array}{l}\text { At the awarded contract site. Issue } \\
\text { another contract when ample volume } \\
\text { is accumulated. }\end{array}$ & $\begin{array}{l}\text { Default: Build onsite } \\
\text { retorting/roasting capability to treat } \\
\text { the waste, or store waste indefuritely. }\end{array}$ \\
\hline & $\begin{array}{l}\text { 1B } 183 \mathrm{H} \text { crystalline solids } \\
\text { IC } 183 \mathrm{H} \text { sludge }\end{array}$ & $\begin{array}{l}\text { Obtain Ecology/EPA treatment } \\
\text { variance for formic acid (U123). } \\
\text { Procure commercial stabilization } \\
\text { treatment services to treat waste to } \\
\text { RCRA } W A C / P A \text { requirements. } \\
\text { Dispose treated waste in radioactive } \\
\text { rixed waste landfill. }\end{array}$ & At the awarded contract site. & $\begin{array}{l}\text { Default: Build onsite stabitization } \\
\text { capability to treat the waste, or store } \\
\text { waste indefinitely. }\end{array}$ \\
\hline
\end{tabular}


Table 8-14. Contact-Handled Low-Level Mixed Waste Stabilization Treatment Program Options. (2 sheets)

\begin{tabular}{|c|c|c|c|c|}
\hline $\begin{array}{l}\text { Treatment } \\
\text { option }\end{array}$ & Waste stream & What has to be done to treat the waste & Where would it be performed & $\begin{array}{l}\text { Contingency plan If primary option } \\
\text { fails }\end{array}$ \\
\hline $\begin{array}{c}\text { Commercial } \\
\text { Treatment }\end{array}$ & $\begin{array}{l}\text { 2A ETF } \mathrm{NH}_{2} / \mathrm{Na} \text { sulfate powder } \\
\text { (50\%) (tank dependent, F001-5 and } \\
\text { others) } \\
\text { 2B ETF/TEDF ion-exchange } \\
\text { resin } \\
9 \mathrm{~A} \text { particulate and sludge }\end{array}$ & $\begin{array}{l}\text { Procure commercial stabilization } \\
\text { treatment services to troat waste to } \\
\text { RCRA/WAC/PA requirements. } \\
\text { Dispose treated waste in radioactive } \\
\text { mixed waste landfill. }\end{array}$ & At the awarded contract site. & $\begin{array}{l}\text { Default: Build onsite stabilization } \\
\text { capability to treat the waste, or store } \\
\text { waste indefinitely. }\end{array}$ \\
\hline
\end{tabular}

$\begin{array}{ll}\text { BDAT } & \text { Best demonstrated available technology } \\ \text { CT } & =\text { Commercial treatmont } \\ \text { CWC } & =\text { Central Waste Complex } \\ \text { Ecology } & =\text { Washington State Department of Ecology } \\ \text { EPA } & =\text { U.S. Environmental Frotection Agency } \\ \text { ETF } & =\text { Effluent Treatruent Facility } \\ \text { GTF } & =\text { Grout Treatment Facility } \\ \text { LDR } & \text { Land disposal restrictions } \\ \text { NDA } & =\text { Nondestructive assay } \\ \text { PA } & =\text { Performance assessment } \\ \text { RCRA } & \text { Regource Conservation and Recovery Act } \\ \text { RMW } & =\text { Radioactive mixed waste } \\ \text { TEDF } & =\text { Treated Effluent Disposal Facility } \\ \text { TSD } & =\text { Treatment, storage, and disposal } \\ \text { WAC } & =\text { Washington Administrative Code } \\ \text { WRAP } & =\text { Waste Receiving and Processing }\end{array}$

- Tank farms backlog debris waste ( 21,200 drums and 200 boxes)-- Pursue Ecology agreement on a plan to use macroencapsulation.

- $\quad 183-\mathrm{H}$ Basin solidified liquid waste $(\approx 2,700$ drums)--Pursue Ecology and EPA approval of a formic acid combustion treatment variance. Pursue acceptance for the solidification or stabilization method already performed on the waste.

- $\quad 183-\mathrm{H}$ Basin crystalline solids waste $(\approx 4,400$ drums $)-$-Pursue Ecology and EPA approval of a formic acid combustion treatment variance. Pursue stabilization in grout to accommodate other treatment requirements.

- $\quad 183-H$ Basin sludge waste ( $~ 4,600$ drums)--Pursue Ecology and EPA approval of a formic acid combustion treatment variance. Pursue stabilization in grout to accommodate other treatment requirements.

- $\quad$ 183-H Basin miscellaneous waste ( $\approx 900$ drums)--Pursue a macro-encapsulation treatment option.

The tank farms backlog soils and 183-H Basin solidified liquid waste streams were determined to be the only waste streams responsive to direct disposal initiatives (i.e., disposal without further treatment). All other waste streams would require treatment (under current regulatory policy) before disposal. 
Additional small waste streams were identified as candidate direct disposal waste streams after the findings of the Direct Disposal Team Report (DOE-RL 1995) were issued. These include some state-only streams, investigation-derived waste (CERCLA/RCRA past-practice characterization), some 200 East Area Effluent Treatment Facility ammonium/sodium sulfate powder waste, and tank farms soil waste (analogous to the tank farms backlog soils waste stream). These waste streams are described in further detail in WHC-SD-WM-TP-442, Sampling and Analysis Plan for Mixed Waste Treatment (Josephson 1996). These waste streams will be further characterized to verify their applicability for direct disposal.

Onsite Noncommercial Treatment. This option category pursues the capability to treat some mixed waste at the Hanford Site using the established work force and facilities. The main logic for selecting which waste to treat onsite was determined from the following criteria.

- Waste that will require substantial further characterization and/or sorting before treatment should be considered for onsite treatment (e.g., lab packs). Because this type of waste must be extensively handled before treatment, it is prudent to pursue treatment at the same time.

- Waste that can be treated using treatment methods or technologies that require only minimal capital improvements to initiate actual waste treatment should only be considered (e.g., debris macroencapsulation). This alleviates DOE's large capital investment liabilities for treatment facilities but still retains some onsite treatment capability for uncertainties in the waste treatment program.

- Small volume waste streams that require specialized treatment should be considered for onsite treatment if the treatment capability exists (i.e., WRAP 1) or requires only minimal capital improvements to initiate treatment (i.e., 2706-T Facility).

Other influencing factors include treatment costs (is treating subject waste stream onsite competitive with that of commercial treatment), treatment timing (can treatment begin earlier than other options), worker safety (reducing hazards to onsite personnel), and union obligations.

Commercial Treatment. This option pursues the capability to procure commercial mixed waste stabilization treatment services. The scope/requirements of the Program's commercial mixed waste stabilization treatment activity will be represented in the request for proposal (RFP) for procuring commercial stabilization treatment services.

The intent of commercial stabilization treatment is to shelter the DOE from large up-front capital expenditures for treatment facilities by passing the obligation to the commercial treater (referred to as the Vendor hereafter), and to take advantage of competitive bid pricing to achieve the lowest treatment costs in conjunction with reducing onsite liabilities.

The commercial stabilization treatment contract would have provisions to treat virtually all waste streams originally designated for the WRAP 2A Facility, including the waste that may 
HNF-SD-WM-RPT-288

Revision 0

default from the other options. The maximum waste volume to be treated under the contract is nominally $2,000 \mathrm{~m}^{3}$ per year; however, the most probable waste volume to be treated under the contract is nominally $950 \mathrm{~m}^{3}$ per year. This is based on a contract extending 10 years (one 5-year contract, and five 1-year extensions) and treatment beginning September 30, 1999. The classification, quantity, and containerization of the mixed waste for treatment is functionally compatible with the stabilization treatment contract scope.

The Vendor would have up to 5 years to prepare for waste treatment. It is mandatory that treatment begin by September 30, 1999, to meet the Tri-Party Agreement M-19-00 Milestone requirements. The Vendor can propose earlier treatment start dates; however, there is no assurance that funding will be available for early treatment. Initiation of waste treatment is contingent on completion of the NEPA process by the Vendor. The Vendor is to allow for the cost of performing an environmental assessment in its bid proposal. If an EIS is mandated, the Vendor is to negotiate costs with the DOE. All facility installation, testing, and permitting activities will be the responsibility of the Vendor.

The scope of the stabilization treatment service procurement requires the treatment Vendor to transport the waste to its treatment facility, treat the waste, and produce a final waste form certified for disposal. The Vendor will be responsible for meeting all regulatory requirements regarding waste transportation, waste treatment, waste analysis, and waste disposal certification. The Vendor will transport the final waste form to the Hanford Site where it will be disposed.

The following paragraph provides a summary of activities to date. Early in 1995, it was decided there was sufficient interest to issue an RFP to commercially treat the non-thermally treatable LLMW inventory (existing and projected) at the Hanford Site. An original RFP was issued on August 11, 1995, and three prospective treatment Vendors submitted their bid proposals on October 27, 1995. The proposals were evaluated by the procurements Technical Review Team for technical responsiveness and WHC Procurement for cost analysis/management reviews. All three proposals were determined to be technically responsive and WHC Procurement submitted the requests for Best and Final Offer to each prospective Vendor on January 16, 1996. The Best and Final Offers were received from each Vendor on January 30, 1996, from which WHC Procurement determined the lowest priced Vendor and submitted the award contract to RL on March 5, 1996, for concurrence. On April 20, 1996, RL declined to approve the contract award and submitted the rejection letter to WHC (Valdez 1996). Westinghouse Hanford Company Procurement terminated the procurement activity on May 21, 1996, with notification to each prospective Vendor. At the time of this revision, WHC is awaiting formal direction from RL regarding the commercial stabilization treatment activity; until that time, WHC will concentrate its attention on the other two previously mentioned path-forwards.

Additional small waste streams were identified as candidate direct disposal waste streams after the findings of the Direct Disposal Team Report (DOE-RL 1995) were issued. These include some state-only streams, investigation-derived waste (CERCLA/RCRA past-practice characterization), some 200 East Area Effluent Treatment Facility ammonium/sodium sulfate powder waste, and tank farms soil waste (analogous to the backlog soils waste stream). These waste streams are described in further detail in WHC-SD-WM-TP-442, Sampling and Analysis 
Plan for Mixed Waste Treatment (Josephson 1996). These waste streams will be further characterized to verify their applicability for direct disposal.

Waste Characterization. Waste to be treated under the LLMW Stabilization Treatment Program (MWSTP) is designated as CH LLMW Category I and Category III as defined in WHC-EP-0063-4 (Willis 1993). The waste is further segregated to include only non-thermally treatable waste under the MWSTP scope. The thermally treatable portion is under the Commercial Thermal Treatment scope (see Section 6.4.4).

The waste feed/streams originally designated for the WRAP 2A facility transferred to the MWSTP. This waste is described in the WRAP 2A Feed Specification (Kruger 1994), which provides detailed waste characterization (e.g., chemical, radiological, and physical), volume summaries, container information, and generator information and history.

Two additional waste feeds/streams were added to the MWSTP during 1995. These waste feeds/streams originated from Tank Farm Operations and are named tank farm backlog soils and tank farm backlog debris. These two waste feeds/streams are described in the Direct Disposal Team Report (DOE-RL 1995). This waste is similar to existing waste feeds/streams found in the WRAP 2A Feed Specification (Kruger 1994) and will be regrouped with them during the next revision of the document.

The total projected waste quantity to be treated under the MWSTP is currently documented at approximately $27,600 \mathrm{~m}^{3}$ (Kruger 1994). This volume includes existing waste stored in the CWC, and the 30-year forecasted waste volume from waste generators. This volume has and will fluctuate dramatically depending on Hanford Site program changes (i.e., cancellation of the Grout and Hanford Waste Vitrification Plant facilities, offsite waste receipts, tank waste retrieval schedules, etc.). The outyear forecasts (e.g., beyond FY 2001) are based on very soft "speculative" generator data. With this consideration, the MWSTP has focused mainly on the existing waste stored at CWC and the first 5 years of the forecast data. This equates to approximately $9,380 \mathrm{~m}^{3}$ of waste through FY 1998.

\subsubsection{Commercial Thermal Treatment}

Sources: $\quad$ WHC-SD-W242-HC-001, Hazard Classification for the Thermal Treatment Facility, Project W-242 (Cillan 1993); Purchase Order No. MW6-SBV-357079, Thermal Treatment Services (Layman 1995); WHC-SD-WM-ES-198, Assessment of High Temperature Thermal Treatment Alternatives for Inclusion Into the Scope of the Hanford WRAP Facility (Place 1991); Internal Memorandum, Thermal Treatment of Hanford's RMW - Summary Discussion of Vendor Capabilities (Place 1992); WHC-SD-W242-ES-001, Hanford Site-Specific Engineering Study for the W-242 Thermal Treatment Facility (Place 1993); Contract No. MLW-SVV-073750, Task S-92-21, Treatment of Hanford's Mixed Waste Streams by INEL's Thermal Treatment Facilities (SAIC 1992); Contract No. MLW-SVV-073750, Task S-93-28, Treatment of Hanford RMW Streams by 
HNF-SD-WM-RPT-288

Revision 0

INEL's Waste Experimental Reduction Facility (WERF) Incinerator (SAIC 1993); WHC-EP-0063-4, Hanford Site Solid Waste Acceptance Criteria (Willis 1993).

Project Background. The purpose of the commercial thermal treatment contract is to provide treatment for radioactive waste management by thermal destruction of the hazardous constituents and subsequent immobilization of the radionuclides in a grouted or slag/glass final waste form. The commercial thermal treatment contract will provide treatment for alpha-contaminated PCB wastes regulated by the TSCA and for most listed and characteristic hazardous wastes restricted from land disposal under RCRA. In addition to TSCA regulated PCBs, a significant quantity of radioactive mixed waste containing RCRA F-coded, ignitable, and reactive organic constituents is presently stored or will be generated at the Hanford Site. Thermal destruction is required for TSCA regulated PCBs, and it is the best demonstrated available (treatment) technologies (BDAT) for RCRA LDR wastes. The DOE has indicated an interest in considering thermal treatment as a primary option for the treatment of radioactive mixed waste because significant volume reduction can be realized using thermal treatment.

Fiscal year 1996 is the fifth year of an activity to implement thermal treatment of Hanford Site radioactive mixed waste. A thermal treatment service contract was awarded in November 1995 (Layman 1995). Treatment is scheduled to begin by December 2000.

A strategy for this activity was initially established that involved consideration and assessment of three treatment options:

- Installation and operation of an onsite thermal treatment facility (Project W-242)

- Treatment at another DOE site

- Contracting for commercial thermal treatment.

Each of the above options was investigated to a varying extent and resulted in the issue of supporting documentation such as waste characterization studies, thermal treatment technology studies, site-specific preliminary engineering designs and cost estimates, and hazard classification analyses.

The option of onsite thermal treatment was investigated in FYs 1991 and 1992. An engineering study was performed to identify the preferred technologies for treating Hanford Site radioactive mixed waste (Place 1991). Two thermal treatment technologies were recommended for further evaluation and development for processing Hanford Site radioactive mixed waste. A plasma-arc furnace was recommended for treating TRUM, and a rotary kiln incinerator was recommended for treating LLMW. A site-specific thermal treatment facility engineering study was partially completed in FY 1992 (Place 1993). The technologies specified were those recommended in the above engineering technology study (Place 1991). The site-specific study includes a facility design and equipment layout, as well as capital and operating cost estimates. The WHC Safety organization also performed a hazard classification study which classified the thermal treatment facility was as a moderate-hazard facility (Cillan 1993). 
HNF-SD-WM-RPT-288

Revision 0

The option of sending the waste to other DOE sites for treatment was investigated in detail for the specific case of treatment at Idaho National Engineering Laboratory's Waste Experimental Reduction Facility, which was being refurbished and permitted for restart (SAIC 1992, 1993). The Idaho National Engineering Laboratory's WAC for offsite waste treatment is presently too limited to be of practical consideration. Other sites such as Savannah River Site and Oak Ridge National Laboratory, have thermal treatment facilities, but facility management at these sites have indicated that their facilities' projected waste acceptance is filled to capacity.

The option of commercial thermal treatment has demonstrated the most desirable combination of technical feasibility and economic attractiveness for the subject activity. Commercial thermal treatment was initially investigated by surveying the thermal treatment industry's capability and interest in addressing the Hanford Site radioactive mixed waste thermal treatment problem (Place 1992). In FY 1994, it was decided that industry interest and capability was sufficient to issue an RFP to treat the thermally treatable CH LLMW inventory (existing and projected), and a thermal treatment contract was awarded in November 1995. The company awarded the contract has proposed a vitrification process to thermally treat the combustible portion of the waste and will produce a glass/slag final waste form for that portion of the waste. The noncombustible portion of the waste will be separated and treated with either microencapsulation (grouting) or macroencapsulation.

The results derived from this procurement activity strongly suggest that thermal treatment by a commercial contractor provides acceptable technical risk accompanied by minimum financial risk to the DOE, and that a unit cost-based thermal treatment service is significantly more cost effective than the construction of an onsite thermal treatment facility (using capital funds).

The other two options (onsite facility and other DOE site facilities) will continue to be considered as possible alternatives until the uncertainty regarding privatizing thermal treatment can be eliminated. One concern has been that a commercial offsite treatment facility might not be capable of thermally treating alpha-contaminated waste. The company that was awarded the thermal treatment contract has indicated that the treatment of alpha-contaminated, non-TRU, radioactive mixed waste will be included in the design of their treatment facilities.

The activities planned for FY 1996 generally support the implementation of a thermal treatment service contract as defined in the purchase order (Layman 1995). 


\section{Project Scope.}

Waste Characterization. Administrative decisions regarding the nonacceptance of offsite waste for thermal treatment at the Hanford Site after October 1995 have stabilized estimates of the projected quantity of radioactive mixed waste that will require thermal treatment by a commercial facility. The Commercial Thermal Treatment facility will be designed to accept CH LLMW. The total projected quantity of waste to be treated is nominally $5,000 \mathrm{~m}^{3}$. Variability in containerization is also a parameter that will be designed into the Commercial Thermal Treatment facility. The classification, quantity, and containerization of the radioactive mixed waste projected for treatment, and the scope of waste acceptance defined for thermal treatment procurement, are functionally compatible.

Project Schedule. The thermal treatment contract was awarded in November 1995. The contractor will have 5 years to prepare for startup of the facility and must start by December 2000. The initial thermal treatment contract will extend for 5 years followed by five 1-year renewable contracts for a total contract time of 10 years. Initiation of waste acceptance for treatment is contingent on completion by the contractor of the NEPA process. All facility installation, testing, and permitting activities will be the responsibility of the thermal treatment contractor.

Project Functions. The scope of the Commercial Thermal Treatment service contract requires the thermal treatment contractor to transport the waste to its thermal treatment facility, thermally treat the waste, and produce a stabilized final waste form certified for disposal. The thermal treatment technology proposed by the contractor will produce a glass/slag final waste form for the combustible portion of the waste. The non-combustible portion of the waste will either be microencapsulated or macroencapsulated. The thermal treatment contractor will be responsible for meeting all regulatory requirements regarding waste transportation, waste treatment, waste analysis, and waste disposal certification. The thermal treatment contractor will transport the final waste form to the Hanford Site where it will be disposed.

\section{Project Requirements.}

Regulatory Compliance Requirements. Waste management operations at the Hanford Site are regulated by a number of agencies through a variety of regulations and administrative orders. The principal regulatory authorities include the DOE, Ecology, the EPA, DOH, and the DOT. In addition, state and local regulations specific to the locale of an offsite thermal treatment facility will be applicable.

The radioactive constituents in the waste are regulated by DOE Order $5820.2 \mathrm{~A}$ (DOE 1988a) that pertain to the management of LLW. The hazardous components in the waste are regulated by RCRA and the TSCA and the RCRA and TSCA implementing regulations contained in 40 CFR. The treatment criteria specified in 40 CFR 268, "Land Disposal Restrictions," and 40 CFR 761.70, "Incineration of PCBs and PCB Items," must be achieved. 
HNF-SD-WM-RPT-288

Revision 0

The treatment process shall generate a stabilized, solid ash/residue final waste form. All ash/residue resulting from thermal treatment of the waste shall be packaged and returned to the Hanford Site for disposal in accordance with WHC-EP-0063-4, Hanford Site Solid Waste Acceptance Criteria (Willis 1993) and DOT Regulations (49 CFR 171-179).

Air emissions from the Commercial Thermal Treatment facility will be in compliance with 40 CFR Part 61, "National Emission Standards for Hazardous Air Pollutants." An application for approval under 40 CFR 61.07 may be required for new facility construction. The application shall include technical information describing the proposed nature, size, design, operating design capacity, and method of operation of the source, including a description of any equipment to be used for control of emissions.

Resolution of the above regulatory concerns will primarily be the responsibility of the thermal treatment contractor.

NEPA. The NEPA regulations were developed to assess the impacts to the environment associated with given proposed actions. If a proposed action may be covered under an existing approved EIS or EA, the relevant EIS or EA could be revised to reflect the proposed action.

The EA is developed to discuss the environmental consequences of the proposed action and the alternatives to that action, including the consequences of accidents and routine operations, and the cumulative and long-term impacts. A discussion of the relationship of the proposed action to federal, state, and local land use plan, policies, and regulations is also discussed in the environmental assessment.

Recently, a draft environmental assessment for the action recommending a Finding of No Significant Impact was submitted to the DOE for review and approval.

\subsubsection{T Plant Facility (221-T Canyon and 2706-T Building)}

The T Plant Facility presently consists of two principle decontamination/treatment buildings, 221-T and 2706-T. Various support structures and storage pads are also present. The 221-T Building was built during 1943 and 1944 to extract plutonium from production reactor fuel. The plant performed this function until it was deactivated in 1956. Most of the original process equipment was subsequently removed. In 1957, T Plant was placed in service as a beta-gamma decontamination facility and a support complex for experiments or other operations requiring containment or isolation. The 2706-T Building was built during 1959 and 1960 to perform low-level radioactive decontamination of railroad equipment, buses, trucks, automobiles, road-building equipment, and plant process equipment. Both 221-T and 2706-T can be used to store waste items as needed. Although the respective facilities are generally handled separately, they are referred to as one facility herein because much of the engineering and safety documentation includes both buildings as a single unit. 
Facility Identification. T Plant was constructed in the mid-1940's to extract plutonium from production reactor fuel. The plant performed this function until it was deactivated in 1956. Most of the original process equipment was subsequently removed. In 1957, T Plant was placed in service as a beta-gamma decontamination facility and a support complex for experiments or other operations requiring containment or isolation. At present, it functions primarily as a treatment/decontamination and waste storage facility.

\section{Facility Scope.}

\section{Basis: WHC-SD-WM-ES-283, Long-Term Decontamination Engineering Study} (Geuther 1995).

T Plant Systems Engineering Team Studies. A series of $T$ Plant Systems Engineering Team studies to analyze technical, economic, and program issues pertinent to the need for performing high dose decontamination activities in the 221-T canyon have been completed. A review of the potential feed streams and current forecasted decontamination work scope for the canyon was performed. Three different alternates where explored to address the forecasted needs of decontamination activities at $T$ Plant.

The following is a list of the options:

- $\quad$ Alternative 1--Leave $T$ Plant as is and maintain current equipment acceptance criteria and throughput in the 2706-T and canyon areas

- $\quad$ Alternative 2--Change the current equipment acceptance criteria at 2706-T to allow an expanded range of feed stream

- $\quad$ Alternative 3--Along with an expanded 2706-T equipment acceptance criteria, as described in Alternative 2 above, provide facility upgrades that would allow increased throughput volumes.

Alternative 1 performs decontamination, sampling, sorting, repackaging, and shipping activities on sample augers, fleet equipment, miscellaneous process equipment, and LLMW at 2706-T. With current average estimates, the throughput capacity committed for 2706-T is $1,416 \mathrm{~m}^{3}$ a year. Alternative 2 performs decontamination, sampling, size reduction, sorting, repackaging encapsulation and shipping activities on augers, miscellaneous contaminated equipment, fleet equipment, CH LLMW, Plutonium-Uranium Extraction towers, and decontamination and decommissioning waste. To achieve the increased feed stream volume and functional capability, administrative changes to the 2706-T equipment acceptance criteria would have to be implemented. The majority of the changes necessary are centered around dose rate and fissile quantity. Alternative 3 performs decontamination, sampling, size reduction, sorting encapsulation, repackaging, shipping, and remote-handling capabilities. All the items covered in Alternative 2 are included in Alternative 3 plus the remote-handling capability of long-length contaminated equipment, TRU boxes, and decontamination and decommissioning waste. In analyzing the volumes of feed stream forecasted for $T$ Plant in Alternative 3, the majority of the 


\section{Revision 0}

increased feed stream comes in 2015 for decontamination and decommissioning of old facilities. This option also requires remote-handling capability which can be extremely costly.

After reviewing existing feed streams and projected feed streams, it appears that the need for a high dose decontamination capability is not needed at the present time (up to the next 10 to 15 years). A majority of the high dose feed stream projected for $T$ Plant in the near term was tank farm long- length contaminated equipment. The current recommendation for treatment of this feed stream is to use $2706-\mathrm{T}$ as the primary decontamination facility. The long-term feed stream forecasted for treatment at $\mathrm{T}$ Plant was primarily wastes generated from site decontamination and decommissioning activities predicted to commence in the outyears (2015 to 2023). This feed stream is also being analyzed as a stream for 2706-T. The recommended treatment of this waste and the facilities involved in the process should follow in the next few years. However, current feed stream and forecasted feed streams show a strong need for an LLW treatment facility. This appears to be a solid short- and long-term mission.

Until a viable mission for the T Plant canyon can be supported, major expenditures to provide the ability to perform high dose decontamination should be postponed. This would include current upgrades for secondary containment to meet regulatory requirements in 1999. With no compliant secondary containment system in place in 1999 , planning should begin now for eliminating feed streams that require secondary containment. A closer look should be given to any liquid currently in the canyon to find ways of eliminating it.

In conclusion, the studies suggested the following findings and recommendations.

- Based on current information, incorporate the new administrative limits defined in Table 1 in Alternative 2 into a revision of the equipment acceptance criteria for low-level decontamination at the 2706-T Facility (WHC-IP-1017 [Blackford 1995]). This revised acceptance criteria should be entered in the technical baseline documents.

- With the projected feed stream volumes, an effort needs to be made in recommending innovative approaches to increase throughput at the 2706- $\mathrm{T}$ Facility. This may require some minimal expenditures in the facility for upgrades to the ventilation system and other support systems.

- Because of the uncertainty of committed waste volume projections, future expenditures to maintain the capability to perform high volume liquid decontamination capability in the 221-T Canyon were not justified at this time. In addition, continued use of the 2706-T Building has been determined to be the most cost- effective alternative to serve as a centralized decontamination facility.

Administrative upgrades to 2706-T that increase the parameters of the acceptance criteria for material/waste handled in that facility would handle a large portion of the forecasted T Plant feed streams.

\section{Waste Types.}




\section{Revision 0}

Waste Types Handled at 221-T Canyon. The 221-T Facility is used for storage, sampling, and limited treatment of radioactive mixed and dangerous waste. The facility restricts introduction of alpha-emitters to control the personnel hazards associated with those radionuclides. However, higher-reading LLMW is currently being stored in the T Plant Canyon.

Waste Types Handled at 2706-T Building. The 2706-T Facility is restricted to low-level radioactive waste associated with decontamination activities. It also is used as a site to characterize low-level radioactive and mixed wastes.

\section{Interfaces.}

Facilities. The 2706-T Facility currently accepts waste from various Hanford Site sources and repackages/characterizes them in compliance with regulations. Prepared waste is then transported to the CWC for interim storage.

Vehicles. The T Plant has no special vehicular needs, except for transport of waste containers into and out of the facility. The facility has a waste container load/unload bay in the railcar tunnel that is used to place higher-reading waste containers into the canyon for storage or future treatment.

Facility Size. The 221-T Canyon is made of reinforced concrete and is $269 \mathrm{~m}$ long by $21 \mathrm{~m}$ wide by $23 \mathrm{~m}$ high. The building consists of the canyon, three galleries, one crane way, and a head-end facility. The canyon consists of 37 cells and 1 railroad tunnel entrance/exit. The cells are in a single row running the length of the canyon with 2 cells, designated left and right, comprising a $12-\mathrm{m}$ section. The building consists of $2012-\mathrm{m}$ sections. The canyon deck is about $12 \mathrm{~m}$ below a 1.0- to 1.2-m-thick concrete roof. Most of the cells are covered by four 3-m-thick reinforced-concrete blocks. Cover blocks for Cells $11 \mathrm{R}, 13 \mathrm{R}$, and $15 \mathrm{R}$ are $0.6 \mathrm{~m}$ thick and are covered with a 0.95 -cm-thick stainless steel decontamination pad. Each cover block is equipped with a lifting bail to allow the bridge crane to lift it for access to the cells. The railroad tunnel used to transport equipment into and out of the canyon, as well as for some decontamination, enters the plant at Cell $2 \mathrm{~L}$. A $4.8-\mathrm{m}$ wide by $6.7-\mathrm{m}$ high opening, covered by a motor-driven rolling steel door provides railroad canyon access.

Building 2706-T is a ground-level building that is $15 \mathrm{~m}$ wide by $20 \mathrm{~m}$ long by $8 \mathrm{~m}$ high and was constructed of prefabricated steel with 6-m-high side walls. Building 2706-T has openings on the west end that are fitted with roll-up metal doors. The larger door is $5 \mathrm{~m}$ high by $3.5 \mathrm{~m}$ wide, and is the entrance to the railroad pit area which is $16 \mathrm{~m}$ long by $5 \mathrm{~m}$ wide by $2 \mathrm{~m}$ deep. The other door is $3 \mathrm{~m}$ wide by $4 \mathrm{~m}$ high, and is the entrance to the automotive pit area which is $9 \mathrm{~m}$ long by $1.3 \mathrm{~m}$ wide by $1.8 \mathrm{~m}$ deep. Other entrances are present for personnel access. An overhead (10-ton) capacity crane is available for maintenance use and can travel the length of the building. The building has an exhaust stack on the southwest side where HEPA filtration and continuous instrument monitoring are provided. The inner building layout provides a large maintenance and decontamination work area. The building has been expanded to the west to include a control room area, auxiliary heater, and the controls of a fire suppression system. Also, four heat pump systems are available to provide heating and air conditioning. 
Facility Schedule. The T Plant is operational at this date and is funded to continue decontamination operations for the Hanford Site.

T Plant Facility Functions. In 1957, T Plant was placed in service as a beta-gamma decontamination facility and a support complex for experiments or other operations requiring containment or isolation. It now functions primarily as a treatment/decontamination and waste storage facility.

The T Plant decontamination/treatment capability is located in the 221-T and 2706-T Buildings and in various support structures and storage pads. The 2706-T Building operates as a low-level radioactive decontamination facility and is used to decontaminate railroad equipment, buses, trucks, automobiles, road-building equipment, and plant process equipment. Building 221-T provides services in radioactive and hazardous constituent decontamination of waste items and process equipment. Both 221-T and 2706-T can be used to store waste items as needed. The support structures and storage units are used for storage, sampling, and limited treatment of mixed and dangerous waste. These physically separated facilities will be handled together and referred to as the T Plant Facility for this baseline.

In addition to decontamination services, $T$ Plant performs the following activities:

- At the 221-T Canyon--Shippingport Pressurized Water Reactor fuel storage in the $\mathrm{T}$ Plant Canyon and storage of higher-level radioactive mixed waste in the canyon

- At the 2706-T Building--waste repackaging and certification.

Decontamination Services at 221-T Canyon. Equipment requiring decontamination services is received and unloaded from the canyon railroad tunnel. The unloaded item is placed on the deck for staging or repair and testing, on a decontamination pad for decontamination, or in one of the in-cell decontamination cells. Before decontamination, the chemical (constituents) and physical (size, shape, materials of construction) nature, and radioactive nature including isotopic breakdown (if possible), are assessed to determine which type of decontamination will be performed.

Decontamination services include chemical spray cleaning, abrasive cleaning, immersion cleaning, and cleaning by hand. Chemical spray cleaning is used to remove contaminants from equipment. Chemical spray cleaning employs acidic and basic chemical solutions which are alternately sprayed on the equipment between water rinse steps. The chemical spraying is repeated as necessary to provide the desired level of decontamination. Abrasive cleaning is used to remove contamination from the surface of equipment. Abrasive cleaning can employ high-pressure water application, dry sandblasting, or wet sandblasting. High-pressure water and wet sandblasting are used to remove caked-on contaminants from equipment which can then be further decontaminated by chemical decontamination. Dry sandblasting is typically not preferred due to airborne contamination and dust problems. Immersion cleaning employs tanks, known as thimbles, for emplacing pieces of equipment into a chemical bath. The thimble also has a steam service connection to heat the system during decontamination and an air service connection to 
provide sparging of the chemical solution. Each chemical bath is followed by a water rinse cycle. When dose rate permits, hand cleaning (wiping) is used to remove loose surface contaminants from equipment. Hand cleaning usually employs small amounts of nonhazardous cleaning agents.

Decontamination Services at 2706-T Building. Equipment requiring decontamination services at the 2706-T Building must meet the radiation/contamination levels for which the building is permitted. Most decontamination of rolling stock, vehicles, and equipment takes place either over the railroad pit, automotive pit, or a stainless steel pad.

Decontamination services include chemical decontamination, abrasive cleaning, steam cleaning, and cleaning by hand. Chemical decontamination includes both spray cleaning and immersion cleaning similar to the methods employed at the 221-T Canyon facility. Abrasive cleaning employs either a high-pressure pump unit for water, sand, or water, and sand application or a vacuum blaster which employs a vacuum to recycle dry abrasive particles reducing the spread of particulate and contamination. Steam cleaning employs a stream of steam expelled from a nozzle at the piece of equipment. Steam cleaning can also use detergents to enhance the capability of the steam cleaning system. When dose rate permits, hand cleaning (wiping) is used to remove loose surface contaminants from equipment. Hand cleaning usually employs small amounts of nonhazardous cleaning agents.

Shippingport Pressurized Water Reactor Fuel Storage at 221-T Canyon. Cell 2R in the 221-T Canyon is designed as a pool cell and is used as the Shippingport Pressurized Water Reactor Core II storage facility area. Cell $2 \mathrm{R}$ contains $723.66-\mathrm{m}$ irradiated blanket fuel assemblies stored underwater in a $4 \mathrm{~m}$ wide by $8.4 \mathrm{~m}$ long by $8.5 \mathrm{~m}$ deep (pool with a capacity of $190,000 \mathrm{~L}$. A catwalk above the pool cell allows for sampling and maintenance.

Higher-Level Radioactive Mixed Waste Storage at 221-T Canyon. Areas of the canyon deck and some of the canyon cells are used for storage and handling of radioactive waste awaiting decontamination or resulting from decontamination efforts.

Waste Repackaging and Certification at 2706-T Building. Low-level waste boxes and drums can be received, opened, sorted, segregated, and repackaged at the 2706-T Building. Verification of container contents can be provided as necessary. Sorting and segregation of unknown or poorly characterized waste allows for the proper characterization of wastes.

\section{Facility Requirements.}

Permits. The 221-T and 2706-T Facilities operate under Consent Order No. DE-91NM-177 for the Permitting of Liquid Effluent Discharges under WAC 173-216. The permit is dated February 1992.

The facilities are included in the Hanford Facility Part A Dangerous Waste Permit Application Form 3, Revision 2, for the T Plant Complex (TSD: T-2-7) (Lerch 1993). The Part B Dangerous Waste Permit Application is currently being prepared (WHC 1994). 
HNF-SD-WM-RPT-288

Revision 0

\subsubsection{Tri-Party Agreement Milestone M-91 Designated Scope}

8.2.3.1 Introduction. Tri-Party Agreement Milestone $M-33$ was established to: (1) begin the development of milestones necessary for the storage, treatment/processing, and disposal of Hanford Site solid wastes and hazardous materials; and (2) begin the development and incorporation of agreement modifications designed to aid in achieving integrated management of all aspects of Hanford Site cleanup.

A new major milestone, M-91 and its subelements, replaces Milestone M-33 and has been established to govern the acquisition of new facilities, the modification of existing facilities, or the modification of planned facilities necessary for the storage, processing, and disposal of Hanford Site TRU/TRUM, LLMW, and GTCIII waste. Milestone M-91 establishes the completion dates for most of its subelements.

8.2.3.2 Waste Types and Applicable M-91-00 Subelements. Milestone M-91 identifies specific solid waste types in its scope. These solid waste types and applicable M-91 subelements are discussed below.

Milestone M-91 Subfunctions Concerned with TRU and TRUM Processing. Since May 1970, solid waste classified as, or suspected of being, TRU waste has been packaged, labeled, and stored to be retrievable for at least 20 years. This inventory can be classified as either $\mathrm{CH}$ (less than $200 \mathrm{mrem} / \mathrm{h}$ at the container surface) or RH (greater than $200 \mathrm{mrem} / \mathrm{h}$ at the container surface). The RH TRU inventory is stored in trenches or caissons within the 200 Area burial grounds and a single burial ground outside the 200 Area known as Burial Ground 618-11. In addition, forecasted volumes of RH TRU waste are expected to be generated during completion of the Hanford Site cleanup mission.

The stored CH TRU and TRUM large container waste is located in four main burial ground sites in the 200 East and West Areas, namely Burial Grounds 218-W-3A, 218-W-4B, 218-W-4C, and 218-E-12B. In addition, forecasted volumes of CH TRU and TRUM in large containers will be expected to be generated during the Hanford Site cleanup mission.

The special $\mathrm{CH}$ TRU waste category includes waste items that will require unique and special considerations during processing. The stored $\mathrm{CH}$ special case waste items that constitute this category are classified waste, drums containing more than $200 \mathrm{~g}$ of ${ }^{238} \mathrm{Pu}$, drums of dirt from the Z-9 crib, drums weighing more than $454 \mathrm{~kg}$, and plutonium nitrate shipping containers. The forecast $\mathrm{CH}$ special case waste inventory would include waste items that are not amenable to processing in WRAP 1. This includes CH TRUM with a hazard classification of "reactive" (RCRA Code D003), and CH TRU and CH TRUM waste with a physical waste form consisting of soil or particulate.

The following M-91-00 subfunctions are concerned specifically with the processing of TRU and TRUM waste. 


\section{HNF-SD-WM-RPT-288}

Revision 0

Milestone M-91-01: Complete the acquisition of new facilities, modification of existing facilities, and/or modification of planned facilities necessary for storage and treatment/processing before disposal of all Hanford Site post-1970 TRU/TRUM. Date: December 2000.

Milestone M-91-02: Initiate processing of CH TRU/TRUM waste at WRAP/WRAP1 (CH, small container). Date: December 1998.

Milestone M-91-03: Submit Hanford Site TRU/TRUM Waste project management plan (PMP) to Ecology pursuant to Tri-Party Agreement Section 11.5. The Hanford Site TRU/TRUM Waste PMP will include all plan elements required by Tri-Party Agreement Action Plan Section 11.5. Approval of the TRU/TRUM PMP and accompanying Tri-Party Agreement change requests will establish all major project tasks and deliverables for treatment/storage of Hanford Site TRU/TRUM including commercial sector management, modification of existing facilities, and construction of new facilities. Date: June 2000.

Milestone M-91-04: Complete construction of small container CH TRU/TRUM retrieval facility(s) and initiate (Project W-113) retrieval of small container TRU/TRUM from 200 Area burial grounds. During initial facility operations, $\mathrm{CH}$, small container integrity will be evaluated and data used in the further development of the retrieval campaign. Date: September 2000.

Milestone M-91-05T: Complete and submit TRU/TRUM retrieval and processing facility engineering study/FDC Study to Ecology. The TRU/TRUM engineering/FDC study will cover activities/facilities not considered commercially viable as documented in the approved TRU/TRUM PMP and associated Tri-Party Agreement change requests. Date: December 2002.

Milestone M-91-06T: Award necessary privatized contracts for processing RH and large size TRU/TRUM. Date: September 2003.

Milestone M-91-07: Complete Project W-113 for post-1970 CH TRU/TRUM retrieval. Date: September 2004.

Milestone M-91-08T: Complete construction and initiate hot operations of RH and large size TRU/TRUM processing facility (a final acquisition schedule for this facility will be established as an interim milestone no later than December 2000). Date: June 2005.

Milestone M-91 Subfunctions Concerned with LLMW and GTCII Processing. The stored RH LLMW waste category consists of RH LLMW stored in the CWC or 200 Area burial grounds. This is waste generated between 1987 and 1995 that is both a RH low-level radioactive waste and a state-regulated dangerous waste. At least seven generators at the Hanford Site (Project W-320 Tank 241-C Sluicing, 222-S Laboratory, Hanford Grout Facility [or its replacement], Surplus Facilities, T Plant Building, PUREX, and Long-Length Equipment) are expected to generate RH LLMW during the next 30 years. Additional RH LLMW may be expected from additional facilities after they become surplus facilities. 
HNF-SD-WM-RPT-288

Revision 0

The stored CHLLMW large container waste consists of CH LLMW stored in the CWC or 200 Area burial grounds. This is waste generated between 1987 and 1995 that is both an RH low-level radioactive waste and a state-regulated dangerous waste. Six items were identified in Burial Grounds 218-E-10 and 218-W-4C. Items from PNNL and Knolls Atomic Power Shipyards are being stored in CWC Building 2403-WD. Only four generators consisting of Bettis Atomic Power Laboratory, Knolls Atomic Power Shipyards, Pluton-Uranium Extraction, and Hanford Grout Facility (or its replacement) are expected to generate CH LLMW in large containers during the next 30 years. Additional CH LLMW in large containers could be generated from facilities after they become surplus facilities.

Two generators, PNNL and the Hanford Site Surplus Facilities Program, are expected to generate GTCIII RH LLW and LLMW during the next 30 years. Additional GTCIII RH LLW could be generated from facilities after they become surplus facilities.

One generator, the Hanford Site Surplus Facilities Program, is expected to generate GTCIII CH LLW during the next 30 years. Five generators consisting of PNNL, Past Practice Remediation Projects, Portsmouth Gaseous Diffusion Plant, 222-S Analytical Laboratories, and the Hanford Site Surplus Facilities Program are expected to generate GTCIII CH LLMW during the next 30 years. Additional GTCIII CH LLW and LLMW may be generated from facilities after they become surplus facilities. The total projected waste volume of GTCIII CH LLMW is approximately $4,400 \mathrm{~m}^{3}$. The total projected waste volume of GTCIII CH LLW over the next 30 years is approximately $42,000 \mathrm{~m}^{3}$.

The following M-91-00 subfunctions are concerned specifically with the processing of LLMW.

Milestone M-91-09: Initiate operations at new CWC storage facilities (Project W-112). Date: June 1997.

Milestone M-91-10: Submit Hanford Site LLMW and GTCIII waste PMP to Ecology pursuant to Tri-Party Agreement Action Plan Section 11.5. The Hanford Site LLMW/GTCIII PMP will include all plan elements required by Tri-Party Agreement Action Plan Section 11.5. Approval of the LLMW/GTCII PMP and accompanying Tri-Party Agreement change requests will establish all major tasks and deliverables for treatment/storage/disposal of Hanford Site RH and large container CH LLMW, and storage of GTCIII waste including commercial sector management activities, construction of new facilities, and modification of existing facilities. Date: June 1999.

Milestone M-91-11T: Complete and submit LLMW treatment facility engineering study/FDC study to Ecology. The LLMW treatment facility engineering study/FDC study will cover activities/facilities not considered commercially viable as documented in the approved LLMW/GTCIII PMP and associated Tri-Party Agreement change requests. Date:

December 2000. 
Milestone M-91-12: Initiate thermal treatment of currently stored and newly generated CH LLMW. At least $600 \mathrm{~m}^{3}$ will be provided for treatment by December 2005. Date: December 2000.

Milestone M-91-13: Initiate disposal of CH LLMW. Date: June 2001.

Milestone M-91-14T: Award commercialization contract(s) for treatment of $\mathrm{RH}$ and large size LLMW in accordance with approved LLMW/GTCIII PMP and associated Tri-Party Agreement change requests. Date: October 2003.

Milestone M-91-15: Complete acquisition of facilities and initiate treatment of RH and large container (CH) LLMW. Date: June 2008.

\subsubsection{Waste Storage and Treatment Functions Associated with the Implementation of} Milestone M-91. Functions associated with storage and processing of the waste within the scope of Milestone M-91 are discussed below. Milestone M-91 includes PMPs for the treatment, storage, and disposal of the waste types of concern. The M-91 subelements include plans addressing the management of waste types and the implementation of specific projects.

RH Waste Storage (Applicable Milestones M-91-09 and -10). Newly generated RH TRU, LLMW, and GTCIII waste will be maintained in either shielded containers (so the package has a surface dose rate consistent with $\mathrm{CH}$ limits) or stored in shielded facilities that are remotely operated and maintained. Remote-handled waste currently located in caissons and retrievable storage trenches will continue to reside in these locations until processing capability exists. Waste that is processed and requires storage before final disposition will also be stored in either shielded containers (so the package has a surface dose rate consistent with $\mathrm{CH}$ limits or in shielded facilities that are remotely operated and maintained). Currently, there are no specific plans concerning the treatment of GTCIII waste.

RH TRU Waste Treatment (Applicable Milestones M-91-01, -06T, and -08T). It is expected that receipt of all RH TRU waste is to be by truck or rail in a cask whether it is waste directly from retrieval or from storage. The receiving function will have crane capability to remove the waste container within the cask from the transport vehicle. The cask will be loaded into a shielded area to minimize radiation exposure to workers. The cask load will be a sequence of specialized processes that allow separation of the waste item from the cask to minimize contamination of the cask. This will allow more expeditious decontamination and release of the cask for reuse.

Once the item is removed from the cask, any packaging (box, drum, plastic wrap, etc.) or overpack is removed from the item. Reuse of any overpack or packaging will be examined. Specialized processes to perform this function should be developed that allow separation of the waste items while minimizing contamination of any packaging or overpack. This would allow either reuse or their disposal as LLW (rather than TRU). Overpacks released for reuse will first be surveyed for contamination and undergo any decontamination processes necessary. Empty waste packaging or overpacks that are not reused are reduced in size through compaction, shredding, or other appropriate methods. This will significantly reduce the volume of LLW 
requiring disposal. The volume-reduced waste will be packaged to meet LLW disposal requirements. Any shielding associated with the waste item will be reused if possible. If it cannot be reused, it will be disposed of as waste. Lead shielding that cannot be reused will be repackaged suitable for interim storage as LLMW before final stabilization and disposition.

Once removed, the radioactive content of the waste will be determined. Radioactive content determination will provide the necessary information for certification of the waste as either TRU or LLW/LLMW.

Waste will be sorted to remove noncompliant items and those requiring further characterization from the primary feed stream. Sorting may also be required to reduce plutonium loading of some items to meet transportation limits. Size reduction will be performed for those large items that will not fit within approved TRU disposal containers.

Restricted waste management will process noncompliant items so they may be disposed at WIPP. This could include the following: depressurizing and draining of aerosol cans, neutralization of corrosive materials, liquid absorption/solidification, particulate immobilization, sample management, and a declassification of classified waste.

The RH TRU waste will be packaged into containers that meet the WIPP WAC, and the containers will be certified for disposal at WIPP. After packaging and certification functions are completed, the waste in its container will be placed in a cask and transferred to the shipping station. Waste will either be shipped to storage awaiting disposal at WIPP or will be loaded into shipping casks for immediate transfer to WIPP.

\section{Large Size CH TRU Waste Treatment (Applicable Milestones M-91-01, -06T, and} $\mathbf{- 0 8 T ) . ~ I t ~ i s ~ e x p e c t e d ~ t h a t ~ r e c e i p t ~ o f ~ a l l ~ l a r g e ~ s i z e ~ C H ~ T R U ~ w a s t e ~ i s ~ t o ~ b e ~ b y ~ t r u c k ~ o r ~ r a i l ~ w h e t h e r ~}$ it is waste directly from retrieval or from storage. The receiving function will have the capability to remove the waste container or overpack from the transport vehicle. The container or overpack will be loaded into a processing area to minimize contamination spread. The container or overpack will be separated from the waste item to minimize contamination of the container or overpack. This will allow more expeditious decontamination and release of the overpack for reuse or disposal of the container as LLW (rather than TRU). Overpacks released for reuse will first be surveyed for contamination and undergo any necessary decontamination processes. Empty waste containers or overpacks that are not reused are reduced in size through compaction, shredding, or other appropriate method. This will significantly reduce the volume of LLW requiring disposal. The volume-reduced waste will be packaged to meet LLW disposal requirements.

Waste will be assayed to determine the radioactive material content of waste. The assay will provide the necessary information for certification of the waste as either TRU or LLW.

Waste will be sorted to remove noncompliant items and those requiring further characterization from the primary feed stream. Sorting may also be required to reduce plutonium loading of some items to meet transportation limits. Size reduction will be performed for items 
that will not fit within approved TRU disposal containers (drums or standard waste boxes). Non-compliant items will be processed to meet the WIPP WAC. Noncompliant item processing could either occur at WRAP 1 or with the waste described in Section 6.4.5.3.6.

The CH TRU waste will be packaged into containers that meet the WIPP WAC and the containers will be certified for disposal at WIPP. After packaging is completed, the waste will be transferred to the shipping station. Depending on the quantity of waste requiring certification and the availability of WRAP 1, the container certification may either occur at WRAP 1 or at the M-33/M-91-designated facility.

Special Processing TRU Waste Treatment. Special processing of a portion of the $\mathrm{CH}$ TRU waste that cannot be accepted into WRAP 1 will be provided. This consists of classified waste, drums with more than $200 \mathrm{~g}$ of plutonium, containers with large quantities of soils and particulate, drums weighing more than $454 \mathrm{~kg}$, and reactive wastes. Special processing of this waste will allow for the certification of the waste for disposal at WIPP.

RH LLMW Treatment (Applicable Milestones M-91-10, -14T, and -15). It is expected that receipt of all RHLLMW is to be by truck or rail in a cask whether it is waste directly from storage or a generator. The receiving function will have the capability to remove the waste container within the cask from the transport vehicle. The cask will be loaded into a shielded area to minimize radiation exposure to workers. The cask load will be a sequence of specialized processes that allow separation of the waste item from the cask to minimize contamination of the cask. This will allow more expeditious decontamination and release of the cask for reuse.

Once the item is removed from the cask, any packaging (box, drum, plastic wrap, etc.) or overpack is removed from the item. Reuse of any overpack or packaging will be examined. Specialized processes to perform this function should be developed that allow separation of the waste items while minimizing contamination of any packaging or overpack. This would allow either reuse or their disposal as LLW (rather than LLMW). Overpacks released for reuse will first be surveyed for contamination and undergo any necessary decontamination processes. Empty waste packaging or overpacks that are not reused are reduced in size through compaction, shredding, or other appropriate methods. This will significantly reduce the volume of LLW requiring disposal. The volume-reduced waste will be packaged to meet LLW disposal requirements. Any shielding associated with the waste item will be reused if possible. If it cannot be reused, it will be disposed of as waste. Lead shielding that cannot be reused will be repackaged suitable for interim storage as LLMW before final stabilization and disposition.

Size reduction will be performed if needed to make large items more manageable and able to fit into smaller containers. Waste will be sorted to batch the waste according to processing requirements. Items requiring thermal treatment will be segregated from those requiring nonthermal stabilization. Stabilization will consist of adding a reagent to the waste to immobilize any hazardous constituents present. The contaminants are not removed or destroyed but the mobility of the contaminants is decreased by adding a stabilizing agent. Waste requiring thermal treatment will not be treated but will be repackaged for long-term storage. 
The RH LLMW will be packaged into containers for disposal. Waste will meet the acceptance criteria of the disposal site. Waste will either be transferred to storage awaiting disposal or will be transferred directly to disposal.

Large Size CH LLMW Treatment (Applicable Milestones M-91-10, -14T, and -15). It is expected that receipt of all large size CH LLMW is to be by truck or rail whether it is waste from storage or directly from a generator. The receiving function will have the capability to remove the waste container or overpack from the transport vehicle. The container or overpack will be loaded into a processing area to minimize contamination spread. The container or overpack will be separated from the waste item to minimize contamination of the container or overpack. This will allow more expeditious decontamination and release of the overpack for reuse or disposal of the container as LLW (rather than TRU). Overpacks released for reuse will first be surveyed for contamination and undergo any necessary decontamination processes. Empty waste containers or overpacks that are not reused are reduced in size through compaction, shredding, or other appropriate method. This will significantly reduce the volume of LLW requiring disposal. The volume-reduced waste will be packaged to meet LLW disposal requirements.

Size reduction will be performed to make the large items more manageable and able to fit into smaller containers. Waste will be sorted to batch the waste according to processing requirements. Items requiring thermal treatment will be segregated from those requiring nonthermal stabilization. Waste requiring stabilization will be packaged in containers no greater than 1.5 by 1.5 by $2.7 \mathrm{~m}$ to accommodate the CH LLMW stabilization program. Waste requiring thermal treatment will be packaged in drums to accommodate the $\mathrm{CH}$ thermal treatment program. Waste will be transferred to storage awaiting transfer to either stabilization or thermal treatment.

Specific Projects Included in the Scope of Milestone M-91. In addition to addressing the management of the above waste types, Milestone M-91 identifies some specific projects and processing activities for implementation. These specific projects and activities are discussed below.

Milestones M-91-04 and M-91-07 concern the implementation of Project W-113, Solid Waste Retrieval, Phase 1, described in detail in Section 6.2.1.

Milestone M-91-09 concerns the implementation of Project W-112, Hanford Central Waste Complex - Enhanced Radioactive Mixed Waste Storage, Phase V, described in detail in Section 6.3.3.

Milestone M-91-12 concerns the implementation of thermal treatment of CH LLMW described in detail in Section 6.4.3. 
HNF-SD-WM-RPT-288

Revision 0

\subsubsection{Disposal Facilities and Projects}

\subsubsection{LLW Burial Grounds}

The information presented in this section is from WHC-SD-WM-ISB-002, Solid Waste Burial Grounds Interim Safety Basis (Bendixsen 1995) unless otherwise referenced.

Since the initiation of the defense materials production mission in 1943, the Hanford Site has disposed or stored more than $600,000 \mathrm{~m}^{3}$ of solid radioactive waste. Disposal of radioactive waste at the Hanford Site burial grounds started in 1944. The LLW burial grounds are located at each of the 100 Area reactors, 200 East and West, 300 Area, and 600 Area. Before April 1970, all solid waste at the Hanford Site, regardless of radionuclide content or hazardous constituents, was placed in trenches and covered with earth. For the purpose of this document, only the active burial grounds located in the 200 East and West Areas will be covered in this section, as they fall under the scope of the Program.

Waste management regulations have changed considerably since waste generation began at the Hanford Site. Until 1970, the burial of Hanford Site solid waste was subject to relatively few restrictions, and all radioactive solid wastes were disposed in shallow land trenches. Beginning in May 1970, TRU waste was segregated from LLW and placed in burial grounds until 1987. In 1987, hazardous components of radioactive waste began to be regulated at the Hanford Site under the RCRA requirements for mixed waste at the CWC. The mixed waste generated after 1987 is stored in aboveground buildings until treatment and a permanent disposal are available. The LLW burial grounds that were closed, inactive, or retired before 1970 are covered under the environmental restoration contract.

Facility Identification. The active solid waste burial grounds consist of two areas in the 200 East Area and six in the 200 West Area. Active burial grounds distinguish those burial grounds currently in service (plus future expansion potential) from those burial grounds classified as inactive or retired. Within the active burial grounds, there may be open trenches and trenches that have been filled with waste and backfilled with soil. The total volume of waste in the active burial grounds is $321,846 \mathrm{~m}^{3}$, as of January 1995 .

Table 8-15 presents summary-level information on each active burial ground as of January 1995 .

Facility Scope. Radioactive wastes have been provided by onsite and offsite waste generators. Table 8-16 presents a chronology of the waste disposed of at the Hanford Site. Early waste streams included laboratory and/or construction wastes. As reactors and processing facilities came on-line, failed equipment and process wastes were added as waste streams. Now the waste streams consist of maintenance and cleanup from the facilities. The waste forms typically consist of paper, plastic, rubber, wood, glass, dirt, and metal. There is also a small amount of irradiated fuel wastes (categorized as RH TRU) placed within the burial grounds. The typical containers used for disposal of LLW were cardboard boxes, metal drums from 3.8 to $416.4 \mathrm{~L}$ in size, wood, 
HNF-SD-WM-RPT-288

Revision 0

concrete, metal, and fiber-reinforced plastic boxes. The boxes are made in various sizes to accommodate the waste items, and some waste is wrapped in plastic.

Table 8-15. Summary Information of Active Burial Grounds.

\begin{tabular}{|c|c|c|c|c|}
\hline Burial ground & Location & Opening date & Waste types & $\begin{array}{c}\text { Approximate waste } \\
\text { volume }\left(\mathrm{m}^{3}\right)^{*}\end{array}$ \\
\hline $218-\mathrm{E}-10$ & 200 East & 1960 & LLW & 21,856 \\
\hline $218-\mathrm{E}-12 \mathrm{~B}$ & 200 East & 1967 & LLW, MW, TRU & 99,260 \\
\hline $218-\mathrm{W}-3 \mathrm{~A}$ & 200 West & 1970 & LLW, MW, TRU & 100,752 \\
\hline $218-\mathrm{W}-3 \mathrm{AE}$ & 200 West & 1981 & LLW, MW & 24,582 \\
\hline $218-\mathrm{W}-4 \mathrm{~B}$ & 200 West & 1968 & LLW, TRU & 10,466 \\
\hline $218-\mathrm{W}-4 \mathrm{C}$ & 200 West & 1978 & LLW, MW, TRU & 16,782 \\
\hline $218-\mathrm{W}-5$ & 200 West & 1986 & LLW, MW & 48,149 \\
\hline $218-\mathrm{W}-6$ & 200 West & Future & Has not received waste & 0 \\
\hline
\end{tabular}

*January 1995.

$\mathrm{LLW}=\mathrm{Low}$-level waste

MW = Mixed waste

$\mathrm{TRU}=$ Transuranic

Table 8-16. Waste Chronology.

\begin{tabular}{|c|c|c|}
\hline Date & Waste type & Disposition \\
\hline 1940's to April 1970 & All types without distinction & $\begin{array}{l}\text { Burial of LLW, TRU waste, } \mathrm{MW} \text { in } \\
\text { trenches, backfilled. Covered storage of } \\
\text { RH waste packages in caissons }\end{array}$ \\
\hline \multirow[t]{2}{*}{ May 1970 to November 1984} & TRU & $\begin{array}{l}\text { Retrievable storage of TRU waste in } \\
\text { trenches, backfilled }\end{array}$ \\
\hline & $\begin{array}{l}\text { Other waste types: LLW, RH, } \\
\text { MW }\end{array}$ & Burial in trenches \\
\hline \multirow[t]{3}{*}{ To November 1987} & MW & Tracking system; ${ }^{1}$ burial in trenches \\
\hline & TRU & $\begin{array}{l}\text { Retrievable storage of TRU in trenches, } \\
\text { backfilled }\end{array}$ \\
\hline & Other waste types: LIW, RH & Burial in trenches \\
\hline \multirow[t]{2}{*}{1987 to present } & $\begin{array}{l}\text { MW, TRU, greater than Class C } \\
\text { LLW }\end{array}$ & $\begin{array}{l}\text { Aboveground storage in Central Waste } \\
\text { Complex }\end{array}$ \\
\hline & Irradiated fuel wastes & Retrievable storage \\
\hline
\end{tabular}


Table 8-16. Waste Chronology.

\begin{tabular}{|c|c|c|}
\hline Date & Waste type & Disposition \\
\hline & Other waste types: $\mathrm{LLW}, \mathrm{RH}$ & Burial in trenches \\
\hline
\end{tabular}

${ }^{1}$ Tracking system was initiated in 1985. Burial of MW was halted in 1987.

${ }^{2}$ small quantity of TRU waste remains uncovered (i.e., stacked in trenches but not backfilled) in the solid waste burial ground.

$$
\begin{aligned}
& \text { LLW }=\text { Low-level waste } \\
& M W=\text { Mixed } \\
& \text { RH }=\text { Remote-handled } \\
& \text { TRU }=\text { Transuranic }
\end{aligned}
$$

Transuranic waste has been packaged in sealed containers and segregated from LLW in retrievable storage trenches since May 1, 1970. Before that time, the TRU wastes were commingled and buried with the LLW. The creation of the TRU waste category in 1970 designated $10 \mathrm{nCi} / \mathrm{g}$ as the lower limit for TRU radionuclide content. This was because the capabilities for the detection of TRU isotopes were not available, and all waste from the onsite plutonium processing facilities (Plutonium-Uranium Extraction and PFP) was suspected to be

\begin{tabular}{|c|c|}
\hline & 218-E-10 \\
\hline & 218-E-12B \\
\hline & 218-W-3A \\
\hline & 218-W-3AE \\
\hline & $218-W-4 B$ \\
\hline • & $218-W-4 C$ \\
\hline • & $218-W-5$ \\
\hline$\bullet$ & $218-W-6$ \\
\hline
\end{tabular}
TRU and sent to retrievable storage within the burial grounds. In 1982, the limit was revised upward to the present value of $100 \mathrm{nCi} / \mathrm{g}$.

The active solid waste burial ground consists of the following areas:

Burial Ground 218-E-10. This burial ground has been in service since 1960 and has 17 trenches. The trenches are oriented north to south and contain RH and CH LLW. Trenches 09 and 12 contain some mixed waste. The waste in this burial ground has been received from the Plutonium-Uranium Extraction Facility, B Plant, and the $100 \mathrm{~N}$ Area. The waste was primarily received in large concrete boxes, with a few wooden boxes having been received. The boxes contained failed equipment and filters. Trench 09 was used before November 23, 1987, and still has room for a few boxes. This burial ground has received $21,856 \mathrm{~m}^{3}$ of waste.

Burial Ground 218-E-12B. This burial ground, in service since 1962, has been used primarily for LLW but does contain three trenches of TRU waste (trenches 16, 17 and 27). The burial ground has 40 trenches (most trenches are oriented in a north-to-south direction while 
Trench 94 is oriented from east to west). There are 39 filled trenches of which 2 are partially filled. Trench 94 is used for the disposal of U.S. Navy defueled submarine reactor compartments composed of various types of steel and lead shielding. Most of the waste received in this burial ground has been generated by facilities in the 200 East Area, with the exception of naval waste. This burial ground has received $99,261 \mathrm{~m}^{3}$ of waste.

Burial Ground 218-W-3A. This burial ground has been in service since 1970 and contains TRU waste, LLW, TRUM waste, and LLMW. Trenches 9 S, 01, 04, 05, 06, 08, 10, 15, and 17 contain LLW and TRU waste. Trench 14 has 10 large concrete boxes of low-level radioactive soil from a tank farm cleanup in 1973. Trench 17 contains TRU fiberglass-reinforced plastic plywood boxes related to the decommissioning of the weapons program. Trench $7 \mathrm{~S}$ contains waste from the cleanup effort at the Three-Mile Island Nuclear Plant. Some buried irradiated fuel elements are contained in Trench 08 . Trenches 40 and 49 contain stacked $\mathrm{CH}$ LLW equipment, large boxes, and drums. This burial ground has 57 trenches, one of which is only partially filled. This burial ground has received $100,752 \mathrm{~m}^{3}$ of waste.

Burial Ground 218-W-3AE. This burial ground was placed in service in 1981. Trenches 02 and 03 have received RH LLW. Trench 16 currently receives RH LLW. Trenches 05 and 10 are wide-bottom stacking trenches. Trench 26 was dug with a wide bottom to dispose of LLW railroad cars and large tanks. The trenches are oriented from east to west. This burial ground has received a total of $24,582 \mathrm{~m}^{3}$ of waste.

Burial Ground 218-W-4B. This burial ground was placed in service in 1968 and has received unsegregated TRU waste, segregated TRU waste, and TRUM waste. This waste was designated as TRU using the original criteria of $10 \mathrm{nCi} / \mathrm{g}$, and the burial records for individual containers report the total quantity of TRU material at $0.0001 \mathrm{~g}$ of plutonium. Pending further investigation, some of this waste may be determined to be low-level. Trenches 01-06, 08-10, and 12 contain unsegregated TRU waste. Trench 07 contains $\mathrm{CH}$ TRU waste on an asphalt pad; the containers are mostly 208-L drums. A few boxes are also located in Trench 07 . This trench was one of the earlier designs for retrievably stored TRU waste. The design is a concrete "V" trench which stores the waste containers on $245^{\circ}$ angle and is covered with a metal roof and soil. There are three storage modules with this design and they contain 13,300 208-L drums. The TRU waste in Trench 11 can contain either $\mathrm{RH}$ or $\mathrm{CH}$ waste; there is no asphalt pad in this trench. Trench 14 contains 12 caissons, which are vaults or tanks underground, for the disposal of 3.8- to 19-L cans of RH waste. There are five alpha caissons but only four have been used (from 1970 to 1979). There are six beta/gamma caissons which are filled with waste, and one caisson that is plugged; these were used from 1968 to 1979 . No additional wastes are planned to be placed in the caissons. All the trenches in this burial ground are covered with earth. This burial ground has received a total of $10,466 \mathrm{~m}^{3}$ of waste.

Burial Ground 218-W-4C. This burial ground was placed in service in 1978. The most northern trench (trench NC) contains core barrels from naval bases. Trench 01 contains mostly noncombustible TRU waste, including the 216-Z-9 Crib drums containing plutonium-contaminated soil. Trench 04 contains mostly combustible TRU waste with little noncombustible TRU waste. Trench 07 contains TRU boxes, organic waste in drums, and drums 


\section{Revision 0}

of TRIGA fuel waste. Additional TRU waste in boxes and drums is located in Trenches 19, 20, and 29. Low-level waste is located in Trenches 19,23, and 28. There are several trenches in this burial ground that remain unused, and are available as needed. This burial ground has received waste from onsite and offsite DOE contractors. There has been a total of $16,782 \mathrm{~m}^{3}$ of waste received in the burial ground.

Burial Ground 218-W-5. This burial ground became operational in 1986 for disposal of LLW and mixed waste. Trenches $03,09,13,14,21,22,24$, and 27 are full and have been backfilled. Trenches 31 and 34 are lined trenches with leachate collection systems. These two trenches are ready to receive waste. The trenches in W-5 are oriented from east to west. Space is available for additional mixed waste trench units. This burial ground receives waste from onsite and offsite DOE contractors. A total of $48,149 \mathrm{~m}^{3}$ of waste has been placed in this burial ground.

Burial Ground 218-W-6. This burial ground will be used for LLMW trenches. All the monitoring wells have been installed and testing of the wells has started. To date this burial ground has not received any waste.

Facility Functions. The main functions of the solid waste burial grounds are the permanent disposal of LLW and mixed waste, and the retrievable storage of TRU waste and irradiated fuel waste. The solid waste burial ground is also used to dispose of RH mixed waste and RH TRU wastes on a case-by-case basis. The mixed waste will be disposed in RCRA-compliant trenches that include a liner-leachate collection system. The solid waste burial ground provides the necessary facilities for safe disposal or storage of these materials, as well as the administrative facility engineering and operation.

Low-level waste is generally received packaged within 20-L steel drums and steel boxes, although concrete burial vaults, other accepted burial containers, and inherently stable waste packages may also be disposed.

Receipt and Inspection of LLW. The waste generator is responsible for preparation of waste records and packaging the waste according to DOE regulations for hazardous materials. The generator must comply with those packaging requirements established by law and the solid waste burial ground acceptance criteria.

Waste shipments are inspected and surveyed at the solid waste burial ground typically for every first-of-a-kind shipment and then randomly on subsequent similar shipments. Surveys are also performed on all special-handled and one-time-only shipments. A health physics technician will determine that the surface dose rates emitted by the waste package and surface contamination are in agreement with the shipping and burial papers and that the waste package does not exceed restrictions given in the Hanford Site Solid Waste Acceptance Criteria (Willis 1993).

The necessary paperwork for all shipments is checked and verified against the actual waste packages received. Each package must be marked or labeled with the necessary identification information. Where applicable, the waste package must be free of punctures, dents, paint 
scratches, loose lids, lock nuts, bulges, corrosion, and other signs of actual or potential contamination breach.

Receiving activities related to a waste package include verification that the documentation accompanying the shipment is complete and accurate. Verification includes cross-checking the shipping and waste management documentation to ensure consistency and accuracy. Instructions for the review and completion of the shipping and waste management documentation are provided in the plant operating procedures.

A general procedure covers the receipt of commonly used waste packages such as drums and boxes on a flatbed truck. Separate procedures are developed for receipt and inspection of various less commonly used packaging that may require some disassembly of the shipping container to gain access to the waste containers and reassembly after the waste containers have been removed.

Waste Handling and Interim Storage. No interim storage requirements are anticipated because shipments from generators can be scheduled to avoid periods when waste is being covered or other commitments do not permit waste operations at the solid waste burial ground.

All handling of waste packages is performed by trained solid waste burial ground personnel. Workers receive safety training that includes radiation safety, contamination control, hazardous materials safety, use of protective clothing and equipment, and emergency procedures. Personnel also have job-specific training based on site operating procedures including inspection, material handling, and packaging procedures and requirements.

Waste Disposal Operations. The operations for the disposal of LLW within the burial grounds consist of waste emplacement, filling of void spaces between containers, waste covering, closure and stabilization, locating disposal units, and ensuring buffer zones are established.

To minimize the void spaces within the trench, like containers are stacked. In box trenches, the waste containers are stacked to maintain a uniform height for backfilling. Drums are placed one layer at a time and backfilled.

Backfilling operations can take place any time after waste is placed in the trench. Immediate burial of waste can occur and is highly dependent on the dose rates of the containers to minimize the exposure to personnel. Classified wastes have also been disposed of at the Hanford Site, and these shipments were backfilled immediately upon placement in the burial grounds.

Buffer zones are established around the open and partially filled trenches. This is to reduce exposure and prevent the spread of contamination. Also, buffer zones have been established in the area of filled trenches where subsidence has occurred. The subsidence has usually been caused by a buried waste box collapsing and the overfill has collapsed around the container creating a depression on the surface. 
Operational Monitoring, Surveillance, and Maintenance. A large portion of the environmental monitoring and surveillance activities for different waste types are shared or common activities take place for each, because the different wastes may be stored in adjacent trenches in the same burial ground. The environmental monitoring consists of a groundwater monitoring system (this consists of 35 wells around the solid waste burial grounds). Sixteen wells are installed in the 200 East Area and 19 wells in the 200 West Area. These wells, which were drilled and installed from July to October 1987, provide information regarding the hydrogeologic properties of the uppermost aquifer beneath the solid waste burial ground and also background water quality data.

Eleven wells in the 200 West Area and all 16 wells in the 200 East Area are installed as single wells. The remaining eight wells in the 200 West Area are drilled as four pairs. Each well of a given pair is drilled 7.6 to $15.2 \mathrm{~m}$ away from the other with one of each pair being a deep well and the other a shallow well. The deep wells penetrate the uppermost aquifer system to a lower semi-confining unit located approximately 61 to $76 \mathrm{~m}$ below the water table. The shallow wells penetrate only the upper 6.1 to $9.1 \mathrm{~m}$ of the uppermost aquifer.

Groundwater sampling is conducted in accordance with the Part B Permit Application, which also describes the parameters analyzed and the sampling frequency. Samples are taken in accordance with WAC 173-303-645(5) (Table 1) drinking water parameters and WAC 173-303-9904, "Dangerous Waste Constituents List" chemical parameters.

Surveillance and inspection of solid waste storage/disposal facilities are addressed in an operating procedure which specifies monitoring and surveillance activities and their minimum frequencies. No additional specific monitoring and surveillance requirements are anticipated for the LLW disposal trenches.

\section{Facility Requirements.}

- DOE/RL-88-20, Low-Level Burial Grounds Dangerous Waste Permit Application (DOE-RL 1988)

- $\quad$ DOE-RL 88-20, Supplement 1, Low-Level Burial Grounds Dangerous Waste Permit Application: Request for Exemption from Lined Trench Requirements for Submarine Reactor Compartments (DOE-RL 1988)

- $\quad$ WHC-EP-0063-4, Hanford Site Solid Waste Acceptance Criteria (Willis 1993)

- WHC-EP-0558, Test and Evaluation Document for DOT Specification 7A Type A Packaging (Kelly 1996)

- WHC-SD-WM-ISB-002, Solid Waste Burial Grounds Interim Safety Basis (Bendixsen 1995)

- WAC 173-303, "Dangerous Waste Regulations" 
HNF-SD-WM-RPT-288

Revision 0

- $\quad 40$ CFR 141, "National Primary Drinking Water Regulations"

- RCRA and as amended by the Hazardous and Solid Waste Amendments of 1984

- $\quad$ DOE Order 5820.2A, Radioactive Waste Management (DOE 1988a).

\subsubsection{LLMW Disposal}

\section{Facility Identification.}

Basis: RCRA.

Source: $\quad$ WHC-SD-W025-FDC-001, Radioactive Mixed Waste Disposal Facility (Johnson, K. D. 1994).

Radioactively contaminated solid waste has been generated during routine defense materials production, research, and waste management activities at the Hanford Site since it began operations in the early 1940 's. Regulations for treatment and disposal of these wastes have evolved along with the nuclear industry. Early regulations were concerned primarily with protecting the workers who handled these wastes from the hazards associated with ionizing radiation emitted by the waste. As waste management knowledge, technology, and awareness evolved, the regulations became increasingly more detailed and began to emphasize protection of the environment and ensuring the stability of the waste form.

Historically, solid waste was disposed at the Hanford Site using shallow land burial techniques because there was no requirement to characterize or segregate the hazardous components in radioactive waste. In 1979, the DOE prohibited the burial disposal of liquid organic materials. Since that time, TRU and low-level liquid organic waste have been packaged in drums and stored intermingled with CH TRU waste for later retrieval and treatment. In June 1987, DOE relinquished the by-product exclusion of solid waste yielding to regulation of the treatment, storage, and disposal of radioactive mixed waste under RCRA (and the Hazardous Solid Waste Amendments of 1984 which established the LDRs) as well as the Atomic Energy Act of 1954.

Since that decision, all low-level radioactive mixed waste at the Hanford Site has been stored for later retrieval, treatment, and uitimate disposal. In 1987, the Hanford Site began constructing a series of buildings for storing these wastes. All radioactive mixed waste stored in trenches and buildings at the Hanford Site will be retrieved when RCRA-permitted treatment and disposal facilities are available.

The Radioactive Mixed Waste Disposal Trench (Project W-025) provides a RCRA-compliant radioactive mixed waste disposal facility necessary for disposal of low-level radioactive mixed waste meeting LDRs. The project will provide disposal for radioactive LLMW 
which is in storage at the Hanford Site, and additional radioactive mixed waste which is projected to be generated during the Hanford Site cleanup mission.

\section{Facility Scope.}

\section{Waste Types.}

Bases: RCRA; WAC 173-303, "Dangerous Waste Regulations."

Source: $\quad$ WHC-SD-W025-FDC-001, Radioactive Mixed Waste Disposal Facility (Johnson, K. D. 1994).

The Radioactive Mixed Waste Land Disposal Facility consists of two disposal trenches. The waste to be disposed in the trenches will consist of radioactive mixed waste, meaning waste which is hazardous and also radioactive. The disposal facility will not accept TRU waste, which contains at least $100 \mathrm{nCi} / \mathrm{g}$ of TRU elements (neptunium, plutonium, and americium). Waste to be disposed of shall be properly identified, labeled, and manifested. The waste will be prepared for disposal according to current regulations and WHC requirements. Acids, explosives, oxidizers, pyrophorics, alkali metals, and free liquids will be appropriately treated before disposal in the trenches.

The trenches shall be designed and operated as RCRA-compliant landfills for disposal of radioactive mixed waste in accordance with 40 CFR 264, 40 CFR 265, and WAC 173-303.

Disposal trenches will include liners and leachate collection systems; cover design and installation are not part of this project. However, covers will be addressed in the future as the closure date draws near for each trench.

\section{Interfaces.}

Basis: WHC-EP-0363, Solid Waste Management Program Plan (Duncan 1991).

Source:

WHC-SD-W025-FDC-001, Radioactive Mixed Waste Disposal Facility (Johnson, K. D. 1994).

Facilities. The Radioactive Mixed Waste Land Disposal Facility is an integral part of the overall solid waste management strategy at the Hanford Site. The Radioactive Mixed Waste Land Disposal Facility interfaces with the Shipping and Receiving Area of the Enhanced Radioactive and Mixed Waste Storage Phase V (Project W-112). Other facilities that handle radioactive mixed waste volumes before disposal via the Phase V Storage Facility include the following:

- CWC

- WRAP 1

- Commercial stabilization treatment

- Thermal treatment. 


\section{Revision 0}

Before operation of the Enhanced Radioactive and Mixed Waste Storage Phase V Facility, compliant-mixed waste ready for disposal will be transported to the Radioactive Mixed Waste Disposal Facility via the CWC or other appropriate facility.

Vehicles. Coordination between treatment facilities and the Radioactive Mixed Waste Land Disposal Facility will ensure that the vehicle on and off-loading equipment is capable of handling the same waste packages. Waste shall be placed using waste-handling equipment, which may include forklifts, cranes, or other waste handling machinery.

Containers. Based on the current planning of the solid waste treatment facilities, the Radioactive Mixed Waste Land Disposal Facility will accept waste volumes in either drums or boxes. This facility is not designed for waste in drag-off packages. In addition, the facility will make provisions for acceptance of non-containerized waste meeting the facility's WAC.

\section{Facility Size.}

Basis: The Project size is driven by the volume of material to be disposed.

Source: $\quad$ WHC-SD-W025-FDC-001, Radioactive Mixed Waste Disposal Facility (Johnson, K. D. 1994).

The capacity of each of the radioactive mixed waste trenches is a minimum of $7,600 \mathrm{~m}^{3}$ of waste. This project will construct two disposal trenches for a total of $15,200 \mathrm{~m}^{3}$ of waste.

\section{Facility Schedule.}

Basis: WHC-EP-0363, Solid Waste Program Plan (Duncan 1991).

Source: $\quad$ WHC-SD-W025-FDC-001, Radioactive Mixed Waste Disposal Facility (Johnson, K. D. 1994).

The Radioactive Mixed Waste Land Disposal Facility shall have a minimum design life of 50 years, of which at least 20 years are for the operational phase and 30 years are required for the post-closure monitoring phase of the facility.

Facility Expansion. The current scope of Project W-025 includes the construction of two trenches in Burial Ground 218-W-5. Burial Grounds 218-W-5 and 218-W-6 have significant areas of unused space available for the expansion of radioactive mixed waste disposal. If additional trenches are required for radioactive mixed waste disposal, either Project W-025 will be extended to cover additional trenches or future trenches will be constructed under other project(s). 


\section{HNF-SD-WM-RPT-288 \\ Revision 0}

\section{Facility Functions.}

\section{Trench Description.}

Bases: WHC-EP-0363, Solid Waste Program Plan (Duncan 1991); Solid Waste Forecasts.

Source: $\quad$ Design Report, Project W-025 Radioactive Mixed Waste Land Disposal Facility Non-Drag-Off (Golder Associates Inc. 1990).

The Design Report, Project W-025 Radioactive Mixed Waste Land Disposal Facility Non-Drag-Off (Golder Associates Inc. 1990) includes the following description:

"The Non-Drag-Off Landfill will be located in the northwest corner of the 200 West Area in Burial Ground 218-W-5 between future burial trenches 39 and 47 . The overall facility measures approximately 450 feet by 300 feet with the landfill's long axis trending east-west. The excavated depth will range from approximately 25 feet at the east end of the floor to nearly 35 feet at the west end. To prevent windblown soil from being deposited in the landfill, the excavation stockpile will be located north of the landfill downwind of the prevailing wind direction. Temporary admix preparation areas will be located south and west of the landfill in proximity to the landfill access ramp during construction."

The trench will be double-lined and will include a leachate collection system in each of the liners (see the following paragraphs).

\section{Trench Liner System.}

Bases: RCRA; WAC 173-303, "Dangerous Waste Regulations."

Source: $\quad$ WHC-SD-W025-FDC-001, Radioactive Mixed Waste Disposal Facility (Johnson, K. D. 1994); Design Report, Project W-025 Radioactive Mixed Waste Land Disposal Facility Non-Drag-Off (Golder Associates Inc. 1990).

The FDC included a requirement that the trenches be double-lined. The liner is to be designed, constructed, and installed to prevent any migration of wastes out of the landfill to the adjacent subsurface soil, groundwater, or surface water at anytime during the active and post-closure period of the landfill. The liner will consist of the following layers from top to bottom:

- Primary leachate collection systern

- Primary high-density polyethylene liner

- Secondary leachate collection system

- Secondary high-density polyethylene liner 
- Secondary admix liner.

WAC 173-303 requires that a hazardous (in this case mixed radioactive and hazardous) waste disposal facility have a double-liner and leachate collection system. The primary and secondary liners and leachate collection system are designed to prevent any liquid that leaks into the disposed waste from reaching the surrounding environment.

High-density polyethylene was selected as the liner material because it has the highest chemical resistance of commercially-available liner materials, has been widely used in similar facilities, and has a high level of regulatory acceptance.

\section{Leachate Collection System.}

Basis: WAC 173-303-640.

Source: $\quad$ Design Report, Project W-025 Radioactive Mixed Waste Land Disposal Facility Non-Drag-Off (Golder Associates Inc. 1990).

The leachate collection and removal system consists of a sump in the polyethylene liner which will collect any liquid that drains into the Land Disposal Facility. Any liquid that collects in the sumps will be drained via a system of pumps to a temporary leachate receiver tank. For most of the life of the waste disposal facility, the flow of leachate is expected to be very low; however, in the "twenty-four-hour, twenty-five-year" storm the amount of liquid may be significant.

Under normal conditions, the leachate collection system sump will be empty. During precipitation events, the sump may fill.

\section{Facility Requirements.}

\section{Permits.}

Bases: RCRA; WAC 173-303, "Dangerous Waste Regulations."

Source: $\quad$ WHC-SD-W025-FDC-001, Radioactive Mixed Waste Disposal Facility

$$
\text { (Johnson, K. D. 1994). }
$$

The Radioactive Mixed Waste Disposal Trench will be RCRA-permitted and will meet the requirements set forth in WAC 173-303.

\section{Inspections.}

Bases: RCRA; WAC 173-303, "Dangerous Waste Regulations." 
HINF-SD-WM-RPT-288

Revision 0

Source: $\quad$ WHC-SD-W025-FDC-001, Radioactive Mixed Waste Disposal Facility (Johnson, K. D. 1994); Design Report, Project W-025 Radioactive Mixed Waste Land Disposal Facility Non-Drag-Off (Golder Associates Inc. 1990).

WAC 173-303-665 requires that Land Disposal Systems have a liner with a leachate collection and removal system capable of collecting and controlling at least the water from a "twenty-four-hour, twenty-five-year" storm. The liner and leachate collection system in the Radioactive Mixed Waste Land Disposal Facility is expected to be operational for a minimum of 30 years following closure of the facility. Inspection of the leachate collection sumps and sensing equipment will be required during operation and following closure.

\subsection{REFERENCES}

36 CFR 800, "Protection of Historical and Cultural Properties," Code of Federal Regulations, as amended.

40 CFR 50, "National Primary and Secondary Ambient Air Quality Standards," Code of Federal Regulations, as amended.

40 CFR 61, "National Emission Standards for Hazardous Air Pollutants," Code of Federal Regulations, as amended.

40 CFR 116, "Designation of Hazardous Substances," Code of Federal Regulations, as amended.

40 CFR 117, "Determination of Reportable Quantities for Hazardous Substances," Code of Federal Regulations, as amended.

40 CFR 131, "Environmental Protection Agency Procedures for Approving State Water Quality Standards," Code of Federal Regulations, as amended.

40 CFR 133, "Secondary Treatment Regulation," Code of Federal Regulations, as amended.

40 CFR 141, "National Primary Drinking Water Regulations," Code of Federal Regulations, as amended.

40 CFR 142, "National Primary Drinking Water Regulations Implementation," Code of Federal Regulations, as amended.

49 CFR 171, "General Information, Regulations, and Definitions," Code of Federal Regulations, as amended.

49 CFR 172, "Hazardous Materials Table, Special Provisions, Hazardous Materiais Communications, Emergency Response Information, and Training Requirements," Code of Federal Regulations, as amended. 
HNF-SD-WM-RPT-288

Revision 0

49 CFR 173, "Shippers--General Requirements for Shipments and Packagings," Code of Federal Regulations, as amended.

49 CFR 174, "Carriage by Rail," Code of Federal Regulations, as amended.

49 CFR 175, "Carriage by Aircraft," Code of Federal Regulations, as amended.

49 CFR 176, "Carriage by Vessel," Code of Federal Regulations, as amended.

49 CFR 177, "Carriage by Public Highway," Code of Federal Regulations, as amended.

49 CFR 178, "Specifications for Packagings," Code of Federal Regulations, as amended.

49 CFR 179, "Specifications for Tank Cars," Code of Federal Regulations, as amended.

40 CFR 191, "Environmental Radiation Protection Standards for Management and Disposal of Spent Nuclear Fuel, High-Level and Transuranic Radioactive Wastes," Code of Federal Regulations, as amended.

40 CFR 260, "Hazardous Waste Management System - General," Code of Federal Regulations, as amended.

40 CFR 261, "Identification and Listing of Hazardous Waste," Code of Federal Regulations, as amended.

40 CFR 263, "Standards Applicable to Transporters of Hazardous Waste," Code of Federal Regulations, as amended.

40 CFR 264, "Standards for Owners and Operators of Hazardous Waste Treatment, Storage, and Disposal Facilities," Code of Federal Regulations, as amended.

40 CFR 265, "Interim Status Standards for Owners and Operators of Hazardous Waste Treatment, Storage, and Disposal Facilities," Code of Federal Regulations, as amended.

40 CFR 268, "Land Disposal Restrictions," Code of Federal Regulations, as amended.

40 CFR 270, "EPA Administered Permit Programs: The Hazardous Waste Permit Program," Code of Federal Regulations, as amended.

40 CFR 300, "National Oil and Hazardous Substances Pollution Contingency Plan," Code of Federal Regulations, as amended.

40 CFR 302, "Designation, Reportable Quantities, and Notification, "Code of Federal Regulations, as amended. 
HNF-SD-WM-RPT-288

Revision 0

40 CFR 370, "Hazardous Chemical Reporting: Community Right-to-Know," Code of Federal Regulations, as amended.

40 CFR 372, "Toxic Chemical Release Reporting; Community Right-to-Know," Code of Federal Regulations, as amended.

40 CFR 761, "Polychlorinated Biphenyls (PCBs) Manufacturing, Processing, Distribution in Commerce, and Use Prohibitions," Code of Federal Regulations, as amended.

40 CFR 761.70, "Incineration of PCBs and PCB Items," Code of Federal Regulations, as amended.

40 CFR 1501, "National Environmental Policy Act Procedures," Code of Federal Regulations, as amended.

40 CFR 1502, "Environmental Impact Statement," Code of Federal Regulations, as amended.

43 CFR 7, "Protection of Archaeological Resources," Code of Federal Regulations, as amended.

50 CFR 17, "Endangered and Threatened Wildlife and Plants," Code of Federal Regulations, as amended.

AEC, 1968, Atomic Energy Commission Manual, Chapter 0511, "Radioactive Waste Management," U.S. Atomic Energy Commission, Washington, D.C.

AEC-RL, 1970, Policy Statement Regarding Solid Waste Burial, Immediate Action Directive No. 0511-21, United States Atomic Energy Commission, Richland, Washington.

Anderson, B. C., 1989, Characterization Plan for Stored Contact-Handled Transuranic Waste, WHC-EP-0223, Westinghouse Hanford Company, Richland, Washington.

Anderson, B. C., 1990, 1989 Solid Waste Forecast Data Summary Report, WHC-SD-WM-DP014, Westinghouse Hanford Company, Richland, Washington.

Anderson, B. C., 1991, Contact-Handled Transuranic Waste Characterization Based on Existing Records, WHC-EP-0225, Rev. 1, Westinghouse Hanford Company, Richland, Washington.

Anderson, G. S., and H. S. Konynenbelt, 1995, 1995 Baseline Solid Waste Management Description, PNL-10743, Pacific Northwest Laboratory, Richland, Washington.

Atomic Energy Act of 1954, 42 USC 2011, et seq.

Barnes, B. M., 1992, Enhanced Radioactive and Mixed Waste Storage Phase V, WHC-SD-W112-CDR-001, Rev. 0A, Westinghouse Hanford Company, Richland, Washington. 
HNF-SD-WM-RPT-288

Revision 0

Bendixsen, R, B., 1995, Solid Waste Burial Grounds Interim Safety Basis, WHC-SD-WM-ISB-002, Rev. 0, Westinghouse Hanford Company, Richland, Washington.

Berneski, L. D., 1995, Facility Description Manual - Hanford 300 Area Treated Effluent Disposal Facility, WHC-SD-L045-TM-001, Rev. 0, Westinghouse Hanford Company, Richland, Washington.

Biebesheimer, E., 1992, Project W-112, Enhanced Radioactive and Mixed Waste Storage Phase V Engineering Study, WHC-SD-W112-ES-001, Rev. 0, Westinghouse Hanford Company, Richland, Washington.

Blackford, L. T., 1995, Equipment/Waste Acceptance Criteria for Low Level Treatment at 2706T Facility, WHC-IP-1017, Westinghouse Hanford Company, Richland, Washington.

Carlson, T. A., 1995, Waste Receiving and Processing Module $2 A$ Termination of Design Closeout Report, WHC-SD-W100-RPT-001, Rev. 0, Westinghouse Hanford Company, Richland, Washington.

Christie, M. A., 1987, Waste Receiving and Processing (WRAP) Facility Draft Functional Design Criteria, WHC-SD-WM-TI-291, Rev. 0, Westinghouse Hanford Company, Richland, Washington.

Cillan, M. R., 1993, Hazard Classification for the Thermal Treatment Facility, Project W-242, WHC-SD-W242-HC-001, Westinghouse Hanford Company, Richland, Washington.

Clean Air Act of 1977, 42 USC 2011, et seq.

Comprehensive Environmental Response, Compensation, and Liability Act of 1980, 42 USC 9601, et seq.

Deichelbohrer, P. R., 1990, Alpha Caisson Data and Evaluation, WHC-SD-WM-RPT-008, Rev. 0 , Westinghouse Hanford Company.

Deichelbohrer, P. R., 1992, Engineering Study - Retrieval of Waste from Alpha Caissons, WHC-SD-WM-ES-181, Rev. 0, Westinghouse Hanford Company, Richland, Washington.

DOE, 1982, Management of Transuranic Material, DOE Order 5820.1, U.S. Department of Energy, Washington, D.C.

DOE, 1983, Defense Waste Management Plan, DOE/DP-0015, U.S. Department of Energy, Washington, D.C.

DOE, 1984, Environmental Protection, Safety, and Health Protection Standards, DOE Order 5480.4, U.S. Department of Energy, Washington, D.C. 
HNF-SD-WM-RPT-288

Revision 0

DOE, 1985, Safety Requirements for the Packaging Transportation of Hazardous Materials,

Hazardous Substances, and Hazardous Wastes, DOE Order 5480.3, U.S. Department of Energy, Washington, D.C.

DOE, 1986, Environment, Safety, and Health Program for Department of Energy Operations, DOE Order 5480.1B, U.S. Department of Energy, Washington, D.C.

DOE, 1986, Environment, Safety, and Health Appraisal Program, DOE Order 5482.1B,

U.S. Department of Energy, Washington, D.C.

DOE, 1987, Final Environmental Impact Statement - Disposal of Hanford Defense High-Level, Transuranic and Tank Wastes, DOE/EIS-0113, U.S. Department of Energy, Washington, D.C.

DOE, 1988a, Radioactive Waste Management, DOE Order 5820.2A, U.S. Department of Energy, Washington, D.C.

DOE, 1988b, Disposal of Hanford Defense High-Level, Transuranic, and Tank Wastes, DOE/EIS-0113, U.S. Department of Energy, Washington, D.C.

DOE, 1989, Environmental Compliance Issue Coordination, DOE Order 5400.2A,

U.S. Department of Energy, Washington, D.C.

DOE, 1989, Comprehensive Environmental Response, Compensation, and Liability Act Requirements, DOE Order 5400.4, U.S. Department of Energy, Washington, D.C.

DOE, 1989, General Design Criteria, DOE Order 6430.1A, U.S. Department of Energy, Washington, D.C.

DOE, 1990, Radiation Protection of the Public and the Environment, DOE Order 5400.5, U.S. Department of Energy, Washington, D.C.

DOE-RL, 1984, Environmental Protection, Safety, and Health Protection Standards for RL, DOE-RL Order 5480.4, U.S. Department of Energy, Richland Field Office, Richland, Washington.

DOE-RL, 1986, Environmental Protection, Safety, and Health Protection Program for Richland Operations, RL Order 5480.1B, U.S. Department of Energy, Richland Field Office, Richland, Washington.

DOE-RL, 1990, Low-Level Burial Grounds Dangerous Waste Permit Application: Request for Exemption from Lined Trench Requirements for Submarine Reactor Compartments, DOE/RL 88-20, Supplement 1, U.S. Department of Energy, Richland Operations Office, Richland, Washington. 
HNF-SD-WM-RPT-288

Revision 0

DOE-RL, 1990, Low-Level Burial Grounds Dangerous Waste Permit Application, DOE/RL-88-20, 5 Vols:, U.S. Department of Energy-Richland Operations Office, Richland, Washington.

DOE-RL, 1992, 224-T Transuranic Waste Storage and Assay Facility Dangerous Waste Permit Application, DOE/RL-91-51, Rev. 0, U.S. Department of Energy, Richland Operations Office, Richland, Washington.

DOE-RL, 1995, Direct Disposal Team Report - Options for Treating and Disposing of Current and Future Mixed Waste Streams on the Hanford Facility, DOE-RL-95-35, Rev. 0, U.S. Department of Energy, Richland Operations Office, Richland, Washington.

DOE/WIPP, 1989, TRUPACT-II Content Codes, DOE/WIPP 89-004, Carlsbad, New Mexico.

Duncan, D. R., 1991, Solid Waste Management Program Plan, WHC-EP-0363, Rev. 1, Westinghouse Hanford Company, Richland, Washington.

Ecology, EPA, and DOE, 1996, Hanford Federal Facility Agreement and Consent Order as amended, Washington State Department of Ecology, U.S. Environmental Protection Agency, and U.S. Department of Energy, Olympia, Washington.

EPA, 1995, EPA Requirements for Quality Assurance Project Plans for Environmental Data Operations, EPA SW-846, EPA QA/R-5, U.S. Environmental Protection Agency, Washington, D.C.

35 FR 4247, 1970, Executive Order 11514, "Protection and Enhancement of Environmental Quality," Federal Register (March 5).

42 FR 26967, 1977, Executive Order 11991, "Relating to Protection and Enhancement of Environmental Quality," Federal Register (May 24).

43 FR 47707, 1978, Executive Order 12088, "Federal Compliance with Pollution Control Standards," Federal Register (October 13).

52 FR 2923, 1987, Executive Order 12580, "Superfund Implementation," Federal Register (January 23).

General Regulations 80-7, Benton-Franklin-Walla Walla Counties Air Pollution Control Authority.

Geuther, W. J., 1995, Long-Term Decontamination Engineering Study, WHC-SD-WM-ES-283, Rev. 0, Westinghouse Hanford Company, Richland, Washington.

Gibson, K. D., 1995, Transuranic Waste Storage and Assay Facility (TRUSAF) Interim Safety Basis, WHC-SD-WM-ISB-004, Rev. 0, Westinghouse Hanford Company, Richland, Washington. 
HNF-SD-WM-RPT-288

Revision 0

Gilles, W. P., 1993, Solid Waste Projects NDA/NDE Review (Internal Memo (Draft) to W. H. Hamilton, February 12), Westinghouse Hanford Company, Richland, Washington.

Golder Associates Inc., 1990, Design Report, Project W-025 Radioactive Mixed Waste Land Disposal Facility Non-Drag-Off, Golder Associates Inc., Richland, Washington.

Harker, M. R., 1991a, Project W-113 Hazardous Classification, WHC-SD-W113-HC-002, Westinghouse Hanford Company, Richland, Washington.

Harker, M. R., 1991b, Engineering Safety Study for Project W-113, WHC-SD-W113-ES-002, Westinghouse Hanford Company, Richland, Washington.

Hazardous and Solid Waste Amendments of 1984, 42 USC 6901, et seq.

Johnson, D. L., 1994, Functional Design Criteria Solid Waste Retrieval Facility Phase 1, WHC-SD-W113-FDC-001, Rev. 2, Westinghouse Hanford Company, Richland, Washington.

Johnson, D. M., 1994a, Engineering Study for the Solid Waste Retrieval, WHC-SD-W113-ES-001, Rev. 2, Westinghouse Hanford Company, Richland, Washington.

Johnson, D. M., 1994b, W-113 FDC Technical Basis, WHC-SD-W113-RD-001, Rev. 0, Westinghouse Hanford Company, Richland, Washington.

Johnson, K. D., 1994, Radioactive Mixed Waste Disposal Facility/W-025 Functional Design Criteria, WHC-SD-W025-FDC-001, Rev. 2, Westinghouse Hanford Company, Richland, Washington.

Josephson, W. S., 1996, Sampling and Analysis Plan for Mixed Waste Treatment, WHC-SD-WM-TP-442, Rev. 0, Westinghouse Hanford Company, Richland, Washington.

Joyce, J. P., 1993, Preliminary Safety Evaluation for Waste Receiving and Processing Facility Module 1 Project W-026, WHC-SD-W026-PSE-001, Rev. OB, Westinghouse Hanford Company, Richland, Washington.

Kelly, D. L., 1996, Test and Evaluation Document for DOT Specification 7 A Type A Packaging, WHC-EP-0558, Rev. 3, Westinghouse Hanford Company, Richland, Washington.

Kruger, O. L., 1994, Waste Receiving and Processing, Module 2A, Feed Specification, WHC-SD-W100-RD-001, Rev. 1, Westinghouse Hanford Company, Richland, Washington.

Lamberd, D. L., 1991, Strategy Assessment Project WI00, Waste Receiving and Processing (WRAP) Module 2, WHC-SD-W100-ES-005, Rev. 0, Westinghouse Hanford Company, Richland, Washington. 
Layman, J. S., 1995, Thermal Treatment Services, Purchase Order No. MW6-SBV-357079, Westinghouse Hanford Company, Richland, Washington.

Lerch, R. E., 1983, Hanford Facility Part A Dangerous Waste Permit Application Form 3, Revision 2, for the T-Plant Complex (TSD: T-2-7) (Letter 9305714/93-RPS-336 to Washington State Department of Ecology, Olympia, Washington), Westinghouse Hanford Company and U.S. Department of Energy, Richland Operations Office, Richland, Washington.

Mayancsik, B. A., 1994, Waste Receiving and Processing (WRAP) Facility Module I Functional Design Criteria, WHC-SD-W026-FDC-001, Rev. 2, Westinghouse Hanford Company, Richland, Washington.

Mayancsik, B. A., 1995, WRAP Module I Treatment Plan, WHC-SD-W026-PLN-007, Rev. 0, Westinghouse Hanford Company, Richland, Washington.

Nester, D. E., 1995, Functional Design Criteria for Enhanced Radioactive and Mixed Waste Storage Phase V, Project W-112, WHC-SD-W112-FDC-001, Rev. 3, Westinghouse Hanford Company, Richland, Washington.

National Environmental Policy Act of 1969, 42 USC 4321, et seq.

Nupac, 1989, TRUPACT II Safety Analysis Report for Packaging, Nupac TRUPACT II-SAR, Rev. 4, Nuclear Packaging, Inc., Federal Way, Washington.

Olson, W. W., 1994, Waste Receiving and Processing Facility Module 1 (WRAP) Preliminary Safety Analysis Report, WHC-SD-W026-SAR-001, Rev. 1, Westinghouse Hanford Company, Richland, Washington.

Pauly, T. R., 1990, Engineering Study for Waste Receiving and Processing (WRAP) Facility, Module 2, WHC-SD-W100-ES-001, Westinghouse Hanford Company, Richland, Washington.

Place, B. G., 1991, Assessment of High Temperature Thermal Treatment Alternatives for Inclusion Into the Scope of the Hanford WRAP Facility, WHC-SD-WM-ES-198, Westinghouse Hanford Company, Richland, Washington.

Place, B. G., 1992, Thermal Treatment of Hanford's RMW - Summary Discussion of Vendor Capabilities (Internal Memorandum, December 14), Westinghouse Hanford Company, Richland, Washington.

Place, B. G., 1993, Hanford Site-Specific Engineering Study for the W-242 Thermal Treatment Facility, WHC-SD-W242-ES-001, Westinghouse Hanford Company. Richland, Washington. 
HINF-SD-WM-RPT-288

Revision 0

PNL, 1994, 1993 Baseline Solid Waste Management System Description, PNL-8990, Pacific Northwest Laboratory, Richland, Washington.

Pollution Prevention Act of 1990, Public Law 101-508, U.S.C. 6601-6610.

PSD-X80-14, Approval of Application to Construct, EPA Region.

Resource Conservation and Recovery Act of 1976, 42 USC 6901, et seq.

RHO, 1985, Waste Receiving and Processing (WRAP) Facility Engineering Study, SD-RE-ES017, Rev. 1, Rockwell Hanford Operations, Richland, Washington.

Rieck, C. A., 1990, Conceptual Design Report Waste Receiving and Processing Module I, Project W-026, WHC-SD-W026-CDR-001, Westinghouse Hanford Company, Richland, Washington.

Roberts, R. J., 1991, WRAP 1 Throughput (WHC Internal Memo to J. A. Swenson, March 27), Westinghouse Hanford Company, Richland, Washington.

Roberts, R. J., 1993, Current Program for the Management of DOE Transuranic Waste (Letter 9350240 to J. M. Hennig, U.S. Department of Energy, Richland Field Office, January 20), Westinghouse Hanford Company, Richland, Washington.

Robles, M. H., 1993, Preliminary Engineering Study for Solid Waste Retrieval Phase 2, WHC-SD-W221-ES-001, Westinghouse Hanford Company, Richland, Washington.

Safe Drinking Water Act, 42 USC 300 fet seq.

SAIC, 1992, Treatment of Hanford's Mixed Waste Streams by INEL's Thermal Treatment Facilities, Contract No. MLW-SVV-073750, Task S-92-21, Science Applications International Corporation, Richland, Washington.

SAIC, 1993, Treatment of Hanford RMW Streams by INEL's Waste Experimental Reduction Facility (WERF) Incinerator, Contract No. MLW-SVV-073750, Task S-93-28, Science Applications International Corporation, Richland, Washington.

Sederburg, J. P., 1996, Solid Waste Program Technical Baseline Description, WHC-SD-WM-RPT-060, Rev. 2, Westinghouse Hanford Company, Richland, Washington.

Smith, K. E., 1993, Conceptual Design Repori, Solid Waste Retrieval Facility, Phase 1, Project WI13, WHC-SD-W113-CDR-002, Rev. 0, Westinghouse Hanford Company, Richland, Washington. 
HNF-SD-WM-RPT-288

Revision 0

Stroup, C. R., 1997, Performance Agreement Waste Management (WM) 3.1.1-a, Cataloging of Hanford Analytical Services (Letter RFSH-9751417 to C. G. Mattsson, Fluor Daniel Hanford, Inc., February 21), Rust Federal Services of Hanford, Inc., Richland, Washington.

Toxic Substances Control Act, 15 USC 2601, et seq.

UE\&C, 1991, Waste Processing System Functional Analysis Study, UE\&C Catalytic, Inc., Englewood, Colorado.

UE\&C, 1992, Waste Receiving and Processing Facility Module I Preliminary Design Report, Rev. 0, UE\&C, Englewood, Colorado.

Valdez, A. R, 1996, Low Level Mixed Waste Stabilization Services Subcontract (RL Letter 96-PRO-182 to President of Westinghouse Hanford Company, May 20), U.S. Department of Energy, Richland Operations Office, Richland, Washington.

Valero, O. J., 1994, Solid Waste 30-Year Volume Summary, WHC-EP-0768, Westinghouse Hanford Company, Richland, Washington.

WAC 173-200, "Water Quality Standards for Groundwater of the State of Washington," Washington Administrative Code, as amended.

WAC 173-216, "State Waste Discharge Permit Program," Washington Administrative Code, as amended.

WAC 173-240, "Submission of Plans and Reports for Construction at Waste Water Facilities," Washington Administrative Code, as amended.

WAC 173-303, "Dangerous Waste Regulations," Washington Administrative Code, as amended.

WAC 173-400, "General Regulations for Air Pollution Sources," Washington Administrative Code, as amended.

WAC 173-460, "Controls for New Sources of Toxic Air Pollutants," Washington Administrative Code, as amended.

WAC 173-470, "Ambient Air Quality Standards for Particulate Matter," Washington Administrative Code, as amended.

WAC 173-474, "Ambient Air Quality Standards for Sulfur Oxides," Washington Administrative Code, as amended.

WAC 173-475, "Ambient Air Quality Standards for Carbon Monoxide, Ozone, and Nitrogen Dioxide," Washington Administrative Code, as amended. 
HNF-SD-WM-RPT-288

Revision 0

WAC 173-480, "Ambient Air Quality Standards and Emission Limits for Radionuclides," Washington Administrative Code, as amended.

WAC 173-481, "Ambient Air Quality and Environmental Standards for Fluorides," Washington Administrative Code, as amended.

WAC 173-490, "Emission Standards and Controls for Sources Emitting Volatile Organic Compounds (VOC)," Washington Administrative Code, as amended.

WAC 173-802, "SEPA Procedures," Washington Administrative Code, as amended.

WAC 197-11, "SEPA Rules," Washington Administrative Code, as amended.

WAC 246-247, "Radiation Protection - Air Emissions," Washington Administrative Code, as amended.

WAC 246-272, "On Site Sewage Systems," Washington Administrative Code, as amended.

Weidert, J. R., 1993, Supplemental Design Requirements Document, Project W026, WHC-SD-W026-SDRD-001, Rev. 3, Westinghouse Hanford Company, Richland, Washington.

WHC-CM-1-3, Management Requirements and Procedures, Westinghouse Hanford Company, Richland, Washington.

WHC-CM-6-1, Standard Engineering Practices, Westinghouse Hanford Company, Richland, Washington.

WHC-CM-7-5, Environmental Compliance Mamal, Westinghouse Hanford Company, Richland, Washington.

WHC, 1995, Project W-113 Title II Detail Design Report, WHC-SD-W113-FDR-001, Rev. 0, Westinghouse Hanford Company, Richland, Washington.

Willis, N. P., 1991, Hanford Site Radioactive Solid Waste Acceptance Criteria, WHC-EP-0063-2, Westinghouse Hanford Company, Richland, Washington.

Willis, N. P, 1993, Hanford Site Solid Waste Acceptance Criteria, WHC-EP-0063-4, Westinghouse Hanford Company, Richland, Washington.

WHC, 1994, Hanford Facility Dangerous Waste Permit Application, Waste Receiving and Processing (Working Draft), DOE/RL 91-16, Rev. 1, Westinghouse Hanford Company, Richland, Washington.

WIPP, 1996, Waste Acceptance Criteria for the Waste Isolation Plant, WIPP/DOE-069, Rev. 5, Westinghouse Electric Corporation, Waste Isolation Pilot Plant, Carlsbad, New Mexico. 
HNF-SD-WM-RPT-288

Revision 0

\section{CONTENTS}

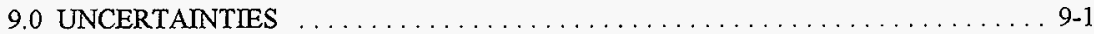

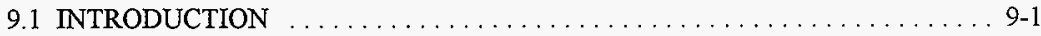

9.2 DOE COMPLEX-LEVEL UNCERTAINTIES . . . . . . . . . . . . . . 9-4

9.2.1 Federal Facility Compliance Act of 1992 (FFCA) . . . . . . . . . . . . 9-5

9.2 .2 WIPP . . . . . . . . . . . . . . . . . . . . . . . . . 9-6

9.2.3 TRU Waste Certification Analytical Laboratories' Needs . . . . . . . . . . . . 9-10

9.2 .4 GTCIII . . . . . . . . . . . . . . . . . . . . . . . 9-11

9.3 DOE HANFORD SITE-LEVEL UNCERTAINTIES . . . . . . . . . . . 9-11

9.3.1 High Alpha, Beta, and Gamma Analytical Services to RCRA Protocol . . . 9 9-11

9.3.2 Sample and Waste Forecast ....................... 9-12

9.3.3 Pre-1970 TRU Waste and Post-WIPP TRU Waste .............. . 9-14

9.3.4 New Services ............................. 9-15

9.3.5 Facility Ownership, Maintenance, and Closure ............... 9-15

9.3.6 Disposition of Sodium Materials ..................... 9-15

9.3.7 Wastes Resulting from Plutonium Disposal . . . . . . . . . . . . . 9-16

9.4 PROJECT-LEVEL UNCERTAINTIES $\ldots \ldots \ldots \ldots \ldots \ldots \ldots \ldots \ldots \ldots . \ldots . \ldots \ldots$

9.4.1 WSCF Privatization . . . . . . . . . . . . . . . . . . . . . .

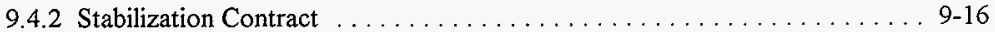

9.4 .3 Budgets . . . . . . . . . . . . . . . . . . . . . . . . 9-16

9.4.4 EEM - Groundwater Monitoring Coordination ............. . 9-17

9.4.5 Effluent Treatment Facility (ETF) Delisting Petition ............. 9-17

9.5 REFERENCES . . . . . . . . . . . . . . . . . . . . . . . . . 9-17

\section{LIST OF FIGURES}

9-1. Actual Receipts versus Previous Year's Forecast Volumes for Onsite LLW, MLLW, and TRU(M) Waste Volumes .

\section{LIST OF TABLES}

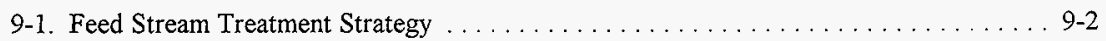


HNF-SD-WM-RPT-288

Revision 0

\section{LIST OF TERMS}

$\begin{array}{ll}\text { CH } & \text { contact-handled } \\ \text { DOE } & \text { U.S. Department of Energy } \\ \text { DST } & \text { double-shell tank } \\ \text { ETF } & \text { Effluent Treatment Facility } \\ \text { FFCA } & \text { Federal Facility Compliance Act of 1992 } \\ \text { FFTF } & \text { Fast Flux Test Facility } \\ \text { FY } & \text { fiscal year } \\ \text { GTCIII } & \text { Greater Than Category III } \\ \text { LLW } & \text { low-level waste } \\ \text { MLLW } & \text { mixed low-level waste } \\ \text { PA } & \text { performance assessment } \\ \text { PCB } & \text { polychlorinated biphenyl } \\ \text { Project } & \text { Waste Management Project } \\ \text { RCRA } & \text { Resource Conservation and Recovery Act of 1976 } \\ \text { RH } & \text { remote-handled } \\ \text { SRE } & \text { sodium reactor experiment } \\ \text { SST } & \text { single-shell tank } \\ \text { TBD } & \text { to be determined } \\ \text { TRU } & \text { transuranic } \\ \text { TRUSAF } & \text { Transuranic Waste Storage and Assay Facility } \\ \text { WAC } & \text { Waste Acceptance Criteria } \\ \text { WIPP } & \text { Waste Isolation Pilot Plant } \\ \text { WRAP } & \text { Waste Receiving and Processing } \\ \text { WRAP I } & \text { Waste Receiving and Processing Module 1 }\end{array}$


HNF-SD-WM-RPT-288

Revision 0

\subsection{UNCERTAINTIES}

\subsection{INTRODUCTION}

This section addresses the uncertainties associated with the Waste Management Project (Project) Technical Baseline Description as defined in the current planning documents. Some of the uncertainties require near-term management action, near-term cognizance (should action not be required immediately), and/or long-term planning to resolve the uncertainty. Note that "uncertainties" include "unknowns" as well as "alternatives" for which decisions have not yet been made.

Uncertainties have been divided into one of three categories based on the level at which the issue needs to be resolved: the U.S. Department of Energy (DOE) Complex level, the Hanford Site level, or the Project level. Section 9.2 addresses the uncertainties related to the overall DOE Complex problems as they may impact Project planning. Although Hanford Site staff cannot control these uncertainties, they will need to react to changes to current assumptions, laws, regulations, and guidelines. Hanford Site staff may be involved in plans to address these uncertainties, but for the most part, Site actions will be limited to being cognizant of the decisions made by external (to the Project) influences and adapting to any required changes made. An example of a DOE Complex uncertainty would be the potential for changes in WIPP/DOE-069, Waste Isolation Pilot Plant Waste Acceptance Criteria (WIPP WAC) (WIPP 1996) to require treatment of mixed waste to land disposal restriction requirements. This change would impact the treatment plans for contact-handled $(\mathrm{CH})$ and remote-handled $(\mathrm{RH})$ transuranic (TRU) waste.

Section 9.3 addresses the uncertainties related to Hanford Site issues. These uncertainties deal with alternatives that are within the control of the Hanford Site, but cross current organizational boundaries. Effort will be required by Project staff to resolve these uncertainties, in either a leadership role or as a team participant. An example of this class of uncertainty would be whether a single facility or multiple facilities will be used to handle ail the types of $\mathrm{RH}$ wastes and materials that exist at the Hanford Site.

Section 9.4 addresses the uncertainties related to areas within the operational scope of the Project. The uncertainties include items within a particular project, as well as issues that cross the boundaries so that two or more projects are involved. Effort will be required by Project staff to resolve these uncertainties. An example of a Project uncertainty would be the performance assessment (PA) currently underway for the low-level waste (LLW) Burial Grounds. Results of the PA will determine if additional measures are required for LLW disposal methods. Until the PA is complete, plans for final LLW Burial Ground closure are uncertain.

Table 9-1 identifies the current waste streams, the primary facility for managing them, and the backup plans. This tabulation is provided for the "baseline" streams and those with more difficult treatment, storage, or disposal requirements. This table is provided for reference and for review of the potential uncertainties, if any, associated with each of those waste streams. Some 
HNF-SD-WM-RPT-288

Revision 0

Table 9-1. Feed Stream Treatment Strategy. (3 sheets)

\begin{tabular}{|c|c|c|}
\hline Feed stream & Primary facility & Contingency plans \\
\hline \multicolumn{3}{|c|}{$\begin{array}{l}\text { Part A: Baseline streams with little or no uncertainty in } \\
\text { treatment, storage, or disposal requirements }\end{array}$} \\
\hline $\begin{array}{l}\text { Newly generated solid } \mathrm{CH} \\
\text { TRU drums }\end{array}$ & $\begin{array}{l}\text { WRAP 1. WIPP WAC certification in } \\
\text { WRAP 1. Sampling of a limited fraction } \\
\text { of the total stream for additional quality } \\
\text { control verification. }\end{array}$ & $\begin{array}{l}\text { TRUSAF for mondestructive examination } \\
\text { and assay; laboratory hot cell for limited } \\
\text { sampling. TRUSAF will close in FY } 1997 \\
\text { and go to transition in mid-1998. }\end{array}$ \\
\hline $\begin{array}{l}\text { Newly generated solid } \mathrm{CH} \\
\text { LLW drums }\end{array}$ & $\begin{array}{l}\text { WRAP 1. Generator certification is } \\
\text { combined with limited batch sample } \\
\text { verification in WRAP } 1 \text {. }\end{array}$ & Limited sampling in $2706-T$. \\
\hline $\begin{array}{l}\text { Newly generated solid } \mathrm{CH} \\
\text { MLLW drums that do not } \\
\text { require thermal treatment }\end{array}$ & $\begin{array}{l}\text { Commercial treatment to } \mathrm{RCRA}^{1} \\
\text { standards. }\end{array}$ & $\begin{array}{l}\text { The selected Milestone M-91 altemative } \\
\text { will provide capability for treating } \mathrm{RH} \\
\text { MLLW (capacity may be limited for } \mathrm{CH} \text { ). }\end{array}$ \\
\hline $\begin{array}{l}\text { Newly generated solid } \mathrm{CH} \\
\text { MLLW dnums that require } \\
\text { thermal treatment }\end{array}$ & $\begin{array}{l}\text { Commercial thermal treatment to } \mathrm{RCRA}^{1} \\
\text { standards. }\end{array}$ & None planned. \\
\hline $\begin{array}{l}\text { Solid CHLLW and MLLW } \\
\text { drums from alpha caisson } \\
\text { retrieval }\end{array}$ & $\begin{array}{l}\text { Segregation in WRAP 1; commercial } \\
\text { treatment to RCRA' standards. }\end{array}$ & $\begin{array}{l}\text { The selected Milestone M- } 91 \text { alternative } \\
\text { will provide capability for treating MLLW } \\
\text { (capacity may be limited). }\end{array}$ \\
\hline $\begin{array}{l}\text { Retrieved solid CH suspect } \\
\text { TRU drums from LLW Burial } \\
\text { Grounds and Burial Ground } \\
618-11 \text {. }\end{array}$ & $\begin{array}{l}\text { WRAP I. WRAP } 1 \text { will perform } \\
\text { inspection, characterization, packaging, } \\
\text { and WIPP WAC certification for this } \\
\text { stream. }\end{array}$ & $\begin{array}{l}\text { The selected Milestone M-9l alternative } \\
\text { will provide capability for treatment of } \\
\text { drums requiring special handling (e.g., } \\
\text { soils, classified cantents, overweight } \\
\text { packages, and shielded inner packages of } \\
\text { RH waste); capacity for other waste } \\
\text { streams may be limited. }\end{array}$ \\
\hline $\begin{array}{l}\text { Newly generated solid } \mathrm{CH} \\
\text { TRU boxes (other than } \\
\text { standard waste boxes) }\end{array}$ & $\begin{array}{l}\text { The selected Milestone M-91 alternative. } \\
\text { The selected altemative will size reduce, } \\
\text { treat, package, and certify waste to the } \\
\text { WIPP WAC. }\end{array}$ & None planned. \\
\hline $\begin{array}{l}\text { Newly generated solid CH } \\
\text { TRU standard waste boxes }\end{array}$ & $\begin{array}{l}\text { WRAP 1. WRAP } 1 \text { will certify waste in } \\
\text { standard waste boxes to the WIPP WAC. }\end{array}$ & $\begin{array}{l}\text { None planned, except the Milestone M-91 } \\
\text { alternative could provide a box } \\
\text { nondestructive assay/nondestructive } \\
\text { examination station, disassemble the boxes, } \\
\text { treat the waste, repackage it in standard } \\
\text { waste boxes or drums, and certify the waste } \\
\text { to WDP WAC; capacity may be limited. }\end{array}$ \\
\hline $\begin{array}{l}\text { Newly generated solid } \mathrm{CH} \\
\text { LLW boxes }\end{array}$ & $\begin{array}{l}\text { WRAP 1. Generator certification is } \\
\text { combined with limited verification in } \\
\text { WRAP } 1 \text {. }\end{array}$ & Limited sampling in $2706-\mathrm{T}$. \\
\hline $\begin{array}{l}\text { Newly generated solid } \mathrm{CH} \\
\text { MLLW boxes that do not } \\
\text { require thermal treatment }\end{array}$ & $\begin{array}{l}\text { Commercial treatment to RCRA } \\
\text { standards for boxes up to } 1.8 \text { by } 2.4 \text { by } \\
3.6 \mathrm{~m} \text {. }\end{array}$ & $\begin{array}{l}\text { The selected Milestone M-9l alternative } \\
\text { will have the capability to handle and treat } \\
\text { mixed waste in boxes; capacity may be } \\
\text { limited. }\end{array}$ \\
\hline $\begin{array}{l}\text { Newly generated solid } \mathrm{CH} \\
\text { MLLW boxes that require } \\
\text { thermal treatment }\end{array}$ & $\begin{array}{l}\text { Commercial thermal treatment. Present } \\
\text { plans are to send this waste to a } \\
\text { commercial plant. }\end{array}$ & $\begin{array}{l}\text { The selected Milestone M-91 altermative } \\
\text { may be used to size reduce the waste before } \\
\text { shipment to a commercial thermal } \\
\text { treatment facility. }\end{array}$ \\
\hline
\end{tabular}


Table 9-1. Feed Stream Treatment Strategy. (3 sheets)

\begin{tabular}{|c|c|c|}
\hline Feed stream & Primary facility & Contingency plans \\
\hline $\begin{array}{l}\text { Retrieved suspect solid TRU } \\
\text { boxes }\end{array}$ & $\begin{array}{l}\text { The selected Milestone M-91 alternative } \\
\text { will size reduce, treat, package, and } \\
\text { certify waste to the WIPP WAC. }\end{array}$ & $\begin{array}{l}\text { WRAP 1. Final drum certification } \\
\text { capability available in WRAP } 1 \text {. Capacity } \\
\text { availability would have to be examined. }\end{array}$ \\
\hline SRE and hallam sodium & Commercial treatment & FFTF sodium treatment facility. \\
\hline Solid hazardous waste & $\begin{array}{l}\text { Send to offsite treatment, storage, and } \\
\text { disposal facility }\end{array}$ & $\begin{array}{l}\text { Store in } 616 \text { Nonradioactive Dangerous } \\
\text { Waste Storage Facility }\end{array}$ \\
\hline Low-level liquid effluent & TBD & TBD \\
\hline Liquid RCRA ${ }^{1}$ effluent & TBD & TBD \\
\hline $\begin{array}{l}\text { Liquid mixed low-level } \\
\text { effluent }\end{array}$ & TBD & TBD \\
\hline Liquid CERCLA ${ }^{2}$ effluent & TBD & TBD \\
\hline Industrial waste water & TBD & TBD \\
\hline Liquid TRU effluent & TBD & TBD \\
\hline Liquid PCB effluent & TBD & TBD \\
\hline \multicolumn{3}{|c|}{$\begin{array}{l}\text { Part B: Baseline streams with significant uncertainty in } \\
\text { treatment, storage, and disposal requirements }\end{array}$} \\
\hline Alpha caisson wastes & $\begin{array}{l}\text { The selected Milestone M-91 alternative } \\
\text { will remotely characterize, package, and } \\
\text { certify waste for disposal at WIPP. }\end{array}$ & None planned. \\
\hline $\begin{array}{l}\text { Burial Ground } 618-11 \text { caisson } \\
\text { wastes }\end{array}$ & $\begin{array}{l}\text { The selected Milestone M-91 alternative } \\
\text { will remotely characterize, package, and } \\
\text { certify waste for disposal at WIPP. }\end{array}$ & None planned. \\
\hline${ }^{238} \mathrm{Pu}$ drummed waste & $\begin{array}{l}\text { The selected Milestone M- } 91 \text { alternative } \\
\text { will remotely characterize, package, and } \\
\text { certify waste for disposal at WIPP. }\end{array}$ & $\begin{array}{l}\text { Ship the } 12 \text { drums to the Savannah River } \\
\text { Site for processing with similar feed } \\
\text { streams. }\end{array}$ \\
\hline $\begin{array}{l}\text { CH TRU drums containing } \\
\text { classified waste }\end{array}$ & $\begin{array}{l}\text { WRAP 1; special campaigning will be } \\
\text { required to meet classified material } \\
\text { handling requirements. }\end{array}$ & $\begin{array}{l}\text { The selected Milestone M-91 alternative } \\
\text { will have similar capability. }\end{array}$ \\
\hline $\begin{array}{l}\text { Greater Than Category III } \\
\text { solid waste }\end{array}$ & $\begin{array}{l}\text { TBD. This waste will remain in storage } \\
\text { until the DOE develops a disposal } \\
\text { strategy. }\end{array}$ & None planned. \\
\hline $\begin{array}{l}\text { TRU waste that does not } \\
\text { comply with the WIPP WAC }\end{array}$ & $\begin{array}{l}\text { TBD. This waste will remain in storage } \\
\text { until the DOE develops a disposal } \\
\text { strategy. }\end{array}$ & None planned. \\
\hline $\begin{array}{l}\text { Spent nuclear fuel stored in } \\
\text { Project-managed facilities }\end{array}$ & $\begin{array}{l}\text { That fuel classified as spent nuclear fuel } \\
\text { will be turned over to the spent nuclear } \\
\text { fuel function for dispositioning. That fuel } \\
\text { reclassified as RH TRU will be processed } \\
\text { in the selected Milestone M-9l alternative } \\
\text { for certification to the WIPP WAC. }\end{array}$ & None planned. \\
\hline $\begin{array}{l}\text { Equipment (including long } \\
\text { components) from DST and } \\
\text { SST clean-out }\end{array}$ & $\begin{array}{l}\text { Size reduction/microencapsulation in the } \\
\text { field. }\end{array}$ & $\begin{array}{l}\text { 2706- } T \text { for size reduction and packaging to } \\
\text { Debris Rule standards. }\end{array}$ \\
\hline $\begin{array}{l}\text { Solid PCB waste or other } \\
\text { thermally treatable wastes co- } \\
\text { contaminated with TRU waste }\end{array}$ & $\begin{array}{l}\text { TBD. This waste will remain in storage } \\
\text { until the DOE develops a treatment } \\
\text { strategy. }\end{array}$ & None planned. \\
\hline
\end{tabular}


Table 9-1. Feed Stream Treatment Strategy. (3 sheets)

\begin{tabular}{|l|l|l|}
\hline \multicolumn{1}{|c|}{ Feed stream } & \multicolumn{1}{|c|}{ Primary facility } & \multicolumn{1}{c|}{ Contingency plans } \\
\hline $\begin{array}{l}\text { TRU-contaminated waste } \\
\text { buried before } 1970\end{array}$ & This waste is considered disposed. & $\begin{array}{l}\text { Retrieve and process through WRAP I for } \\
\text { characterization, packaging, and } \\
\text { certification. }\end{array}$ \\
\hline $\begin{array}{l}\text { RH TRU waste, boxes, and } \\
\text { drums }\end{array}$ & $\begin{array}{l}\text { The selected Milestone M-91 altemative } \\
\text { will remotely characterize, package, and } \\
\text { certify waste for disposal at WIPP. }\end{array}$ & None planned. \\
\hline
\end{tabular}

${ }^{1}$ Resource Conservation and Recovery Act of 1976, 42 USC 6901, et seq.

${ }^{2}$ Comprehensive Environmental Response, Compensation, and Liability Act of 1980, 42 USC 9601, et seq.

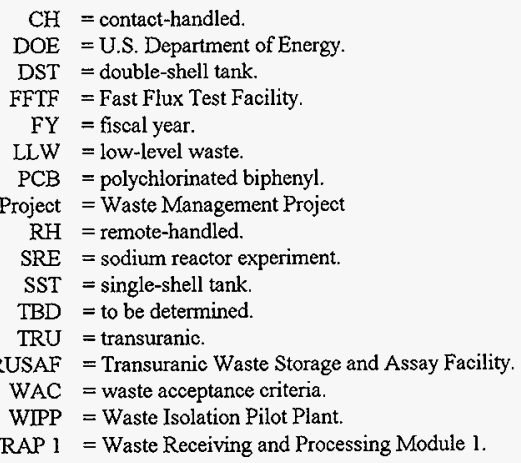

of the streams with the highest uncertainty are very small (e.g., 12 drums of ${ }^{238} \mathrm{Pu}$ ), while others require programmatic decisions from the DOE (e.g., Greater Than Class III [GTCIII] waste). Those waste streams with identified uncertainties are addressed in specific subsections of this document.

\subsection{DOE COMPLEX-LEVEL UNCERTAINTIES}

This section summarizes the uncertainties regarding DOE Complex-wide waste management issues. This includes alternatives that may be determined by the DOE, the Waste Isolation Pilot Plant (WIPP), the U.S. Environmental Protection Agency, the Washington State Department of Ecology, and other outside organizations. 
HNF-SD-WM-RPT-288

Revision 0

\subsubsection{Federal Facility Compliance Act of 1992 (FFCA)}

The FFCA requires the DOE to identify all mixed waste at the DOE sites and enter into agreement with the host states on the treatment of those wastes. The FFCA specifically excludes sites that have signed agreements with the host states, such as the Hanford Site with the Tri-Party Agreement (Ecology et al. 1996). However, the uncertainty associated with the volumes of waste to be shipped to the Hanford Site from other sites and the DOE strategy for Complex-wide treatment have an impact on the Waste Management Project Technical Baseline Description.

\subsubsection{Quantity of Offsite Waste Shipped to Hanford Site/Site Treatment Plans.}

Discussion. From 1992 through 1994, approximately $30 \%$ of the solid mixed waste received at Project facilities has been from offsite generators. This waste volume, and the volume projected to come from the offsite generators in the future, is used in conjunction with the current and projected volumes from the onsite generators to determine treatment requirements and capacities. As part of the requirements of the FFCA, the DOE (including the offsite generators that ship waste to the Hanford Site) is required to report on the mixed wastes generated and the treatment plans and treatment locations for those wastes in site-specific treatment plans. The host generating states and treatment states are then required to concur with the proposed plans and locations. Because the concurrence process is incomplete, the volume of mixed waste that will come to the Hanford Site from the offsite generators is uncertain at this time.

Required Action. The Project will continue to plan for offsite waste forecasted to come to the Hanford Site. As part of this planning process, contracts being written for commercial treatment of the waste must be flexible enough to allow the forecasted volume for offsite waste to be treated but not require this waste as part of the minimum waste to be treated. In addition, plans for waste storage must continue to address the offsite forecasted volumes but also be flexible enough to allow "just in time" storage capacity to be available.

Decision Time Line. Data are unavailable on the DOE decision time line. Negotiations between the states and the DOE were to be complete in the fall of 1995, but finalization of plans does not appear imminent. As long as the Project maintains a flexible treatment and storage strategy, the lack of a decision does not seriously impact the Project.

\subsubsection{DOE Complex-Wide Treatment Scenario.}

Discussion. Currently, the DOE complex-wide treatment method for solid MLLW is undecided. Work has been initiated on the draft Environmental Waste Management Programmatic Environmental Impact Statement. Alternatives are expected to be examined for the treatment of $\mathrm{CH}$ non-alpha mixed low-level waste (MLLW) within the following alternative categories: no action, decentralized, regionalized, and centralized.

The no action alternative provides a baseline for the analysis by considering treatment of MLLW at facilities that are capable of treating waste according to land disposal restrictions. Three sites that meet these criteria are the Idaho National Engineering Laboratory, Oak Ridge 
National Laboratory, and Savannah River Site. The remaining generating sites would undergo onsite waste water treatment only, as required. Under this alternative, no new treatment facilities would be built. However, this alternative would not comply with Resource Conservation and Recovery Act of 1976 (RCRA) because all the waste could not be treated to land disposal restriction regulations.

The decentralized alternative considers treatment of waste to meet RCRA requirements at all $37 \mathrm{MLLW}$ sites. Onsite treatment was considered for all sites with the exception of Lawrence Berkeley Laboratory; in this case, waste from Lawrence Berkeley Laboratory would be treated at Lawrence Livermore National Laboratory.

Four regionalized treatment alternatives were considered, each examining the consolidation of waste for treatment. The regionalized alternatives were developed to bound a reasonable range of intermediate treatment variations. In each of the alternatives, the Hanford Site was considered as a treatment site for its own waste, as well as waste from a combination of the following sites: Lawrence Berkeley Laboratory, Lawrence Livermore National Laboratory, Laboratory for Energy-Related Health Research, Mare Island, Pearl Harbor, and Puget Sound.

Under the centralized alternative, MLLW treatment was considered at a single site within the DOE Complex. In this alternative, all MLLW would be shipped to the Hanford Site for treatment. Currently, the Hanford Site has the second largest volume of MLLW. However, as the Hanford Site's TRU and high-level wastes are treated, a substantial portion will be separated and managed as MLLW, making the Hanford Site the largest MLLW site.

Required Action. Because of the uncertainty associated with the DOE Complex-wide treatment decisions, and the impact of the FFCA on these decisions, the Project needs to continue to pursue commercial treatment for MLLW. In addition, Project personnel responsible for treatment decisions must remain cognizant of planning at the national level to ensure decisions at the national level do not invalidate the Hanford Site strategy: Also, for those waste streams for which the Hanford Site has no path forward, national planning must encompass appropriate treatment strategies.

Decision Time Line. A schedule is not required. The Project must provide input to national planning and consider this planning in Site-specific decisions as appropriate.

\subsubsection{WIPP}

Several uncertainties related to WIPP directly impact the Project at the Hanford Site. This section addresses the TRU certification and analytical services that may be required for disposal of TRU waste at the WIPP.

9.2.2.1 Waste Volumes. The original objective of WIPP was to demonstrate the deep geologic disposal of TRU waste. The initial volume of waste to be disposed in WIPP is $175,000 \mathrm{~m}^{3}$. This volume was to be allocated to the generating sites and shipped to WIPP in the first 20 years of 
HNF-SD-WM-RPT-288

Revision 0

operations. The original WIPP opening date was scheduled for 1988; current plans are targeting 1998 for the first waste shipment to WIPP.

\subsection{WIPP Opening Date and Initial Acceptance of Hanford Site Waste.}

Discussion. According to current planning at WIPP, the earliest that WIPP will be able to accept waste is 1998 . Recognizing that this is the earliest date, and that internal DOE and external forces may result in a delay, the date for actual waste shipment becomes somewhat questionable. Additionally, the Rocky Flats Plant and Idaho National Engineering Laboratory may receive higher priority in determining waste acceptability for WIPP. This suggests that when WIPP actually opens, the Hanford Site would not be shipping waste as soon as the Rocky Flats Plant and the Idaho National Engineering Laboratory. Current planning within the Project is uncertain regarding shipments to WIPP. In addition, head gas sampling to support shipping in the TRUPACT II container must be available.

Required Action. The Hanford Site must maintain a flexible program in support of an earlier shipping date to WIPP. The Waste Receiving and Processing Module 1 (WRAP 1) is scheduled to come on line in fiscal year (FY) 1997 with the startup of the MLLW line. Following the initial operations of the MLLW line, planning for operation of the TRU line should be developed based on experience with the MLLW line. This planning should identify resources and schedule such that an accelerated shipping date can be integrated into the Project should WIPP request early shipping. Implementation of an accelerated startup of TRU processing would require allocation of the necessary funding.

Decision Time Line. Steps are being taken to ensure the Hanford Site has shipping capability within a 2-year time frame.

\subsection{WIPP Waste Acceptance Rates.}

Discussion. The WIPP, like all plants, has a processing throughput plan and the facility design and equipment capability are targeted to meeting the acceptance and emplacement rates included in the facility planning. The WIPP is also chartered with the task of developing and providing the transportation fleet that will receive waste (at sites like Hanford) and deliver the waste to WIPP.

The generating sites (e.g., the Hanford Site) are planning treatment facilities with throughput capacities that are reasonable from the standpoint of site clean-out schedules, coupled with an operating window for acceptance of waste by WIPP. The shipping facilities must have the necessary capability to package and ship their waste to WIPP in a timely manner. The shippers and WIPP must coordinate their efforts to reach a satisfactory solution.

Because of the changing WIPP schedules, uncertain WAC, and changing treatment facility operational schedules (e.g., delay in the WRAP 1 TRU line operation), it is possible that the waste generation rates, and the timing of waste becoming available for shipment (i.e., the Hanford Site 
TRU waste work-off plan), may not correspond to the equivalent work-off plans by the other generating sites and the WIPP acceptance plan.

Required Action. The WIPP acceptance plan is not yet available. It is not possible to evaluate the potential courses of actions with either a waste acceptance rate or transportation availability until WIPP information and plans become firm. It is important that the Hanford Site staff involved in coordination with WIPP integrate the Hanford Site TRU waste work-off plan with the WIPP acceptance plan. Finalizing these plans will then help to establish Project priorities. This has the potential to impact TRU waste storage capacity and plans for TRU retrieval.

Project modeling provides insight into the requirements for acceptance of waste from the Hanford Site, given no restriction by WIPP. The Project modeling tool can be used to perform "what-if" scenarios on alternate waste acceptance rates, all of which are likely to increase the need for local storage of TRU drums and standard waste boxes. When WIPP starts addressing the TRU waste work-off planning, the Hanford Site will be an active participant in the planning and negotiation of TRU volume allocations and acceptance rates.

In the interim, the planning for shipping rates is based on essentially unlimited WIPP transportation capability and receipt rates (i.e., WIPP will accept the waste at the rate it is generated). Facility treatment, storage, and shipping rates are continually reviewed with the use of the Project's model to evaluate the treatment rates versus the inventory and work-off planning.

Decision Time Line. A decision is not required at this time. The WIPP waste acceptance rates will be incorporated into the Hanford Site shipping plans.

\subsubsection{WIPP WAC.}

Discussion. There is no definite time for any decision to be made with respect to major changes in the WIPP WAC (WIPP 1996). Minor changes can be expected on a routine basis up to the time WIPP starts up.

Required Action. An evaluation of the impacts of the WAC uncertainties at WIPP was completed in August 1993 (Mayancsik 1993). This evaluation concluded there was little risk in proceeding along the current path for solid waste facilities. The WIPP WAC did not incorporate major criteria changes. The Project staff involved in WIPP must keep abreast of the developments in the WAC to allow the Hanford Site the opportunity to be a constructive participant in any major changes to the WAC. This participation is vital to minimize the impact to Project planning.

Decision Time Line. The Project will need the appropriate WIPP WAC at least 1 year before shipping waste in order to incorporate the WAC into the waste certification process. 


\subsubsection{RH TRU Transportation Casks.}

Discussion. The WIPP had initiated the design on a transportation cask for the RH TRU waste. The cask that has been designed (but not approved by the U.S. Nuclear Regulatory Commission) is a cask that holds an RH TRU canister, which in turn holds either three 208-L drums or undrummed waste of equal volume. The cask is designed to shield the content's radiation to acceptable transportation levels with the canister having hot spots no greater than $1,000 \mathrm{R} / \mathrm{h}$. The canister and the remote welding system to place the head on the canister after loading the waste have been designed and tested (at the Hanford Site). The cask itself and the truck-trailer system have had much work completed on them, but they are not ready for submission to the sites for comment, nor ready for submission to the U.S. Nuclear Regulatory Commission for approval. This work is deferred as WIPP concentrates on CH issues.

Assuming this transportation system is eventually pursued, the user sites will have to provide the appropriate interfaces to receive, operate, and load the cask. Decontamination and servicing of the cask will be necessary on an as-required basis.

The cask holds three drums of waste. The latest modeling performed by the Project suggests that with unlimited transportation and WIPP support, the Hanford Site will have several years during which casks will be shipped.

Most of the waste is much lower in radiation levels than the cask is designed to accommodate. Accordingly, the RH TRU Task Force Team has recommended that a lower radiation level drum cask be provided. The threshold recommended is $30 \mathrm{R} / \mathrm{h}$ and the minimum capacity recommended is 6 drums, with 12 drums per shipment desirable. This cask would permit much more efficient loading and shipping of RH TRU drums. In addition, WIPP is researching the possibility of using shielded containers to reduce surface dose rates to CH levels for RH TRU.

These alternative RH TRU containers would add a significant amount of additional work on WIPP to redesign its system to accommodate the new cask and drum handling concepts. However, because WIPP is not designed to accept waste at the rate the Hanford Site alone generates RH TRU drums plus the RH TRU from the other DOE sites, the additional shipping options may be attractive to WIPP.as well.

Required Action. Should these recommendations be pursued by WIPP, three cask interfaces will need to be developed: one for the current canister cask concept, one for the new drum cask concept, and one for the shielded drum. These interfaces will have to be developed in time to incorporate them into the Title I design requirements for the selected Milestone M-91 alternative.

Decision Time Line. Remote-handled TRU transportation interface requirements must be identified and input into the functions and requirements for the selected Milestone $\mathrm{M}-91$ alternative. 
HNF-SD-WM-RPT-288

Revision 0

\subsubsection{TRU Waste Certification Analytical Laboratories' Needs}

Discussion. Certification of TRU waste is needed to support planned storage, treatment, and transportation activities as well as the final disposal of this waste at WIPP. The specific analytical procedures needed to support certification and the number of waste samples that will need to be analyzed have not been definitively identified. As a result, the sufficiency of existing analytical laboratories to meet the capability and capacity requirements for TRU waste certification is uncertain.

Several reasons exist for the uncertainties regarding types of analyses and sample numbers that will be required to be sent to an analytical laboratory in support of waste certification. These include the following.

- The final WIPP WAC have not been approved. The specific physical properties and analytes that will need to be analyzed to meet waste characterization requirements, as well as the detection limits required, will drive the analytical procedures that are necessary to generate the characterization data in support of certification.

- The proportion of samples that will be able to be analyzed using real-time instrumentation and analytical techniques during waste handling and processing activities in Project facilities has not yet been defined. Samples characterized using these methods will not require analysis in a separate laboratory facility.

- Transuranic waste that is now held in retrievable storage (both above and below grade) will need to be certified for shipment to WIPP. This waste was emplaced from 1970 to the present. Records for the waste emplaced before 1987 are not as detailed as the records for waste emplaced after 1987. Although the older records do not contain detailed characterization information, particularly for hazardous chemicals, the processes that generated these wastes are well known. It is anticipated that this process knowledge will be key in determining the additional analyses that will be needed to confidently certify these wastes. The degree to which process knowledge will reduce the need for extensive laboratory analysis is unknown.

- Programmatic decisions, such as the delay in removing TRU waste from retrievable storage, affect the total analytical services load. The total need for waste analysis, as well as the laboratory capacity to do that analysis, depends on the number of waste streams and quantity of waste packages in those streams to be certified at a given time.

Earlier assessments of laboratory capacity needs for the certification of TRU waste indicated that sufficient laboratory capacity did not exist within the DOE Complex. Since that time, greater definition of the number of TRU waste packages that will need to be analyzed as well as the methods proposed for their analysis makes this earlier conclusion uncertain. Existing laboratory capabilities and capacities need to be evaluated to determine their sufficiency to meet the estimated needs for TRU waste certification. 
Required Action. Waste certification plans need to be developed for Hanford Site TRU wastes. These plans should address the estimated number and types of samples that will be sent for laboratory analysis. Sample estimates can then be compared with available laboratory capabilities and capacities at onsite laboratories, other DOE laboratories throughout the country, or commercial laboratories. A national strategy for ensuring laboratory support for the certification of TRU wastes needs to be established and implemented.

Decision Time Line. Earlier revisions of WHC-SD-WM-RPT-060 (Carlson 1994, Carlson 1995a, and Sederburg 1996) discussed the impact that insufficient laboratory capacity would have on WRAP 1, which was scheduled to begin processing TRU waste in March 1997. Since the issuance of WCH-SD-WM-RPT-060 (Carlson 1994), the retrieval of TRU waste has been delayed. Initial plans for WRAP 1 include operation of the MLLW line only. The time line for resolving uncertainties regarding the sufficiency of laboratory capacity and capability will be closely coupled with the processing of TRU waste at WRAP 1.

\subsubsection{GTCDI}

Discussion. Approximately $1,000 \mathrm{~m}^{3}$ of GTCIII LLW are in retrievable storage in caissons or trenches at the LLW Burial Grounds. This waste will need to be retrieved because it requires greater confinement at the disposal site than other LLW types. However, there are no disposal options identified for this waste. Pending a DOE decision, this waste will continue to be retrievably stored onsite.

Required Action. Disposal options for GTCIII waste must be determined for the entire DOE Complex.

Decision Time Line. Planning for the retrieval of stored GTCIII waste, as well as the development technologies and facilities that may be needed to treat this waste, depends on the choice of a final disposal option.

\subsection{DOE HANFORD SITE-LEVEL UNCERTAINTIES}

This section summarizes the uncertainties regarding Hanford Site waste management issues. This category includes uncertainties that crosscut one or more projects/programs outside the Project and must be resolved by a joint effort of those projects/programs involved. In addition, the U.S. Environmental Protection Agency and the Washington State Department of Ecology may be involved in the resolution of these uncertainties through the Tri-Party Agreement and its milestones.

\subsubsection{High Alpha, Beta, and Gamma Analytical Services to RCRA Protocol}




\subsubsection{Sample and Waste Forecast}

Discussion. Each year, the Project asks all known or potential suppliers of waste, samples, and materials to forecast the annual volumes, types, and package numbers they expect to send to the Project during the life cycle. These forecast data are used by the Project to obtain near-term information from which to plan next year's operations and to plan the treatment, storage, and disposal facility capacities and capabilities that will be required in the out-years. The analytical tool used in making capacity judgements is the Project's model. The feedstock information used in the model is a combination of existing waste, sample, and material inventory (the Solid Waste Information and Tracking System database) plus the life-cycle forecasts.

The forecast data are estimates that reflect generator plans at a given point in time, and many things can change the anticipated waste generation rate. Mission plan changes and funding profile changes are major perturbations over which the forecaster may or may not have any insight or control. Future decisions by the DOE could add generators to those currently shipping waste, samples, and materials from offsite to the Hanford Site, and future cleanup decisions at other sites could increase volumes from those that are currently forecast. Standards for waste cleanup, characterization, treatment, or acceptance by offsite facilities are evolving, and changes during the evolution will affect waste management plans.

The forecasts for waste, sample, and material volumes and other characteristics typically are less certain the longer the time frame. Because the budget cycle for projects requires several years from inception to completion, uncertainties in volume forecasts tend to have far-reaching effects.

To assess the accuracy of the forecast data, past forecasts have been reviewed to compare actual receipt of waste, samples, and materials with the forecast data (see data in Figure 9-1). The annual forecast summary report identifies areas where the forecast is believed to be a good approximation of future schedules, given current mission plans. The summary report also seeks to identify areas where there is potential for significant changes to the forecast.

In addition to the uncertainties implicit in generator estimates, there are several potential sources of additional waste, samples, and materials for which only preliminary estimates are known. The forecast summary report provides a preliminary quantification of the volumes associated with these sources, and shows the impact of including these wastes, samples, and materials in the life-cycle forecast.

Required Action. Characterization knowledge has improved markedly during the time period of receiving waste, sample, and material volume forecasts. Additional characterization information is being requested to further refine the expected streams. An aggressive "Generator Assistance" Program is being employed to further develop knowledge about the potential waste and its characteristics as well as to reduce uncertainties about projected volumes, types, and receipt times. 
HNF-SD-WM-RPT-288

Revision 0

Figure 9-1. Actual Receipts versus Previous Year's Forecast Volumes for Onsite LLW, MLLW, and TRU(M) Waste Volumes.

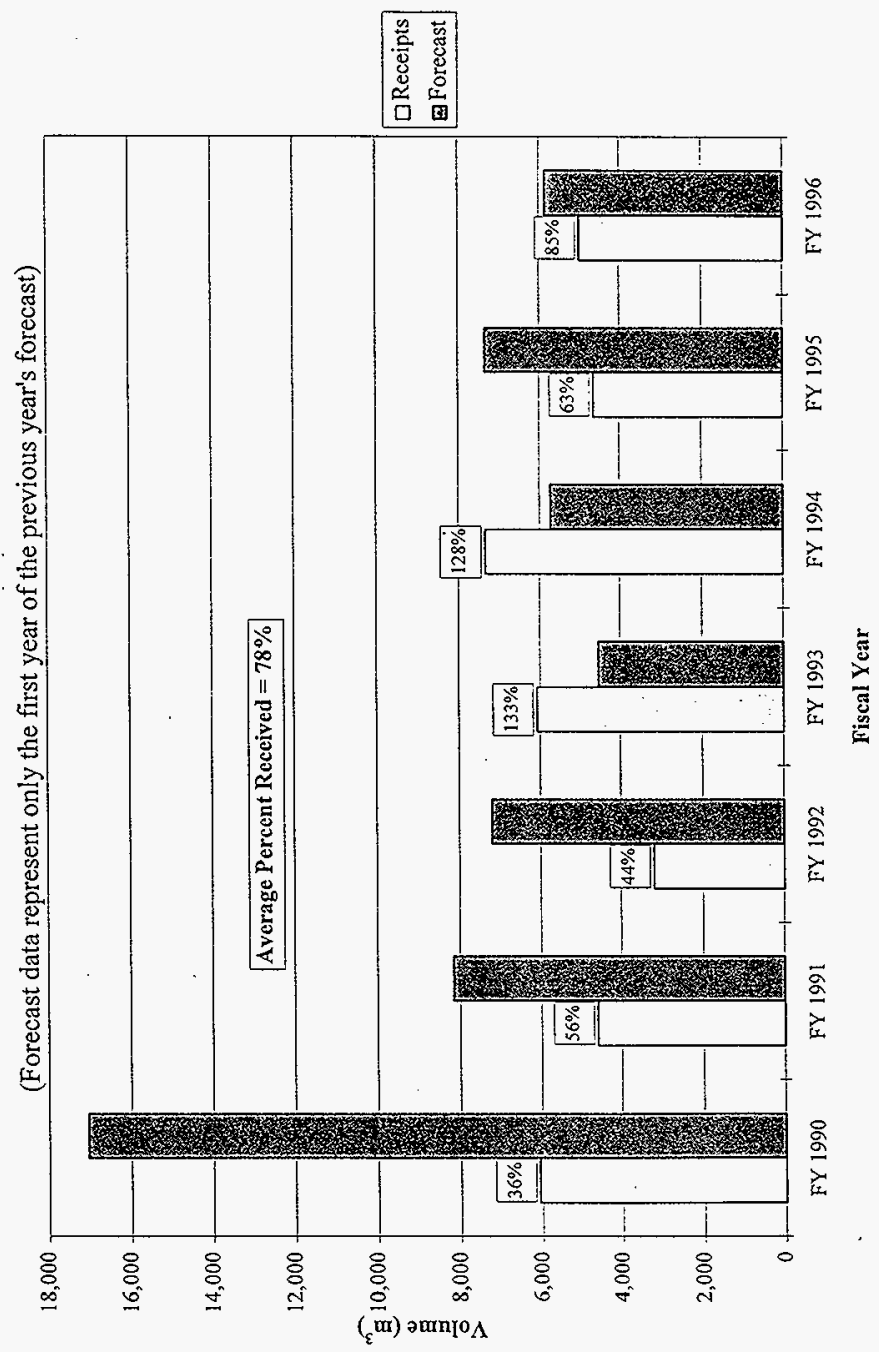


Decision Time Line. A decision is not required because the generator forecasts are estimates based on assumptions made by cognizant individuals and, as such, will always include an element of uncertainty. The Generator Assistance Program is already in place to minimize the intrinsic uncertainties.

\subsubsection{Pre-1970 TRU Waste and Post-WIPP TRU Waste}

Discussion. In DOE/EIS-0113, Final Environmental Impact Statement - Disposal of Hanford Defense High-Level, Transuranic, and Tank Wastes (HDW-EIS) (DOE 1987), the DOE made a comprehensive effort to identify and select the means for permanently disposing of existing and future defense wastes at the Hanford Site. A wide range of methods was examined for permanently disposing of, among other wastes, pre-1970 buried suspect TRU-contaminated solid waste. The DOE decided to conduct additional development and evaluation before making decisions on final disposal (DOE 1988). This development and evaluation effort, as yet incomplete, will focus on methods to retrieve and process these wastes for disposal as well as to stabilize and isolate the wastes near surface.

It is estimated that $109,000 \mathrm{~m}^{3}$ of pre-1970 buried suspect TRU-contaminated solid waste are buried at the Hanford Site. A decision has not been made regarding disposition of this material based on a development and evaluation effort subsequent to the HDW-EIS. A stream of this magnitude, with distinct characteristics, could drive or significantly impact the design of facilities identified to treat it. Because of the high level of uncertainty regarding the ultimate disposition of this waste stream, it was not included in the scope of the Solid Waste and Material Systems Alternatives Study (Carlson 1995b) and was deferred to an unspecified future date.

The WIPP, by definition, is a pilot-scale program designed to evaluate the bedded salt deposits as a final repository for TRU-contaminated wastes. The WIPP is planning a limited operation lifetime which, based on current schedules, stops receiving waste in 2033. Cleanup of the Hanford Site is going to extend beyond 2033, which means TRU waste may be generated after WTPP closure.

Another geological repository may become available. Above-ground storage may be required if another repository is not available. Alternative local treatments (e.g., in-situ encapsulation of canyon buildings) may be acceptable for selected TRU wastes. A large number of potential alternatives will be evaluated in the out-years.

Required Action. Hanford Site staff involved in TRU waste planning must complete the analysis required to determine the ultimate disposition of the pre-1970 TRU waste. Only after the Record of Decision (ROD) for the Environmental Impact Statement is complete can the uncertainties regarding this waste stream be resolved. In addition, plans must be developed for waste that will be generated after WIPP stops receiving waste. However, given the uncertainty associated with the WIPP operating window, startup date, and volume allocation (see Section 9.2.2), plans for post-WTPP are premature. 
HNF-SD-WM-RPT-288

Revision 0

Decision Time Line. The Project has no action at this time. The DOE will make decisions regarding retrieval of pre-1970 TRU waste and the WIPP operations window.

\subsubsection{New Services}

TBD

\subsubsection{Facility Ownership, Maintenance, and Closure}

Discussion. Institutional control and the future mission of the Hanford Site remain an issue regarding closure of the waste management buildings and LLW Burial Grounds. Because of the proximity of facilities in the 200 Areas, use of land for utilities, access roads, and other adjacent activities will impact the current closure schedule for the LLW Burial Grounds. This section will be developed as issues surrounding the 340 Facility, Transuranic Waste Storage and Assay Facility, and other facilities are better understood.

Required Action. Hanford Site staff involved in Site planning must communicate frequently and specifically concerning the areas affected.

Decision Time Line. Specific action is not required at this time. However, with an ongoing integration effort specific decisions and actions could evolve.

\subsubsection{Disposition of Sodium Materials}

Discussion. A significant quantity of sodium materials (not yet declared waste) will need to be dispositioned. Sodium is currently stored in the following areas:

- Small storage modules close to the Central Waste Complex

- Large tanks behind the U Plant

- T Plant piping

- Piping in a sinall 300 Area building

- Fast Flux Test Facility (FFTF).

Many options have been, are being, and will be considered for these materials. One option under consideration was to send the sodium to FFTF, but because of the decision to keep FFTF in a hot standby mode, this plan is now on hold. A second option, to sell the sodium commercially for recycle, is also on hold while the DOE evaluates a possible use for it in the TWRS vitrification project.

In addition to the sodium and its disposition, a second (related issue) is an anticipated rail tank car shipment of 2 to $4 \mathrm{~m}^{3}$ of LLW water that will need to be shipped to TWRS at the completion of fuel washing at FFTF. 
HNF-SD-WM-RPT-288

Revision 0

Required Action. Hanford Site staff will need to monitor these closely related issues involving sodium materials and incorporate any decisions into the appropriate baselines when needed.

Decision Time Line. The Project has no action at this time. Decisions regarding sodium disposition will be determined by the DOE.

\subsubsection{Wastes Resulting from Plutonium Disposal}

Discussion. The Plutonium Finishing Plant is storing unirradiated plutonium and highly enriched uranium fuel elements pending a decision on plutonium disposal. Furthermore, the FFTF's Category K unirradiated fueled assemblies will be sent to the Plutonium Finishing Plant Activities associated with these nuclear materials could result in additional waste for which the Project would have to plan.

Required Action. Hanford Site staff will need to closely monitor these activities and incorporate any decisions into the appropriate baselines when needed.

Decision Time Line. The Project has no action at this time. Decisions regarding plutonium disposal will be determined by the DOE, FFTF, and the Plutonium Finishing Plant.

\subsection{PROJECT-LEVEL UNCERTAINTIES}

This section summarizes the uncertainties regarding Project issues. This includes those issues specific to the Project that do not depend on outside entities for resolution.

\subsubsection{WSCF Privatization}

TBD

\subsubsection{Stabilization Contract}

TBD

\subsubsection{Budgets}

TBD 
HNNF-SD-WM-RPT-288

Revision 0

\subsubsection{EEM - Groundwater Monitoring Coordination}

TBD

\subsubsection{Effluent Treatment Facility (ETF) Delisting Petition}

Discussion. The treated effluent from the ETF is discharged to a state-approved land disposal site. A delisting petition for the treated effluent was approved by the EPA (60 FR 31115). The delisting petition exempts the treated effluent from the requirements of the hazardous waste regulations under RCRA and imposes certain effluent quality restrictions. Because the treated effluent is no longer subject to the hazardous waste regulations, the land disposal restrictions do not apply to the treated effluent stream. The delisting petition is limited to the waste codes F001 to F005, and F039 leachate derived from waste codes F001 to F005.

Initially, process condensate from the 242-A Evaporator was the only mixed waste stream identified for storage and treatment in the Liquid Effluent Retention Facility and ETF. However, the ETF was designed to treat a variety of radioactive and hazardous aqueous wastes generated during cleanup of the Hanford Site. The ETF delisting petition must be revised before wastes having other waste codes can be treated.

Required Action. The ETF delisting petition needs to be revised to include the other possible waste codes that may be treated. Other issues also need to be resolved including annual limits in the delisting petition on the volume of treated effluent, and whether waste streams other than process condensate are addressed by the delisting petition.

Decision Time Line. The Project is planning to start up the mixed waste trench in FY 2000. Solid waste having waste codes other than F001 to F005 will be disposed of in the trench. Regulator approval of a revised delisting petition could take up to 1 year. The revised delisting petition must be completed in FY 1998 to enable the mixed waste trench to begin operation on schedule.

\subsection{REFERENCES}

Carlson, A. B., 1994, Solid Waste Program Technical Baseline Description, WHC-SD-WM-RPT-060, Rev. 0, Westinghouse Hanford Company, Richland, Washington.

Carison, A. B., 1995a, Solid Waste Program Technical Baseline Description, WHC-SD-WM-RPT-060, Rev. 1, Westinghouse Hanford Company, Richland, Washington. 
HNF-SD-WM-RPT-288

Revision 0

Carlson, A. B., 1995b, Solid Waste and Material Systems Alternatives Study,

WHC-SD-WM-ES-341, Rev. 0, Vol. 1-6, Westinghouse Hanford Company, Richland, Washington.

Comprehensive Environmental Response Compensation and Liability Act of 1980, 42 USC 9601, et seq.

DOE, 1987, Final Environmental Impact Statement - Disposal of Hanford Defense High-Level, Transuranic, and Tank Wastes, DOE/EIS-0113, U.S. Department of Energy, Washington, D.C.

DOE, 1988, Disposal of Hanford Defense High-Level, Transuranic, and Tank Wastes, Hanford Site, Richland, Washington; Record of Decision, Federal Register V.53, No. 72, pp. 12449-12453, U.S. Department of Energy, Washington, D.C.

Ecology, EPA, and DOE, 1996, Hanford Federal Facility Agreement and Consent Order, as amended, Washington State Department of Ecology, U.S. Environmental Protection Agency, and U.S. Department of Energy, Olympia, Washington.

Federal Facility Compliance Act of 1992, 42 USC 6901, et seq.

Mayancsik, B. A., 1993, WIPP Uncertainty Study - Impacts on the Hanford Site Solid Waste Operations Complex, WHC-SD-W026-ES-005, Rev. 1, Westinghouse Hanford Company, Richland, Washington.

Resource Conservation and Recovery Act of 1976, 42 USC 6901, et seq.

Sederburg, J. P., 1996, Solid Waste program Technical Baseline Description, WHC-SD-WM-RPT-060, Rev. 2, Westinghouse Hanford Company, Richland, Washington.

WIPP, 1996, Waste Isolation Pilot Plant Waste Acceptance Criteria, WIPP/DOE-069, Rev. 5, Westinghouse Electric Corporation, Waste Isolation Pilot Plant, Carlsbad, New Mexico. 


\section{HNF-SD-WM-RPT-288}

Revision 0

\section{CONTENTS}

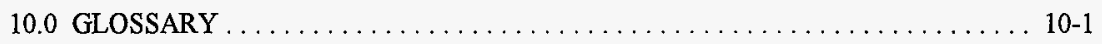

10.1 ACRONYMS AND ABBREVIATIONS $\ldots \ldots \ldots \ldots \ldots \ldots \ldots \ldots \ldots \ldots$ 10-1

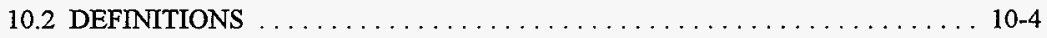


HNF-SD-WM-RPT-288

Revision 0

This page intentionally left blank.

10-ii 
HNF-SD-WM-RPT-288

Revision 0

\subsection{GLOSSARY}

\subsection{ACRONYMS AND ABBREVIATIONS}

ACT

ALARA

ATP

AWC

BDAT

BHI

BWP

CDR

CERCLA

CEQ

$\mathrm{CH}$

CPS

CSER

CT

CVI

CWC

CY

D\&D

DDR

DNFSB

DOE

DOE-HQ

DOT

DST

DynCorp

Ecology

EIS

EM

EPA

ERC

ERDA

ETF

FDC

FDH

FDNW

FFCA

FFTF

FY

GTC acceptance test procedure

as low as reasonably achievable

acceptance test procedure

award of contract

best demonstrated available (treatment) technology

Bechtel Hanford, Inc.

B\&W Protec, Inc.

conceptual design report

Comprehensive Environmental, Response, Compensation, and Liability Act of 1980

Council on Environmental Quality

contact-handled

criticality prevention specification

criticality safety evaluation report

commercial treatment

certified vendor information

Central Waste Complex

calendar year

decontamination and decommissioning

detailed design report

Defense Nuclear Facilities Safety Board

U.S. Department of Energy

U.S. Department of Energy-Headquarters

U.S. Department of Transportation

double-shell tank

DynCorp Tri-Cities Services, Inc.

Washington State Department of Ecology

environmental impact statement

Office of Environmental Restoration and Waste Management

U.S. Environmental Protection Agency

Environmental Restoration Contractor

Energy Research and Development Administration

Effluent Treatment Facility

functional design criteria

Fluor Daniel Hanford, Inc.

Fluor Daniel Northwest, Inc.

Federal Facility Compliance Act of 1992

Fast Flux Test Facility

fiscal year

Greater Than Category 
HNF-SD-WM-RPT-288

Revision 0

\begin{tabular}{ll} 
GTCIII & Greater Than Category III \\
GTCC & Greater Than Class C \\
HDW-EIS & Hanford Defense Waste Environmental Impact Statement \\
HEHF & Hanford Environmental Health Foundation \\
HEPA & high-efficiency particulate air \\
HL & high-level \\
HLW & high-level waste \\
HVAC & heating, ventilation, and air conditioning \\
ICD & interface control document \\
INS & Interstate Nuclear Services \\
ISB & interim safety basis \\
LATA & Los Alamos Technical Associates \\
LAW & low-activity waste \\
LDR & land disposal restriction \\
LEF & Liquid Effluent Facility \\
LERF & Liquid Effluent Retention Facility \\
LL & low-level \\
LLW & low-level waste \\
LLWTF & Low-Level Waste Treatment Facility \\
LMHC & Lockheed Martin Hanford Corporation \\
LMSI & Lockheed Martin Services, Inc \\
LWPF & Liquid Waste Processing Facility \\
MEL & master equipment list \\
MLLW & mixed low-level waste \\
MP & Management Plan; maintenance procedure \\
MS/RD & micro standards/requirements identification document \\
MWSTP & Mixed Waste Stabilization Treatment Program \\
N/A & not applicable \\
NAS & National Academy of Sciences \\
NDA & nondestructive assay \\
NDE & nondestructive examination \\
NEPA & National Environmental Policy Act of 1969 \\
NF & nuclear fuel \\
NHC & Numatec Hanford Corporation \\
NRDWSF & Nonradioactive Dangerous Waste Storage Facility \\
NM & nuclear material \\
NRC & U.S. Nuclear Regulatory Commission \\
ORR & operational readiness review \\
OSR & operational safety requirement \\
OTP & operational test procedure \\
PA & performance assessment \\
PCB & polychlorinated biphenyl \\
PDR & preliminary design report \\
PFP & Plutonium Finishing Plant \\
PHMC & Project Hanford Management Contract \\
& \\
\hline &
\end{tabular}




\section{Revision 0}

PMM

PMP

PNNL

POP

Project

PRTR

PSAR

PSE

PUREX

PWR

RCRA

RFP

RFSH

RH

RINM

$\mathrm{RL}$

ROD

RWM

RWP

SALDS

SAR

SEL

SESC

SNF

SNM

SRE

S/RD

SST

SW

SWD

SWIFT

SWITS

SWPM

TBD

TEDF

TRIGA

TRU

TRUM

TRUPACT

TRUSAF

TSCA

TSD

TSR

TWRS

WAC procurement and materials management

project management plan

Pacific Northwest National Laboratory

plant operating procedure

Waste Management Project

Plutonium Recycle Test Reactor

preliminary safety analysis report

preliminary safety evaluation

Plutonium-Uranium Extraction

Pressurized Water Reactor

Resource Conservation and Recovery Act of 1976

Request for Proposal

Rust Federal Services of Hanford, Inc.

remote-handled

reactor-irradiated nuclear material

U.S. Department of Energy, Richland Operations Office

Record of Decision

restricted waste management

radiation work procedure

state-approved land disposal structure

safety analysis report

safety equipment list

SGN Eurisys Services Corporation

spent nuclear fuel

special nuclear material

sodium reactor experiment

standards/requirements identification document

single-shell tank

solid waste

Solid Waste Disposal

Solid Waste Information Forecast Tool

Solid Waste Information and Tracking System

Solid Waste Projection Model

to be determined

Treated Effluent Disposal Facility

Training Reactor, Isotopes, General Atomics

transuranic

transuranic mixed

transuranic package transporter

Transuranic Waste Storage and Assay Facility

Toxic Substances Control Act of 1978

treatment, storage, and disposal

technical safety requirement

Tank Waste Remediation System

Washington Administrative Code 
HNF-SD-WM-RPT-288

Revision 0

WBS

WESF

WIPP

WRAP

WRAP 1

WRAP 2

WSCF work breakdown structure

Waste Encapsulation and Storage Facility

Waste Isolation Pilot Plant

Waste Receiving and Processing

Waste Receiving and Processing Module 1

Waste Receiving and Packaging Module 2

Waste Sampling and Characterization Facility

\subsection{DEFINITIONS}

These definitions are based on referenced definitions to the maximum extent possible.

Category I Low-Level Waste. Waste that contains radioactivity and is not classified as highlevel waste, transuranic waste, or spent nuclear fuel or $11 \mathrm{E}(2)$ byproduct material as defined by DOE Order 5820.2A, Radioactive Waste Management. Test specimen of fissionable material irradiated for research and development only, and not for the production of power or plutonium, may be classified as low-level waste provided the concentration of transuranic is less than $100 \mathrm{nCi} / \mathrm{g}$. If the radionuclide concentration does not exceed the value listed in WHC-EP-0063-4, Hanford Site Solid Waste Acceptance Criteria, Table 3-1, Column 1, the waste is considered Category I low-level waste.

Category III Low-Level Waste. Waste that contains radioactivity and is not classified as highlevel waste, transuranic waste, or spent nuclear fuel or $11 \mathrm{E}(2)$ byproduct material as defined by DOE Order 5820.2A, Radioactive Waste Management. Test specimen of fissionable material irradiated for research and development only, and not for the production of power or plutonium, may be classified as low-level waste provided the concentration of transuranic is less than $100 \mathrm{nCi} / \mathrm{g}$. If the radionuclide concentration does not exceed the value listed in WHC-EP-0063-4, Hanford Site Solid Waste Acceptance Criteria, Table 3-1, Column 2, the waste is considered Category III low-level waste.

Greater than Category III Low-Level Waste. Waste that contains radioactivity and is not classified as high-level waste, transuranic waste, or spent nuclear fuel or $11 \mathrm{E}(2)$ byproduct material as defined by DOE Order 5820.2A, Radioactive Waste Management. Test specimen of fissionable material irradiated for research and development only, and not for the production of power or plutonium, may be classified as low-level waste provided the concentration of transuranic is less than $100 \mathrm{nCi} / \mathrm{g}$. If the radionuclide concentration exceeds the value listed in WHC-EP-0063-4, Hanford Site Solid Waste Acceptance Criteria, Table 3-1, Column 2, the waste is considered Greater Than Category III low-level waste.

Certified Waste. Waste that has been confirmed to comply with disposal site waste acceptance criteria (e.g., WIPP/DOE-69, Waste Acceptance Criteria for the Waste Isolation Pilot Plant) under an approved certification program. 
HNF-SD-WM-RPT-288

Revision 0

Chemical Conversion. The action of substances undergoing chemical change or a process that produces change.

Closure. (1) Operational Closure. Actions taken on completion of operations to prepare the disposal site or disposal unit for custodial care (e.g., addition of cover, grading, drainage, erosion control).

(2) Final Site Closure. Actions taken as part of a formal decommissioning or remedial action plan whose purpose is to achieve long-term stability of the disposal site and eliminate to the extent practical the need for active maintenance so that only surveillance, monitoring, and minor custodial care are required.

Contact-Handled Transuranic Waste. Packaged transuranic waste whose external surface dose rate does not exceed 100 mrem per hour. This may be extended to 200 mrem per hour on a case-by-case basis with the approval of the manager of Solid Waste Operations.

Combustible Material. Material that will sustain combustion in atmospheric air when exposed to an ignition source of $805^{\circ} \mathrm{C}$ for a period of 5 minutes, according to WIPP/DOE-069, Waste Acceptance Criteria for the Waste Isolation Pilot Plant.

Dangerous Waste. Those waste types designated dangerous by Washington Administrative Code (WAC) 173-303, "Dangerous Waste Regulations."

Degradation. Conversion of a compound into a simpler compound, usually less noxious than the original compound.

Disposal. Emplacement of waste in a manner that ensures isolation from the biosphere for the foreseeable future with no intent of retrieval and that requires deliberate action to regain access to the waste.

Disposal Facility. The land, structures, and equipment used for the disposal of waste.

Disposal Site. That portion of a disposal facility that is used to dispose of waste. For low-level waste, it consists of disposal units and a buffer zone.

Disposal Unit. A discrete portion (e.g., a pit, trench, tumulus, vault, or bunker) of the disposal site into which waste is placed for disposal.

Engineered Barrier. A structure or device that is intended to improve the performance of a disposal facility.

Hazardous Waste. Those waste types that are designated hazardous by Title 40 Code of Federal Regulations (CFR) Part 261, "Identification and Listing of Hazardous Waste." 
Institutional Control. A period of time, assumed to be about 100 years, during which human institutions continue to control waste management facilities.

Long-Term Storage. Storage for a period of more than 2 years.

Low-Level Waste. Waste that contains radioactivity and is not classified as high-level waste, transuranic waste, or spent nuclear fuel or $11 \mathrm{E}(2)$ byproduct material. Test specimens of fissionable material irradiated for research and development only, and not for the production of power or plutonium, may be classified as low-level waste provided the concentration of transuranic is less than $100 \mathrm{nCi} / \mathrm{g}$.

Monitoring. The making of observations and measurements to provide data to evaluate the performance of a waste management operation.

Mixed Waste. Waste containing radioactive and dangerous waste components as defined by the Atomic Energy Act of 1954 and WAC 173-303, "Dangerous Waste Regulations," respectively.

Near-Surface Disposal. Disposal in the upper $30 \mathrm{~m}$ of the earth's surface (e.g., shallow land burial).

Processing. See Treatment, definition 2.

Radioactive Solid Waste. Solid waste that contains radionuclides regulated under the Atomic Energy Act of 1954 and of negligible economic value, considering the cost of recovery. Solid waste generated in radiologically controlled areas and contaminated above threshold limits is to be considered radioactive solid waste.

Radioactive Waste. Solid, liquid, or gaseous material that contains radionuclides regulated under the Atomic Energy Act of 1954 and of negligible economic value considering the cost recovery.

Remote-Handled Transuranic Waste. Packaged transuranic waste whose external surface dose rate exceeds $200 \mathrm{mrem}$ per hour. Test specimens of fissionable material irradiated for research and development purposes only and not for the production of power or plutonium may be classified as remote-handled transuranic waste.

Retrieval. The recovery of stored waste for the purpose of treatment and/or final disposal.

Solid Waste. Any discarded solid, semisolid, or solidified liquid material such as garbage, refuse, sludge, or discarded commodity resulting from industrial, commercial, mining, agricultural, or community operations or activities that are not a primary product of such operations or activities. This includes solid materials, containerized liquid or semisolid materials, and containerized gaseous materials contained in drums, boxes, or other containers. The scope of solid waste within 


\section{HNF-SD-WM-RPT-288}

\section{Revision 0}

this document is any solid waste managed by the Restoration and Upgrades Program function within the Solid/Liquid Waste Remediation Division.

Stabilization. Any method, technique, or process designed to prevent the migration of hazardous and/or radioactive constituents contained within a waste matrix.

Storage. Retrievable retention of waste pending disposal.

Storage Facility. Land area, structures, and equipment used for the storage of waste.

Storage Unit. A discrete part of the storage facility in which waste is stored.

Top Level. Pertains to high-level topics related to the Waste Management Project. This level is considered a top-level document because it is written to assist the Waste Management Project to perform the functions of waste scope development and defense to the Project Hanford Management Contractor upper management and the U.S. Department of Energy, Richland Operations Office.

Transuranic Waste. Without regard to source or form, waste that is contaminated with alphaemitting transuranium radionuclides with half-lives longer than 200 years and concentrations higher than $100 \mathrm{nCi} / \mathrm{g}$ at the time of assay.

Transuranium Radionuclide. Any radionuclide with an atomic number higher than 92 .

Treatment. (1) Any method, technique, or process designed to change the physical or chemical character of waste to render it less hazardous; safer to transport, store, or dispose of; or reduce it in volume. (2) Any method, technique, or activity required for transport, storage, treatment, or disposal of waste regardless of whether the physical or chemical nature of the waste is changed.

Treatment Facility. The specific area of land, structures, and equipment dedicated to waste treatment and related activities.

Waste Container. A receptacle for waste, including any liner or shielding material that is intended to accompany the waste in disposal (DOE Order 5820.2A, Radioactive Waste Management). In the case of contaminated, damaged, leaking, or breached containers, any overpack shall be considered the container and the original container shall be considered part of the waste (WIPP/DOE-069, Waste Acceptance Criteria for the Waste Isolation Pilot Plant).

Waste Management. The planning, coordination, and direction of those functions related to generation, handling, treatment, storage, transportation, and disposal of waste, as well as associated surveillance and maintenance activities. 
Waste Package. The waste, waste container, and any absorbent that are intended for disposal as a unit. In the case of surface contaminated, damaged, leaking, or breached waste packages, any overpack shall be considered the waste container and the original container shall be considered part of the waste. 


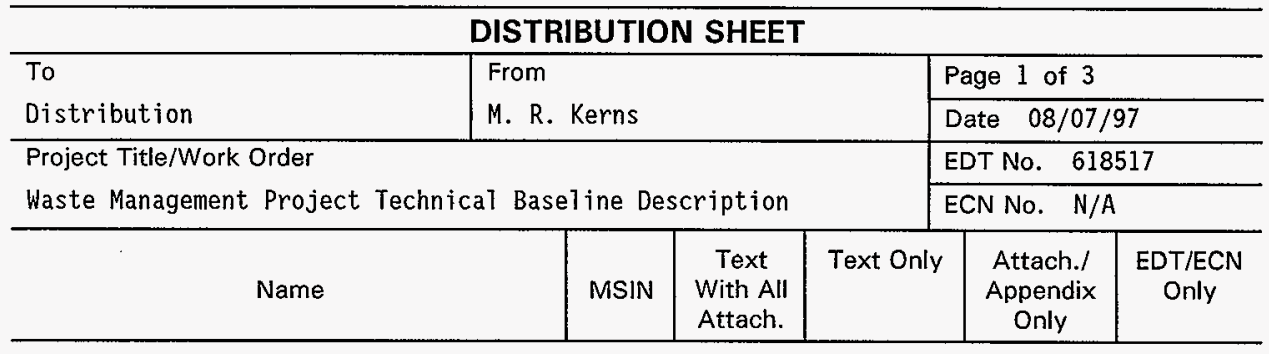

U. S. Department of Energy, Richland Operations Office

E. M. Bowers

R. P. Carter

R. F. Guercia (5)

$\begin{array}{ll}\$ 7-55 & X \\ 57-55 & X \\ 57-55 & X\end{array}$

Fluor Daniel Hanford, Inc.

R. L. Bisping

J. W. Golden

C. G. Mattsson

$\mathrm{N} 1-26$

$\mathrm{N} 1-26$

$\mathrm{N} 1-26$

K. J. Svoboda

N1-26

$X$
$X$
$X$

Lockheed Martin Hanford Corporation

P. A. Baynes

M. L. Grygiel

A. K. Lee

D. J. Sommer

H8-71

$\mathrm{H8}-71$

H8-71

H8-71

$X$
$X$
$X$
$X$

Lockheed Martin Services, Inc.

S. R. Nelson

H6-31 X

Waste Management Federal

Services of Hanford, Inc.

E. J. Adams

E. S. Aromi

A. E. Aughey

W. S. Ayers

T. L. Baker

R. A. Barcot

R. B. Barmettlor

L. T. Blackford

R. J. Bottenus

H. C. Boynton

P. B. Brannan

J. B. Buckley

F. M. Coony

A. F. Crane

P. J. Crane

R. H. EngeTmann

$\begin{array}{ll}\text { T3-03 } & X \\ \text { H6-30 } & X \\ \text { T3-01 } & X \\ \text { T3-28 } & X \\ H 6-06 & X \\ \text { H6-06 } & X \\ \text { L6-04 } & X \\ \text { T4-05 } & X \\ \text { T4-52 } & X \\ \text { T4-52 } & X \\ \text { T4-62 } & X \\ \text { T3-04 } & X \\ \text { H6-06 } & X \\ \text { S6-72 } & X \\ \text { T4-04 } & X \\ H 6-26 & X\end{array}$


DISTRIBUTION SHEET

\begin{tabular}{|c|c|c|c|c|c|}
\hline \multirow{2}{*}{$\begin{array}{l}\text { To } \\
\text { Distribution }\end{array}$} & \multirow{2}{*}{\multicolumn{3}{|c|}{$\begin{array}{l}\text { From } \\
\text { M. R. Kerns }\end{array}$}} & \multicolumn{2}{|l|}{ Page 2 of 3} \\
\hline & & & & \multicolumn{2}{|c|}{ Date $08 / 07 / 97$} \\
\hline \multirow{2}{*}{\multicolumn{3}{|c|}{$\begin{array}{l}\text { Project Title/Work Order } \\
\text { Waste Management Project Technical Baseline Description }\end{array}$}} & & \multirow{2}{*}{\multicolumn{2}{|c|}{$\begin{array}{ll}\text { EDT No. } & 618517 \\
\text { ECN No. } & \text { N/A }\end{array}$}} \\
\hline & & & & & \\
\hline Name & MSIN & $\begin{array}{l}\text { Text } \\
\text { With All } \\
\text { Attach. }\end{array}$ & Text Only & $\begin{array}{l}\text { Attach./ } \\
\text { Appendix } \\
\text { Only }\end{array}$ & $\begin{array}{l}\text { EDT/ECN } \\
\text { Only }\end{array}$ \\
\hline
\end{tabular}

Waste Management Federa]

Services of Hanford, Inc. (cont.)

D. L. Flyckt.

A. Garcia

J. E. Geary

R. J. Giroir

C. K. Girres

E. M. Greager

T. M. Greager

D. L. Hage]

D. L. Halgren

D. J: Hart

P. L. Hemsworth

K. L. HTadek (20)

R. M. Irwin

P. H. Jacobsen

W. G. Jasen

W. S. Josephson

S. M. Joyce

M. R. Kerns

M. J. La Barge

J. J. Lang

C. J. Lewis

D. W. Lindsey

S. S. Lowe

E. F. Mares

K. M. McDonald

D. E. McKenney

G. G. Meade

D. S. Merry

D. E. Nester

R. J. Nicklas

T. K. Orgil1

B. L. Oswald

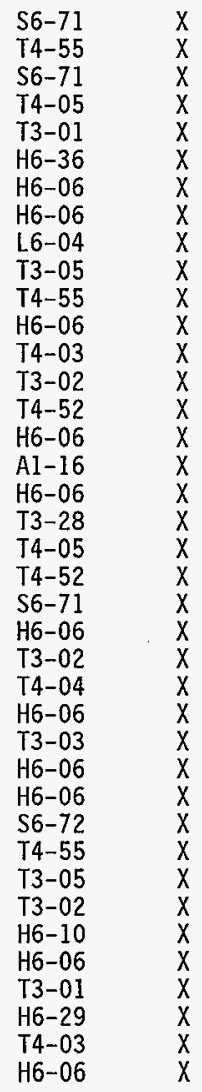

F. H. Penn

R. D. Pierce

B. G. Place

D. B. Powell

L. L. Powers

D. A. Pratt

K. M. Quigley 


\section{DISTRIBUTION SHEET}

\begin{tabular}{|c|c|c|c|c|c|}
\hline \multirow{2}{*}{$\begin{array}{l}\text { To } \\
\text { Distribution }\end{array}$} & \multirow{2}{*}{\multicolumn{3}{|c|}{$\begin{array}{l}\text { From } \\
\text { M. R. Kerns }\end{array}$}} & \multicolumn{2}{|l|}{ Page 3 of 3} \\
\hline & & & & \multicolumn{2}{|c|}{ Date $08 / 07 / 97$} \\
\hline \multirow{2}{*}{\multicolumn{3}{|c|}{$\begin{array}{l}\text { Project Title/Work Order } \\
\text { Waste Management Project Technical Baseline Description }\end{array}$}} & & \multirow{2}{*}{\multicolumn{2}{|c|}{ EDT No. 618517}} \\
\hline & & & & & \\
\hline Name & MSIN & $\begin{array}{l}\text { Text } \\
\text { With All } \\
\text { Attach. }\end{array}$ & Text Only & $\begin{array}{l}\text { Attach./ } \\
\text { Appendix } \\
\text { Only }\end{array}$ & $\begin{array}{l}\text { EDT/ECN } \\
\text { Only }\end{array}$ \\
\hline
\end{tabular}

Waste Management Federal

Services of Hanford, Inc. (cont.)

R. W. Reddinger

D. L. Renberger

J. G. Riddelle

L. W. Roberts

F. C. Schmidt

R. A. Spohr

S. M. Stitt

N. J. Sullivan

G. C. Triner

B. H. Von Bargen

A. G. Weiner

J. L. Westcott

R. T. WiTde

C. M. Winkler

J. A. Winterhaider

M. I. Wood

$\begin{array}{ll}\text { T3-01 } & X \\ \text { T3-03 } & X \\ \text { T4-51 } & X \\ \text { T4-51 } & X \\ \text { S6-30 } & X \\ T 6-04 & X \\ T 4-12 & X \\ S 6-72 & X \\ T 3-05 & X \\ \text { S6-72 } & X \\ H 6-21 & X \\ T 3-04 & X \\ H 6-10 & X \\ \text { S6-71 } & X \\ H 6-21 & X \\ H 6-06 & X \\ \end{array}$

Rust Federal Services Northwest

P. K. Brockman

J. G. Field

H1-11

H1- 15

D. L. McCall

H1-11

Pacific Northwest National Laboratory

T. J. DeForest

M. S. Peffers

K. J. Templeton

J. D. Vick

Central Files (orig. + 1) Document Processing Center SWDPC SAT 1
$\begin{array}{ll}K 7-97 & X \\ \text { K8-18 } & X \\ \text { K7-94 } & X \\ \text { K8-18 } & X\end{array}$

A3-88 $X$

A3-94

T3-05 $x$
$x$
$x$

$x$
$x$
$x$ 